\title{
Hanford Site Development Plan
}

\author{
C. A. Rinne \\ R. H. Curry \\ J. W. Hagan \\ S. W. Seiler \\ D. J. Sommer \\ Westinghouse Hanford Company \\ E. F. Yancey \\ Pacific Northwest Laboratory \\ Date Published \\ January 1990
}

Approved:
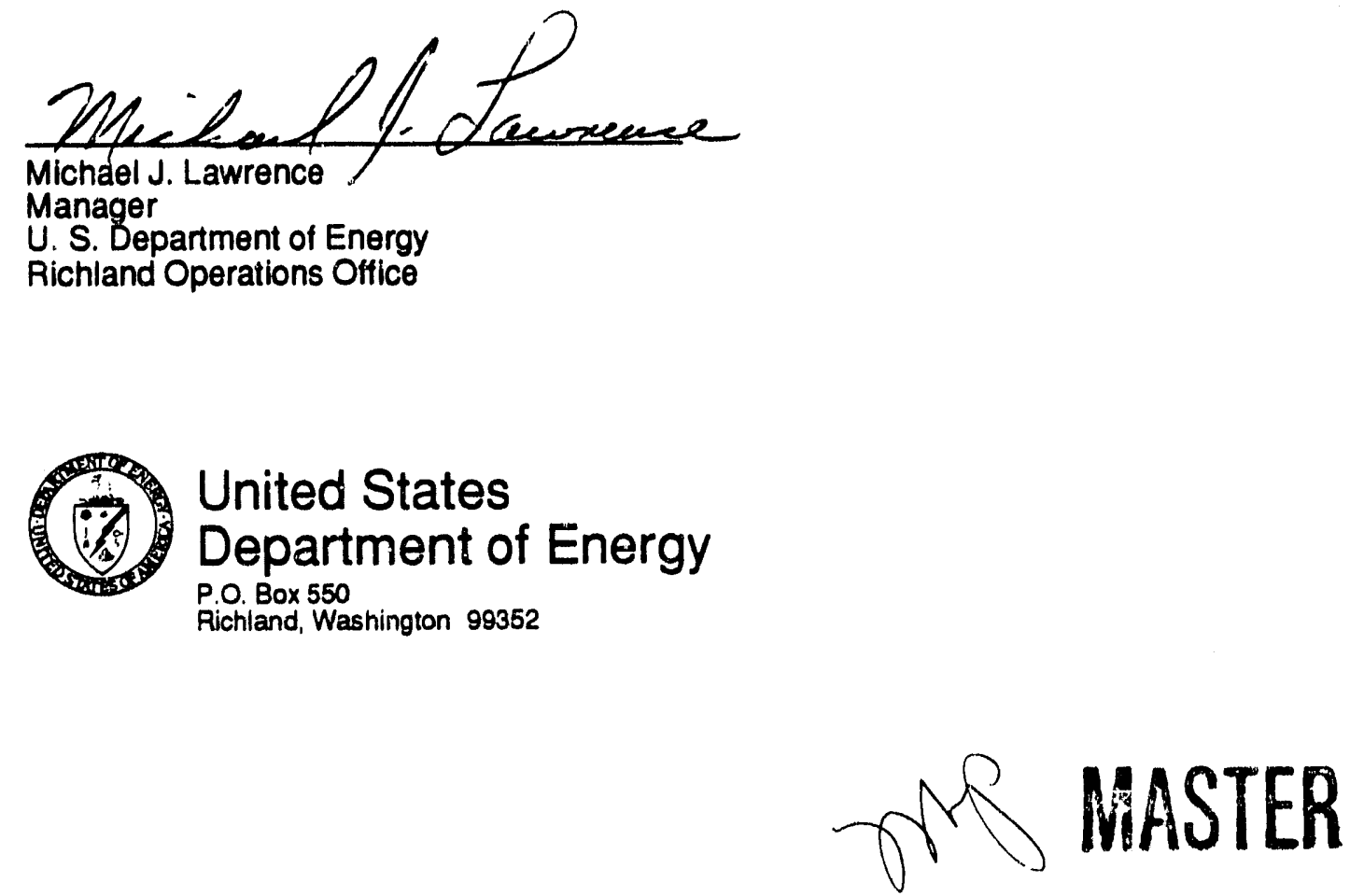


\section{DISCLAIMER}

This report was prepared as an account of work sponsored by an agency of the United States Government. Neither the United States Government nor any agency thereof, nor any of their employees, nor any of their contractors, subcontractors or their employe日s, makes any warranty, express or implied, or assumes any legal liability or responsibility for the accuracy, completeness, or any third papty's use or the results of such use of any information, apparatus, product, or process disclosed, or represents that its use would not intringe privately owned rights. Reference herein to any specific commercial product, process, or service by trade name, Irademark, manufacturer, or otherwise, does not necessarily constitute or imply its endorsement, recommendation, or favoring by the United States Government or any agency thereof or its contractors or subcontractors. The views and opinions of authors expressed herein do not necessarily state or reflect those of the United States Government of any agency thereof.

Printed in the Unitod Stater of America

DISCLM-2.CHP (7.80) 


\section{PREFACE}

Facilities are expensive to acquire, have long lives, require significant outlays of operating dollars over their economic lives, and involve long lead times for budgeting and construction. These attributes require careful advance planning to ensure that future operations and facilities development can be economically accommodated. This Hanford Site Development Plan is prepared to meet this planning need since it serves as an outline for the orderly development and continued effective use of the Hanford Site for U.S. Department of Energy (DOE) programs.

This plan complies with the Hanford Site development planning policy stated in the following DOE documents:

- DOE-RL 4320.1A, Site Development and Facility Utilization Planning, dated April 8, 1986

- DOE/AD/06212-1, Site Development Planning Handbook, dated January 1981

- DOE Order 4300.1B, Real Property and Site Development Planning, dated July 1,1987

- DOE-RL Order 4320.2B, Site Selection, dated April 1, 1986.

The Hanford Site contains several smaller "operating areas." Detailed site development plans for each of these areas (100, 200 East, 200 West, $300,400,600,700,1100$, and 3000) will be prepared to complement this overall site plan.

The Hanford Site Development Plan was prepared by Westinghouse Hanford Company for DOE-Richland Operations Office. Pacific Northwest Laboratory staff provided technical support. Each of the contractors at Hanford has reviewed this plan and concurs with its content.

As with any planning document, this plan will be updated as necessary to respond to the changing demands on the Site. 


\section{CONTENTS}

1.0 Executive Summary .................... . . 1-1

1.1 General Site Information ................ . 1-1

1.1.1 History .................. 1-1

1.1.2 Regional Overview ............... 1-1

1.1.3 Local and Regional Attitudes............. 1-3

1.1.4 Land Use ................... 1-3

1.1.5 Transportation .............. 1-3

1.1 .6 Utilities .................. $1-4$

1.2 Existing Conditions ................ . . . . $1-4$

1.2.1 Land Use and Leased Facilities..... . . . . . . 1-4

1.2.2 Missions and Programs .............. 1-5

1.2.3 Hanford Site Employment . . . . . . . . . . 1-6

1.2.4 Site Improvements ................ 1-6

1.2.5 Physical Characteristics............. 1-8

1.2 .6 Security ................. 1-9

1.2.7 Safety .................. . . 1-10

1.2.8 Safety Considerations for Principal Facilities... 1-11

1.2.9 Environmental Issues ............... 1-11

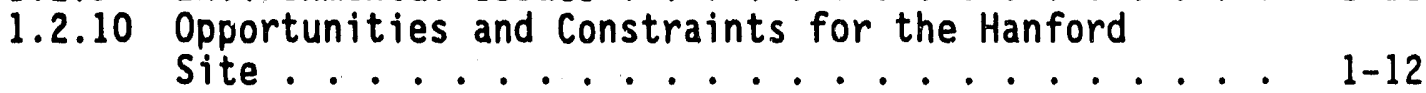

1.3 Planning Analysis ................. . . . . . . . . .

1.3.1 Goals ..................... 1-14

1.3 .2 Assumptions . . . . . . . . . . . . . . . 1-16

1.3.3 Activity Scenarios .............. 1-16

1.3.4 Ideal Plan ................... 1-19

1.3.5 Master Plan Development ........... 1-19

1.4 Master Plan . . . . . . . . . . . . . . . 1-22

1.5 Five-Year Plan .................... 1-24

1.5.1 Goal Number 1 .................. $1-24$

1.5.2 Goal Number 2 .................. . . 1-24

1.5.3 Goal Number 3 .................. $1-25$

1.5 .4 Goal Number 4 .................. $1-25$

1.5.5 Goal Number 5 .................. 1-26

1.5 .6 Goal Number 6 ................. $1-26$

1.5.7 Goal Number 7 ................ . 1-27

1.6 References ................... 1-27

2.0 General Site Information ................. 2-1

2.1 History ..................... . . . 2-1

2.1.1 Hanford Site-Eariy Years ............ 2-1

2.1.2 Hanford Site Expands ................ 2-3

2.1.3 Electrical Power Production Begins . . . . . . . . . 2-3

2.1.4 Operations Divided Among Contractors . . . . . . . 2-3

2.1.5 Hanford Site Technologies Expand ........... 2-4

2.1.6 Reemphasis on Production of Nuclear Materials and
Consolidation of Operations . . . . . . . . . 2-5

2.1.7 Emphasis on Environmental Research and Compliance:
Slowdown on Production of Nuclear Materials . . . . 2-6 


\section{CONTENTS (cont.)}

2.2 Regional Overview ................. 2. 2-8

2.2.1 Demographics............... 2-9

2.2.2 Housing ................. 2-14

2.2.3 Schools ................. 2-14

2.2.4 Labor Supply. . . . . . . . . . . . . . 2-15

2.2.5 Materials Availability ............. 2-16

2.2.6 Local/Regional Attitudes and Issues ....... 2-19

2.2.7 Other Factors .............. 2-20

2.3 Specific Locale Data . . . . . . . . . . . . . . . 2-21

2.3.1 Nearby Zoning and Land Use... . . . . . . . 2-21

2.3.2 Laws, Regulations, and Agreements Affecting
. . . . . 2-21

2.4 Public Transportation ................ 2. . . . . . . . .

2.4.1 Road Networks ............... 2-31

2.4.2 Airlines and Airports ........... 2-33

2.4.3 Railroads ................. 2-35

2.4 .4 Waterways ................. 2-37

2.4.5 Public Transit............... 2-... 2 27

2.5 Utilities,.................. 2-... 2-. . . . . .

2.5.1 Electricity ................ 2-38

2.6 References.................... 2-39

3.0 Existing Conditions .................. . . . . . 3-1

3.1 Land Use and Leased Facilities.............. . . 3-1

3.1.1 Land Use ................. 3-1

3.1.2 Leased Facilities .............. 3-4

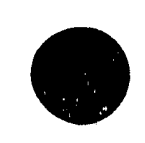

3.2 Mission, Programs, and Contractors . . . . . . . . . 3-4

3.2.1 Present Mission ............... 3-4

3.2.2 Present Programs ............... 3-4

3.2.3 Present Contractors . . . . . . . . . . 3-8

3.3 Hanford Site Employment . . . . . . . . . . . . 3-12

3.4 Site Improvements ................. 3-14

3.4.1 Utility Systems ............... 3-14

3.4.2 Site Improvenent Statistical Data ....... . 3-22

3.5 Physical Characteristics ............. 3-33

3.5.1 Physiography and Geomorphology ........ . 3-33

3.5.2 Stratigraphy ................. 3-33

3.5.3 Soils .................. 3-... . . . . . 35

3.5.4 Geology/Structures ............. 3-. . . . . 36

3.5.5 Hydrology ................... 3-46

3.5.6 Wetlands................... 3-52

3.5.7 Wildlife................... 3-54

3.5.8 Vegetation ................ 3-55

3.5.9 Ecological Areas ............... 3-55

3.5.10 Historic, Archaeological, and Cultural Resources . 3-59

3.5.11 Endangered Species.............. 3-60

3.5.12 Meteorology ................. 3-62 
3.6 Security ..................... $3-72$

3.6.1 Buffer Zones.............. 3-. . 32

3.6.2 Security Zones ............. 3-73

3.6 .3 Lighting . . . . . . . . . . . . 3-74

3.6 .4 Fencing .................... 3-74

3.6 .5 Barriers ............... 3-. . . 36

3.6 .6 Gates ............. 3-. . . 36

3.6.7 Hanford Patrol ........... 3-. . . 36

3.7 Safety: Policy and Organizational Responsibilities ... 3-76

3.7.1 Industrial Safety and Health ......... 3-79

3.7.2 Radiological Safety ........... 3-. 30

3.7.3 Criticality Safety............ 3-80

3.7.4 Reactor Safety. . . . . . . . . . . . 3-82

3.7.5 Emergency Response ............. 3-83

3.8 Safety Considerations for Principal Hanford Site ..... 3-84

Facilities ............ $3-34$

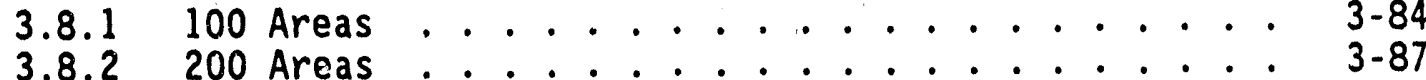

3.8.3 300 Area ................ 3-.94

3.8.4 400 Area .............. 3-98

3.9 Management and Implementation of Environmental ..... 3-100

3.9.1 U.S. Department of Énergy-Richl and Operations

Office Management Structure and Approach . . . . . 3-100

3.9.2 Hanford Site Prime Contractor Organization and

3.9.3 Interaction with offsite Agencies and ..... $3-102$

3.9.4 Environmental Monitoring Activities ....... 3-104

3.10 Assessment . . . . . . . . . . 3-106

3.10.1 Tri-Cities Region ........... 3-107

3.10.2 Hanford Site........... 3-109

3.10.3 Hanford Site Opportunities and Constraints.... 3-113

3.11 References.................... 3115

4.0 Planning Analysis ................. 4- . . . .

4.1 Goals ........................... 4-.

4.1.1 Business Goals ............... 4-2

4.1.2 Land Use ................ 4-4

4.1.3 Facilities/Infrastructure Systems ...... 4-4

4.2 Assumptions and Future Needs . . . . . . . . 4-5

4.3 Projected Scenarios of Activity at the Hanford Site . . . 4-6

4.3.1 Low-Case Scenario ............... 4-8

4.3.2 Medium-Case Scenario ............. 4-11

4.3.3 High-Case Scenario............ 4-14

4.4 Evaluation of Scenario Impacts ........... 4-18

4.4.1 Low-Case Scenario ............... 4-18

4.4.2 Medium-Case Scenario ............. 4-24

4.4.3 High-Case Scenario............ 4-25 
CONTENTS (cont.)

4.5 Master P1an Development ............... 4-31

4.6 Ideal Site Plan ................. 4-32

4.7 Analysis of Alternatives ............ 4-34

4.7.1 Environmental Restoration and Technology

4.7 .2 Development. . . . . . . . . 4-34

4.7.3 Reactors .............. 4 4-36

4.7.4 Fuel Fabrication .............. 4-39

4.7.5 Interim Storage of Spent Fuel ......... 4-39

4.8 Alternatives Colnbined With Scenarios .......... 4-41

4.9 References.................. 4-46

5.0 Master Plan .................... 5-1

5.1 Future Land Use and Functional Location ......... 5-1

5.1.1 Acquisition cost ........... 5-6

5.1.2 Operation and Maintenance .......... 5-6

5.1 .3 Design Life ..... . . . . . . . . . 5-6

5.1 .4 Location ............... 5-7

5.1.5 Prioritization/Justification ......... 5-7

5.1.6 Energy Conservation ............ 5-7

5.1.7 Ecological/Environmental Benefits ........ 5-7

5.1.8 Efficiency of Operation. . . . . . . . . . . . 5-8

5.1.9 Changing Security and Regulatory Requirements . . 5-8

5.1 .10 Working Conditions .............. 5-8

5.1.11 Community Relations .............. 5-8

5.1.12 Program Effectiveness. . . . . . . . . . . . 5-9

5.1 .13 Cost Effectiveness . . . . . . . . . . . . 5-9

5.1.14 Space Planning . . . . . . . . . . . . . 5-9

5.2 Future Facility/Mission Planning . . . . . . . . . 5-9

5.3 Utilities . . . . . . . . . . . 5-12

5.3.1 Electrical Utilities ............ 5-12

5.3.2 Water Utilities ............... 5-13

5.3.3 Telecommunications ............ 5-13

5.4 Future Transportation ............. 5-13

5.5 Future Security . . . . . . . . . . . . 5-14

5.5.1 Hanford Site Safeguards and Security Program .... 5-14

5.5.2 Safeguards and Security Planning Bases ....... 5-14

5.6 Future Safety .. . . . . . . . . . . . . 5-18

5.6.1 Policy and Organization Responsibilities . . . . 5-18

5.6.2 Safety Considerations for Principal Hanford Site
Facilities . . . . . . . . . . .

5.7 Future Environmentai issues . . . . . . . . . 5-20

5.7.1 Low-Case Scenario ............. 5-21

5.7 .2 Medium-Case Scenario ............ 5-21

5.7.3 High-Case Scenario ............... 5-21

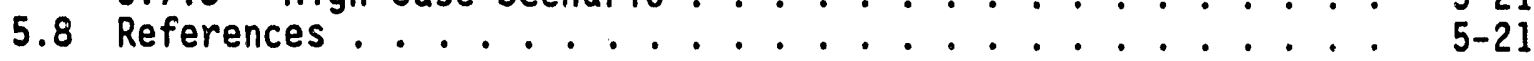




\section{CONTENTS (cont.)}

6.0 Five-Year Plan ................... . . 6-1

6.1 Goal Number 1 ................. . . 6-1

6.2 Goal Number $2 . . . . . . . . . . . . . . . . .6-6$

6.3 Goal Number 3 ................. . . 6-6

6.4 Goal Number 4 .................. . . 6-6

6.5 Goal Number 5 ..................... . . 6-11

6.6 Goal Number 6. . . . . . . . . . . . . . . . 6-11

6.7 Goal Numbar 7 ................... . . 6-15

6.8 References................... . . 6-16

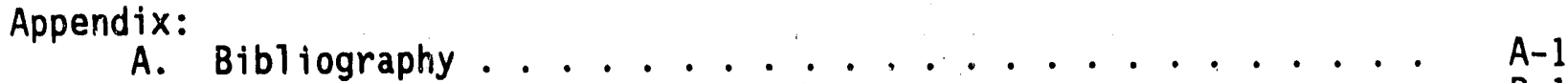

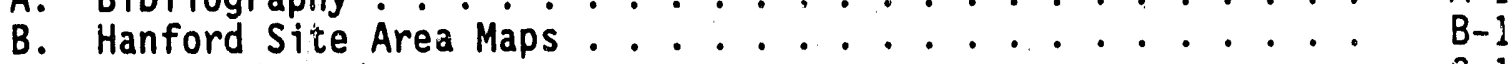

C. Proposed Projects .................. . . C-1 


\section{LIST OF FIGURES}

1-1 Location and Regional Map of the Hanford Site.......... . 1-2

1-2 Opportunities and Constraints of the Hanford Site........ 1-13

1-3 Ideal Site Plan ................... . . . . . . . . .

1-4 Master Plan Development . . . . . . . . . . . . . . 1-21

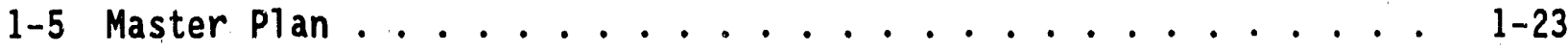

2-1 Location and Regional Map of the Hanford Site.......... 2-2

2-? Hanford Contractor History . . . . . . . . . . . . . 2-7

2-3 Population for Cities Within a 50-Mile Radius of the Hanford Meteorology Station............. . . 2-10

2-4 Population Trends for Benton and Franklin Counties: 1965 to 1988 ....................... 2-13

2-5 Population Trends for Cities Near the Hanford Site: 1965 to 1988 . . . . . . . . . . . . . . . . 2-13

2-6 Location of Yakima Indian Reservation, Umatilla Indian Reservation, and Nez Perce Indian Reservation . . . . . . . . 2-22

2-7 Local and Regional Highway Network Linking the Tri-Cities with Major Interstate Highways .................. 2-32

2-8 Major Pacific Northwest Interstate Highways Providing Access to the Tri-Cities ................ . 2-34

2-9 Major Pacific Northwest Rail Lines Providing Access to the Tri-Cities ................. . 2-36

3-1 Land Use on the Hanford Site . . . . . . . . . . . . 3-2

3-2 Facilities Leased by the U.S. Department of Energy Contractors ................ . . . 3-6

3-3 Funding Levels and Shift; in Program Emphasis . . . . . . . . 3-9

3-4 Hanford Site Budget by Fiscal Year . . . . . . . . . . . . . 3-9

3-5 Functional Relationships Among Hanford Site Contractors . . . . 3-10

3-6 Functional Locations of Hanford Site Contractors . . . . . . . 3-11

3-7 Hanford Site Employment by Program . . . . . . . . . . . 3-12

3-8 Total Hanford Site Employment, 1967 to 1989 . . . . . . . . . 3-13 


\section{LIST OF FIGURES (cont.)}

3-9 Electrical Transmission Lines on the Hanford Site . . . . 3-16

3-10 20-Year Power History and Forecast for the Hanford Site . . . 3-17

3-11 Export Water System for the Hanford Site . . . . . . . . 3-18

3-12 Hanford Site Radio Systems .............. 3-21

3-13 Hanford Site Roads and Rail .............. 3-32

3-14 Geologic Cross-Section of the Hanford Site ........ 3-34

3-15 Generalized Geologic Structure Map of the Central $\ldots$. . . . 3-38

3-16 Structure Map of the Hanford Site and Surrounding Area . . . . 3-39

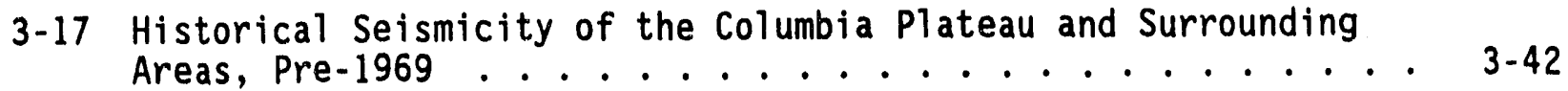

3-18 Recent Seismographic Seismicity of the Columbia Plateau and
Surrounding Areas Since 1969..................... 3-43

3-19 Drainage Areas for Cold Creek and Dry Creek on the Hanford

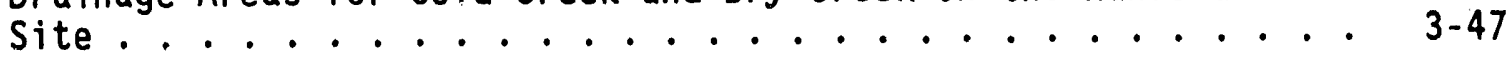

3-20 Probable Maximum Flood ............. 3-. . . . . .

3-21 Water Table Elevatior.s .............. 3-51

3-22 Surface Water Bodies, Including Ephemeral Streams on
the Hanford Site..... 3-53

3-23 Location of the Four U.S. Department of Energy National
Environmental Research Parks . . . . . . 3-56

3-24 Ecological Study Areas of the Hanford Site ......... 3-58

3-25 Wind Roses for the Hanford Telemetry Network, 1979
Through 1982. . . . . . . . . 3-63

3-26 Monthly Wind Roses for the Hanford Meteorology Station Based on Wind Data, 1955 Through $1980 \ldots$ 3-65

3-27 Normal, Extreme, and Daily Temperatures at the Hanford Site . 3-66

3-28 Example of Area Concentric Security Zones . . . . . . 3-75

3-29 The Role of Safety at the Hanford Site . . . . . . . . 3-77 
LIST OF FIGURES (cont.)

3-30 Lost Workday Case Incidence Rates . . . . . . . . . 3-81

3-31 Recordable Injury Incidence Rates ... . . . . . . . . . 3-81

3-32 History of Annual Skin Contaminations ... . . . . . . 3-82

3-33 Hanford Site Capabilities ............ 3- . . . . . . . .

3-34 Opportunities and Constraints on the Hanford Site . . . . . 3-114

4-1 Existing Activity Centers on the Hanford Site . . . . . . . 4-19

4-2 Activity Centers for Low-Case Scenario . . . . . . . . . 4-20

4-3 Conceptual Drawing of the Hanford Waste Vitrification Plant . . 4-22

4-4 Characterization and Location of the Activity Centers

Associated with the Medium-Case Scenario at the Hanford Site . . 4-26

4-5 The Mothballed Washington Public Power Supply System Nuclear Plant No. 1 .................. 4 4-27

4-6 Fast Flux Test Facility's Multiple Mission Capability . . . . 4-29

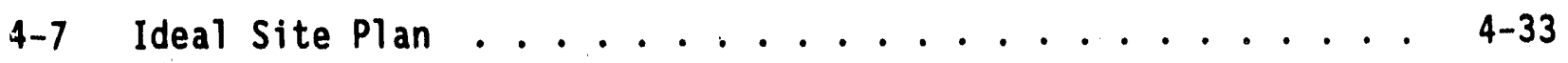

4-8 Alternative Locations for R\&D/Engineering Development on the
Hanford Site. 4-37

4-9 Alternative Locations for Reactors on the Hanford Site . . . . 4-38

4-10 Alternative Locations for Fuel Fabrication Facilities on the 4-40

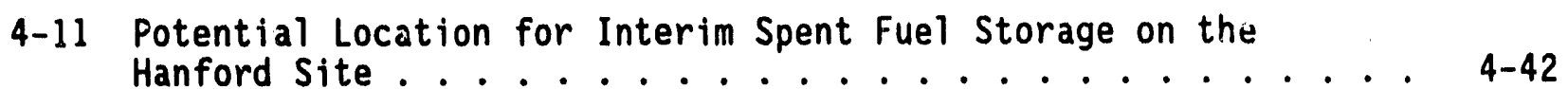

4-12 Low-Case Scenario, Including Alternatives ... . . . . . 4-43

4-13 Medium- and High-Case Scenarios, Including Alternatives . . . 4-44

4-14 Master Plan Development . . . . . . . . . . . . 4-45

5-1 Land Use and Functional Location for Low-Case Scenario . . . . 5-2

5-2 Land Use and Functional Location for Medium-Case Scenario ... 5-3

5-3 Land Use and Functional Lccation for High-Case Scenario ... 5-4 
DOE/RL-89-15

\section{LIST OF FIGURES (cont.)}

5-4 Ideal Site Plan ................... . . 5-5

5-5 Locations of New Facilities ............... . 5-11 


\section{LIST OF TABLES}

2-1 1965 to 1988 Population of Benton and Frankl in Counties . . . 2-11

2-2 1980 to 1988 Population, Tri-Cities Metropolitan Statistical

Area .................. . 2-12

2-3 Professional and Technical Workers of the Tri-Cities

Metropolitan Statistical Area, 1988............ 2-16

2-4 1988 Area Wage Survey, Tri-Cities Metropolitan Statistical

Area .................... 2-17

2-5 Energy Consumption and Costs for Buildings and Facilities on the Hanford Site from 1985 to 1988 ........... 2-38

3-1 Commercial Buildings Leased by the U.S. Department of Energy Contractors ..................... 3-5

3-2 Hanford Site Population Distribution by Area . ........ 3-14

3-3 Peak Power Demands at the Hanford Site for Fiscal Yezir 1988 . 3-17

3-4 Existing Facility Baseline Description for Hanford Facilities With Greater than 10,000 Gross Square Feet......... 3-23

3-5 Building Use Code Key .................. . 3-29

3-6 Conditions/Adequacy Table for Buildings and Structures . . . . 3-30

3-7 Estimated Peak Discharge Rates for Floods on the Columbia River Below Priest Rapids Dam ............ 3-50

3-8 Annual High/Low/Average Temperature . . . . . . . . . 3-64

3-9 Severe Thunderstorm Occurrences at the Hanford Site . . . . 3-68

3-10 Tornado Occurrences Within 100-Mile Radius of the Hanford Meteorology Station ................ 3-69

3-11 Notable Wet Periods . . . . . . . . . . . . 3-70

3-12 Notable Dry Periods .................. 3-70

3-13 Monthly and Annual Averages and Extremes of Hirecipitation for Hanford Meteorology Station Yersus Richland, July 1946 Through December 1980 ................... 3-71

3-14 Hanford Site Characteristics................ 3-111

5-1 Locations of New Facilities/Missions . . . . . . . . . 5-10

5-2 Expected Electrical Requirements for New Facilities Under the Medium-Case Scenario............... 5-12 


\section{LIST OF TABLES (cont.)}

6-1 Goal Number 1--Low-Case Projects . . . . . . . . . . . . 6-2

6-2 Goal Number 1--Medium-Case Projects . . . . . . . . . . . 6-5

6-3 Goal Number 1--High-Case Pirojects . . . . . . . . . . . . 6-5

6-4 Goal Number 2--Low-Case Projects . . . . . . . . . . . . . . 6-7

6-5 Goal Nuniber 2--Medium-Case Projects . . . . . . . . . . . 6-9

6-6 Goal Number 3--Low-jase Projects . . . . . . . . . . . . . . 6-10

6-7 Goal Number 3--Medium-Case Projects . . . . . . . . . . . 6-10

6-8 Goal Number 4--Hanford Surp] us Facilities Program Projects . . . 6-11

6-9 Goal Number 5--Low-Case Projects . . . . . . . . . . . . 6-12

6-10 Goal Number 5--Medium-Case Projects . . . . . . . . . . . . 6-13 


\section{LIST OF TERMS}

$A D P$

AEC

ALARA

ALE

ANSI

BCSR

BMI

BPA

BWIP

CAT

CBC

CCTV

CERCLA

CSMA/CD

D\&D

DBE

DECS

DOD

DOE

DOE-HQ

DOE-RL

DSHS

Ecology

EIS

EMSL

EOC

EPA

ERD

ERDA

ERDS

ESRC

FCP

FFTF

FMEF

FY

GAO

GE

GES

GPP

GSA

GTF

HAZWRAP

HEC

HEHF

HEMP

HEPA

HLW

HMS

HSFP automatic data processing

Acomic Energy Commission

as low as reasonably achievable

Arid Lands Ecology Reserve

American National Standards Institute

BCS Richland, Inc.

Battelle Memorial Institute

Bonneville Power Administration

Basalt Waste Isolation Project

Computerized axial tomography

Columbia Basin College

closed circuit television

Comprehensive Environmental Response, Compensation, and Liability Act

carrier sense multiple access with collision detection

decontamination and decommissioning

design basis earthquake

Distributed Electroric Control System

U.S. Department of Defense

U.S. Department of Energy

DOE-Headquarters

DOE-Richland Operations Office

Washington State Department of Social and Health

Services

Washington State Department of Ecology

environmental impact statement

Environmental and Molecular Sciences Laboratory

Emergency Operations Center

U.S. Erivironmental Protection Agency

Environmental Restoration Division

Energy Research and Development Administration

Emergency Radiological Detection System

Environmental Science Research Center

Fuel Cycle Plant

Fast Flux Test Facility

Fuels and Materials Examination Facility

fiscal year

Government Accounting Office

General Electric Company

Ground Engineering System

general piant project

General Services Administration

Grout Treatment Facility

Hazardous Waste Remedial Action Program

Hanford environmental compliance

Hanford Environmental Health Foundation

Hanford Environmental Management Program

high-efficiency particulate air (filter)

high-level waste

Hanford Meteorology Station

Hanford Surplus Facilities Program 


\section{LIST OF TERMS (cont.)}

HSSFP
HWVP
INEL
KEH
LAN
LI
LLW
LMR
MASF
MC\&A
MM
MSA
MSL
MSRC
NASA
NEPA
NERP
NPDES
NRC
O\&E
OFN
OPD
OSHA
PAX
PC
PFM
PFP
PMF
PNL
PNTC
PRF
PSD
PUREX
PWR
R\&D
RCRA
RCW
RMW
RPIS
RPSF
RTG
SCADA
SDC
SDI
SED
SFI
SFUP
SIS
Sit Development Plan
SMES/ETM

Hanford Site Strategic Facilities Plan

Hanford Waste Vitrification Plant

Idaho N'ational Engineering Laboratory

Kaiser Engineers Hanford

local area network

line itern

low-level waste

liquid metal reactor

Maintenance and Storage Facility

material control and accountability

modified mercalli

metropolitan statistical area

mean sea level

Molecular Science Research Center

National Aeronautics and Space Administration

National Environmental Policy Act

National Environmental Research Park

National Pollutant Elimination System

U.S. Nuclear Regulatory Commission

Operations and Engineering

Washington State Office of Financial Management

Operations Division

Occupational Safety and Health Administration

private automatic exchange

personal computer

Process Facility Modification

Plutonium Finishing Plant

probable maximum flood

Pacific Northwest Laboratory

Pacific Northwest Technology Complex

Plutonium Reclamation Facility

prevention of significant deterioration

Plutonium-Uranium Extraction

Pressurized Water Reactor

research and development

Resource Conservation and Recovery Act

Revised Code of Washington

radioactive mixed waste

real property inventory system

Radioisotope Power Systems Facility

radioactive thermoelectric generators

supervisory control and data acquisition

standard design criteria

Strategic Defense Initiative

Safety and Environment Division

Strategic Facility Initiative

Strategic Facilities Utilization Program

Special Isotope Separation

Hanford Site Development Plari

Superconducting Magnetic Energy Storage/Engineering

Test Mode 1 


\section{LIST OF TERMS (cont.)}

SNM

SSE

Supply System

Tri-Cities

Tri-Party Agreement

TRIDEC

TRT

TRU

TSD

UBC

$\mathrm{UO}_{3}$

UWGP

VISTA

WAC

WESF

WHC

WHETS

WISHA

WMD

WNP - 1

WNP-2

WNP-4

WRAP

WSU

WSU Tri-Cities

WTCIMC special nuclear material

safe shutdown eartr.quake

Washington Public Power Supply System

Richland, Kennewick, and Pasco, Washington

Hanford Federal Facility Agreement and Consent Order

Tri-City Industrial Development Council

Tactical Response Team

transuranic (waste)

treatment, storage, and disposal

Uniform Building Code

uranium oxide

University of Washington Geophysics Program

Vertical Integration of Science and Technology

Applications

Washington Administrative Code

Waste Encapsulation and Storage Facility

Westinghouse Hanford Company

Washington Higher Education Telecommunication Services

Washington Industrial Safety and Health Act

Waste Management Division

Washington Public Power Supply System Nuclear Power Plant No. 1

Washington Public Power Supply System Nuclear Power Plant No. 2

Washington Public Power Supply System Nuclear Power Plant No. 4

Waste Receiving and Processing Facility

Washington State University

Washington State University at Tri-Cities

Westinghouse Tri-Cities Investment Management Council 


\section{INTRODUCTION}

The Hanford Site, a United States government reservation in Washington state, employs a highiy specialized technical staff and an extensive and varied array of production research and technology development facilities. Several nationally important programs are conducted at the Hanford site for the U.S. Department of Energy (DOE), including defense programs, nuclear energy development, environmental and waste management, and research and development.

The Hanford Site Development Plan is a short- and long-term planning guide that (1) examines the Site operations, (2) describes and analyzes existing conditions and capabilities, (3) defines the long-range scope and objectives of Hanford Site missions and programs, and (4) presents the long- and short-range plans for land use, development, and facilities use at the Hanford Site.

The Hanford Site Development Plan is divided into six major sections and three appendices.

- 1.0 Executive Summary--Presents a brief overview of the essential information and conclusions contained in the remaining sections of the plan.

- 2.0 General Site Information--Describes regional influences on the Hariford Site including past history, demographics, community attitudes, laws and regulations, transportation, and utility services.

- 3.0 Existing Conditions--Identifies Hanford Site-specific characteristics including current Site missions, programs, and employment, as well as the present conditions and capabilities of the Site and its facilities.

- 4.0 Planning Analysis--Presents the basis for which the long-range Master Plan (Section 5.0) for the Hanford Site was developed. Identifies alternatives to forecasted missions if certain contingencies were to develop.

- 5.0 Master Plan--Presents the long-range (20-yr), comprehensive $\mathrm{plan}$ for the development and use of the Hanford Site and its facilities.

- 6.0 Five-Year Plan--Presents a short-range implementation plan for the long-term strategies and objectives that were identified in the Master Plan (Section 5.0).

- Appendix A--A bibliography that lists other sources for data or information on topics found in Sections 1.0 through 6.0. A reader who wants more details on a specific topic of interest can identify the appropriate documents in the bibliography by finding that topic addr sssed in the titles. 
- Appendix 8--Contains the Hanford Site development maps, showing the constraints and improvements at the Hanford Site. Site features shown on the maps include Site boundaries, all existing facilities (buildings, roads, structures, and fences), and terrain features that present significant constraint to development, such as landfills, rivers, or ridges. All permanent buildings are labeled with the building number used in the DOE's Real Property Inventory System. Proposed new facilities and marginal facilities associated with the Strategic Facilities Initiative or Surplus Facilities Management Program, which are recommended for removal, have also been identified.

- Appendix C--Contains detailed information about line item and general plant projects proposed for funding in fiscal years 1990 through 1994 along with some proposed for fiscal year 1995. These projects are divided into eight categories [Chemical Processing, Waste Management, Advanced Reactor, Landiord Program, Research and Development (R\&D) Contractor General Purpose Facilities, R\&D Contractor Programmatic Facilities, Hanford Strategic Facilities Utilization Program, and the Hanford Surplus Facilities Program]. 


\section{HANFORD SITE DEVELOPMENT PLAN}

\subsection{EXECUTIVE SUMMARY}

The Hanford Site Development Plan (Site Development Plan) is intended to guide the short- and long-range development and use of the Hanford Site. A 11 acquisition, development, and permanent facility use at the Hanford Site will conform to the approved plan. The Site Development Plan also serves as the base document for all subsequent studies that involve use of facilities at the Site. This revision is an update of a previous plan.

The executive summary presents the highlights of the five major topics covered in the Site Development Plan: general site information, existing conditions, planning analysis, Master Plan, and Five-Year Plan.

\subsection{GENERAL SITE INFORMATION}

This section presents background information on local and regional factors that affect the way the Hanford Site is planned.

\subsubsection{History}

The Hanford Site is owned by the United States and administered by the U.S. Department of Energy (DOE). It occupies a mostly flat, semiarid site of $560 \mathrm{mi}^{2}$ in southeastern Washington State's Pasco Basin (Figure 1-1). In 1943 it was chosen as the location to produce plutonium for the world's first nuclear weapons. Operations began in 1944.

Since 1944, the Hanford Site has experienced many changes. It changed from a small rural area to a large technological center. The emphasis changed from one of defense production programs to energy research, then changed back to defense production programs. The emphasis is now on energy research, environmental management and technology, and Hanford Site cleanup. The site management changed from the U.S. Army Corps of Engineers to the Atomic Energy Commission (AEC) to the Energy Research and Development Administration (ERDA) to the DOE. The number of operating contractors changed from one contractor to a high of eight contractors, which has now been consolidated to four contractors.

\subsubsection{Regional Overview}

Population in the area surrounding the Hanford Site is sparse, consisting primarily of farms and farming communities to the north, east, and west of the Hanford Site. In 1980, an estimated 341,000 people were living within a 50-mi radius of the center of the Hanford Site. The Hanford Site draws most of its professional and technical service employees from the Richland, 
Figure 1-1. Location and Regionai Map of the Hanford Site.

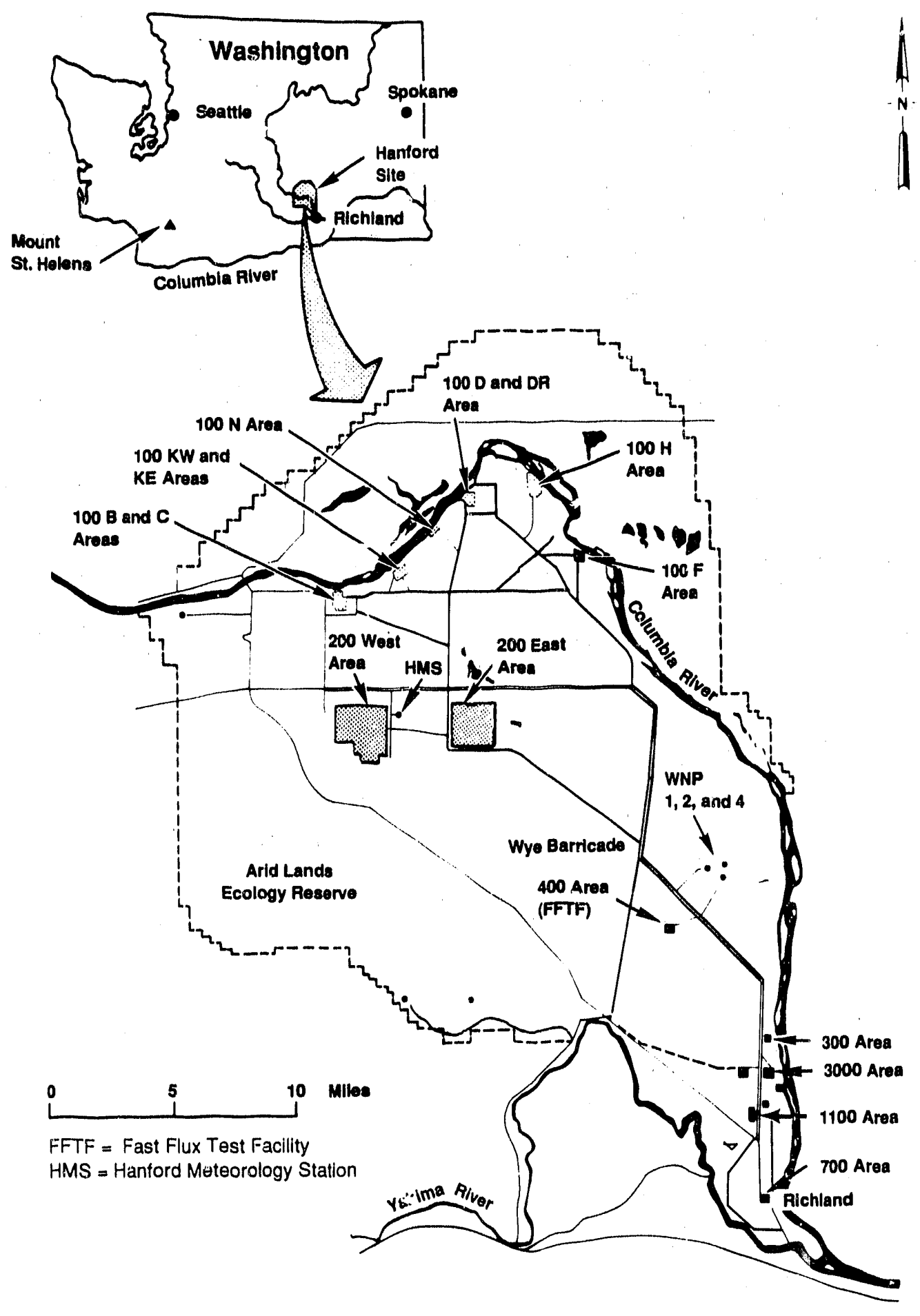

39001069.1 
Kennewick, and Pasco (Tri-Cities) metropolitan statistical area (MSA) population, which is south of the Hanford Site. The MSA labor force in 1988 was 68,000 , which was approximately $50 \%$ of the total MSA population. The Hanford Site is located near several population centers. Because if its location near major transportation networks, these centers become important sources for raw materials and technical services.

\subsubsection{Local and Regional Attitudes}

Members of communities surrounding the Hanford Site have, in general, successfully co-existed with the Hanford Site for more than $45 \mathrm{yr}$. Thus, many community members have an understanding of, and a familiarity with, nuclear energy that is well beyond that of the average public. The communities are generally very supportive of Hanford Sice activities.

On a regional level, general knowledge of nuclear energy and activities at the Hanford Site is limited. In jeneral, regional support is low for defense production and disposal of offsite wastes. At the same time, regional support for environmental cleanup, research, and compliance is very high.

\subsubsection{Land Use}

Lano use in the area surrounding the Hanfors Site includes urban and industrial development, irrigated and dryland farming, and livestock grazing.

Land adjacent to the Hanford Site is privately owned except for those areas controlled by Washington State and county and city governments. The state exercises control over state and federal highways and special-use areas (e.g., parks and wildlife reserves). The Hanford Site, however, tialls under the federal regulatory authority of the DOE. All Site activities require compliance with applicable federal, state, and local regulations and under the applicable DOE orders.

\subsubsection{Transportation}

An excellent public transportation network within and surrounding the Tri-cities area facilitates travel and the marketing of goods and commodities. Commercial air transportation is available at the Tri-Cities Airport, which offers direct service to major regional cities with connections to cities nationwide via several airlines. Transportation of bulk commodities along the Columbia and Snake Rivers is available via barge lines. A freight rail transportation network is provided by the Burlington Northern, Washington Central, and Union Pacific railroads. Interstate highways and state routes connect the region to major metropolitan areas throughout the Pacific Northwest. 


\subsubsection{Utilities}

Electricity is the only regional utility service supplied to the Hanford Site. Electricity is supplied by the Bonneville Power Administration (BPA). The DOE has a contract with the BPA that gives the Hanford Site priority in electricity supply over other users. With planned upgrades, capacity of the existing system is adequate to meet forecasted needs. Electrical power to facilities at the top of Rattlesnake Mountain is provided by the Benton County Public Utility District. All utilities for the 700,1100 , and 3000 Areas are provided by the city of Richland. All other utility services are generated on the Hanford Site.

\subsection{EXISTING CONDITIONS}

This section identifies and describes current Hanford Site missions, programs, and employment characteristics, as well as the present conditions and capabilities of the site and its facilities. Areas where improvements are needed are identified.

\subsubsection{Land Use and Leased Facilities}

The DOE controls the 560-mi2 Hanford Site; it is anticipated that DOE will continue to maintain control of the Hanford Site until at least the decommissioning, decontamination, and cleanup activities are completed. There are several operating areas within the Hanford Site with specific access requirements (see Figure 1-1). The major activities carried out in each area are as follows:

- 100 Areas. The 100 Areas contain eight retired plutonium production reactors and the dual-purpose $N$ Reactor, which produced plutonium for weapons production and steam for electrical power generation. The $\mathrm{N}$ Reactor is currently in dry standby status as a contingency source for weapons grade plutonium or tritium.

- 200 East and 200 West Areas. The 200 East and 200 West Areas (200 Areas) are dedicated to nuclear materials processing and defense waste disposal activities and will be the centerpiece for Hanford Site environmental cleanup.

- 300 Area. The major activities in the 300 Area are nuclear research and development (R\&D). The fuel fabrication facility for $\mathrm{N}$ Reactor is in standby. The pressure tube fabrication facility ( $313 \mathrm{Bldg}$ ) is also in standby. The fuel fabrication facility for the Fast Flux Test Facility (FFTF) is being relocated to the 400 Area.

- 400 Area. The FFTF, the Fuels and Materials Examination Facility (FMEF), and related support facilities involved in the i iquid metal reactor program are located in the 400 Area. The Radioisotope Power Systems Facility (RPSF) is being established in the FMEF. 
- 600 Area. The 600 Area includes all of the Hanford Site not occupied by the 100, 200, 300, 400, 700, 1100, and 3000 Areas. Land uses include the Arid Lands Ecology Reserve (ALE), a 1,000-acre tract leased by Washington State (100 acres of which are privately subleased for the disposal of commercial low-level nuclear waste), the Washington Public Power Supply System land lease for the construction and operation of nuclear power plants, a section (1 $\mathrm{mi}^{2}$ ) that is owned by Washington State, a U.S. Fish and Wildlife refuge, and a recreational game site leased to the Washington State Department of Game. Also located in this area are an observatory and radio-telescope facilities atop Rattlesnake Mountain, and the Hanford Meteorology Station (HMS) near the center of the Hanford Site. Various Hanford Site utilities and services cross the 600 Area. The BPA has three substations and several major transmission lines located in/across this area.

- 700 Area. Two major functions are located in the 700 Area: (1) goiernment employees involved in overseeing contractor-operated facilities and programs at the Hanford Site, and (2) contractor employees involved in automatic data processing (ADP) activities for the Hanford Site. In addition, the Hanford Environmental Health Foundation's (HEHF) environmental health sciences function is located there.

- 1100 Area. The DOE-owned portion of the 1100 Area serves as a center for central warehousing, vehicle maintenance, and transportation/distribution. This area also includes part of the city of Richland where privately owned facilities are leased for administrative and support functions.

- 3000 Area. The engineer/constructor contractor uses the DOE-Owned portion of this area for general office space, warehousing, and shops. This area also includes part of the city of Richland. The R\&D contractor has several privately owned laboratory facilities here. The HEHF occupational medicine services are also located in this area.

\subsubsection{Missions and Programs}

The present mission of the DOE-Richland Operations Office (DOE-RL) contains a long-term goal "to successfully conduct the environmental, energy, and research and development programs of the DOE in the most cost-effective, safe, secure and environmentally acceptable means possible."

There are four major operating programs presently conducted at the Hanford Site: Environmental Restoration and Waste Management, R\&D, Advanced Reactors, and Defense Production.

Four contractors perform operating and services functions at the Hanford Site: (1) Kaiser Engineers Hanford (KEH) as the engineer/constructor contractor; (2) Westinghouse Hanford Company (WHC) as the operations and engineering contractor; (3) Battelle Memorial Institute (BMI) as the R\&D contractor; and (4) HEHF as the medical and health services contractor. 


\subsubsection{Hanford Site Employment}

In May 1989, approximately 12,200 people held jobs associated with the DOE activities on the Hanford Site. The greatest percentage of these people $(5,218$ people, or $43 \%)$ worked within or immediately adjacent to the Richland city limits in the 700,1100 , and 3000 Areas. The 200 and 300 Areas were the next most populated areas (3,557 pecple, or 29\%, and 1,864 people, or $15 \%$, respectively). Another $6 \%$ (about 756) were 1ocated in the 100 Area. Another onsite population included 1,400 people employed by the Washington Public Power Supply System.

\subsubsection{Site Improvements}

Improvements to the Hanford Site over the years have included utility systems, buildings, structures, and transportation systems.

1.2.4.1 Utility Systems. Electricity, water, and telecommunications are the only utilities distributed on a site-wide basis. Other utilities, such as steam and sewage, are confined to specific operating areas.

The BPA is contractually obligated to meet all Hanford Site electrical power requirements before other custoner requirements. Line iteili (LI) upgrades in 1979 and 1981 rebuilt the transmission and distribution systems in the 100 and 200 Areas and provided a system for remote control and monitoring of major substations. Line item upgrades in 1978 and 1983 improved reliability of the primary substation and allowed access for future loads in the 300 Area. The electrical utility system would probably survive an earthquake of less than 5.0 on the Richter scale, but would be vulnerable to a tornado. For instance, if the transformers at the 251-West substation were damaged, service through that substation could take up to 2 wk to restore. The 100,200, and 300 Areas backup power source is a combination of steam and steam-generated electricity from the centrally located power houses and stationary diesel-electric generation. The electrical systems in the specific areas are in need of upgrades which will be considered in Local Area Planning Analyses.

Export water system maintenance was performed to comply with reactor standards until 1967 when reactor operations were curtailed. From 1970 to 1977, the system was maintained on a breakdown and repair basis. Since 1978, equipment has been maintained on a rehabilitation basis, and approximately $\$ 3.9$ million has been spent on pumps, valves, screens, and buildings. The system is now in a highly reliable and very good condition with life expectancy in excess of $40 \mathrm{yr}$. As with electrical systems, the water systems in the specific areas need upgrades which will be considered in Local Area Planning Analyses.

The telecommunications systems comprise three main categories: voice, data, and radio. The existing modernization program for the telecommunications system will be initiated in fiscal year (FY) 1991. Most notable is the replacement of the entire Hanford Site Telephone System with an Integrated Voice/Data Telecommunications System, which will broaden the voice and data capabilities at the Hanford Site. 
1.2.4.2 Buildings and Structures. Hanford Site facilities, as documented in the DOE real property inventory system (RPIS), consist of over

1,100 buildings. Of these, 149 have a gross floor area of over $10,000 \mathrm{ft}^{2}$. Most of these larger facilities are 30 to 40 yr old. Approximately $30 \%$ of the space in these facilities is now being used differently from its designed use. Seventy percent of the facilities are reported to be in adequate condition.

Recently, all of the Hanford Site facilities were evaluated to determine which ones were considered to be strategically required or mission essential. Strategically required or mission essential refers to facilities required to accomplish program missions and facilities necessary to support Hanford Site functions, based on 5-yr projections. The results of this evaluation are described in the Hanford Site Strategic Facilities Plan (WHC 1989), a document required by the Strategic Facilities Utilization Program (SFUP). A brief summary of this report can be found in Section 1.5 .2 of this plan.

In January 1989, general-purpose facilities comprised nearly $7.4 \mathrm{milli}$ ion $\mathrm{ft}^{2}$ of owned space. The construction costs, which have not been escalated to present value, for these facilities was $\$ 726$ million. In addition to these DOE-owned facilities, Hanford Site contractors leased 22 facilities (totaling approximately $511,000 \mathrm{ft}^{2}$ ) and 8 trailers. Eighteen of the leased facilities were larger than 10,000 $\mathrm{ft}^{2}$.

The R\&D contractor (BMI) has also invested about $\$ 47$ million in private facilities and equipment at sites in Richland, Seattle, and Sequim, Washington. Through a unique contractual agreement with DOE, these facilities are consolidated with government-owned laboratory and office space. These facilities are used interchangeably in performing work for DOE, other federal agencies, and industry. At the Hanford Site, there are 24 BMI-owned facilities and 4 trailers, totaling nearly 475,000 $\mathrm{ft}^{2}$. The BMI al so has one commercially leased facility with $75,400 \mathrm{ft}^{2}$.

1.2.4.3 Railroad Transportation Systems. The Hanford Site rail system consists of approximately $127 \mathrm{mi}$ of track. The rail system currently handles approximately 4,000 commercial and 1,000 onsite shipments each year. It is a Class III Railroad System, as identified by the Federal Railroad Administration.

When the rail system was originally installed during World War II, it was built with rail acquired from various sources throughout the United States. Varying rail weights and configurations were used. Some rail was manufactured as early as 1896; most was manufactured before 1936 when controlled cooling became the standard of the rail manufacturers. None of the rail was new when installed. A 1979 Federal Railroad Administration inspection report recommended replacement of any rail manufactured prior to 1936 or lighter than $90 \mathrm{lb} / \mathrm{yd}$.

In 1981, a rail replacement project was started. The project upgraded approximately $27 \mathrm{mi}$ of the 600 Area rail system. An FY 1990 LI has been authorized to continue this upgrade. Under this LI the main line serving the 100 and 200 Areas will be brought up to Federal Railroad Administration standards. Additional upgrades to the main line of the Hanford Site rail 
system are planned for FY 1993. After these planned projects are completed, and with proper maintenance, the Hanford Site rail system should continue to meet all needs projected for the Hanford Site.

1.2.4.4 Road Transportation Systems. The Hanford Site road system consists of approximately $261 \mathrm{mi}$ of primary and secondary roads. Currently, Routes 45 and $4 N$ are the primary highways from the Tri-Cities to $t^{\text {t. }}$ outer areas (100 and 200) of the Hanford Site. As major routes, th, highways carry approximately $90 \%$ of the traffic from the Wye Barricade co the outer areas.

Most of the Hanford Site road system was built in the early 1940's. Since these highways were built, a number of maintenance and upgrading projects have been completed. These projects sealed the road surface, widened the pavement, reconstructed and added shoulders, and added extra lanes where either terrain or traffic movements dictated.

\subsubsection{Physical Characteristics}

The following natural factors will influence future development on the Hanford Site.

- The immediate Hanford Site (310 $\mathrm{mi}^{2}$ of DOE-owned 1 and bounded by State Highway 240, the Columbia River, city of Richland, and private property) has $130 \mathrm{mi}^{2}$ with slopes greater than $2 \%$.

- Fifteen different soil types have been identified, with loamy sand being predominant.

- Some geologic faults on the Hanford Site are thought or assumed to be seismically capable, others are assumed to be noncapable, and still others are indeterminant.

- A major flood of the Columbia River could significantly impact some Hanford Site facilities and operations, but the probability of this happening has been greatly lowered due to upstream regulation by dams.

- Confined and unconfined aquifers are present beneath the Hanford Site. The unconfined or water table aquifer has been affected more than the uppermost confined aquifer by waste water disposal at the Hanford Site. However, the unconfined aquifer has been extensively and thoroughly monitored.

- The major wetland ecological area on the Hanford Site is the Columbia River, which provides a natural spawning habitat for a large number of fish and provides islands for nesting of geese, gulls, and other water fowl.

- There are two general classifications of wildlife on the Site: game species (elk, deer, rabbit) and nongame species (coyote, bobcat, badger). 
- The natural vegetation of the Hanford Site is a mosaic of plant communities representative of semiarid, shrub-steppe regions.

- The Hanford Site was designated as a Natural Environmental Research Park (NERP) in 1977. Within the NERP is the ALE, a smaller area of $120 \mathrm{mi}^{2}$ dedicated to long-term praservation of pristine vegetational locations for ecological research.

- The site is known to be rich in cultural resources. It contains numerous, well-preserved sites representing the prehistoric and historic periods and is stiil thought of as the homeland of many Native American people. As of December 1989, there were nine properties listed on the National Register of Historic Places, and there are plans to nominate two more sites in 1990.

- There are six species of animals on the Hanford Site that are listed on the Washington State Department of Game classification register as endangered, threatened, or sensitive.

- Meteorological and climatological data are available from the HMS, which is located beiween the 200 East and 200 West Areas. Data for temperature, precipitation, and wind means and extremes have been collected at the HMS since 1945. Temperatures and precipitation data from nearby locations are available from 1912 through 1943.

\subsubsection{Security}

The Hanford Site Safeguards and Security Program has three main operating objectives: (1) to ensure the physical protection, control, and accountability of special nuclear materials (SNM); (2) to provide physical protection for operating facilities, sensitive property, and equipment; and (3) to protect against the release of classified information to unauthorized personnel. These program objectives are satisfied by the selective application of a variety of security measures, including the following:

- DOE site-wide protective force

- Personnel security screening and clearance procedures

- Human reliability programs

- Access control zones

- Automated and manual access control systems

- Computerized alarm systems to electronically detect intrusion

- Access denial and delay systems

- Security lighting, fencing, gates, and barriers. 
The DOE orders define the minimum security requirements for given types of security interests and specific types of operations. These requirements may increase or decrease depending on special site or $\mathrm{pl}$ int conditions, cost effectiveness, and the level of acceptable risk. Appropriate security measures for any given Hanford Site operating area are selected after the applicable risks or threat have been thoroughly evaluated. This approach has provided a coordinated Hanford Site security program tailored to meet the needs of individual operating locations within the Hanford Site.

\subsubsection{Safety}

The varied and complex activities conducted on the Hanford Site create the potential for exposure to a variety of nuclear, radiological, toxic, and industrial hazards. It is the policy of the DOE to do the following:

- Ensure protection of the environment, the safety and health of the public, and government property against accidental loss and damage

- Provide safe and healthful workplaces and conditions of employment for all employees of the DOE and DOE contractors

- Ensure compliance with applicable statutory requirements affecting federal facilities and operations

- Ensure that research, development, demonstration, and production activities are performed in accordance with approved procedures; that facilities, components, systems, and processes are designed, developed, constructed, tested, operated, and maintained according to sound engineering standards, quality practices, and technical specifications or operational safety requirements; and that resulting technology data are valid and retrievable.

Each Hanford Site contractor has primary responsibility for ensuring that the hazards associated with their areas of responsibility have been identified and appropriate controls are in place to limit risks to acceptable levels. The health and safety requirements placed on Hanford Site operations originate from many sources: DOE orders, the Occupational Safety and Health Administration (OSHA), the Washington Industrial Safety and Heal th Act (WISHA), the Washington State Department of Social and Health Services (DSHS), and the Washington State Department of Ecology (Er,ology).

The activities of each contractor differ, and the nature and degree of hazards associated with those activities also differ. However, all contractors are committed to the operating philosophy of placing safety first with various forms of independent oversight, i.e., from within the contractor's organization; from other DOE contractors' assigned responsibilities for Site surveillance and monitoring; and from DOE reviews, appraisals, and use of outside evaluators. 
Some health and safety support services have been consolidated to serve the whole Hanford Site: fire protection, ambulance, and patrol services; radiation dosimetry evaluation and maintenance of associated records, and radiation instrumentation calibration; and employee medical services. Principal contractors are responsible for the emergency control centers for assigned work areas.

\subsubsection{Safety Considerations for Principal Facilities}

Safety considerations for principal DOE facilities at the Hanford Site were analyzed in this Site Development Plan. The safety discussion is categorized in terms of the four operating areas where these facilities are located $(100,200,300$, and 400 Areas). It includes a detailed analysis of each principal facility in regard to potential safety impacts to either the environment or the public.

\section{1.i.9 Environmental Issues}

The DOE-RL has the overall responsibility for the saie and environmentally sound operation of specific facilities, for facility upgrades, and for environmental monitoring of operations. Each Hanford Site contractor is responsible for the safe, environmentally sound maintenance and operation of its designated facilities, specific facility upgrades, operational support, waste management, and monitoring of operations and effluents. This is to ensure compliance with environmental protection criteria designated by $\mathrm{DOE}-\mathrm{RL}$ and requirements of all applicable laws and regulations.

The Hanford Environmentol Management Program (HEMP) was established in November 1986 to incorporate a structured program/project management approach for achievement of Hanford Site environmental objectives. At that time, the following four basic objectives were established:

1. Monitor to ensure compliance

2. Modify activities to attain compliance

3. Mitigate environmental consequences

4. Minimize future environmental impacts.

Specific tasks were assigned within DOE-RL and to its contractors. Since its initial inception, several key organizational changes have occurred. The DOE-RL contractors were consolidated from eight to four. Environmental compliance has become a more significant driving force and is now receiving significant attention in all facilities. In addition, state and federal oversight and involvement [e.g., in the Tri-Party Agreement (Ecology et al. 1989)] has increased significantly in the last $3 \mathrm{yr}$. 


\subsubsection{Opportunities and Constraints for the Hanford Site}

In summarizing existing conditions on the Hanford Site and the surrounding regions, a variety of assets, liabilities, and needs become apparent. The regional assets range from the large pool of technical expertise to good transportation systems. Regional 1iabilities include geographic isolation from major markets and suppliers. Various promotional activities have been and continue to be proposed by non-DOE parties to overcome regional liabilities. The operations and engineering contractor has pledged to invest between $\$ 10$ and $\$ 12$ million in the economy of the Tri-Cities over a 5-yr period. The engineer/constructor contractor has pledged to expand the opportunities for higher education in the Tri-Cities.

The Hanford Site's assets include an abundant water supply and an inexpensive electrical power supply, as well as over 40 yr of technical experience in a broad range of technical activities. Public perception of the Hanford Site as unsafe and a source of health problems are among the liabilities. Recommended activities to address the Hanford Site liabilities include increased efforts to make the public aware of the Hanford Site's outstanding safety and operations record, and to accomplish environmental restoration through approved programs.

The map in Figure 1-2 illustrates the ability of the Hanford Site to accommodate development. This map was created by overlaying individual factors, (i.e., physical features of the Hanford Site, Hanford Site activities, and regional impacts) to analyze their planning implications. "Developable" areas are those areas that would be considered first in an expansion program. "Developable ireas with constraints" designates areas that would require considerable effort to develop (too costly, or detrimental to existing resources).

\subsection{PLANNING ANALYSIS}

The primary purpose of this section is to provide the rationale for the Master Plan (Section 1.4). As part of that effort, specific goals and associated assumptions about the future of the Hanford Site are presented. A secondary purpose of the planning analysis is to show alternatives that can be implemented if forecasted missions take a significantly different direction than planned, or if certain contingencies develop. These alternatives were grouped into three possible scenarios of future activities at the Hanford Site.

This Site Development Plan, which assumes production of $238 \mathrm{Pu}$ at FFTF, was written before President Bush's budget proposal was issued on January 26 , 1990. The President's proposal did not support production of $238 \mathrm{pu}$ at the FFTF. Other potential missions or funding sources for the FFTF were in the development stages at the time of issuance of this document, and continue to be pursued. Therefore, the mission and other support possibilities for FFTF are not definitive. Thus, it was decided to issue this site Development Plan without changing the FFTF assumption. Impacts from deletion of the 238 Pu mission or other possible FFTF mission changes would be assessed in the next update of this plan. 
Figure 1-2. Opportunities and Constraints on the Hanford Site.

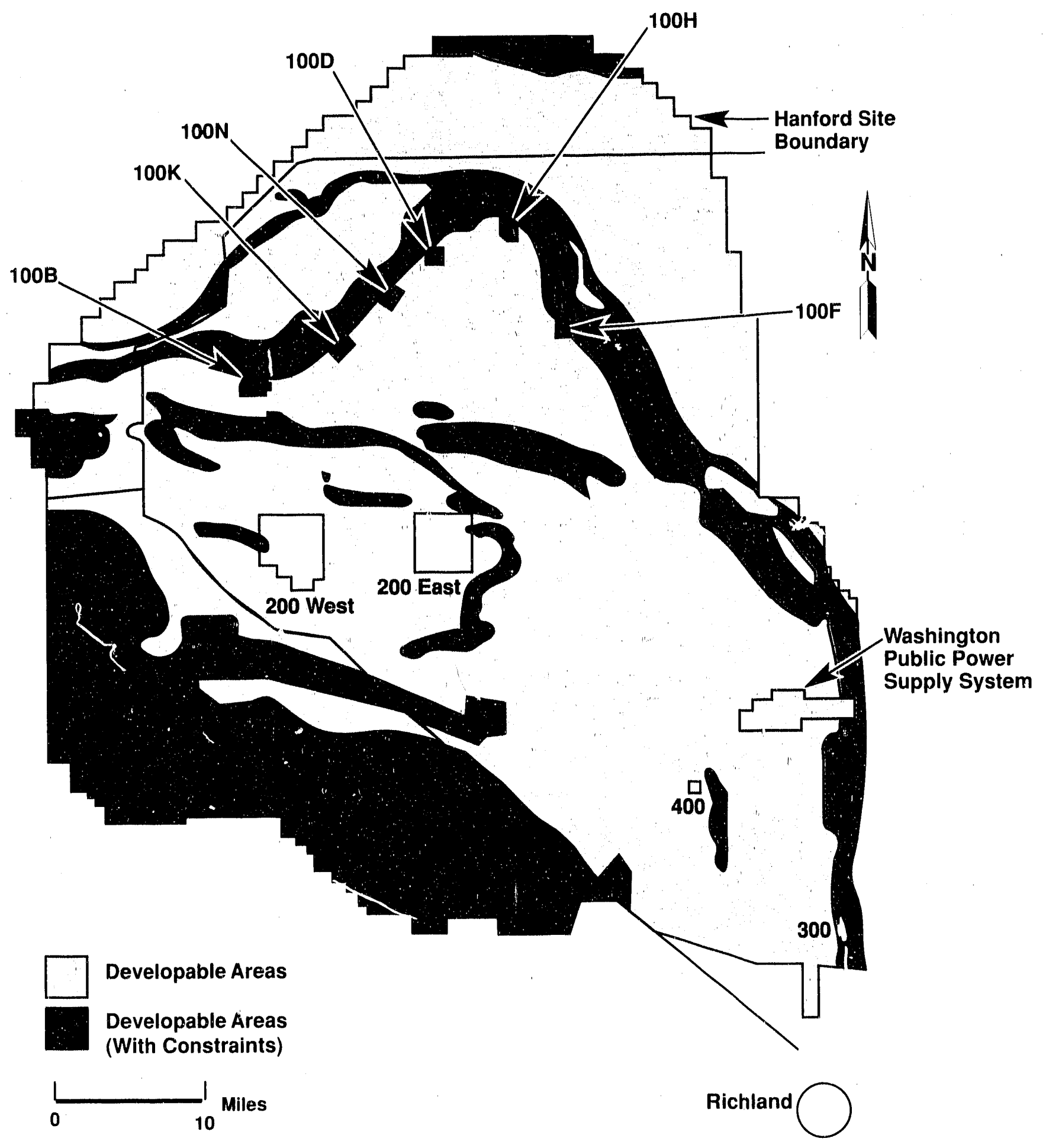




\subsubsection{Goals}

As set forth in the Hanford Strategic Plan, the overall goal of the DOE-RL is for the Hanford Site to become ar acclaimed national asset recognized for scientific and engineering excellence, environmental responsibility, and reliable and safe products and services. A vital part of this goal is to successfully conduct the environmental, energy, and R\&D programs of the DOE in the most safe, secure, environmentally acceptable, and cost-effective means possible.

The Hanford Site's future evolves out of three major business areas:

- Energy. The conceptualization, design, construction, and operation of major energy-related test and evaluation facilities.

- Science. The performance of a broad spectrum of R\&D/engineering development activities.

- Environment. The activities necessary to meet requirements for environmental restoration and waste management.

These goals are further described below.

1.3.1.1 Energy Development. Business in major test and evaluation facilities (Energy Development) involves projects from $\$ 10$ to $\$ 100$ million that demonstrate new technology and processes developed at the Hanford Site, at other sites, or in industry.

At present, this business is focused on the arlergy-related market. Major segments of this market are space, advanced power concepts, isotopes, and civilian nuclear waste.

The market for energy-related technology and projects is dynamic and will require that global and national trends be followed closely to ensure that the United States energy position is secure. A growing fraction of this business will be funded by sources other than DOE.

1.3.1.2 Science. R\&D/engineering development (Science) are other critical businesses at the Hanford Site and provide key sources of new mission opportunities. The scope extends from basic sciences to technology demonstration and development and applications to technology transfer. A strong emphasis on basic science will feed the technology evolution cycle.

Establishing "centers of excellence" with linkages to universities and industry will ensure both scientific credibility and relevance to regional economic development. The market will be as broad as the federal missions of the DDE, U.S. Department of Defense (DOD), National Aeronautics and Space Administration (NASA), and U.S. Environmental Protection Agency (EPA).

1.3.1.3 Environment. The Hanford Site business in environment will focus on the cleanup and management of hazardous wastes at the Hanford Site and at ther DOE and federal sites. This Site intends to become acclaimed as the DOE "Flagship" for environmental restoration and waste management through cleanup and technology development at the Hanford Site and other sites. Key object les include lower cost, timely implementation, and responsible compliance with regulations. The Site's workscope will include planning and 
strategy formulation, National Environmental Policy Act (NEPA 1970) and regulatory compliance, site characterization, innovative technology and processes, and cost-effective remediation.

1.3.1.4 Land Use and Facilities/Infrastructure Systems. In support of the above business goals, the following land use goals were established.

Effective use of Hanford Site land is centered on the following:

- Continuing to plan and allocate suitable areas of 1 and for future program and facility needs

- Cleaning up land areas and stabilizing or restoring land for which no further use is foreseen

- Restricting new processing and storage of radioactive and mixed waste to the 200 Areas and 400 Area

- Maintaining the ALE, existing archaeological sites, and existing leased and permitted land (i.e., Washington Public Power Supply System, U.S. Ecology, U.S. Fish and Wildlife Service, and Washington State Department of Wildlife)

- Establishing the 300 Area as the primary site of the multiprogram R\&D laboratory at the Hanford Site.

The planning and utilization of facilities/infrastructure systems are based on the following seven goals:

1. Renovating existing facilities or constructing new facilities based on the life cycle plan, cost effectiveness, and functional requirements

2. Siting new facilities based on functional requirements, type of occupancy, utility availability, safety and environmental requirements, and relationship to existing facilities

3. Minimizing the use of trailers, temporary, substandard, and leased facilities

4. Continuing to implement the Hanford Surplus Facilities Program's (HSFP) long-term deactivation and decommissioning program

5. Meeting General Services Administration (GSA) space use standard for office space

6. Consolidating, converting, mothballing, or disposing of marginal, deteriorated, and underutilized facilities

7. Develop a viable and attractive plan for private enterprise to finance, design, construct, operate, and decommission 1arge and complex facilities. 


\subsubsection{Assumptions}

Numerous assumptions were used to develop long-range (20-yr) mission projections and to assess future needs for the Hanford Site. The foilowing assumptions are of particular importance.

- To support DOE programs, the Hanford Site shall build on existing base strengths. This includes advanced reactor development, isotope production, energy technologies, SNM production, basic science, environmental research, space technologies, and nuclear and hazardous waste management.

- To ensure efficient utilization of this national resource, the Hanford Site shall pursue programmatic diversification, which is compatible with existing missions.

- The Hanford Site will be the major DOE site for the development and demonstration of technologies for environmental restoration and disposing of nuclear and other wastes.

- The science and technology capabilities of Pacific Northwest Laboratory (PNL) will be made available to foster cooperative laboratory R\&D efforts with industrial and educational institutions. Appropriate technologies will be transferred to United States industrial firms to enhance their economic competitiveness in global markets.

- Management of risks associated with civilian power production and defense nuclear materials production will continue as a major public issue. Public concern will continue to focus on environmental, health, and safety impacts of potentially hazardous pollutants and wastes from civilian energy production, general industry, and defense nuclear materials production.

- Inactive Hanford Site lands wili not normally be open for use by other non-DOE public or private business until decommissioning, decontamination, and Site cleanup are complete. This is also due to the desire to maintain ecologically undisturbed areas. Sufficient land reserves are available for anticipated future programmatic use and new missions. Non-DOE activities that are authorized shall be compatible with DOE-RL land use policy and DOE science, energy, environment, or defense-related missions.

\subsubsection{Activity Scenarios}

Three scenarios were identified that cover the range of activities believed possible at the Hanford Site during the next $20 \mathrm{yr}$ : low-case, medium-case, and high-case.

The low-case scenario encompasses termination of the plutonium production mission after the existing supply of $\mathrm{N}$ Reactor irradiated fuel is processed, little change to R\&D growth trends, completion of Hanford Environmental Compliance (HEC) projects and Tri-Party Agreement objectives, and continuation 
of existing engineering development activities in the areas of space isotope production and space power systems.

The medium-case scenario builds on the low-case and also includes the processing of offsite scrap at the Plutonium Finishing Plant (PFP) until a replacement facility is provided. The R\&D/engineering development programs expand in the areas of environment, science, energy (including conservation and renewable), national defense, and space fabrics, isotopes, and power systems. Environmental restoration cortinues at an accelerated rate.

The high-case scenario builds on the medium-case. It also includes establishment of the Hanford Site as a major site for production of SNM. The R\&D programs expand with establishment of a regional science and engineering park. Engineering development programs expand further with the implementation of systems testing and demonstration programs.

As funding and program emphases change with time, the actual development at the Hanford Site will probably not be strictly the low-, medium-, or highcase scenarios, but more likely some combination of the three. For current planning purposes, the medium-case scenario represents the most likely forecast of future activities at the Hanford Site.

The concept of three activity scenarios is carried through the last three chapters of the Site Development Plan: Chapter 4.0, Planning Analysis; Chapter 5.0, Master Plan; and Chapter 6.0, Five-Year Plan.

The three planning scenarios are all characterized by the reduction of existing marginal facilities, increased waste management and environmentai restoration activities, increased decontamination and decommissioning (D\&D), and the construction of new facilities with multiple capabilities. In all scenarios, activities will be initiated and implemented to ensure compliance with the terms and objectives of the Tri-Party Agreement (Ecology et al. 1989). The Hanford Site infrastructure, to support these scenarios, will be maintained consistent with Site missions. Key aspects of each scenario follow.

1.3.3.1 Low-Case Scenario. A major characteristic associated with the lowcase scenario is the termination of the Hanford Site's defense production mission after the existing supply of $N$ Reactor irradiated fuel is processed. The associated facilities that would be shut down include the $N$ Reactor, Plutonium-Uranium Extraction (PUREX) facility, Uranium Oxide $\left(\mathrm{UO}_{3}\right)$ Plant, the PFP, and, contingent on disposition of strontium and cesium capsules, the Waste Encapsulation and Storage Facility (WESF). Decontamination and decommissioning activities would increase.

Another major characteristic associated with this scenario is the control and disposal of radioactive, hazardous chemical, and mixed wastes at the Hanford Site. Two new facilities, the Waste Receiving and Processing Facility (WRAP) ar.d the Hanford Waste Vitrification Plant (HWVP), would be constructed and B Plant would be upgraded to support these activities. Also, the Northwest Hazardous Waste Research, Development, and Demonstration Center, receilitly established at PNL as part of the Superfund Reauthorization Act, would continue. 
Basic science and energy programs, along with space nuclear power technology development, would be maintained. The RPSF would be operated in the FMEF. Isotope targets and FFTF fuel would be fabricated in the FMEF. Operation of the FFTF/FMEF would continue at minimum funding levels on $238 \mathrm{Pu}$ and other isotope production. The Environmental and Molecular Sciences Laboratory (EMSL) would be constructed and operated.

1.3.3.2 Medium-Case Scenario. Site defense production facilities would be shut down as in the low-case, except that added missions for PFP would extend its operating life to later in the planning period. The $N$ Reactor would be placed in dry standby and Washington Public Power Suppiy System Nuclear Power Plant No. 1 (WNP-1) would continue as a contingency option for tritium production. New solid waste burial grounds and a Hazardous Waste Treatment Facility would be constructed. The expansion of environmental restoration and waste management tasks will maintain the overall level of activity at the Hanford Site.

In basic science and energy programs, FFTF would be producing $238 \mathrm{Pu}$ and other isotopes and performing irradiation testing. The SP-100 Ground Engineering System (GES) would be built and operating. The Superconducting Magnetic Energy Storage/Engineering Test Model (SMES/ETM) would be constructed and operated. A Special Analysis Facility would be constructed and operated.

1.3.3.3 High-Case Scenario. The major characteristic of the high-case scenario is the construction and operation of new production facilities. Two alternatives are being studied. One alternative would be the acquisition and conversion of an unfinished commercial ruclear power plant (WNP-1) at the Hanford Site. The plant is estimated to be $63 \%$ complete. Estimates indicate that conversion would halve both the construction cost and the completion schedule. The other alterriative would be the development and construction of a linear accelerator, along with support facilities, to meet the Nation's defense requirements. A third alternative (not studied) would be to start up the $N$ Reactor for tritium production.

Accelerated or enhanced environmental restoration and waste management tasks will require an increase in overall activity at the Hanford Site.

A major goal will be the development of a Northwest Space Technology and Energy Park with facility complexes in space power distribution, fabrics, and advanced space technology.

other major new facilities associated with this scenario include new analytical facilities to support expanded missions, facilities for weapons return, and an expansion of HWVP to do waste pretreatment.

In addition to the DOE mission facilities listed above, this scenario also includes a utility-owned power generation addition onto the FFTF; an expansion of FFTF capabilities into a multi-mission facility. 


\subsubsection{Ideal Plan}

After identifying thr range of possibilities and associated impacts to people and programs, an Iaeal Plan (Figure 1-3) was developed to describe the optimum relationships among these functions without regard for physical or environmental site constraints. The plan contains two general areas, as designated by the two bracketed areas in the figure: (1) the area farthest from populated areas is reserved for nuclear fuel cycle activities (the location of activities in the north area was derived from the sequential nature of the nuclear fuel cycle); and (2) the area closest to populated areas is reserved for common support activities (central services) such as engineering, maintenance, ccinputing, storage, administration, and centralized utilities. Also in this general area is R\&D consisting primarily of laboratories and related support facilities. The R\&D functions are consolidated to maximize operational efficiency and technical capabilities. In this location, the R\&D area can support the nuclear fuel cycle missions, including R\&D associated with SNM, or interact with industry and government to apply technology developed in the laboratories to commercial products and services.

Numerous alternatives were developed to evaluate how future activities could be "ideally" arranged on the Hanford Site, while also considering existing site constraints. The basic elements of the nuclear fuel cycle, fuel fabrication, reactors, R\&D, interim storage for spent fuel, processing, and long-term storage were used during the evaluation. Because environmental restoration is a reclamation issue rather than development, it is not considered as part of the "Ideal Plan."

\subsubsection{Master Plan Development}

The results of these analyses show that all three planning scenarios require at least three primary centers of work activity. The work activity centers will be located in the 200, 300, and 400 Areas (Figure 1-4).

Treatment, storage, and disposal of wastes will primarily be located in the 200 Areas. The 200 Areas will also have a primary focus on cleanup and environmental restoration activities.

Operations-related activities will concentrate in the 200 and 400 Areas. Research and development activities will locate primarily in the 300 and 400 Areas, with support services nearby. Advanced reactors will be located near the 400 Area. Plan.

These primary activity areas became the basic concept for the Master 
DOE/RL-89-15

Figure 1-3. Ideal Site Plan.
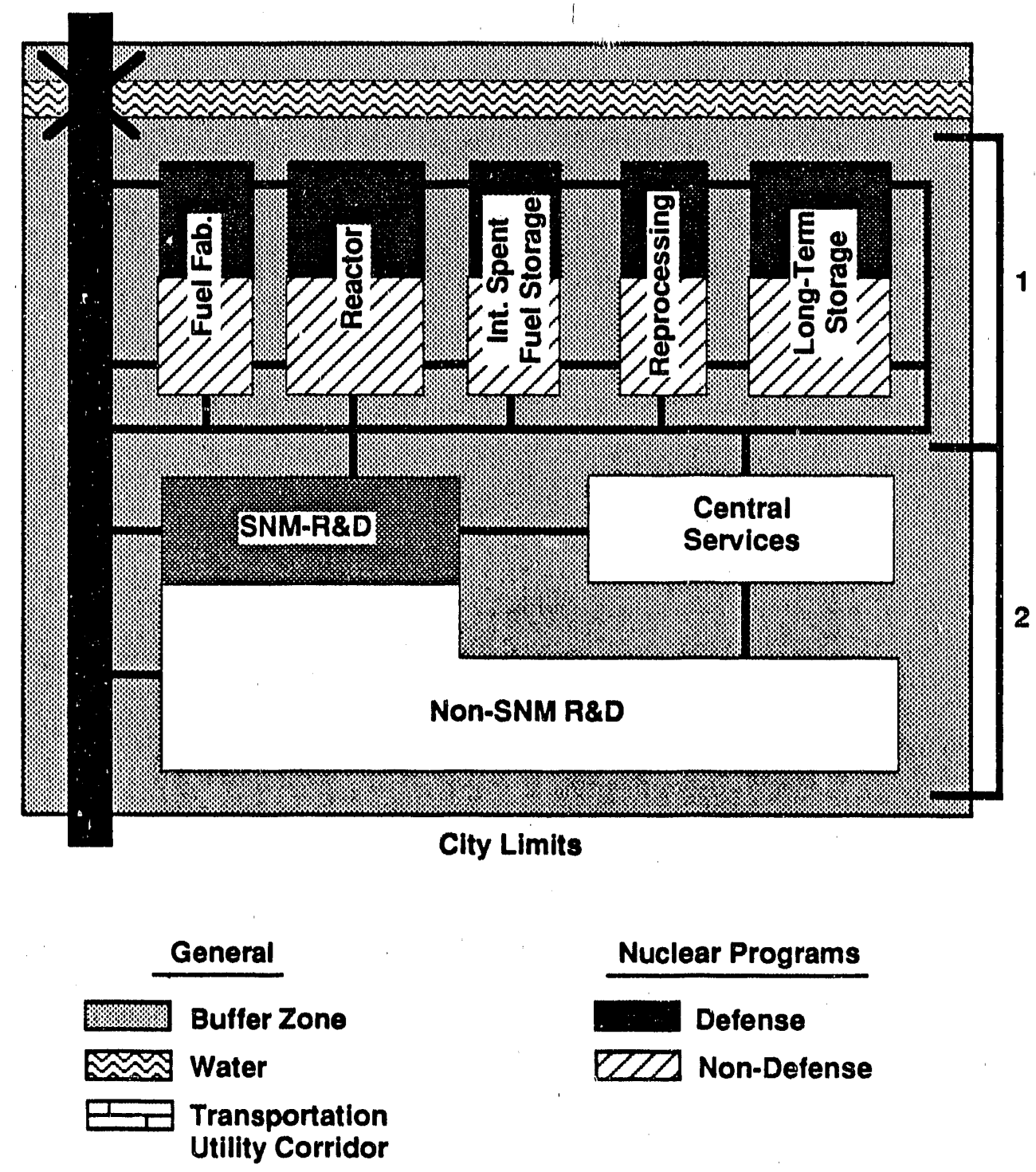

39001069.26 
Figure 1-4. Master Plan Development.

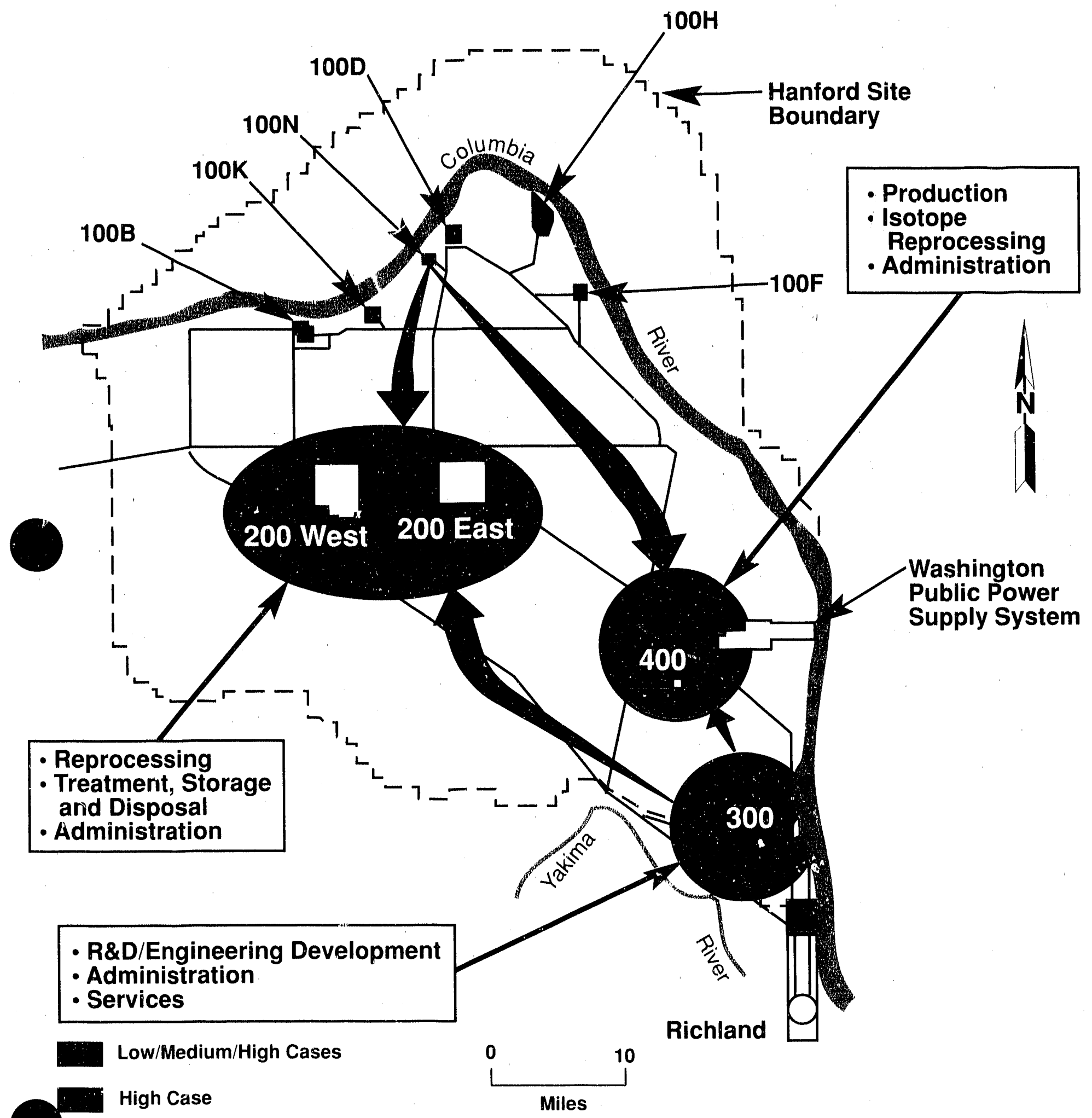




\subsection{MASTER PLAN}

The Master Plan for the Hanford Site is illustrated in Figure 1-5. It shows the major land use and functional locations associated with the three activity trends (scenarios) that could occur at the Hanford site during the next $20 \mathrm{yr}$. The low- and medium-case land use needs are actually subsets of the high-case scenario.

To a great extent, this configuration, in its arrangement of plant functions, approaches the Ideal Plan. Unlike the Ideal Plan, though, the Master Plan reflects Hanford Site constraints.

The R\&D activities and central services are located in the southernmost part of the Hanford Site. They provide a buffer zone between the population center of the Tri-Cities, to the south and east, and the nuclear fuel cycie activities to the north and west.

The area $r$ : rved for chemical processing and waste management is in and around the. A Areas, which are located in the center of the Hanford Site. Located liearby are the interim and long-term spent fuel storage areas, fuel fabrication area, and reactor sites. Fuel fabrication and interim spent fuel storage areas have benn optimally located next to their respective reactors.

Defense and nondefense activities are located close to each other to take advantage of similar functional requirements. The SNM and non-SNM R\&D areas are also located near each other. Environmentally sensitive activities, however, are relocated from the 300 Area to the central portion of the Hanford Site.

Consistent with the concept of the Ideal PIan, the non-SNM research and development area is located on the southern edge of the Site to serve as a buffer between two areas: (1) the Richland city limits and (2) the nuclear fuel cycle and SNM R\&D areas.

Ecologically important areas and/or buffer zones continue to be preserved around the periphery of the Hanford Sile, except at the 300 Area and Washington Public Power Supply System sites. No changes to the existing Site boundaries are identified.

Administrative and related support activities are located near the principal activity centers in the central and southern parts of the Hanford Site. Unused land areas will be held in reserve for future needs not presently identified.

The Hanford Site is one of DOE's larger sites in terms of geographical area. The Master $\mathrm{Plan}$ reflects functional relationships and siting in the broadest sense. Local Area Planning Analyses, which are detailed area plans, will be used to convey more specific information. 
Figure 1.5. Master Plan.

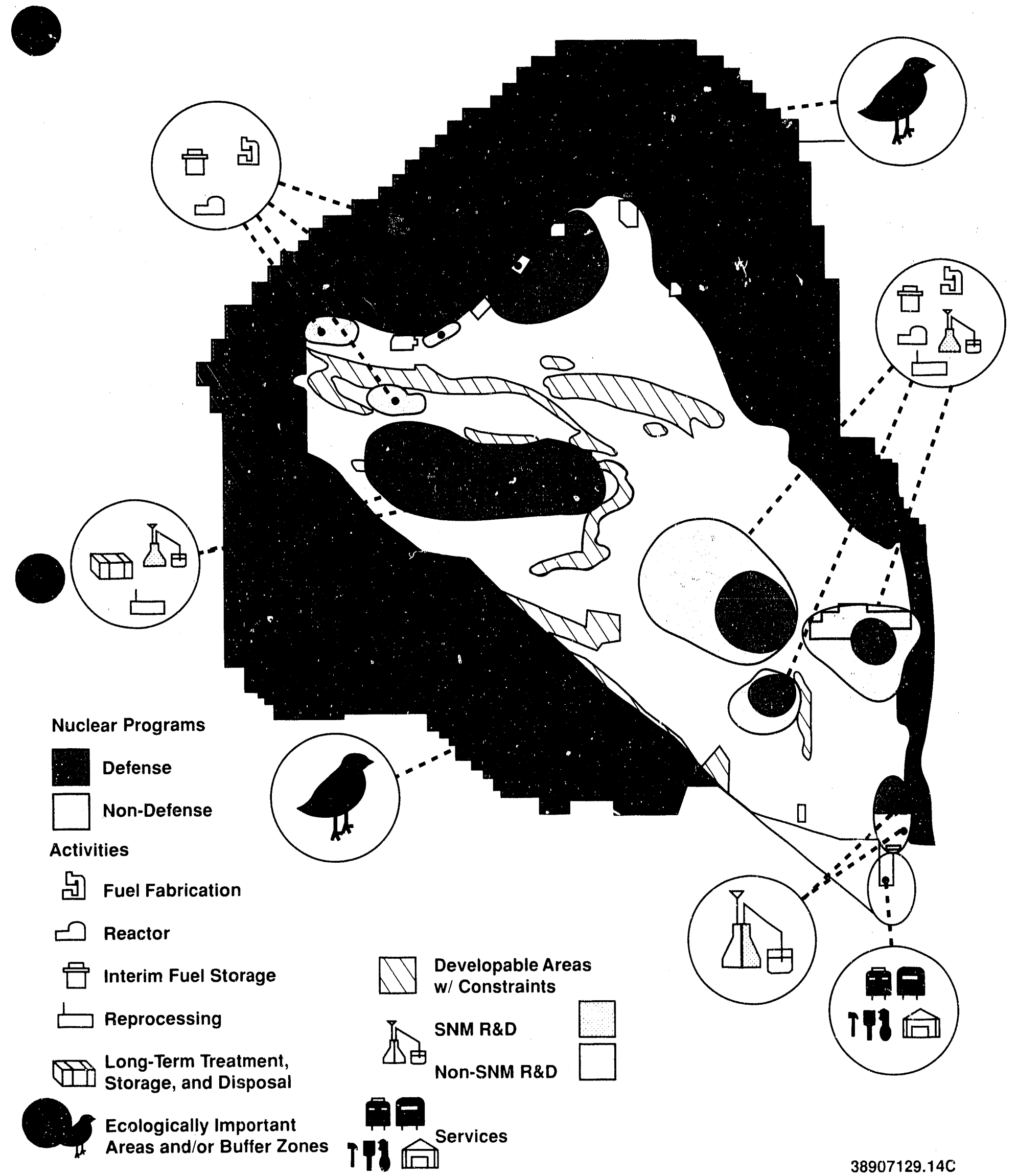




\subsection{FIVE-YEAR PLAN}

The Five-Year Plan is presented in seven sections that correspond to the seven facilities/infrastructure goals outlined at the end of Section 1.3.1. Each section is further subdivided to show what facilities actions are planned for each scenario described in the planning analysis. Except for the HSFP and the SFUP [formerly Strategic Facilities Initiative (SFI) (Davenport 1988)] projects, project information presented in the Five-Year Plan is iimited to projects proposed for LI or General Plant Projects (GPP) funding.

The projects currently identified in this plan are for FY 1990 to FY 1994 though some are listed before 1990 and some for 1995. Those listed that occur before 1990 are currently in capital design phases. Under normal circumstances, this iteration of the Site Development Plan would have covered FY 1991 through FY 1995. However, this year the project information was collected before much data for FY 1995 was available.

Costs associated with each scenario are additive, which means that, to determine the total cost for the high-case, the medium- and low-case project costs must be added to the high-case project costs. Likewise, to determine the total cost for the medium-case scenario, low-case scenario project costs must be added to medium-case project costs.

\subsubsection{Goal Number 1}

Goal No. 1 is to renovate existing facilities or construct new facilities based on the life cycle plan, cost effectiveness, and functional requirements. A11 LI and GPP capital projects meet this objective. New construction projects, however, are broken out and addressed separately under Section 1.5.2.

There are 82 renovation/upgrade-type projects in the low-case scenario. These 82 projects total approximately $\$ 527$ million.

There are 28 additional renovation/upgrade-type projects in the mediumcase scenario. These 28 additional projects total approximately $\$ 47$ million.

There are only 4 renovation/upgrade-type projects in the high-case sceriario in addition to the 110 projects of this type in the low- and mediumcase scenarios. These four projects total approximately \$145 milition.

\subsubsection{Goal Number 2}

Goal No. 2 is to site new facilities based on functional requirements, type of occupancy, utility availability, safety and environmental requirements, and relationship to existing facilities. Projects that construct new facilities are grouped under this goal, although they also are justified by Goal No. 1 . 
There are 46 new facility projects in the low-case scenario proposed for funding in between FY 1989 and FY 1995. These projects total approximately $\$ 1,702$ million. This includes an additional facility, which is yet to be constructed, that began design using capital funding in FY 1988. This facility is the HWVP which will total \$1,261 million.

There are 25 new facility projects in the medium-case scenario in addition to those in the low-case scenario. These additional projects total approximately $\$ 187$ million.

There are currently no new facility projects in the high-case scenario in addition to the 71 projects of this type in the low- and medium-case scenarios.

Included in the high-case scenario, but beyond the 5-yr planning time, is the conversion of WNP-1 or construction of a production accelerator and support facilities, analytical laboratory, power addition to FFTF, and weapons return facilities.

\subsubsection{Goal Number 3}

Goal No. 3 is to minimize the use of trailers, temporary, substandard, and leased facilities. In general, office projects relate to all aspects of this goal, while the other projects usually do not contribute to the elimination of trailers at the Site. It is hoped that programs or actions resulting from ongoing modernization studies will be a viable source of funding for some of these projects to replace old, substandard buildings with new facilities to meet long-term needs.

There are 10 projects in the low-case scenario that support this goal. These projects total approximately $\$ 51$ million.

Thirteen additional projects would contribute to attaining this goal in the medium-case scenario. The additional projects total approximately $\$ 13$ million.

There are no high-case projects in addition to the 23 included as part of the low- or medium-case scenarios that contribute to achieving Goal No. 3.

\subsubsection{Goal Number 4}

Goal No. 4 is to continue to implement the HSFP long-term D\&D program. The HSFP long-term D\&D program is a prioritized plan that will continue to proceed regardless of scenario. The rate of decommissioning activity will depend on the amount of funding allocated specifically for the HSFP. The HSFP has consolidated surveillance D\&D activilies for the facilities under their purview, into twelve logical multi-year projects. The HSFP is proposing a funding level of $\$ 172$ million spread over FY 1990 to FY 1995. 


\subsubsection{Goal Number 5}

Goal No. 5 is to meet GSA space use standards for office space. This goal is a primary consideration in the development and maintenance of office and light laboratory space. In the low- and medium-cases, temporary

facilities, additional leased space, and some new construction projects will be needed to accommodate the gradual increase in the workforce size. New construction will be the primary method used to meet this goal in the highcase scenario.

No capital projects for the acquisition of leased or temporary facilities are planned. In general, these standards are designed into new construction and upgrade projects whenever office or laboratory space is involved.

There are 20 new construction or upgrade projects (including HWVP) in the low-case scenario that involve office or laboratory space. These projects total approximately $\$ 1,466$ million.

There are an additional 24 projects in the medium-case scenario. These additional projects total approximately $\$ 195$ million.

There are no projects in the high-case scenario that are not part of the low- or medium-case scenario which involve office or laboratory space.

\subsubsection{Goal Number 6}

Goal No. 6 is to consolidate, convert, mothball, or dispose of marginal, deteriorated, and underutilized facilities. The Hanford Site Strategic Facilities Plan (WHC 1989), which is required by the SFI (Davenport 1988), was developed in parallel and in full coordination with the Site Development Plan. Approximately 1,355 facilities were evaluated in the Strategic Facilities Plan. The facilities included buildings as well as support systems (i.e., roads, rail, steam, electricity, water, and telecommunications). The Hanford Site Strategic Facilities Plan identified and proposed an action plan for facilities not required to support the Hanford Site mission.

Seventy-two such facilities were identified for disposition between FY 1990 and 1992, showing tangible cost savings as follows:

- Project costs-- $\$ 8,201,400$

- Annuar cost savings-- $\$ 808,100$

- One-time cost savings-- $\$ 6,814,100$

- Payback, in years--1.72 yr.

Facilities identified for demolition will cost $\$ 19,240,000$, and show no real tangible savings. These facilities will be demolished to reduce potential fire, safety, security, and radiation hazards. No facilities were identified for action in FY 1993 and 1994. 


\subsubsection{Goal Number 7}

Goal No. 7 is to develop a viable and attractive plan for private enterprise to finance, design, construct, operate, and decommission large and complex facilities. Five candidate projects were presented to private sector representatives in Nivember 1989. They were as follows:

- WRAP

- Raw material (flyash) feed for the Hanford Site Grout Program

- PFP liquid waste immobilization

- Treated Effluent Disposal Facility for the Hanford Site 200 Areas

- PUREX Liquid Effluent Treatment Facility.

Project values are expected to range from $\$ 5$ million to $\$ 150$ million. It is hoped that institutional issues such as contracting mechanisms and liability can be resolved so that at least two of these projects can be contracted in FY 1990.

\subsection{REFERENCES}

Davenport, L. F., 1988, Strategic Facilities Initiative, Detailed Guidance for Execution of the FY 1990 Program, 880133.0B, U.S. Department of Energy, Washington, D.C. (November).

Ecology, EPA, and DOE, 1989, Hanford Federal Facility Agreement and Consent Order, Washington State Department of Ecology, U.S. Environmental

Protection Agency, and U.S. Department of Energy, 01ympia, Washington.

National Environmental Policy Act of 1970, Public Law 91-190, 83 stat. 852, 422 USC 4321 et seq.

WHC, 1989, Hanford Site Strategic Facilities Plan, DOE/RL 89-01, Westinghouse Hanford Company for the U.S. Department of Energy, Richland, Washington. 


\subsection{GENERAL SITE INFORMATION}

The Hanford Site is owned by the United States Government and administered by the U.S. Department of Energy (DOE). It occupies a mostly flat, semiarid site of about $560 \mathrm{mi}^{2}$ in southeastern Washington (Figure 2-1).

The Tri-Cities Metropolitan Statistical Area (MSA) is centered along the Columbia River downstream south and southeast of the Hanford Site. It represents the major population concentration in the area with a population of about 139,600 people.

Other areas surrounding the Hanford Site are predominantly agricultural and sparsely populated.

The Hanford Site is an isolated, controlled access area that has been used for production and test reactor operations and related activities since 1943. Current major operations on the Site include nuclear fuel processing and waste management activities, the Fast Flux Test Facility (FFTF), alternate energy research and development (R\&D), environmental technology development, and site cleanup.

The Washington Public Power Supply System leases an area along the Columbia River to operate a commercial power reactor.

This section provides an overview of several facets of the Hanford Site and surrounding region: site history, regional data and issues, legal restrictions affecting the Site and its future use, public transportation, and utilities.

\subsection{HISTORY}

This section briefly highlights the major trends in the history of the Hanford Site from 1943 to the present.

\subsubsection{Hanford Site--Early Years (1943 to 1945)}

In January 1943, the Manhattan District of the U.S. Corps of Engineers chose the Hanford Site as the location for the Hanford Engineering Works, where facilities would be built to produce plutonium for the world's first nuclear weapons. The federal government acquired $620 \mathrm{mi}^{2}$ of public and privately owned land. This included Richland, a town with a 1942 population of approximately 250, located just south of the Hanford Site. In March 1943, construction was started on 3 reactors, 3 chemical processing plants for recovering plutonium in the irradiated fuel, and 64 underground waste storage tanks. The Hanford Works Laboratory was built in the 300 Area to support reactor fuel fabrication and other production activities.

More than 4,300 new homes were constructed along with utilities, stores, schools, and other municipal facilities in Richland. The total construction effort for the town and production facilities required a force of more than 50,000 construction workers and dependents who lived in a temporary camp 
Figure 2-1. Location and Regional Map of the Hanford Site.

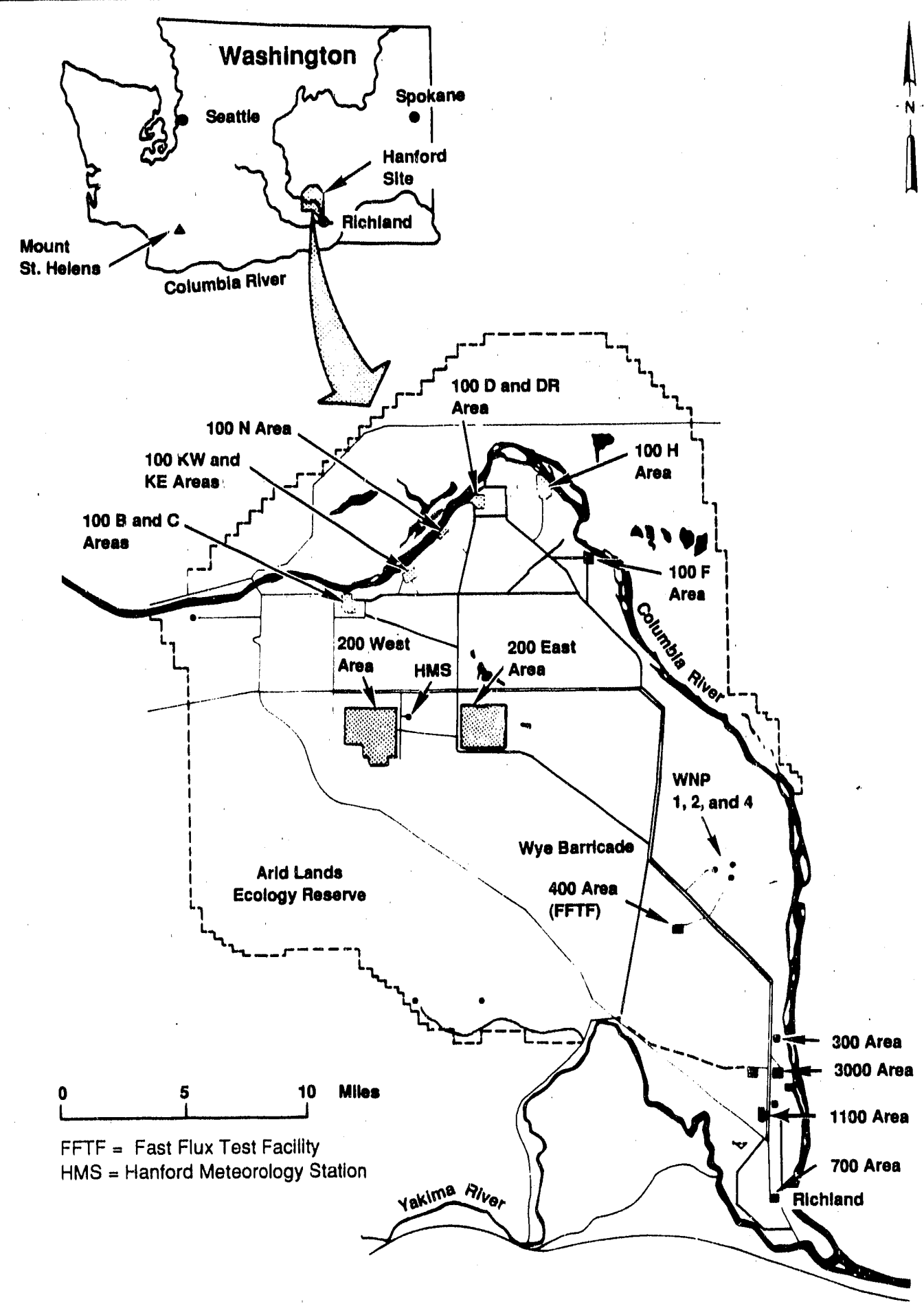

39001069.1 
near the town site of Hanford, making it the fourth largest city in Washington State.

The B Reactor began operation in September 1944; it was followed within a few months by the $D$ and $F$ Reactors. In 1945, World War II ended after the bombing of Hiroshima and Nagasaki, Japan. Plutonium produced at the Hanford Site was used in the Nagasaki bomb.

\subsubsection{Hanford Site Expands (1946 to 1959)}

In 1946, E. I. Du Pont de Nemours \& Company, which had built and operated the Hanford Site during World War II, asked to be released from its contract. The General Electric Company (GE) took over as the operating contractor on January $1,1947$.

The Atomic Energy Commission (AEC) was estabiished in 1946 to replace the Manhattan District and give civilian control to the Nation's nuclear complex. In the late 1940 's, the AEC ordered an increase in plutonium production, and the Hanford Site underwent a major expansion program between 1947 and 1955. About 15,000 workers, living in a campsite in north Richland, built 5 additional plutonium production reactors, 2 chemical fuel processing plants, a plutonium finishing plant, and 81 additional underground waste storage tanks. The former Hanford Works Laboratory was expanded to include new facilities to support the postwar production expansion program, along with Civilian Applications programs. Two thousand homes were added to the city of Richland.

In 1957, the AEC implemented legislation authorizing the sale of the city of Richland to its residents. The city of Richland was incorporated in 1959 .

\subsubsection{Electrical Power Production Begins (1959)}

The $N$ Reactor was built between 1959 and 1963. Unlike the eight earlier production reactors, which had the sole mission of producing plutonium, $N$ Reactor also produced steam to generate electricity, making it the Nation's only dual-purpose reactor. From 1963 to 1966, the Washington Public Power Supply System built the 860-MW Hanford Generating Plant adjacent to $N$ Reactor. Between 1966 and 1987, the combination of $N$ Reactor and the Hanford Generating Plant produced more than 60 billion $\mathrm{kW}$ of electrical power.

\subsubsection{Operations Divided Among Contractors (1964)}

Beginning in 1964, the Hanford Site underwent a series of dramatic changes. Plutonium production was sharply reduced. By 1971 , eight of the nine production reactors were shut down. By 1972, all related fuel cycle facilities, such as the Plutonium-Uranium Extraction (PUREX) Plant, were shut down.

To offset the economic impact of these shutdowns on the local communities, a plan called "Contract Segmentation and Diversification" was developed by the AEC in the mid-1960's. The plan was implemented in January 1964, when GE and the AEC announced they had mutually concluded that transfer of 
contract work at the Hanford Site to other contractors during a period of several years would be in the best interests of the government and GE and would contribute to the future development of the communities of the Hanford Site area. Under this plan, GE's operations were segmented into a number of functions: reactors, laboratories, chemical processing, and support services.

New contractors were selected for these functions. Each successful proposer was required to invest private capital in the community to aid economic development. New businesses emerging from the diversification effort included Battelle's Pacific Northwest Laboratory (PNL), Donald W. Douglas Laboratories, the Hanford House hotel, a meat packing plant, Sandvik Special Metals, and a cattle feedlot.

The reduction of production activities at the Hanford Site refocused attention on the resources and capabilities of the Hanford Site to develop peaceful applications of the atom, particularly in energy research. During the 1960's, laboratory facilities were constructed to support newer programs such as the liquid metal fast breeder reactor, nuclear waste management studies, and biological and environmental sciences. Substantial assistance was also provided toward developing and supporting a graduate education facility, the Joint Center for Graduate Studies, now the Tri-cities branch of Washington State University.

\subsubsection{Hanford Site Technologies Expand (1970 to 1980)}

During the 1970's, under the Energy Research and Development Administration (ERDA), the emphasis on energy research programs continued to grow. Major programs included nuclear energy; environment and safety; solar, geothermal, and advanced systems; fossil energy; national security; conservation; and "other" (e.g., energy policy analysis, resource assessment).

Typical of this emphasis was the start of construction for the FFTF. The purpose of this sodium-cooled, 400-MW thermal, fast flux reactor is to test fuels and materials for advanced reactors. The FFTF achieved initial criticality in February 1980; it operates today as one of the most successful advanced reactor test facilities in the world. Additional laboratory facilities were also constructed during the 1970's.

The Hanford Site radioactive waste management program was also upgraded during the 1970's. The main objective was to transfer liquids from the single shell waste storage tanks to more stable double-shell tanks. The liquid waste volume was reduced by evaporation before the transfer. After evaporation and transfer of the remaining liquid, about 40 million gal of solids and some interstitial liquids remain in the single-shell tanks. The final facet of the waste management program for the Hanford Site calls for permanent disposal of all radioactive wastes, which is proposed to begin in the 1990 's.

Another project that began in the 1970's was the Basal' Waste Isolation Project (BWIP). The Hanford Site was one of three niational sites recommended by the DOE for detailed investigation as a possible location for a permanent 
repository for high-level, commercial radicactive waste. Iritense geologic and hydrologic studies were initiated at each site to determine whether any of them were suitable repository sites.

\subsubsection{Reemphasis on Production of Nuclear Materials and Consolidation of Operations (1980 to 1986)}

In the late 1970's and early 1980's, the emphasis at the Hanford Site sififted back to nuclear materials production. This emphasis included reopening the uranium oxide $\left(\mathrm{UO}_{3}\right)$ and PUREX Plants in 1983, enhancing waste management facilities, upgrading site infrastructure, and increasing the production rate at the $N$ Reactor. It also involved upgrading security precautions and proposals for new facilities such as the Special Isotope Separation (SIS) Facility [later iransferred to the Idaho National Engineering Laboratory (INEL)] and the Process Facility Modification (PFM) project (1ater cancelled) to process fuel from FFTF.

The suitability of multiple Hanford Site contractors became a concern to the DOE during the early 1980's. In the fall of 1984, DOE-Richland Operations office (DOE-RL) studied the feasibility of reducing the number of contractors from eight to four via consolidation.

In March 1985, a consolidation plan was prepared and approved by then DOE Secretary of Energy, J. S. Herrington. The consolidation plan called for four onsite contractors: (1) an engineer/constructor contractor, (2) an operations and engineering contractor, (3) an R\&D contractor, and (4) a medical and health services contractor, which is required by state legislation to be a separate function. The objectives of consolidation were the following:

- Improve management effectiveness

- Provide greater flexibility and response to changing national program requirements

- Reduce overall costs

- Integrate site planning

- Make better use of site resources (people, space, and facilities).

The DOE-RL consolidation plan outlines a production cost saving of approximately $\$ 150$ million in $5 \mathrm{yr}$. These savings are being realized as a result of reductions in management, indirect function duplications, and technical services duplications.

The Hanford Environmental Health Foundation (HEHF) is responsible for providing onsite health services. The term of their contract expired December 1989, at which time the contract was renewed for a 3-yr period.

Battelle Memorial Institute (BMI) is responsible for onsite R\&D. In June 1987, the term of the BMI contract was extended to September 30, 1992 . The R\&D contractor performs studies and analyses, basic and applied research, advanced development, and independent environmental monitoring and analysis of Hanford Site operations and future missions. 
Westinghouse Hanford Company (WHC) was awarded the operations and engineering contract in December 1986. The term of the contract runs through September 30, 1992. The WHC is responsible for fuel fabrication, reactor operations, chemical processing, waste management, decontamination and decommissioning (D\&D), and site support services, including automated data processing.

Kaiser Engineers Hanford (KEH) was awarded the engineer/constructor contract in September 1986. The term of this contract runs through February 29, 1992. The KEH is responsible for engineering design, and constructor and construction management services.

The history of contractor responsibilities at the Hanford Site is presented in Figure 2-2. This figure outlines the primary Hanford Site function: and the contractor(s) who have been responsible for each of these functions over time.

\subsubsection{Emphasis on Environmental Research and Compliance: Slowdown on Production of Nuclear Materials (1986 to 1989)}

In 1986, several Hanford Site-related issues created public controversy that played a part in major prograin changes and a shifting of the general focus for future operations at the Hanford Site.

In February 1986 and again in April 1987, the DOE-RL made public extensive data regarding radiological releases at the Hanford Site during the prior years of operation. This information created regional concern for potential contamination downstream and downwind from the Hanford Site. The effects on agricultural production and public health within the region were of main concern. Subsequently, in February 1988, DOE-RL initiated the independently directed Hanford Environmental Dose Reconstruction Project designed to estimate potential historical doses to populations presiding primarily downwind of the Hanford Site.

In April 1986, the rhernobyl accident occurred in the Soviet Union. Initial, inaccurate media comparisons of the $N$ Reactor to the Chernobyl plant resulted in regional and national concern about future operation of the $N$ Reactor. Studies conducted by the DOE, the General Accounting Office (GAO), Oregon State, the Roddis Committee, and the National Academy of Science concluded that the basic designs of the two plants are so different that a Chernobyl-like accident could not occur at the $N$ Reactor. A number of safety upgrades were identified for $N$ Reactor that have since been implemented.

In May 1986, the Hanford Site BWIP was selected as one of three sites for further site characterization for a high-level radiological waste repository. This selection met with poor public acceptance throughout the Northwest. Public concern focused primarily on groundwater movement under the site and the site selection process used by the DOE. Later in 1986, the states of Washington and Oregon passed measures by $84 \%$ and $74 \%$, respectively, to oppose the DOE site selection process. 
DOE/RL-89-15

Figure 2-2. Hanford Contractor History.

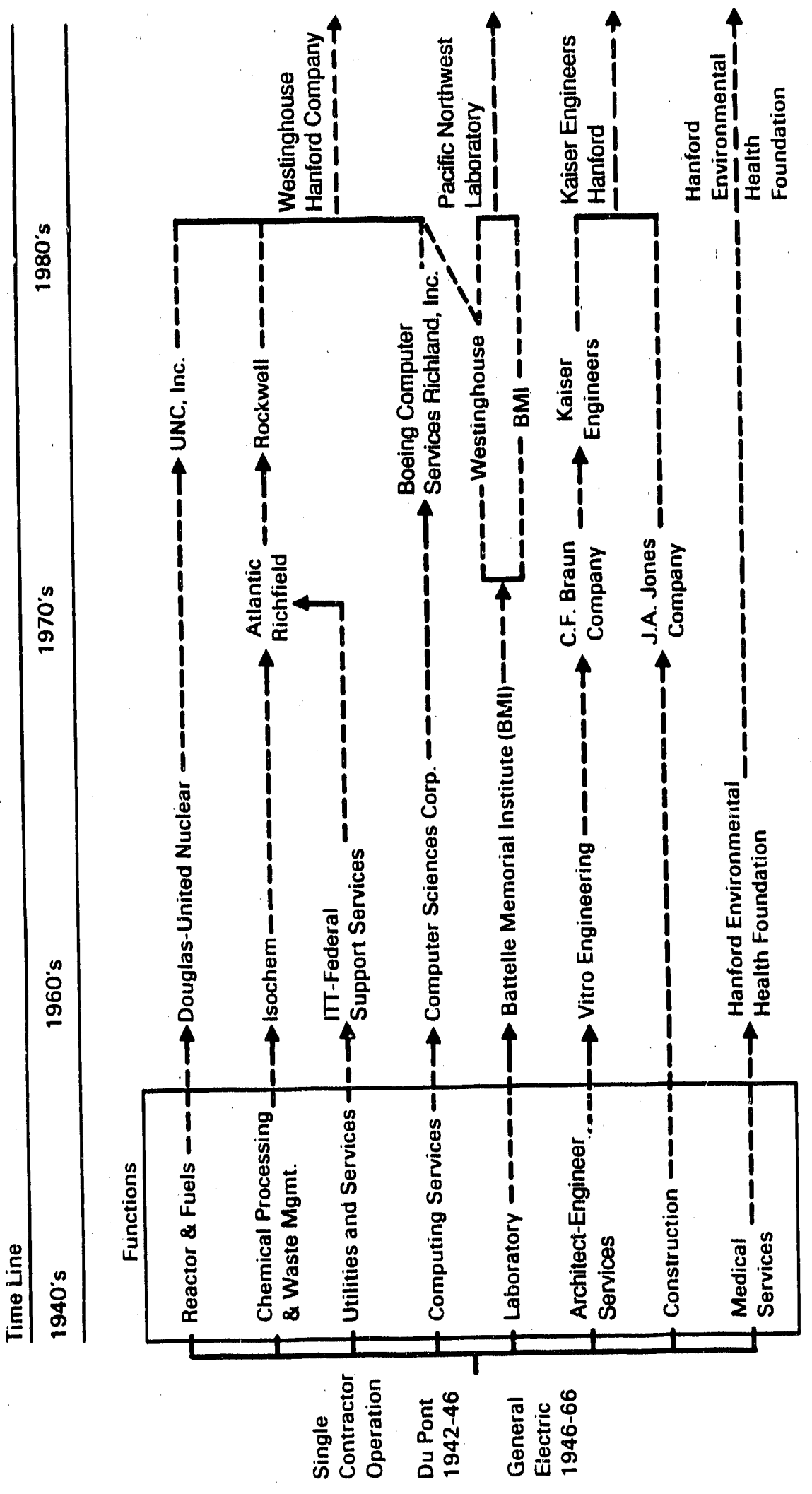


Throughout 1986, extensive media and political attention was focused on the Hanford Site. This continued focus served to solidify regional opinions regarding past and future operations at the Site. In general, regional support for defense production and storage of offsite-generated wastes became low, while regional support for environmental research, cleanup, and compliance became very high.

In December 1987, a congressional decision to confine site characterization for a high-level radiological waste repository to the Nevada site effectively terminated the BWIP program at the Hanford Site. Also, in February 1988, DOE officials decided to concentrate defense reactor activities at the Savannah River Site and ordered $N$ Reactor to be placed in cold standby.

While these actions generally met with regional approval, the combined loss of an estimated 2,800 Hanford Site jobs and an additiona? 3,200 secondary service sector jobs created mounting concern for the economic stability of the Tri-Cities economy. The federal government, Washington State, and the local community pursued economic diversification programs aimed at mitigating current and future impacts of Hanford Site program changes.

In July 1988, Congress reallocated $\$ 44$ million in unobligated Hanford Site funds to begin environmental restoration activities at the Hanford Site. Also, the DOE, the U.S. Environmental Protection Agency (EPA), and Washington State entered into the Hanford Federal Facility Agreement and Consent Order (Tri-Party Agreement) in May 1989 (Ecology et al. 1989). This agreement is intended to ensure a coordinated effort for environmental cleanup at the Hanford Site during the next $30 \mathrm{yr}$. Currently, the Hanford Site is looked upon as the flagship site for DOE cleanup activities.

Defense waste disposal efforts continue to progress. In August 1988, the Grout Treatment Facility (GTF) went through startup operations and began processing and solidifying low-level wastes. The grout treatment process stabilizes low-level radioactive waste by mixing it into a cementitious substance, which is then stored in monitored cribs. The Hanford Waste Vitrification Plant (HWVP) is scheduled for hot startup in 1999. The Waste Receiving and Processing (WRAP) facility is scheduled for hot startup in 1996.

Addjfjonal programs currently under consideration at the Hanford Site are the ${ }^{38} \mathrm{Pu}$ program, which will provide nuclear materials for use as a power source in space exploration, and the conversion of the mothballed WNP-1 reactor for defense production.

\subsection{REGIONAL OVERVIEW}

This section addresses regional issues that directly or indirectly affect Hanford Site operations. Demographic information, as well as data on existing housing and schools, is presented. The availability of labor and materials is discussed. Local and regional attitudes and issues are addressed. 
DOE/RL-89-15

\subsubsection{Demographics}

Population in the area surrounding the Hanford Site is sparse, consisting primarily of farms and farming communities in 211 directions. In 1980, an estimated 341,000 penple were living within a 50-mi radius of the Hanford Meteorology Station (HMS).

2.2.1.1 Population Trends in the Tri-Cities. The Tri-Cities area, designated as tr.? Richland-Kennewick-Pasco MSA by the U.S. Census Bureau, is located south and southeast of the Hanford Site (Figure 2-3). It represents the major population concentration in the are.. and was ranked as one of the fastest growing metropolitan areas in the Nation between 1970 and 1980.

The Tri-Cities MSA reached its peak population of 150,100 in 1981. From 1981 to 1988, the MSA population decreased by 10,500 people. This decrease is attributed to the cessation of construction activities at two of the three Washington Public Power Supply System nuclear plants at the Hanford Jite, completion of FFTF construction, termination of the BWIP program, diversion of the SIS Project to another DOE site, and orders to place $N$ Reactor in cold standby.

Outmigration was expected to continue through early 1990 as layoffs from placing $N$ Reactor in cold standby are completed and the resulting loss of secondary sector employment occurs. This expected trend was reversed in 1989, however, as community diversification and unexpected environmental program growth at the Hanford Site took place. The environmental program growth was prompted, in part, by the Tri-Party Agreement (Ecology et al. 1989).

2.2.1.2 Regional Population Trends. Within $50 \mathrm{mi}$ of the Hanford Site, approximately $60 \%$ of the population is concentrated in the Tri-Cities MSA. The ratio between the population of the Tri-Cities and the bi-county area (Benton and Franklin Counties) has remained relatively constant since the mid-1960's, despite the exceptionally rapid growth in population between 1973 and 1981 .

Data on population size for Benton and Franklin Counties are provided in Table 2-1. The population density for Benton County is 64 people per square inile. It is 28 people per square mile for Franklin County. Data for each of the five cities located nearest to the Hanford Site are provided in Table 2-2. Figures $2-4$ and 2-5 show trends in regional population size.

2.2.1.3 Age and Income. The Tri-Cities population is relatively young. In 1986, 18\% of the population was under 10 yr of age, 33\% was under $20 \mathrm{yr}$, and $68 \%$ was under $40 \mathrm{yr}$. The population is generally well educated.

Based on the most recently available data, the 1985 median household effective buying income for the area was $\$ 32,672$. In 1985 , Benton County ranked seventh in the state for per capita income; Frankl in County ranked seventeenth. Since 1985, personal income has dropped an average of $1.5 \% / y r$ and is expected to fall similarly in 1989. By the end of 1989, it is estimated that median household buying income will have fallen to approximately $\$ 31,000$. 
Figure 2-3. Population for Cities Within a 50-Mile Radius of the Hanford Meteorology Station.

Sources: U.S. Census, 1980. Washington State Office of Financial Management, 1988, Population Trends for Washington State.

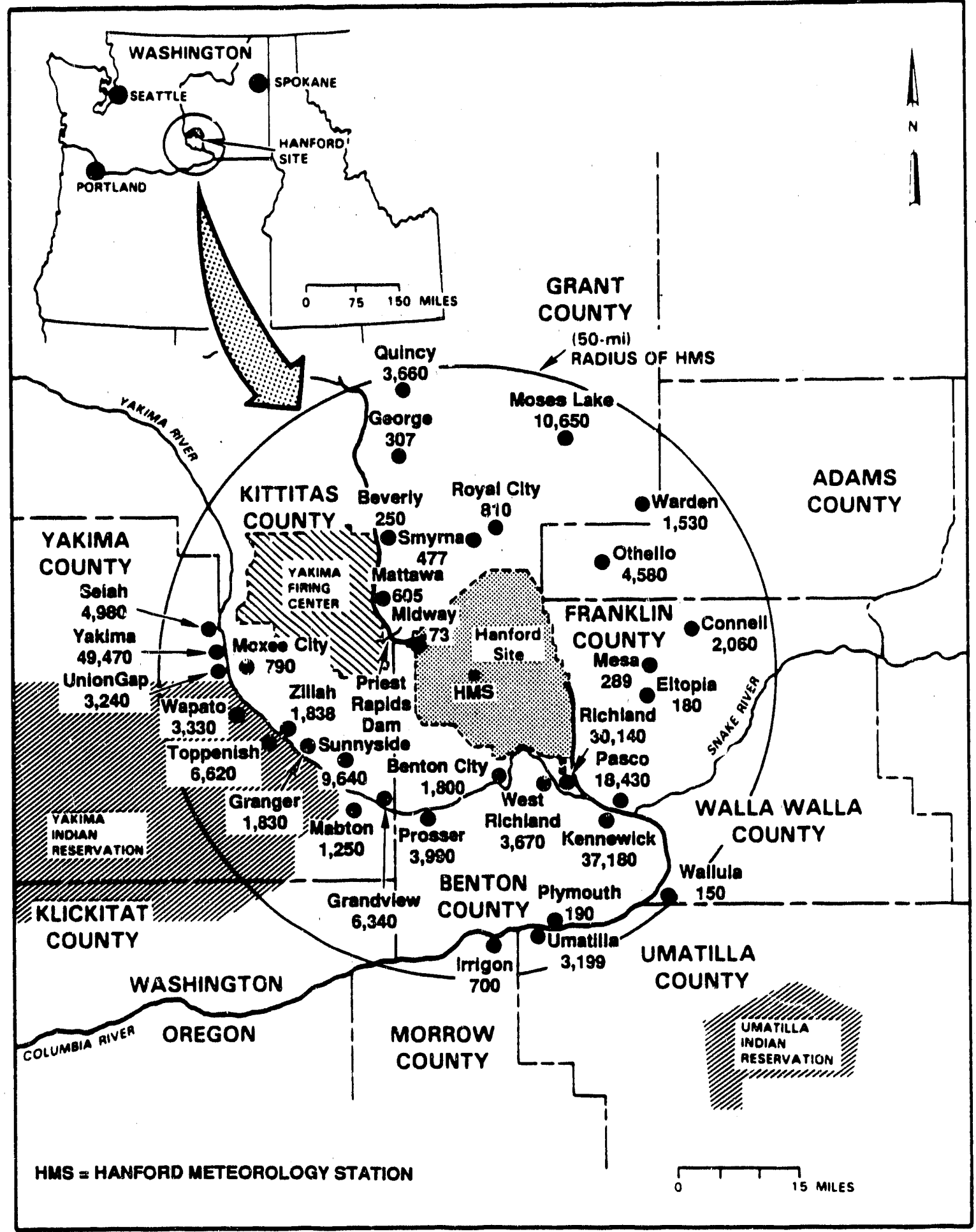

38907129.11 
DOE/RL-89-15

Table 2-1. 1965 to 1988 Population of Benton and Frankl in Counties.

\begin{tabular}{|c|c|c|c|c|c|c|}
\hline Year & $\begin{array}{l}\text { Benton } \\
\text { County }\end{array}$ & $\begin{array}{l}\text { Average } \\
\text { annual } \\
\text { rate of } \\
\text { change }(\%)\end{array}$ & $\begin{array}{c}\text { Frankl in } \\
\text { County }\end{array}$ & $\begin{array}{l}\text { Average } \\
\text { annual } \\
\text { rate of } \\
\text { change }(\%)\end{array}$ & $\begin{array}{l}\text { Total } \\
\text { Benton- } \\
\text { Frankl in } \\
\text { County }\end{array}$ & $\begin{array}{l}\text { Average } \\
\text { annual } \\
\text { rate of } \\
\text { change (\%) }\end{array}$ \\
\hline
\end{tabular}

Pre-Washington Public Power Supply System Period

\begin{tabular}{|c|c|c|c|c|c|c|}
\hline $\begin{array}{l}1965 \\
1966 \\
1967 \\
1968 \\
1969 \\
1970 \\
1971 \\
1972 \\
1973\end{array}$ & $\begin{array}{l}63,301 \\
64,019 \\
64,433 \\
65,276 \\
65,418 \\
67,540 \\
67,069 \\
67,214 \\
68,988\end{array}$ & 1.1 & $\begin{array}{l}24,158 \\
24,504 \\
24,865 \\
25,061 \\
24,891 \\
25,816 \\
26,430 \\
26,508 \\
26,301\end{array}$ & 1.1 & $\begin{array}{l}87,459 \\
88,523 \\
89,298 \\
90,337 \\
90,309 \\
93,356 \\
93,499 \\
93,722 \\
95,289\end{array}$ & 1.1 \\
\hline
\end{tabular}

Washington Public Power Supply System Construction Period

\begin{tabular}{|c|c|c|c|c|c|c|}
\hline $\begin{array}{l}1973 \\
1974 \\
1975 \\
1976 \\
1977 \\
1978 \\
1979 \\
1980 \\
1981\end{array}$ & $\begin{array}{r}68,988 \\
72,202 \\
76,880 \\
84,453 \\
89,472 \\
97,825 \\
104,838 \\
109,444 \\
113,400\end{array}$ & 6.1 & $\begin{array}{l}26,301 \\
27,101 \\
28,004 \\
29,510 \\
30,592 \\
32,824 \\
34,228 \\
35,025 \\
36,700\end{array}$ & 4.0 & $\begin{array}{r}95,289 \\
99,303 \\
104,884 \\
113,963 \\
120,064 \\
130,649 \\
139,066 \\
144,469 \\
150,100\end{array}$ & 5.5 \\
\hline
\end{tabular}

Washington Public Power Supply System Rampdown--Basalt Waste Isolation Project Termination $-\mathrm{N}$ Reactor Standby Period

\begin{tabular}{|c|c|c|c|c|c|c|}
\hline $\begin{array}{l}1981 \\
1982 \\
1983 \\
1984 \\
1985 \\
1986 \\
1987 \\
1988\end{array}$ & $\begin{array}{l}113,400 \\
111,700 \\
108,700 \\
107,700 \\
105,200 \\
104,000 \\
104,100 \\
104,100\end{array}$ & -1.2 & $\begin{array}{l}36,700 \\
36,200 \\
36,000 \\
36,300 \\
35,700 \\
35,300 \\
35,500 \\
35,500\end{array}$ & -0.5 & $\begin{array}{l}150,100 \\
147,900 \\
144,700 \\
144,000 \\
140,900 \\
139,300 \\
139,600 \\
139,600\end{array}$ & -1.0 \\
\hline
\end{tabular}

Sources: U.S. Bureau of the Census (1960, 1970, 1980). Washington Public Power Supply System.

Washington State Office of Financial Management, 1988, Population Trends for Washington State. 
DOE/RL-89- 15

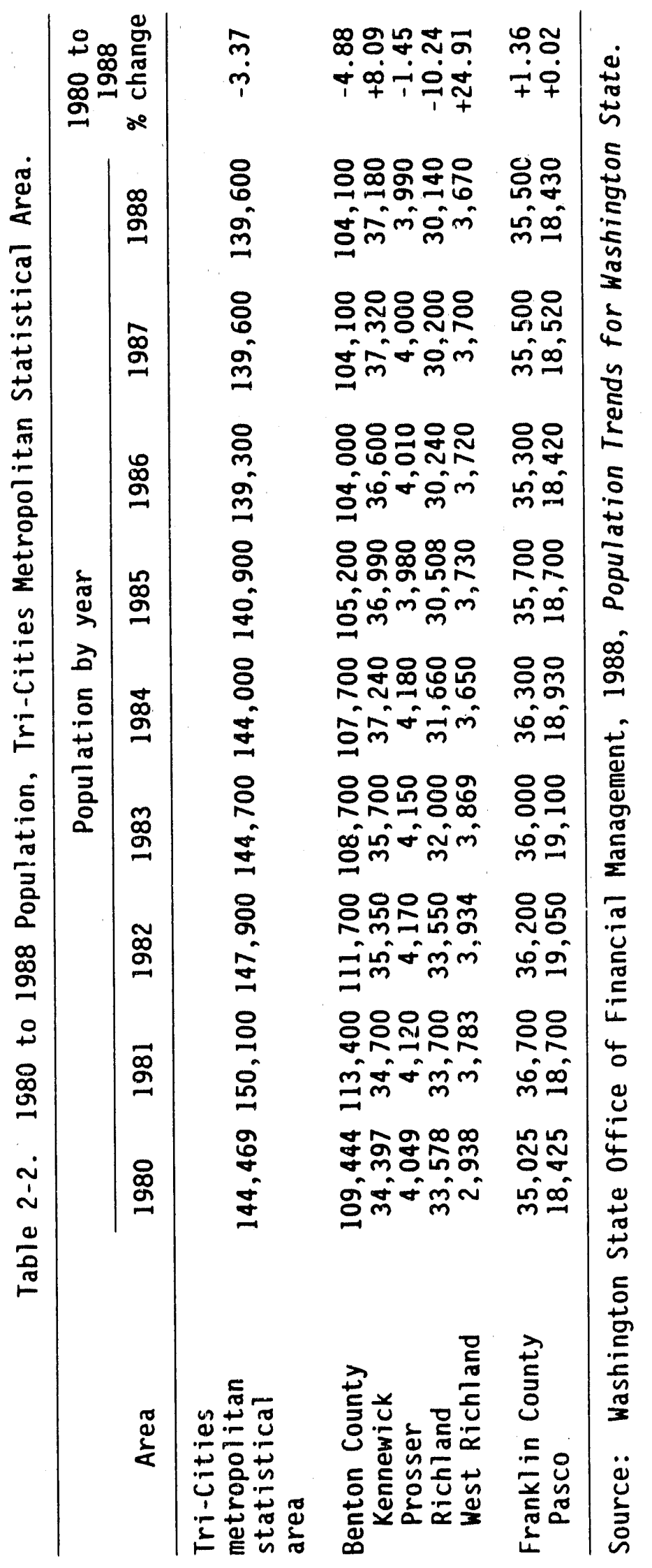


Figure 2-4. Population Trends for Benton and Frankl in Counties: 1965 to 1988.

Sources: Draft Environmental Assessment Reference Repository Location, Hanford Site, Washington, DOE/RW-0017, U.S. Department of Energy, Washington, D.C., 1984. Washington State Office of Financial Management, 1988, Population Trends for Washington State.

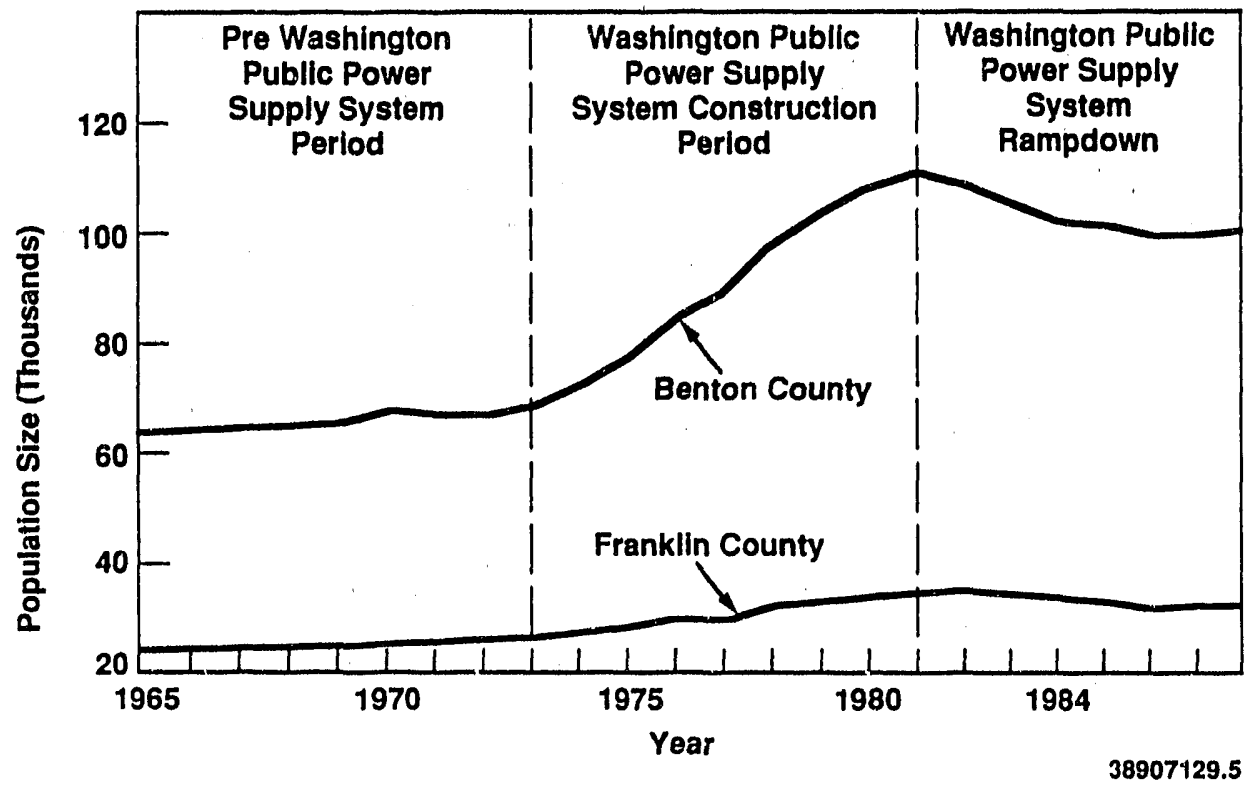

Figure 2-5. Population Trends for Cities Near the Hanford Site: 1965 to 1988.

Sources: Draft Environmental Assessment Reference Repository Location, Hanford Site, Washington, 1984. Washington State Office of Financial Management, 1988, Population Trends for Washington State.

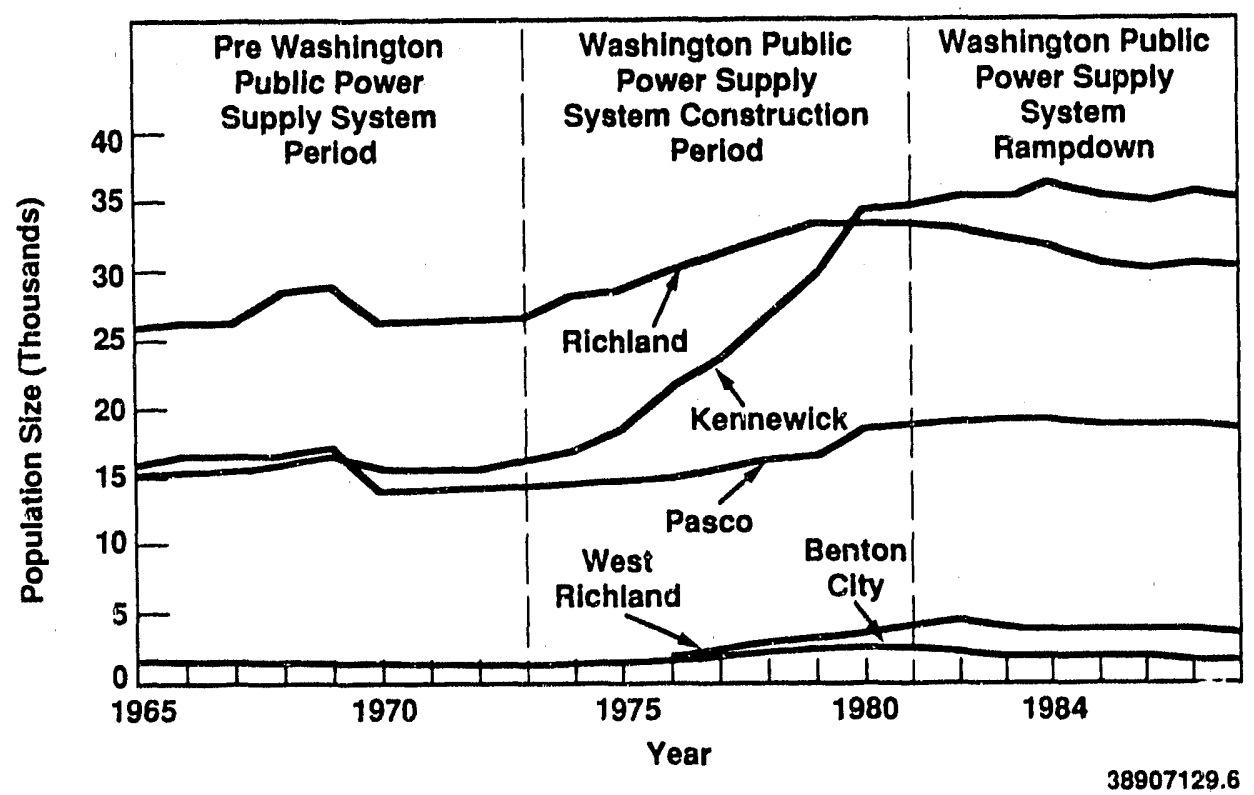




\subsubsection{Housing}

In the 1970's, the large expansion of population and employment demanded an increase in Tri-Cities housing units. The Washington State Office of Financial Management (OFM) reported that housing units in the Tri-Cities MSA nearly doubled between 1970 and 1980, reaching a total of 55,967 units by 1980. The 1988 OFM reports show that housing units have increased $6.6 \%$ since 1980 , totalling 59,672 .

Of the total housing units available in 1988, $60 \%$ are single family, $28 \%$ are multifamily, and $14 \%$ are manufactured/mobile. This represents a $2 \%$ shift from single family to mobile units since 1980, while multifamily units have maintained the same percentage of total units during this time.

The average selling price of a single family home in the Tri-Cities area has steadily declined since reaching a 1981 high of $\$ 73,000$, according to the Tri-Cities Board of Realtors. From 1981 to 1985, the average selling price fell sharply $(16.9 \%)$ to $\$ 60,900$. From 1986 to 1988 , the decline slowed but still fell (2.9\%) to $\$ 58,800$. Projections showed prices still dropping slightly through 1989 and flattening out in 1990, assuming there are no major changes in economic and job activity. However, in the fall of 1989, prices started to increase because of a high demand for homes.

Residential construction costs in the Tri-Cities are lower than those in other cities in the western United States. In the fall of 1989, residential construction activities began to grow in response to the demand for singlefamily homes.

\subsubsection{Schools}

There are nearly 30,000 students in the Tri-Cities MSA who attend primary and secondary schools in 11 public school districts. The Tri-Cities area is credited with diverse learning programs that are designed for a broad crosssection of student needs and that are backed by strong community involvement and support. Many facilities are new or renovated, and located on spacious grounds.

Several Tri-Cities schools have received national recognition for their success in responding to the expanding demands of a rapidly changing society. Recent awards include recognition of Pasco and Hanford High Schools by the U.S. Department of Education as 2 of the top 144 secondary schools in the United States in 1983. The standardized fourth and eighth grade testing programs consistently show Tri-Cities students to be above average. Graduating students are well prepared for college, which is indicated by a higher-than-average percentage attending and graduating from college. Students from the Tri-Cities area also exit high school with excellent vocational skills, as demonstrated by the high placement of students and percentage and retention rate of employment.

An important area-wide educational program for secondary students is the Tri-City Area Vocational Skills Center, which is sponsored by six Tri-Cities school districts. The vocational center functions as an extension to the home high schools of students, offering specialized vocational instruction in 23 career fields. 
There are 12 private schools within the Tri-Cities. They provide education at the preschool level through grade 12.

The Tri-cities is served by two institutions of higher learning: Washington State University (WSU) at Tri-Cities [WSU Tri-Cities (formerly Tri-Cities University Center)] and Columbia Basin College (CBC). Located in north Richland, WSU Tri-Cities is a satellite campus of Washington State University. The main campus is located in Pullman, Washington, which is approxinately $130 \mathrm{mi}$ to the east. The WSU Tri-Cities campus offers undergraduate- and graduate-level degree programs. Enrollment averages 1,000 students per semester.

Columbia Basin College is a community college offering 2-yr Associate of Arts degrees and 2-yr Applied Science degrees. Several of the Applied Science programs are geared specifically to meet the demand for the numerous types of technical positions required at the Hanford Site. The campus is located in Pasco, with extended service facilities available in Richland. Enrollment averages 6,000 students per quarter.

\subsubsection{Labor Supply}

The labor force in the Tri-Cities MSA currently numbers 68,000, which represents $50 \%$ of the total MSA population. In addition, many industries in the Tri-Cities employ individuals living in adjoining areas, such as Adams, Walla Walla, or Yakima Counties, as well as from communities in nearby northeastern Oregon. Therefore, it is estimated that the total available labor force within a 50-mi radius of the Hanford Site exceeds 100,000 people.

There are two distinct categories of labor within the Tri-Cities MSA. The first category comprises highly technical activities: energy research, energy production, and nuclear materials production activities conducted on, or in association with, activities at the Hanford Site. This labor category largely accounts for the concentration of managerial, professional, and technical employees in the local labor force. Currently, approximately 8,500 workers are professional and/or technically skilled (Table 2-3).

The second labor category involves the employees who fill a variety of positions across the broad spectrum of manufacturing activities not related to the Hanford Site activities.

A diverse industrial base involving food processing, chemical production, and general manufacturing supports a strong labor force in the areas of precision production, crafts, repair workers, machine operators, assemblers, inspectors, operators, and laborers. In total, more than 20,000 people comprise this industrial sector of the labor force in the Tri-Cities. 
Table 2-3. Professional and Technical Workers of the

Tri-Cities Metropolitan Statistical Area, 1988.

\begin{tabular}{lr}
\hline \multicolumn{1}{c}{ Occupation } & Number \\
\hline Engineers & 3,370 \\
Life and physical scientists & 920 \\
Mathematical specialists & 80 \\
Technicians & 2,550 \\
Medical workers (excluding technicians) & 980 \\
Computer specialists & 360 \\
Social scientists & 210 \\
\multicolumn{1}{c}{ Total } & 8,470 \\
\hline
\end{tabular}

Source: Washington State Employment Security Department (1988).

An area wage survey was completed for Benton and Franklin Counties in April 1988 by the Washington State Employment Security Department. The results of this survey are summarized in Table 2-4.

\subsubsection{Materials Availability}

The Hanford Site is located near several population centers. Because the Hanford Site is located near major transportation networks, these major population centers become important sources for raw materials and technical services.

Many specialized and technical service organizations are located in the Tri-cities. Specialty areas are nuclear-, medical-, and energy-related R\&D.

Firms such as Chevron Chemical Company, Sandvik Special Metals, Advanced Nuclear Fuels, WHC, BMI, KEH, Welch Foods, Lamb-Weston, and Neil F. Lampson Company create a nucleus for labor and industrial development that is unusually diverse for an area the size of the Tri-Cities.

Additional capabilities located nearby include storage space at the Port of Pasco and the Umatilla Army Depot, lumber yards, concrete batch plants, modular office manufacturing, fabrication/machine shops, several large general and specialty construction contractors, architect/engineering firms, and rock quarries.

Many firms in the Tri-Cities are engaged in the state-of-the-art hightechnology manufacturing that is related to nuclear facilities on the Hanford site. These range in size from large companies, such as WHC, to small R\&D firms. A summary of several types of current high-technology work follows:

- Utilization of acoustic emission technology for the integrity analysis of welds, plate materials, and cladding

- Design and manufacture of microprocessor-controlled neurological equipment 
Table 2-4. 1988 Area Wage Survey, Tri-Cities Metropolitan Statistical Area.

Title

Mean wage

$(\$)$
Absolute range

(\$)

\section{Clerical Occupations (monthly wage)}

\begin{tabular}{llr}
\hline Accounting clerk/specialist & 1,368 & 695 to 3,090 \\
Bookkeeper & $1, ! 18$ & 800 to 2,445 \\
Computer operator & 1,735 & 810 to 2,605 \\
Data entry operator & 1,370 & 870 to 2,215 \\
Payroll clerk & 1,770 & 1,000 to 2,350 \\
Secretary & 1,600 & 800 to 2,485 \\
General office clerk & 1,350 & 580 to 2,310 \\
Word processing operator & 1,348 & 1,045 to 2,005 \\
Medical transcriber & 1,137 & 825 to 1,430 \\
Switchboard operator & 1,250 & 645 to 1,940 \\
Receptionist & 1,081 & 615 to 2,350 \\
\hline
\end{tabular}

Managerial, Professional, Technical Occupations (monthly wage)

\begin{tabular}{llr}
\hline General manager & 2,757 & 905 to 7,915 \\
Supervisor & 2,744 & 1,100 to 5,425 \\
Clerical supervisor & 2,106 & 1,400 to 3,900 \\
Accountant/auditor & 2,700 & 1,430 to 4,985 \\
Buyer/purchasing agent & 2,319 & 1,170 to 3,775 \\
Engineer & 3,580 & 1,625 to 5,275 \\
Computer programmer & 2,564 & 1,350 to 4,150 \\
Drafter & 1,400 & 1,005 to 2,310 \\
Electronics technician & 2,480 & 1,045 to 2,910 \\
Engineering technician & 2,458 & 1,125 to 3,385 \\
Registered nurse & 2,070 & 1,475 to 2,710 \\
Science technician & 1,641 & 1,030 to 2,845 \\
Sales representative/agent & 1,910 & 800 to 4,000
\end{tabular}

General List Occupations (hourly wage)

\begin{tabular}{lrr}
\hline Carpenter, maintenance & 13.18 & 9.50 to 17.45 \\
Desk clerk & 3.87 & 3.35 to 5.00 \\
Electrician, maintenance & 16.24 & 9.50 to 18.10 \\
Forklift operator & 8.79 & 4.80 to 13.40 \\
Laborer, material handling & 6.74 & 4.00 to 16.15 \\
Machinist & 13.8 & 10.80 to 18.05 \\
Maintenance mechanic & 12.31 & 6.00 to 16.10 \\
Sales clerk & 5.40 & 3.35 to 12.55 \\
Stock clerk & 7.20 & 3.35 to 13.40 \\
Truck driver, heavy & 10.83 & 8.00 to 16.60 \\
Maintenance mechanic & 12.31 & 6.00 to 16.10 \\
Grocery clerk & 6.89 & 4.00 to 10.70 \\
Cook, dinner & 5.66 & 4.00 to 11.60 \\
Assembler, general & 6.63 & 3.35 to 18.25
\end{tabular}

Source: Washington State Employment Security Department, Tri-Cities Area Wage Survey, April 1988. 
- Development and application of biological technologies for use in agricultural production

- Development of equipment for process automation and robotics

- Custom assembly of electronic products and electromechanical components to customer specifications

- Manufacture of ultrasonic test equipment for nondestructive test evaluations and medical diagnostic testing

- Application of borehole sonar and underwater acoustic techniques for geological and geophysical testing

- Manufacture of microcomputer modules used in microprocessor-based systems

- Research, development, and manufacture of ultrasonic and optical instrumentation for quality assurance

- Production of single-sided printed circuit boards in volume for commercial applications.

Companies that perform one or more of the functions outlined above in the Tri-Cities are as follows:

- AE International

- Austin McDaniel Corporation

- Cadwell Laboratories

- Electronic Systems Technology

- Interropoint, Inc.

- Manufacturing Services

- R\&A Plant/Soil, Inc.

- Scitec Corporation
- Sigma Transducers

- Sonex

- Stavley Instruments

- Systek

- Sterling Technology

- Uniwest

- Xactex.

Specific companies that make significant technical contributions to the Hanford Site are described below.

Advanced Nuclear Fuels Corporation. An international company with headquarters in Bellevue, Washington, Advanced Nuclear Fuels is a wholly owned affiliate of Kraftwerk Union. Nuclear fuel assemblies are manufactured in Richland. The company is also engaged in R\&D of advanced nuclear fuel designs.

Sandvik Special Metals Corporation. The Sandvik Special Metals Corporation is the world's largest independent producer of zirconium alloy nuclear fuel tubing. The Finley plant (near Kennewick) manufactures zirconium and titanium tubing for the aerospace, aircraft, and sporting goods industry. 
Neil F. Lampson Company. The Neil F. Lampson Company's world headquarters is in Kennewick, with major manufacturing and assembly facilities in Pasco. This company produces the world's largest lifting and transport equipment, which is used occasionally at the Hanford Site to move equipment such as reactor vessels and steam generators.

The recent emphasis on environmental cleanup activities at the Hanford Site has brought several technical firms to the Tri-cities. These include IT Corporation and Golder and Associates. As environmental activities increase, more companies are expected to open offices in the Tri-cities, and these firms will assume more active roles in Hanford Site cleanup.

\subsubsection{Local/Regional Attitudes and Issues}

Because the Tri-City population has successfully coexisted with the Hanford Site for more than four decades, most local people have an understanding of, and familiarity with, nuclear energy well beyond that of the average public. The community is generaliy very supportive of Hanford Site activities.

On a regional level, general knowledge of nuclear energy and activities at Hanford is limited. In general, regional support is low for defense production and disposal of offsite wastes. At the same time, regional support for environmental cleanup, research, and compliance is very high.

2.2.6.1 Tri-cities Economic Tie to the Hanford Site. Employment at the Hanford Site plays a major, direct role in the local economy. Throughout the history of the Hanford Site, major program changes have created economic "boom and bust" cycles within the local economy. Creating economic diversity in the Tri-cities economy continues to be a primary concern of the community and the federal government.

Economic diversification was an integral part of the Hanford Site contract changes in the 1960's and 1980's. The economic development programs created as a part of these contract proposals have been successful in attracting non-Hanford-related businesses, but not to such a level that economic dependence has been mitigated.

In 1962, the Tri-City Nuclear Industrial Council was formed as a private organization that was focused on marketing the business opportunities made available in the area as a result of the Hanford Contract Segmentation and Diversification program. This council also provided federal lobbying support for maintaining and acquiring Hanford Site programs.

In 1985, the Tri-City Nuclear Industrial Council was merged with the TriCities Chamber of Commerce to form the Tri-City Industrial Development Council (TRIDEC). The TRIDEC is a private, nonprofit, membership funded, economic development council that is focused in two main areas. The Hanford Development Division essentially continues the missions of the Tri-City Nuclear Industrial Council, while the Commerce and Industry Division concentrates on diversification of the non-Hanford Site economy. 
To date, TRIDEC has been a successful influence in developing the Tri-Cities Coliseum; consolidating the Tri-Cities University Center under the single jurisdiction of WSU; and attracting the Lamb Weston Headquarters, the Cascade Columbia Food Processing Plant, Rotary Marine Industries, and Cam-Flight International to the Tri-Cities area. The TRIDEC currentiy is focusing on issues such as the Columbia River Water Front Enhancement Project, expanding the Columbia Basin Irrigation Project, upgrading State Route 395 to four 1 anes from the Tri-Cities north to I-90 at Ritzville, and the continued marketing of the Tri-Cities area to potential business developments.

Community support for TRIDEC has been very strong. A recent TRIDEC funding campaign raised $\$ 2.3$ million, which was $\$ 500,000$ greater than the original goal.

\subsubsection{Other Factors}

Two other regional factors broadly affect the Hanford Site: the Hanford Reach Study legislation and treaties with the Yakima, Umatilla, and Nez Perce tribes.

2.2.7.1 Hanford Reach Study Legislation (PL 100-605). In November 1988, Congress passed the Comprehensive River Conservation Study Act, Public Law 100-605, which directs the Secretary of the Interior, in consultation with the Secretary of Energy, to conduct a "comprehensive river conservation study" of the Hanford Reach. This area is a 51-mi-long corridor, 1/4-mi wide, beginning $1 \mathrm{mi}$ below the Priest Rapids Dam and ending at the upper end of McNary pool north of Richland, the greatest portion of which is on the Hanford site. The act directs the agencies to evaluate the natural and cultural resources, scenery, and recreational activities of the reach and investigate alternative strategies for the protection of important values. The act also established rules for the development of new projects and the operation of existing projects along the reach for a period of $8 \mathrm{yr}$ (until November 1996). Major projects, such as dam and navigation developments previously proposed for the reach, are specifically prohibited during this 8-yr period.

2.2.7.2 Indian Treaties and Reservations. The Hanford Site occupies 1 and ceded to the United States by two treaties in 1855. The Yakima and Umatilla Indian Reservations were also established by these treaties. The Yakima Reservation was created under treaty with Yakima bands, and the Umatilla Reservation under the treaty with the confederated Walla Walla, Cayuse, and Umatilla tribes. Each treaty cedes, to the United States, all rights, titie, and interest in 1 ands that were formerly the territories of the respective tribes and bands, and retains certain use rights for the tribal members. The issue of retained fishing, hunting, pasturing of animals, food-gathering rights, and the protection of the natural resources for potential future use by Native Americans is a concern expressed by the Tribes. These treaty rights have led to consolation and cooperation agreements with DOE-RL in the past and can be expected to be the subject of future agreements.

The Eastern boundary of the Yakima Indian Reservation is approximately $20 \mathrm{mi}$ west of the Hanford Site boundary. Native Americans comprise approximately $20 \%$ of this total reservation population of 25,363 people. The Umatilla Indian Reservation is approximately $75 \mathrm{mi}$ south of the Hanford Site 
in northeastern Oregon. Based on the 1980 census, the Native American population of Umatilla County totaled about 1,618. The Nez Perce Indian Reservation is approximately $135 \mathrm{mi}$ east of the Hanford Site in Idaho. The total population of Native Americans living on or adjacent to this reservation is about 1,500. All three of these tribes were declared to be "Affected Indian Tribes" as defined in the Nuclear Waste Policy Act of 1982. These Indian tribes were active in the site selection process for the national geologic repository for commercial high-level waste and have also had input in the decision-making process for the disposal of existing defense wastes at the Hanford Site. The Wanapum Indian band, located approximately $5 \mathrm{mi}$ west of the Hanford Site boundary is consulted (as are the above tribes) relative to Site activities that may have potential cultural impacts. The locations of these reservations are provided in Figure 2-6.

\subsection{SPECIFIC LOCALE DATA}

This section discusses zoning and land use near the Hanford Site, as well as applicable laws and regulations.

\subsubsection{Nearby Zoning and Land Use}

Land use in the area surrounding the Hanford Site includes urban and industrial development, irrigated and dryland farming, and 1ivestock grazing.

Principal agricultural crops include hay, wheat, potatoes, corn, apples, soft fruit, hops, grapes, and vegetables. In recent years, wine grapes have gained importance. Industries in the region are mainly those related to agriculture and energy production.

Land adjacent to the Hanford Site is privately owned, with the exception of those areas controlled by the Washington State and county and city governments. The state exercises control over state and federal highways and special use areas such as parks and wildlife reserves.

\subsubsection{Laws, Regulations, and Agreements Affecting the Hanford Site and Its Future Use}

The Hanford Site is owned by the United States Government. All site activities must comply with all applicable federal, state, and local laws and regulations, and applicable DOE orders. 
Figure 2-6. Location of Yakima Indian Reservation, Umatilla Indian Reservation, and Nez Perce Indian Reservation.

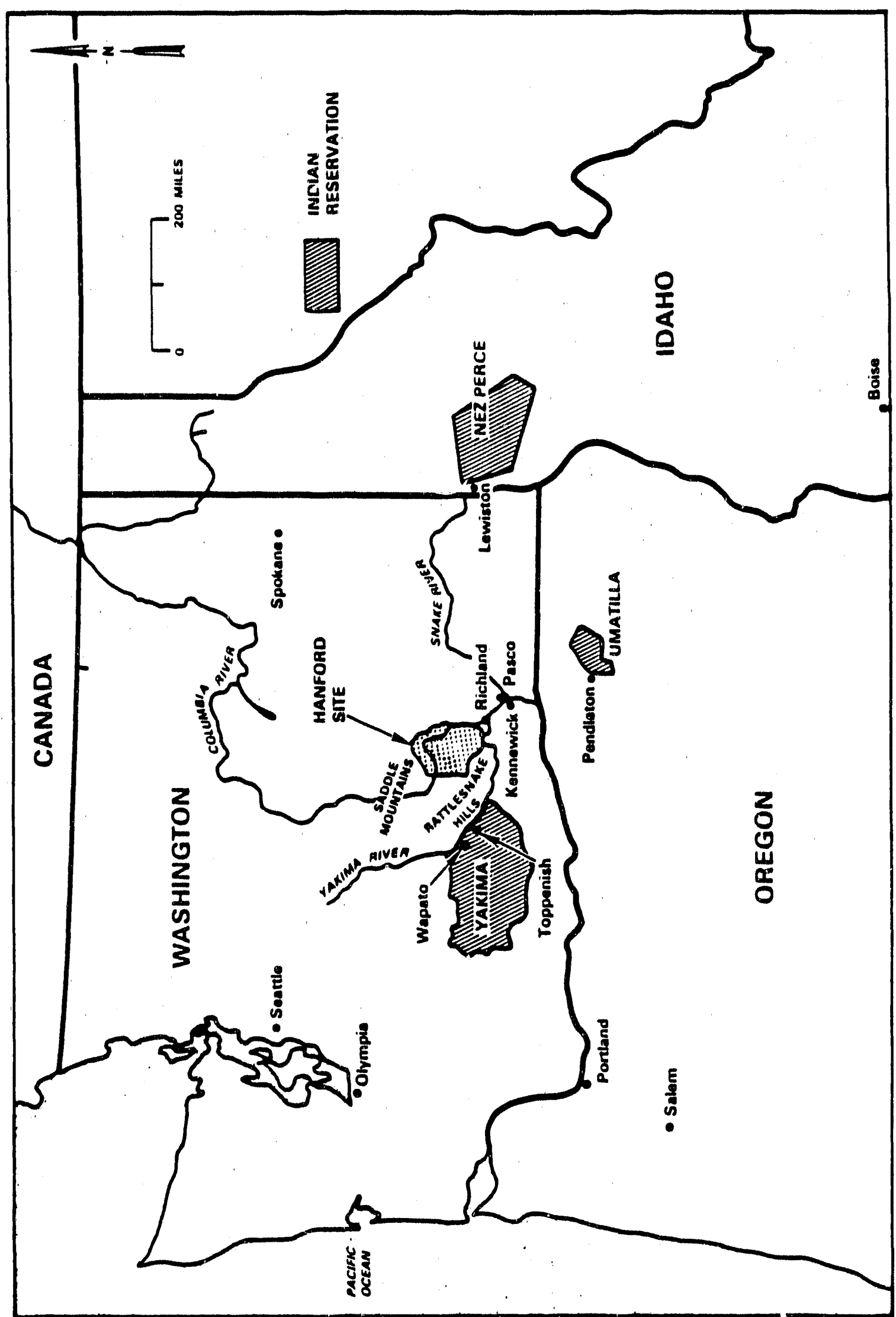


This section lists and summarizes some of the most significant laws, regulations, and DOE orders that impact current and future use of the Hanford Site.

2.3.2.1 Laws, Regulations, and Acts. This section lists several applicable laws, regulations, and acts that are implemented at the federal and/or state levels.

- Federal Government

Antiquities Act, 16 USC 433

Archaeological Resources Protection Act of 1979, PL 96-95, 16 USC 470aa et seq.

Atomic Energy Act of 1954, as amended, PL 83-703, 42 USC 2011 et seq.

Clean Air Act, PL 88-206, as amended, 42 USC 7401 et seq.

Clean Water Act, PL 92-500, as amended, 33 USC 1251 et seq.

Code of Federal Regulations: 10 CFR 1021-1022, 40 CFR 50-87, 40 CFR 61,40 CFR 141-144, 40 CFR 191, 40 CFR 260-270, 40 CFR 280, 40 CFR 761

Comprehensive Environmental Response, Compensation and Liability Act of 1980, PL 96-510, 42 USC 9601 et seq., as amended by the Superfund Amendments and Reauthorization Act of 1986

Comprehensive River Conservation Study Act, PL 100-605, November 4, 1988

Endangered Species Act, PL 93-205 as amended, 16 USC 1531 et seq.

Federal Insecticide, Fungicide, and Rodenticide Act, PL 92-516 as amended, 7 USC 136 et seq.

Fish and Wildlife Coordination Act, PL 85-624 as amended, 16 USC 661 et sea.

Hanford Reach Study Act, PL 100-605

Historic Site Buildings and Antiquities Act, 16 USC 461 et seq.

National Environmental Policy Act of 1970, PL 91-190, 83 Stat. 852 , 422 USC 4321 et sea.

National Historic Preservation Act, PL 89-665 as amended, 16 USC 470 et seq.

Noise Control Act of 1972, PL 92-574 as amended, 42 USC 4901 et sea.

Resource Conservation and Recovery Act of 1976, PL 94-580, as amended,

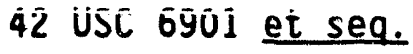


Rivers and Harbors Act of 1899, 33 USC 401, 403, 404, 406, 407, 408, 409,411

Safe Drinking Water Act, PL 93-523, 42 USC 300 f et seq.

Toxic Substances Control Act, PL 94-469 as amended, 15 USC 2601 et sea.

- State of Washington [Revised Code of Washington (RCW)]

Hazardous Waste Management Act, RCW 70.105

Hydrautic Projects Act, RCW 75.20.100

Onsite Disposal of Solid \& Liquid Wastes Act, RCW 43.20.050

Water Pollution Control Act, RCW 90.48.

Washington Administrative Code (WAC):

Water Quality Standards, WAC 173-201

State Waste Discharge Program, WAC 173-216

Submission of Plans \& Reports for Construction of Wastewater Facilities, WAC 173-240

Dangerous Waste Regulations, WAC 173-303

Standards for Solid Waste Handling, WAC 173-301

General Regulations for Air Pollution Sources, WAC 173-400 and 495

Hydraulic Codes, WAC 220-110

Onsite Sewage Disposal, WAC 248-96.

Washington Clean Air Act, RCW 70.94.

2.3.2.2 Summary of Specific Federal and State Environmental Laws, Orders, and Regulations. Most major federal environmental laws contain specific language defining their applicability to federal facilities and specifying the requirements for federal facilities to comply with certain state and local pollution control laws and regulations. This section discusses the applicability of each law to the Hanford Site.

2.3.2.2.1 Environmental Laws Relevant to Existing Operations and New Projects. Requirements of the environmental laws discussed below provide the bases for operating specifications for effluent releases from Hanford Site facilities and onsite activities. These requirements are also incorporated into the design of new facilities. 
2.3.2.2.1.1 Clean Air Act. The Clean Air Act provides mechanisms for the prevention and control of air pollution from stationary and mobile sources. Section 118 of the Clean Air Act (PL 88-206 as amended by PL 91-604, 42 USC 7401 , et seq.) states that Cederal agencies will comply with federal, state, and iocal requirements. Applicable requirements are contained in regulations issued by the EPA (in 40 CFR 50-87), and by the State of Washington Department of Ecology, pursuant to the Washington Clean Air Act (RCW 70.94), as set forth in WAC 173-400 through 495. Applicable requirements also include local regulations established by the Benton-Frankl in/Walla Walla Counties Air Pollution Control Authority (General Regulation 80-7).

The regulations promulgated by EPA (in 40 CFR 61) include standards for the emission of radionuclides. Washington State has adopted radionuclide control emission standards (WAC 173-480) and an associated permit program (WAC 402-80). The Washington State program applies to the Hanford Site.

2.3.2.2.1.2 Clean Water Act. Section 313 of the Clean Water Act ( $P L$ 92-500 as amended, 33 USC 1251 , et seq.) requires federal facilities to obtain National Pollutant Discharge Elimination System permits to discharge into navigable waters, so that discharges into navigable waters are within EPA-approved state water quality standards and technology-based requirements. Washington State standards are contained in WAC 173-201. The permit for DOE facilities at the Hanford Site is currently issued by the EPA Region $X$. Source, special, and byprodict materials are not subject to regulation under the Clean Water Act or state programis implementing the Clean Water Act.

\subsection{Resource Conservation and Recovery Act. The Resource} Conservation and Recovery Act (RCRA) (PL 94-580, as smended, 42 USC 6501, et seg.) provides for protertion of health and the environment from activities associated with the manageinent and disposal of solid wastes. It sets forth requirements for generators and transporters of hazardous waste and also establishes a specific permit program for the treatment, storage, and disposal of hazardous wastes. The statute is intended to place primary responsibility for control of solid waste activities on s:ate and local governments. Under Section 6001 of RCRA, the Hanford Site is subject to applicable federal, state, interstate, and local solid and hazardous waste requirements.

The RCRA specifically exempts special nuclear material (SNM), source, and byproduct materials from the definition of a solid waste in Section 1004 of RCRA. The RCRA also provides that its provisions shall not apply, nor shall it authorize any state or local entity to regulate any activity or substance, that is subject to the Atomic Energy Act of 1954, as amended, except to the extent that such an application is not inconsistent with requirements of that Act. In accordance with 10 CFR Part 962, radioactive (source, special, and byproduct material component) is regulated under the AE?.

The EPA has promulgated regulations to implement RCRA requirements in 40 CFR 260-270. The hazardous waste regulations contain interim status standards that are applicable before a final permit is issued, and final status standards applicable after issuance of a final status permit. Washington State has promulgated hazardous waste regulations in Washington Administrative Code (WAC) 173-303, pursuant to Chapter 70.105 of the Revised Code of Washington (RCW). The EPA has authorized Washington State to conduct the major portions of the RCRA hazardous waste interim status and final status 
permit program for nonradioactive hazardous wastes. The EPA has retained authority to implement those sections of the hazardous waste program mandated by the 1984 amendments to RCRA.

Washington State standards relative to disposal of nonhazardous solid waste are set forth in WAC 173-301 and 304, Regulations Relating to Minimum Functional Standards for Solid Waste Handling.

2.3.2.2.1.4 Comprehensive Environmental Response, Compensation, and Liability Act. Generally referred to as the "Superfund" statute, the Comprehensive Environmental Response, Compensation, and Liability Act (CERCLA) ( $P L$ 96-510, 42 USC 9601, et seq.) establishes reporting requirements for nonfederally permitted releases of hazardous substances (e.g., spills) and establishes a program for funding and undertaking remedial action at inactive hazardous waste sites. Federal agencies are subject to the reporting and inactive waste site requirements of CERCLA, but are not entitled to use the trust fund established by CERCLA for cleanup. Inactive waste sites at DOE facilities are evaluated under DOE Order 5480.14 (DOE 1985a).

\subsection{Safe Drinking Water Act. The Safe Drinking Water Act} (PL 93-523, 42 USC $300 f$ et seq.) is intended to protect the public health by setting standards for the water supplied for public consumption by protecting public drinking water sources. The Act protects these water sources from underground injection of materials that affect drinking water quality. Section 1447 of the Act requires that federal agencies maintaining a public water system or engaging in underground injection that endangers drinking water must comply with federal, state, and local requirements concerning the provision of safe drinking water and underground injection. Regulations implementing the Safe Drinking Water Act are contained in 40 CFR, Part 141-144.

2.3.2.2.1.6 Toxic Substances Control Act. Federal agencies are subject to the requirements of the Toxic Substances Control Act (PL 94-469 as amended, 15 USC 2601, et sea.). The Act is designed to protect human health and the environment from exposure to chemical substances and mixtures. It also enables the EPA to regulate the manufacture, distributior, processing, use, and disposal of substances that, as determined by the EPA, may present an unreasonable risk of injury to health or the environment.

The primary program of relevance of the Act to the Hanford Site is that for regulation of activities associated with use or disposal of polychlorinated biphenyls, pursuant to Section 6 of the Act. Pertinent regulations are codified as 40 CFR 761 .

2.3.2.2.1.7 Federal Insecticide, Fungicide, and Rodenticide Act. The Federal Insecticide, Fungicide, and Rodenticide Act (PL 92-516 as amended, 7 USC 136, et sea.) regulates the manufacture and use of pesticides. The Act authorizes state programs to certify applicators of pesticides. Washington State has a federally apnroved program to certify pesticide applicators, including those at the Hantord Site.

2.3.2.2.1.8 Atomic Energy Act of 1954. The Atomic Energy Act of 1954 (PL 83-703 as amended, 42 USC 2011, et seq.) authorizes DOE to conduct nuclear materials production, $R \& D$, and associated activities. The Act authorizes the agency to regulate its research, development, and production activity and to adopt such orders and standards as it may deem necessary to protect health and 
safety. The DOE has issued an extensive set of orders to regulate operations of its facilities. Pursuant to the Act and Reorganization P7an No. 3 of 1970 , the EPA promulgates generally applicable standards for control of environmental radiation. Pursuant to that authority, the EPA has promulgated standards for the management and disposal of spent fuel, high-level, and transuranic (TRU) waste (40 CFR 191).

\subsection{Noise Control Act. The Noise Control Act (PL 92-574 as} amended, 42 USC 4901 , et sea.) authorizes the EPA to establish regulations and guidelines for the reduction of noise. Additional state and local requirements for equipment not covered by federal standards must also be met by Hanford Site activities.

2.3.2.2.2 Environmental Laws Relevant to New Projects. Certain laws require that the potential environmental impact of new projects be identified and appropriate measures planned before the start of construction and operation. The requirements of these laws are incorporated into the planning and construction of new facilities and modifications to existing facilities at the Hanford Site. These laws are described below.

\subsection{National Environmental Policy Act. The National} Environmental Policy Act (PL 91-190, 83 Stat. 852, 422 USC 4321, et seq.) establishes a national policy requiring consideration and disclosure of environmental impacts and protection of the natural environment during the planning of proposed activities. The Act requires federal agencies to demonstrate that decision-making is conducted in an integrated systematic manner. It also requires that environmental amenities and values be given appropriate consideration along with economic and technical factors. All major federal actions that significantly affect the quality of the human environment must be accompanied by an environmental impact statement (EIS) prepared in accordance with the Council of Environmental Quality requirements.

For Hanford Site programs and projects, the DOE-RL implements the Act through DOE Order 5440.1C (DOE 1985b), DOE-RL Order 5440.1A (DOE-RL 1987), and DOE Guidelines for Compliance with the National Environmental Policy Act, 45 FR 20694, as amended.

2.3.2.2.2.2 Comprehensive River Conservation Act (Hanford Reach Study) directs the Secretary of the Interior, in consultation with the Secretary of Energy, to conduct a "comprehensive river conservation study" of the Hanford Reach. The Act directs the agencies to evaluate the natural and cultural resources, scenery and recreational activities of the reach, and investigate alternative strategies for the protection of important values. Major new projects such as dam and navigation developments are specifically prohibited and other new projects within the study area are subject to review by the Secretary of the Interior to ensure that the important values of the Hanford Reach are protected.

2.3.2.2.2.3 Endangered Species Act of 1973. The Endangered Species Act of 1973 (PL 93-205 as amended, 16 USC 1531, et seg.) is intended to prevent the further decline of threatened or endangered species, and to promote the restoration of these species and their habitats. Under Section 7 of this Act, the Hanford Site is required to consult, as appropriate, with the U.S. Fish and Wildi ife Service to determine whether threatened or endangered species wi1! ? be affected by a proposed project. 
2.3.2.2.2.4 Fish and Wildlife Coordination Act. The Fish and Wildlife Coordination Act (PL 85-624 as amended, 16 USC 661, et seq.) requires that consideration be given to the conservation of fish and wild ife during the development of water-related projects. The Hanford Site is required to consult, as appropriate, with the U.S. Fish and Wildlife Service and with state wildlife agencies. Measures to mitigate, prevent, or compensate for wildlife losses must be included in the project plan.

\subsection{Executive Order 11988 (Floodplain Management) and Executive} Order 11990 (Protection of Wetlands). These executive orders require governmental agencies to implement regulations that will protect wetlands and minimize adverse effects of development in floodplains. The DOE has established regulations under 10 CFR 1022, establishing procedures for compliance with these executive orders.

2.3.2.2.2.6 Rivers and Harbors Act of 1899 (33 USC 401) and Section 404 of the Clean Water Act (PL 92-500 as amended, 33 USC 1251 et seq.). These Acts require that a permit be obtained from the U.S. Army Corps of Engineers before any alteration of the course, location, conditions or channels, or discharges of dredge or fill materials into any navigable waters (Columbia and Yakima Rivers at the Hanford Site).

2.3.2.2.2.7 National Historic Preservation Act. Section 106 of the Historic Preservation Act (PL 89-665 as amended, 16 USC 470, et seg.) requires the federal agency with jurisdiction over a federal project to provide the Advisory Council on Historic Preservation with an opportunity to comment on the effect the activity may have on properties included in or eligible for nomination to the National Register of Historic Places. The Hanford Site is required to consult with the State Historic Preservation Office to determine whether the site of a proposed action contains structures or objects 1 isted or eligible for listing in the Register.

Related acts that must also be considered include the Antiquities Act (16 USC 433), Archaeological Resources Protection Act (PL 96-95, 16 USC 470), and Historic Site Buildings and Antiquities Act (16 USC 461).

\subsection{The American Indian Religious Freedom Act (42 USC 1996)} establishes the policy of the United States to protect and preserve the rights of Native Americans to believe, express, and exercise their traditional religions. It requires federal land managers to obtain and consider the views of Indian leaders when a project may interfere with the free exercise of traditional Indian religions and avoid unnecessary interference with Indian religious practices.

2.3.2.2.2.9 0ther State Environmental Laws. In addition to the laws described above, there are several state laws whose substantive requirements are factored into the design of new facilities and major modifications to existing facilities. These laws are discussed below. 
2.3.2.2.2.10 The Hydraulics Projects Act (RCW 75.20.100). This Act and its implementing regulations (WAC 220-110) are designed to protect fishery resources. The 1 aw and regulations require state approval before conducting activities within the stream bed of any river if those activities will use, divert, obstruct, or change the natural flow of the river. The DOE-RL has and will continue to obtain approval from the state, as a matter of comity, before undertaking a project within the stream bed of the Columbia or Yakima rivers.

2.3.2.2.2.11 The State Board of Health Act (RCW Ch. 43.20). This Act and associated implementing regulations (WAC 248-96) establish criteria for onsite sewage disposal systems. They al so authorize local health boards to establish rules governing such systems. New facilities at the Hanford Site are designed to meet the intent of these regulations.

The state has established programs to control the discharge of waste materials from industrial, commercial, and municipal operations into ground and surface waters of Washington State, pursuant to the Water Pollution Control Act (RCW 90.48). The regulations are contained in WAC 173-216 and WAC 173-240. New facilities at the Hanford Site are designed to meet the intent of these regulations.

2.3.2.3 U.S. Department of Energy Orders. The following is a list of several applicable DOE Orders.

- U.S. Department of Energy. Washington, D.C.

DOE 5000.3, Unusual Occurrence Reporting System, 1984

DOE 5400.1, General Environmental Protection Program, 1988

DOE 5440.1C, National Environmental Policy Act, 1985

DOE 5480.1B, Environment, Safety, and Health Program for DOE

Operations, 1986

DOE 5480.4, Environment, Safety, and Health Protection Standard, 1984

DOE 5480.14, Comprehensive Environmental Response, Compensation, and Liability Act Program, 1985

DOE 5481.1B, Safety Analysis and Review System, 1986

DOE 5482.1B, Environment, Safety, and Health Appraisal Program, 1986

DOE 5484.1, Environment, Safety, and Health Protection Information Reporting Requirements, 1981

DOE 5500.1A, Emergency Management System, 1987

DOE 5500.3, Reactor and Nonreactor Nuclear Facilities Emergency Planning, Preparedness, and Response for DOE Operations, 1981

DOE 5500.4, Public Affairs Policy and Planning Requirements for Emergencies, 1981 
DOE 5700.6B, Quality Assurance, 1986

DOE 5820.2A, Radioactive Waste Management, 1988.

- U.S. Department of Energy-Richland Operations Office, Richland, Washington

DOE-RL 5440.1A, Implementation of the National Environmental Policy Act at Richland Operations, 1987

DOE-RL 5480.1, Environmental Protection, Safety, and Health Protection for Richland Operations (Chapters III \& VI), 1982

DOE-RL 5480.4A, Environmental Protection, Safety, and Health Protection Standards, 1987

DOE-RL 5480.11A, Requirements for Radiation Protection, 1986

DOE-RL 5481.1, Safety Analysis and Review System, 1983

DOE-RL 5482.1B, Environment, Safety, Health, and Quality Assurance Appraisal and Surveillance Program, 1987

DOE-RL 5484.1, Environment Protection, Safety, and Health Protection Information Reporting Requirements, 1983

DOE-RL 5484.2A, Unusual Occurrence Reporting System for Richland Operations, 1984

DOE-RL 5700.1A, Quality Assurance, 1983.

2.3.2.4 Regulatory Documentation. The following section lists regulatory documentation applicable to the Hanford Site.

Office of Management and Budget, Circular No. A-106, December 31, 1974.

Reporting Requirements in Connection with the Prevention, Control and Abatement of Environmental Pollution at Existing Federal Facilities

Executive Order 12088, Federal Compliance with Pollution Control Standards, October 13, 1978

Executive Order 11988, Floodplain Management

Executive Order 11990, Protection of Wet 7 ands

Hanford Federal Facility Agreement and Consent Order.

2.3.2.5 Easements. The following organizations have easements across the Hanford Site:

- Big Bend Alberta (mineral rights)

- Bonneville Power Administration 
- Benton County Public Utility District No. 1

- City of Richland

- Columbia Communication

- GTE Northwest, Inc.

- Mobilfone N.W.

- Motorola Inc.

- Pacific Power and Light

- Port of Benton

- Richl and Amateur Radio

- South Columbia Irrigation District

- U.S. Army Corps of Engineers (300-ft flowage right by agreement, 7-18-68)

- United Telephone

- Washington Public Power Supply System

- Washington State Department of Transportation (Road 240). .

The U.S. Army Corps of Engineers has also identified the site of a proposed dam (Ben Franklin Dam) and dredging of the Columbia River through the Hanford Site to extend river transportation as far as Wenatchee, Washington. However, the Comprehensive River Conservation Study Act prohibits these projects until at least November 1996.

\subsection{PUBLIC TRANSPORTATION}

An excellent transportation network within and surrounding the Tri-Cities area facilitates travel and the marketing of goods and commodities. Commercial air transportation is available at the Tri-Cities Airport, which offers direct service to major regional cities with connections to cities nationwide via several airlines. Barge lines are used to transport bulk commodities along the Columbia and Snake Rivers. A network of freight rail transportation is provided by the Burlington Northern, Washington Central, and Union Pacific railroads. Interstate highways and state routes connect the region to major metropolitan areas throughout the Pacific Northwest.

\subsubsection{Road Networks}

Interstate highways provide ready access to the Tri-Cities area. Interstates 84 and 90 run east/west and are located to the north and south of the Tri-Cities, respectively (Figure 2-7). These two highways are connected to the Tri-Cities by Interstate 82 . These three highways provide the major links to Seattle and Spokane, Washington; Boise, Idaho; and Portland, Oregon. 
Figure 2-7. Local and Regional Highway Network Linking the

Tri-Cities with Major Interstate Highways.

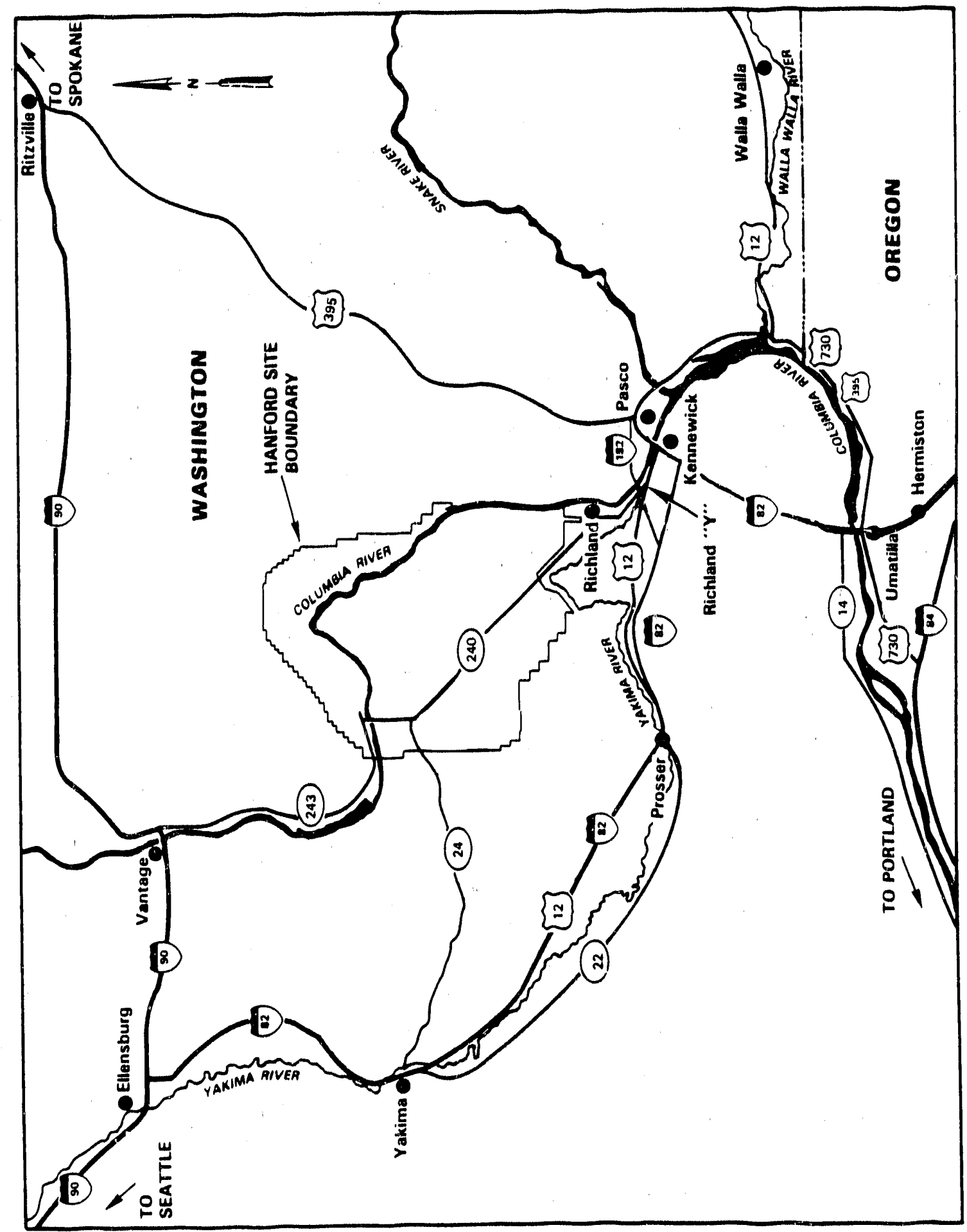


Four important United States and state routes provide access to the major interstate highways (see Figure 2-7). The U.S. Highway 12 comes from the Puget Sound area and continues through to the Midwest via Walla Walla, Washington, and Lewistion, Idaho. The U.S. Highway 395 begins north of Spokane at the Canadian border and extends to southern California. State Route 14 connects with U.S. Highway 395 to provide intrastate traffic between the Tri-Cities and Vancouver, Washington. State Route 240 provides access to Interstate 90 at Vantage. Interstate 5 connects Seattle and Portland and runs the entire length of the West Coast (Figure 2-8).

Interstate 90 extends from Seattle through the Midwest to Chicago, Cleveland, Buffalo, and Boston.

Major highways in the Tri-cities area carry between 30,000 and 50,000 vehicles per day. Highway capacities are generally adequate to meet highway transportation needs. the DOE.

The Hanford Site is served by roadways that are owned and maintained by

\subsubsection{Airlines and Airports}

The Tri-cities is served by four public airports, seven private airports, and six heliports. The public airports are the Tri-Cities Airport in Pasco, Vista Field in Kennewick, Richland Airport in Richland, and the Prosser Airport in Prosser. The Tri-Cities Airport is classified as an air carrier airport, Richland as a commuter service airport, and Vista Field and Prosser as general aviation airports.

The Tri-Cities Airport is the major air carrier airport in the area. A regional air facility, it serves portions of seven counties in Washington. and Oregon. It is one of four air carrier airports in Washington State; the other three are Seattle-Tacoma International Airport, Spokane International Airport, and the Yakima Air Terminal.

Total annual commercial passenger boardings at the Tri-Cities Airport by year since 1985 are as follows:

- $1985--142,911$

- $1986--189,994$

- $1987--180,934$

- $1988--160,121$

- $1989--158,598$. 
Figure 2-8. Major Pacific Northwest Interstate Highways Providing Access to the Tri-Cities.
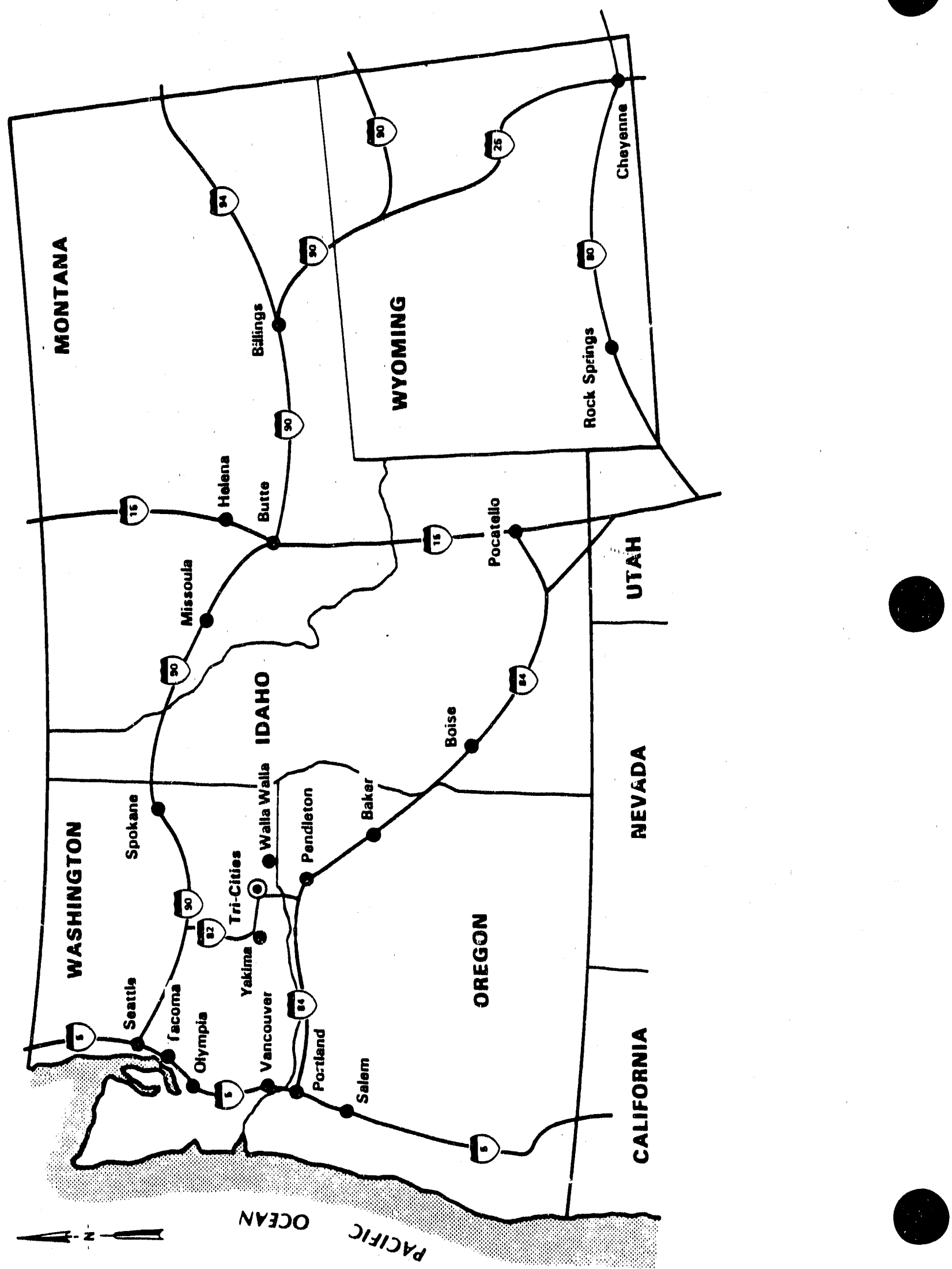
Projected commercial passenger boardings for 1990, as of January 1990, are in a range of 160,000 to 170,000 . Current air carriers include Delta, United Express, and Horizon Air.

A new 58,000- $\mathrm{ft}^{2}$ terminal building, completed in 1986, provides state-ofthe-art air traffic control, ticketing, baggage handling, and related services for Tri-Cities airline customers. Convenient features of the airport include adjacent parking facilities operated by the Port of Pasco, numerous automobile rental agencies, and passenger transport services to all Tiri-cities points by the Ben FrankT in Transit Authority.

\subsubsection{Railroads}

The Tri-Cities is served by the Burlington Northern, Washington Centra1, and Union Pacific Railroads, making the area one of the few between the Cascade Range and the Rocky Mountains to be linked by these systems. Passenger services are provided by Amtrak. In addition, a short line, operated by the DOE, runs in the Richiand/Hanford Site area.

Agricultural products, fuel, and fertilizer, plus construction materials and equipment, are the principal commodities shipped by rail. Manufactured fertilizer products, grain, and frozen food make up the greatest share of outgoing commodities. Large quantities of other food products also leave the Tri-cities by rail. The inbound freight includes fertilizer, raw material, chemical, fuel, farm equipment, and construction supplies and equipment.

The Tri-cities is the hub of the Burlington Northern lines in the Pacific Northwest, which extends $232 \mathrm{mi}$ southwest to Portland, $145 \mathrm{mi}$ northeast to Spokane, and $251 \mathrm{mi}$ northwest to Seattle (Figure 2-9). Washington Central Railroad recently acquired the Burlington Northern Iine between the Tri-Cities and Yakima. A computerized classification yard is located in Pasco. Trains move into the yard and are broken up and blocked to move east, west, north, or south.

The Union Pacific connects the Pacific Northwest and the cities of San Francisco and Los Angeles on the west coast to the Great Lakes region and the Gulf of Mexico to the east and southeast, respectively. All service to the Pacific Northwest over the Union Pacific system goes through the modern, computerized regional classification yard at Hinkle, Oregon, approximately $50 \mathrm{mi}$ south of the Tri-Cities. The Tri-Cities is serviced by the Yakima branch line, which connects directly to the regional classification yard at Hinkle.

The DOE controls the rail access into the Hanford Site; their tracks tie into the Union Pacific tracks southeast of the Richland "Y" area near U.S. Highway 12. The Washington Central Railroad Company and Union Pacific have trackage rights over the DOE trackage between the Richland "Y" area and the DOE 1100 Area in north Richland. The DOE tracks serving the Hanford Site are parallel to the Route 240 bypass. 
Figure 2-9. Major Pacific Northwest Rail Lines Providing Access to the Tri-Cities.

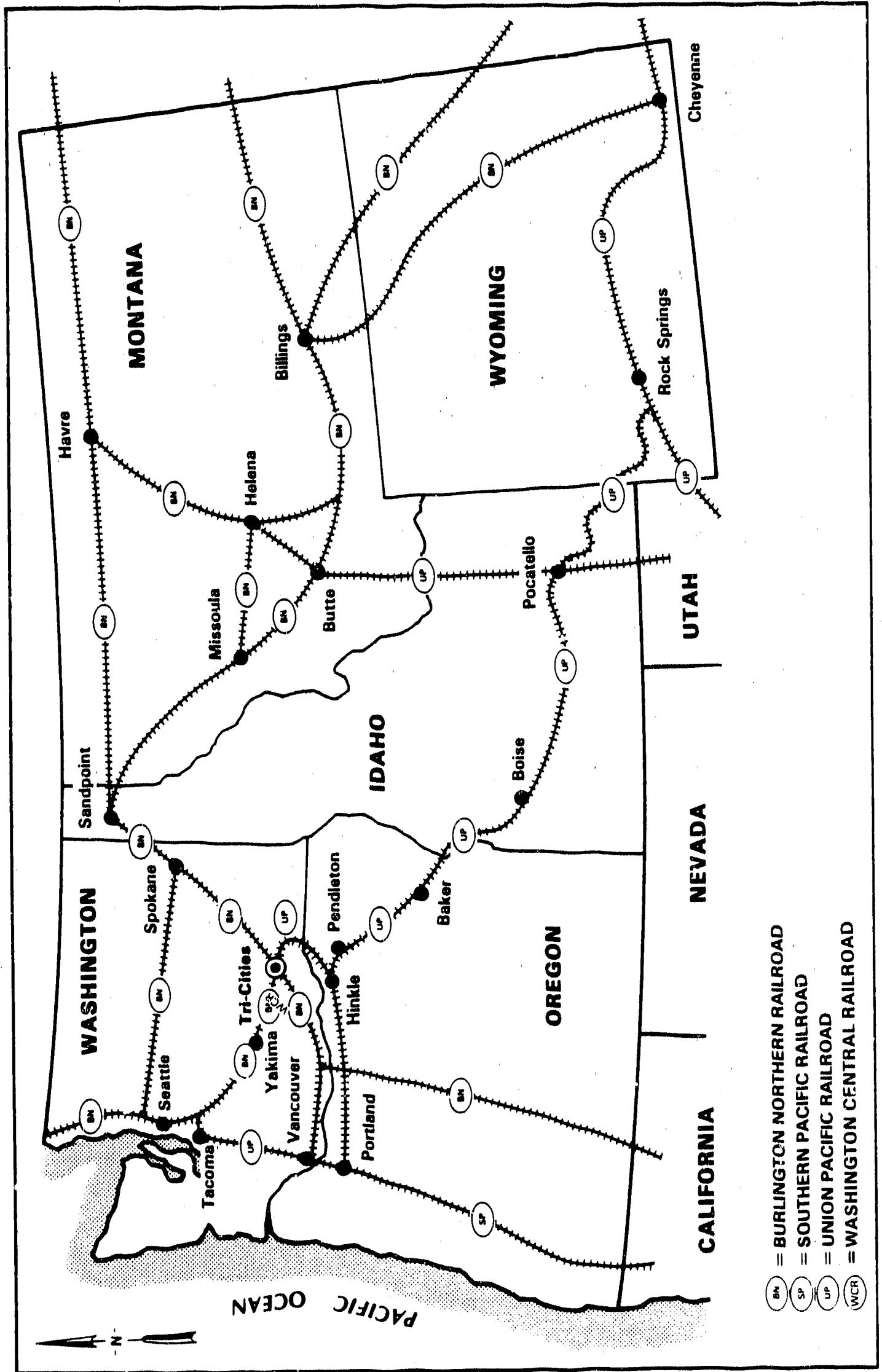




\subsubsection{Waterways}

The Columbia-Snake River System is one of the most modern internodal transportation networks in the world. This commercial waterway extends $465 \mathrm{mi}$ from the Pacific Ocean to Lewistor. Idaho. The system inclides eight dams and lock complexes that allow the numerous barge lines serving the river system to trarisport commodities. The Panamax vessels, which transport the commodities, are operated by 35 steamship lines that call at several ports along the $40 . \mathrm{ft}$ channel in the lower Columbia River. The lower Columbia River ports offer the shortest route to the Orient, which is approximately 4,217 nautical miles from the mouth of the river to Japan.

Numerous docking facilities in the Tri-cities are available for commercial use or for serving specific industries. These facilities are only $325 \mathrm{mi}$ inl and from the Pacific Ocean and offer an average barge movement time of $36 \mathrm{~h}$ to the deepwater ports in the lower Columbia River.

Several barge companies currently offer service to the Tri-Cities area with specialized barges that handle a wide variety of cargo. These barge companies have Interstate Commerce Commission authority to the Tri-Cities area and provide service up the Snake River to ports as far inland as Clarkston, Washington, and Lewiston, Idaho.

\subsubsection{Public Transit}

The Ben Franklin Transit Authority serves the Tri-Cities MSA in Benton and Franklin Counties. It operates buses on 15 routes spanning $300 \mathrm{mi}$. Service includes regular and express bus service, van pools, dial-a-ride for the elderly and disabled, park-and-ride lots, and computerized ride matching.

\subsection{UTILITIES}

Electricity is the only regional utility service supplied to the Hanford site. Utilities located onsite are described in jection 3.4.1.

Table 2-5 summarizes the energy consumption and costs for all the areas of the Hanford Site from 1985 to 1988. 


$$
\text { DOE/RL-89-15 }
$$

Table 2-5. Energy Consumption and Costs for Buildings and Facilities on the Hanford Site from 1985 to ? 988.

\begin{tabular}{|c|c|c|c|c|}
\hline $\begin{array}{l}\text { Energy source } \\
\text { (unit) }\end{array}$ & Year & Consumption & $\begin{array}{l}\text { Total cost } \\
(x \$ 1,000)\end{array}$ & $\begin{array}{l}\text { Actual unit } \\
\text { cost }(\$)\end{array}$ \\
\hline $\begin{array}{l}\text { Electricity } \\
\text { (MWh) }\end{array}$ & $\begin{array}{l}1985 \\
1986 \\
1987 \\
1988\end{array}$ & $\begin{array}{l}542,253 \\
539,527 \\
510,109 \\
497,337\end{array}$ & $\begin{array}{l}11,847.9 \\
11,753.6 \\
10,876.3 \\
11,486.7\end{array}$ & $\begin{array}{l}21.85 \\
21.78 \\
21.32 \\
23.09\end{array}$ \\
\hline $\begin{array}{l}\text { Fuel oil } \\
\qquad(1,000 \mathrm{gal})\end{array}$ & $\begin{array}{l}1985 \\
1986 \\
1987 \\
1988\end{array}$ & $\begin{array}{l}8,039 \\
6,967 \\
2,847 \\
3,028\end{array}$ & $\begin{array}{l}5,739.5 \\
3,954.6 \\
1,075.9 \\
1,295.6\end{array}$ & $\begin{array}{l}713.96 \\
567.62 \\
377.94 \\
427.93\end{array}$ \\
\hline $\begin{array}{l}\text { Natural gas } \\
\left(1,000^{\left.\mathrm{ft}^{3}\right)}\right.\end{array}$ & $\begin{array}{l}1985 \\
1986 \\
1987 \\
1988\end{array}$ & $\begin{array}{l}14,984 \\
23,409 \\
18,223 \\
16,400\end{array}$ & $\begin{array}{r}98.8 \\
136.4 \\
87.9 \\
114.5\end{array}$ & $\begin{array}{l}6.59 \\
5.83 \\
4.82 \\
6.98\end{array}$ \\
\hline $\begin{array}{l}\text { Liquified petroleum } \\
\text { gas }(1,000 \text { gal) }\end{array}$ & $\begin{array}{l}1985 \\
1986 \\
1987 \\
1988\end{array}$ & $\begin{array}{r}17.4 \\
17.2 \\
14.4 \\
874.6\end{array}$ & $\begin{array}{r}12.6 \\
12.1 \\
9.8 \\
400.4\end{array}$ & $\begin{array}{l}724.14 \\
703.49 \\
680.55 \\
457.78\end{array}$ \\
\hline Coal (short tons) & $\begin{array}{l}1985 \\
1986 \\
1987 \\
1988\end{array}$ & $\begin{array}{l}114,079 \\
133,755 \\
101,339 \\
101,210\end{array}$ & $\begin{array}{l}5,797.29 \\
7,843.45 \\
6,066.52 \\
6,085.62\end{array}$ & $\begin{array}{l}50.82 \\
58.64 \\
59.86 \\
60.12\end{array}$ \\
\hline
\end{tabular}

\subsubsection{Electricity}

Except for a minor amount of total site needs provided by the city of Richland to the 700,1100 , and 3000 Areas, electricity for the Hanford Site is supplied by the BPA. Currently, the Northwest generates a surplus of power, but unofficial projections now estimate that the surplus will be fully utilized within the next $10 \mathrm{yr}$ or less depending on the strength of the economy, usage growth, and export to other regions.

The DOE's contract with the BPA gives the Hanford Site a Priority Firm supnly rating. This rating ensures that in the event of regional power shortages, the Hanford Site, along with other Priority Firm customers, would be the last level of BPA service to be shut off. 
The cost of electrical power per megawatt hour (MWh) charged by the BPA to the DOE in recent years was as follows:

- 1984--\$20.81

- $1985--\$ 21.57$

- $1986--\$ 21.80$

- $1987--\$ 20.94$

- $1988--\$ 22.41$

- $1989--\$ 22.41$.

In addition to the use charge, a demand rate is applicable, depending on the season of the year.

\subsection{REFERENCES}

DOE, 1985a, Comprehensive Environmental Response Compensation, and Liability Act Program, DOE Order 5480.14, U.S. Department of Energy, Washington, D.C.

DOE, 19856, National Environmental Policy Act, DOE Order 5440.1C, U.S. Department of Energy, Washington, D.C.

DOE-RL, 1987, Implementation of the National Environmental Policy Act at the Richland Operations office, DOE-RL Order 5440.1A, U.S. Department of Energy-Richland Operations Office, Richland, Washington.

Ecology, EPA, and DOE, 1989, Hanford Federal Facility Agreement and Consent Order, Washington Sitate Department of Ecology, U.S. Environmental Protection Agency, and U.S. Department of Energy, 01ympia, Washington.

Nuclear Waste Policy Act of 1982, Public Law 97-425, 96 stat. 2201, 42 USC 10101. 
DOE/RL-89-15

\subsection{EXISTING CONDITIONS}

This section describes the current conditions specific to the Hanford Site, in terms of the following topics: land use and leased facilities; mission, programs, and contractors; Hanford Site employment; Site improvements (utilities, buildings, and other structures); physical characteristics; security; safety; and environmental issues.

\subsection{LAND USE AND LEASED FACILITIES}

This section describes the use of the major areas of the Hanford Site. Facilities that are leased by the U.S. Department of Energy (DOE) contractors are identified.

\subsubsection{Land Use}

The DOE controls the $560 m \mathrm{mi}^{2}$ Hanford Site. The DOE intends to maintain control of the Site in the future, at least until decommissioning, decontamination, and cleanup are completed. Within the Site are several DOE operating areas where specific access requirements exist (Figure 3-1). Descriptions of these major areas follow.

3.1.1.1 100 Areas. The 100 Areas occupy six sites, which are approximately $4.25 \mathrm{mi}^{2}$. They border the south shore of the Columbia River in the northern portion of the Hanford Site. Eight retired plutonium production reactors and the dual-purpose $\mathrm{N}$ Reactor, which produced plutonium for weapons and steam for electrical power generation, are located in these areas. The $N$ Reactor is currently in dry standby status as a contingency source for weapons grade plutonium or tritium.

3.1.1.2 200 West and 200 East Areas. The 200 Areas occupy approximately $6 \mathrm{mi}^{2}$ on a plateau approximately 5 and $7 \mathrm{mi}$, respectively, from the Columbia River. The 200 Areas are dedicated to fuel processing and waste disposal activities.

3.1.1.3 300 Area. The 300 Area occupies approximately $1.10 \mathrm{mi}^{2}$ north of Richland and adjacent to the Columbia River. Research and development (R\&D) and engineering technology development are the major functions at this area. The fuel fabrication facility for $N$ Reactor is in standby status. The pressurt tube fabrication facility ( 313 Building) is also in standby status.

3.1.1.4 400 Area. Approximately $5 \mathrm{mi}$ north of the 300 Area and $4 \mathrm{mi}$ west of the Columbia River is the 400 Area, where the Fast Flux Test Facility (FFTF) and the Fuels and Materials Examination Facility (FMEF) are located. This area occupies approximately $0.24 \mathrm{mi}^{2}$.

3.1.1.5 600 Area. The 600 Area includes all of the Hanford Site not occupied by the 100, 200,300,400,700, 1100, and 3000 Areas. Land uses within the 600 Area include the following.

- The Arid Lands Ecology Reserve (ALE) is a 120-mi² tract set aside for long-ierm ecological studies. For a detailed description of the ALE see Section 3.5.9. 
Figure 3-1. Land Use on the Hanford Site.

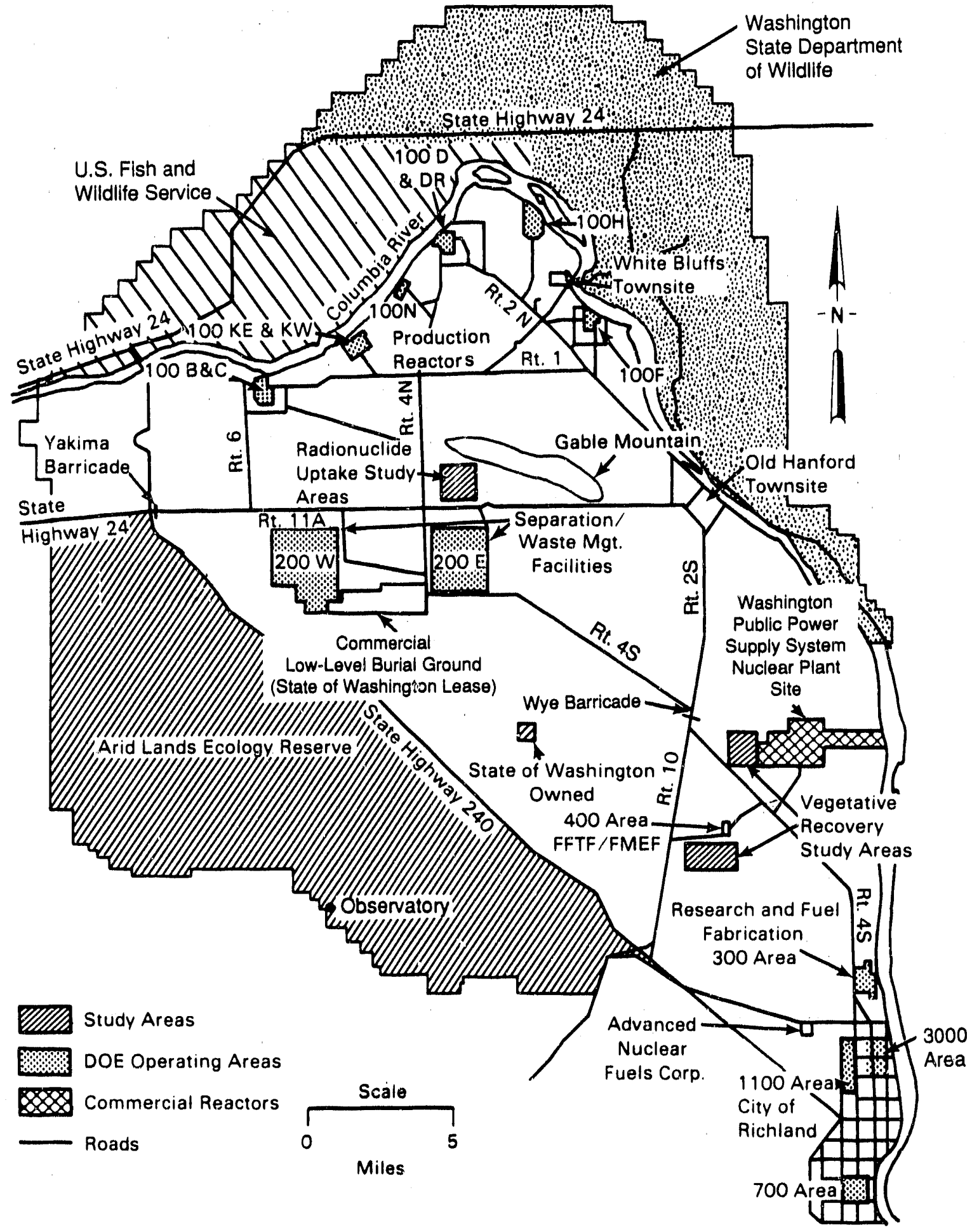

39001069.7 
- Washington State leases a $1.56-\mathrm{mi}^{2}$ tract to encourage the location of nuclear-related industry. The "Indenture of Lease" signed on September 10, 1964, is for a period of $99 \mathrm{yr}$.

- A 100-acre tract of the Washington State lease has been subleased by thie state to California Nuclear, Inc. (U.S. Ecology), who operates

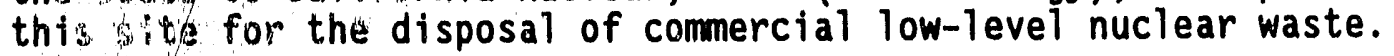

- In the 1970's. national emphasis was placed on each state having its own hazardous waste disposal location. In response to this emphasis, Washington State purchased a section $\left(1 \mathrm{mi}^{2}\right)$ of land south of the 200 Areas near State Route 240. The deed states that the express purpose of the 1 and is for developing a state-administered hazardous waste disposal site. This emphasis no longer exists, and development of the land for that purpose is not expected.

- The Washi gton Public Power Supply System leases two parcels of land on the Hanford Site from the federal government. Three commercial nuclear power plants are located on this land. Parcel A consists of $1.65 \mathrm{mi}^{2}$ and is the site of the Washington Public Power Supply System nuclear power plant No. 2 (WNP-2). Parcel $A$ is leased for $50 \mathrm{yr}$ with an additional 10-yr option. Parcel B consists of $1.56 \mathrm{mi}^{2}$ and is the location of Washington Public Power Supply System nuclear power plants No. 1 and 4 (WNP-1 and WNP-4). Parcel B is leased for $30 \mathrm{yr}$ with an option for additional time as requested by the Washington Public Power Supply System.

- The U.S. Fish and Wildlife Service refuge occupies approximately $50 \mathrm{mi}^{2}$ on the Wahluke Slope, under a revocable-use permit from the DOE.

- The Washington State Department of Wildlife administers a $90-\mathrm{mi}^{2}$ site on the Wahluke Slope. This site is used for recreational game management under a revocable-use permit from the DOE.

- The observatory and radiotelescope facilities are located on top of Rattlesnake Mountain, in the southwest portion of the Site.

- The Hanford Meteorology Station (HMS) is located between the 200 Areas. It consists of a 410-ft-tall steel tower equipped with wind and temperature sensors.

The areas occupied by the ALE, U.S. Fish and Wibdl ife Service refuge, and the Washington State Department of Wildlife total about $260 \mathrm{mi}^{2}$. They provide a buffer zone around the areas of nuclear activity.

3.1.1.6 700 Area. This area occupies approximateiy 2.4 acres within the city limits of Richland. The 700 Area once encompassed all of the original city of Richland. Reduction to its present size occurred in 1958 when the federal government liquidated its city properties. The 700 Area serves as an administrative center for government employees involved in supervising contractor-operated facilities and programs at the Hanford Site. The Emergency Decontamination Facility (748 Building) is located on non-federal land, adjacent to Kadlec Medical Center. It is operated under the provisions ô a $9 y-y r$ iease. 
3.1.1.7 1100 Area. The 1100 Area occupies 160 acres of owned 1 and in the southern part of the Hanford Site. This area serves as a central warehousing, vehicle maintenance, and transportation/distribution center.

3.1.1.8 3000 Area. The 3000 Area is south of the 300 Area and north of the 1100 Area. The engineering/constructor contractor uses 60 acres of owned land in this area for general office space, warehousing, and shops. The R\&D contractor has privately owned and leased laboratory facilities here.

The 1100 and 3000 Areas also include parts of the city of Richland where privately owned facilities are leased for administrative and support functions.

\subsubsection{Leased Facilities}

The DOE contractors lease 22 facilities from private companies for office and support facilities. Acquisition is accomplished according to regulations provided in DOE Order 4300.1B (DOE 1987b) and DOE-Richland Operations office (DOE-RL) Order 4300.1A (DOE-RL 1987). The Umatilla Army Depot is also used by the operations and engineering contractor for storage under an agreement between DOE and the U.S. Department of Army. Table 3-1 and Figure 3-2 describe these facilities. The R\&D contractor uses approximately $1.4 \mathrm{million} \mathrm{ft}^{2}$ of DOE- and privately owned facilities. The R\&D contractor also rents facilities from private companies. Approximately 3,000 R\&D contractor employees use these facilities interchangeably in performing work for the DOE, other federal agencies, and private industry. Use of these facilities for multiprogram activities is through a formal arrangement with the DOE.

\subsection{MISSION, PROGRAMS, AND CONTRACTORS}

This section identifies the present mission, programs, and contractors at the Hanford Site. Major Hanford Site programs are briefly jescribed, as are the several DOE contractors.

\subsubsection{Present Mission}

The mission of the Hanford Site is to successfully conduct the environmental, energy, R\&D, and defense production programs of the $D O E$ in the most economical, safe, secure, and environmentally acceptable means possible.

\subsubsection{Present Programs}

There are four major programs presently operating at Hanford:

Environmental Restoration and Waste Management, Advanced Reactors, R\&D, and Defense Production. 
Table 3-1. Commercial Buildings Leased by the U.S. Department of Energy Contractors (July 1989).

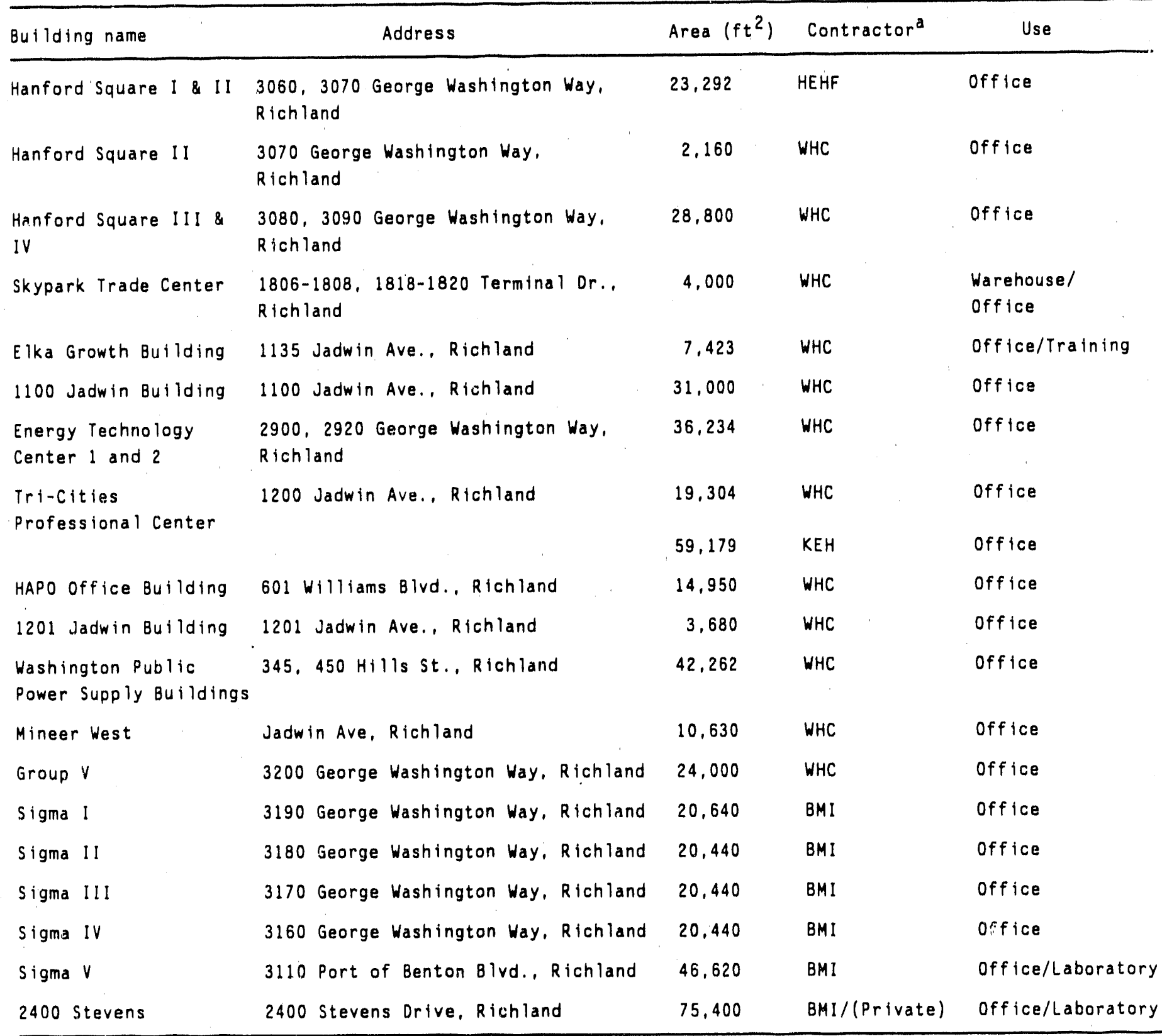

${ }^{a_{W H C}}=$ Westinghouse Hanford Company.

$K E H=K a i s e r$ Engineers Hanford.

$B M I$ = Battelle Memorial Institute.

HEHF = Hanford Environmental Health Foundation. 
Figure 3-2. Facilities Leased by the U.S. Department of Energy Contractors.

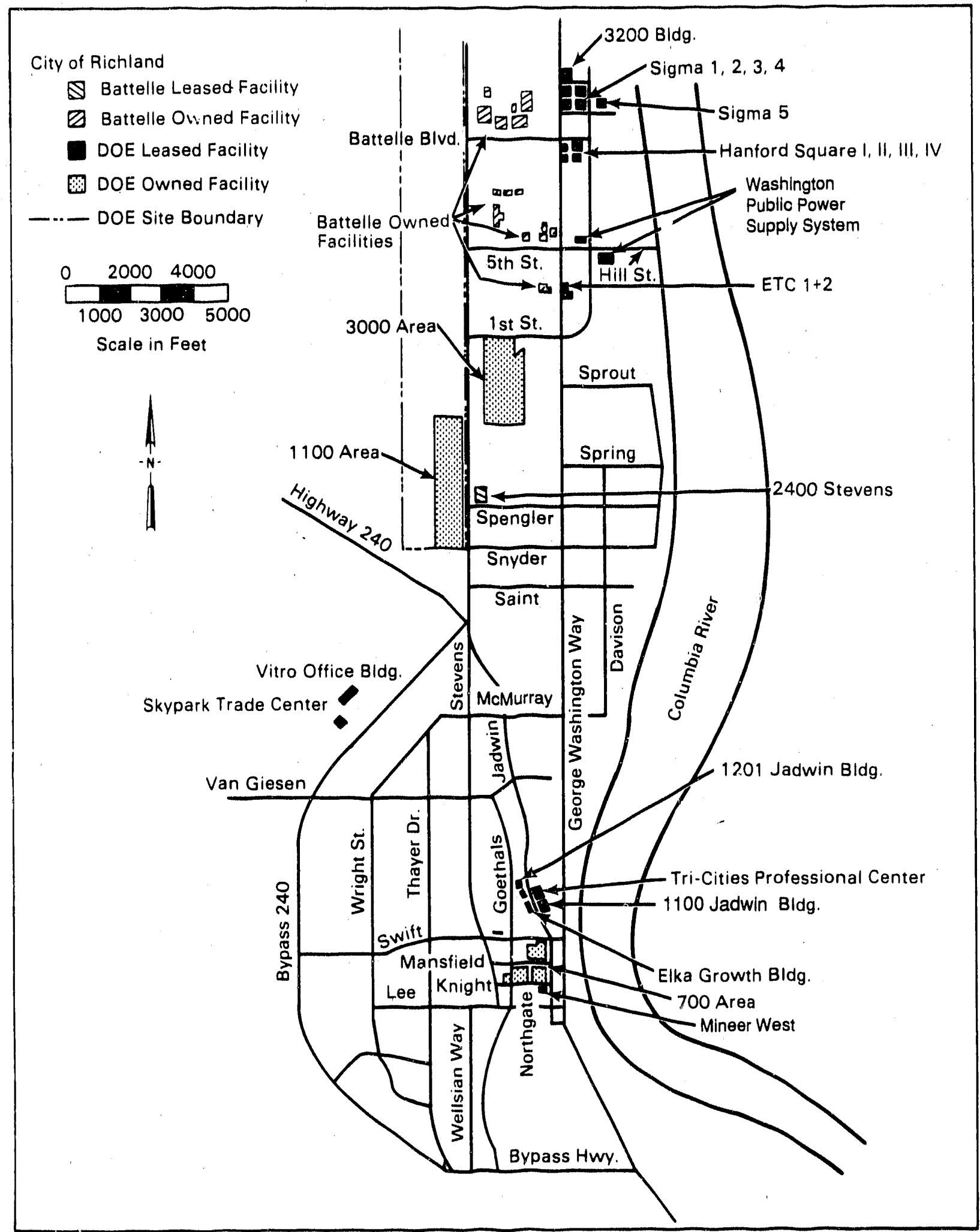


3.2.2.1 Environmental Restoration and Waste Management. The DOE, U.S. Environmental Frotection Agency (EPA), and Ecology have made an agreement, called the Tri-Party Agreement (Ecology et al. 1989). The primary. objectives of the Tri-Party Agreement are to bring the Hanford Site into compliance with state and federal hazardous waste laws, and to clean up the Hanford Site in a timely manner.

Approximately $440,000 \mathrm{yd}^{3}$ of high-level, transuranic, and tank wastes generated in the production of defense materials are stored and managed at the Hanford Site. Older liquids, which are stored in tanks, are being solidified into a salt form. Double-shell tanks are being used to store remaining liquids. Technology is being developed and options are being considered for ultimate disposal of all defense high-level, transuranic, and tanks wastes at the Hanford Site.

The Hanford Waste Vitrification Plant (HWVP) is currently in the design stage. This facility will be used for converting highly radioactive liquid wastes into glass for disposal in a offsite geologic repository. Liquid low-level radioactive and low-level mixed wastes will be mixed with grout and disposed of as solid in vaults located near the surface on the Hanford Site.

Work has begun on the planning, characterization, and remediation of the approximately 1,400 inactive hazardous and mixed waste sites and on the decontamination and decommissioning (D\&D) of about 100 surplus facilities.

3.2.2.2 Advanced Reactor Development. The FFTF provides irradiation test conditions for fuels and materials for the liquid metal reactor (LMR). Associated with the FFTF are two support facilities: the Maintenance and Storage Facility (MASF), which provides decontamination and sodium-removal facilities to support the reactor operation; and the Fuel Storage Facility, which provides spent fuel storage for the reactor in a liquid sodium environment. The FFTF also provides irradiation support for international programs. Research and development of advanced materials and fuels is also ongoing in the 300 Area facilities.

The FMEF is a six-story $151,540-\mathrm{ft}^{2}$ facility built to contemporary nuclear facility standards. Fuel fabrication for FFTF is being transferred to this facility. The FMEF, in conjunction with the FFTF, is the primary candidate for $238 \mathrm{Pu}$ and other isotope production and testing in support of power for space applications.

The SP-100 Ground Engineering System (GES) will support the testing of the advanced space reactor applications for the National Aeronautics and Space Administration (NASA), the DOE, and the U.S. Department of Defense (DOD).

3.2.2.3 Research and Development. Research is conducted in basic energy sciences, health and environmental research, and magnetic fus ' $(1)$ research and development, as well as energy research analys is and university research programs for the Office of Energy Research. Research in basic energy sciences focuses on molecular science, chemical sciences, materials sciences, geosciences, and applied mathematics. Environmental and heal th research programs are directed toward enhancing scientific knowledge about environmental and atmospheric transport of contaminants and the risks to ecosystems and humans 
in developing our Nation's energy resources. The Magnetic Fusion Energy program is focused on advancing first-wall and blanket technology through materials research.

Routine environmental, safety, and maintenance activities are applicable to all activities at the Hanford Site. Included here are monitoring, sampling, analysis, and operation of filtering, ventilation, and poliutioncontrol equipment. Safety and health activities include procurement and maintenance of protective equipment, an employee occupational health program, as low as reasonably achievable (ALARA) regulations, fire protection services, criticality control, etc. Support activities, such as fire protection and emergency preparedness, are also included in all budgets.

Figure 3-3 shows the increase in funding levels, in terms of year of expenditure, at selected periods for the three operations agencies that have guided Hanford Site programs over the years. It also depicts the shift from defense to energy to defense and environmental management.

Figure 3-4 depicts the changes in the Hanford Site budget from fiscal year (FY) 1980 through FY 1989 in terms of year of expenditure.

3.2.2.4 Defense Production Program. Before the decision to place $N$ Reactor in dry standby, uranium fuel assemblies were irradiated in $N$ Reactor to produce plutonium. The $N$ Reactor can supply byproduct steam to the Washington Public Power Supply System for the production of up to 860 MW of electricity. Irradiated fuel is chemically processed at the Plutonium-Uranium Extraction (PUREX) Plant, where plutonium and uranium are recovered and purified. The uranium is further processed at the Uranium Oxide $\left(\mathrm{UO}_{3}\right)$ Plant to prepare it for recycling offsite. The plutonium is then processed into metal at the Pluconium Finishing Plant (PFP) for shipment offsite.

\subsubsection{Present Contractors}

Westinghouse Hanford Company (WHC) is the Hanford Site operations and engineering contractor. Boeing Computer Services Richland, Inc. (BCSR) provides automated data processing (ADP) and telecommunications services for the Site and is a subcontractor to WHC. Battelle Memorial Institute (BMI) is the R\&D contractor at the Hanford Site and, as such, operates the Pacific Northwest Laboratory (PNL). The R\&D is conducted by BMI to support WHC in performance of the operations and engineering function and to carry out a variety of R\&D program activities for the DOE. Kaiser Engineers Hanford (KEH) is the engineer/constructor contractor. The KEH supports both WHC and BMI by providing architect engineer services, as well as labor, material management, and supervision necessary to perform construction and construction management activities. Medical services are provided to WHC, KEH, and BMI by the Hanford Environmental Health Foundation (HEHF), which is the medical and health services contractor. Figure 3-5 illustrates the relationship of these contractors to one another. Figure 3-6 identifies where each contractor and its associated functions are located on the Hanford Site. 
Figure 3-3. Funding Levels and Shifts in Program Emphasis.

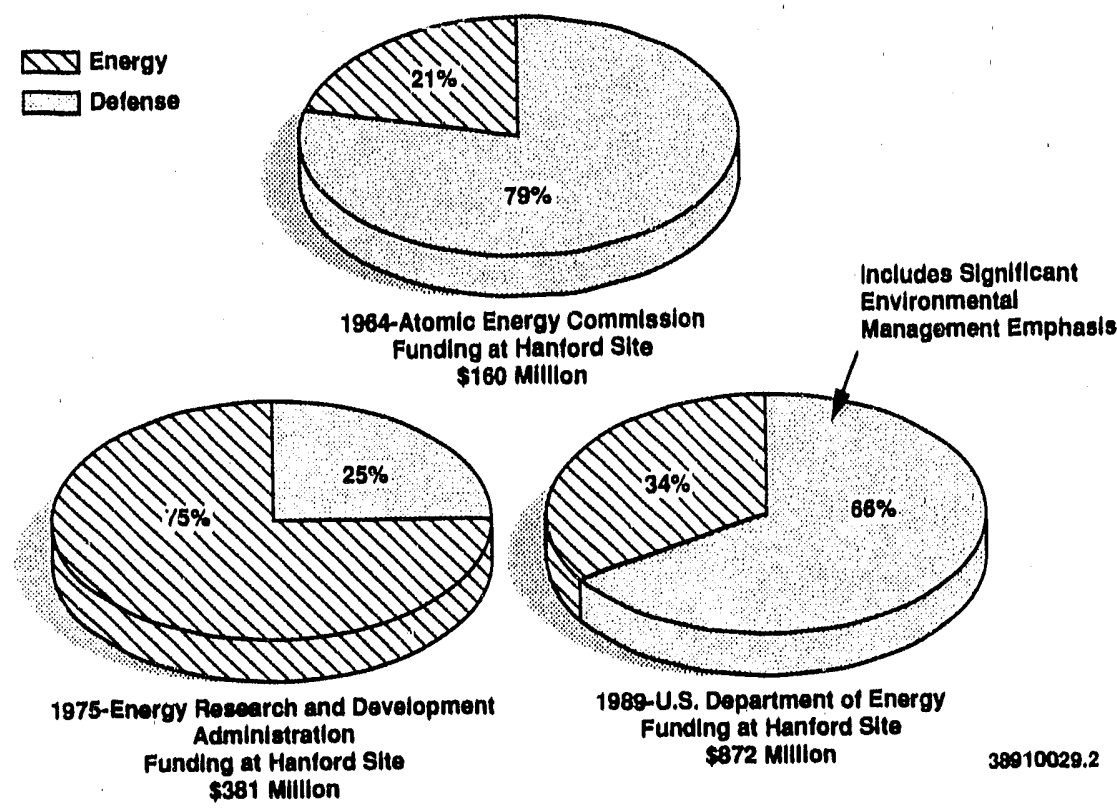

Figure 3-4. Hanford Site Budget by Fiscal Year.

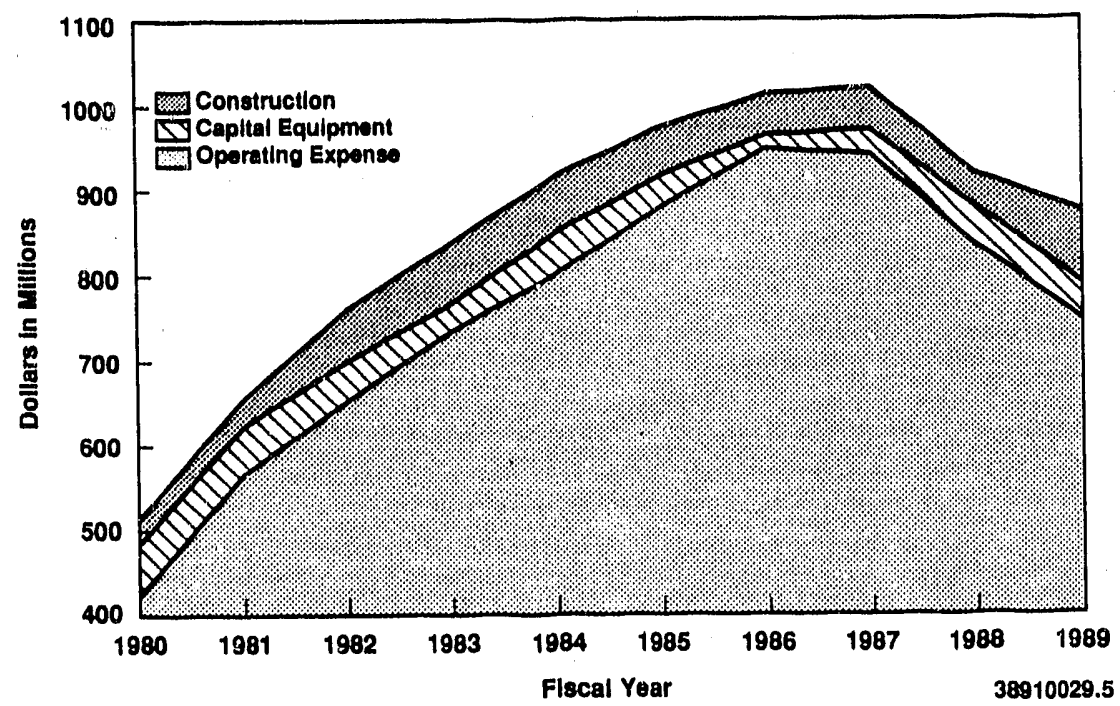


Figure 3-5. Functional Relationships Among Hanford Site Contractors.

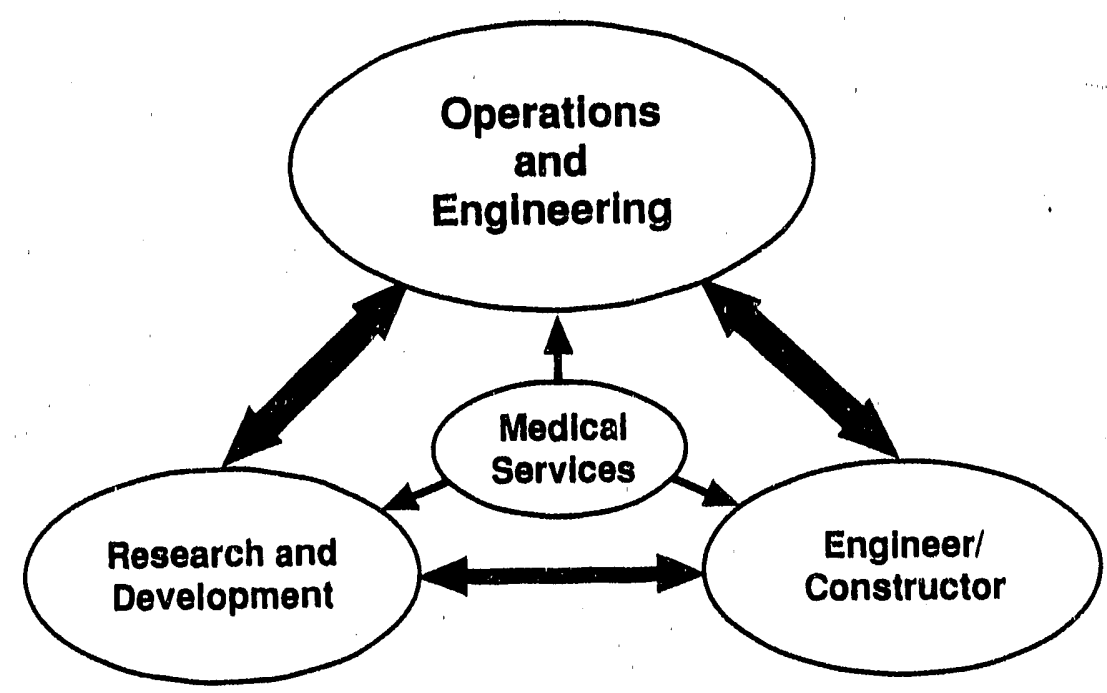

Note: Arrow width indicates interface level.

38910029.1 
Figure 3-6. Functional Locations of Hanford Site Contractors.

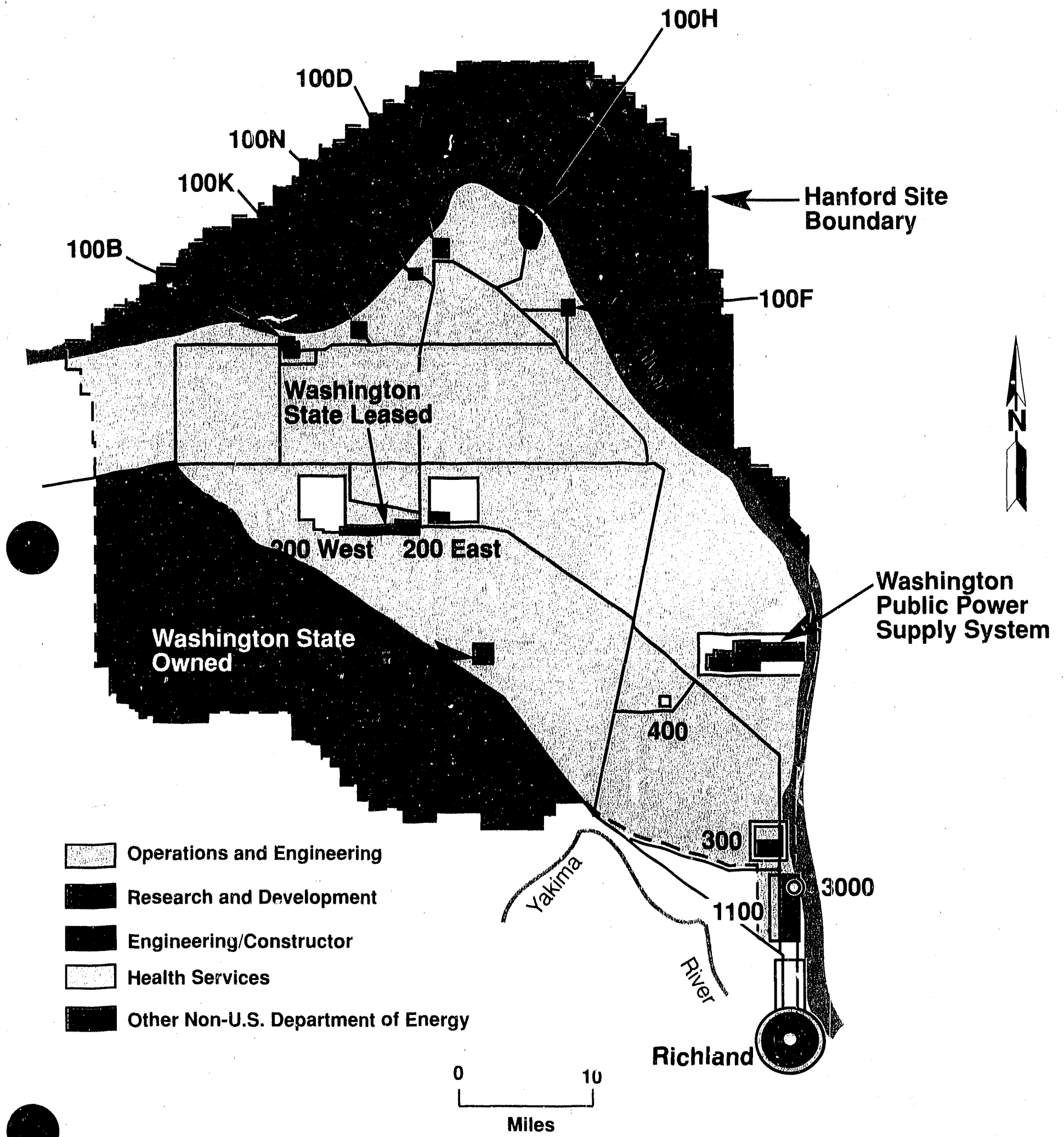




\subsection{HANFORD SITE EMPLOYMENT}

In December 1989, there were approximately 13,300 contractor employees associated with the DOE activities on the Hanford Site. Figure 3-7 shows the distribution of Hanford Site employment by major program. About 4,300 employees, or $33 \%$ of all workers at the Hanford Site, were directly or indirectly employed in nuclear materials production. When the 3,900 environmental restoration and waste management employees were added, more than $63 \%$ were involved in the Hanford Site defense mission. The Basalt Waste Isolation Project (BWIP) no longer supports a staff at the Hanford Site.

Nuclear energy, principally the FFTF and the Space Reactor Program, employed about $12 \%$, and the remaining $25 \%(3,200$ employees) were employed in a wide variety of miscellaneous technology, R\&D, and environmental programs.

Most of the people work in the 700, 1100, and 3000 Areas, which are within or immediately adjacent to the Richland city limits. The 200 and 300 Areas have the next highest number of people. Hanford Site emplcyment from 1967 to 1989 is shown in Figure 3-8.

The Hanford Site population distribution by area is shown in Table 3-2. Included in these figures are leased facilities in Richland (700 Area) and Port of Benton property (3000 Area). The BMI private facilities are included in the 3000 Area data; they account for approximately 1,100 of the total 2,740 contractor personnel located there. The PNL-leased facilities in the 3000 Area are also the largest of the contractors, housing approximately 600 staff members.

Figure 3-7. Hanford Site Employment by Program.

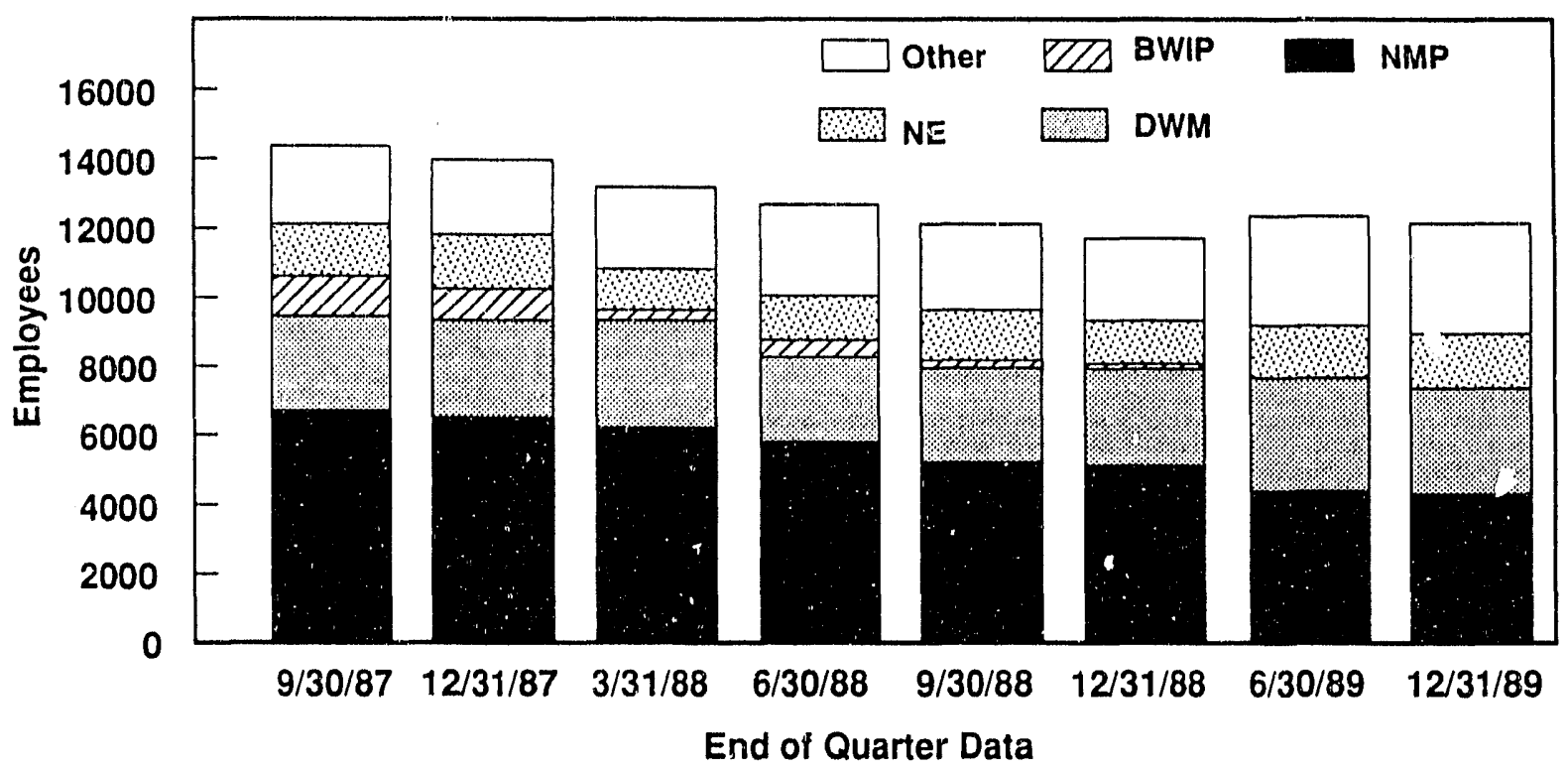

Source: U.S. Department of Energy-Richland Operations Office. 
DOE/RL - 89- 15

Figure 3-8. Total Hanford Site Employment, 1967 to 1989.

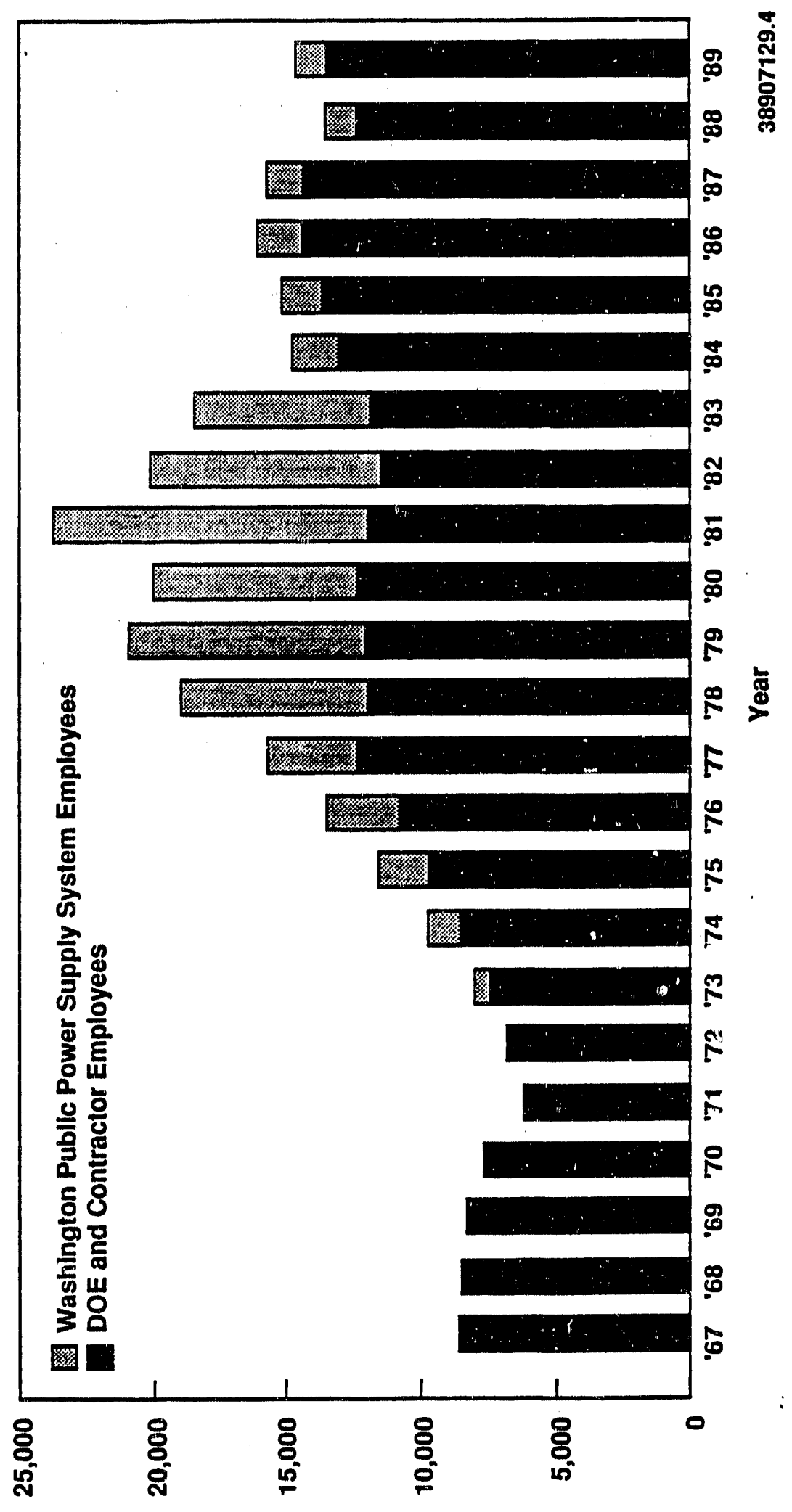


Table 3-2. Hanford Site Population Distribution by Area (December 1989 Data).

\begin{tabular}{|c|c|c|c|c|c|c|c|c|c|}
\hline \multirow{2}{*}{ Contractor } & \multicolumn{8}{|c|}{ Head count by area } & \multirow{2}{*}{ Total } \\
\hline & 100 & 200 & 300 & 400 & 600 & 700 & $1100^{a}$ & $3000^{a}$ & \\
\hline WHC & 735 & 3,688 & 956 & 734 & 143 & 646 & 1,156 & 795 & 8,853 \\
\hline BMI & -- & -- & 1,061 & -- & 16 & 42 & 169 & 1,675 & 2,963 \\
\hline KEH & 36 & 314 & 82 & 14 & 2 & 1 & 371 & 182 & 1,002 \\
\hline HEHF & 2 & 7 & 4 & 1 & -- & 32 & -- & 84 & 130 \\
\hline DOE & -- & -- & - & -- & -- & 335 & -- & -- & 335 \\
\hline \multirow[t]{2}{*}{ Total } & 773 & 4,009 & 2,103 & 749 & 161 & 1,056 & 1,696 & 2,736 & 13,283 \\
\hline & $6 \%$ & $30 \%$ & $16 \%$ & $5 \%$ & $1 \%$ & $8 \%$ & $13 \%$ & $20 \%$ & $100 \%$ \\
\hline
\end{tabular}

ancludes leased facilities in the city of Richland.

Other onsite populations include 1,400 people employed by the Washington Public Power Supply System. Most of the Washington Public Power Supply System staff is located in the facilities on the 3.3-mi2 reactor site that has been leased to the Washington Public Power Supply System.

\subsection{SITE IMPROVEMENTS}

Appendix B contains several maps showing the facilities on the Hanford Site. Included are buildings, structures, and transportation systems, such as roads, railroads, parking areas, entrances, and exits. Lands that are contaminated with radioactive and hazardous waste are also designated.

This section discusses onsite utility systems and presents statistical data on past and planned improvements of facilities.

\subsubsection{Utility Systems}

The scope of this section is limited to electricity, water, and telecommunications because these are the only utilities distributed on a Hanford Site-wide basis. Other utilities, such as steam and sewage, are confined to specific operating areas, which are considered in the Hanford Site Infrastructure Plan and will be evaluated in more detail in Local Area Planning Analyses.

3.4.1.1 Electrical Utilities. The city of Richland provides electric power to the 700, 1100, and 3000 Areas. The Bonneville Power Administration (BPA) supplies electric power to the rest of the Hanford Site. The BPA is contractually obligated to supply as much power as Hanford Site requires. 
Further, in the event of a power shortage, the BPA must meet Hanford Site requirements before other customer requirements. The Hanford Site also has a load-shedding procedure to be used in the event of a power shortage. The contract also specifies the rate structure for the Hanford Site.

Figure 3-9 shows the electrical system for the Hanford Site. The parts that belong to the BPA and the Benton County Public Utility District are not included in the following discussion.

In FY 1979 and FY 1981, major upgrade line items (LI) rebuilt the transmission and distribution systems in the 100 and 200 Areas, and provided a supervisory control and data acquisition (SCADA) system for remote control and monitoring of major substations. Major upgrade LIs for the 300 Area were funded in FY 1978 and FY 1983, which improved the reliability at the primary substation to allow access for future loads. Smaller projects and capital equipment support during the early 1980's replaced switchgear, expanded the SCADA system, and separated normal and emergency powerlines.

The electrical utility system would probably survive an earthquake of less than 5.0 magnitude on the Richter scale, but not a tornado. If the transformers at the 251-West substation were damaged, service could be restored within 2 wk, depending on the nature of the damage and availability of equipment. Within the various areas, backup systems would come online if electrical services were interrupted. These provisions are discussed in the Local Area Planning Analysis for each area. However, the 200 Area may be more vulnerable than the other Hanford Site areas because the backup power source at the processing plants is steam from the centrally located powerhouses. An event that disrupted electrical service might disrupt steam distribution. The greatest concern involves the ability of the ventilation systems to maintain a positive pressure and continue to move air out the stacks. The $B$ Plant and PFP do not have standby power to keep the ventilation systems going; the PUREX Plant does.

Table 3-3 shows the actual, maximum electrical demand for FY 1988 compared with the transformer capacities.

Figure 3-10 shows past and maximum projected megawatt usage. The 700 , 1100 , and 3000 Area usages are not included because their demand is only approxinately $2 \%$ of the total Hanford Site usage.

3.4.1.2 Export Water Utilities. Figure 3-11 illustrates the export water system external to the individual areas of the Hanford Site. The system was originally designed to support reactor operations at $100-B,-D,-F$, and $-H$ Areas, with the 200 Area supply extended off the cross-country main water lines. The 100-N Area branch water line provides an emergency water supply to the 100-N Area.

The water source for the export water system is the Columbia River. The average annual river flow past the Hanford Site is approximately $53.8 \mathrm{million}$ gal/min. Since 1960 , the minimum average, 7 -day-running, mean flow rate has exceeded $24.2 \mathrm{million}$ gal $/ \mathrm{min}$ at all times. The current 200 Areas demands are approximately $0.1 \%$ of this amount. 
Figure 3-9. Electrical Transmission Lines on the Hanford Site.

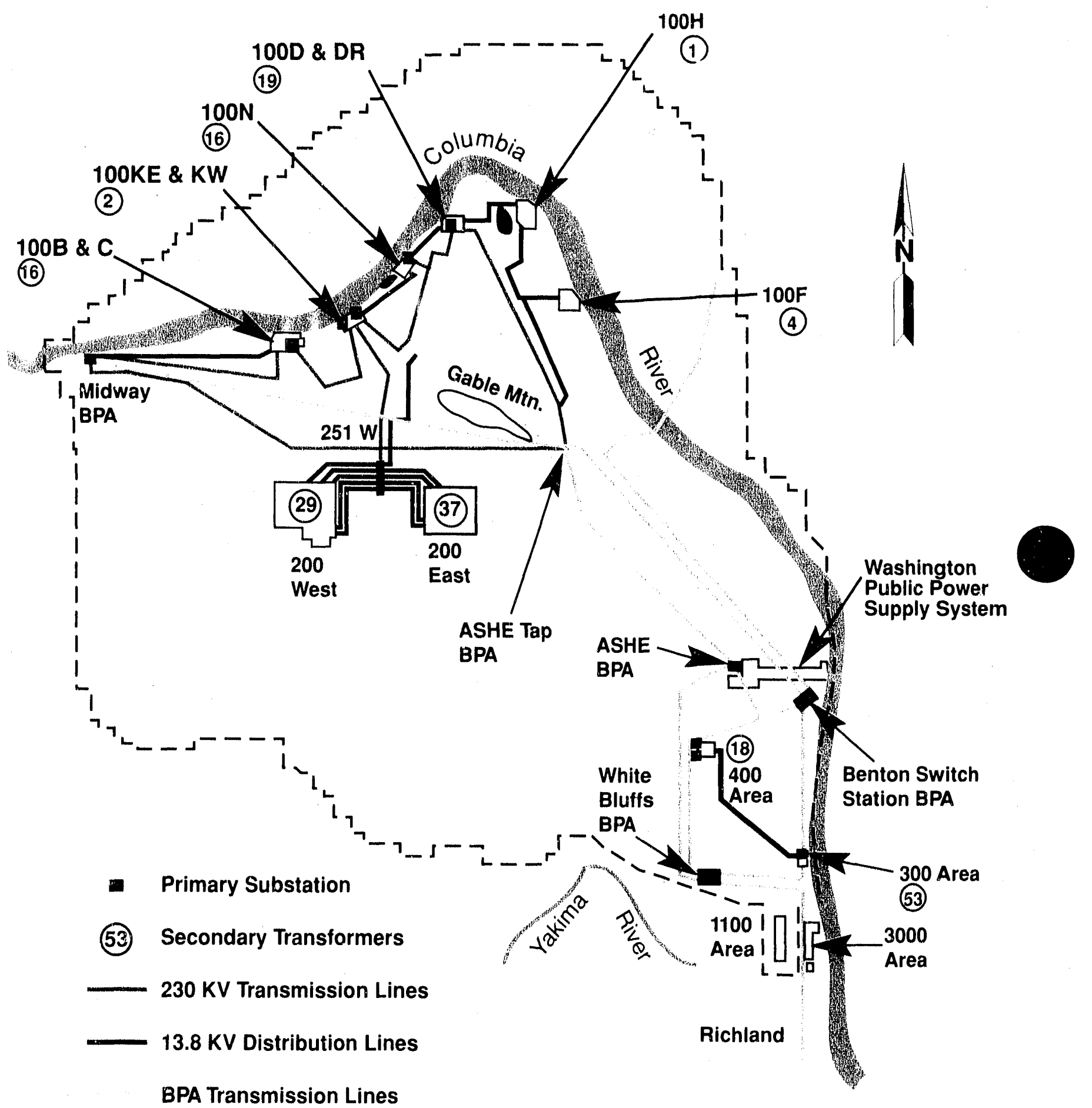


Table 3-3. Peak Power Demands at the Hanford Site for Fiscal Year 1988.

\begin{tabular}{lcc}
\hline Hanford Site & $\begin{array}{c}\text { Transformer } \\
\text { capacity } \\
\text { (MW) }\end{array}$ & $\begin{array}{c}\text { Peak demand per 1-hour } \\
\text { period (MW) }\end{array}$ \\
\hline $100-B$ & 31.5 & 5.4 \\
$100-K$ & 50.0 & 3.9 \\
$100-N$ & 50.0 & 20.9 \\
$100-D$ & 31.5 & 5.5 \\
200 East and West & 50.0 & 19.0 \\
300 & 28.0 & 25.4 \\
400 & 50.0 & 26.4 \\
\hline
\end{tabular}

Figure 3-10. 20-Year Power History and Forecast for the Hanford Site.

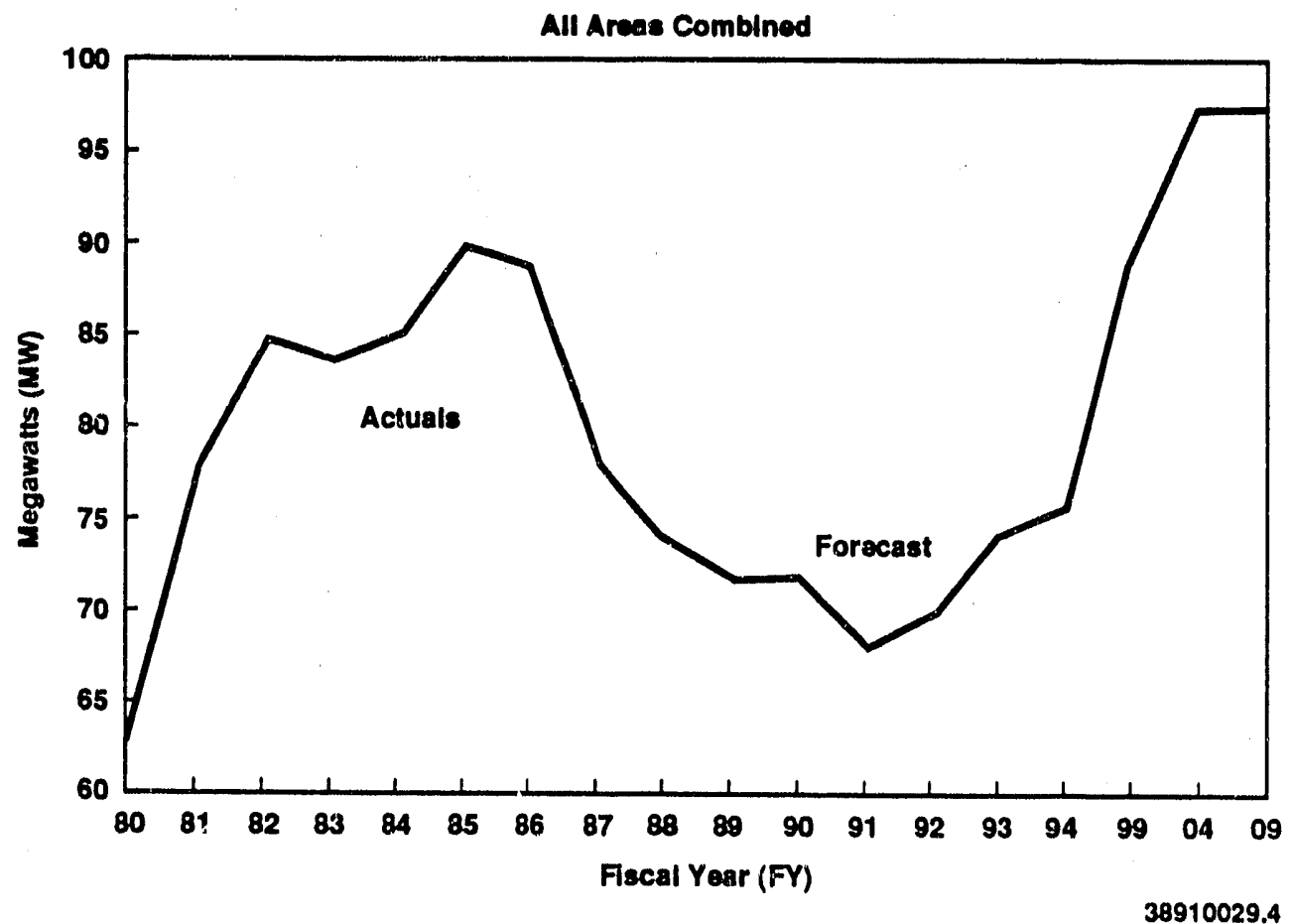


Figure 3-11. Export Water System for the Hanford Site.

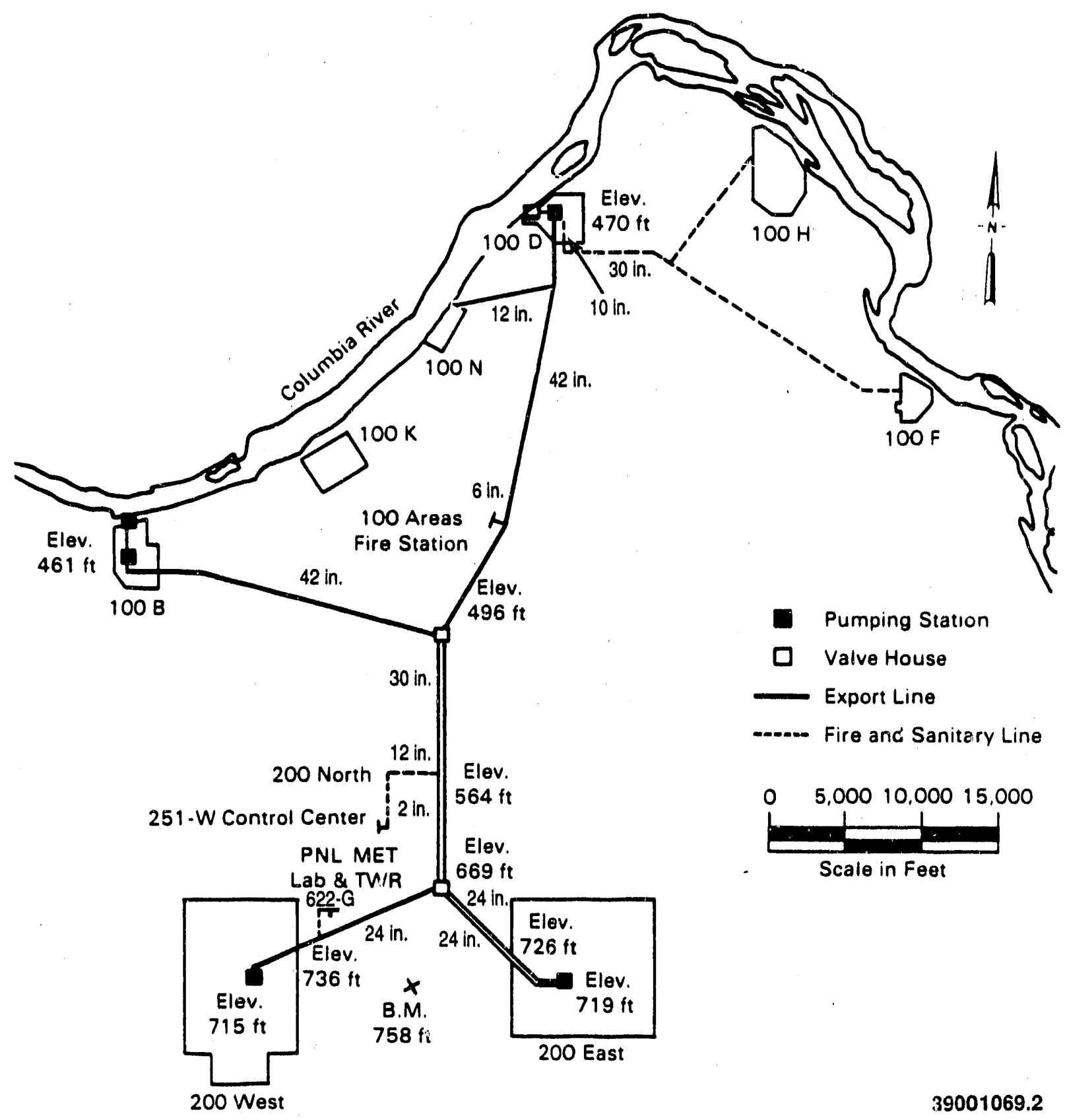

39001069.2 
The current demand requirements for the 200 Areas are approximately $15,000 \mathrm{gal} / \mathrm{min}$, based on historical average high flows in the summer time. During a normal year, demand ranges from 12,000 to $22,000 \mathrm{gal} / \mathrm{min}$. The total system capacity is $33,000 \mathrm{gal} / \mathrm{min}$. The future requirements (consistent with the missions identified in Section 4.0) for the medium-case scenario are 23,500 gal/min. Less than 5.0 Richter scale magnitude earthquakes and tornadoes are not expected to severely affect the export water system.

Water system maintenance was performed to reactor standards until 1967 when reactor operations were curtailed. From 1970 to 1977, the system was maintained on a "breakdown and repair" basis. Since 1978, equipment has been maintained on a rehabilitative basis, and approximately $\$ 3.9$ million has been spent on pumps, valves, screens, and buildings. However, some major aspects could be improved, as identified below.

Fire Protection. The water system does not comply with the DOE fire protection guidelines as stated in DOE-RL Order 6430.1B (DOE-RL 1988). The requirements for a shared water system require a 4-h water reserve to supply a designed, base-case "worst fire" while concurrently supplying peak process water usage. Therefore, the renitirement is a fire requiring $2,500 \mathrm{gal} / \mathrm{min}$, a peak historical process usage of $22,000 \mathrm{gal} / \mathrm{min}$, and a 4-h reserve of 6 million gal. The requirements al so call for a noninterruptible, continuously available water supply source. A 6.5-million-gal reservoir and a 200 East and 200 West Areas tieline are being planned to meet this need.

Energy Use. The system is not energy efficient because it pumps against a high-pressure head. The high-point pressure is maintained by throttling the end-of-line valves and running the pumps at the 182-B pumphouse without regard to the required volume. This scheme forces the pumps to operate above optimum operating pressure. To increase efficiency, a 200 Area feedline to $622-R$ will be installed so the head pressure can be reduced and pumping can be for flow volume only'.

Instrumentation Network. Manpower requirements are high because a centrally located instrumentation network is not available to monitor and control the system. Instead, telephone and vehichlar transportation are used.

Several LIs and general plant projects have been submitted for FY 1987 to 1992, comprising a total of $\$ 17$ million to correct the current problems.

There are some other water systems located onsite. The 300 Area and the Washington Public Power Supply System areas draw water directly from the Columbia River. Groundwater wells supply the 400 and 600 Areas. The 700, 1100, and 3000 Areas purchase domestic water from the city of Richland.

3.4.1.3 Telecommunications. The Hanford Site telecommunications systems comprise three main categories: voice, data, and radio. All major systems have battery-powered backup capabilities in case of electrical failure.

3.4.1.3.1 Voice Systems. The Hanford Site telephone system consists of two exchanges, 200 Areas and north Richland, connected by a trunking network. The 200 Areas exchange is controlled by the north Richland exchange. Both exchanges have access to direct distance dialing, the federal telephone 
system, and operator assistance. Total capacity of the system is 16,848 lines with approximately 11,000 lines connected. The entire system is $p 1$ anned to be replaced in 1992 with an integrated voice/data switching system, which will broaden the voice and data capabilities at the Hanford Site.

A digital voice/data private telephone system was installed at BMIowned factilities in 1982 . The system, which serves approximateiy 1,250 staff, has 1,800 active ports, of which 620 are both voice- and data-equipped. The system connects to the Hanford Site telephone system via 26 tielines.

There are 14 separate private automatic exchange (PAX) systems on the Hanford Site. Tweive are located in operating plant facilities and are used where operations, safety, and time are essential to the performance of work. They are not connected to any public common carrier systems. One system is installed in the 700 Area Federal Building, in support of the Emergency Operations Center (EOC), and another is used as a simulator in the 100-N Area.

3.4. 1.3.2 Data Systems. The general usage network is a Site-wide, integrated communications architecture providing distributed access to computing capabilities for users lorated throughout the Hanford Site and several leased buildings in Richland. Dedicated offsite data communications are limited to a maximum speed of $9,600 \mathrm{~b} / \mathrm{s}$ with some circuits operating slower. There are 16 circuits.

The Hanford Site has one of the most extensive local area networks (LAN) in the United States. The majority of Hanford Site LANs are equipped with Ungermann-Bass Net/One* $\mathrm{XNS}^{* *}$, and LAN products connecting more than 5,000 personal computers $(P C)$ and terminal users. The user community is expected to continue to increase in FY 1990.

The Hanford Site LANs are an integrated network of baseband and broadband systems using fiber optics, coaxial cable, microwave, and carrier frequencies on copper cable. The two main transmission methods, baseband and broadband, use the IEEE 802.3 Carrier Sense Multiple Access with Collision Detection (CSMA/CD) standard (ANSI/IEEE 1985). All major areas have LANs installed. Current activities include expansion of LANs within areas.

All LANs have the ability to communicate with one another and to the central computer facility. This is accomplished through the use of the Site microwave system, some leased lines, and remote bridges operating at speeds of up to 1.544 megabytes/s.

3.4.1.3.3 Radio Systems. The Hanford Site radio communications utilize the VHF band at 162 to $174 \mathrm{MHz}$ and the UHF band at 406 to $420 \mathrm{MHz}$. Primary usage is in the VHF band, where repeater technology provides Site-wide coverage. The UHF band is used primarily for simplex radio systems within selected process buildings. Repeaters are being installed to expand usage for Site-wide coverage. The radio systems are shown in Figure 3-12.

*Ungerman-Bass Net/one is a trademark of Ungermann-Bass, Inc. **XNS is a trademark of the Xerox Corporation. 
DOE/RL-89-15

Figure 3-12. Hanford Site Radio Systems.

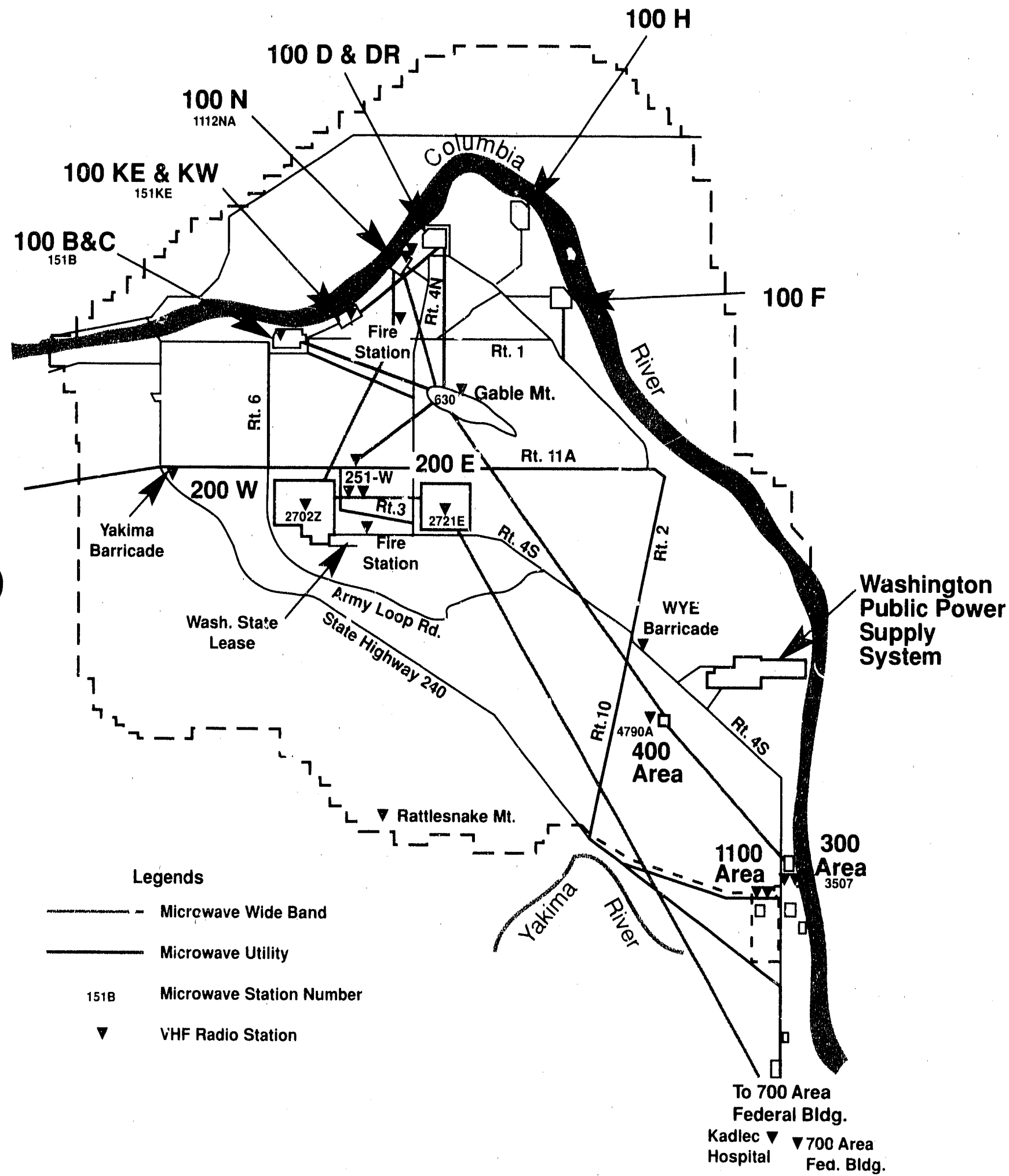

$39001069.25 \mathrm{C}$ 
High-speed ( $\mathrm{Tl}$ and $\mathrm{T} 2$ ) data radio systems are used in the $\mathrm{K}$ band $(23 \mathrm{GHz})$ to extend the backbone microwave system to user groups. Some low-speed data radio systems use the VHF band and UHF band to gather seismic, weather, and hydrologic data.

The VHF band systems support security/patrol, fire protection, safety and emergency communications, transportation (bus and rail), maintenance (all Site areas), tank farm surveillance operations, and construction activity for both site engineers and DOE oversight management. The VHF systems also support a utilities and transportation network, a Site-wide Emergency Radiological Detection System (ERDS) data collection system, and a local plant operations network at the advanced FFTF. The Hanford Site Fire Alarm System uses radio-transmitted alarm boxes as the site standard. Main VHF repeaters use tone-coded squelch techniques to promote more efficient usage of the spectrum.

The Plant Radio Paging System is an automatic, telephone-interconnected paging system, with more than 1,000 radio pagers, and major component redundancy.

The SCADA system provided remote energy control, indication, and monitoring of electrical parameters for substations in the 100-N, 200 East, 200 West, and 300 Areas.

In the event of an emergency, approximately 45 hand-held radios are available for coordinated activities with 6 base stations providing Site-wide co'verage.

\subsubsection{Site Improvement Statistical Data}

Statistical data is given on Hanford Site buildings, utilities, rail system, and road system.

3.4.2.1 Buildings. The Hanford Site facilities, as documented in the real property inventory system (RPIS), consist of over 1,100 buildings. Of these buildings, 149 have a floor area of over 10,000 $\mathrm{ft}^{2}$ gross. These larger facilities are described in Table 3-4. Keys for the columns called "Current Usage Codes" and "Current Adequacy Codes" are provided in Tables 3-5 and 3-6, respectively.

Most of the facilities shown in Table 3-4 are 30 to $40 \mathrm{yr}$ old. Approximately $30 \%$ of the space in these facilities is now being used differently than the designed use. Of these facilities, $70 \%$ are reported to be in adequate condition.

Recently, all of the Hanford Site facilities were evaluated to determine which ones are considered strategically required or mission-essential.

These terms refer to facilities required to accomplish program missions and facilities necessary to support site functions, based on 5 -yr frojections. The results of this evaluation are described in the Hanfoid site Strategic Facilities Plan (WHC 1989), a document required by the Strategic Facilities Utilization Program (SFUP), formerly the Strategic Facility Initiative (SFI). A summary of this report can be found in Section 6.6 of this plan. 
DOE/RL -89-15

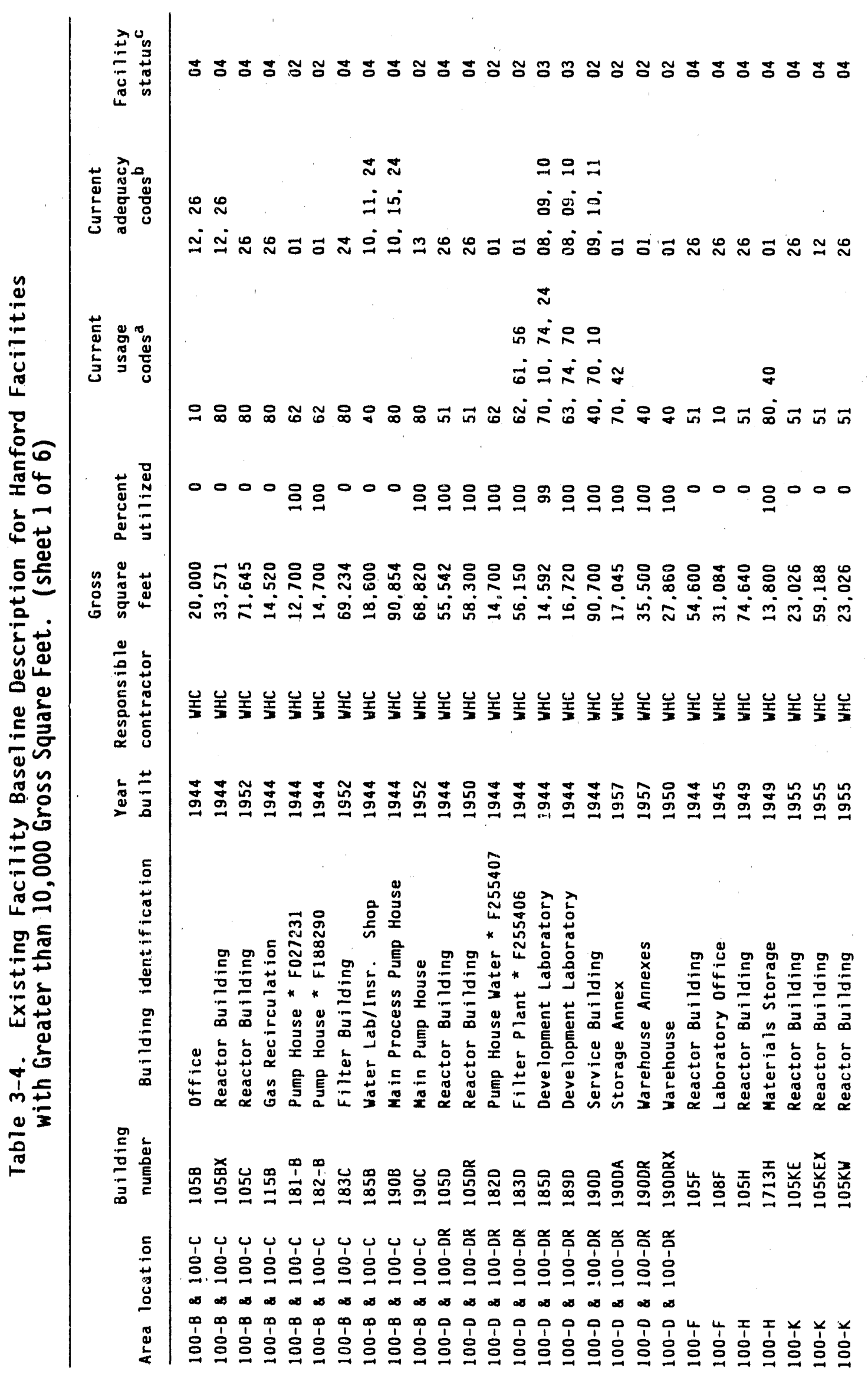




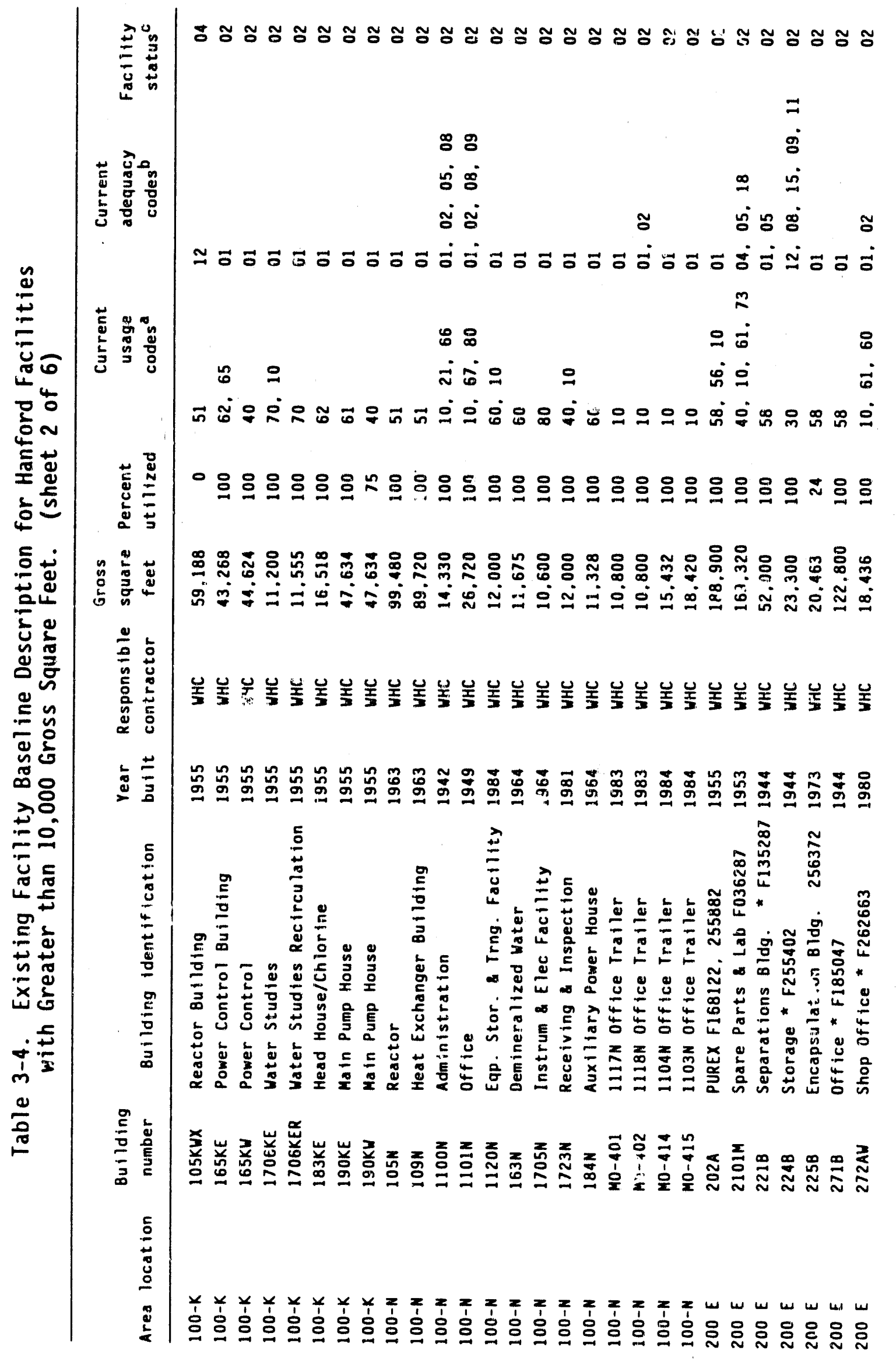




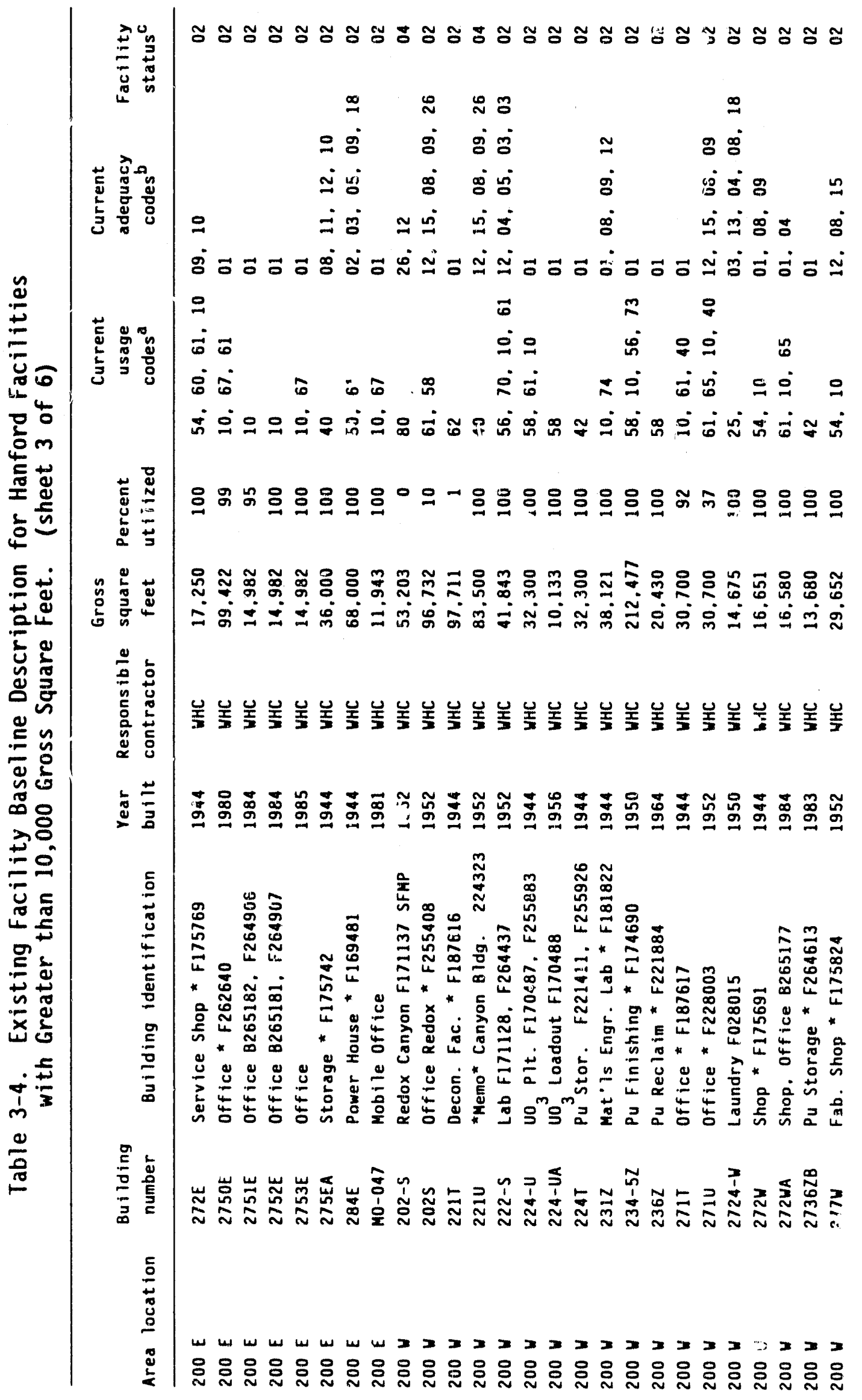




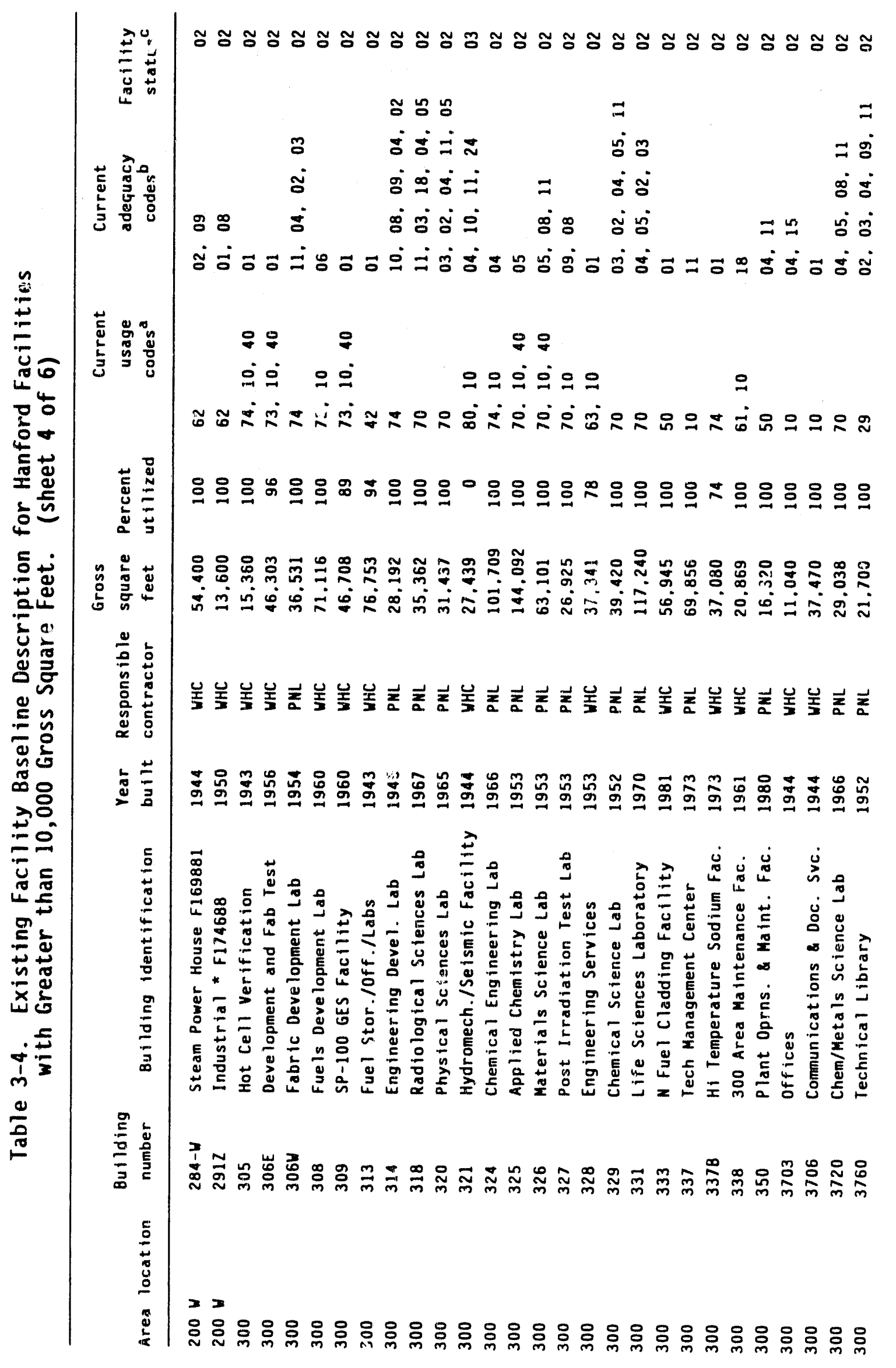




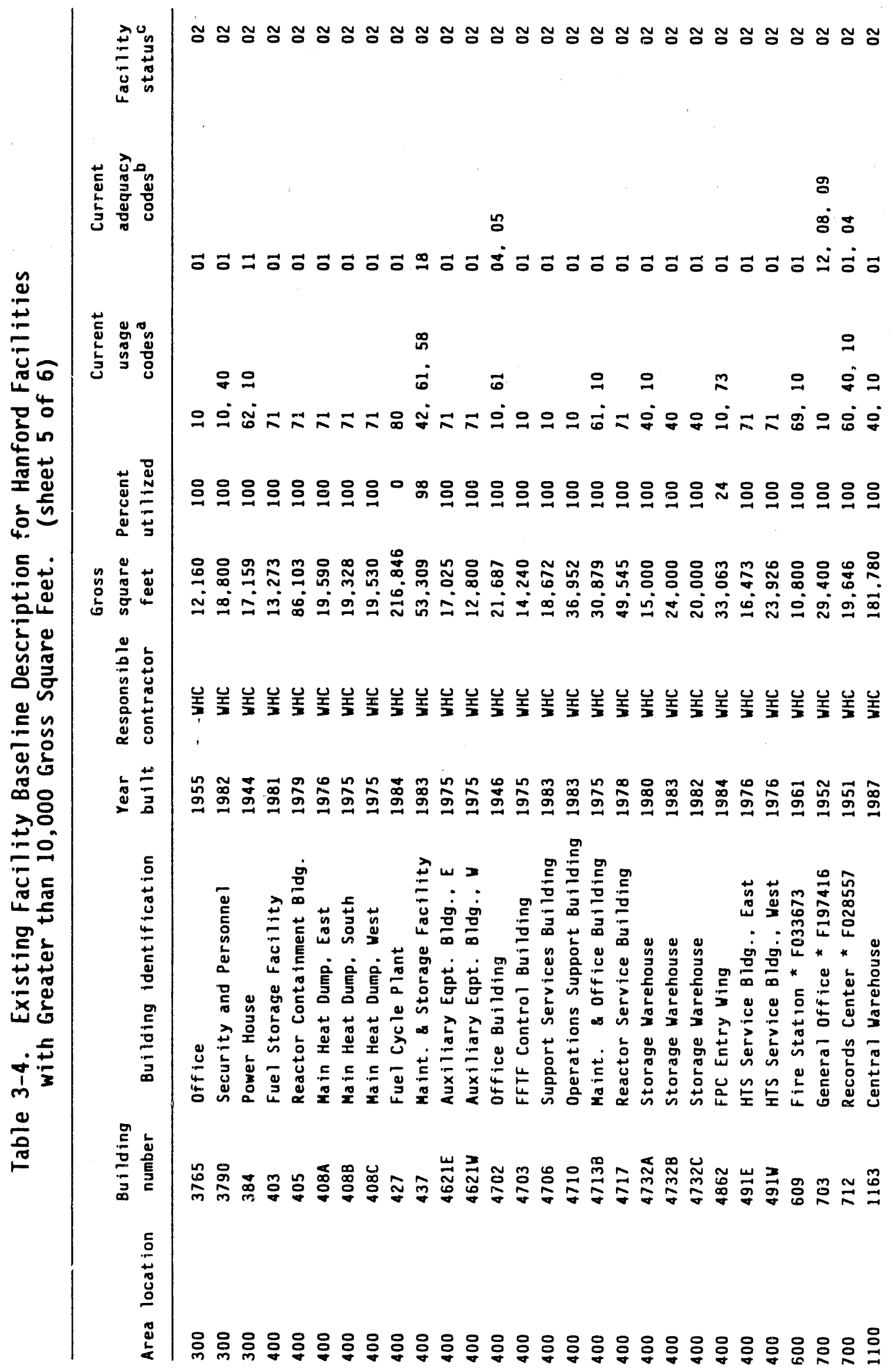




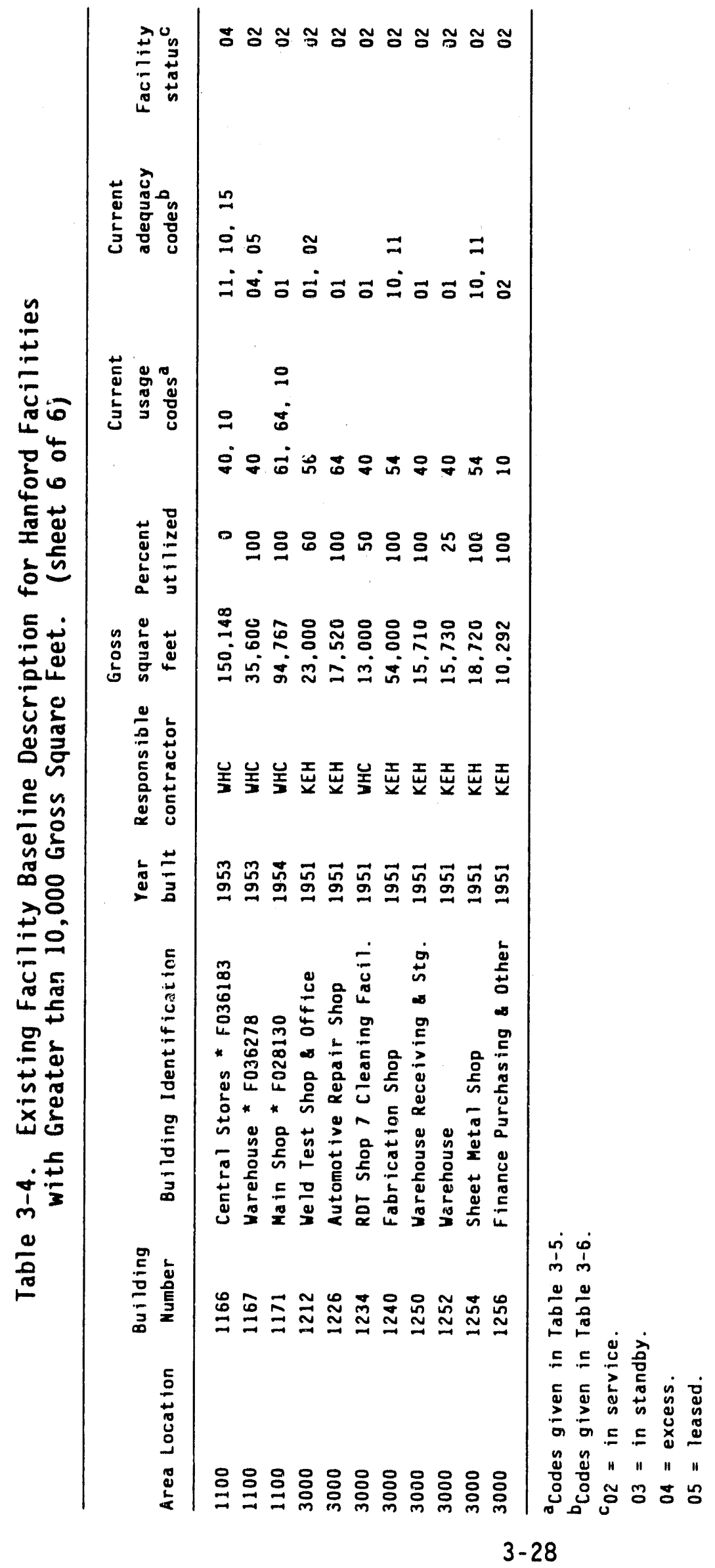


DOE/RL-89-15

Table 3-5. Building Use Code Key.

\begin{tabular}{ll}
\hline Codes & \multicolumn{1}{c}{ Descriptions } \\
\hline 10 & Office \\
14 & Post Office \\
21 & Hospital \\
22 & Prison \\
23 & School \\
24 & Cafeteria \\
25 & Laundry \\
26 & Auditorium \\
27 & Visitor's Center \\
29 & Other Institutional Uses \\
30 & Housing \\
40 & Storage \\
41 & Flammable Storage \\
42 & Programmatic Material Storage \\
50 & Industrial \\
51 & Reactor: Process-Production \\
52 & Accelerator \\
53 & Uranium Enrichment Process \\
54 & Fabrication \\
55 & Assembly \\
56 & Lab--Non-Research and Development \\
57 & Inspection \\
58 & Nuclear Waste Process/Rec. \\
60 & Service \\
61 & Maintenance Shops \\
62 & Utility Buildings \\
63 & Machine Shops \\
64 & Garages \\
65 & Change Rooms \\
66 & Guard Houses and Headquarters \\
67 & Computer Buildings \\
68 & Communication/Control Centers \\
69 & Fire Stations \\
70 & Research \& Development \\
71 & Reactor: Test, Research, and \\
72 & Accelerator: Test, Research, \\
73 & and Development, Demo \\
80 & Trust Buildings \\
99 &
\end{tabular}


Table 3-6. Conditions/Adequacy Table for Buildings and Structures.

\begin{tabular}{ll}
\hline Codes & \multicolumn{1}{c}{ Descriptions } \\
\hline 01 & Adequate \\
02 & Overcrowded Office Function \\
03 & Overcrowded Operations \\
04 & Mechanical Systems Inadequate for Current Use \\
05 & Electrical Systems Inadequate for Current Use \\
06 & Framing or Layout Design Inadequate for Current Use \\
08 & Mechanical Systems Deteriorated \\
09 & Electrical Systems Deteriorated \\
10 & Structural Systems Deteriorated \\
11 & Roof Deteriorated \\
12 & Noncompliance with Applicable Regulations \\
13 & Location Inadequate for Current Use \\
14 & Urireliable Due to Design \\
15 & Unreliable Due to Deterioration \\
16 & Redundant Systen Required \\
17 & Distribution Inappropriate for Current Use \\
18 & Capacity Inadequate for Current Use \\
19 & Deterioration of Roadbed or Deck \\
20 & Geometric Design Inadequate for Current Use \\
21 & Roadbed Surface Inadequate for Current Use \\
22 & Traffic Control Devices Inadequate for Current Use \\
23 & Drainage System Inadequate \\
24 & Use to Indicate Abandoned Building \\
25 & Radioactively Contaminated/No Maintenance \\
26 & Maintenance Provided for Control \\
\hline
\end{tabular}

General-purpose facilities comprise a \$726-million investment in nearly 7.4 million $\mathrm{ft}^{2}$ of owned space. In addition to these DOE-owned facilities, the Hanford Site contractors leased 22 buildings, and another 8 mobile office trailers. Eighteen of the leased facilities were larger than $10,000 \mathrm{ft}^{2}$.

3.4.2.2 Other structures. This section describes the current status of the Hanford Site rail system and road system. The status and conditions of the utility systems, which are largely area-specific, will be addressed in the Hanford Infrastructure Plan and the followon Local Area Planning Analyses.

3.4.2.2.1 Hanford Site Rail System. he Hanford Site rail system consists of approximately $127 \mathrm{mi}$ of track. The rail system currently handles approximateily 4,000 commercial and 1,000 onsite shipments each year. It is a Class III railroad system as identified by the Federal Railroad Administration.

During World War II, the rail system was built with rail acquired throughout the United States. Yarying rail weights and configurations were used. Some of the rail was manufactured as early as 1896; most was mailufactured before 1936 when controlled cooling became the standard of the rail manufacturers. None of the rail was new when installed. In 1979, a 
Federal Railroad Administration inspection was conducted. It recommended replacement of any rail manufactured before 1936 or lighter than 90 1b/yd.

In 1981, Project B-320, "Rail Replacement--Hanford Railroad," began. This project upgraded approximately $27 \mathrm{mi}$ of the 600 Area rail system. An FY 1990 LI (B-468) will continue this upgrade to an additional $17 \mathrm{mi}$ of the mainline serving the Hanford Site 100 and 200 Areas. This will bring the mairiline up to Federal Railroad Administration standards. Additional upgrades to the mainline of the Hanford Site rail system are planned for FY 1993.

On completion of these planned projects, and with proper maintenance, the Hanford Site rail system should continue to be meet Site needs indefinitely.

3.4.2.2.2 Hanford Site Road System. The Hanford Site road system consists of approximately $279 \mathrm{mi}$ of primary and secondary roads. Routes $4 \mathrm{~S}$ and $11 \mathrm{~A}$ serve as the principal highways between the Wye and Yakima Barricades.

These barricades are the only access points to the security area on the Hanford Site. Route $4 \mathrm{~N}$ provides the primary access to the Hanford Site $\mathrm{N}$ Reactor, which is in dry standby status.

Most of the Hanford Site road system was built in the early 1940's. The initial surface widths were 18 or $20 \mathrm{ft}$. Since these highways were built, a number of maintenance-type projects have been completed. These projects sealed the road surface, widened the pavement, reconstructed and added shoulders, and added extra lanes where either terrain or traffic movements dictated.

Currently, Routes $4 S$ and $4 N$ are the primary highways from the Tri-Cities to the outer (100 and 200) areas of the Hanford Site. As the major route, these highways carry approximately $90 \%$ of the traffic from the Wya Barricade to the outer areas.

The existing roadway conditions in relationship to construction, traffic volumes, and highway standards were determined to be inadequate. To meet highway standards, a series of highway improvements were initiated. Route 10 from State Highway 240 to the Wye Barricade and Route 45 from the 1100 Area to the Wye Barricade were recently upgraded. Over the next $15 \mathrm{yr}$, a series of general plant projects (GPP) are planned to upgrade the remaining roads in the Hanford Site road system.

On completion of these planned projects, and with the proper maintenance, the Hanford Site road system should continue to meet Hanford Site needs indefinitely.

Figure 3-13 presents a Hanford Site map detailing the locations of the railroad and highiway systems. 
Figure 3-13. Hanford Site Roads and Rail.

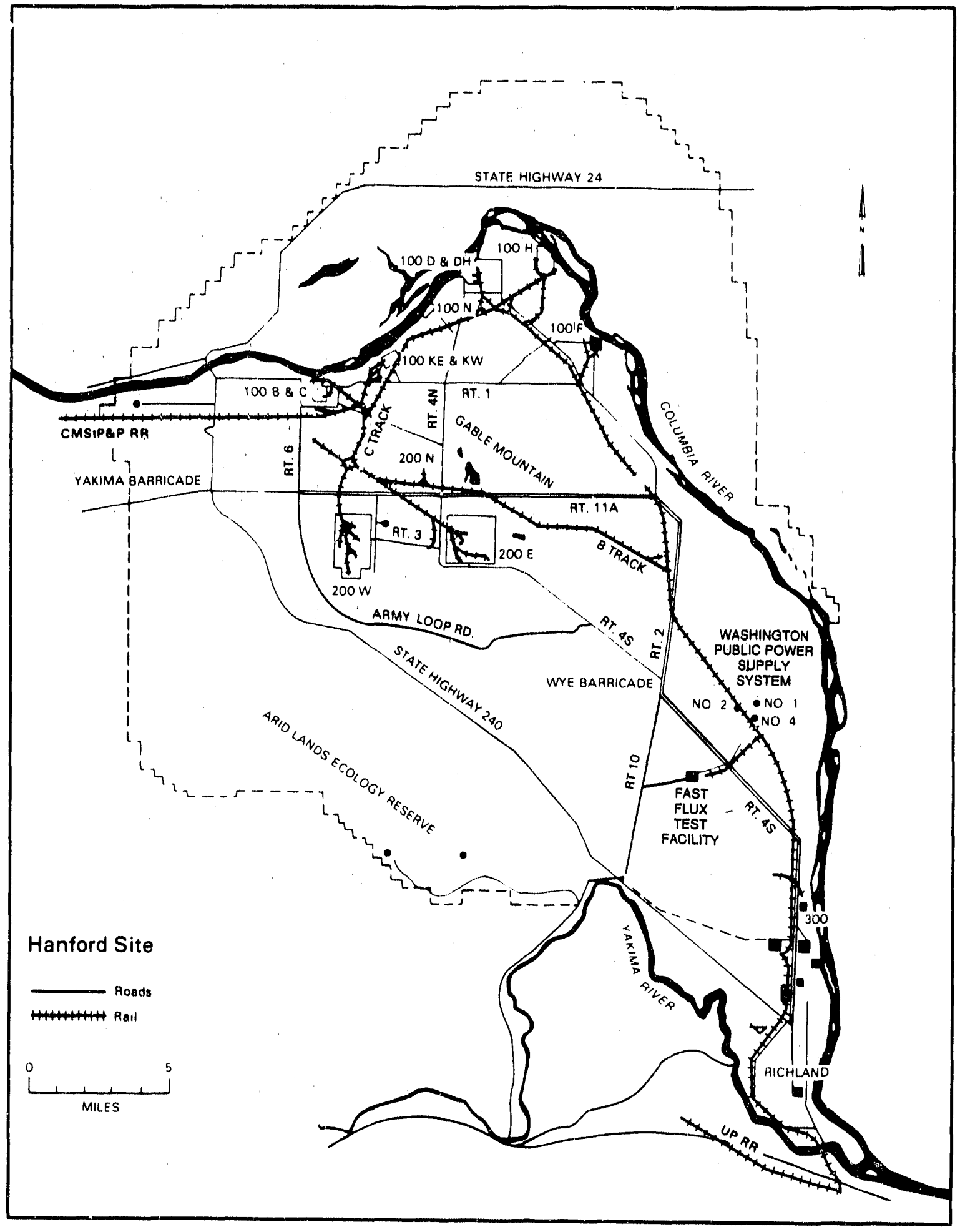

39001069.8 
DOE/RL-89-15

\subsection{PHYSICAL CHARACTERISTICS}

This section describes the natural factors and associated constraints of the Hanford Site. The following topics are covered: geomorphology and slopes, stratigraphy, soils, geology/structures, hydrology, wetlands, wildlife, vegetation, ecological areas, endangered species, meteorology, and cl imatology.

\subsubsection{Physiography and Geomorphology}

The Hanford Site is located with in the Columbia Intermontane Physiographic Province, which is bounded on the east by the Rocky Mountains and on the west by the Cascade Range. The site lies in the Pasco Basin, a major topographic and structural basin within the province. The Saddle Mountains form the northern boundary of the Site and Rattlesnake Mountain and the Rattlesnake Hills form the southern boundary. Umtanum Ridge with its eastern extensions, Gable Mountain and Gable Butte, divide the Site into northern and southern parts.

Elevations at the Site range from $345 \mathrm{ft}$ near the Columbia River in the southeast corner of the Site to $3,586 \mathrm{ft}$ above mean sea level (MSL) on Ratilesnake Mountain along the southwestern border of the Site. The immediate Hanford Site (between Highway 240 and the Columbia River) comprises about $310 \mathrm{mi}^{2}$ of terrain, $180 \mathrm{mi}^{2}$ of which have slopes that are less than $2 \%$. In the south-central part of the site, where the main waste management operations are located, elevations range from 620 to $800 \mathrm{ft}$ above MSL.

The highest elevations on the Hanford site occur on basalt ridges. The intervening valleys are depositional basins. The basalt ridges resulted from tectonic forces, which folded and faulted basalt flows of the Columbia River Basalt Group.

The geomorphology of the south-central Hanford Site is the product of two primary geomorphic processes: Pleistocene cataclysmic flooding, and Holocene eolian activity. The cataclysmic flooding, which ended 13,000 yr ago, created the Cold Creek bar, the prominent bench on which the 200 Areas are located. The last floods covered the 200 Areas with a blanket of coarsegrained deposits. Since the end of the Pleistocene, winds have deposited a thin veneer of eolian sand in places. Alluvium deposits occur south of the 200 Areas in the Cold Creek-Dry Creek alluvial plain.

\subsubsection{Stratigraphy}

There are three principal geologic units beneath the Hanford Site: the Columbia River Basalt Group with interbedded sediments of the Ellensburg Formation, the Ringold Formation, and the Hanford formation (Figure 3-14). The Columbia River Basalt Group, which is over 11,000-ft thick, was emplaced between 6 and 17 million yr ago. These basalt flows are interbedded with Miocene-Pliocene epiclastic and volcaniclastic sediments of the Ellensburg Formation. 
Figure 3-14. Geologic Cross-Section of the Hanford Site.
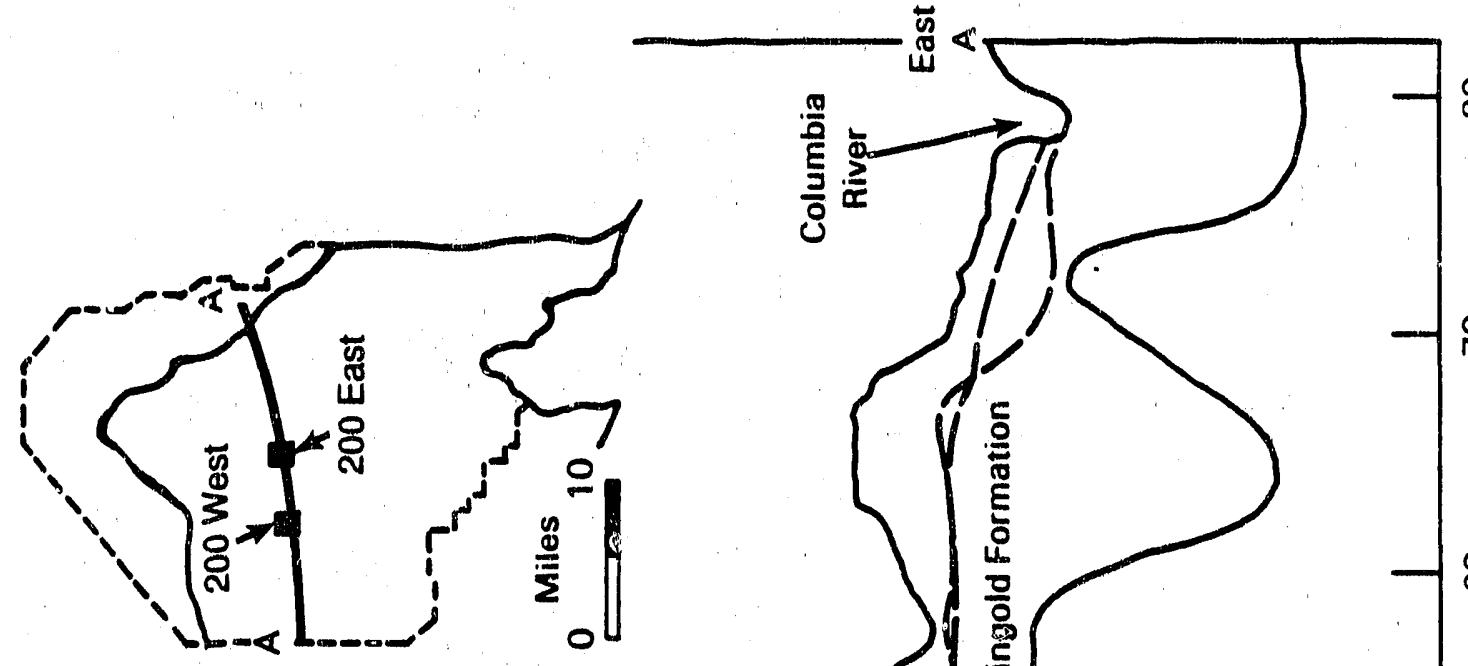

$\$$

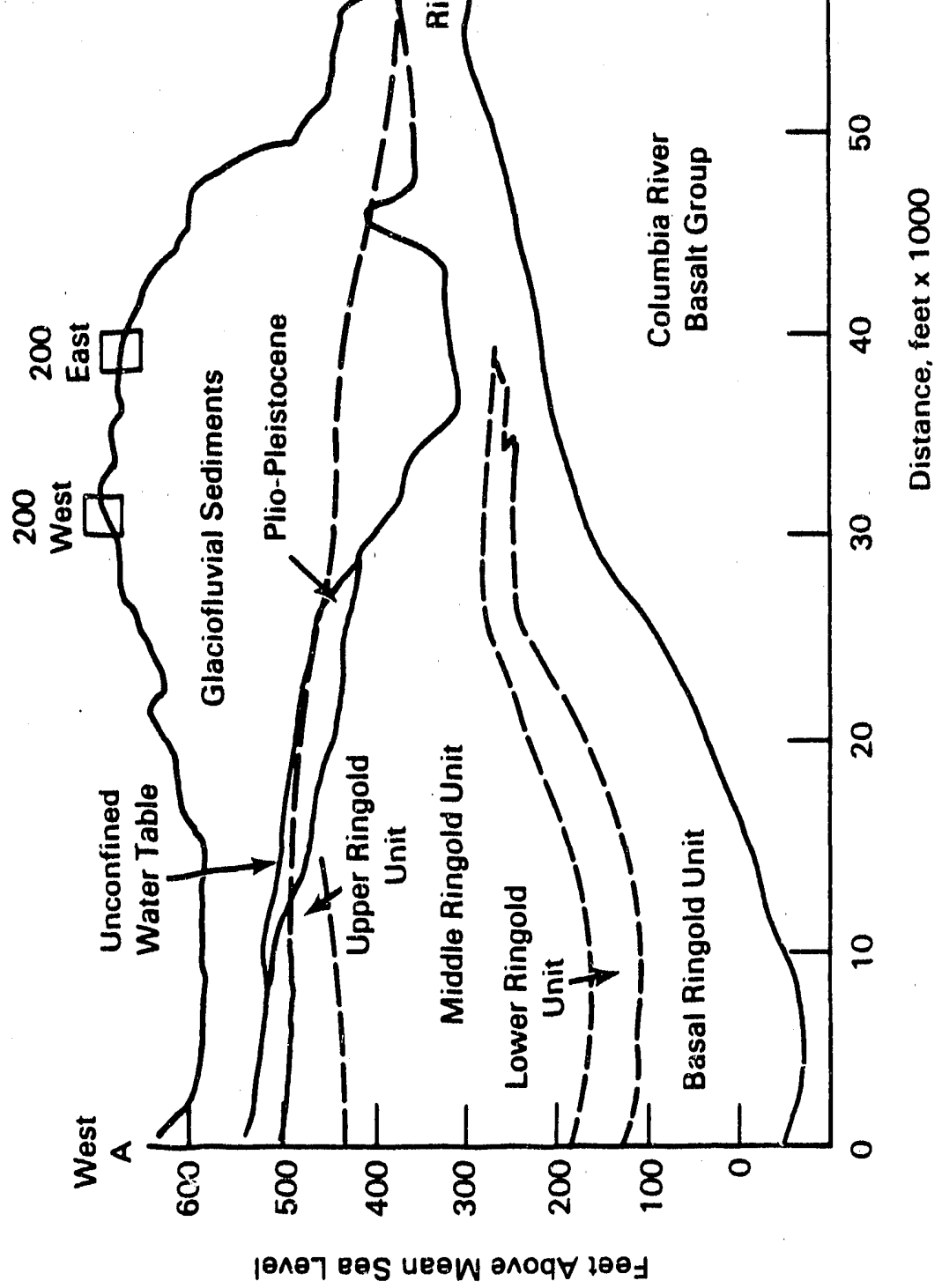



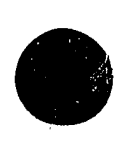


The sediments of the Hanford formation overlie the Miocene-Pliocene Ringold Formation, a Plio-Pleistocene sedimentary deposit, and the Columbia River Basalt Group. The Hanford formation was deposited by catastrophic floods when glacial dams in western Montana and northern Idaho were breached and large volumes of glacial melt water spilled abruptly across eastern and central Washington. The last major depositional sequence from such flooding has been dated at about 13,000 yr ago. The Hanford formation consists of the fine-grained Touche beds, which are slack water deposits, and the Pasco Gravels.

\subsubsection{Solls}

Fifteen different soil types have been identified on the Hanford Site ino data are available for the area across the Columbia River):

- Ritzville silt loam

- Rupert sand

- Hezel sand

- Koehler sand

- Burbank ioamy sand

- Ephrata sandy loam

- Lickskillet silt loam

- Ephrata storiy loam

- Kiona silt loam

- Warden silt loam

- Scootney stony silt loam

- Pasco silt loam

- Esquatzel silt loam

- Riverwash

- Dunesand.

At the lower elevations on the Site (mainly the central, eastern, and southeastern portions), the predominant soil type is Burbank loamy sand. Although some Burbank loamy sand is found in the northern portion of the Site, the major type located there is Ephrata sandy loam. 
At the higher elevations (the ALE and Rattlesnake Mountain), there are nine different soil types scattered throughout the area. The predominant soil is Warden silt loam, with Ritzville silt loam and Hezel sand secondary. The remaining six types are present in smaller amounts, but again are scattered widely throughout the area.

A large amount of Dunesand (several square miles) is located just to the north of the Washington Public Power Supply System-leased land with several smaller areas west of the Wye Barricace between there and State Route 240.

\subsubsection{Geology/Structures}

The Hanford Site is in the geologic region known as the Columbia Plateau. The Columbia Platean is a broad plain made up of basalt flows of the Columbia River Basalt Group, and intercalated and overlying sedimentary rocks. The Hanford Site lies within the eastern part of the Yakima Fold Belt, a series of anticlinal ridges and synclinal valleys in the western part of the Columbia Plateau. The Yakima Fold Belt developed as the basalt flows were faulted and folded during the past 17 million yr by forces generated by plate tectonic activity in the Pacific Northwest.

Geologic activities currently at the Hanford Site are directed toward supporting waste management and hazardous waste cleanup activities. These activities include geologic and hydrologic characterization of the Hanford Site and seismic monitoring activities.

3.5.4.1 Geologic History. The geologic development of the Hanford Site is closely linked to the geologic history of the Pacific Northwest. The present geologic features of the Site are the product of Plate Tectonic activity off the west coast of North America. The pre-Cenozoic history of the Pacific Northwest is dominated by the accretion of lithospheric plates to the North American continent. The Cenozoic history is dominated by mountain building and igneous activity. The Hanford Site lies in an area of past volcanic activity.

The geologic history of the Hanford Site is directly tied to the volcanic eruptions of the Columbia River Basalt Group and the deformational processes that occurred simultaneously with and after the eruptions. The Columbia River basalt is one of the world's youngest and smallest continental floodbasalt provinces. Beginning about $17 \mathrm{milli}$ ion yr ago, large volumes of basaltic lava were extruded from fissures along the eastern border of Washington, Oregon, and western Idaho. The basalts flowed westward down a preexisting paleoslope, some spreading as far west as the Pacific Ocean. The Columbia River Basalt Group eventually covered $164,000 \mathrm{~km}^{2}$ and has a total volume of $175,000 \mathrm{~km}^{3}$. The last basalt flow occurred 6 million yr ago at the end of the Miocene.

Simultaneously with the eruptions, the area was undergoing north-south directed compression which resulted in folding and faulting of the basalt flows. The present ridges that bound the Site are anticlinal ridges and the valleys are synclinal structures. These anticlinal ridges and synclinal valleys continued to grow after basaltic volcanism ceased on the columbia Plateau. The present relief developed in the 10 million yr since the last 
DOE/RL-89-15

basalt was erupted. Present tectonic activity is very low as indicated by the absence of active faults and the very low microseismic activity. A generalized geologic structure map is shown in Figure 3-15.

Since the end of the Columbia River Basalt Group volcanic eruptions, the area received sediments of the Pliocene Ringold Formation and the Pleistocene Hanford formation. Ringold sediments were derived from the ancestral Columbia River and were deposited in the synclinal valleys. Overlying the Ringold sediments are glacial-fluvial sediments deposited by catastrophic flood waters of glacial-lake Missoula. The last fiood occurred over 13,000 yr ago but prior to that the area was inundated many times by these floods. The 200 Areas plateau is a flood bar formed by these floods.

3.5.4.2 Structural Geology of the Hanford Site. The principal geologic structures at the Hanford Site are folds that formed the anticlinal ridges and the synclinal valleys.* As the folds grew, faults developed along many of the anticlines such as Rattlesnake Mountain. Figure 3-16 is a structure map of the Hanford Site and adjacent area showing the location of the principal folds and faults. The principal fault zones are confined to the north flanks of the anticlinal ridges and are frontal faults that developed as the anticlines grew. The greatest allount of tectonic jointing and faulting occur's along the axes of the anticlinal ridges in the hinge zones and in the more steeply dipping beds. Very little faulting occurs in the synclinal valleys. Faults in the synclines are typically small faults occurring in conjugate pairs and usually limited to individual basalt flows or strata. There is no evidence of major through-going faults in the synclinal areas.

Detailed investigations at the Hanford Site over the past 20 yr have shown that there are no active faults on the Site. In general, faults on the Hanford Site show no evidence for movement younger than 13,000 yr before present and most have not moved in the last 50,000 yr or more. The Rattlesnake Mountain fault is the largest fault on the Site and is assumed capable.** This fault is part of the Rattlesnake-Wallula deformed zone that extends from Rattlesnake Mountain to Wallula Gap on the Columbia River. Five faults on Gable Mountain are also considered capable but the U.S. Nuclear Regulatory Commission (NRC) and the U.S. Geological Survey consider these faults to have low seismic potential. A conservative approach was taken during reactor construction at the Hanford Site in the past. Those faults for which evidence was inconclusive, as to capability, were considered capable. This conservative approach is currently used on the Site.

\footnotetext{
*Anticlines are folds in which layered strata are folded downward and away from the axes (convex downward). Synclines are folds which are convex upward.

**Appendix A of 10 CFR 100 defines a capable fault as having exhibited one or more of the following characteristics:

- Movement at or near the ground surface at least once within the past j5,000 yr or movement of a recurring nature within the last 500,000 yr

- Macro-seismicity instrumentally determined with records of sufficient precision to demonstrate a direct relationship with the fault

- A structural relationship to a capable fault according to one of the two characteristics above such that movement on one could be reasonably expected to be accompanied by movement on the other.
} 
Figure 3-15. Generalized Geologic Structure Map of the Central Columbia Plateau.

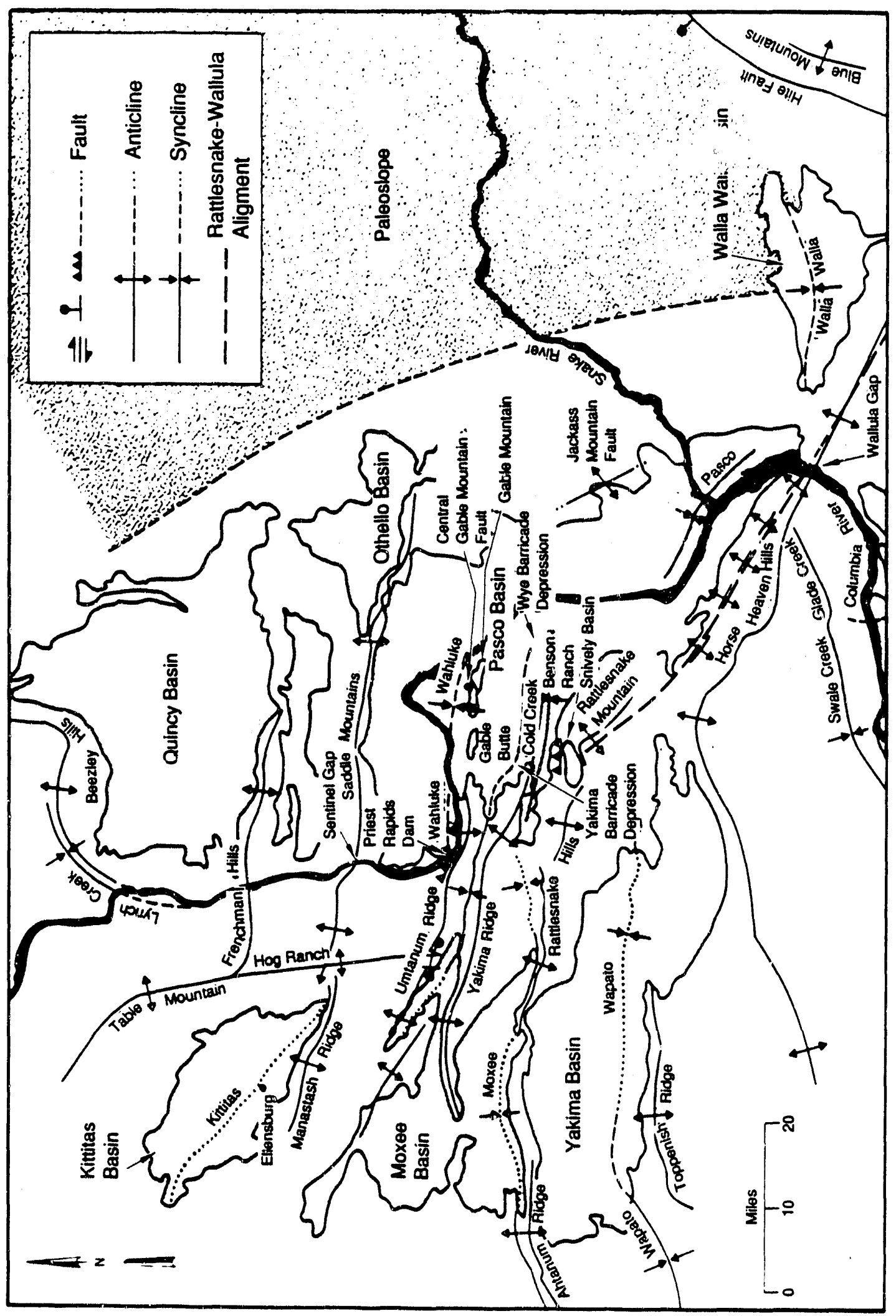


DOE/RL- $89-15$

Figure 3-16. Structure Map of the Hanford Site and Surrounding Area.

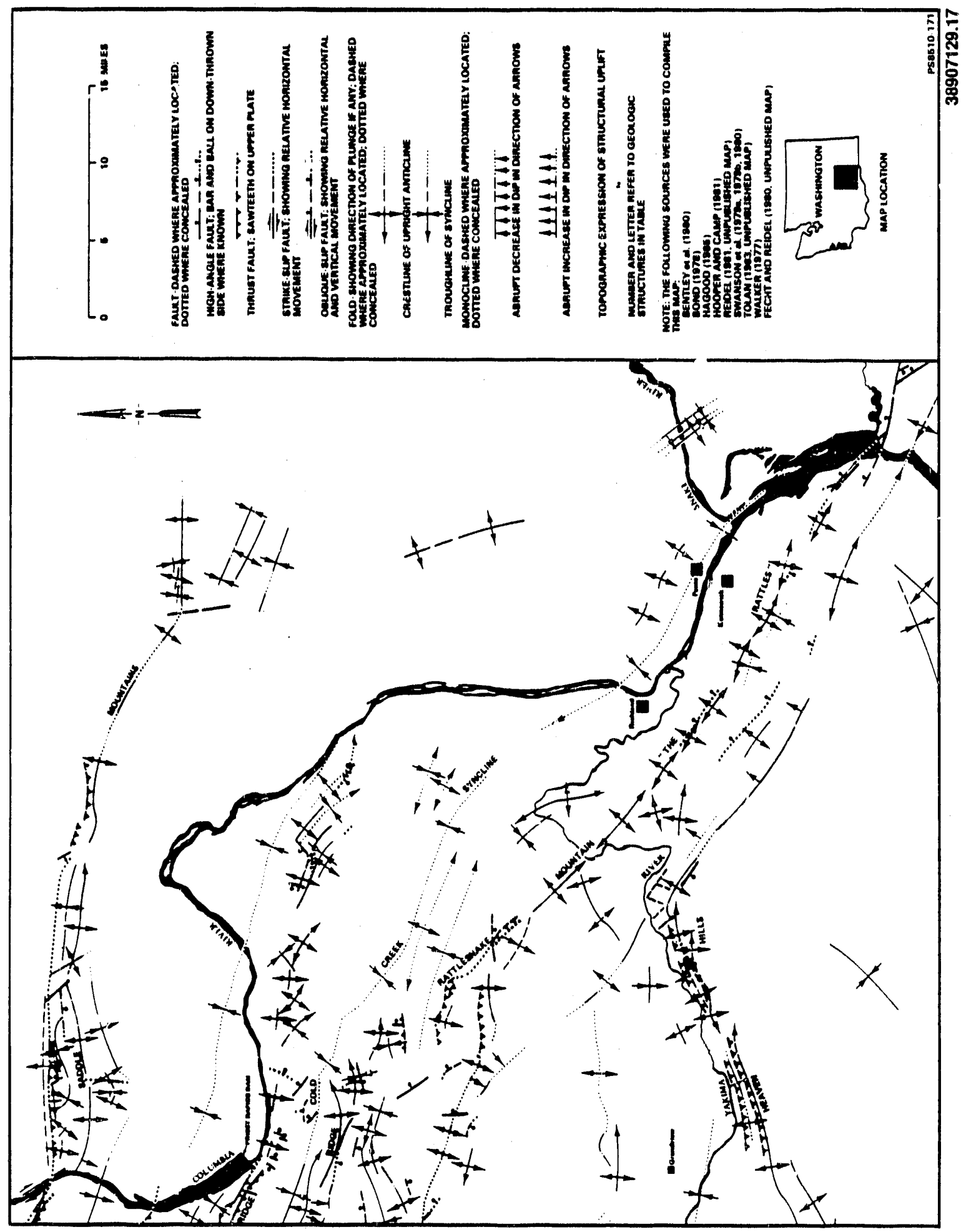


3.5.4.3 Earthquake Potential. Before 1969, the instrumental detection of earthquakes in eastern Washington State, northeastern Oregon, and northern Idaho was limited to a few events that were sufficiently large to have been recorded by the sparse network of stations that existed. This restricted the instrumental record to events that were generally larger than Richter magnitude 4. Since the installation of additional networks in 1969 by the U.S. Geological Survey, the University of Washington, and the BWIP, the instrumental record has become far more complete and accurate.

There have been a few seismic events in eastern Washington that warrant discussion because of their possible significance to the Hanford Site.

On December 4, 1872, a major earthquake occurred in the vicinity of north-central Washington State. Because of the sparse population and 1 ack of recording instruments at that time, the location and size of this earthquake are uncertain. A Washington Public Power Supply System study concluded that the earthquake occurred within the Northern Cascades tectonic province in a broad meizoseismal zone extending nortinward from the vicinity of Lake Chelan to southern British Columbia. The NRC concluded that the boundary between the North Cascades tectonic province and the Columbia Plateau is about $140 \mathrm{~km}(88 \mathrm{mi})$ north of the Hanford Site at its closest approach (NRC 1982).

On March 5, 1893, an earthquake occurred near Umatilla, Oregon, which is about $70 \mathrm{~km}$ ( $44 \mathrm{mi}$ ) south of the Hanford Site. Early estimates suggested that this earthquake had a maximum modified mercalli (MM) intensity of VII, but this was subsequently reduced to MM intensity VI (WPPSS 1981, p. 123).

An earthquake occurred in the vicinity of the Saddle Mountains and Frenchman Hills on Noyember 1, 1918, which was followed by several smaller events over subsequent weeks. The original report of this event (BSSA 1918; WPPSS 1981, p. 2.5-120) estimated a Rossi-Fore1 epicentral intensity of IV, which is equivalent to an MM intensity IV to V (Richter 1958, Appendix III). Recently, the instrumental location and magnitude of this event have been estimated from the lone seismogram recorded at Spokane or station SPO (WPPSS 1981 , pp. 2.5J-36 to -37). A surface-wave magnitude of 4.4 was estimated on the basis of the recorded waveform and an empirical moment-magnitude relationship (WPPSS 1981, p. 2.5J-36).

The largest earthquake known to have occurred within the Columbia Plateau was the July 16, 1936, Milton-Freewater, Oregon, earthquake. This earthquake was felt over much of eastern Washington State and northeastern Oregon and was accompanied by a number of foreshocks and aftershocks (Rasmussen 1967, p. 468; WCC 1980, p. 28). The maximum epicentral intensity was estimated to be MM VII, and the surface-wave magnitude was originally estimated to be 5-3/4 (Gutenberg and Richter 1965, p. 164). An evaluation of Gutenberg's original seismographic data suggested that the Richter magnitude could be as high as 6.1 (WCC 1980, p. 12). A reevaluation using station corrections (WCC 1982) yielded a surface wave magnitude of 5.7 to 5.8 (NRC 1982, G-17). 
The location of the 1936 earthquake and, therefore, its association with a known geologic structure are uncertain. A summary of the various locations of the event is given in WCC (1980). Most recently, WCC (1980) estimated a location at $45^{\circ} 12.3^{\circ} \mathrm{N}, 118^{\circ} 14.0^{\circ} \mathrm{W}$ from a reexamination of the instrumental data.

On December 20,1973 , a coda magnitude 4.4 earthquake occurred near the same location as the November 1,1918 event. This was a shallow earthquake, near the base of the basalt and was followed by numerous aftershocks and swarm-type activity over the next few months (Malone $e^{+}$a1. 1975; BSSA 1918, Vol. 65, No. 4, pp. 855-864).

A coda-length magnitude 4.1 earthquake occurred near College Place, Washington, on April 8, 1979. This was a shallow event with a focal depth of between 3 and $6 \mathrm{~km}$ ( 1.9 to $3.7 \mathrm{mi})$.

The historic record of events with epicentral intensities of MM IV or greater (Figure 3-17) and the seismographic record of events of magnitude 3 or greater (Figure 3-18) are remarkably similar and indicate that the major sei micity of the Columbia Plateau is broadly scattered. The instrumental seismic record, which commenced in 1969, reveals that arear of concentrated seismicity occur near Lake Chelan and in the central Columbia Plateau.

Most of the currently observed seismicity of the central Columbia Plateau is concentrated between the Saddle Mountains and Frenchman Hills, and between the Saddle Mountains and the Gable Mountain-Gable Butte area. The regional detection threshold has varied over time as the seismographic coverage has evolved (WPPSS 1981, Table 2.5J-1) but for events of magnitude 2 or greater, concentrations have persisted (WPPSS 1981, p. 2.5J-14).

The densest groups of exicenters are swarms. An earthquake swarm may be defined as a cluster of events of comparable magnitude that first wax and then wane in number with no one outstanding event; the main criterion here is that no "outstanding" (large) event occurs. An outstanding event is considered a mainshock, and any earthquakes that precede or follow it are considered foreshock or aftershock activity. However, because of the low seismicity rates and generally small magnitudes of events that have been observed in the central plateau region (roughly 90\% have magnitudes of 2 or less), the distinction between swarm and nonswarm activity is not always clear.

Based on the seismic record, Columbia Plateau seismicity segregates by depth into three zones: $0-4 \mathrm{~km}, 4-8 \mathrm{~km}$, and deeper than $8 \mathrm{~km}$ (WPPSS 1981, Figures 2.5J-11 to -14 ). On the order of $90 \%$ of the seismicity occurs at depths less than $8 \mathrm{~km}$, and most of this shallow seismicity (70-80\%) occurs in the uppermost $4 \mathrm{~km}(2.5 \mathrm{mi})$ (WPPSS 1981, pp. $2.5 \mathrm{~J}-15$ to -17$)$. No seismicity has been observed below the local Moho depth of $30 \mathrm{~km}$. These shallow, intermediate, and deep zones coincide approximately with zones of basalt, sub-basalt sediment, and crystalline basement.

In the subsequent discussions, the seismicity of the shallow and intermediate zones are discussed together. 
Figure 3-17. Historical Seismicity of the Columbia

Plateau and Surrounding Areas, Pre-1969.

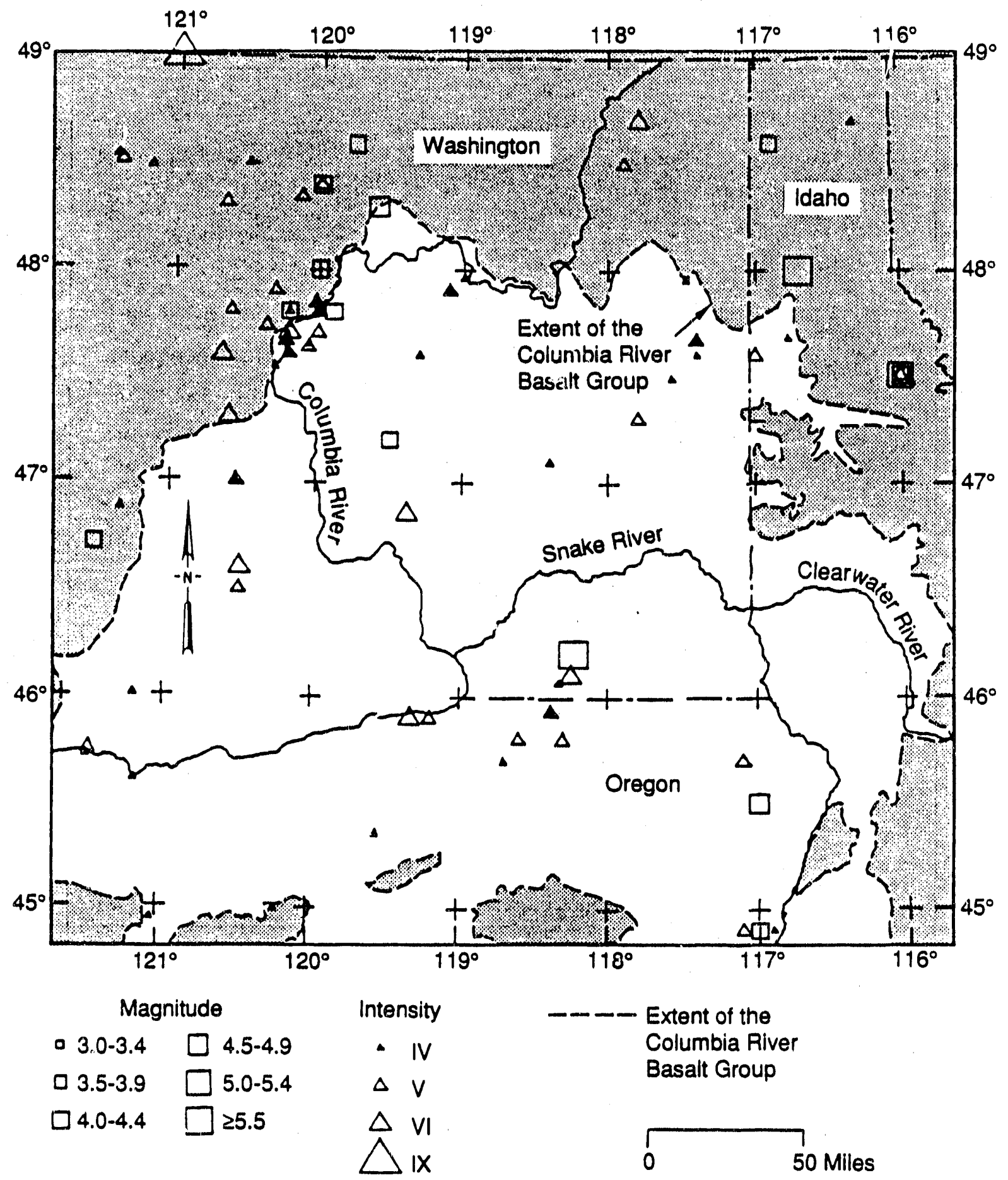

PS8609-267A

38907129.15 
Figure 3-18. Recent Seismographic Seismicity of the Columbia Plateau and Surrounding Areas Since 1969.

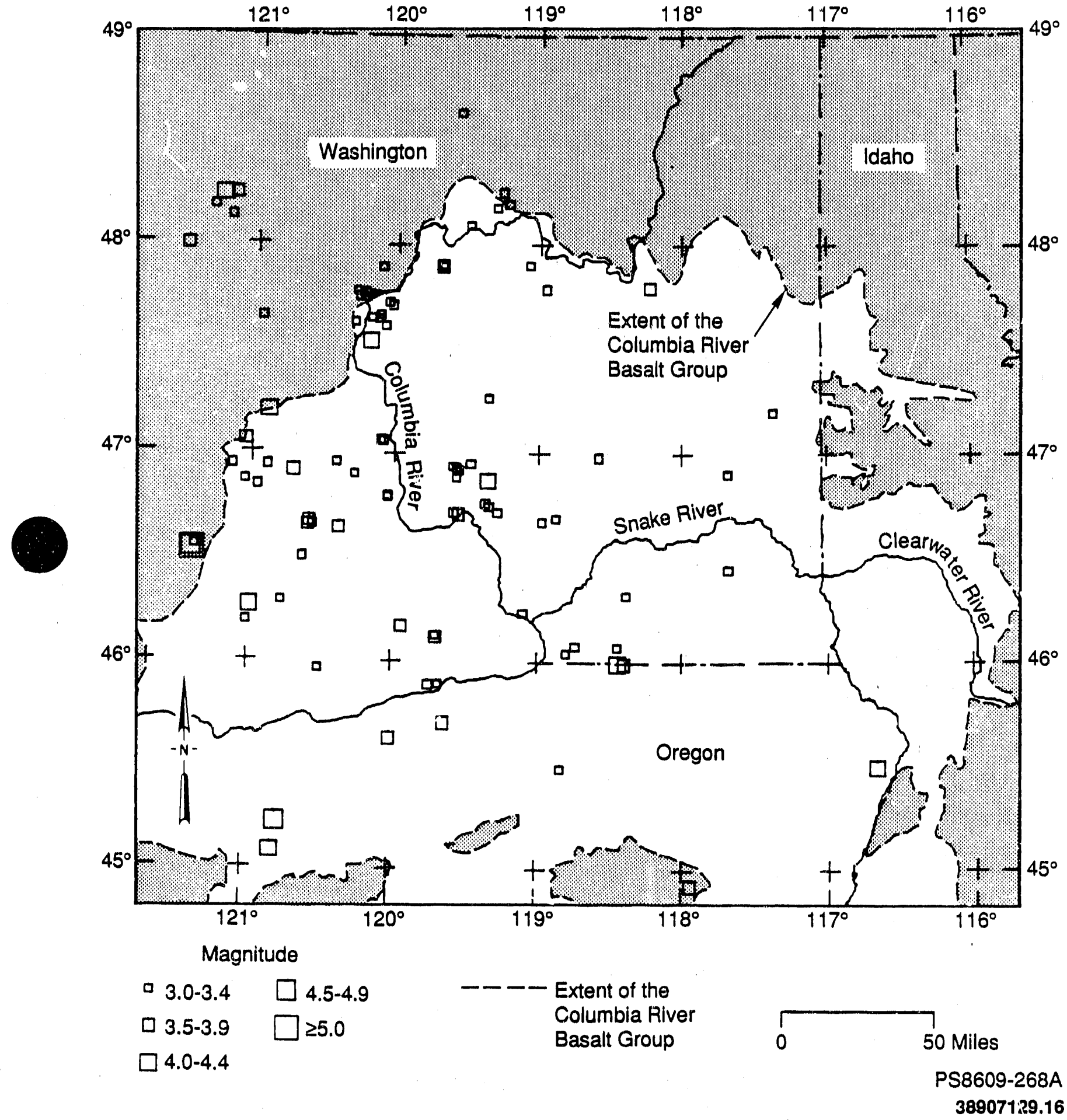


Most central Columbia Plateau earthquakes are located at depths less than $8 \mathrm{~km}(5 \mathrm{mi})$ and occur north and northeast of the Columbia River. The shallowest seismicity is predominantly swarm activity.

Using well-located events, the University of Washington Geophysics Program (UWGP 1979) outlined 13 swarm areas in the Columbia Plateau. The boundaries of the areas, which were subjective to some degree, have a typical dimension on the order of $10 \mathrm{~km}(6.2 \mathrm{mi})$ on a side. They did not analyze the disiribution of swarm depths or the vertical extent of individual swarms, but they classified the swarms as shallow seismicity, which were defined as having focal depths of less than approximately $6 \mathrm{~km}$ (3.7 mi) (UWGP 1979, p. 24).

A Washington Public Power Supply System study established 28 additional swarm areas (21 in the central plateau region), and modified the boundaries of 4 of the UWGP's areas; however, the typical dimension of these swarms remained on the order of $10 \mathrm{~km}(6.2 \mathrm{mi})$ on a side. Individual swarms were found to cluster within areas on the order of $25 \mathrm{~km}^{2}\left(9.65 \mathrm{mi}^{2}\right)$ (WPPSS 1981, p. 2.5J-26) and have depths on the order of 0 to $6 \mathrm{~km}$. The depth precision is 2 to $4 \mathrm{~km}$ ( 1.3 to $2.5 \mathrm{mi})$.

Since 1969 when the collection of local Columbia Plateau seismographic data began, most swarm events have been observed to have coda-length magnitudes of about 1.5 or less. The largest swarm event has been the 4.4 codalength magnitude 1973 Royal slope shock, which in some ways exhibited mainshock characteristics. As stated previously, only about $10 \%$ of the seismicity at depths less than $8 \mathrm{~km}$ ( $5 \mathrm{mi}$ ) exceed (coda-length) magnitude 2.0 .

Below about $8 \mathrm{~km}(5 \mathrm{mi})$ depth, the seismicity in the central Columbia Plateau displays characteristics that are quite distinct from shallower seismicity. Deeper seismicity is generally diffusely distributed throughout the Columbia Plateau. Clusters of events occur at the eastern end of the Saddle Mountains where the Scootney Reservoir and Connell swarm areas extend to 10 and $12 \mathrm{~km}(6.2$ and $7.5 \mathrm{mi})$, respectively, at a single area between the Frenchman Hills and the Saddle Mountains near Corfu, and south of the Horse Heaven Hills near Prosser.

Delineation of patterns suggestive of faulting surfaces is hampered in the central Columbia Plateau by the combination of low seismicity, location precision, and small swarm dimensions and magnitudes. In general, the pattern and distribution of earthquakes deeper than about $8 \mathrm{~km}(5 \mathrm{mi})$ do not exhibit an obvious relationship to known folds or faults having surface expression. Also, this seismicity generally does not coincide with areas of intense shallow swarm activity, but rather, it occurs in a diffuse pattern.

Estimates for the earthquake potential of structures and zones in the central Columbia Plateau have been developed during the licensing of nuclear powerplants at the Hanford Site. The NRC (1982, pp. 2-22 to 2-30), in its seview of the operating license application for the WNP-2 at the Hanford site, concluded that four earthquake sources should be considered for the purpose of seismic design: the Rattlesnake-Wallula alignment, Gable Mountair a floating earthquake in the tectonic province, and a swarm area. 
For the Rattlesnake-Wallula alignment, the NRC assumed strike-slip motion with minor amounts of oblique slip and a seismogenic length of $120 \mathrm{~km}$ $(74.5 \mathrm{mi})$. Using the relationship developed by Slemmons between fault length and surface-wave magnitude (NRC 1982, Appendix H) yields a surface-wave magnitude of 6.5 .

of the five Gable Mountain faults, the NRC assumed that the Ceritral Fault, which has the largest rupture area, is capable of generating the largest event (NRC 1982, Pp. 2-27 to 2-29). The NRC staff extended the reverse-oblique slip data of Wyss (1979, pp. 336-340) on fault area versus maximum magnitude to the lower values appropriate to the Gable Mountain faults and estimated a maximum surface-wave magnitude of $5.0 \pm 0.5$.

The floating earthquake for the tectonic province was developed from the largest event felt or recorded on the Columbia Plateau, which occurred in 1936 near Milton-Freewater, Oregon, and had a surface-wave magnitude of 5.75 (Gutenberg and Richter 1965, p. 164; NRC 1982, p. 2-25). Because of uncertainty in the association of this event with a specific structure, the NRC stance was that a similar event could occur in the immediate vicinity of tiie WNP-2 site.

The magnitude and location characteristics of the hypothetical swarm were based on the observed seismicity. The largest Columbia Plateau swarm event thus far observed (1973 Royal slope earthquakes) had a coda-length magnitude of 4.4 (Malone et al. 1975). The NRC has interpreted this event (NRC 1982, Pp. 2-26 to 2-27) as a Richter mrgnitude 4.0 to reflect the relative overestimation by the coda-length scale. On the basis of studies that suggest that swarms preferentially occur in areas of irrigation (WPPSS 1981, pp. 2.5J-39 to 2.5J-49), the NRC adopted the distance to the nearest areas of irrigation [ $3 \mathrm{~km}(1.9 \mathrm{mi})]$ as the minimum distance of the maximum swarm event to the WNP-2 site.

The maximum magnitudes for the potentially seismogenic structures identified above were estimated from empirical fault dimension-magnitude relationships. This approach was adopted because no significant seismicity is located on the structures. However, the applicability of relationships in these cases is questionable (NRC 1982. Appendix H) because they were developed for larger events and fault surfaces than those of the Columbia Plateau, and furthermore, they were developed for plate boundaries rather than plate interiors.

Below are brief descriptions for estimating recurrence intervals of earthquakes from seismogeric sources that might affect the Hanford Site.

Reliable recurrence calculations are available for events of codalength magnitude less than 4.5 in the Pasco Basin. Extrapolation of these calculations to magnitudes greater than 4.5 for the Columbia Plateau may not be valid because the data suggest that earthquake processes may be different at higher magnitudes (Rothe 1978, Chapter VII).

Past determinations of recurrence intervals in eastern Washington State vary depending on the investigator, the areas studied, and method of analysis. Some recurrence intervals for events in the Pasco Basin, Columbia Plateau, and specific structures are found in WPPSS (1981, pp. 49-52 and

Fig. 2.5-16, 2.5-17, 2.5-18, and 2.5-29) and NRC (1982, pp. 20-32). 
Instrumentally recorded seismicity alone was not sufficient to provide recurrence estimates for individual structures. The Washingtion Public Power Supply System based their recurrence intervals for earthquakes on specific structures on stratigraphic data as well as instrumental data. The earthquake recurrence characteristics they determined for specific structures are as follows (WPPSS 1981, Appendix 2.5K, pp. 2.5K-49 to 2.5K-53):

- On the central fault of Gable Mountain--10,000 yr for a magnitude $5.0 \pm 0.5$

- In the Finley Quarry area--at least several tens of thousands of years, and possible longer for a surface rupture

- For surface rupture on the Wallula Fault Zone--in exces: of $10,000 \mathrm{yr}$, and may be much longer

- For surface rupture on the Toppenish Ridge---on the order of thousands to a few tens of thousands of years

- For surface rupture on Ahtanum Ridge--on the order of at least tens of thousands of years.

\subsubsection{Hydrology}

The primary surface-water features associated with the Hanford Site are the Columbia and Yakima Rivers. Several surface ponds and ditches are present, which are generally associated with fuel and waste processing activities.

Flow from approximately two-thirds of the Hanford Site drains directly into the Columbia River; runoff is extremely low, if not zero. The section of the Columbia River along the Hanford Site Reach, which extends from the headwaters of Lake Wallula to the Priest Rapids Dam, is the last free-flowing stretch of the Columbia River. Flow along this reach is controlled by the Priest Rapids Dam. Several drains and intakes are also present along this reach. Most notably, these include irrigation outfalls from the columbia Basin Irrigation Project and Hanford Site intakes for the onsite water export system.

Cold Cree. and its tributary, Dry Creek, are ephemeral streams within the Yakima River drainage system along the southern boundary of the Hanford Site. Approximately one-third of the Hanford Site is drained by the Yakima River system. Figure 3-19 shows the drainage areas for Cold Creek and Dry creek.

The Yakima River, bordering the southern portion of the Hanford Site, has a low annual flow compared with the Columbia River. The average discharge of the Yakima River, measured at Kiona, Washington, is about $7,000 \mathrm{ft}^{3} / \mathrm{s}$. 
Figure 3-19. Drainage Areas for Cold Creek and

Dry Creek on the Hanford Site.

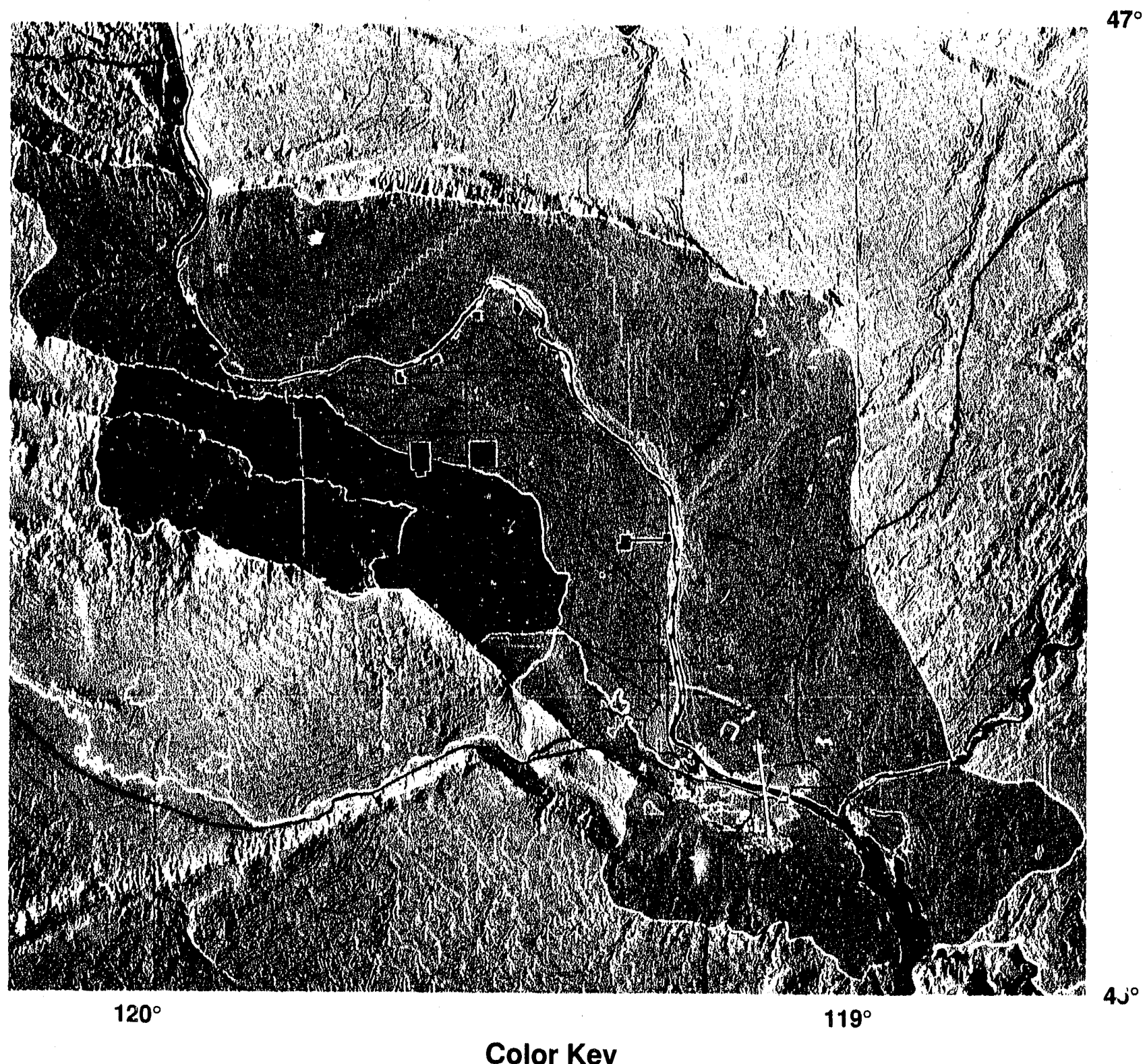

\section{Color Key}

Color

Description

Color

Description

Water

Pasco Drainage Basin

Cold Creek Drainage Basin

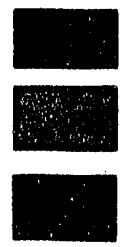

Nuclear Facilitles

Urban

Roads

Dry Creek Drainage Basin

$38907129.18 a$ 
West Lake, a 10-acre pond less than $3 \mathrm{ft}$ deep, is the only natural pond within the Hanford Site. Its presence is probably due to a combination of factors, such as its location within a topographic depression (which places it closer to the water table) and vertical groundwater leakage from shallow confined aquifers (caused by erosional windows in the basalt flows).

3.5.5.1 Flood Potential. Flooding of the Columbia River could significantly impact the Hanford Site facilities and operations. Major fioods on the Columbia River are characteristically the result of rapid melting of the winter snowpack over a wide area, augmented by above-normal precipitation. The maximum historical flood on record occurred June 7, 1894. The peak discharge at the Hanford Site was $740,000 \mathrm{ft}^{3} / \mathrm{s}$. The largest recent flood took place in 1948, with an observed peak discharge of $690,000 \mathrm{ft}^{3} / \mathrm{s}$ at the Hanford Site. The probability of flooding at the magnitude of the 1894 and 1948 floods has been greatly lowered as a result of upstream regulation at Priest Rapids Dam. Actual river flows currently range between 36,000 and $160,000 \mathrm{ft}^{3} / \mathrm{s}$, whereas unregulated flows (before Priest Rapids Dam construction) ranged between 70,000 and $380,000 \mathrm{ft}^{3} / \mathrm{s}$.

The 1894 flood inundated areas less than $400 \mathrm{ft}$ MSL. A flood of this magnitude would inundate the 100-F Area and sections of Richland. The major four-lane highway on the Hanford Site would be flooded near the old Hanford townsite, cutting off a direct route to Richland. However, access from the west via Route 240 would still be possible. Today's regulated maximum flow, $160,000 \mathrm{ft}^{3} / \mathrm{s}$, has no effect on any facilities on the Hanford Site. The probable maximum flood* (PMF) for the Columbia River below Priest Rapids Dam is calculated as $1.4 \mathrm{million} \mathrm{ft}^{3} / \mathrm{s}$. This magnitude of flooding would inundate the 100-F Area, part of the 100-B and -C Area, part of the 100-H Area, and large areas within the city of Richland. The 200 and 300 Areas, as well as the central portion of the Hanford Site, would remain unaffected (Figure 3-20).

Flooding of the Yakima River would have only a minor impact on the Hanford Site. Yakima River floods occur as a result of the same hydrometeorologic events that induced the Columbia River flood flows, In addition to spring snowmelt and warm rains, ice and debris jams contribute to flooding on the Yakima River. Since 1862, there have been 16 major floods on the Yakima River. The most severe ones occurred in November 1906, December 1933, and May 1948. The peak discharge magnitude of these floods measured at Kiona, Washington, were $66,000,67,000$, and $37,000 \mathrm{ft}^{3} / \mathrm{s}$, respectively. The recurrence interval for the 1933 and 1948 floods are estimated at 170 and $33 \mathrm{yr}$, respectively. The most recent flood occurred in December 1977 with a peak discharge of $29,000 \mathrm{ft}^{3} / \mathrm{s}$ and a recurrence interval of $14 \mathrm{yr}$.

The only major source of local or surface flooding on the Hanford Site is the cold creek watershed. This is divided into the upper and lower cold Creek. At its headwaters along the Yakima Ridge, the elevation is above 4,000 ft above MSL; at the point where it drains into the Yakima River, it is about $420 \mathrm{ft}$ above MSL. The Cold Creek floodplain is located in the

*A probable maximum flood is a concept where evaluation of flood conditions is determined from upper limits of precipitation falling on a drainage area, moisture conditions, snowmeit, and tributary conditions that result in maximum runoff. 
Figure 3-20. Probable Maximum Flood $\left(1,450,000 \mathrm{ft}^{3} / \mathrm{s}\right)$.

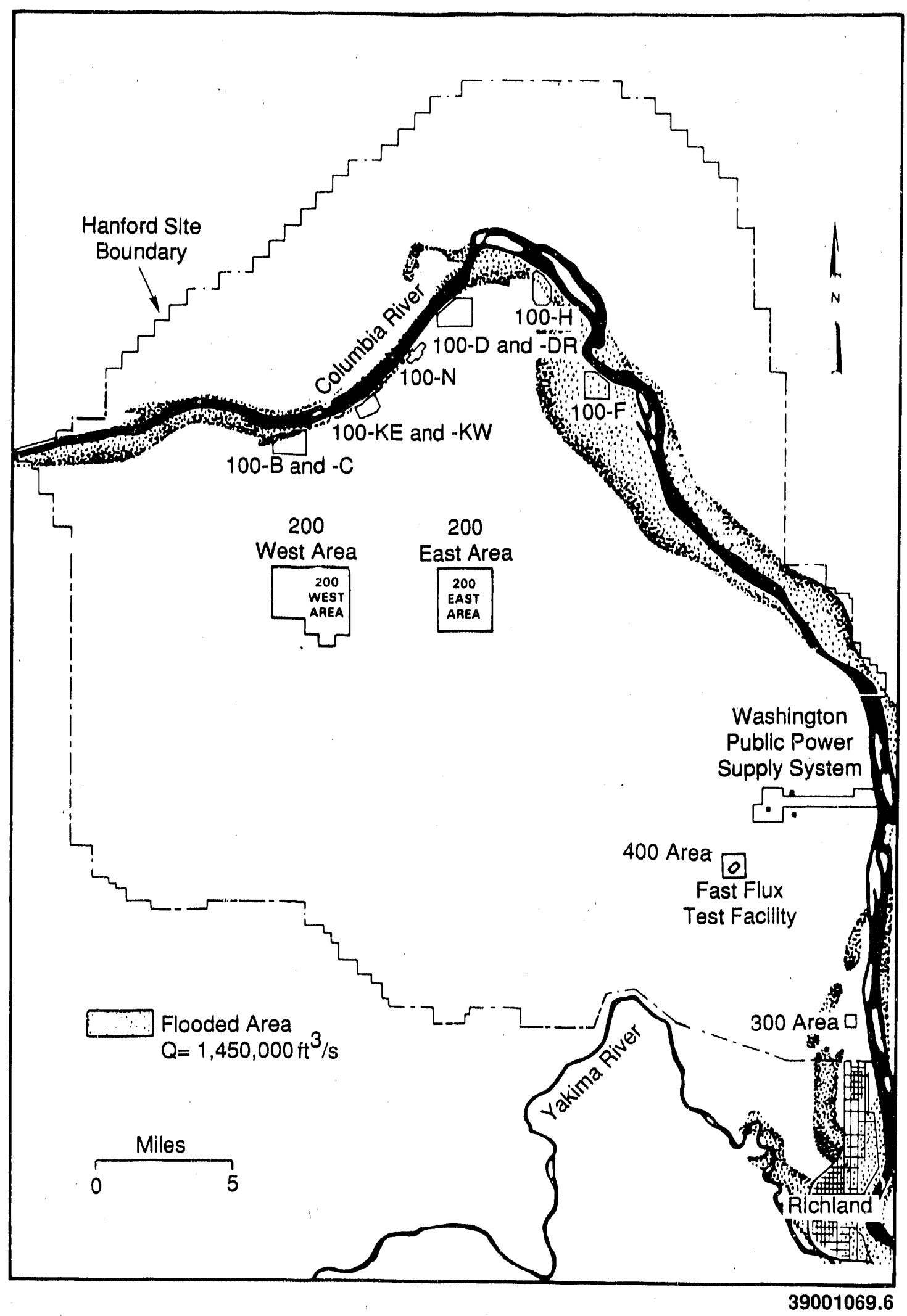


lower Cold Creek southeast of the 200 Areas. A PMF for the Cold Creek and Dry Creek streams would result in little damage other than localized scouring and deposition within the Site boundaries.

Table 3-7 shows some historical events and estimates of peak discharge rates at the Hanford Site.

Table 3-7. Estimated Peak Discharge Rates for Floods on the Columbia River Below Priest Rapids Dam.

\begin{tabular}{lc}
\hline \multicolumn{1}{c}{ Event } & $\begin{array}{c}\text { Peak discharge rates } \\
\text { at Hanford }\left(\mathrm{ft}^{3} / \mathrm{s}\right)\end{array}$ \\
\hline Dam-regulated probable maximum flood & $1,400,000$ \\
Seismic damage to Grand & \\
Coulee Dam (50\% breach) & $8,000,000$ \\
$500-y r$ flood & 840,000 \\
Greatest flood on record & 740,000 \\
(1894-estimated) & \\
Second highest flood on & 690,000 \\
record (1948) & 700,000 \\
100-yr flood & \\
\hline
\end{tabular}

The water table has been mapped using water level data from the numerous wells. Figure 3-21 shows the water table map with the contour lines linking points of equal hydraulic potential. If the hydraulic conductivity of the aquifer is assumed to be uniform in all directions at a given location, the groundwater flow will be perpendicular to the contour lines and toward lower hydraulic potential (water table elevation). In Figure 3-21, the groundwater flow is predominantly north and east toward the Columbia River, which is mainly a discharge boundary for the confined aquifer. The average discharge rate from the aquifer into the river has been calculated at about $99 \mathrm{ft}^{3} / \mathrm{s}$; however, the rate and direction of flow within several miles of the river can be affected by the seasonal river-level fluctuations.

The boundary between the confined and unconfined aquifers is at the top of the Columbia River basalt group. A number of confined aquifers lie beneath the Hanford Site. They are composed primarily of permeable sediments primarily between basalt flows.

3.5.5.2 Groundwater. Both confined and unconfined aquifers are present beneath the Hanford Site. The confined aquifers are aquifers bounded by upper and lower confining boundaries. These occur within the Columbia River basalts at the Hanford Site. In general, the unconfined aquifers occur in the Ringold Formation and the Hanford formation, as well as some more recent alluvial sediments in areas adjacent to the Columbia River. The water table is the top of the unconfined aquifer. This relatively shallow aquifer has been impacted more than the uppermost confined aquifer by wastewater disposal at the Hanford Site. 
DOE/RL - 89- 15

Figure 3-21. Water Table Elevations (1986).

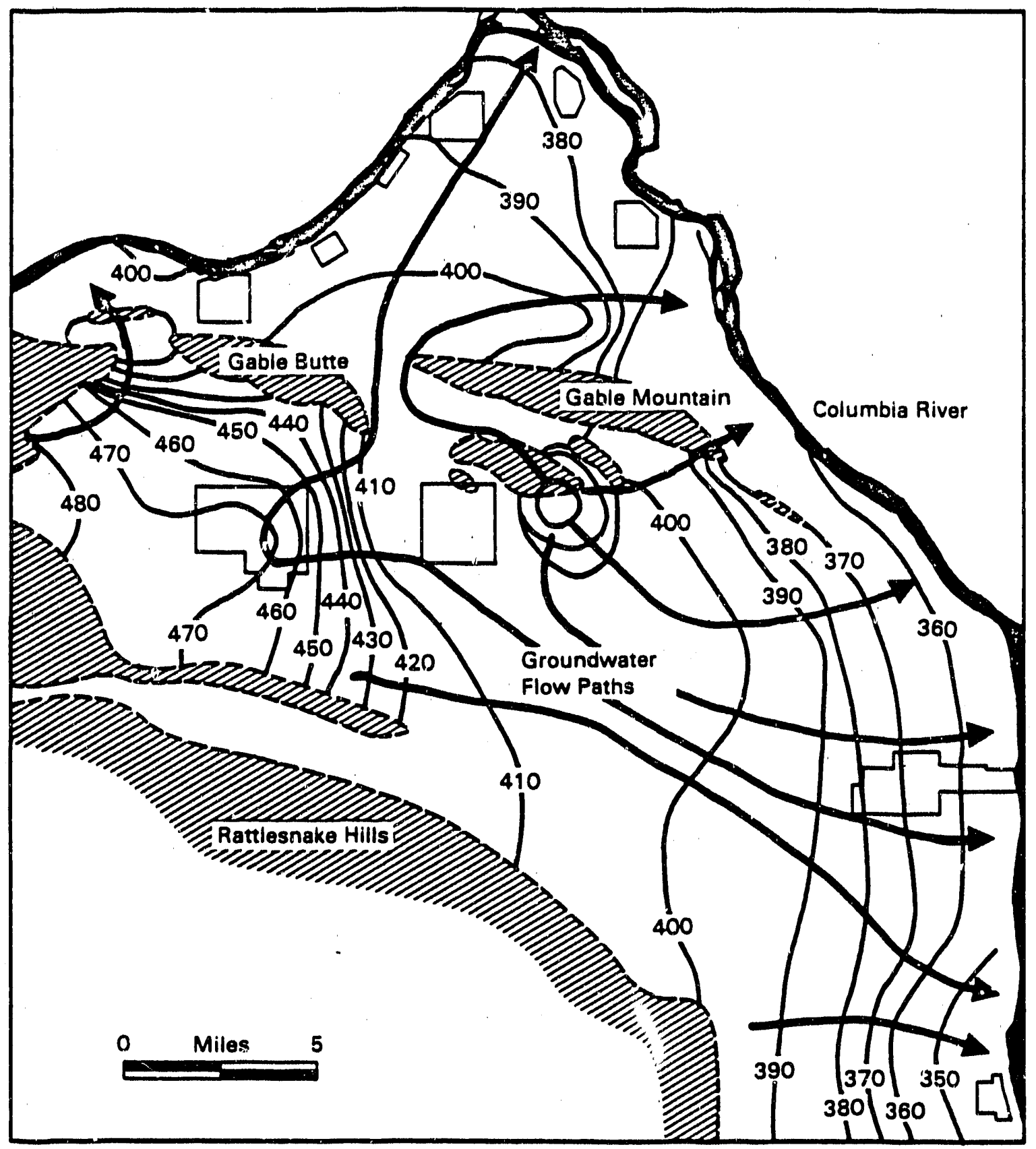


Recharge to the unconfined system comes from several sources. Natural recharge from precipitation and runoff occurs principally to the west from the Cold Creek and Dry Creek areas. The Yakima Rivar recharges the unconfined aquifer as it flows along the southwest boundary of the Hanford Site. The Columbia River recharges the unconfined aquifer during its high stages when river water is transferred to bank storage. The unconfined system receives little, if any, recharge from precipitation within the perimeters of the Hanford Site.

Artificial recharge occurs predominantly from liquid-waste disposal operations in, or adjacent to, the 200 West and 200 East Areas. It has been estimated that recharge to the groundwater from the Separations Area (which includes $B$ Pond as well as the various cribs and trenches in the 200 West and 200 East Areas) adds ten times as great an annual volume of water to the unconfined aquifer as is contributed by natural inflow to the area froin precipitation and irrigation waters to the west. The discharge of water has created groundwater mounds near each of the major wastewater disposal facilities in the Separations Area, and the 100 and 300 Areas (see Figure 3-21). These mounds alter the general flow pattern in the aquifer, from the recharge areas in the west to the discharge areas (primarily the Columbia River) it e east.

Gruundwater levels have changed continuously over the years because of variations in the volume of wastewater discharged. Consequently, the movement of the groundwater and its associated constituents has al so changed with time. Although groundwater mounding occurs in the 100 and 300 Areas, the volume of liquid discharged to the ground is less. The mounding is also affected by the proximity of these areas to the Columbia River, where river stages may play a part. Therefore, groundwater mounding in these areas may not be as significant as in the Separations Area. The effect on the quality of the groundwater that enters the Columbia River from the 100 and 300 Areas may be more pronounced because of the short travel times involved, compared with the longer travel times required to move possible contaminants from the 200 Areas.

\subsubsection{Wetlands}

The Columbia River is the largest su iace water area and supports the most important aquatic ecosystem on the Hanford Site. Forty-five species of fish have been identified from the Hanford Reach of the river. Several species of salmon and steelhead trout use the river to migrate to and from upstream spawning and rearing areas. The Hanford Site serves as the spawning area for more than one-third of the fall chinook salmon in the mid-columbia.

Aquatic habitats on the Hanford Site include the ponds and ditches in or near the 200 Areas, the Columbia River, and several very small streams, including Rattlesnake Springs and Snively Springs west of the 200 Area plateau (Figure 3-22). The wastewater disposal sites have similar waterquality characteristics, and support similar kinds of algae, rooted plants, and invertebrates; all contain introduced populations of goldfish.

The ponds and ditches are the only sources of water in the arid environment of the 200 Area plateau and, therefore, provide habitat for many birds and mammals. The ditches are generally less productive than the ponds 
Figure 3-22. Surface Water Bodies, Including Ephemeral Streams on the Hanford Site.

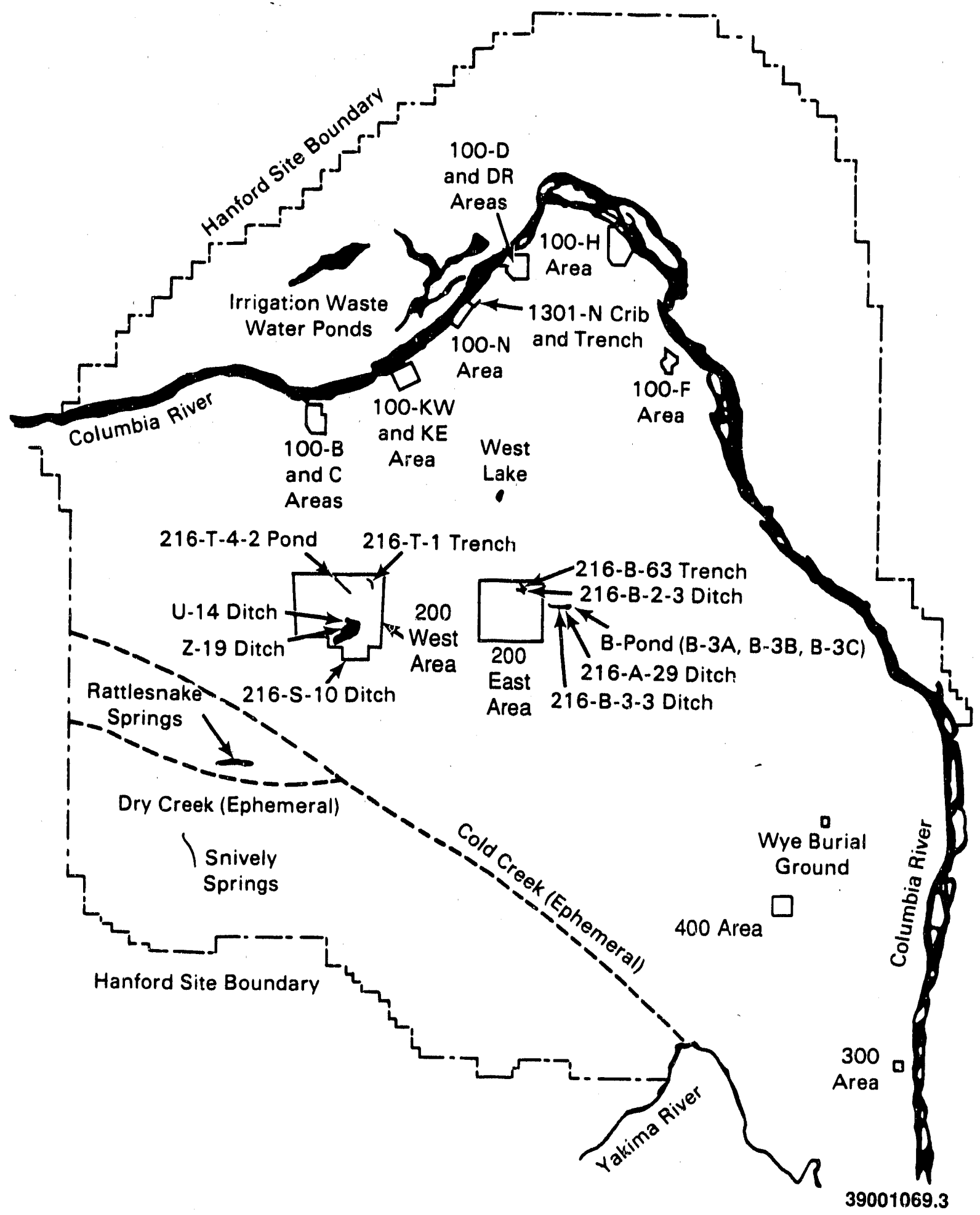


in terms of available bionlass. Streams formed by Rattlesnake and Snively Springs are quite productive and are in remote locations from the waste sites.

There are 20 sparsely vegetated sand and cobble islands in the Hanford Reach of the Columbia River that provide nesting habitat for Canada geese (Branta canadensis moffitti), ring-billed gulls (Larus delawarensis), California gulls (L. californius), and Forster terns (sterna forsteri).

Shoreline trees provide nesting locations for two colonies of great blue herons (Ardea herodias). These shoreline trees al so provide night roosts for groups of bald eagles (Haliaeetus leucocephalus) that winter along the Hanford Reach and forage upon carcasses of salmon.

\subsubsection{Wildilfe}

There are two general classifications of wildlife on the Hanford Site: game species and nongame species. The important game mammals are Rocky Mountain elk (Cervus elaphus), mule deer (Odocoileus hemionus), blacktail jackrabbit (Lepus californicus), and cottontail rabbit (Sylvilaqus nuttallii). The important fur bearers in the dryland habitats are the coyote ( $C_{a r}{ }_{1}$ latrans), bobcat (Lynx rufus), and badger (Taxidea taxus). The important fur bearers associated with the Columbia River are beaver (Castor canadensis), muskrat (Ondatra zibethica), mink (Multela vison), raccoon (Procyon lotor), and striped skunk (Mephitis mephitis).

The elk herd consists of approximately 90 animals that are confined mostly to remote areas in the Rattlesnake Hills. The number of mule deer on the Hanford Site is unknown, but the animals range across the entire Site with major populations distributed along the Columbia River shoreline.

The important upland game birds are the chukar partridge (Alectoris chukar), Hungarian partridge (Perdix perdix), Cal ifornia quail (Lophortyx californicus), mourning dove (Zenaida macroura), and Chinese ring-necked pheasant (Phasianus colchichus). Sage grouse (Centrocercus urophasianus) are scarce on the Hanford Site. A few grouse are resident in the remote areas of the Rattlesnake Hills.

The Columbia River serves as a major resting and wintering habitat for waterfowl migrating along the Pacific flyway. The greatest numbers of waterfowl are present in the winter months; the most abundant species is the mallard (Anas platyrhynchos).

There are many species of nongame birds on the Hanford Site. Of special concern are nesting birds with very small populations that require uninterrupted patches of native vegetation and relative freedom from threatening human activities to ensure reproductive success, e.g., the sage sparrow (Amphispiza belli). Other species that appear to be threatened because of diminishing native habitats by encroachment of cultivated land are the long-billed curlew (Numenius americanus), ferruginous hawk (Buteo regalis), Swainson's hawk (Buteo swainsoni), and burrowing owl (Athene cunicularia). 


\subsubsection{Vegetation}

The natural vegetation of the Hanford Site is a mosaic of plant communities representative of the semi-arid, shrubsteppe region of southeastern Washington. The dominant shrubs are big sagebrush (Artemisia tridentata) and bitterbrush (Purshia tridentata), with smaller populations of spiny hopsage (Grayia spinosa), greasewood (Sarcobatus vermiculatus), winterfat (Eurotia lanata), and two species of rabbitbrush (Chrysothamums nauseosus) and ( $\underline{C}$. viscidiflorus). The abundant herbaceous plants are Sandberg bluegrass (Poa sandbergii), bluebunch wheatgrass (Agropyron spicatum), and cheatgrass (Bromus tectorum).

Shorelines of the Columbia River usually support a narrow zone of riparian plants characterized by small isolated stands of tree and shrub willows (Salix spp.) interspersed with semiaquatic herbaceous plants, such as reed canary grass (Phalaris araundinacea) and others.

Wildfires usually occur in late summer when the plants are dried from the characteristic summer drought of the shrubsteppe region. Burning kills sagebrush, bitterbrush, and spiny hopsage, but rabbitbrush and greasewood shrubs sprout after burning. The herbaceous plants usually survive summer burning.

A few deciduous trees that were planted and irrigated at small, scattered farmsteads, before establishment of the Hanford Site, have survived without benefit of irrigation. Presumably these trees have root access to groundwater. Today these trees provide nesting sites for Swainson's hawks that could not otherwise nest on the interior areas of the Hanford Site.

\subsubsection{Ecological Areas}

The Hanford Site is especially suitable for environmental research because of its large size and its land-use history. Although the primary technological use of the Hanford Site has been plutonium production, most of the land surrounding the reactors and chemical processing buildings has remained devoid of any significant environmental impact from the nuclear technology. The land has benefited from protection from livestock grazing and agricultural uses that most likely would have been imposed upon the land in the absence of the nuclear technology.

The Hanford Site was designated as a National Environmental Research Park (NERP) in March 1977. This designation ensured the preservation of study areas over long periods of time to (1) obtain useful environmental study results, (2) encourage its use by scientists located throughout the United States, and (3) provide a base site from which to integrate Pacific Northwest steppe research done at other sites with other ecosystems, e.g., forest and desert. Major elements of the NERP program have been in place for years, and the program has antecedents dating to 1952 and earlier. The Hanford Site represents a major ecosystem in the northwestern United States (Figure 3-23). 
Figure 3-23. Location of the Four U.S. Department of Energy National Environmental Research Parks.

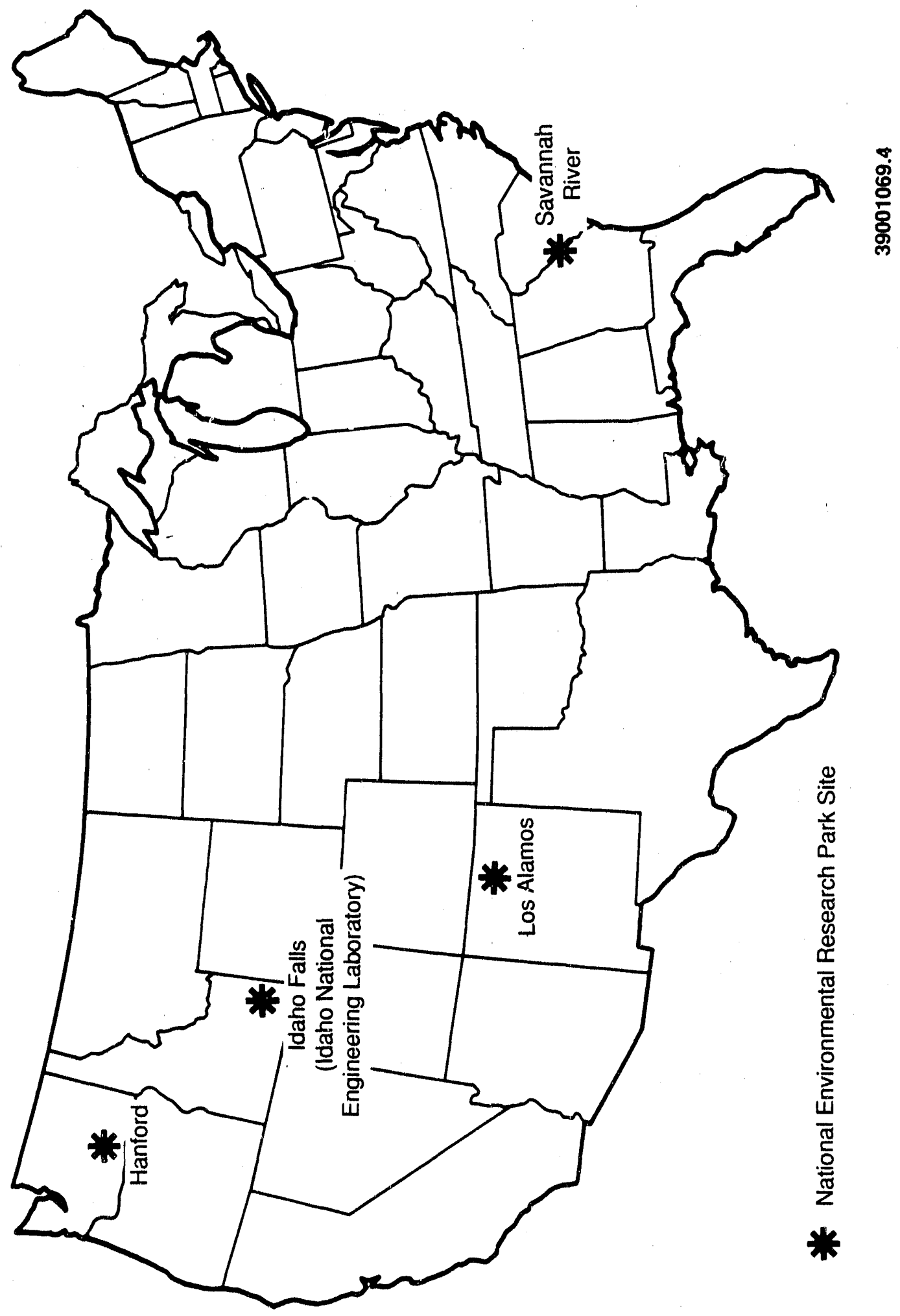


Within the Hanford NERP is the ALE, a smaller area of $120 \mathrm{mi}^{2}$. Special policies for land use apply within its boundaries: the dedication to longterm preservation of pristine vegetational locations and the restriction to "modulation" experiments of those other locations where the landscape can be disturbed. Modulation experiments are defined as procedures that do not irreversibly alter the landscape; e.g., controlled grazing and modification of the precipitation regime by controlled overhead sprinkiing. Other types of intervention procedures that permanently alter the landscape are carried out on locations within the Hanford Site outside the ALE.

The ALE also became the Rattlesnake Hills Research Natural Area in 1971 , as part of a five-agency federal cooperative agreement. A key element in that designation was the idea of preserving undisturbed sites and the gene pools represented by all types of organisms found naturally at those sites, especially rare and endangered or threatened types. These goals were consistent with the prior intent in establishing large segments of the ALE. In 1977, the U.S. Department of Agriculture examined suitable sites for the Biosphere Reserve Program. They stated that "... It was seldom possible to identify a single area that satisfied all criteria - a large, strictly preserved tract for conservation of a full array of organisms with a substantial history of research and monitoring and potential for major experimental treatments. (The only area that is clearly of this type is the Arid Lands Ecology Reserve at Hanford, Washington...)." Thus, policies for the ALE are more restrictive than those for other parts of the Hanford NERP.

The major dryland ecological areas are the steep basalt cliffs located along the crests of the Rattlesnake Hills, Umtanum Ridge, Saddle Mountains, Gable Mountain, and Gable Butte. These areas provide nest locations for prairie falcons (Falco mexicanus) and other birds of prey.

The steep riverine bluffs along the Columbia River, known as White Bluffs, also provide nesting sites for birds of prey and thousands of cliff and bank swallows. There are several square miles of unstabilized sand dunes that are of ecological interest because they support plants that are adapted for growth in a nutrient-poor rooting media, e.g., scurf pea (Psoralea lanceolata) and pale evening primrose (Denothera pallida).

Burned areas --1 abandoned cultivated fie]ds on the Hanford Site support sparse stands of cheatgrass that are used as nesting habitat by the longbilled curlew (Numenius amercanus).

An extensive research program on the study of environmental pathways and food chain relationships using strontium and cesium tracers has been under way for $30 \mathrm{yr}$. This radionuclide uptake study area is north of the 200 East Area and southwest of the 100-F Area.

Over the years, there have been eight primary ecological study areas at the Hanford Site (Figure 3-24):

1. Arid Lands Ecology Reserve--Headquarters. Control plots, experimental cattle grazing, mammal and bird population studies, studies of uptake of transuranic elements by plants from soil, invertebrate population studies, soil and decomposer organism studies, microclimate studies and micrometeorology, and fire as an environmental stress 
Figure 3-24. Ecological Study Areas of the Hanford Site.

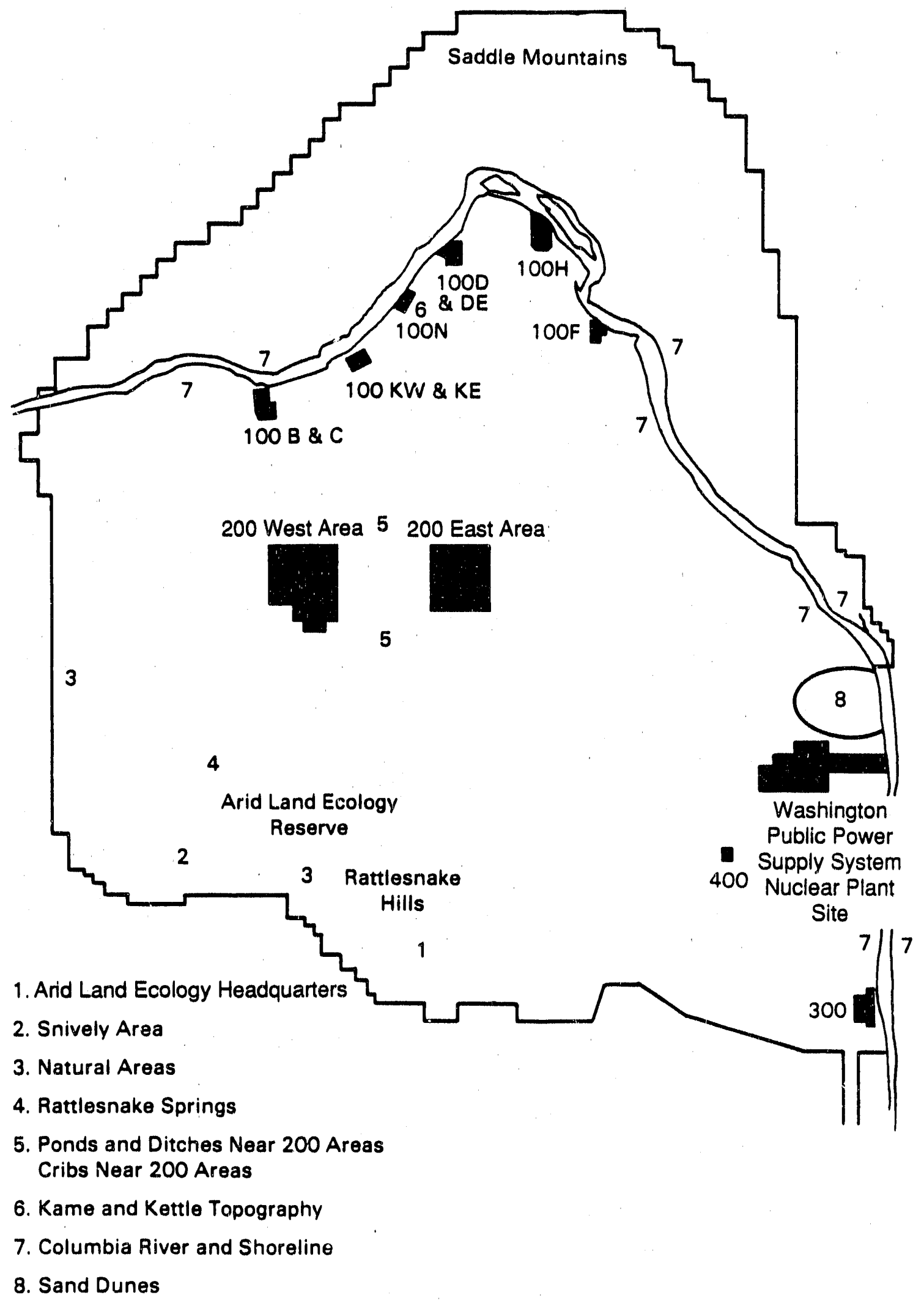


2. Arid Lands Ecology Reserve--Snively Area. Abandoned agricultural fields. Primary and secondary productivity studies, insects and small mammal populations, soil and decomposition studies, mineral uptake studies, secondary $\mathrm{plan}$ succession, bird census of stramside communities

3. Arid Lands Ecology Reserve--Natural Area. These areas are preserved for nondestructive sampling and observations only

4. Arid Lands Ecology Reserve--Rattlesnake Springs. Freshwater ecology studies, saline-sodic soils and halophyte ecology, sprinkler irrigation trails and herbicide applications, darkling beetle population studies

5. Ponds and Ditches Near 200 Areas. Lake and pond radioecology; studies of phyto- and zooplankton, algae, fish, waterfowl, and mammals

Cribs Near 200 Areas. Terrestrial ecology of waste disposal practices, revegetation of disturbed soil, dispersal of radionuclides via food habits of insects and jackrabbits, small mammals, root distribution of native plants, soil-plant uptake studies, foodchain dynamics

6. Kame and Kettle Topography. Study of plant communities and small mammal populations

7. Columbia River and Shoreline. Study of anadromous and resident fish populations, plant siting, water intake structures, thermal and chemical effluent outfalls, mule deer tagging studies, Canada goose nesting studies, heron and gull colonies, swallows

8. Sand Dunes. Study of plant communities, small mammals, and birds.

\subsubsection{Historic, Archaeological, and Cultural Resources}

The Hanford Site has many cultural resources. It contains numerous well-preserved sites representing the prehistoric and historic periods and is still thought of as the homeland of many Native American people.

There are over 150 prehistoric archaeological sites recorded in the files of the Washington State Office of Archaeology and Historic Preservation for the Hanford Site. Forty-seven of these sites are included in nine properties listed on the National Register of Historic Places (National Register). In addition, nominations have been prepared for one archaeological/cultural district (Gable Mountain/Gable Butte), and two other archaeological districts are under consideration. Archaeological sites include pithouse villages, various types of open cariisites, and cemeteries, along the river banks (Rice 1968a, 1980); rock cairns, hunting camps and game drive complexes on mountains and rocky bluffs, and temporary camps near perennial sources of water located away from the river (Rice 1968b). Intensive archaeological survey has revealed that no sites are located in the 200 Areas. The 100 Arisas have not been systematically surveyed. 
The pre-1943 historic period is represented by 11 recorded and numerous unrecorded archaeological sites. 7 standing structures, and a variety of roads, mines, and water delivery systems. None of these sites is currently listed on the National Register, although some may be eligible. Only one (White Bluffs Road) occurs in the 200 Areas; there are none located in the 100 Areas. The post-1943 period includes reactors, materials processing facilities, laboratories, and other buildings associated with significant world events. A National Register nomination has been prepared for the 100-B Reactor, and other decommissioned reactors and facilities will be evaluated before any further demolition.

Native Americans of the Yakima, Umatilla, and Colville Reservations, and the non-treaty Wanapums retair traditional secular and religious ties to the Hanford Site. The Seven Drums religion, which had its start on the Hanford Site among the Wanapums, is still practiced by many members of all the above-named reservations. Native plant and animal foods, which can be found on the Hanford Site, are a part of the ceremonies performed by Seven Drums practitioners.

Native Americans hold the land sacred, so in their terms the entire Hanford Site is culturally important. However, within that larger area there are places with greater importance that have been identified by Native Americans, including Rattlesnake Mountain, Gable Mountain, Gable Butte, Goose Egg Hill, Coyote Rapids, and the White Bluffs segment of the Columbia River (Relander 1956; Chatters 1989). The hill and mountains figure in the mythology of creation and have long been used as sites for the spirit quest. Coyote Rapids was the site of the first Seven Drums ceremony and was also an important fishing place. The White Bluffs Reach of the Columbia River was an important winter camp location and offered the best salmon fishing. The many cemeteries that are found along the Columbia River are also considered to be sacred. The 200 Areas are not in close proximity to any areas of special cultural importance, but the 100-K, 100-D, 100-H, and 100-F Areas are all adjacent to at least one of the above-named localities.

Before any 1 and is disturbed or there is any decommissioning activity, a cultural resource review is conducted, following the regulations and guidelines pursuant to the National Historic Preservation Act of 1966 and the American Indian Religious Freedom Act of 1978. Details of this process and other policies and procedures for managing cuitural resources are detailed in Chatters (1989).

\subsubsection{Endangered Species} Site.

This section identifies endangered animals and plants on the Hanford

3.5.11.1 Animals. The bald eagle (Haliaeetus leucocephalus) is the only bird species that regularly resides on the Hanford Site that is listed by the U.S. Fish and Wildlife Service as in need of special protection. It is listed as "threatened" in Washington State. In recent years, between 30 and 50 bald eagles have regularly used the islands and shorelines of the Hanford Reach of the Columbia River. 
The State of Washington Department of Wildlife has prepared a tentative list of animal species in Washington State that are classified as endangered, threatened, or "sensitive." Those that are known to occur or may occur on the Hanford Site are listed below:

- Endangered Species

- American white pelican (Pelecanus erythrorhynchus)

- Peregrine falcon (Falco peregrinus)

- Aleutian Canada goose (Braniō canadensis leucopareia)

- Sandhil1 crane (Grus canadensis).

- Threatened Species

- Bald eagle (Haliaeetus leucocephalus)

- Ferruginous hawk (Buteo regalis).

- Sensitive Species

- None listed.

Wildlife biologists are concerned with a proposal by the U.S. Army Corps of Engineers to dredge $57 \mathrm{mi}$ of the Columbia River, including the Hanford Reach, the last free-flowing section of the Coiumbia. This section of the Columbia River offers prime spawning grounds for salmon and steelhead. Dredging would affect the birds' ability to find carcasses of spawned-out fish.

3.5.11.2 Plants. No plant species known or thought to occur on the Hanford Site are currently listad as "endangered" or "threatened" by the U.S. Fish and Wildlife Service.

The Washington State Department of Natural Resources' Natural Heritage Program has identified several native vascular plants with low populations that are likely to occur on the Hanford Site. These species, which are listed as endangered, threatened, or sensitive, are shown below:

- Endangered Species

- Persistentsepal Yellowcress (Rorippa columbiae) Suksd. ex Howell.

- Threatened Species

- Thompson's Sandwort (Arenaria franklinii var. thompsonii) Peck

- Columbia Milk-Vetch (Astragalus columbianus) Barneby

- Hoover's Desert Parsley (Lomatium tuberosum) Hoover. 
DOE/RL-89-15

- Sensitive Species

- Gray Cryptantha (Cryptantha leucophaea) Doug1. Pays

- Piper's Daisy (Erigeron piperianus) Cronq.

\subsubsection{Meteorology}

Climatological data are available from the HMS, which is located between the 200 Areas. The HMS consists of a 410-ft steel tower with booms spaced at 50-ft intervals. At each interval, except at the $150-$ and $350-\mathrm{ft}$ intervals, there is a temperature sensor. A wind sensor is located at several of these intervals except at the 150-, 250-, and 350-ft intervals. Data have been collected at the HMS since 1945. Tem lerature and precipitation data from nearby locations are available for 192 through 1943. Data from the HMS are assumed to be representative of the general climatic conditions for the region.

The Cascade Mountains greatly affect the climate of the Hanford Site, although they are not visible from the HMS. Because the Hanford Site is in the rain shadow of these mountains, precipitation averages only $6.25 \mathrm{in}$. annually. Extremes in precipitation have been as follows: a record storm of October 1-2, 1957, in which rainfall totaled 1.88 in. in $12 \mathrm{~h}$, or $30 \%$ of the annual average. At the other extreme, there have been 81 consecutive days without measurable rain (June 22 to September 10, 1967). The months of September through December account for $40 \%$ of the total annual precipitation. Normal rainfall for this period of time is $2.50 \mathrm{in}$.

About 38\% of all precipitation during the months of December through February is in the form of snow. The record greatest depth of snow on the ground was 24.5 in., which occurred in February 1916. However, since that date, the greatest depth has been 15.6 in., which occurred in December 1985. Annual snowfall is 13.7 in.

Temperatures at the Hanford Site are colder in winter and warmer in summer than would be the case without the Cascade Mountains. Other mountain ranges to the north and east shield the area from many of the arctic surges, and in half of all winters, temperatures remain above $0^{\circ} \mathrm{F}$. Al though winter minimum temperatures have varied from -27 to $+22^{\circ} \mathrm{F}$, summer maxima have varied only from 100 to $115^{\circ} \mathrm{F}$. However, there is considerable variation in the frequency of such maximum temperatures. Although temperatures reach $90^{\circ} \mathrm{F}$ or above an average of 55 days/yr, minimum temperatures of $70^{\circ} \mathrm{F}$ or above occur only an average of 8 days/yr.

3.5.12.1 Wind. Wind data are collected routinely at the HMS. In addition to the surface wind data $(7-\mathrm{ft})$, wind data are collected at the $50-, 100-$, $200-, 300-$, and $400-\mathrm{ft}$ intervals of the 410-ft tower at the HMS. Telemetry stations distributed on and around the Hanford Site provide supplementary surface $(30-f t)$ wind data for defining wind patterns. These data are essential to Hanford Site emergency response programs in the event of a release of radioactive material to the atmosphere (Figure $3-25$ ). 
Figure 3-25. Wind Roses for the Hanford Telemetry Network, 1979 Through 1982. (The points of each rose represent the directions from which the wind comes. The lengths of the points represent the percentage of time the wind blows from that direction.)

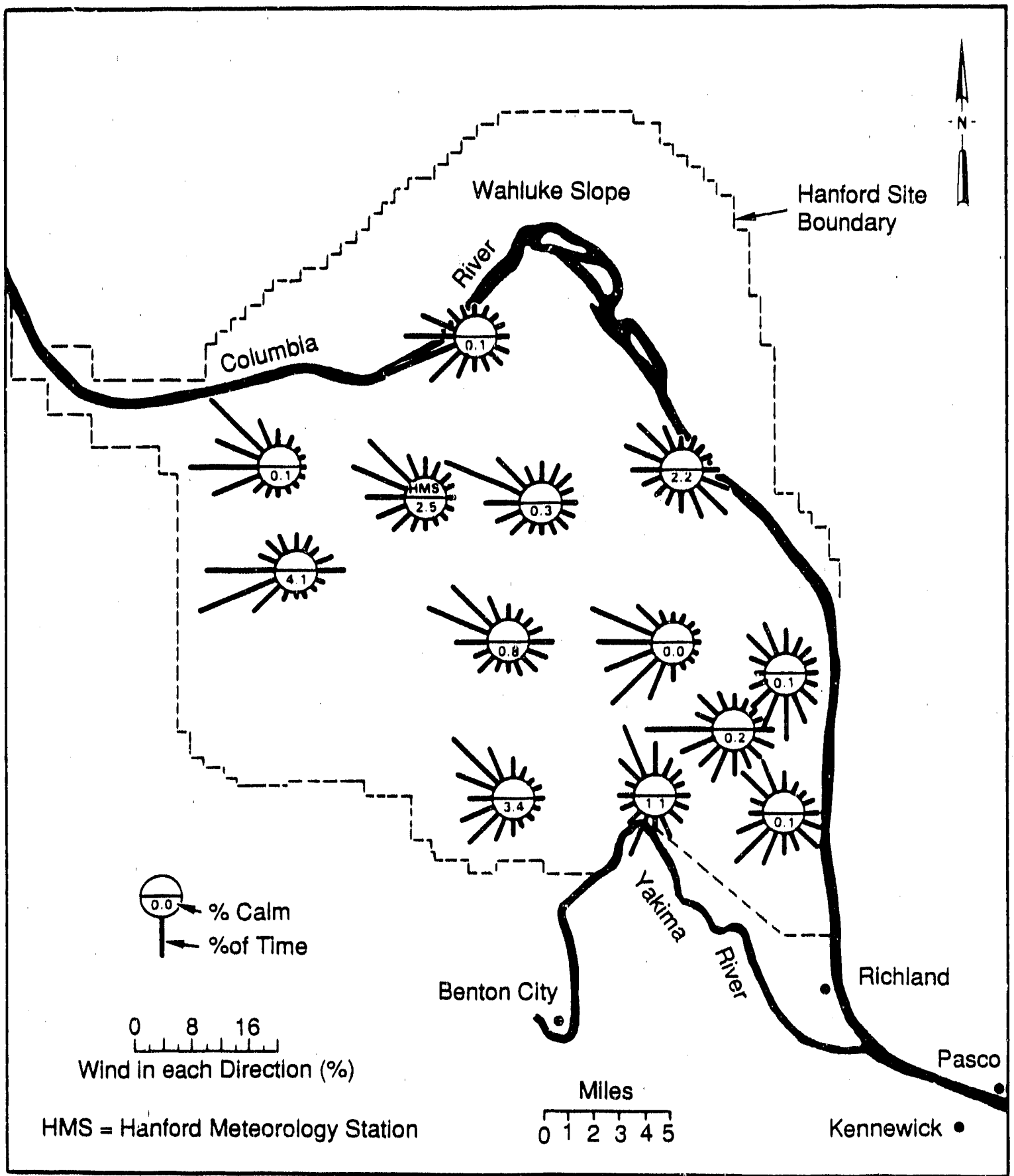


Prevailing wind directions are from the northwest in all months (Figure 3-26). Southwesterly winds are of secondary importance. Wind direction summaries indicate that winds from the northwest quadrant occur most often during the winter (December, January, February) and summer (June, July, and August). During the spring and fall, the frequency of southwesterly winds increases with a corresponding decrease in northwesterly flow. Winds blowing from other directions (e.g., northeast) display minimal variation from month to month.

Monthly average wind speeds are lowest during the winter months, averaging 6 to $7 \mathrm{mi} / \mathrm{h}$, and highest during the summer, averaging 9 to $10 \mathrm{mi} / \mathrm{h}$. Wind speeds that are well above average are usually associated with southwesterly winds. In the summer, high-speed winds from the southwest are responsible for most of the dust storms experienced in the region.

3.5.12.2 Temperature. From 1951 through 1980, the average monthly temperatures ranged from a low of $30.1^{\circ} \mathrm{F}$ in January to a high of $76.6^{\circ} \mathrm{F}$ in July. During the winter, the highest monthly average temperature at the HMS was $44.5^{\circ} \mathrm{F}$ in February 1958, and the record low was $14.0^{\circ} \mathrm{F}$, which occurred during January 1979. During the summer, the record, maximum, monthly average temperature was $82.2^{\circ} \mathrm{F}$ in July 1985 , and the record lowest was $63.0^{\circ} \mathrm{F}$ in June 1953. Table 3-3 shows the annual high/low/average temperatures by month.

Table 3-8. Annual High/Low/Average Temperature (1951 to 1980).

\begin{tabular}{|c|c|c|c|c|c|c|c|c|c|c|c|c|c|}
\hline \multicolumn{2}{|c|}{ Temperature } & \multicolumn{11}{|c|}{ Month } & \multirow{2}{*}{ Annual } \\
\hline$(\cdot F)$ & Jan & Feb & Mar & Apr & May & June & July & Aug & Sept & Oct & Nov & Dec & \\
\hline $\mathrm{High}$ & 37.4 & 46.8 & 56.0 & 65.5 & 75.2 & 83.5 & 92.1 & 89.7 & 80.6 & 65.8 & 48.1 & 39.9 & 65.0 \\
\hline Low & 22.9 & 28.8 & 32.8 & 39.2 & 07.4 & 55.1 & 61.1 & 59.5 & 51.7 & 40.5 & 31.0 & 26.2 & 41.4 \\
\hline Average & 30.1 & 37.8 & 44.4 & 52.3 & 61.3 & 69.3 & 76.6 & 74.6 & 66.2 & 53.1 & 39.5 & 33.1 & 53.2 \\
\hline
\end{tabular}

Figure 3-27 is a graph of daily extremes of maximum and minimum temperatures and the daily normal temperatures. The longest departures from normal for both the maximum and minimum occur during the winter months.

3.5.12.3 Probability and Intensities of Severe Storms and Tornadoes. This subsection discusses the probability and intensity of severe storms and tornadoes on the Hanford Site. In general, the Site does not experience a large number of severe storms or tornadoes. 
Figure 3-26. Monthly Wind Roses for the Hanford Meteorology Station Based on (50-foot) Wind Data, 1955 Through 1980. (The points of the rose represent the directions from which the wind blows. The length of the point represents the percent of time the wind blows from that direction.)

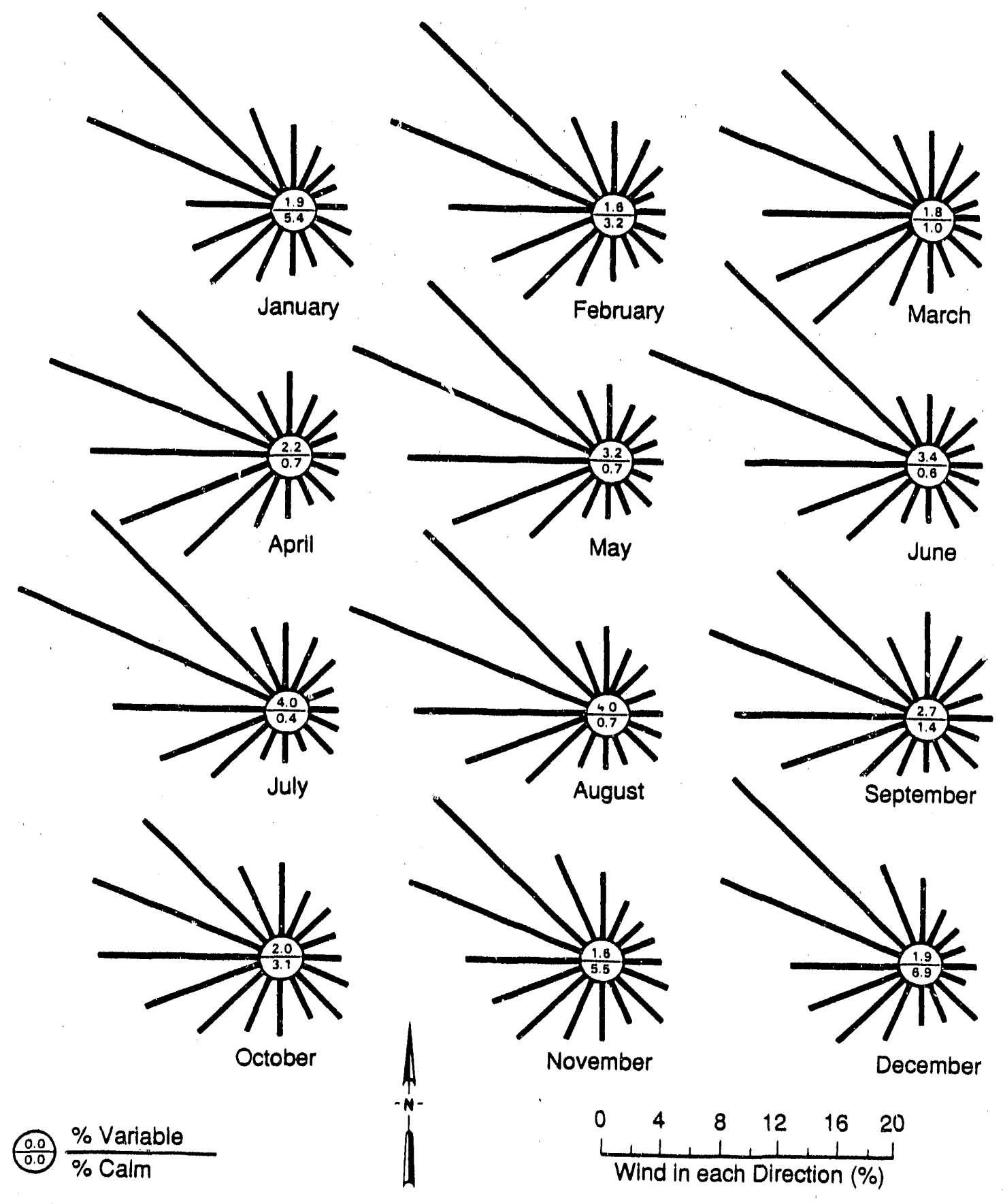


Figure 3-27. Normal, Extreme, a:d Daily Temperatures at the Hanford Site.

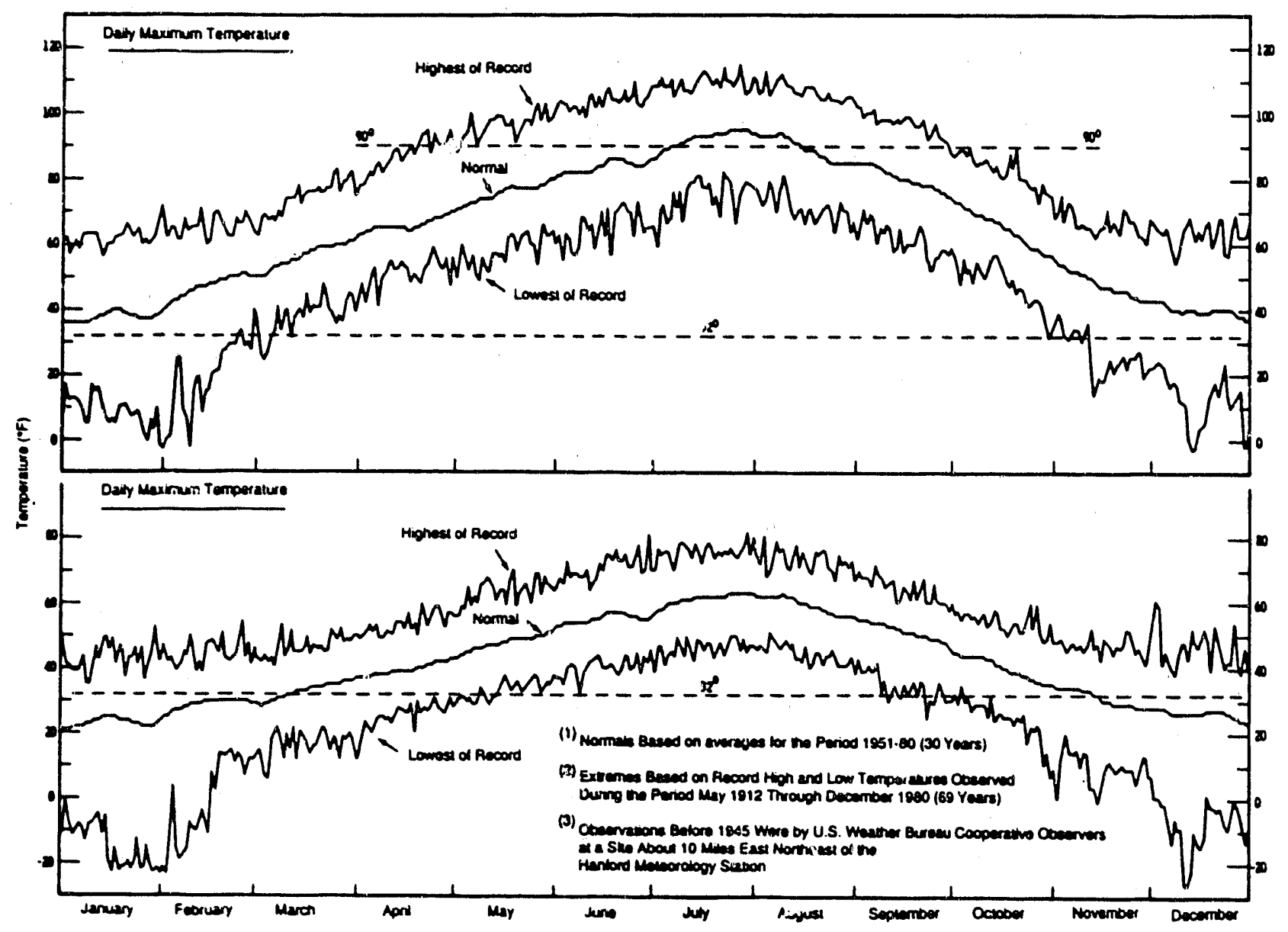


3.5.12.3.1 Severe Storms. The Hanford Site experiences numerous thunderstorms due to its geographic location, but very few are classified as "severe." The National Weather Service criteria for classifying a thunderstorm as severe requires hail with a diameter of greater than $3 / 4$ in., or wind gusts of greater than $58 \mathrm{mi} / \mathrm{h}$. Applying this same definition at the Hanford Site, there have been only eight severe storms recorded from 1945 to 1986 (Table 3-9), and all met the definition based on the wind-gust criteria. of the total number of thunderstorm events observed at the HMS (430), only $2 \%$ have been severe storms.

Thunderstorms have been observed at the station in every month except November and January. Although severe ones are rare, lightning strikes have occasionally ignited grass fires that have burned thousands of acres of Hanford Site land, resulting in considerable wind erosion.

3.5.12.3.2 Tornadoes. Tornadoes are infrequent and generally small in the Pacific Northwest. The HMS climatological summary and the National Severe Storms Forecast Center database 1 ist 22 separate tornado occurrences within a 100-mi radius of the Hanford Site from 1916 through September 1982; 2 additional tornadoes have been reported since September 1982 . Table 3-10 lists the 22 tornadoes by data and location. The two additional tornadoes both occurred on April 23, 1983, $3 \mathrm{mi}$ south of Conne11, Washington, and $8 \mathrm{mi}$ south of Connel1, approximately $20 \mathrm{mi}$ from the Hanford Site boundary.

The probability for an occurrence in any year at any one point within the 100-mi radius is 0.000006824 or one tornado each $146,000 \mathrm{yr}$. The best estimates of the maximum tangential wind speed expected from a tornado similar to those that have occurred within the 100-mi radius over the last $70 \mathrm{yr}$ is $145 \mathrm{mi} / \mathrm{h}$. Facilities at the Hanford Site are designed with tornado probabilities incorporated. The Hanford Plant Standards Design Criteria (SDC 4.1) uses a maximum horizontal wind velocity of $165 \mathrm{mi} / \mathrm{h}$ for reactor facilities and $120 \mathrm{mi} / \mathrm{h}$ for nonreactor facilities.

3.5.12.4 Prolonged Rainy or Dry Seasons. The Hanford Site is in a semiarid region; however, there have been some abnormally rainy and dry seasons. These seasons are detailed below.

3.5.12.4.1 Notable Wet Periods. There are five periods of abnormally high precipitation listed in Table 3-15. The years of record are from 1946 through 1980. From a precipitation standpoint, 1973 was an unusual year.

Total precipitation for the year was 8.27 in., which was $132 \%$ of normal (6.25 in.). March 30 through September 18, 1973, was dry, while October 31 through December 7, 1973 was a notable wet period (Table 3-11). During the months of October, November, and December 1973, 6.38 in. were recorded, which was $289 \%$ of normal (2.21 in.) for those months.

3.5.12.4.2 Notable Dry Periods. There have been many dry periods at the Hanford Site. January and December are the only months that have always received measurable precipitation (1912 through 1980). There have been a total of 75 months in the period of record (1912 through 1980) without measurable precipitation; July and August account for 43 of the 75 total. 
Table 3-9. Severe Thunderstorm Occurrences at the Hanford Site (1945 through 1986).

\begin{tabular}{|c|c|c|c|c|c|c|}
\hline \multirow{2}{*}{ Date } & \multicolumn{2}{|c|}{ Time } & \multicolumn{3}{|c|}{ Peak gusts $(\mathrm{mi} / \mathrm{h})$} & \multirow{2}{*}{ Remarks } \\
\hline & Begin & End & $50 \mathrm{ft}$ & $200 \mathrm{ft}$ & $400 \mathrm{ft}$ & \\
\hline $05-26-48$ & $\mathbf{a}$ & $a$ & 71 & 82 & 80 & $\begin{array}{l}\text { Accompanied by dust storm } \\
\text { (visibility less than } \\
5 / 8 \text { mi). Cold front } \\
\text { passage at } 2035 \text { PST; hail. }\end{array}$ \\
\hline $06-09-48$ & a & $a$ & 61 & 82 & 84 & $\begin{array}{l}\text { Accompanied by dust storm } \\
\text { (visibility less than } \\
5 / 8 \text { mi). Cold front } \\
\text { passage at } 1935 \text { PST. }\end{array}$ \\
\hline $06-16-48$ & & & & & & $\begin{array}{l}\text { Tornado observed near east } \\
\text { end of Rattlesnake Moun- } \\
\text { tain, } 10 \text { mi south of the } \\
\text { HMS. }\end{array}$ \\
\hline $06-05-57$ & 1650 & 1925 & 72 & 89 & 93 & $\begin{array}{l}\text { Visibility reduced to zero } \\
\text { in blowing dust. Cold } \\
\text { front passage at } 1725 \text { PST. }\end{array}$ \\
\hline $08-15-61$ & 1950 & 2015 & 66 & 73 & 76 & $\begin{array}{l}\text { Several grass fires } \\
\text { observed in vicinity of } \\
\text { HMS. Cold front passage } \\
\text { at } 1850 \text { PST. }\end{array}$ \\
\hline $04-05-72$ & 1545 & a & 73 & 86 & 75 & $\begin{array}{l}\text { Visibility reduced to } \\
3 / 4 \mathrm{mi} \text { in blowing dust. }\end{array}$ \\
\hline $07-09-79$ & 2137 & 2205 & 69 & 72 & 78 & $\begin{array}{l}\text { Accompanied by dust storm } \\
\text { (visibility } 1 / 4 \mathrm{mi} \text { ). Cold } \\
\text { front passage at } 2030 \text { PST. }\end{array}$ \\
\hline $06-05-81$ & & & 62 & 67 & 72 & $\begin{array}{l}\text { Downburst occurred at } \\
1634 \text { PST. Cumulonimbus } \\
\text { clouds in vicinity; no } \\
\text { thunder audible. }\end{array}$ \\
\hline
\end{tabular}

aUnknown.

HMS = Hanford Meteorology Station.

PST = Pacific Standard Time. 
Table 3-10. Tornado Occurrences Within 100-Mile Radius of the Hanford Meteoroiogy Station. a

\begin{tabular}{|c|c|c|}
\hline No. & Date & Location \\
\hline 1 & $06-26-16$ & Southeast of Walla Walla, Washington \\
\hline 2 & $05-15-25$ & Condon, Oregon \\
\hline 3 & $09-02-36$ & Walla Walla, Washington \\
\hline 4 & $05-20-48$ & Yakima, Washington \\
\hline 5 & $05-29-48$ & Yakima, Washington \\
\hline 6 & $06-11-48$ & Ephrata, Washington. \\
\hline 7 & $06-16-48$ & $\begin{array}{l}10 \mathrm{mi} \text { south-southeast of Hanford Meteorology } \\
\text { Station }\end{array}$ \\
\hline 8 & $05-10-56$ & $10 \mathrm{mi}$ southeast of Kennewick, Washington \\
\hline 9 & $04-12-57$ & Ione, Oregon \\
\hline 10 & $04-30-57$ & Yakima, Washington \\
\hline 11 & $05-06-57$ & Harrington, Washington \\
\hline 12 & $04-24-58$ & $20 \mathrm{mi}$ northwest of Walla Walla, Washington \\
\hline 13 & $06-26-58$ & Wallula Junction, Washington \\
\hline 14 & $03-14-66$ & Little Goose Dam, Washington \\
\hline 15 & $08-30-71$ & Near Colfax, Washington \\
\hline 16 & $04-05-72$ & $\begin{array}{l}40 \text { to } 80 \mathrm{mi} \text { west of Geiger Field, Spokane, } \\
\text { Washington }\end{array}$ \\
\hline 17 & $07-01-78$ & Southeast of Hatton, Washington \\
\hline 18 & $08-15-78$ & Almira, Washington \\
\hline 19 & $05-01-79$ & Near Davenport, Washington \\
\hline 20 & $07-01-79$ & $10 \mathrm{mi}$ south of Moses Lake, Washington \\
\hline 21 & $05-12-80$ & 2 mi east of Ritzville, Washington \\
\hline 22 & $09-13-82$ & $12 \mathrm{mi}$ west of Walla Walla, Washington \\
\hline
\end{tabular}

aRecorded or referenced in official National Weather Service documents. 
DOE/RL-89-15

Table 3-11. Notable Wet Periods.

\begin{tabular}{|c|c|c|c|c|c|}
\hline \multirow{2}{*}{ Pertod } & \multirow[b]{2}{*}{ Tota } & \multicolumn{2}{|c|}{$\begin{array}{l}\text { Number of days } \\
\text { Precipitation. Trace, }{ }^{a} \text { or More }\end{array}$} & \multicolumn{2}{|c|}{ Total (in.) } \\
\hline & & $\begin{array}{l}\text { Greatest } \\
\text { consecut tre }\end{array}$ & $\begin{array}{c}\text { With } \\
\text { measurable } \\
\text { precipitation } \\
\text { (in.) }\end{array}$ & $\begin{array}{l}\text { Water } \\
\text { equivalent }\end{array}$ & $\begin{array}{l}\text { Snow- } \\
\text { fall }\end{array}$ \\
\hline Oct 7 to Nov 4, 1947 & 23 of 29 & 10 & 17 & 2.21 & 0 \\
\hline Jan 3 to 28,1950 & 21 of 26 & 10 & 15 & 1.80 & 23.4 \\
\hline Nor 11 to Dec 19,1950 & 33 of 39 & 12 & 15 & 1.37 & 3.7 \\
\hline Nov 16 to Dec 22, 1955 & 31 of 37 & 15 & 24 & 3.19 & 22.7 \\
\hline Oct 31 to Dec 7, 1973 & 32 of 38 & 14 & 20 & 3.45 & 8.1 \\
\hline
\end{tabular}

Table 3-12 shows some long periods with small amounts of precipitation.

Table 3-12. Notable Dry Periods.

\begin{tabular}{lcc}
\hline \multicolumn{1}{c}{ Period } & $\begin{array}{c}\text { Number } \\
\text { of days }\end{array}$ & $\begin{array}{c}\text { Total } \\
\text { precipitation } \\
\text { (in.) }\end{array}$ \\
\hline May 29 to Nov 1, 1917 & 157 & 0.16 \\
Apri1 1 to Aug 26, 1927 & 148 & 0.14 \\
Feb 24 to Aug 13,1968 & 172 & 0.32 \\
Mar 30 to Sept 18, 1973 & 173 & 0.29 \\
Aug 26 to Dec 31, 1976 & 128 & 0.15 \\
\hline
\end{tabular}


The driest year of record (from 1912 through 1980) was 1976. Total precipitation for that year was 2.99 in., which was only $48 \%$ of ncrmal (6.25 in.). During the period September through December 1976, the total precipitation was 0.15 in., which is $6 \%$ of normal (2.52 in.) for those months.

3.5.12.4.3 Averages and Extremes. Table 3-13 compares the precipitation records of Richland and the HMS. Richland is on the Columbia River about $25 \mathrm{mi}$ southeast of the HMS and approximately $375 \mathrm{ft}$ lower in elevation than the HMS. From 1946 through 1980, the average annual precipitation was higher in Richland than at the HMS, with December and February being significantly higher. Because of the elevation difference, the HMS received a higher annual snowfall (13.7 in. seasonal average compared with 11.2 in. for Richland).

Table 3-13. Monthly and Annual Averages and Extremes of Precipitation for Hanford Meteorology Station Versus Richland, July 1946 through December 1980.

\begin{tabular}{|c|c|c|c|c|c|c|c|c|c|c|}
\hline & & & & & & Extrem & $(\ln )$. & & & \\
\hline & erages & in.) & & HMS & & & & Rich 1 & & \\
\hline Month & HMS & Richland & Greatest & Year & Least & Year & Greatest & Year & Least & Year \\
\hline Jan & 0.96 & 1.00 & 2.47 & 1970 & 0.08 & 1977 & 3.02 & 1970 & 0.10 & 1947 \\
\hline Feb & 0.57 & 0.70 & 2.10 & 1961 & Trace & 1967 & 1.58 & 1980 & Trace & 1967 \\
\hline Mar & 0.42 & 0.51 & 1.86 & 1957 & 0.02 & 1968 & 1.98 & 1957 & 0.04 & 1964 \\
\hline Apr & 0.41 & 0.42 & 1.22 & 1969 & Trace & $1977^{\star}$ & 1.16 & 1969 & Trace & $1977^{*}$ \\
\hline May & 0.53 & 0.57 & 2.03 & 1972 & 0.02 & 1947 & 2.07 & 1945 & 0.01 & 1966 \\
\hline June & 0.56 & 0.53 & 2.92 & 1950 & Trace & 1979 & 2.64 & 1948 & Trace & 1949 \\
\hline July & 0.18 & 0.17 & 0.81 & 1966 & Trace & $1980^{*}$ & 0.93 & 1948 & 0 & $1967^{*}$ \\
\hline Aug & 0.29 & 0.30 & 1.36 & 1977 & 0 & 1955 & 1.82 & 1977 & 0 & $1974^{\star}$ \\
\hline Sept & 0.31 & 0.29 & 1.34 & 1947 & Trace & $1976^{\star}$ & 1.12 & 1959 & 0 & $1975^{*}$ \\
\hline Oct & 0.56 & 0.55 & 2.72 & 1957 & Trace & $1978^{\star}$ & 2.41 & 1947 & Trace & 1978 \\
\hline Nov & 0.81 & 0.88 & 2.64 & 1973 & Trace & 1976 & 2.78 & 1973 & 0.07 & 1946 \\
\hline Dec & 0.90 & 1.04 & 2.34 & 1964 & 0.11 & $1976^{*}$ & 2.83 & 1973 & 0.13 & 1946 \\
\hline Annual & 6.50 & 6.96 & 11.45 & 1950 & 2.99 & 1976 & 11.35 & 1948 & 3.12 & 1967 \\
\hline
\end{tabular}

\footnotetext{
HMS = Hanford Meteorology Station.

Trace $=<0.005 \mathrm{in}$.

*Also in earlier years.
}

During the 1955 and 1956 season, Richland received a seasonal record of 41.6 in., compared with 38.5 in. for the HMS. The maximum depth of snow in Richland was 14.0 in. (January 10, 1980) compared with 15.6 in. (December 2, 1985 ) at the HMS. Richland's record 24-h snowfall of 12.5 in. on January 8 to 9, 1980, exceeded the HMS record of $8.8 \mathrm{in}$. on November 21 to $22,1985$. During the $35 \mathrm{yr}$ of record, less than half of the extremes at the HMS and Richland occurred in the same years. 


\subsection{SECURITY}

Security at the DOE Hanford Site is provided through an overall Hanford Safeguards and Security Program. The mission of the Hanford Safeguards and Security Program is to effectively protect the security interests of the DOE-RL. The primary security interests at the Hanford Site are the protection of DOE facilities, materials, and information.

The Hanford Safeguards and Security Program has three main operating objectives: (1) ensure the physical protection, control, and accountability of special nuclear materials (SNM); (2) provide physical protection for operating facilities, sensitive property, and equipment; and (3) protect against the release of classified information to unauthorized personnel. These program objectives are satisfied by the selective application of a variety of security measures, including the following:

- DOE site-wide protective force

- Personnel security screening and clearance procedures

- Human reliability programs

- Designated access control zones

- Automated and manual access control systems

- Computerized alarm systems to electronically detect intrusion

- Access denial and delay systems

- Security lighting, fencing, gates, and barriers.

The DOE orders define minimum security requirements for given types of security interests and specific types of operations. These requirements may increase or decrease depending on special site or plant conditions, costeffectiveness considerations, and the level of acceptable risk. Appropriate security measures for any given Hanford Site operating area are selected after the applicable risks or threat has been thoroughly evaluated. This approach has provided a coordinated Hanford Site security program tailored to meet the needs of individual operating locations within the Site.

\subsubsection{Buffer Zones}

Distance, in the form of a clear isolation zone, acts as a security barrier or buffer between an area to be protected and any potential threats.

To control access, the Hanford Site is continuously patrolled by protective forces. Public access to the Site is controlled by only allowing travel through the Site on State Highways 24 and 240 , and on roads to the Wye and Yakima Barricades. Any other access requires special authorization and an identification credential. 
Although the Hanford Site does not include any formally designated buffer zones, the Site has effective natural buffers for each operating area. It is bounded on the north and west sides by relatively large specialuse land areas for which access is also limited. These areas, which include a recreation area, game refuge, and an ecology reserve, collectively provide a substantial buffer area around almost $75 \%$ of the Site.

\subsubsection{Security Zones}

Each Hanford Site operating plant or facility has its own appropriate and independent physical security system. Each plant security system arrangement follows the philosophy of protecting security interests with concentric layers of protection or security zones, the number of which is determined by the nature of the particular security interest. The lowest level security zone is at the perimeter of the plant location or area, while the highest level zone is at the center. This approach provides effective access control for an area and ensures that the most sensitive plant functions are also the most highly protected. Security zone designations used at the Hanford Site include the following:

- A designated Property Protection Area, which is controlled to prevent theft and destruction of government property. Protection is normally a security fence, or (as appropriate) a secured facility to prevent unauthorized access.

- A designated Limited Area, which is controlled to prevent unauthorized individual access to classified matter. A minimum of a "5" security clearance* and proper authorization are required for unescorted access. Boundary protection typically consists of a security fence surrounding the area. Access to the area also is monitored and controlled by protective forces.

- A designated Exclusion Area controlled to prevent unauthorized individual access to an area where mere access would result in access to classified matter. A minimum of a "5" security clearance (or an access authorization consistent with the highest classification of matter contained in open storage) and proper authorization are required for access. A boundary equivalent to a security fence typicaliy surrounds the area.

- A Protected Area is designated and controlled to protect specified amounts of SNM. This area must be located within a Limited Area and typically is surrounded by electronic intrusion detection systems, appropriate security barriers, and two security fences. A "3" security clearance and proper authorization are required for unescorted access. Protective forces monitor access to the area and provide vehicle and package searches. They are assisted in some locations by automated access control systems and search equipment.

*Security clearances are granted by the DOE. 
$\mathrm{DOE} / \mathrm{RL}-89-15$

- A Material Access Area is designated and controlled to protect specified quantities of SNM in an easily transportable form. This area is located within a. Protected Area. Also, a minimum of two properly cleared and authorized people must be together while inside the area. A " 3 " security clearance and proper authorization are required for unescorted access. Intrusion detection and access control systems are employed to detect unauthorized access when the area is not attended.

- A Vital Area is designated and controlled to plotect key equipment that, if damaged, could result in the release of radioactive material in excess of accepted standards or an unacceptable interruption to the program. Such an area must be located within a Protected Area and requires specific authorization for access.

The physical protection strategy for each of the individual Hanford Site operating areas is dictated by the types of activities conducted in each area. This strategy employs concentric rings of security fences, personnel and vehicle barriers, building walls, and compartment walls to guide vehicle and pedestrian traffic through controlled access points and to delay forced entry or exit elsewhere. Figure 3-28 graphically depicts this strategy. In many cases, security zones a? so incorporate intrusion detection and monitoring systems to allow assessment and surveillance by the protective force.

\subsubsection{Lighting}

Appropriate interior and exterior lighting is an integral part of the physical protection system for each Hanford Site operating area. Lowmaintenance, low-energy security lighting is installed along fence lines that form security zone boundaries. Security lighting is also provided to illuminate Protected Area yard spaces anc areas adjacent to security guard stations.

Typical exterior security lighting is supplied by low-pressure sodium lamps strategically positioned to produce a minimum average illumination level of approximately 2 footcandles near boundary fence lines and other areas where nocturnal access must be closely monitored. Special consideration is also given to producing the lighting levels required for satisfactory operation of closed-circuit television cameras (CCTV). Some areas make use of pan-tilt-zoom and fixed CCTV cameras with searchlights as aids for protective force assessment.

\subsubsection{Fencing}

Security fencing provides personnel barriers around the perimeter of designated security zones. Typical security fencing consists of a 7-ft-high, woven-wire, chain-link fence topped by three strands of outward-facing barbed wire (8-ft total height). Fences may occasionally be higher than $8 \mathrm{ft}$ in areas that are within $20 \mathrm{ft}$ of other structures, trees, or obstructions that might be used to aid in scaling the fence. A Limited Area is enclosed by a single security fence, while a Protected Area is normally surrounded by two 
Figure 3-28. Example of Area Concentric Security Zones.

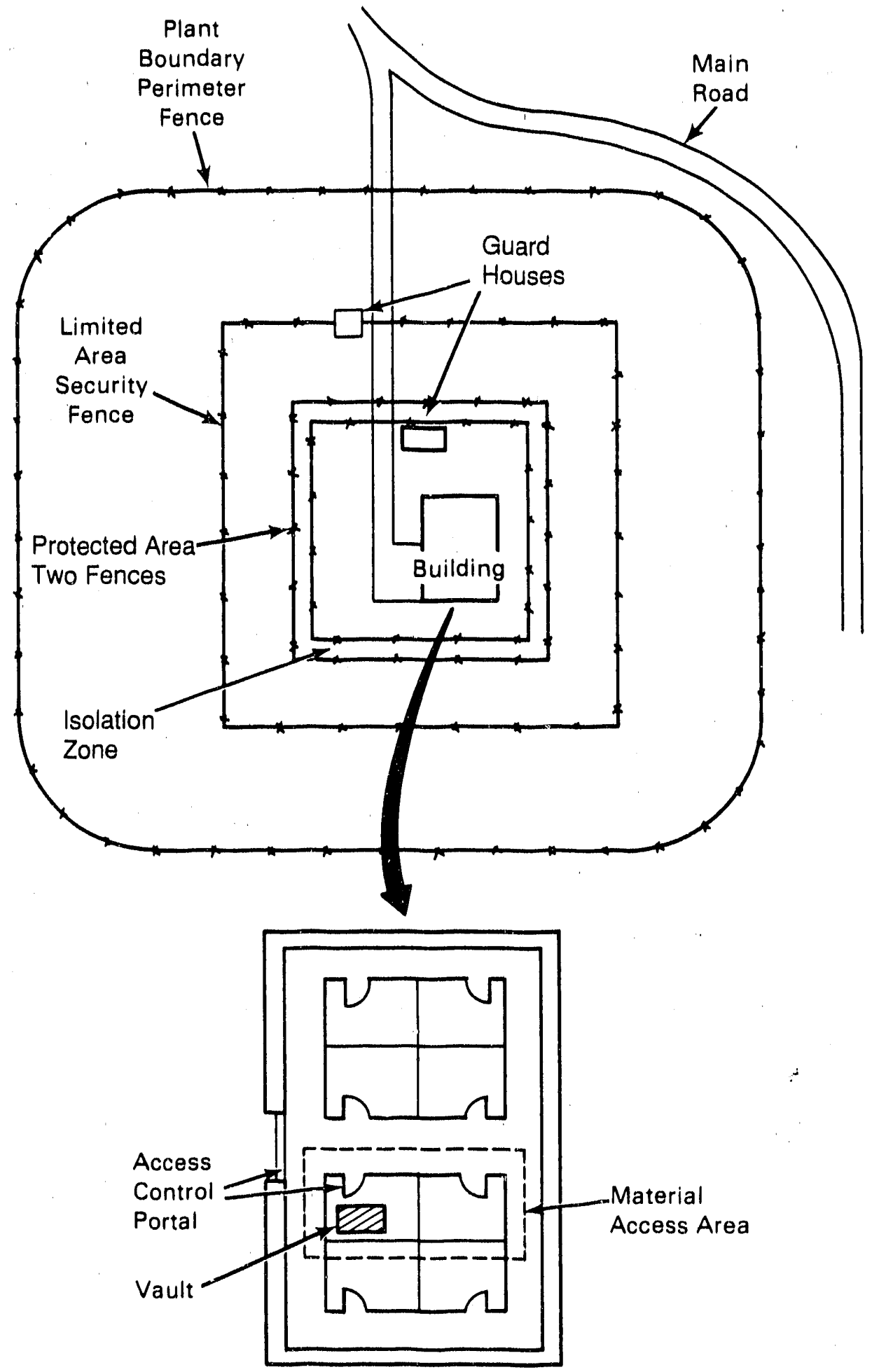


security fences with an isolation zone located between the fences. The isolation zone provides an open space (usually approximately $100 \mathrm{ft}$ wide) to ensure an unobstructed view of the perimeter area.

The isolation zone includes vehicle barriers and intrusion sensing and alarm equipment. In all cases, security fencing is designed to minimize the number of gates and access points that must be monitored and controlled.

\subsubsection{Barriers}

All security zones require some form of a perimeter personnel barrier, i.e., a security fence, building walls, or compartment/vault walls. Protected Areas at the Hanford Site also include some type of barrier to prevent forced entry by vehicles.

\subsubsection{Gates}

Several types of personnel and vehicle access gates are used throughout the Hanford Site. These include turnstiles, vestibules, chainlink gates, rails, and truck locks. At some remote gate locations, electric locks, electronic surveillance, and CCTVs are used as cost-effective measures for controlling access through the gate.

\subsubsection{Hanford Patrol}

The Hanford Patrol is a Site-wide protective force that operates $24 \mathrm{~h} /$ day, 7 days/wk. In addition to security system monitoring, the Hanford Patrol verifies badges for access authorization, conducts vehicle and package searches, and regulates traffic for the overall Hanford Site and for each of the Hanford Site operating areas. The Hanford Patrol also includes a Tactical Response Team (TRT) equipped with modern weaponry and equipment necessary to respond to all credible site security emergencies. This equipment includes armored and fast attack vehicles and helicopters.

\subsection{SAFETY: POLICY AND ORGANIZATIONAL RESPONSIBILITIES}

The varied and complex activities conducted on the Hanford Site create the potential for human and environmental exposure to a variety of radiological, toxic, and industrial hazards. Environmental protection, safety and health, and property protection is an integral part of all the DOE programs. The following is the DOE policy:

- Ensure the protection of the environment, and the safety and health of the public, and protect government property against accidental loss and damage

- Provide safe and healthy workplaces and conditions of employment for all employees of the DOE and the DOE contractors

- Ensure compliance with applicable statutory requirements affecting federal facilities and operations 
- Ensure that R\&D, demonstration, and production activities are performed in a controlled manner; that facilities, components, systems, and processes are designed, developed, constructed, tested, operated, and maintained according to sound engineering standards, quality practices, and technical specifications or operational safety requirements; and that resulting technology data are valid and retrievable.

The manager, DOE-RL, communicated the emphasis and priority given to environmental, safety, and health protection. "We will have safety first, with strict adherence to the rules and regulations." The manager further illustrates the importance of safety's role relative to the importance of environmental acceptability and security in supporting Hanford Site missions:

"I liken safety procedures to a three-legged stool. Hanford Programs all are resting on the stool and if one leg of safety starts to slip, the stool becomes imbalanced, thereby upsetting all programs."

(Figure 3-29)

Figure 3-29. The Role of Safety at the Hanford Site.

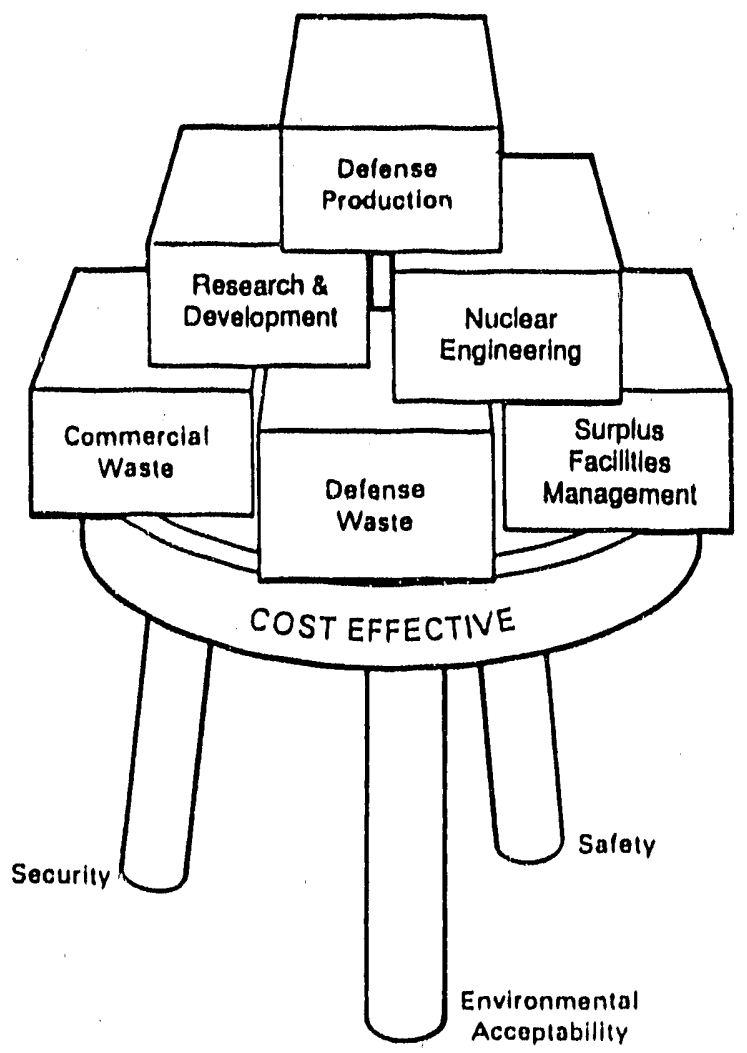

38907129.9

The following sections contain a discussion of the primary organizational responsibilities for safety at the Hanford Site. The safety systems that were developed for dealing with industrial, radiological, and nuclear emergencies are described, as are the principal Hanford Site facilities that have the potential for significant impact on either the environment or the public. 
Hanford Site contractors have primary responsibility for ensuring that the hazards associated with their areas of responsibility have been identified and that appropriate controls are in place tc limit risks at acceptable levels. The health and safety requirements placed on Hanford Site operations originate from many sources.

- U.S. Department of Energy Orders

5480.1B, Environmental Protection, Safety and Health Protection Programs for DOE Operations (DOE 1986b)

5481.1B, Safety Analysis and Review System (DOE 1986C)

5482.1B, Environmental Protection, Safety and Health Appraisal System (DOE 1986a)

5483.1A, Occupational Safety and Health Program for Government-Owned Contractor-Operated Facilities (DOE 1983)

5484.1, Environmental Protection Safety and Health Protection Information Reporting Requirements (DOE 1981a)

5500.2, Emergency Planning, Preparedness and Response for Operations (DOE 1987a)

5500.3, Reactor and Nonreactor Nuclear Facility Emergency Planning Preparedness and Response Program for DOE Operations (DOE 1981b)

- Occupational Safety and Health Act (OSHA)

- Washington State

Washington Industrial Safety and Health Act (WISHA)

Washington State Department of Social and Health Services

Washington State Department of Ecology.

The activities of each contractor differ. The nature and degree of hazards associated with those activities also differ. However, all contractors are committed to the operating philosophy of placing safety first with various forms of independent oversight, i.e., from with in the contractor's organization; from other DOE contractors' assigned responsibilities for site surveillance and monicoring; and from DOE reviews, appraisals, and use of outside evaluators.

Some safety and health support services have been consolidated to serve the whole Hanford Site: fire protection, ambulance, and patrol emergency services assigned to WHC; radiation dosimetry evaluation and records, and radiation instrumentation calibration assigned to PNL; and employee medical services assigned to HEHF. The DOE-RL is responsible for the Site-wide emergency control center. The appropriate principal contractors are responsible for the emergency control center for an assigned work area. 


\subsubsection{Industrial Safety and Health}

Although the principal hazards identified with the Hanford Site are nuclear in nature, most of the accidents and injuries at the site result from industrial hazards usually identified with non-nuclear manufacturing activities, e.g., fires, explosions, falls, vehicle accidents, and electrical and chemical activities. Even in many of the incidents iniolving nuclear hazards, the originating event is often an industrial one, e.g., fires and explosions can release radioactive materials to the environment and the public.

Prevention of accidents is a main goal for the Hanford Site. Several mechanisms are used to prevent accidents: identifying and evaluating potential hazards at work locations, providing engineered safeguards to control the hazard and protect workers, using safe work procedures to accomplish tasks, training staff in the safe performance of work, and involving senior management in promot.ing staff safety awareness.

The DOE Order 5481.1B requires that a safety analysis of the DOE operations be performed to identify hazards, define means of their elimination and control, assess the risk, and document management authorization of the operation (DOE 1986c). The extent of the safety analysis is commensurate with the degree of the hazard. For safety analys is purposes, hazards are classified into three categories:

- Low Hazard. Hazards that present potential minor onsite and negligible offsite impacts to people and the environment

- Moderate Hazard. Hazards that present considerable potential onsite impacts to people or the environment and, at most, only minor offsite impacts

- High Hazard. Hazards with the potential for onsite and offsite impacts to many people or for major impacts to the environment.

To segregate personnel from sources of hazards, engineered safeguards and physical barriers such as radiation shields, welding screens and grinding curtains, guards on moving equipment parts, fire barriers, and key-lock equipment controi are used, wherever feasible. When required, workers must al so use prescribed protective clothing, such as eye protection, face shields, fire retardant clothing, and protective hand coverings and footwear.

A safety consciousness among the workforce is essential to a safe work performance. Contractors use various means to reinforce to workers the importance of safety in the work place and in work performance. Training programs, safety awards, individual recognition, postings, and safety meetings are standard safety activities to increase employee awareness. At the Hanford Site, safety is a line management responsibility; all managers are responsible for safe operation and are expected to participate in safety enhancement activities, conduct worksite inspections, and take appropriate and prompt measures to correct identified safety concerns. 
The previous 5-yr safety performance of the Hanford Site is summarized in Figures 3-30 and 3-31. The data presented, which are the DOE Safety Performance Indicatirs, are compared with the national data for both the DOE and private industry.

\subsubsection{Radiological Safety}

Since plutonium production started in 1944, with the initial startup of B Reactor, the radiological protection of workers, the environment, and the public has received paramount attention at the Hanford Site. Protective equipment, proper operational practices, and engineering designs that are technicaliy and economically sound are applied to ensure that the safety requirements are met. Occupational exposures of personne? to ionizing radiation and releases of radioactivity to the environment are ALARA. Figure 3-32 summarizes the history of skin contaminations for the years 1984 through 1988.

The Hanford Site radiological safety and engineering standards are based on Hanford Site historical experience, professional standards of health physics, and recommendations and requirements of the National Council on Radiation Protection and Measurements, the International Commission on. Radiological Protection, the EPA, and the American National Standards Institute (ANSI). The principal governing DOE regulation on radiation safety is DOE Order 5480.11 (DOE 1988b).

Areas that have actual or potential presence of radiation or radioactive contamination are identified by radiological posting and labeling. The radiation symbols used on radiological signs and lags conform with ANSI Standard N2.1-1969 (ANSI 1969) or, when fissile material is involved, ANSI Standard N12.1-1971 (ANSI 1971). Entry and work in these areas are governed by radiation work procedures prepared to cover the activities in specific areas.

Each of the principal operating contractors (BMI, WHC, and KEH) have radiation protection organizations that support and monitor radiation work and perform routine surveillance of radiological activities to ensure personnel safety and control of radioactive materials. These organizations are staffed with health physics professionals to direct and administer the radiation protection programs and radiation protection technologists who provide personnel monitoring services and carrying out surveillance and assessment activities.

\subsubsection{Criticality Safety}

On the Hanford Site, numerous operations require the handling, processing, and storing of fissiorable materials. In some cases, the quantity of fissionable material involved is sufficient to have the potential for an zccidental criticality (an accidentally produced, self-sustaining nuclear chain reaction).

Analyses of such events indicate that their impacts primarily would be expected to be localized. The dose to personnel within a few feet of the event, from the high radiation field, would be substantial, and probabiy 
DOE/RL- $89-15$

Figure 3-30. Lost Workday Case Incidence Rates.

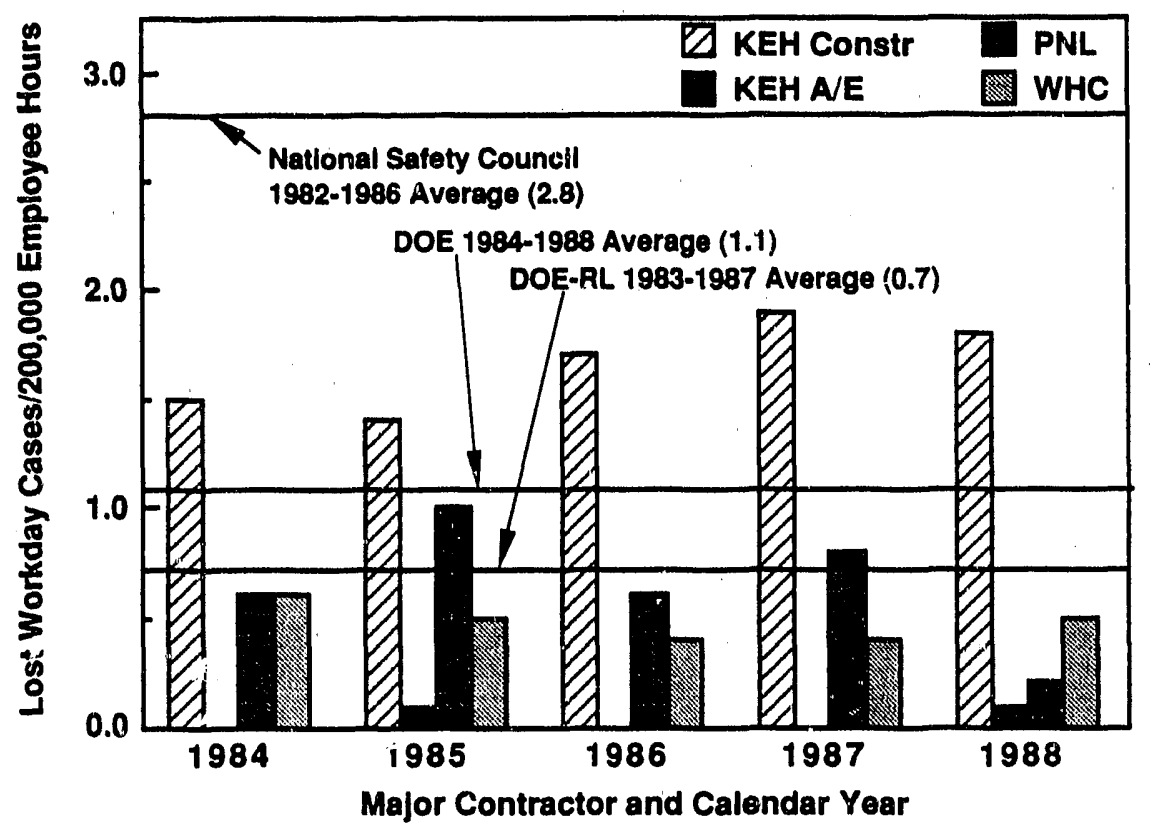

38907129.1

Figure 3-31. Recordable Injury Incidence Rates.

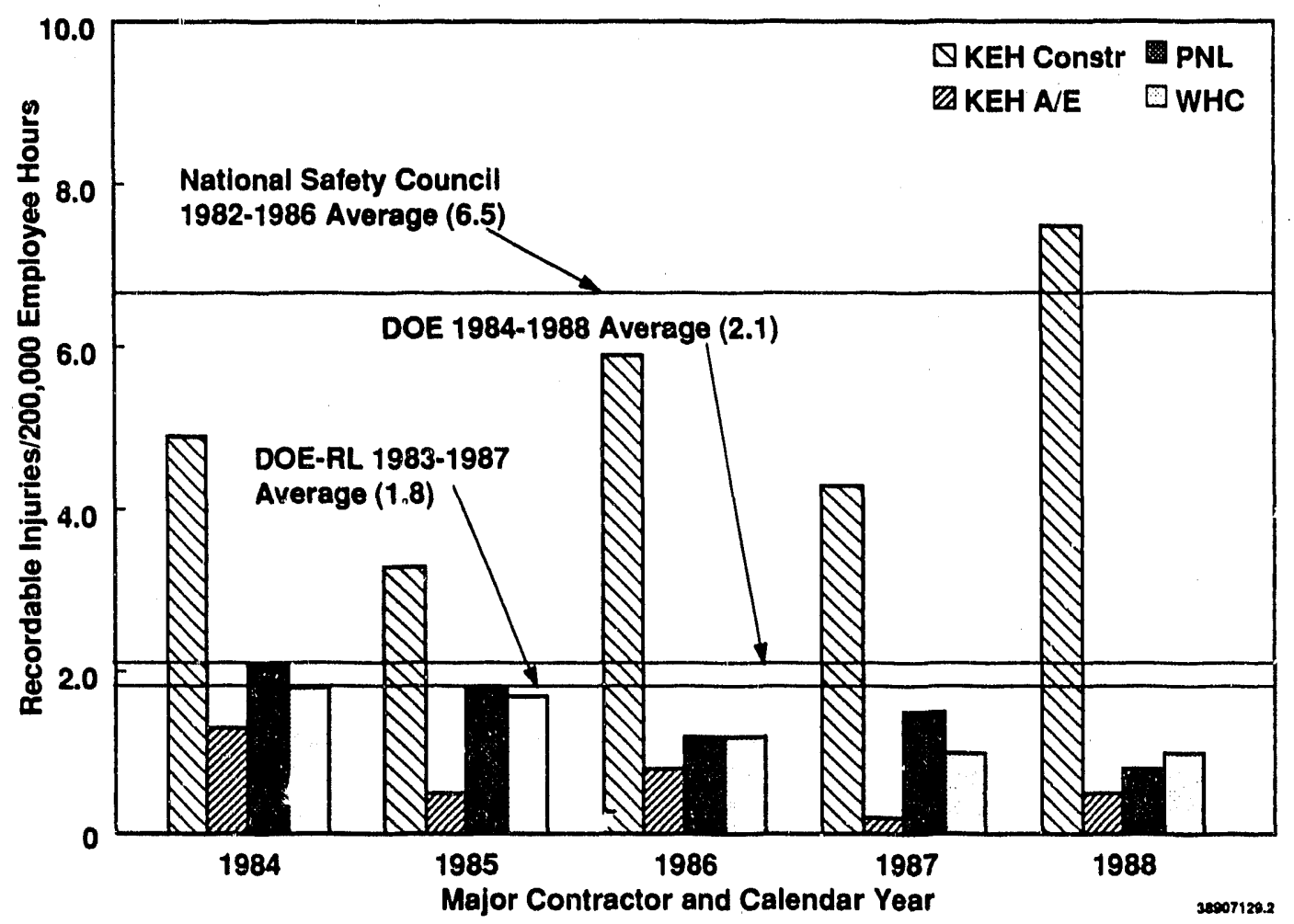


Figure 3-32. History of Annual Skin Contaminations.

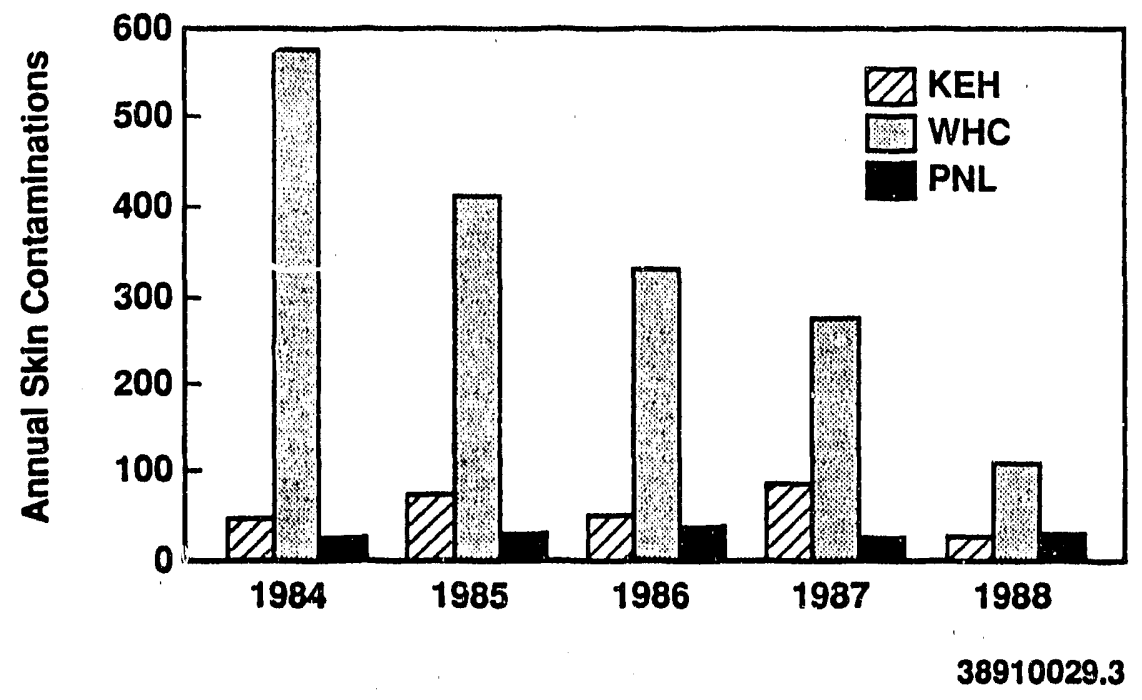

lethal. Also, the negative political and public reactions to the occurrence of such an event would severely impact the safety image of the whole nuclear industry. Thus, safety requirements featuring wide safety margins are rigorously applied to the operations that use fissionabie materials to preclude a criticality.

A nuclear hazard class is assigned to each facility based on radioactive inventory (not necessarily fissile) and location of the facility. Those facilities containing sufficient amounts of fissionable materials to have the potential for a criticality are classified as either high-or moderatehazard facilities. The cognizant contractor must establish a criticality safety program in compliance with DOE Order 5480.5 (DOE J986e). The principal components comprising such a program are (1) geometrically safe design of vessels, etc., where possible, (2) a system for establishing procedural limits on operations to prevent a criticality, (3) training of operational staff on the criticality aspects of their operations,

(4) installation and maintenance of a criticality detection and alarm system in appropriate facilities, and (5) establishinc a criticality safety audit and inspection system.

\subsubsection{Reactor Safety}

The initial construction and operations of nuclear reactors during World War II were directed by technical and engineering professionals who had experience in the operation of large chemical plants, e.J., the production of high explosives. Therefore, it was natural for these professionals to establish formal safety and operating systems similar to those developed for cheinical plant operations, e.g., safety analysis, erigineered safety features and barriers, administrative controls and limits, and trained operating staffs. The systems established at that time have evolved into those currently required by the NRC for commercial reactors and by the DOE for their own reactors. Requirements for the DOE-owned reactors are established in 
DOE 5480.6 (DOE 1986d). The objectives of these requirements are to ensure the following:

- The safety of each DOE-owned reactor is properly analyzed, evaluated, documented, and approved by the DOE

- Reactors are sited, desigried, constructed, modified, operated, maintained, and decommissioned in a manner that gives adequate protection for health and safety and will be in accordance with generally uniform standards, guides, and codes that are consistent with those applied to comparable NRC-1 icensed reactors.

There are four DOE reactors or critical facilities on the Hanford Site: (1) the $N$ Reactor, a plutonium production reactor that also produces steam for generating $860 \mathrm{MW}$ of electrical power, currently defueled and in dry standby, (2) the FFTF, a sodium-cooled, 400-MW thermal fast flux reactor for testing fuels and materials for advanced reactors, (3) the TRIGA reactor, used for performing quality assurance testing on FFTF fuel pins (currentiy in standby), and (4) the Critical Mass Laboratory, for conducting critical experiments in support of chemical reprocessing of reactor fuels. The Critical Mass Laboratory does not currently have a mission and is awaiting D\&D. Because each of these facilities differs in its purpose and role, each was uniquely designed to meet its intended objectives and to achieve margins of safety commensurate with its respective level of hazard. Additionally, the Washington Public Power Supply System operates a commercial reactor within the Hanford Site.

The safety systems are designed to override any possible positive reactivity transient. An example is $\mathrm{N}$ Reactor. Like the Chernobyl reactor, $N$ Reactor is graphite moderated; unlike the Soviet reactor, however, the moderating status of $\mathrm{N}$ Reactor is designed so that the reactor reactivity is reduced upon the loss of water coolant. Thus, a "run-away" reactivity transient such as that experienced at Chernobyl is impossible at $N$ Reactor.

\subsubsection{Emergency Response}

The DOE-RL has developed and maintains a comprehensive set of emergency preparedness $\mathrm{pl}$ ans and procedures to support onsite and offsite emergency management actions in the event of an accident or incident. The DOE-RL also provides technical assistance to other federal agencies and to state and local governments. Hanford Site contractors are responsible for ensuring that emergency plans and procedures are prepared and maintained for all facilities, operations, and activities under their jurisdiction; and for directing the implementation of those plans and procedures during emergency conditions. The DOE-RL, contractor, state, and local government plans are fully coordinated and integrated.

Emergency control centers have been established by DOE-RL and its contractors for the principal work areas to provide oversight and support to emergency response actions within those areas. The DOE-RL Emergency Action and Coordination Team is responsible for the overall coordination of emergency response activities to major emergencies affecting the Hanford Site. The DOE-RL Emergency Control Center is located in the Federal Building. 
A considerable investment has been made in establishing emergency facilities and systems to respond to the potential emergency conditions identified for the Hanford Site. These centers are equipped with telephone lines, base radio stations, portable radios, area and facility maps, status display boards, computers, office supplies, emergency equipment kits, and appropriate emergency reference manuals and procedures. All centers are linked by communication systems, i.e., telephones, facsimile machines, and radios. Located adjacent to the DOE-RL Emergency Control Center is the Unified Dose Assessment Center, where assessments are made of emergency situations and guidance is provided to stabilize and recover from the emergency.

Several types of emergency conditions may occur on the Hanford Site for which emergency planning is directed. Emergency conditions may stem from four types of sources: natural phenomena, operations, terrorists, or national enemy attack. Natural phenomena events that may affect the Site are flooding, earthquakes, range fires, high winds, and volcanic ash fallout. Operational events that may require activation of emergency resources are fire; explosion, local flooding, total power outage, criticality, reactor excursion, breach-ofcontainment system, defective machinery, toxic material spread, and significant industrial accident events. Terrorist threats inciude bomb threat, theft of nuclear materials, riot, and sabotage. Enemy attack against the United States could be directed against the Hanford Site facilities and personne1.

Incidents such as small fires, falls, and automobile accidents may require response from the Hanford Fire Department (for fire control and/or ambulance service), the Hanford Patrol, and medical staff from HEHF. However, these types of accidents do not normally require the response of contractor emergency organizations.

\subsection{SAFETY CONSIDERATIONS FOR PRINCIPAL HANFORD SITE FACILITIES}

The principal facilities on the Hanford Site that have potential to significantly impact either the environment or the public are individually discussed in the following sections.

\subsubsection{Areas}

The 100 Areas consist of six sites with a total of nine reactors built on these sites. Each site is located on the southern side of the Columbia River and in the northern portion of the Hanford Site. The 100-B/C Area contains Reactors $B$ and $C$ and is the farthest upriver of the six sites. The 100-K Area (almost $2.5 \mathrm{mi}$ downriver from the $100-B / C$ Complex) contains $K E$ and KW Reactors. The 100-N Area (1.5 mi downriver from the 100-K Complex) contains the $N$ Reactor and the 860-MW Washington Public Power Supply System electrical generating plant. The 100-D/DR Area (2.5 mi downriver from the 100-N Complex) contains Reactors $D$ and DR. The 100-H Area (5 mi downriver from the 100-D/OR Complex) contains the $H$ Reactor. Finally, the 100-F Area (3.5 mi downriver from 100-H) contains the $F$ Reactor. The 100-F Area is the closest to the city of Richland. Construction started on Reactors $B, D$, and $F$ in 1943. Following World War II, the other reactors were constructed for continued plutonium production and research. All the reactors are now 
deactivated except for the $\mathrm{N}$ Reactor, which is defueled and being maintained in a cold standby status. Some water and electrical utility systems are in use at all sites. The fuel pool storage basins at Reactors KE and KW are currently being used to store irradiated fuel from the $N$ Reactor. Some reactors have various support facilities that are still in use.

3.8.1.1 N Reactor. The $N$ Reactor is graphite moderated, pressurized, water cooled, and uses slightly enriched uranium fuel in the production of SNM and byproduct steam. The excess steam can be used by the Washington Public Power Supply System to produce up to $860 \mathrm{MW}$ of electricity. The N Reactor has multiple independent safety features to prevent the release of radionuclides to the environment. These safety features include the following:

1. Negative void temperature and power coefficients (if loss of coolant and overheating were to occur, the nuclear reactor would slow down)

2. Successive physical barriers to fission product release from the reactor

3. Numerous manual and automatic safety systems that operate rapidly to avoid or mitigate accidents

4. Comprehensive training programs and procedures to ensure safe operation and effective response to possible emergencies

5. Recent design analysis and seismic upgrades plus conservatism in the original design ensure that the reactor structures, systems, and components required for safe shutdown, safety reactor maintenance on emergency cooling, and safe storage of spent fuel will survive the greatest expected earthquake.

The $\mathrm{N}$ Reactor currently is defueled and approaching the completion of the transition to dry standby status. Major cooling systems have been drained and a controlled atmosphere is being implemented for corrosion control for $\mathrm{N}$ Reactor systems. Dry standby 's defined as an unfueled reactor with all critical safety and support systems sustained consistent with the preservation of their integrity for an extended period of reduced activity. This will ensure retention of the capability to restart while minimizing required maintenance and operating equipment. Restart capability, as used here, is the ability to restart $N$ Reactor within 3 yr on receipt of direction from the DOE.

3.8.1.2 Retired Production Reactors. The eight retired reactors ( $B, C, D$, $D R, F, H, K E$, and $K W$ ) were shut down in the following condition: fuel elements were removed, cooling water was drained, control and backup safety rods were inserted, and power to the drive mechanisms of these rods was deactivated. All eight reactors have been inactive since 1971 .

Each reactor block (consisting of a graphite moderator stack encased in a thermal shield surrounded by a biological shield) remains radioactive. Most of the remaining accessible sections of the reactor buildings and other ancillary support buildings are free from radioactive contamination or have background or direct dose rate readings from 1 to $30 \mathrm{mrad} / \mathrm{h}$. 
The retired reactors are isolated by security fences and locked and barred entrances. Periodic inspections, routine surveillances, heat detection systems, and strategically located fire hydrants further enhance radiological protection for humans and the environment. The $H$ Reactor, however, has no fire protection system. No credible accidents have been identified that would result in releases of the radioactive material from the reactor blocks. A typical reactor block is encased in cast iron thermal shielding ( 8 to 10 in. thick) and a biological shield (alternating layers of steel plate and masonite, or heavy aggregate concrete 40 to 83 in. thick). A severe earthquake or tornado could damage the reactor building structure and the reactor shields could be damaged by falling debris. However, the shields around the reactor block would not be significantly impacted.

The dam-regulated standard project flood is defined as one having a recurrence interval of 500 to $1,000 \mathrm{yr}$ and one in which the Columbia River dams remain in operation. The water level from this critical flood will not reach the elevation of the bottom of any fuel storage basin nor the first floor of the reactors. Thus, a dam-regulated standard project flood would not have the potential for spreading radioactive contamination from reactor buildings.

Several hazardous materials are present in the reactor buildings. These include lead, mercury, friable asbestos, polychlorinated biphenyls, and cadmium. Mercury, friable asbestos, and polychlorinated biphenyls are being removed or will be removed for recycle, storage, or disposal under separate environmental programs. Nonirradiated cadmium and lead may be left in place for in-site decommissioning or relocated to low-level waste (LLW) burial grounds.

3.8.1.3 Spent Fuel storage Facilities. A spent fuel storage basin is contained in each reactor building. These storage facilities are large concrete basins that, when operated, contained a 20-ft-deep pool of water as a coolant and shielding for spent fuel. The total area of each basin is 7,000 to $10,000 \mathrm{ft}^{2}$. Over the years, considerable sludge had collected on the bottoms of the basins. The sludge contained transuranics and fission products as well as activated coolant materials. Each of the basins contained an estimated 55 tons of sediment. The basins at 100-B, 100-C, 100-D, and 100-DR have been cleaned and are now in a clean dry condition. The 100-KE and 100-KW storage basins have been cleaned, modified, and reactivated for storage of $\mathrm{N}$ Reactor spent fuel.

A number of spent uranium fuel elements were found in the basins when the siudge was removed. It is thus expected that spent fuel elements also remain in the storage basins at $F$ and $H$ reactors, which have been filled with soil. Plans are being developed to remove the soil and other contents from these two basins.

The impact of natural forces, such as tornadoes, earthquakes, and flooding, on the retired storage basins would have an inconsequential impact on their safety.

3.8.1.4 Retired Waste Systems. During the course of production reactor operation and research work in the deactivated 100 Areas, 50 radioactive liquid waste disposal sites, 25 solid waste disposal grounds, and 20 liquid waste leakage areas were established and are no longer used. These waste 
disposal systems are grouped into the following facility classifications: retention basins, miscellaneous cribs and trenches, and disposal grounds.

The typical retention basin was a 20-ft-deep concrete or steel reservoir that provided a short "holdup" time to allow the water temperature to drop and to allow short half-life radioisotopes in reactor coolant to decay before the water was discharged to the Columbia River. Following deactivation, the retention basins were partially covered with fill dirt to stabilize contamination. Some contamination was deposited in the soil where leaks had occurred in the basins and effluent lines. Effluents from the basins that contained debris from fuel failures were diverted to liquid trenches located within about $200 \mathrm{ft}$ of the basins. These trenches were also covered with fill dirt to stabilize contamination.

The miscellaneous cribs and trenches, which were usually located within a few hundred feet of the reactor buildings, were used for ground disposal of liquid wastes from fuel fajlures, decontamination efforts, and liquids and sludges from spent fuel storage basins. Cribs were small open pits or underground French drains, generally about 10 to $20 \mathrm{ft}^{2}$. Trenches were open $V$-shaped excavations about $50 \mathrm{ft}$ deep, $10 \mathrm{ft}$ wide, and several hundred feet long. These trenches are now typically covered with 5 to $20 \mathrm{ft}$ of uncontaminated earth.

Twenty-three disposal grounds were used for disposal of miscellaneous radioactive solid waste from the 100 Area operations. The wastes include contaminated paper, rags, structured concrete, wood, and a variety of activated metal such as aluminum, steel, iron, and zircaloy. Most of the metallic wastes were reactor hardware that was removed during maintenance projects. The remaining two disposal grounds received wastes from biological research PNL formally conducted in the 100-F Area. A typical major disposal ground was several hundred feet wide by several hundred feet long. A disposal ground contained numerous disposal trenches and pits; the size and orientation of the pits varied, depending upon the material being buried.

Under normal conditions, there are no offsite hazards associated with the deactivated 100 Area waste disposal sites. No measurable offsite radiological releases or population doses can be attributed to these sites. No cave-ins have been experienced, and animal dispersion of contamination has not been a problem. The backfill used at the sites is generally too stony to provide a burrowing medium for pocket mice, ground squirrels, etc. Possibly the greatest long-term effect of transporting radioactivity into an uncontrolled environment is via biotic transport into plants, primarily Russian thistle. Problems of radionuclides transported by animals, insects, or wind could arise if deep-rooted plants were permitted to grow indefiniteiy. Contaminated land in the deactivated 100 Areas has been stabilized by applying clean overburdens and using selected herbicides. Under these current conditions, a range fire would not result in a measurable radioactive release from 100 Area facilities.

\subsubsection{Areas}

The 200 Areas are located in the plateau region of the Hanford Site, south of the 100 Areas. Facilities here were constructed to process the spent fuel from the production reactors. 
3.8.2.1 Plutonium-Uranium Extraction Facility. The mission of the PUREX $\mathrm{Plant}$ is to process irradiated fuels from $\mathrm{N}$ Reactor to recover the uranium and plutonium. The process steps consist of chemically decladding the fuel elements, dissolving the metal, decontaminating the product, and separating and purifying it by solvent extraction. The uranium product is stored in large tanks and ultimately converted to uranium trioxide at the $\mathrm{UO}_{3} \mathrm{Pl}$ ant. The plutonium nitrate is converted to plutonium oxide at PUREX or is shipped to the PFP for conversion to metal. The oxide or metal is placed in temporary storage on the Hanford Site.

Liquid wastes ( 30 billion gal/yr), essentially free of radioactive contamination, are discharged to artificial ponds. Slightly contaminated steam condensate is discharged to an underground trench (crib). The liquid wastes containing mixed fission products are neutralized and routed to underground double-shell storage tanks. Noncontaminated solid wastes are compacted and buried in a sanitary landfil1. Contaminated solid wastes are segregated as to level and type of contamination. Those contaminated with fission products are buried in regulated zone disposal trenches, white those containing transuranics are packaged and buried in 20-yr retrievable storage.

All radioactive elements in gaseous effluents (except krypton and tritium) from the PUREX Plant are below concentration 1 imits for unrestricted areas specified by DOE Order 5480.11 (DOE 1988b). Krypton and tritium are present in concentrations above those limits in the gases at the top of the 200-ft-high stack; however, these elements are dispersed by factors of $10^{6}$ to $10^{8}$ as the gases move away from the stack. The concentrations are well below the limits before the stack plume reaches the Site boundary.

The PUREX Plant comprises the main canyon building (202-A) and a number of auxiliary structures and facilities and contaminated equipment disposal tunnels. Other facilities directly supporting the PUREX operations are tank farms, cribs, retention basins, etc. The plant structures were built to safely handle materials of varying degrees of radioactivity.

The 202-A Building is serviced by four separate ventilation systems designed and operated so that the normal work areas are kept free of airborne radioactive contamination.

A serious earthquake could damage the water supply system; however, the plant can be brought to a safe shutdown with a minimal amount of water. A water drown tank is needed to maintain dissolver process safety during shutdown and for $\mathrm{H}$ - and $\mathrm{J}-\mathrm{Ce} l 1$ fire suppression systems hardened for earthquake protection.

The massive structure of the 202-A Building can withstand all credible tornado winds; however, some utilities could be lost and some process systems rendered inoperable through loss of control features. Exposure to the public outside the structure of the 202-A Building would be minor. Missile damage to the laboratory has not been analyzed in depth. The aggregate release is estimated to be less than $2.0 \mathrm{~g}$ of plutonium and 1 ess than $5.0 \mathrm{~g}$ of mixed fission products. A preliminary study concluded that no significant consequence woulo result from these releases.

3.8.2.2 Plutonium Finishing Plant. The initial $Z$ Plant Building was built in 1949 to provide the capability for purifying concentrated plutonium nitrate 
solution, reducing the nitrate to metal, and fabricating the plutonium metal into weapon parts. The $Z$ Plant is now called the PFP. The PFP

(234-52 Building) houses the plutonium processing lines, the product handling facilities, analytical laboratory, development laboratory, and major service and support facilities. The adjacent 291-Z Building houses ventilation exhaust fans and mechanical service equipment. The current mission of the facility comprises three main activities: (1) process liquid plutonium nitrate to metal, which is a shippable or storable form; (2) recover plutonium from scrap or stabilize it for storage, which takes place in the plutonium reclamation portion of the facility; and (3) package other plutonium product (oxide) for offsite shipment.

The ventilation systems provide a constant flow of air, away from workeroccupied areas toward zones of increasing contamination potential. All potentially contaminated areas are maintained at a negative pressure. Exhaust air is filtered by high-efficiency particulate air (HEPA) filters. Discharges to the atmosphere through the 291-z-1 stack are monitored and sampled. Two automatically operated steam-driven exhaust fans are activated in case of power loss.

The fire protection systems, such as early warning alarms, automatic sprinklers, deluge systems, manual hydrants, and hoses, have been extensively upgraded. Fire protection has also been provided in gloveboxes.

All handling, storing, and processing of fissile materials in the PFP facilities is controlled by criticality prevention specifications so that, in unshielded locations, no two credible equipment or process failure or human errors could cause a criticality.

The 234-5Z Building was designed according to the Uniform Building Code (UBC) of 1945 (ICBO 1945), and the operating auxiliaries in accordance with the UBC of 1960 (ICBO 1960).

Because the facility is used to process plutonium, current design criteria would require it to withstand a safe shutdown earthquake (SSE) and design basis tornado wind forces. An anaiysis of the facility in 1978 showed that it would not withstand a SSE and that support services would be lost in the event of a severe earthquake or tornado. The DOE subsequently commissioned a seismic evaluation using more sophisticated analysis techniques and more data on consequences of earthquakes. This evaluation indicated that the structure would withstand the SSE of $0.25 \mathrm{~g}$.

3.8.2.3 Plutonium Storage Facilities. The 2736-Z Building is the main plutonium storage facility at the Hanford Site. A variety of plutonium metal and powder forms are stored in the facility. All material is packaged in metal containers; the quantity of fissile material and spacing of the containers both in cubicles and in open rooms is prescribed by criticality prevention requirements. Criticality detectors are strategically located to alarm for immediate evacuation in the unlikely event of a criticality.

The ventilation system is connected to the 234-52 Building ventilation system and maintains the facility at a negative pressure with respect to atmosphere. 
All rooms in the 2736-2 Building are equipped with an electrically supervised, early warning, smoke or heat detector and alarm system. A wetpipe sprinkler system has been installed in the southwest corner room; the fire load in the remaining rooms is low, so no sprinkler system is installed. The 2736-Z Building was designed to withstand the SSE.

3.8.2.4 Evaporator-Crystallizers. The 242-A facility is an evaporatorcrystallizer, which is used to concentrate liquid wastes. It is located in the 200 East Area and has operated since 1977.

Another evaporator, the 242-S facility in the 200 West Area, operated from 1973 to 1981 and is in standby condition. A third evaporator, 242-T in the 200 West Area, operated from 1955 to 1976. The evaporator-crystal1izers use a conventional forced circulation vacuum-evaporation system to concentrate radioactive waste solutions to salt crystals.

The potentially contaminated areas in the buildings ar maintained at a negative pressure with respect to the atmosphere. Detection of radioactivity above preset limits automatically shuts down the building ventilation exhaust fans.

Fire protection for both evaporator facilities is provided by fusedlink detectiun and water spray extinguisher systems in all rooms except the condenser room. The condenser rooms, where combustible organic liquids may be present, have thermopneumatic detection and water deluge extinguisher systems.

The most serious hypothetical accident is judged to be a waste transfer line failure. The maximum dose commitment offsite would be less than DOE guidelines.

3.8.2.5 Waste Fractionization Facility. The B Plant was built in 1944 and was operated as a separation facility for irradiated production reactor fuels until 1952. In 1968, it was converted to a waste fractionization plant to purify and store the $90 \mathrm{Sr}$ and ${ }^{137} \mathrm{Cs}$ from PUREX and other plant wastes. The purified strontium nitrate and the cesium carbonate, were sent to the Waste Encapsulaticn and Storage Facility (WESF) for further processing. The final products (dry strontium fluoride and cesium chloride) were doubly encapsulated in metal containers for storage in water pools. The WESF is attached to the west end of B Plant and has operated since 1974. The B Plant is being upgraded for a third mission, waste pretreatment.

Liquid wastes are discharged from B Plant by four liquid waste streams: cooling water, chemical effluents, process condensates, and steam condensates.

Cooling water and chemical effluent wastes are discharged to surface disposal sites. Process condensates go to the tank farms and steam condensates are discharged to subsurface disposal sites (cribs). These streams are monitored with alarms for radioactivity contents before they are discharged. Should the radioactivity content exceed alarm setpoints, the cooling water and steam condensate streams are diverted to a retention system for subsequent recycling or routing to underground tank storage. The chemical effluent within 221-B can be diverted to a B Plant processing cell for recycling. 
Radioactive liquid waste from the WESF is routed to B Plant for processing; the raw water used for cooling is directed to B Plant for discharge. A11 raw water in the WESF for cooling radioactive systems (except G-Celi) is isolated by a secondary heat exchanger that provides double-barrier protection in the case of a radioactive leak. The $G-C e 11$ is used for in-process storage of singly encapsulated radionuclides; its cooling water discharge is monitored and automatically diverted if radioactivity limits are exceeded.

The most severe hypothetical accident for B Plant is postulated to be a ventilation system fire that would cause breaching of all except the final HEPA filter bank. The radiological exposure to the offsite population from such an accident would be inconsequential.

The maximum postulated hypothetical accident in the WESF would be a spill of strontium fluoride powder and the simultaneous failure of two of the inline filters. If such an unlikely event should occur, a person in the 200 East Area would receive an occupational exposure of less than established DOE guidelines for the yearly allowable.

The 221-B Building was designed according to the UBC of 1940 . It is currently on standby. Because the facility is designed to process radioactive material, current design criteria require it to withstand an SSE (MM VIII) and an $87-\mathrm{mi} / \mathrm{h}$ wind. Although overstressing would occur, the main building (221-B) would probably maintain a basic structural shell of confinement following an SSE. The cask station was designed to meet an MM VII earthquake. The underground HEPA filters that are normally in use would survive an SSE, but the sand filter (the backup filter) probably would not. The B Plant structures were designed for a lateral force equivalent to an $87-\mathrm{mi} / \mathrm{h}$ wind, with the exhaust stack designed for an equivalent 100-mi/h wind. Services and utilities do not possess inherent tornado resistance; however, no adverse consequences are expected should services and utilities be lost.

The WESF is designed to meet present Hanford Site design criteria for an SSE. The WESF can withstand winds in excess of the present design basis for straight winds of $87 \mathrm{mi} / \mathrm{h}$.

\subsubsection{222-S Laboratory. The 222-S Laboratory was built during 1950 to} 1951 in the 200 West Area. It currently houses an analytical laboratory, part of the chemical standards laboratory, and the chemical sciences laboratory.

The building interior is subdivided into three general areas, two of which contain radionuclides. The storage areas in the east end contain the most active radionuclides and the central section contains low-to-intermediate activity materials. The west end of the building is free of radionuclides. The potential contamination areas are maintained at a negative pressure with respect to atmosphere; exit air passes through two-stage HEPA filters. Potentially contaminated liquid waste is diverted to a retention basin for analysis.

If the liquid waste is within DOE concentration guidelines, it is discharged to a wastewater pond; if not, it is pumped to an underground storage tank. 
The most serious hypothetical accident evaluated involves a release from a propane-air mixture exploding in a laboratory room containing $1 \mathrm{~kg}$ of plutonium in solution. The offsite radionuclide release that would result was determined to be within DOE limits. Currently, the entire building inventory of fissile material is 1 imited to $20 \%$ of $1 \mathrm{~kg}$.

The 222-S Laboratory was designed to the UBC of 1945. No comprehensive analysis has yet been performed of the facility's ability to withsiand the severe natural forces events.

3.8.2.7 T Plant. The 221-T canyon building was built in the 200 West Area in 1944 as a separation facility for irradiated production reactor fuels. In 1957, it also began to be used as an equipment decontamination and repair facility. In 1978, the building was used to store the blanket fuel modules from the pressurized water reactor core 2 of the Shippingport Atomic Power Station. To carry out these services, the following additions and modifications to the original facility have been made.

- The head end of 221-T (two cells) was partitioned as a Containment Systems Test Facility.

- Cell 4 (pool) was equipped to store the blanket assemblies.

- 2706-T was built as a low-level decontamination facility.

The original sand filter ventilation system has been augmented with a roof-mounted canyon exhaust system featuring a pre-filter and two stages of HEPA filtration. Discharges are continuously monitored and al armed for radioactive discharges. The ventilation system of the 2706-T addition has dust-stop filters and a radiation alarm, and the discharges are routinely sampled and analyzed. The 221-T radioactive liquid wastes are collected in a deep-cell tank and transferred to the tank farm in 12,000-gal batches. The 2706-T waste is pumped to the tank farm via 221-T. Pool water cooling is a closed-10op refrigeration system with the secondary coolant system discarded to the chemical sewer routed to a pond. Though the liquid waste stream is normally free of radioactive contaminants, it is periodically sampled.

The 221-T Building was designed according to the 1940 UBC. A preliminary analys is indicates that although overstressing would occur as a result of an SSE, the main building, 221-T, would probably maintain a basic structural shell of confinement. A tornado would probably disrupt certain support services, ventilation systems, and utilities; however, no severe consequences are expected from their losses. The most serious hypothetical accident, module cladding breached in the pool storage, would cause a release of about $100 \mathrm{Ci}$ of mixed fission products to the storage pool. The resultant exposures to employees and the public would be well below DOE limits.

3.8.2.8 Uranium Oxide Facility. The $\mathrm{UO}_{3} \mathrm{Pl}$ ant began operating in 1952; in 1972 it was placed in a standby condition and reactivated in 1983. Its mission is to convert uranyl nitrate hexahydrate solution to $\mathrm{UO}_{3}$ powder.

During standby operations, miscellaneous streams of very low-level contaminants from roof drains and sumps discharge to an underground crib. 
The $\mathrm{UO}_{3}$ Plant was not designed to present-day natural force criteria. Though the plant usually is in standby mode, a quantity of $\mathrm{UO}_{3}$ powder is in inventory.

No serious consequences are expected from a natural force event in the standby mode.

The most serfous hypothetical accident involving the $\mathrm{UO}_{3}$ Plant would be a spill of $1,000 \mathrm{lb}$ of $\mathrm{UO}_{3}$ powder onto the outside pavement. Analysis of this event indicates that the resulting occupational exposure would be less than DOE guidelines.

3.8.2.9 Underground Waste Storage Tanks. As a result of the several plutonium recovery processes used at the Hanford Site and past practices in the management of tank waste, the chemical and radionuclide compositions of existing individual tank contents are varied. Volumes and compositions were strongly dependent on the separation processes used to generate the waste, and methods for treating the waste in tanks have had major impacts on their content compositions. Also, tank contents have been mixed by transfer of slurries among tanks and tank farms. Most of the waste in underground storage tanks is in the form of salt cake, sludge, and interstitial liquors stored in 12 tank farms containing 149 tanks with single-shell construction.

The underground single-shell tanks vary in size from 50,000 to $1,000,000 \mathrm{gal}$. The bottom and sides of the tanks are steel encased in reinforced concrete. The dome is reinforced concrete and is covered with a minimum of approximately $7 \mathrm{ft}$ of earth. The tank domes have penetrations for pumps, ventilation systems, airlift circulator inlet pipes, and surveillance instrumentation.

Residual liquids and slurries are contained in 28 newer tanks of doubleshell construction. Each of the double-shell waste tanks is a 1-million-gal steel tank within another steel tank. The annulus between tanks will contain any leakage from the primary tank. The outer tank is enclosed in a reinforced concrete shell and the tank dome is reinforced concrete within a steel liner.

The dome has penetrations for pumps, airlift circulators, level gauges, and temperature measuring devices. Other associated equipment includes pumps, piping, airlift circulators, steam coils, and leak detection pits.

Existing analyses of the hazards associated with the single-shell tanks indicate that no serious offsite consequences would result from accidents caused by abnormal operations or natural forces. The underground single-she11 tanks were designed before the SSE criteria were established; however, it has been concluded that, in general, the tanks would withstand such an event. Failure of the aboveground ventilation systems due to tornado winds could result in measurable releases of contaminants. The offsite impact is not expected to be significant.

Some tanks contain a combination of chemicals that, with the right combination of component concentrations and temperature, could be explosive. Studies have been completed which conclude that the explosive potential is extremely low. 
The most serious hypothetical accident for a double-shell waste tank would be rapid and complete failure of the ventilation exhaust filters. Offsite dose commitments predicted to result from such an occurrence are less than the DOE limits. The double-shell tanks are designed for an SSE; the support facilities are designed to resist wind forces of $87 \mathrm{mi} / \mathrm{h}$. A tornado may destroy the vent system, but the resulting offsite dose commitment would be less than thi DOE guidelines.

\subsubsection{Waste Ponds, Ditches, Cribs, and Disposal Grounds. Operations at} the 200 Area facilities generate a variety of liquid effluents, some of which are radioactive. Means of disposing of these liquid effluents have included use of the ponds, ditches, cribs, trenches, French drains, and reverse wells. Pond's are primarily used for disposal of high-volume, low-level, radioactive liquid effluents by evaporation and/or percolation. Ditches are also used for evaporation and/or percolation disposal, but for smaller volumes of low-level radioac a liquids. The ditches are also used to transport liquid effluents to pond. Cribs of various designs have been used to discharge liquid waste to the grounc at depths great enough to preclude causing a radioactive field at the surface. Tile fields have been used along with crijs to disperse liquid wastes over a wider area.

The most significant accident involving these sources would be airborne radioactive particulates caused by fire and subsequent wind dispersal. The estimated radiation dose offsite would be well within DOE guidelines. An earthquake could collapse crib timbers and cause a release of radioactive aterial. Also, tornado winds (or any high wind) might entrain some lowlevel contamination from ponds and ditches.

3.8.2.11 Critical Mass Laboratory. Pacific Northwest Laboratory operated the Critical Mass Laboratory until 1988 to conduct approach-to-critical and critical experiments in support of chemical reprocessing of reactor fuels. From these experiments, criticality parameters were obtained for fissionable material solutions and other fissionable fuels to provide design and control parameters for precluding accidental criticality in chemical processing operations.

The Critical Mass Laboratory was constructed in 1959 to 1960 to UBC zone 2 requirements then in force. Althuugh a natural force analysis has not been performed for the critical assembiy room, the heavy concrete-steel shielding structure of the room would withstand the current seismic and wind force criteria. However, serious damage to the mixing room could result from such natural events. The fuel solution in the mixing room is a nitrate solution; any resulting contamination would likely be localized to the Critical Mass Laboratory site. The facility is currently in unmanned safe shutdown. It will be transferred to the Surplus Facilities Management Project for D\&D if no future programmatic work can be identified.

\subsubsection{Area}

The reactor fuel fabrication facilities for the $N$ Fictor and FFTF are located in the 300 Area. The 300 Area is also the primis location of the R\&D facilities that serve the Hanford Site. 
3.8.3.1 N Reactor Fuel Fabrication Facilities. The $N$ Reactor fuel fabrication facilities (in standby status) are located in the northern portion of the 3CO Area. Although the operations entailed hundred-ton quantities of enriched metallic uranium, they posed little risk to either the environment or the public. The uranium enrichment was relatively low; to achieve criticality would have required both moderation and precise geometrical arrangement. In the fuel fabrication operations, geometry concrol was used wherever possible to preclude the possibility of a criticality...

The fuel fabrication facility buildings were designed to withstind the wind and roof loadings expected in the Hanford Site area. A maximum tornado, however, would likely damage the buildings. In the event that the facilities did not withstand the effect of an earthquake, chemical and waste spills could result. These spills would not have significant consequences to the environment and the public. It is also highly unlikely that a fire involving fines or chips would result from either a tornado or earthquake, or that criticality could be achieved upon rearrangement of the fuel. Also, the impact of the probable maximum flood would be inconsequential from the standpoint of criticality or environmental releases. These fuel fabrication facilities are currently in standby status.

\subsubsection{Fast Flux Test Facility Fuel Fabrication Facility. The FFTF fuel} fabrication operations in the 308 Building are scheduled to be terminated in 1990. The dispersible oxide fuels will be removed, and the gloveboxes will be cleaned such that only residual contamination remains. The gloveboxes will be left in a standby mode.

The remaining principal hazards in the 308 Building are those associated with the continued operation of the TRIGA reactor that is housed in the 308 Annex. The reactor's primary use has been for neutron radiographic examination of FFTF fuel pins, and its secondary use is as a source of neutrons for activation analysis. The majority of the equipment and facilities used in this reactor are typical of those for many other TRIGA reactors and systems that have well-established operating experience.

The reactor facility superstructure is constructed to withstand an $85 \mathrm{mi} / \mathrm{h}$ wind and simultaneous ground accelerations (earthquake) of $0.125 \mathrm{~g}$ horizontally and $0.083 \mathrm{~g}$ verticaliy. The reactor pool and contained equipment are constructed to withstand simultaneous ground accelerations of $0.25 \mathrm{~g}$ horizontally and $0.167 \mathrm{~g}$ vertically, which is the Hanford Site SSE. The reactor facility has a sprinkler system for fire protection that was extended to the 308 Annex from the 308 Facility.

3.8.3.3 Radiochemical Engineering Facility. The 324 Building has a partial basement, first, second, and partial third floors. The foundation is poured reinforced concrete; the superstructure is fluted steel, with insulated industrial panels supported on a structural steel frame. Most of the building is occupied by two groups of shielded cells and their operating and service galleries, i.e., the Shielded Materials Facility and the Radiochemical Engineering Cells.

The Shielded Materials Facility, which is located in the southeast portion of the 324 Building, has an airlock cell, two operating cells, and a cask handling cell. The facility is used primarily for detailed evaluation of irradiated fuels and structural materials. 
The Radiochemical Engineering Cells were designed for process and equipment studies involving megacurie quantities of radioactive materials. The shielding of the five cells is high-density concrete up to 54 in. thick. Each cell is equipped with overhead crane service, has direct viewing through shielded windows, and has master-slave manipulator provisions. Cells $A$ and $B$ can handle equipment up to $25 \mathrm{ft}$ high; cells $C$ and $D$ can handle heights up to $11 \mathrm{ft}$. The fifth cell (the airlock cell) is located at the junction of the cells and functions primarily as a transition, maintenance, and decontamination zone.

Approximately 50\% of the 324 Building is protected by a wet pipe sprinkler system. The Shielded Materials Facility and the Radiochemical Engilleering Cells are protected by total flooding Halon systems that can be activated manually or by heat detectors. All protection and detection systems alarm in the 300 Area fire station.

The reactor fuels and accompanying process materials in the shielded Materials Facility and the Radiochemical Engineering Cells may involve significant quantities of fissionable materials and have the potential for criticality. Geometry control is applied to preclude criticality. If a criticality occurs within a cell, operating personnel will be protected from high exposure by the heavy concrete shielding of the cell walls. A ninedetector criticality alarm system serves the 324 Building to alert personnel to criticalities in unshielded areas.

The 324 Building was constructed in compliance with the UBC (ICBO 1952) and Hanford Design Criteria; as a result, it can withstand an $85 \mathrm{mi} / \mathrm{h}$ wind. Structural analyses of the 324 Building show that the steel frame system of the building will experience major structural damage when subjected to a seismic event of $0.20 \mathrm{~g}$ horizontal acceleration. However, the Radiochemical Engineering Cells and vault area have been shown to be capable of withstanding a seismic event in excess of $0.25 \mathrm{~g}$. The analyses also concluded that the calculated 50-yr dose commitments to the maximum offsite individual are within DOE guidelines. Because the cells in the Shielded Materials Facility are similar in structure to the Radiochemical Engineering Cells, and the material types and quantities are less hazardous, its earthquake consequence should a) so be similar or less. The PMF river elevation is less than basement level for the 324 Building; therefore, flooding to the depth of the basement is highly improbable.

\subsubsection{Post-Irradiation Testing Laboratory. The Post-Irradiation Testing} Laboratory ( 327 Building) provides specially shielded facilities for physical and metallurgical examination and testing of irradiated fuels, concentrated fission products, and structural materials. The facility inciudes 12 shielded hot cells, 3 water-filled basins, and a dry storage pit. Other engineered safety features are a high-efficiency filtration ventilation system, extensive fire protection system, and emergency power system.

The ventilation system is designed to confine radioactive materials by maintaining pressure differentials and filtering exhaust air through at least one HEPA filter stage. All highly contaminated areas, such as the shielded cells, the Dry Storage Facility, and fume hoods, are exhausted through

${ }^{\star}$ Halon is a trademark of Allied Chemical Corporation. 
additional HEPA filters and activated charcoal filtration. All exhaust gases released from the building are continuously monitored and sampled.

The building is protected by a wet-pipe sprinkler system supplemented with manual fire extinguishers located throughout the facility. The examination cells and the charcoal filter room are provided with heat detectors that, along with the building's fire suppression sprinkler heads, alarm in the 300 Area fire station and locally within the 327 Building.

The 327 Building (first occupied in 1953) was designed and constructed in accordance with UBC Zone 2 criteria (ICBO 1952) then in effect for the Hanford Site. The shielded cell structures are similar to those in the 324 Building and their resistance to earthquake forces are also expected to be similar. All facilities except the water-filled storage basins are above the PMF level. Because the storage basins are already filled with water, the impact of the PMF would be inconsequential.

3.8.3.5 Radiochemistry Building. The Ra'iochemistry Building (325 Building) provides specially shielded, ventilated, and equipped laboratories for radiochemical experimentation. The building consists of a central portion containing general purpose laboratories for low-level radiochemical work, a south wing containing office space, and east and west wings containing shielded cells for high-level radiochemical work. The materials handied in the facility include irradiated and nonirradiated mixed-oxide fuels, irradiated cladding samples, high-level liquids, and various forms of transuranic radionuclides. Potential hazards associated with the building activities include nuclear criticality, personnel radiation exposure, radiological contamination, and fire. Engineered safety features include fume hoods, gloveboxes, shielded cells, a ventilation system for contamination control, a comprehensive fire protection system, and an emergency power system.

The 325 Building was first occupied in 1953 and was designed and constructed in accordance with UBC Zone 2 criteria in effect at that time (ICBO 1952). The earthquake resistance status of the shielded cells are probably similar to those in the 324 Building. The basement of the building is several feet above the PMF level and thus would not be significantly impacted.

3.8.3.6 300 Area Waste Management Facility. The 340 Waste Management Facility was built primarily to handle radioactive liquid waste. The radioactive liquid wasto sewer collects low to moderately contaminated waste from a limited number of sinks and drains. This waste is received, neutralized, and loaded out of the facility for transport by railroad car to the 200 Area. Buildings served by the system include 309, 324, 325, 326, 327 , and 329. The retention waste sewer, if contaminated, is diverted into the radioactive liquid waste sewer; otherwise, the normally nonradioactive material in the retention waste sewer is pumped into the process sewer. The retention waste sewer services buildings $308,309,324,325,326,327$, and 329.

Engineered safety features include shielding, ventilation systems designed to prevent the spread of contamination, leak prevention and containment features, an extensive system for controlling radioactive contaminated wastes, and a fire protection system. Where applicable, safety interlocks 
are installed on operating equipment. Leak and overflow control and monitoring features are used throughout the facility. The ventilation systems of the facilities include HEPA filtration and sampling and/or monitoring of exhausts.

The facilities are equipped with manual fire extinguishers, smoke detectors, and manually activated fire alarms that sound at the 300 . Area fire station. The probability of a serious fire or explosion is very low because of the close control over combustible materials and the noncombustible nature of building structure and equipment.

The 340 Facility structures were placed in service in 1953 and were designed and constructed in accordance with the UBC then in effect for the Hanford Site (ICBO 1952). The only portion of the facility below the PMF level is a portion of the 340 vault. In the event of a flood, the concrete walls and floor of the vault would permit some seepage that would not impact the safety to personnel or the continued operation of the facility.

\subsubsection{Area}

The 400 Area, which is scutheast of the 200 East Area, was created as the construction site for the FFTF and its support facilities.

3.8.4.1 Fast Flux Test Facility. The FFTF consists of the Fast Test Reactor and numerous support facilities. The reactor uses plutonium-uranium oxide fuel and sodium coolant, and has a power rating of 400 MW thermal.

The primary coolant system consists of three circulating loops, each with an intermediate heat exchanger, through which heat is transferred from the primary to the secondary coolant system. The secondary coolant system transports heat to another heat exchanger that releases the heat into the atmosphere. The primary structural material for the reactor and all systems containing sodium is austenitic stainless steel.

Service and auxiliary buildings and facilities are provided for control of the plant, receiving and shipping of fuel and cquipment, storage of irradiated fuel, secondary coolant system equipment, service systems, equipment decontamination and repair, and other operating and administrative services. The principal auxiliary facilities are the Fuel storage Facility for long-term storage of irradiated fuel and test pins; and the MASF for cleaning, manual/remote decontamination, and storage and repair of a variety of equipment and nonfuel nuclear components.

The Fuel Storage Facility, located adjacent to the FFTF, consists primarily of a large, below-grade, sodium-filled vessel for storing up to 466 fuel assemblies and canisters containing fuel pins. Decay heat of the irradiated fuel is removed by natural circulation of the sodium to the atmosphere through two natural draft heat exchangers.

The MASF is a reinforced-concrete substructure and a steel-framed structure with paneled construction above grade. A rail spur that connects to the FFTF track extends through the facility and is served by 60 -ton and 200-ton bridge cranes. This permits the entry and handling of large equipment components that are radioactive or contaminated by radioisotopes. The 
components can be cleaned, decontaminated, repaired, and/or stored in the facility. Presently, fissionable materials are not permitted in the facility except for trace amounts of contamination.

The FFTF and Fuel Storage Facility structures, systems, and components important to safety, including their foundations and supports, are designated Seismic Category is and are designed to remain functional in the event of an SSE and the impact af tornado. The design wind velocity of all FFTF design structures is $100 \mathrm{minh} /$ for heights up to $50 \mathrm{ft}$ above grade and $120 \mathrm{mi} / \mathrm{h}$ for heights from 51 to, $150 / \mathrm{ft}$ above grade, with a 1.1 gust factor applied to each velocity.

The MASF is designed to conform to UBC 1976 Edition, Seismic Zone 2 (ICBO 1976). It was not necessary to design the facility to Caregory I because the consequences from credible natural phenomena would be well below the 10 CFR 100 limits for highly improbable accidents.

The FFTF was designed to comply with applicable NRC Regulatory Guides for 1 ight-water-cooled reactors.

3.8.4.2 Fuels and Materials Examination Facility. The FMEF was constructed to provide confinement of hazardous materials for the duration of a number of postulated accidents and natural events. The building is designed to withstand the design basis earthquake (DBE) and is tornado hardened. Further protection is provided by the facility safety systems and administrative limits and controls. All Class I safety systems are seismic qualified to withstand the DBE.

The enclosures inside the facility that will house dispersible radioactive materials are isolated from the environment by three sets of HEPA filters. At least two of these filters are testable.

The ventilation system is set up to provide ventilation zones with varying pressures to draw air from areas of least hazard to those of greatest hazard thus aiding in the prevention of contamination spread. The ventilation system is Safety Class I.

Criticality detection is provided by local detectors operating on a twotrip to alarm mode. The signal is transmitted to local howler alarms and the Distributed Electronic Control System (DECS) control panel. All enclosures and storage locations with criticality potential are Safety Class I.

The radiation area monitors and continuous air monitors also alarm locally and in the DECS control room.

Waste collection will be handled depending on type. Liquid radioactive waste will be pumped to the liquid radioactive waste tanks located on the minus 35-ft level. Ultimately, the liquid waste will be solidified in a concreting process to be installed in the FMEF. Solid waste will be packaged and sent to the appropriate burial location.

Hazardous and mixed hazardous waste will be sent to the appropriate waste handling facility in the 200 Areas. 
The facility's fire protection system includes a sprinkler system, 2-h and 4-h fire barriers between zones, and is backed up by the 400 Area Hanford Fire Station. Combustible loading of the building is to be administratively controlled and fire retardant materials utilized in construction.

All effluent pathways will be monitored for radioactive materials. Detection of elevated releases will actuate alarms. All alarms are monitored in the DECS control room. Backup capability of the monitoring system will be provided.

\subsection{MANAGEMENT AND IMPLEMENTATION OF ENVIRONMENTAL ACTIVITIES}

The following sections define the roles and responsibilities for organizations performing environmental activities at the Hanford Site. The sections alsc discuss the roles of external agencies with respect to environmental activities at the Hanford Site.

The Hanford Environmental Management Program was established in November 1986 to incorporate a structured program/project management approach for achievement of Hanford Site environmental objectives. At that time, the following four basic objectives were established:

1. Monitor to ensure compliance

2. Modify activities to attain compliance

3. Mitigate environmental consequences, and

4. Minimize futu:e environmental impacts.

Specific tasks were assigned within DOE-RL and to its contractors. Since its initial inception, several key organizational changes have occurred. One of these was the consolidation of DOE-RL contractors from eight to four. Second, environmental compliance has become a more significant driving force and is now receiving significant attention in all operating or active facilities. In addition, state and federal oversight and involvement has increased significantly in the last $3 \mathrm{yr}$.

\subsubsection{U.S. Department of Energy-Richland Operations office Management Structure and Approach}

The DOE is responsible for defining, budgeting, and managing the environmental activities at the Hanford Site and for supporting the conduct of environmental activities at other sites.

The DOE-Headquarters (HQ) has assigned DOE-RL responsibility and authority for the management of the Hanford Site, including responsibility for the Hanford Site's environmental activities. The DOE-RL prepares budget submittals necessary to meet environmental requirements. The DOE-RL also reviews and approves all submittals related to environmental activities to agencies and organizations outside of the Hanford Site. 
Within the DOE-RL, the Environmental Restoration Division (ERD) is assigned responsibility for the Hanford Site environmental management activities. The ERD reports to the Office of Assistant Manager for Environmental Management. Within ERD are two branches: the Restoration Branch and the Policy and Permits Branch. The Restoration Branch plans and oversees the remedial actions for inactive waste sites and D\&D of surplus facilities. The Policy and Permits Branch supports Hanford Site operational programs to ensure environmental compliance and to implement environmental policy at the Hanford Site; represents DOE-RL with Washington State and the EPA Region X; and coordinates preparation of environmental permits for the Hanford Site.

The Waste Management Division (WMD) performs management oversight of Hanford Site waste management operations and supports waste management activities at other DOE sites. The WMD reports to the Office of Assistarit Manager for Operations and contains an Operations Branch and a Programs Branch. The WMD is responsible for the programmatic and environmental compliance aspects of waste management facilities and operations (e.g., B Plant, Grout Treatment Facility (GTF), tank farms, single-she11 tanks, 324 and 325 Building Hot-Cell Cleanout, West Valley support, and Civilian GreaterThan-Class-C Low-Level Waste Management) and the Hanford Environmental Compliance (HEC) project. The HEC project is comprised of 15 construction subprojects, with a $\$ 180$ million budget through completion, which provide enhanced environmental operations at the Hanford Site.

The Environmental Compliance Branch of the Safety and Environment Division (SED) performs oversight of the environmental activities at the Hanford Site. The SED reports to the Office of Assistant Manager for Safety, Environment, and Security.

The Operations Division (OPD) is responsible for the operation of production facilities and environmental compliance within these facilities. The OPD reports to the Office of Assistant Manager for Operations and contains the Reactor Operations Branch, the Nuclear Processing Branch, and the Nuclear Energy Programs Branch.

Most other DOE-RL organizations are involved in environmental and waste management activities. These include the Waste Vitrification Project Division, Quality Assurance Division, Safeguards and Security Division, Project Management Division, Research and Development Division, Financial Resources Division, Procurement Division, Personnel Division, Site Management Division, Office of Chief Counsel, and Office of Communications.

Each DOE-RL division is responsible for monitoring operations to ensure compliance and for completing identified environmental corrective actions in facilities and systems under their direction.

\subsubsection{Hanford Site Prime Contractor Organization and Responsibilities}

Each contractor is responsible for the safe, environmentally sound maintenance and operation of its designated facilities, specific facility upgrades, operational support, waste management, and monitoring of operations and effluents for environmental compliance. Plant or building managers have 
first-line responsibility to operate their facilities in a safe, environmentally sound manner.

Most waste operations activities, environmental corrective and remedial actions and D\&D of surplus facilities conducted at the Hanford site are performed by or under contract to WHC, the operations and engineering contractor. The WHC has been assigned responsibility for management of the Defense Waste Management Program, implementation of the Environmental Restoration Program, and management of the Hanford Environmental Compliance project. The engineering and construction services contractor ensures environmental design requirements are met and provides project support. The HEHF provides nonradiological-effluent and sanitary-water environmental surveillance services for the Hanford Site.

The R\&D contractor (BMI) performs environmental R\&D, provides an independent Site-wide environmental surveillance program and applies waste management technology to support operations and environmental restoration at other DOE sites. The R\&D contractor is responsible for waste management and environmental compliance at its assigned facilities. The R\&D contractor will manage and staff the newly created Environmental Science Research Center, which will conduct R\&D activities to support development technologies for environmental cleanup and site characterization. Environmental technology initiatives will be defined in the Office of Energy Research Five-Year Plan.

Hanford Site contractors also conduct programs that apply waste management technology to support Waste Management Operations, Environmental Restoration, and Environmental Corrective Actions at other DOE sites.

\subsubsection{Interaction with Offsite Agencies and Organizations}

Several federal, state, and local agencies are responsible for enforcing environmental regulations at the Hanford Site. Principal among these agencies are the EPA, Washington State Department of Ecology, Washington State Department of Social and Health Services (DSHS), and the Benton, Franklin, and Walla Walla Counties Air Pollution Control Authority. These agericies issue permits, review compliance reports, participate in joint monitoring programs, inspect facilities and operations, and enforce compliance with applicable regulations. Washington State DSHS, for example, provides radiological support to state agencies, is the primary authority for Washington state drinking water and radionuclide air emission permit programs, and participates with DOE-RL in radiological monitoring of the environment.

The EPA develops, promulgates, and enforces environmental protection standards and regulations as directed by statutes passed by the U.S. Congress. In instances where regulatory authority can be delegated, the EPA delegates regulatory authority to Ecology for Washington State programs which meet or exceed the EPA's requirements. Where reguiatory authority is not delegated, EPA Region $X$ (which includes Washington State and the Hanford Site), is responsible for reviewing and evaluating compliance with the EPA regulations as they pertain to the Hanford Site. This includes interpreting regulations, consulting with DOE-RL and its contractors to aid regulation implementation, inspecting facilities and operations at the Hanford Site, and assisting appropriate Washington State agencies in regulating operations at the Hanford Site. 
Other external organizations are also involved in the Hanford Site's environmental activities. The U.S. Army Corps of Engineers regulates activities and 1 and use between the high water marks on the banks of the Columbia River on the Hanford Site. The U.S. Department of Transportation regulates interstate transport of commodities, including hazardous substances and hazardous waste. The Washington State departments of Fisheries and Game assist in wildlife and fisheries management on and around the Hanford Site. The Washington State Department of Agriculture certifies and 1 icenses all Hanford Site applications of pesticides. The Agency for Toxic Substances and Disease Registry is required to perform heaith assessments for each of the four National Priority List sites nominated at the Hanford Site.

The Tri-Party Agreement (Ecology et al. 1989) is an agreement among Ecology, EPA, and DOE. The agreement addresses those actions necessary to: (1) achieve full Resource Conservation and Recovery Act of 1976, et seq. (RCRA) compliance for treatment, storage, and disposal of hazardous wastes and obtain a final RCRA permit for the Hanford Site, and (2) clean up inactive waste sites as RCRA corrective actions or remedial actions under the Comprehensive Environmental Response, Compensation, and Liability Act of 1980, et seq. (CERCLA).

The Tri-Party Agreement is a legal agreement that establishes jurisdictions, authorities, and other legal responsibilities between the parties. The agreement includes three attachments: (1) a letter from the U.S. Department of Justice recognizing the enforceability provision of the Tri-Party Agreement, (2) an action plan for carrying out the Tri-Party Agreement, and (3) a mutual funding agreement between DOE and Washington state. The action plan defines how the parties will work together, describes the processes and procedures to be followed, defines the units to be addressed, and provides the enforceable milestones work schedule for conduct of work. (Note that this agreement does not cover all environmental requirements.)

The potential impacts of not performing the activities required for full compliance with the law include: litigation by the regulatory agencies or citizen suits; regulatory orders by the regulatory agencies to either shut down or modify the noncompliant facility or installation; assessment of fines/penalties against DOE and/or its contractors (up to $\$ 25,000 /$ day per each violation); and potential criminal prosecution by the State Attorney General or the U.S. Department of Justice against DOE employees and/or its contractor employees (maximum of $\$ 50,000 / \mathrm{d}$ per violation and/or $5 \mathrm{yr}$ in jail; penalties for knowing endangerment are up to $\$ 1$ million and/or $115 \mathrm{yr}$ in jail). In the event that enforceable milestones identified in the Tri-Party Agreement (Ecology et al. 1989) are not performed, the agreement is enforceable including the assessment of stipulated penalties set forth in the Tri-Party Agreement.

Federal laws and regulations protecting cultural resources require consultation with the Washington State Historic Preservation Office, the President's Advisory Council on Historic Preservation, and Native Americans when projects or activities may adversely affect historic resources or areas of religious significance to Native Americans. 
Consultation and cooperation occurs between the DOE-RL and the Confederated Tribes and Bands of the Yakima Indian Nation, the Confederated Tribes of the Umatilla Reservation, Nez Perce Tribe, and Wanapum Band on issues concerning Native Americans.

In addition an agreement is being negotiated between the Yakima Indian Nation and DOE-RL which provides for their participation in the DOE's Environmental Restoration and Waste Maridgement Programs.

\subsubsection{Environmental Monitoring Activities}

The impacts of Hanford Site operations on the public and the onsite and offsite environment are reported in annual environmental reports. Pacific Northwest Laboratory conducts environmental monitoring at the Hanford Site for the DOE. The environmental report represents a single, comprehensive source of environmental monitoring data collected in the offsite, onsite, and subsurface envircnments. Radiological monitoring results for air, groundwater, surface water, foodstuffs, wildlife, soil, vegetation, and penetrating radiation are reported, as are results from nonradiological monitoring for air quality, Jroundwater, and the Columbia River.

Comprehensive quality assurance programs are maintained to ensure that the data collected are representative of actual concentrations in the environment. These programs cover surface, chemical materials, and groundwater monitoring. Standard quality assurance-quality control techniques are employed in the sample collection, laboratory analysis, data management, and dose calculation activities.

Annuai effluent discharge reports and environmental reports are required by DOE-HQ in DOE Order 5400.1 (DOE 1988a). These reports provide Site-wide overview on the status of the Hanford environment.

Descriptions of environmental monitoring activities at the Hanford Site in 1988 are presented in the following sections.

\subsubsection{Environmental Monitoring Results for 1988.}

3.9.4.1.1 Air. With the exception of $85 \mathrm{Kr}$ and $129 \mathrm{I}$, offsite annual average air concentrations of radionuclides could not be distinguished from background. (Concentrations at some Site boundary locations were numerically higher but not statistically different from distant locations.) The $85 \mathrm{Kr}$ and 129 I concentrations were statistically higher at the Site boundary than at distant locations; however, the average boundary concentrations of these two radionuclides were only $0.1 \%$ and $0.00001 \%$ of the standard, respectively.

The total dose as a result of air emissions is compared to the Clean Air Act dose standards in Section 3.9.4.2. Annual average nitrogen dioxide concentrations at all sampling locations remained well below federal and Washington State ambient air standards.

3.9.4.1.2 Groundwater. Although groundwater at the Hanford Site is not used as a public drinking water supply, except as stated later in this section, all concentrations were compared to EPA drinking water standards and DOE-Derived Concentration Guides. The observed impacts on groundwater during 
1988 were generally similar to those in previous years. Tritium and nitrate are still the most widespread constitlients attributable to Hanford Site operations. These two constituents continue to move slowly with the general groundwater flow and discharge to the Columbia River. years.

Radionuclide distribution and concentrations were similar to previous

Concentrations of gross alpha, gross beta, ${ }^{3} \mathrm{H},{ }^{60} \mathrm{Co},{ }^{90} \mathrm{Sr},{ }^{99} \mathrm{Tc},{ }^{106} \mathrm{Ru}$, $129 \mathrm{I}$, and $137 \mathrm{Cs}$ in the immediate vicinity of operational areas were above the EPA drinking water standards.

Nitrate concentrations at isolated locations in the 100,200 , and 300 Areas, and in the 600 Area near the old Hanford townsite exceeded the drinking water standard.

Chemical monitoring in 1988 showed levels above drinking water standards for chromium beneath 100-D, $-\mathrm{H}$, and $-\mathrm{K}$ Areas; cyanide beneath the 200 East Area; and fluoride, carbon tetrachloride, and trichloroethylene beneath the 200 West Area. None of these locations are used as drinking water sources. Groundwater is used for drinking water at the FFTF, Yakima Barricade Guardhouse, and Hanford Patrol Training Academy. These and al1 other onsite drinking water supplies meet the Washington Drinking Water Standards.

Sampling of new and existing monitoring wells near Richland water supply wells showed that concentrations of regulated groundwater constituents in this area are below drinking water standards, and in general below detection levels.

\subsection{Surface Water. Very low levels of some radionuclides} continued to be detected in samples of Columbia River water collected upstream of the Site at Priest Rapids Dam and downstream of the Site at the Richland Pumphouse during 1988. As in past years, radionuclides consistently observed in measurable quantities in the river water were ${ }^{3} \mathrm{H},{ }^{0} \mathrm{Sr}, 129 \mathrm{I}, 234 \mathrm{U}, 238 \mathrm{U}$, $239 \mathrm{Pu}$, and $240 \mathrm{Pu}$. Concentrations of $234 \mathrm{U}, 238 \mathrm{U}, 239 \mathrm{Pu}$, and $240 \mathrm{Pu}$ were similar in water collected from both locations. Tritium, ${ }^{90} \mathrm{Sr}$, and $129 \mathrm{I}$ concentrations were higher in water collected at the Richland Pumphouse than in water from Priest Rapids Dam. All of the radionuclides observed in Columbia River water during 1988 exist in worldwide fallout as well as in effluents from the Hanford Site's facilities. Tritium and uranium are al so naturally occurring in the environment. Concentrations of radionuclides identified in Columbia River water during 1988 were very low and in all cases well below concentration limits established for drinking water by the EPA and Washington State.

Nonradiological water quality parameters measured upstream and downstream of the Site during 1988 were generally within washington State water qual ity standards. Results observed during 1988 were similar to those reported during previous years and there was no indication during the year of any deterioration of the water quality along this stretch of the Columbia River.

Three onsite ponds were routinely sampled for radiological constituents during 1988. Concentrations of radionuclides observed diring the year in the water collected from these ponds were similar to those observed diring past 
years. The concentration of some radionuclides was higher than those in the Columbia River.

3.9.4.1.4 Food and Farm Products. Low levels of radionuclides attributable to worldwide fallout were observed in most samples of foodstuffs and fa:m products. Foodstuffs irrigated with water taken from the columbia River downstream of the Site were sampled again in 1988 to determine if elevated concentrations of radionuclides were present. All results were similar to the low concentrations found in foodstuffs grown in other adjacent sampling areas, indicating no measurable impact as a result of Hanford Site operations.

3.9.4.1.5 Wildlife. Samples of deer, rabbits, game birds, ducks, and fish were collected where the potential for radionuclide uptake was considered most likely, or at locations nearby where wildlife samples were available. Samples of rabbits collected onsite near operating facilities contained low levels of $90 \mathrm{Sr},{ }^{60} \mathrm{Co},{ }^{137} \mathrm{Cs}, 239 \mathrm{Pu}$, and $240 \mathrm{Pu}$ attributable to Hanford Site operations.

3.9.4.1.6 Soil and Vegetation. Low concentrations of radionuclides were measured in onsite and offsite samples of soil and vegetation during 1988. Levels were similar for perimeter and distant sampling locations. Results from special soil samples collected offsite and downwind of the Hanford Site did not indicate a buildup of radionuclides attributable to Hanford Site operations.

3.9.4.1.7 Penetrating Radiation. Dose rates from external penetrating radiation measured in the vicinity of local residential areas were similar to those observed in previous years, and no contribution from Hanford Site activities could be identified. Measurements made in the vicinity of onsite operating areas and along the Hanford Reach of the Columbia River continued to indicate several locations where dose rates were somewhat higher than those attributable to background sources but still well below applicable DOE radiation protection standards.

3.9.4.2 Potential Radiation Doses from 1988 Hanford Operations. Measured external radiation exposure and calculated radiation doses to the public from 1988 Hanford Site operations were well below applicable regulatory limits. The calculated effective dose potentially received by a maximally exposed individual (i.e., the individual who receives the maximum calculated radiation dose using maximum assumptions for a 11 routes of exposure) was approximately $0.08 \mathrm{mrem}$ for 1988 . This is similar to the dose of $0.05 \mathrm{mrem}$ estimated for 1987. The collective effective dose to the population residing within $80 \mathrm{~km}$ of the site was 5 person-rem, compared to 4 person-rem in 1987. These doses are much less than the doses received from common sources of radiation, such as natural background radiation. They are also much less than the recently recommended DOF radiation protection standards for protection of the public, which are an average of $100 \mathrm{mrem} / \mathrm{yr}$ for prolonged exposure and $500 \mathrm{mrem} / \mathrm{yr}$ for occasional annual exposure to a maximally exposed individual.

\subsection{ASSESSMENT}

This section summarizes the existing conditions--the assets, problems, and needs--of the Tri-Cities region and the Hanford Site. 


\subsubsection{Tri-Cities Region}

Several companies that conducted background research in 1986 as part of their proposals to win the operations and engineer/constructor contracts at the Hanford Site identified the assets and liabilities of the Tri-cities region. The companies interviewed officials from educational institutions, the Tri-city Industrial Development Council (TRIDEC), city and county governments, chambers of commerce, agricultural organizations, banks, port districts, state government, and businesses involved in manufacturing, service, and technology. The findings are outlined in the following sections.

3.10.1.1 Regional Assets. The Tri-Cities' regional assets include the following:

- Large, stable population of scientists and engineers

- Pool of scientific and technological ideas and knowledge

- Outstanding primary and secondary school systems

- University center for extended learning

- Unique DOE facilities

- Adequate 1 and and real estate

- Low taxes

- Good rail, air, water (barge), and highway transportation

- Attractive environment

- Outdoor recreational activities

- Hospitable communities with active advocacy (TRIDEC).

3.10.1.2 Regional Problems. The Tri-Cities' regional liabilities include the following:

- Isolation from major markets

- Isolation from suppliers

- High wages

- No outside awareness of Tri-Cities' assets

- Isolation from major sources of capital

- Intense national competition for high technology industry

- Perception of the region as a federal reserve

- Negative perception of JOE activities on the Hanford Site 


$$
\text { DOE/RL-89-15 }
$$

- Economic base dependence on Congressional appropriations

- Limited state support of business and education.

3.10.1.3 Regional Needs. The Tri-Cities' liabilities were analyzed. The following list outlines the activities required to overcome the liabilities:

- Identify and explore potential markets for Tri-Cities' services and products

- Develop a marketing plan that promotes competitive labor rates

- Promote local image and awareness campaign for the Tri-Cities

- Provide venture capital and assistance in identifying additional funding sources

- Promote and assist the commercialization of federally developed technology through technology transfer

- Develop a plan that will promote the Tri-Cities as an industrially diversified community.

3.10.1.4 Proposed Solutions. Many of these findings confirmed the strengths anc weaknesses recognized earlier by regional officials. Existing and future plans will strive to satisfy these regional needs. The companies that won the operations and engineering contract at the Hanford Site, the Westinghouse Electric Corporation and its subcontractor, the Boeing Company, have promised to invest between $\$ 10$ and $\$ 12$ million in the economy of the Tri-Cities over a 5-yr period. During the first 2 yr of this commitment, the following has been accomplished.

- The Northwest Environmental Center was established in the Tri-Cities. The center operates as a regional branch of the Westinghouse Enyironmental Systems and Services Division and has. quickly gained national recognition within the fields of asbestos technology and environmental engineering. A staff of 20 full-time and 6 part-time positions comprised primarily of environmental engineers, environmental technicians, and laboratory analysts perform structural analysis, environmental surveys, field assessments for asbestos, and laboratory analysis of asbestos samples. Continued increases in manpower are projected based on existing business opportunities.

- A $\$ 400,000$ donation to the TRIDEC for use in supporting TRIDEC's marketing, lobbying, and development efforts.

- The creation of the Westinghouse Tri-Cities Investment Management Council (WTCIMC), whose mission is to assist in the economic development and diversification efforts in the area. Since its creation, the WTCIMC has invested a combined total of approximately $\$ 3$ million in direct support to business efforts and the creation 
of additional educational opportunities in the Tri-Cities. These investments have included:

- A $\$ 300,000$ commitment towards establishing a chair for a Materials Science Program at the WSU Tri-Cities campus

- A $\$ 600,000$ donation of computing hardware to Colunbia Basin College $(C B C)$ to support C $B C$ 's administrative computing needs and provide hands-on training opportunities for students

- Several joint venture and equity position investments in small technological businesses located in the Tri-Cities, that are homogenous with Westinghouse Corporate missions

- Facility and equipment donations to small business startup efforts in the Tri-Cities, that are outside the scope of Westinghouse Corporate missions

- Administrative support to TRIDEC for fund raising and project management efforts.

The economic development proposal of $\mathrm{KEH}$, the engineer/constructor, calls for expanding the opportunities for higher education in the Tri-cities. To date, KEH has accomplished the following towards this goal:

- Provided a $\$ 400,000$ commitment to WSU Tri-Cities, dedicated $1: 0$ establishing an Engineering Management Masters Degree Progran at the WSU Tri-Cities campus

- Committed $\$ 10,000 / y r$ for 5 yr to CBC for use in the development of a multipurpose auditorium facility at that campus

- Committed $\$ 25,000$ to CBC dedicated to establishing Construction Management and Pre-Engineering Programs within CBC's curriculumi

- Committed $\$ 6,000 / y r$ for 5 yr to support the newly established Tri-Cities Public Broadcast Station

- Worked with WSU Tri-Cities to establish a program to provide select $\mathrm{KEH}$ individuals for faculty services to support future engineering programs.

\subsubsection{Hanford Site}

An abundant water supply, a relatively flat and remute 1 and area, an arid climate, and an inexpensive electric power supply are physical attributes that make Hanford a good site for a nuclear complex involved in energy production or national defense activities. Figure 3-33 illustrates the location of Hanford's facilities, and Table 3-14 summarizes some of the characteristics of the workforce and facilities. This section describes the Hanford Site's other assets, challenges, and needs. 
DOE/RL-89-15

Figure 3-33. Hanford Site Capabilities.

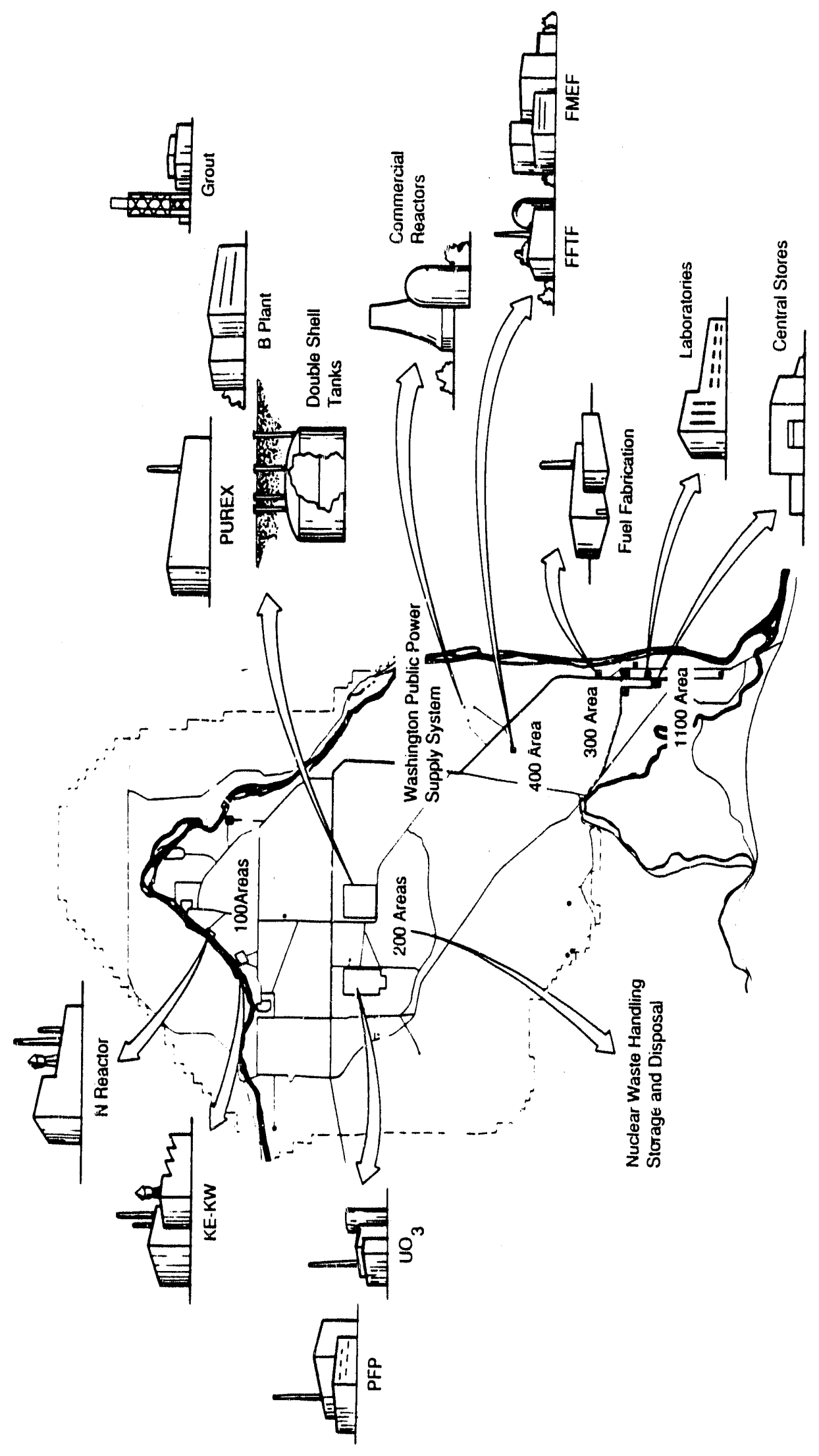


Table 3-14. Hanford Site Characteristics.

Employees: 335 Federal; 12,948 contractor (December 1989 Data) Facilities: 750 major buildings

Land: $560 \mathrm{mi}^{2}$ of semiarid 1 and

Roads: $279 \mathrm{mi}$ of paved and improved roads

Rail: 127 mi of rail, with 114 pieces of rolling stock

Water: 5 major water treatment and distribution systems

Steam: 4 steam plants with a total of 18 boilers

3.10.2.1 Hanford Site Assets. Hanford Site assets include the following examples of expertise and specialized facilities and programs:

- Over 45 yr of experience in nuclear materials production

- Experience with the nuclear materials production fuel cycle-fabrication through storage (with the exception of feed material)

- Comprehensive experience with production, power, and advanced reactor systems

- Multiprogram and engineering development laboratory support

- Extensive breadth of operations, manufacturing/processing, engineering, basic and applied R\&D, and physical and life sciences experience

- "Centers of excellence" for materials, remote/secure handling, high-level waste $(H L W)$, and molecular science

- Extensive experience in environmental technologies and waste management

- Consistently high ratings in the areas of safety, safeguards and security, and environmental management

- Diversity of major project experience (FFTF, BWIP, PUREX) and NEPA expertise

- High-grade services recently upgraded, including inexpensive multiple power supplies and microwave telecommunications system

- Engineering and large project management capabilities located onsite

- Capability of handling and storing large quantities of radioactive materials 
- State and federal cooperative agreements (Tri-Party Agreement) regarding environmental restoration

- Significant numbers of environmental assessments completed

- Expertise in materials research, irradiation testing of fuels and materials, and post-irradiation examination

- Unique neutron energy spectrum

- Relatively large irradiation facilities (N Reactor--4,000 MW; and FFTF- $-400 \mathrm{MW}$ )

- Extensive inventory of nuclear and non-nuclear facilities.

3.10.2.2 Hanford Site Challenges. Hanford Site challenges include overcoming the following:

- Loss of regional credibility as a safe nuclear production site

- Public concern about potential health effects resulting from release of radioactive materials in the early years of nuclear operation

- Large accumulation of radioactive waste from defense activities

- Intense national competition for high technology projects

- Dependence on Congressional appropriations

- Limited regional support for defense production and waste storage.

3.10.2.3 Hanford Site Needs. Attempts to meet the challenges of the Hanford Site will include the following activities:

- Comply with the actions outlined in the Tri-Party Agreement and maintain documented environmental compliance across the Site

- Complete construction of HWVP and Waste Receiving and Processing (WRAP) facility and gain an operational track record for waste management through the GTF, HWVP, and WRAP programs

- Implement improvements in operations and physical features of nuclear material production facilities that will enhance continued and/or future operations

- Establish full utilization of the FFTF and the FMEF

- Revitalize key Site facilities and efficiently use capabilities

- Continue to implement the Hanford Surplus Facilities Program (HSFP) for long-term D\&D of surplus nuclear facilities

- Continue to expand regional information outreach programs designed to educate the public on Hanford Site issues. 


\subsubsection{Hanford Site Opportunities and Constraints}

To conclude this section of the plan and set the stage for future activities at the Hanford Site, regional and site-specific influences on the Hanford Site were mapped out. The opportunities and constraints map (Figure 3-34) illustrates the ability of the Site to accommodate development. Data were collected pertaining to the natural factors at the Site, plant functions, traffic, Site activities, and regional impacts presented earlier in the plan. By mapping these individual factors, overlaying the related elements, and analyzing their planning implications, a clear picture of the development potential at Hanford Site is established.

During the planning process, areas of the Hanford Site were mapped according to their ability to accommodate development. The criteria used for area designations were the relative sensitivity, permanence, and jurisdiction over the resource. After careful evaluation in accordance with these criteria, each area was categorized as developable or developable with constraints.

3.10.3.1 Developable Areas. This category designates areas that would be considered first in an expansion program, and could be used with additional, nonextraordinary effort. In general, costs and/or controls for development would be minimal. The following constraints are placed in this category:

- Existing operating areas

- Existing land use commitments

- Bureau of Sport Fisheries and Wildlife Game Refuge areas

- Washington State Department of Game areas

- Radionuclide uptake study areas

- Mineral rights owned by Big Bend-Alberta Land Company

- ALE Reserve

- Washington State leased area

- Vegetative recovery study areas

- Buffer zones from populated areas and Richland airport

- 500-yr and a PMF plain of the Columbia River

- Subsurface groundwater contamination

- Capable, undetermined, and noncapable faults (including 5-mi buffer zone area)

- Nonradioactive waste disposal sites

- Wildlife habitats 
Figure 3-34. Opportunities and Constraints on the Hanford Site.

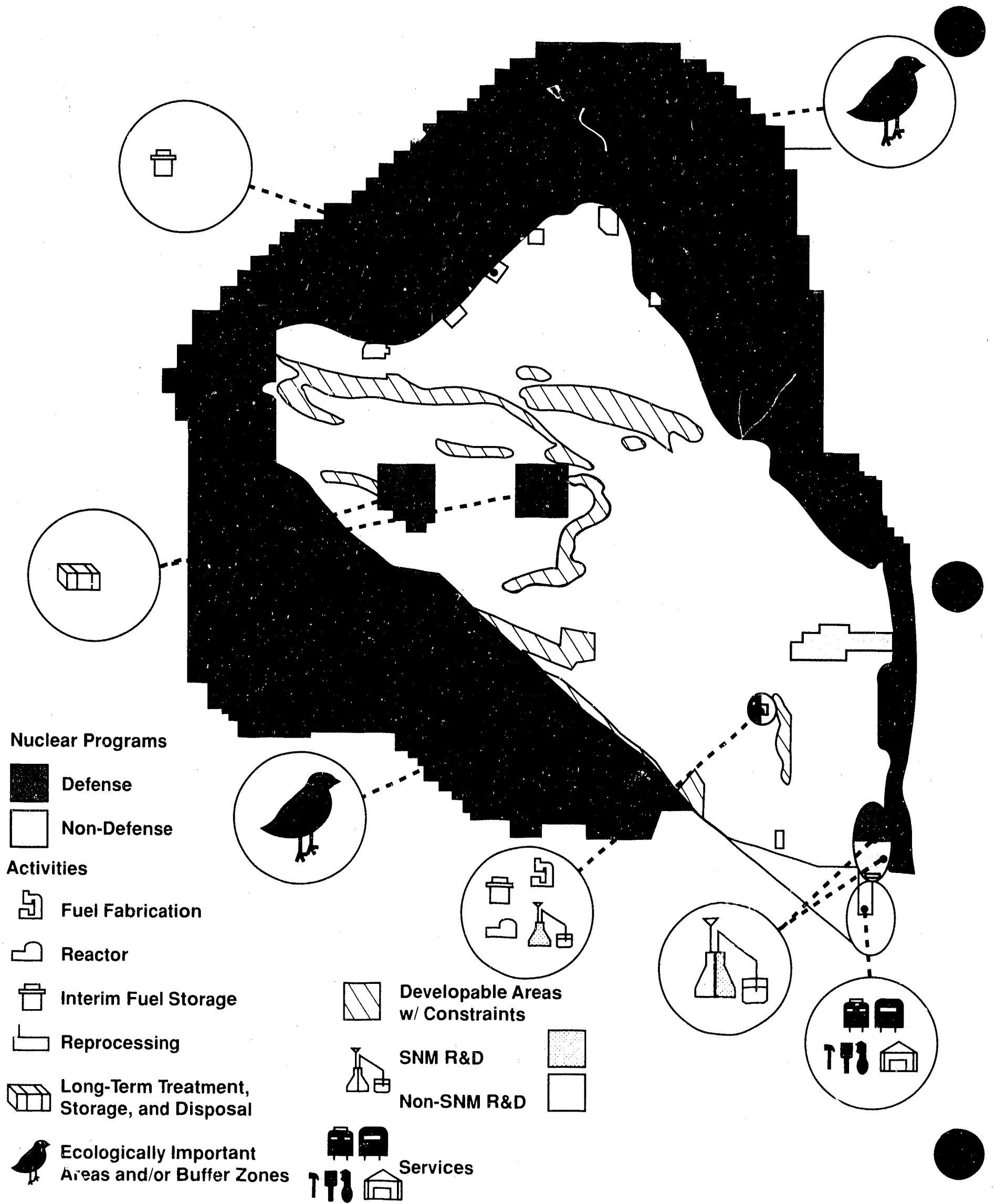


- Spawning areas for commercial or sport fish

- Site utility corridors

- Routine public access areas.

3.10.3.2 Developable Areas With Constraints. The second category, developable areas with constraints, designates areas that would require considerable effort to develop. In most cases, mitigation of the constraints would either be so costly or detrimental to the resource that another site for the proposed development would be considered. In those cases where development is compatible with the resources and structures, or is justified by the magnitude of the project, strict controls would be required to preserve the integrity of the resources. The following physical constraints are placed in this category:

- 100-yr floodplain of the Columbia River

- Major substations

- Historic and national landmarks and other cultural resources

- Critical habitat for threatened or endangered species

- Slopes greater than $6 \%$

- Washington Public Power Supply System leased area

- Land owned by Washington State

- Basalt cutcroppings above water table

- State highway corridors.

\subsection{REFERENCES}

ANSI, 1969, Radiation Symbol, N2.1, American National Standards Institute, New York, New York.

ANSI, 1971, Fissile Materials Symbol, ANSI N12.1, American National Standards Institute, New York, New York.

ANSI/IEEE, 1985, Carrier Sense Multiple Access with Collision Detection, 802.3-85, Institute of Electrical and Electronics Engineers, New Jersey.

BSSA, 1918. "Earthquake Notes," Bulletin of the Seismological Society of America, vol. 8, p. 138 [MF 4660].

Chatters, J. C., 1989, Hanford Cultural Resources Management P7an, PNL-6942, Pacific Northwest Laboratory, Richland, Washington.

DOE, 1981a, Environmental Protection--Safety and Health Prutection Information Reporting Requirements, DOE Order 5484.1, U.S. Department of Energy, Washington, D.C. 
DOE, 1981b, Reactor and Nonreactor Nuclear Facilities Energy Planning Preparedness and Response Program for DOE Operations, DOE Order 5500.3, U.S. Department of Energy, Washington, D.C.

DOE, 1983, Occupational Safety and Health Program for Government-Owned, Contractor-Operated Facilities, DOE Order 5483.1A, U.S. Department of Energy, Washington, D.C.

DOE, 1986a, Environment, Safety and Health Appraisal Program, DOE Order 5482.1B, U.S. Department of Energy, Washington, D.C.

DOE, 1986b, Environment, Safety and Health Program for DOE Operations, DOE Order 5480.1B, U.S. Department of Energy, Washington, D.C.

DOE, 1986c, Safety Analysis and Review System, DOE Order 5481.1B, U.S. Department of Energy, Washington, D.C.

DOE, 1986d, Safety of DOE-Owned NUclear Reactors, DOE Order 5480.6, U.S. Department of Energy, Washington, D.C.

DOE, 1986e, Safety of Nuclear Facilities, DOE Order 5480.5, U.S. Department of Energy, Washington, D.C.

DOE, 1987a, Emergency Preparedness Program and Notification Systems, DOE Order 5500.2 , U.S. Department of Energy, Washington, D.C.

DOE, 1987b, Real Property and Site Development Planning, DOE Order 4300.1B, U.S. Department of Energy, Washington, D.C.

DOE, 1988a, General Environmental Protection Program, DOE Order 5400.1, U.S. Department of Energy, Washington, D.C.

DOE, 1988b, Radiation Protection for Occupational Workers, DOE Order 5480.11, U.S. Department of Energy, Washington, D.C.

DOE-RL, 1987, Real Estate Management, DOE-RL Order 4300.1A, U.S. Department of Energy-Richland Operations Office, Riciland, Washington.

DOE-RL, 1988, Hanford Plant Standards/Specifications, DOE-RL Order 6430.1B, U.S. Department of Energy-Richl and Operations Office, Richland, Washington.

Ecology, et al., 1989, Hanford Federal Facility Agreement and Consent Order, Washington State Department of Ecology, U.S. Environmental Protection Agency, and U.S. Department of Energy, Washington, D.C.

Gutenberg, B. and C. F. Richter, 1965, Seismicity of the Earth and Associated Phenomena, 2nd Edition, Hafner Publishing Company, New York, New York [MF 2202].

ICBO, 1985, 1976, 1960, 1958, 1952, and 1945, Uniform Building Code, International Conference of Building Officials, Whittier, California. 
Malone, S. D., G. H. Rothe, and S. W. Smith, 1975, "Details of Microearthquake Swarms in the Columbia Basin, Washington, "Bulletin of the Seismological Society of America, Vol. 65, pp. 855-864 [MF 2313].

NRC, 1982, Safety Evaluation Report Related to the Operation of WPPSS Nuclear Project No. 2, NUREG-0892 Supplement No. 1, U.S. Nuclear Regulatory Commission, Washington, D.C. [MF 1001].

Rasmussen, N. H., 1967, "Washington State Earthquakes, 1940 through 1965," Seismological Society of America Bulletin, Vol. 57, p. 463-476 [MF 1002].

Relander, C., 1956, Drummers and Dreamers, Caxton Printers, Caldwell, Idaho.

Rice, D. G., 1968a, Archaeological Reconnaissance: Ben Franklin Reservoir Area, Washington State University, Laboratory of Anthropology, Pullman, Washington.

Rice, D. G., 1968b, Archaeological Reconnaissance: Hanford Atomic Works, Washington State University, Laboratory of Anthropology, Pullman, Washington.

Rice, D. G., 1980, Overview of Cultural Resources on the Hanford Reservation in South Central Washington State, report submitted to U.S. Department of Energy-Richland Operations Office, Richland, Washingtion.

Richter, C. F., 1958, "Intensity Scales-Notes and Addendum," Elementary Seismology, Appendix III, pp. 650-652, W. H. Freeman and $\mathrm{Co}_{\text {., Inc., }}$ San Francisco, California.

Rothe, G. H., 1978, Earthquake Swarms in the Columbia River Basalts, Ph.D. dissertation, University of Viashington, Seattle, Washington [MF 0584].

UWGP, 1979, Annual Technical Report 1979 on Earthquake Monitoring of the Hanford Region, Eastern Washington, University of Washington Geophysics Program, Seattle, Washington [MF 1032].

WCC, 1980, Seismological Review of the July 16, 1936, Milton-Freewater Earthquake Source Region, Woodward-Clyde Consultants for Washington Public Power Supply System, Richland, Washington [MF 0609].

WCC, 1982, Review of the Magnitude of the July 16, 1936, Walla Walla Area Earthquake, Woodward-Clyde Consultants for Washington Public Power Supply System, Richland, Washington.

WHC, 1989, Hanford Site Strategic Facilities Plan, DOE/RL 89-01, Westinghouse Hanford Company for the U.S. Department of Energy, Richland, Washington.

WHC, 1990, Hanford Infrastructure PIan, DOE/RL-89-031, Westinghouse Hanford Company for the U.S. Department of Energy, Richland, Washington.

WPPSS, 1981, Final Safety Analysis Report, WPPSS Nuclear Project No. 2, Amendment 18, Washington Public Power Supply System, Richland, Washington [MF 1060]. 
DOE/RL-89-15

Wyss, M., 1979, "Estimating Maximum Expectable Magnitude of Earthquakes from Fault Dimensions," Geology, Vol. 7, pp. 336-340 [MF 4701]. 


$$
\text { DOE/RL-89-15 }
$$

\subsection{PLANNING ANALYSIS}

The Master Plan, presented in Section 5.0 , is a long-range (15- to 20-yr) comprehensive plan for the development and use of the Hanford Site and its facilities. Section 4.0 presents the rationale on which the Master Plan was developed.

Existing conditions affecting the Hanford Site, both regionally and locally, were identified in Sections 2.0 and 3.0 , respectively. The impact of future activities on existing conditions is described in Section 4.0. The missions and programs that are anticipated for the next $20 \mathrm{yr}$, aiong with long-term goals and practical alternatives for meeting those goals, are identified. To evaluate the ability of the Hanford Site to adjust to changing program requirements, the use of facilities and land is projected under three development scenarios: (1) a low-case, (2) a medium-case, and (3) a high-case. These scenarios identify the range of activities believed possible at the Hanford Site during the next $20 \mathrm{yr}$. Given this range of activities, an "ideal" site concept was developed. The Ideal Plan was used to identify the erficient grouping of facilities by function and relationship to others. Compromises were made to the Ideal Plan to develop a mere realistic model, the Master Plan.

This Site Development $P l a n$, which assumes production of $238 \mathrm{Pu} a^{\text {t }}$ FFTF, was written before President sush's budget proposal was issued on January 26 , 1990. The President's proposal did not support production of ${ }^{238} \mathrm{Pu}$ at the FFTF. Other potential missions or funding sources for the FFTF were in the development stages at the time of issuance of this document, and continue to be pursued. Therefore the mission and other support possibilities for FFTF are not definitive. Thus, it was decided to issue this site Development Plan without changing the FFTF assumption. Impacts from deletion of the ${ }^{238}$ Pu mission or other possible FFTF mission changes would be assessed in the next update of this plan.

\subsection{GOALS}

As set forth in the Hanford Site Strategic Plan, the overall goal of the U.S. Department of Energy-Richland Operations Office (DOE-RL) is sustained recognition of the Hanford Site as an acclaimed national asset, for scientific and engineering excellence, environmental responsibility, and reliable and safe products and services. A vital part of this goal is to successfully conduct the environmental, energy, and research and development (R\&D) programs of the DOE in the most safe, secure, environmentally acceptable, and costeffective means possible. The Site Development Plan supports the strategic goals for the Hanford Site by providing a flexible framework for economically and effectively developing the Hanford Site to accommodate a possible range of missions and programs proposed throughout a 20-yr period. Emphasis will continue on the Hanford Site cleanup activities through the implementation of the Environmental Restoration and Waste Management Five-Year Plan, TriParty Agreement (Ecology et al. 1989), and other efforts. The following business goals are consistent with the Hanford Strategic Plan. 


\subsubsection{Business Goals}

The future of the Hanford Site evolves from the following three major business areas:

- Energy--the conceptualization, design, construction, and operation of major energy-related test and evaluation facilities

- Science--the performance of a broad spectrum of R\&D/engineering development activities

- Environment--the activities necessary to meet requirements for environmental restoration and waste management.

These goals are further described below.

4.1.1.1 Energy Development. Business in major test and evaluation facilities (ene:'gy developinent) involves projects on the order of $\$ 10$ to $\$ 100$ million that demonstrate new technology and processes developed at the Hanford Site, at other sites, or in industry.

At present, this business is focused on the energy-related market. Major segments of this market are space, advanced power concepts, isotopes, and civilian nuclear waste.

The market for energy-related technology and projects is dynamic, and it will require that global and national trends are foliciwed closely to ensure that the United States maintains a secure energy. A growing portion of this business will be funded by sources other than DOE.

The following are major business goals in the energy development area:

- Develop a Northwest Space Technology and Energy Park with facility complexes in space power, electric propulsion, weapons testing, and advanced space technology

- Play a major role in developing both fusion and fission power systems, including a multi-mission irradiation test capability [Fast Fiux Test Facility (FFTF)/Fuels and Materials Examination Facility (FMEF)], high-temperature superconductors for electric power [Superconducting Magneti: Energy Storage (SMES)], fusion reactors, and advanced light-water reactors

- Become a center for R\&D and commercialization of radioisotopes, using the FFTF as a flexible producer and other Hanford Site facilities for recovery.

4.1.1.2 Science. R\&D/engineering development are other critical businesses at the Hanford Site and provide key sources of new mission opportunities. Its scope extends from basic sciences to technology demonstration and applications to technology transfer. A strong emphasis on basic science will feed the technology evolution cycle. Establishing centers of excellence with links to universities and industry will ensure scientific credibility and relevance to regional economic development. The market will be as broad 
as the federal missions of the DOE, the U.S. Department of Defense (DOD), the National Aeronautics and Space Administration (NASA), and the

U.S. Environmental Protection Agency (EPA).

The following are major business goals in the area of science:

- Become a robust national center for science and engineering in the Northwest--recognized for quality and focused on areas where unique contributions can be made to solve national problems. These contributions wil? be made through the Molecular Science Research Center (MSRC) and the Environmental anci Molecular Sciences Laboratory (EMSL) as a user facility.

- Perform a major role in health and environmental research for DOE and other government agencies. This effort will include the research $0:$ the Environmental Science Research Center (ESRC), Vertical Integration of Science and Technology Applications (VISTA), Global Environmental Change, and the Northwest Hazardous Waste Research Ceritier.

- Provide quality, cost-effective technologies for improving the Nation's infrastructure and for retiring plutonium from nuclear weapons. These technologies apply to modernizing DOD manufacturing plants and systems, facility infrastructures, and the DOE complex.

- Beconie a national asset for developing and demonstrating a variety of energy supply/end-use technologies. These +ochnologies, which will enhance the international competitiveness of United States industrial firms and contribute to industrial diversification in the Tri-Cities, include alternative transportation fuels, clean coal processes, municipal solid waste treatment, and energyefficient buildings systems.

4.1.1.3 Environment. The Hanford Site business in environment will focus on the cleanup and managenis? other DOE and federal sites. This Site intends to become acclaimed as the DOE "Flagship" for environmental restoration and waste management through cleanup and technology davelopment at Hanford and other sites. Key objectives include lower cost, timely implementation, and responsible compliance with regulations. The scope of work will include plarining and strat $7 y$ formulation, the National Environmental Policy Act (NEPA) and : julatory compliance, site characterization, innovative technology and processes, and cost-effective remediation.

Major goals in the environment area include the following:

- Continue in full compliance with the Tri-Party Aareement through cleanup and restoration of the Hanford Site's environmental units that meet the requirements of modern regulatory standards, with productivity that establishes new levels of competonce

- Successfully desigr, construct, and operate the Hanford Waste Vitrification Plant (HWVP) to dispose of previously generated high-level waste (HLW) 
- Create inncvative and effective technology that offers an array of options for cleanup of sites in a timely, cost-effective, environmentally safe manner

- Reduce the generation of hazardous wastes in ongoing and future Hanford Site missions through the development and validation of new technology and processes

- Successfully complete specific tasks and full-range turnkey projects for other DOE and federal sites based on experience at the Hanford Site

- Pursue opportunities for enhancing private sector participation in remediation and waste management activities

- Transfer technology and experience from the Hanford Site cleanup and knowledge gained at the MSRC to solve environinental problems at other sites.

\subsubsection{Land Use}

Effective use of the Hanford Site land is centered on the following:

- Continue to plan and allocate suitable areas for future program and facility needs

- Clean up, stabilize, or restore land for which no further use is foreseen

- Restrict processing and storage of radioactive and mixed waste to the 200 and 400 Areas

- Maintain the Arid Lands Ecology Reserve (ALE), preserve existing archaeological sites, and continue existing leases and permits (i.e., Washington Public Power Supply System, U.S. Ecology, U.S. Fish and Wildlife Service, and Washington State Department of Wildlife)

- Establish the 300 Area as the primary site of the multiprogram R\&D laboratory at the Hanford Site.

\subsubsection{Facilities/Infrastructure Systems}

The planning and use of facilities/infrastructure systems are based on the following:

- Renovate existing facilities or construct new facilities based on project life, cost effectiveness, and functional requirements

- Site new facilities based on functional requirements, type of occupancy, utility availability, safety and environmental requirements, and relationship to existing facilities 
DOE/RL-89-15

- Minimize the use of trailers, temporary, substandard, and leased facilities

- Continue to implement the Hanford Surplus Facilities Program (HSFP) long-term deactivation and decommissioning (D\&D) program

- Meet the Generar Services Administration (GSA) space use standard for office space

- Consolidate, convert, mothbal1, or dispose of marginal, deteriorated, and underutilized facilities

- Investigate the use of private funding to design and construct facilities and to procure private sector technology, services, and expertise.

\subsection{ASSUMPTIONS AND FUTURE NEEDS}

During the next $20 \mathrm{yr}$, many events couid significantly affect Hanford Site operations as well as the previously stated goals. This section describes the assumptions that were used to reduce the number of such uncertainties and to better define the types of missions, programs, and activities projected to occur at the Hanford Site during the next $20 \mathrm{yr}$.

The following key assumptions were used to develop long-range (20-yr) mission projections and assess future needs for the Hanford Site.

- The Hanford Site shall remain a federally controlled site within the current borders during the next decade.

- The Hanford Site will continue as a prime or contingency DOE site for production of special nuclear material (SNM).

- The Hanford Site will be the "Flagship" DOE site for the development and demonstration of technologies through cleanup and technology development, for disposing of nuclear and other wastes.

- The Hanford Site shall build on existing base strengths. These include advanced reactor development, isotope production, energy technologies, SNM production, basic science, molecular science, environmental research, space technologies, and nuclear and hazardous waste management.

- The Hanford Site shall pursue programmatic diversification that is compatible with existing missions.

- Inactive Hanford Site lands normally will not be open for use by other non-DOE, public or private businesses until D\&D and site cleanup are complete. This is also due to the desire to maintain ecologically undisturbed areas. Sufficient land reserves are available for anticipated future programmatic. use and new missions. Non-DOE activities that are authorized shall be compatible with DOE-RL land-use policy and DOE science-, energy-, environment-, or defense-related missions. 
- The Hanford Site will make the science and technology capabilities of the Pacific Northwest Laboratory (PNL) available to foster cooperative laboratory R\&D efforts with industrial and educational institutions. Appropriate technologies will bs transferred to U.S. industrial firms to enhance their economic competitiveness in global markets.

- The DOE will support the development of a science and engineering park.

- Management of risks associated with civilian power production and defense nuclear materials production will continue as a major public issue. Public concern will continue to focus on environmental, health, and safety impacts of potentially hazardous pollutants and wastes from civilian energy production, general industry, and defense nuclear materials production.

\subsection{PROJECTED SCENARIOS OF ACTIVITY AT THE HANFORD SITE}

"Forecasting is difficult, especially if it involves the future," is an amusing but realistic quote. The many changes the Hanford Site has experienced in its 45 yr of operation have not always been easy to predict. The land changed from a sparsely populated, rural area to a large technological center. Trends in programs changed from an emphasis on nuclear materials production programs to energy research, back to nuclear materials production, then to energy research, environmental restoration, and waste management. The Hanford Site management has changed from the U.S. Army Corps of Engineers to the Atomic Energy Commission (AEC) to the Energy Research and Development Administration (ERDA) to the DOE.

Many successful programs have been accomplished at the Hanford Site, including the following recent examples:

- Implementation of the Tri-Party Agreement

- Construction and operation of the FFTF

- Restart of the Plutonium-Uranium Extraction (PUREX) facility

- Stabilization and isolation of single-shell tanks

- Cleanup and stabilization of contaminated surface areas (totaling about 800 acres) throughout the Hanford Site

- Startup of the Grout Treatment Facility (GTF), which converts lowlevel liquid waste to a stable grout for shallow burial in concrete vaults

- Developments like the liquid-fed ceramic melter, which converts HLW to a glass-like form for disposal.

The Hanford Site programs have also faced uncertainties. A major uncertainty at the Hanford Site was the closure of eight production reactors by the early 1970's. An N Reactor upgrade had been previously planned to 
extend its lifespan into the next century. The April 1986 accident at Chernobyl was a catalyst for technical comparisons between $N$ Reactor and the Chernobyl reactor. Subsequent studies of $N$ Reactor confirmed that many different design and operating procedures exist at $\mathbf{N}$ Reactor that preclude a Chernobyl-type accident from occurring. The studies also suggested an acceleration of previously identified safety enhancements. In January 1987 , the reactor was put in a "stand-down" mode to undergo safety enhancement upgrades costing $\$ 70$ million. In February 1988, the $\mathbf{N}$ Reactor was ordered placed in cold standby, with cold standby to be achieved by October 1, 1989 . Then in October 1989, the $N$ Reactor was ordered placed in dry standby with dry standby status to be achieved by October 1990. The reactor currently is being maintained in a manner consistent with guidance from DOE-RL.

Other programs have also been affected by uncertainties. Between 1980 and 1987, programmatic support for the FMEF had steadily declined. The facility was originally designed for post-irradiation examination of fuels and materials from the liquid metal reactor (LMR) program. Subsequently, the post-irradiation examination mission was dropped. At the same time, construction of the FMEF was stopped at approximately $90 \%$ completion. (Construction is complete except for the remaining work on the hot cells.) The FMEF is built to present-day plutonium facility criteria with state-ofthe-art safeguards and security features. The facility also contains the Secured Automated Fabrication Line, which was developed and installed (approximately $98 \%$ complete) before the decision was made to not use mixedoxide fuel for the FFTF at the Hanford Site. The Secured Automated Fabrication Line is presently in a layup condition. It could be used to manufacture fuel for the Washington Nuclear Plant-One (WNP-1) reactor if WNP-1 were to be converted to a DOE production facility. It could al so be used to manufacture fuel for some of the advanced reactor types to be considered for a new DOE production reactor. The Radioisotope Power Systems Facility (RPSF) project is underway to equip part of the FMEF to produce radioisotope thermoelectric generators (RTG). The FMEF is also being considered for processing of fuel and targets for $238 \mathrm{Pu}$ production.

Three scenarios were identified to develop a flexible site plan to address the future needs at the Hanford Site. These scenarios, which comprise the range of activities believed to be possible at the Hanford Site during the next $20 \mathrm{yr}$, include a low-case, a medium-case, and a high-case. As funding and program emphases change with time, the real development at the Hanford Site will probably not be strictly a low-, medium-, or high-case scenario, but more likely some combination of the three. For current planning purposes, the medium-case represents the most likely scenario.

These three scenarios are based on the goals and assumptions stated earlier. In the following sections, each scenario is described in terms of its major program activities. Important characteristics associated with each scenario are also identified.

The low-case scenario encompasses termination of the plutonium production mission after the existing supply of $N$ Reactor irradiated fuel is processed, little change to R\&D growth trends, completion of Hanford Environmental Compliance (HEC) projects and Tri-Party Agreement objectives, and continuation of existing engineering development activities in the areas of space isotope production and space power systems. 
The medium-case scenario builds on the low-case and al so includes the processing of offsite scrap at the Plutonium Finishing Plant (PFP) until a replacement facility is provided. The R\&D/engineering development programs expand in the areas of environment, science, energy (including conservation and renewable), national defense, and space fabrics, isotopes, and power systems. Environmental restoration continues at an accelerated rate.

The high-case scenario builds on the medium-case. It also includes establishment of the Hanford Site as a major site for production of SNM. The R\&D programs expand with establishment of a regional science and engineering park. Engineering Development programs expand further with the implementation of systems testing and demonstration programs.

The information used to generate these scenarios comes from a variety of sources, including recent strategic planning data, previous studies, and newly generated estimates. Many of these assessments are preliminary. Some of the quantitative assessments are estimated within a rough order of magnitude and will require additional refinement in future updates of the site Development Plan.

Many of the programs listed as part of the scenarios are new projects that are required to accomplish the goals stated earlier. Major new projects will be discussed in greater detail in Section 4.4.

\subsubsection{Low-Case Scenario}

Important characteristics of the low-case scenario include the following:

- Plutonium production activities are terminated and facilities used to support that mission are decontaminated and decormissioned

- The R\&D contractor will continue at its current growth trend through 1995 and is unaffected by the completion of plutonium production missions

- Waste management and environmental restoration activities increase in this and all scenarios

- Operation of the FFTF is included as the cornerstone of nuclear development for the DOE

- Activities will be initiated and implemented to ensure compliance with the terms and objectives of the Tri-Party Agreement (Ecology et al. 1989).

Nuclear materials production activities would include the following:

- Close N Reactor

- Stop production at PUREX after 1996, close PUREX after deactivation/cleanup

- Stop uranium trioxide $\left(\mathrm{UO}_{3}\right)$ production, close the $\mathrm{UO}_{3}$ Plant after deactivation/cleanup 
- Stop plutonium scrap recovery at the PFP

- Stop the Plutonium Reclamation Facility (PRF) after PFP deactivation/cleanup, close the PFP.

Activities involving transuranic waste (TRU) would include the following:

- Construct the Waste Receiving and Processing Facility (WRAP) for stored and retrievable TRU

- Provide final disposition of stored and retrievable TRU

- Provide final disposition of cribs and buried TRU

- Stabilize surface sites

- Continue surveillance and monitoring.

Activities involving HLW would include the following:

- Construct the HWVP

- Upgrade B PTant to support HWVP

- Provide final disposition of the Waste Encapsulation and Storage Facility (WESF) capsules and close the WESF

- Provide final disposition of single- and double-shell tank wastes

- Isolate and stabilize tank farms

- Continue surveillance and monitoring.

Activities involving low-level waste (LLW) would include the following:

- Operate the GTF and then close it within the planning timeframe

- Construct and operate the Waste Sampling and Characterization Facility

- Continue burial ground operations

- Provide in situ stabilization of all sites

- Continue surveillance and monitoring.

Hanford Surplus Facilities Program activities would include the following:

- Continue surveillance and maintenance of facilities on current HSFP list

- Continue decommissioning of current HSFP facilities 
- Add the following facilities to HSFP 1ist: $\mathrm{N}$ Reactor, PUREX, $\mathrm{UO}_{3}$, the PFP, the 209-E Critical Mass Laboratory, various single- and double-shell tanks, waste transfer lines, other selected tank farm facilities, the 308 Fuels Development Laboratory including the TRIGA reactor, and some 300 Area hot laboratories.

Activities involving hazardous waste would include the following:

- Continue to operate Building 616, the Hazardous Waste Storage Facility

- Send hazardous waste offsite.

R\&D/engineering development activities would include the following:

- Continue FFTF/FMEF operation on $238 \mathrm{Pu}$ and other isotope production, which includes testing in support of space power

- Determine final disposition of stored and retrievable TRU, TRU in cribs, and buried single- and double-shell tank wastes,

WESF capsules, and empty tanks

- Maintain basic science and energy programs

- Maintain space nuclear power technology development

- Continue environmental surveillance (e.g., ALE, study areas) in accordance with regulatory requirements

- Continue Strategic Defense Initiative (SDI) (nonreactor) technology development

- Continue the growth of the ESRC

- Continue the growth of the MSRC

- Construct the EMSL

- Fabricate isotope targets and FFTF fuel in the FMEF

- Develop and operate the RPSF in the FMEF

- Maintain technology transfer activities

- Promote user facility development and participation

- Continue conservation and renewable energy program activities

- Promote educational/industry collaborations

- Become a significant contributor in the Technology Development program for site cleanup. 


\subsubsection{Medium-Case Scenario}

The important characteristics of the medium-case scenario include the following:

- Added missions for PFP will extend its operating life to later in the planning period; plutonium production activities are then terminated and the facilities used to suppori that mission are decontaminated and decommissioned

- R\&D activities increase in the areas of environment, science, energy (including conservation and renewable), and national defense

- Space power and SDI programs experience moderate growth

- Hanford continues as a contingency site for SNM production

- Activities will be initiated and implemented to ensure compliance with the terms and objectives of the Tri-Party Agreement.

Nuclear materials production activities would include the following:

* Continue WNP-1 as a contingency option for tritium production*

* Maintain $N$ Reactor in dry standby, as a contingency, until the new production reactor comes on line*

- Stop production at PUREX after 1996 and close PUREX after deactivation/cleanup

* Continue to operate PFP to process PUREX nitrate and offsite scrap for an interim period until capability can be transferred to a facility (e.g., FMEF or offsite) meeting all contemporary design criteria.*

Activities involving TRU would include the following:

- Construct the WRAP for stored and retrievable TRU

- Provide final disposition of stored and retrievable TRU

- Provide final disposition of cribs and buried TRU

- Stabilize surface sites

- Continue surveillance and monitoring.

Activities involving HLW would include the following:

* Construct the HWVP* and vitrify newly produced HLW*

*Designates change from low-case scenario. 
DOE/RL-89-15

- Upgrade B Plant to support the HWVP

- Provide final disposition of WESF capsules and close the WESF

- Provide final disposition of single- and double-shell tank wastes

- Isolate and stabilize the tank farms

- Continue surveillance and monitoring.

Activities involving LLW would include the following:

- Operate the GTF throughout the planning timeframe

- Construct and operate the Waste Sampling and Characterization Facility

* Construct new solid-waste burial grounds*

- Continue burial ground operations

- Provide in situ stabilization of all sites

- Continue surveillance and monitoring.

The HSFP activities would include the following:

- Continue surveillance and maintenance of facilities on current HSFP list

- Continue decommissioning of current HSFP facilities

* Add the following facilities to HSFP lists: N Reactor, PUREX, $\mathrm{UO}_{3}$, the *WESF, the *PFP, various single- and double-shell tanks, other tank farm facilities, waste transfer lines, the 209-E Critical Mass Laboratory, the 308 Fuels Development Laboratory including the TRIGA Reactor, and some 300 Area hot laboratories* (of these, $N$ Reactor, the PFP, and the WESF will be added later in the planning timeframe).*

Activities involving hazardous waste would include the following:

- Continue to operate Building 616, the Hazardous Waste Storage Facility

* Open new hazardous waste burial grounds at the Hanford Site*

* Construct and operate a Hazardous Waste Treatment Facility in the 300 Area.*

*Designates change from low-case scenario. 
R\&D/engineering development activities would incl:ade the following:

- Use the FFTF to produce ${ }^{238} \mathrm{Pu}$ and other isotopes and perform irradiation testing

- Determine final disposition of stored and retrievable TRU, TRU in cribs and buried, single- and double-shell tank wastes, WESF capsules, and empty tanks

* Expand basic science and energy programs*

* Build and operate SP-100 Ground Engineering Systems (GES)*

* *Expand* SDI technology development program, *and be the test site for several concepts*

* Move environmentally sensitive facilities out of the 300 Area*

- Continue environmental surveillance (e.g., ALE, study areas) in accordance with regulatory requirements

* Operate a minimal fusion program*

- Continue growth of the ESRC

- Continue growth of the MSRC

- Construct the EMSL

* Develop new processes for improved plutonium scrap recovery in the PFP*

* Develop new processes for tritium production and separation*

- Develop and operate the RPSF in the FMEF

- Fabricate isotope targets and FFTF fuel in the FMEF

* Expand conservation and renewable energy program activity and assume a leadership role in cooperative Northwest energy conservation initatives*

* Construct and operate SMES/ETM*

* *Expand* technology transfer activities

- Promote user facility development and participation

- Promote education/industry collaborations

- Become a significant contributor in the Technology Development program for site cleanup

*Designates change from low-case scenario. 
* Construct and operate the Special Analysis Facility*

* Construct a major beaming facility for the Space Power Generation Distribution program*

* Expand space fabrics activities.*

\subsubsection{High-Case Scenario} following.

Important characteristics of the high-case scenario include the

- The Hanford Site will have an expanding role in the U.S. nuclear materials production mission and nuclear energy programs. Additional major initiatives are growth in environmental and basic sciences.

- Hanford Site R\&D activities will expand in the areas of science and energy.

- Space power and SDI programs will experience accelerated growth.

- Activities will be initiated and implemented to ensure compliance with the terms and objectives of the Tri-Party Agreement (Ecology et al. 1989).

- When facilities are upgraded and then closed, upgrading is done early in the planning timeframe with closure occurring several years later.

Nuclear materials production activities would include the following:

** Use the FFTF to produce specialty isotopes**

** Operate $N$ Reactor for tritium production until new production facility is on line**

** Complete WNP-1 or build new production reactor or accelerator and support facilities for tritium production**

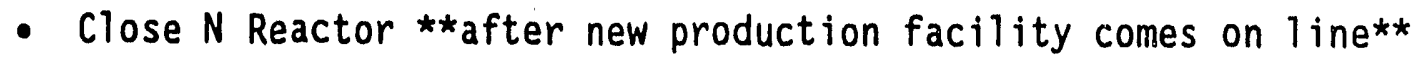

- Stop production ac PUREX after 1995--close PUREX after deactivation/cleanup

- Continue to operate the PFP to process PUREX nitrate and offsite scrap for an interim period until capability can be transferred to a facility (e.g., FMEF or offsite) meeting all contemporary design criteria

** Construct new analytical facilities to support expanded missions**

\footnotetext{
*Designates change from low-case scenario.

**Designates change from medium-case scenario.
} 
DOE/RL-89-15

** Perform diversified role in plutonium, scrap processing, and handling**

** Construct facilities for added production-related missions**

** Construct and operate weapons return facility.**

Activities involving TRU would include the following:

- Construct WRAP facilities for stored and retrievable TRU

- Provide final disposition of stored and retrievable TRU

- Provide final disposition of cribs and buried TRU

- Stabilize surface sites

- Continue surveillance and monitoring.

Activities involving HLW would include the following:

- Construct the HWVP and vitrify newly produced HLW

- Upgrade B Plant **(near term)** to support the HWVP

- Provide final disposition of WESF capsules and close the WESF

** Expand the HWVP to pretreat waste, then close B Plant**

- Provide final disposition of single- and double-shell tank wastes

- Isolate and stabilize the tank farms

- Continue surveillance and monitoring.

Activities involving LLW would include the following:

** Operate GTF **on accelerated schedule**

- Construct and operate the Waste Sampling and Characterization Facility

- Construct new solid-waste burial grounds

- Continue burial ground operations

- Provide in situ stabilization of all sites

- Continue surveillance and monitoring.

**Designates change from medium-case scenario. 
The HSFP activities would include the following:

- Continue surveillance and maintenance of facilities on current HSFP list

- Continue decommissioning of current HSFP facilities

** Add the following facilities to HSFP list: if Reactor, PUREX, $\mathrm{UO}_{3}$, the PFP, the WESF, $\star \star B B P$ Plant, 222-S**, var us single- and doubleshell tanks, other tank farm facilities, te transfer lines, the 209-E Critical Mass Laboratory, 308 TRIGA Reactor, and some 300 Area hot laboratories. Of these, $N$ Reactor, the PFP, the WESF, $* * B$ Plant, and $222-S^{* *}$ will be added later in the planning timeframe:

Activities involving hazardous wastes would inciude the following:

- Continue to operate Building 616, the Hazardous Waste Storage Facility

- Open new hazardous waste burial grounds at the Hanford Site

- Construct and operate a Hazardous Waste Treatment Facility in the 300 Area.

R\&D/engineering development activities would include the following:

** Produce ${ }^{238} \mathrm{Pu}$ at the FFTF and **add power generation capability and expand multi-mission scope ${ }^{\star \star}$

** Construct the EMSL and **expand the ESRC and MSRC**

- Expand conservation and renewable energy program activity and assume a leadership role in cooperative Northwest energy conservation initiatives

- Develop new processes for improved plutonium scrap recovery in the PFP

- Develop new processes for tritium production and separation

- Build and operate the RPSF in the FMEF

- Fabricate isotope targets and FFTF fuel in the FMEF

- Determine final disposition of stored and retrievable TRU, TRU in cribs, and buried single- and double-shel, tank wastes, WESF capsules, and empty tanks

** Conduct new production reactor and support facilities research**

**Designates change from medium-case scenario. 
* Develop new shemical processes for Hanford Site production operations**

** Process FFTF fuel in the FMEF**

** Use linear accelerator for medical and applied research applications**

- Expand basic science and energy programs

** Operate SP-100 GES, **conduct testing of advanced space reactors**

** **Diversify** and expand SDI (nonreactor) advanced development program **engineering test underway**

- Move environmentally sensitive facilities out of 300 Area

** Become test site for major fusion program facility**

- Construct and operate the SMES/ETM

- Expand technology transfer activities

- Promote user facility cievelopment and participation

- Promote educational/industry collaborations

- Become a significant contributor in the Technology Development program for site cleanup

- Construct and operate the Special Anarysis Facility

* Construct and operate sevelal space power generation distribution facilities**

** Operate space fabrics prototype and production facilities**

** Operate a High-Temperature Superconductivity Power Applications Center including transmission and distribution testing. **

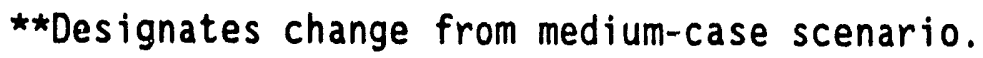


DOE/RL-89-15

\subsection{EVALUATION OF SCENARIO IMPACTS}

This section evaluates the estimated impacts of the low-, medium-, and high-case scenarios on Hanford Site operations. Needs associated with each of the scenarios are also discussed. Figure 4-1 illustrates the general location of the activities as they exist today. This figure can be compared to following figures, which illustrate each scenario, to understand the changes that will occur in each case. No new land should be required in these scenarios. In each, a major effort would probabily be undertaken to consolidate, convert, mothball, or dispose of major unused and underutilized facilities.

\subsubsection{Low-Case Scenario}

Three major components of the low-case scenario are discussed: nuclear materials production, waste management and environmental restoration, and R\&D.

4.4.1.1 Nuclear Materials Production. This scenario assumes an orderly and time-phased closure of all defense production facilities at the Hanford Site. Key milestones in this hypothetical process are as follows.

- The decision is made to terminate nuclear materials production at the Hanford Site. No other missions are assumed to be affected.

- In 1990, $\mathrm{N}$ Reactor status changes from dr:' standby to closure. Layoffs and cleanup begin at the $N$ Reactor.

- In 1993, $N$ Reactor cleanup is completed to a monitoring and surveillance level. About 60 personnel remain indefinitely to perform maintenance and surveillance activities at the facility.

- From 1990 to 1996, PUREX, the UO $\mathrm{O}_{3}$ Plant, ard the PFP complete processing of existing inventories of irradiated fuel, including Pressurized Water Reactor (PWR) Core 2 fuel and FFTF fuel, and plutonium scrap. Each facility is then cleaned up to a monitoring and surveillance level. Layoffs continue during phaseout of operations.

- In 1999, PUREX, $\mathrm{UO}_{3} \mathrm{Pl}$ ant, and PFP cleanup activities are complete. About 250 personnel remain indefinitely to perform maintenance and surveillance activities at these facilities.

This scenario assumes no spillover effects on other programs at the Hanford Site, i.e., (1) that the loss of nuclear materials production is managed so that there are no higher fixcd costs for remaining missions, and (2) that there is no loss of support for these other missions. These assumptions are questionable; however, it is extremely difficult to quantify the probable spillover effects. Consequently, the closure scenario, which does not include spillover effects, is less severe than what might happen.

Figure 4-2 characterizes and locates the activity centers associated with the low-case scenario at the Hanford Site. 
Figure 4-1. Existing Activity Centers on the Hanford Site.

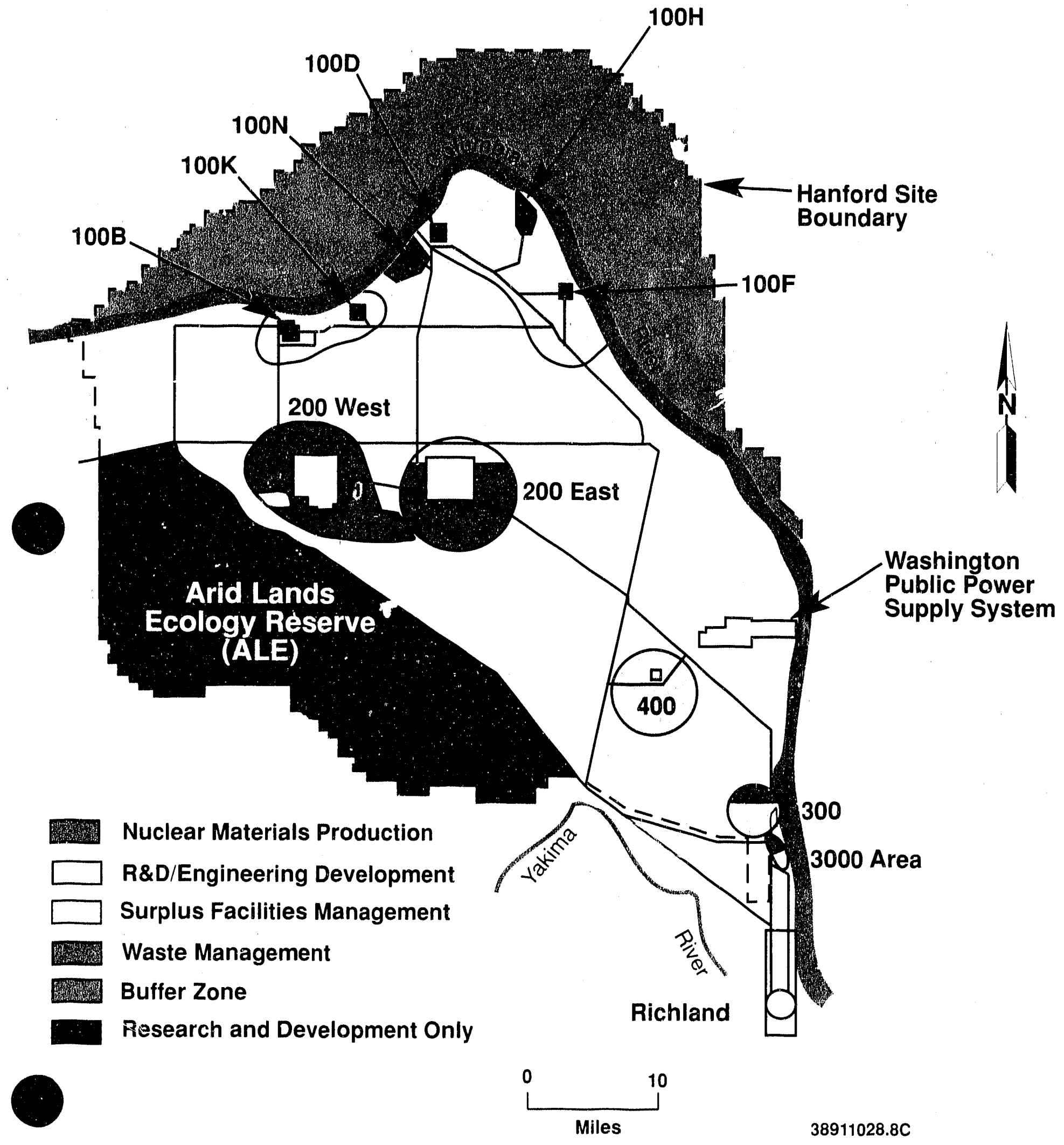




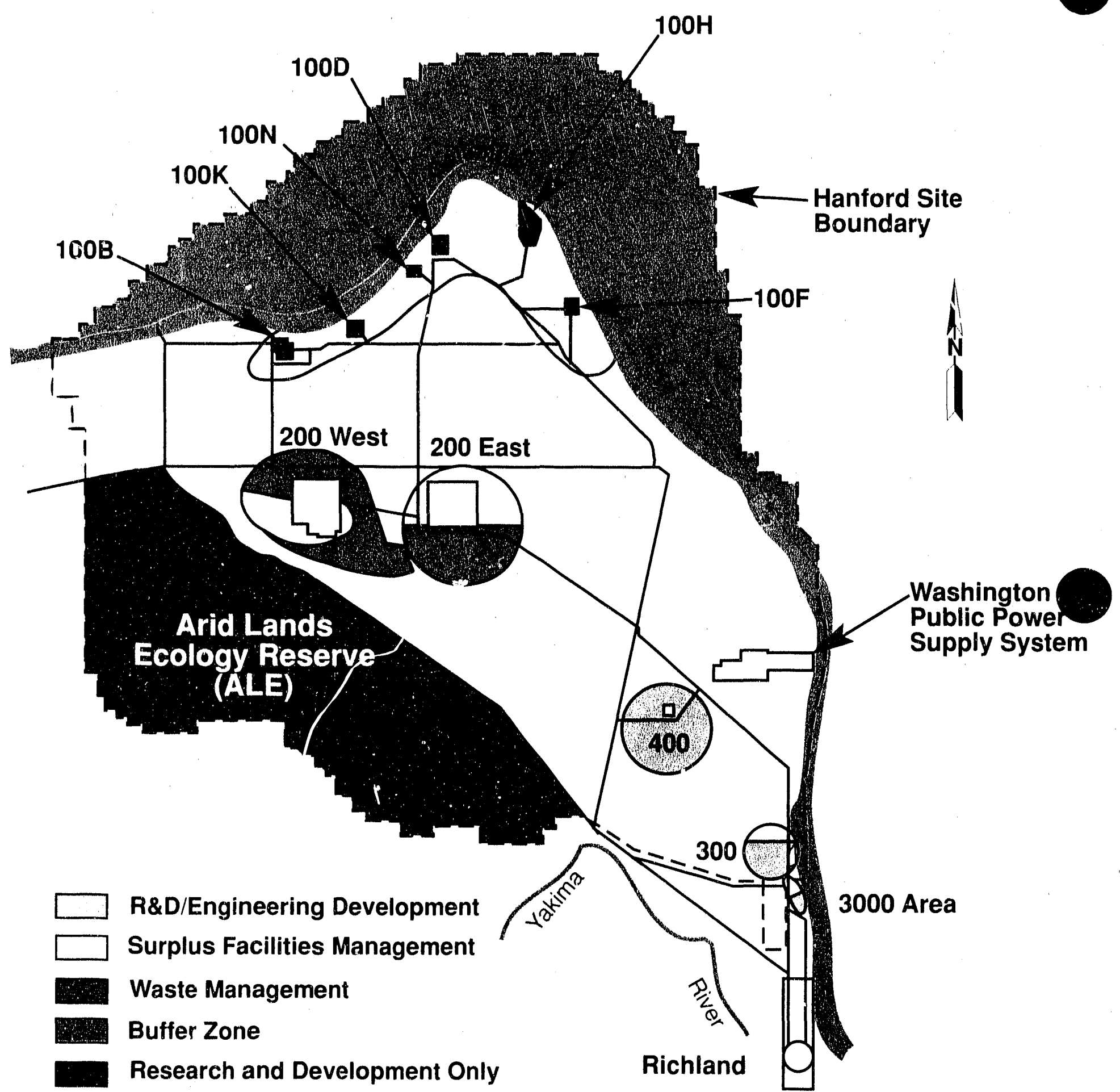

Note: No nuclear materials production in low-case scenario.

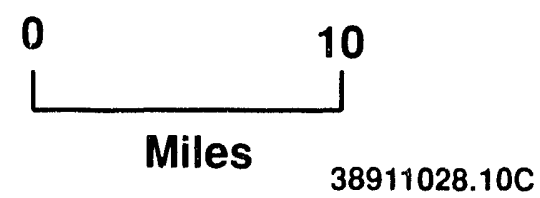


4.4.1.2 Waste Management and Environmental Restoraition. Waste management and environmental restoration activities are increasing and expected \pm 0 continue increasing in all three scenarios. This will minimize social, economic, and environmental risks. A major emphasis associated with this scenario is the control and disposal of radioactive, hazardous chemical, and mixed wastes at the Hanford Site.

In 1983, the DOE initiated work on an Environmental Impact Statement (EIS) that would provide the basis for decisions concerning disposal of the Hanford Site's defense waste. The document was issued in draft form for public review in April 1986. Comments from the review were incorporated into a final document that was issued in December 1987 (DOE 1987). The document recommends that the DOE begin now to dispose of high-level liquid wastes from the double-shell tanks.

The EIS recommendation calls for disposal of these wastes by vitrification into borosilicate glass (similar to obsidian) and storage of this glass in a geologic repository. Cesium-137 and $90 \mathrm{Sr}$, two isotopes currently separated from high-level liquid wastes and now encapsulated and stored temporarily, would also be disposed of in a repository.

In addition, the EIS recommends that the low-level component of the liquid wastes be made into a cement-like material called grout and disposed of in underground vaults. Single-shell tank wastes (now in semi-solid form) and other buried wastes from earlier Hanford Site operations will either be retrieved and disposed in a geologic repository, or stabilized and disposed in situ.

The EIS recommends all retrievably stored and newly generated TRU be examined, processed, packaged, and certified for shipment for repository disposal.

The EIS identifies three new facilities.

1. Hanford Waste Vitrification Plant (Figure 4-3). This facility will receive the high-level liquid waste that has been pretreated in B Plant, and vitrify the waste into borosilicate glass using a liquid-fed ceramic melter. The vitrified glass product would be stored in canisters for eventual disposal in an underground HLW repository. This facility is expected to add 700 to 1,000 people to the Hanford Site workforce during its 10-yr construction and maintain a stafi of 200 to 300 when operational.

2. Grout Treatment Facility. This facility was constructed and used to process 1 million gal of low-level liquid waste inta a cement-like mixture for disposal in a shallow land vault. Beginning in 1991, it is planned to use this facility to process low-level liquid mixed waste into the same type of mixture for disposal in additional shallow lard vaults.

3. Waste Receiving and Processing Facility. This facility will sort, shred, compact, grout, and certify all retrievably stored and newly generated TRU for shipment to the Waste Isolation Pilot Plant. 
DOE /RL $-89-15$

Figure 4-3. Conceptual Drawing of the Hanford Waste Vitrification Plant.
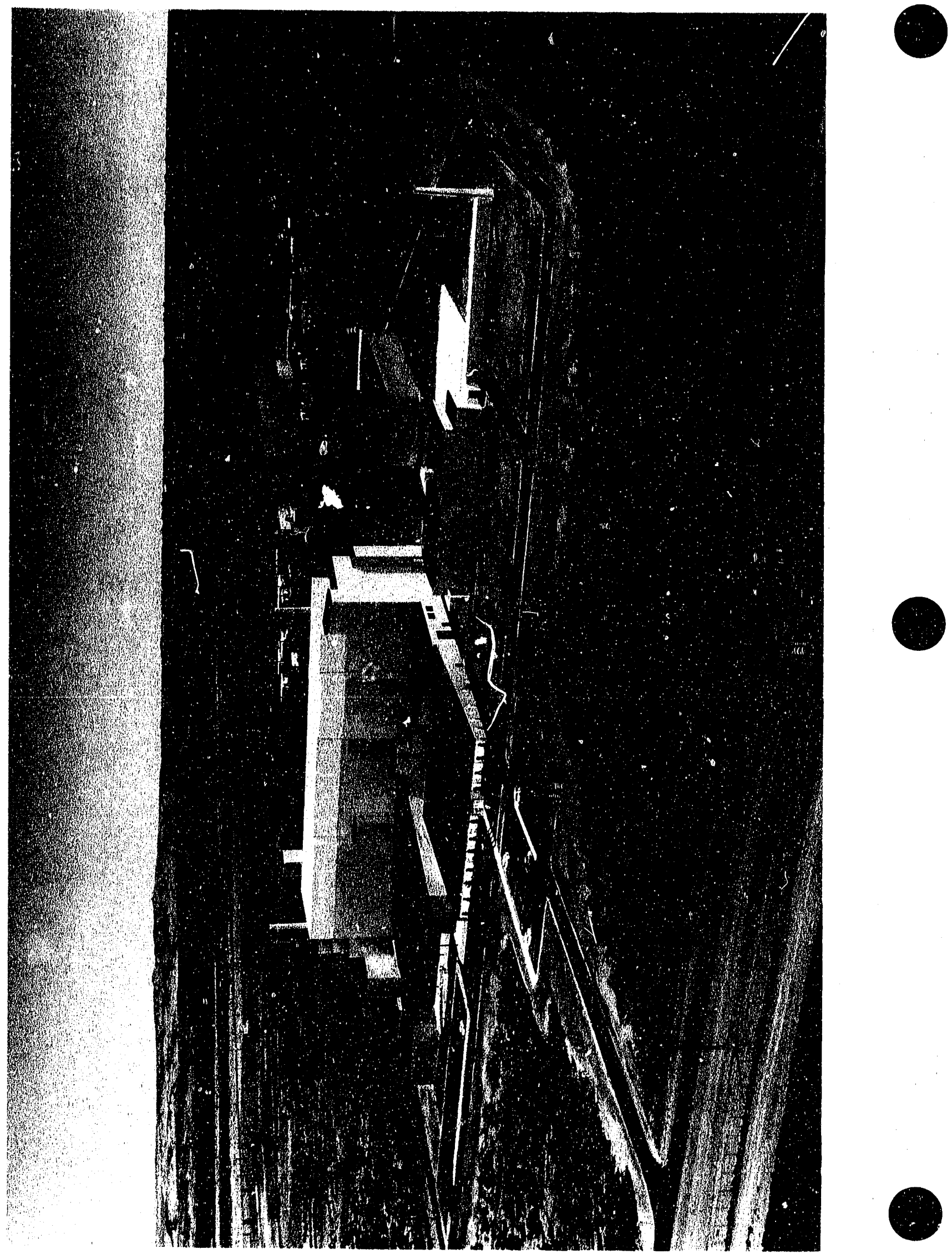
Recently, the Tri-Party Agreement (Ecology et al. 1989) between the Washington State Department of Ecology, the EPA, and the DOE established a schedule for achieving Resource Conservation and Recovery Act (RCRA) and Comprehensive Environmental Response Compensation and Liability Act (CERCLA) (DOE 1985) compliance. All milestones, with the exception of one, occur within the 20-yr scope of this plan. Compliance with the Tri-Party Agreement will require a significant increase to the Environmental Program staff during the next $5 \mathrm{yr}$.

Estimates for the cost of cleaning the Hanford Site have ranged from $\$ 37$ to $\$ 57$ billion during the next $30 \mathrm{yr}$. The cleanup effort will easily replace the materials production activities from a Hanford Site employment perspective.' In the low-case scenario, R\&D activities are expected to continue expanding at the current growth rate and are relatively unaffected by the completion of plutonium production missions.

\subsubsection{R\&D/Engineering Development. In the low-case scenario,} R\&D activities are expected to ccntinue expanding at the current growth rate and are relatively unaffected by the completion of plutonium production missions. The FFTF and the FMEF primarily will operate in support of $238 \mathrm{Pu}$ and other isotope production and testing in support of space power. The Northwest Hazardous Waste Research, Development, and Demonstration Center (estabiished as part of the Superfund Reauthorization Act) will continue to research the adaptation and development of innovative technologies to assess and remedy the impacts of inactive hazardous and mixed-waste sites.

The ESRC will continue to suppor? future technologies and methods that are expected to (1) reduce the time/cost to characterize waste management and environmental restoration problems, (2) provide remedial action, and (3) increase the legal and regulatory defensibility of the future DOE actions in these problem areas.

A MSRC will be established to provide a strong link between basic and applied R\&D for application to DOE missions and to encourage collaborative research with scientists from universities, industry, and other national laboratories. This world-class research center will focus on fundamental interdisciplinary research in molecular science emphasizing interfaces and structure/function studies. Thus, the MSRC, in conjunction with existing site research capabilities and those of visiting scientists, will foster fundamental discoveries and their rapid incorporation into the solution of problems important to DOE missions.

The EMSL will be constructed to support the activities of the ESRC and MSRC. The EMSL will provide the capability to perform basic research at the molecuiar level for application in solving major environmental and waste cleanup problems and achieving new breakthroughs in related energy and health areas. The EMSL will operate as a national DOE user facility that will be open to scientists and engineers from the academic community, industry, and other government laboratories. The unique mix of equipment and computers combined with staff expertise in the environmental, chemical, material, and biological sciences, will make the EMSL and the Hanford Site a focal point of molecular-level research in the United States. 


\subsubsection{Medium-Case Scenario}

The activities described in the medium-case scenario build on those described in the low-case scenario. Waste Management and Environmental Restoration activities (a major component of this scenario) will continue to increase for all scenarios as described in Section 4.4.1.2. Three other major components of the medium-case scenario are discussed below: nuclear materials production, the space nuclear power program, and R\&D.

\subsubsection{Nuclear Materials Production. This scenario includes maintaining} the $N$ Reactor in dry standby, as a contingency for short-term materials requirements, until the new production reactor is operating. In addition, WNP-1 will continue as a contingency option for tritium production.

Additional Hanford Site returns and scrap processing missions extend the operating life of the PFP to later in the planning period. This will add approximately 200 workers at the PFP in support of materials production through the year 2000 .

4.4.2.2 Space Nuclear Power Program. A major effort associated with this scenario is the expansion of the space nuclear power program. This program is divided into two parts: the SP-100 effort, which is geared toward smaller reactors that would power communications and sensors, and the multi-megawatt program, which is geared to providing much higher power. Testing of fuel and certain components wouid take place in the FFTF. The GES for the SP-100 reactor would be constructed in the 309 Building in the 300 Area.

4.4.2.3 R\&D/Engineering Development. The R\&D/engineering development activities are as described in the low-case scenario except the SMES/ETM would be constructed. The SMES/ETM would be a new major mission for the Hanford Site. Its original function would be to demonstrate, as jointly proposed by the DOE-RL and the BPA to the DOD, the ability of SMES technology to provide reliable, highly efficient storage of electrical power that can be delivered at high power with fast response. The SMES/ETM project is fully consistent with the energy research and defense missions of the Hanford Site, and it would provide a key facility for attracting and supporting a number of future research activities in both areas. The DOE intends to operate the SMES/ETM facility as a user facility for superconductivity research in conjunction with needs of the BPA after completion of the design base tests.

The benefits that could be obtained by universities, utilities, the DOE-RL, industries, and the Pacific Northwest region are considerable. The BPA would obtain information and experience on the impacts of a large SMES/ETM facility on its transmission system and the possibie utility of such a system for storage and dynamic breaking. As a federal agency, the BPA, is free 01 : many proprietary constraints that can hamper information exchanges with a private host utility. It is expected that the SMES/ETM would become a working component of the BPA system after completion of the test programs.

In addition to the SMES/ETM, the Special Analysis Facility would be constructed and operated. It would accommodate classified analys is and computing activities supporting national security and defense proyrams. 
The facility would be approximately $21,000 \mathrm{ft}^{2}$ with a capacity for 60 people. The facility would be in the 300 Area, where the bulk of R\&D activities will be performed.

Figure 4-4 provides the characterization and location of the activity centers associated with the medium-case scenario at the Hanford Site.

\subsubsection{High-Case Scenario}

The high-case scenario features an expanding role in the national mission of nuclear materials production, in addition to the characteristics described in the medium-case scenario. The LMR program is also expanding, particularly in new missions for the FFTF. Other major areas of technological growth irclude the possibility of the Hanford Site becoming a major space nuclear power center for the Nation, the establishment of a Laboratory Science Education Center, and the establishment of a Hazardous Materials Management and Emergency Response Training Center.

4.4.3.1 New Production Facilities. This scenario includes establishing a tritium production mission at the Hanford Site. This scenario could involve completing WNP-1 and constructing the associated fuel processing facilities. Figure 4-5 shows the mothballed WNP-1. Alternately, an accelerator or new production reactor and support facilities could be constructed to meet national defense requirements. New analytical facilities would be constructed to support the expanded missions. The construction force for the tritium production facilities could add 5,000 to 8,000 people onsite for 5 to 8 yr, depending on which alternative is used.

A recent report states that the conversion of WNP-1 is both economically and technically feasible. Financial problems halted construction in 1982 when it became evident that the planned construction of additional nuclear power plants had been based on faulty economic data. The WNP-1 is approximately $63 \%$ complete. Estimates indicate that conversion of WNP-1 would halve the construction cost of building a new reactor. The cost of modifying and completing WNP-1 and modification or construction of support facilities at the Hanford Site is approximately $\$ 1,954$ million capital and $\$ 514$ million preoperational. This figure does not include the funding needed for R\&D, which is about $\$ 108$ million.

None of these financial estimates include a purchase price for WNP-1. The Washington Public Power Supply System is officially neutral on the conversion issue. The Washington Public Power Supply System managing director has stated that the federal government could acquire WNP-1 by purchasing the plant for approximately $\$ 2$ billion, or by a "hostile takeover" of the plant. A take sver attempt would lead the Washingtori Public Power Supply System to file lawsuits to protect interests of ratepayers.

Other possibilities for the acquistion of WNP-1 include transfer of is title to the federal government in exchange for the 1,200 MW of power that it would generate. The estimated worth of that power is between $\$ 160$ and $\$ 180$ million annually. Another possibility is for the federal government to reduce the BPA's debt to the U.S. Treasury by the cost of transfer of WNP-1 to federal ownership. 
Figure 4-4. Characierization and Location of the Activity

Centers Assoclated with the Medium-Case Scenario at the Hanford Site.

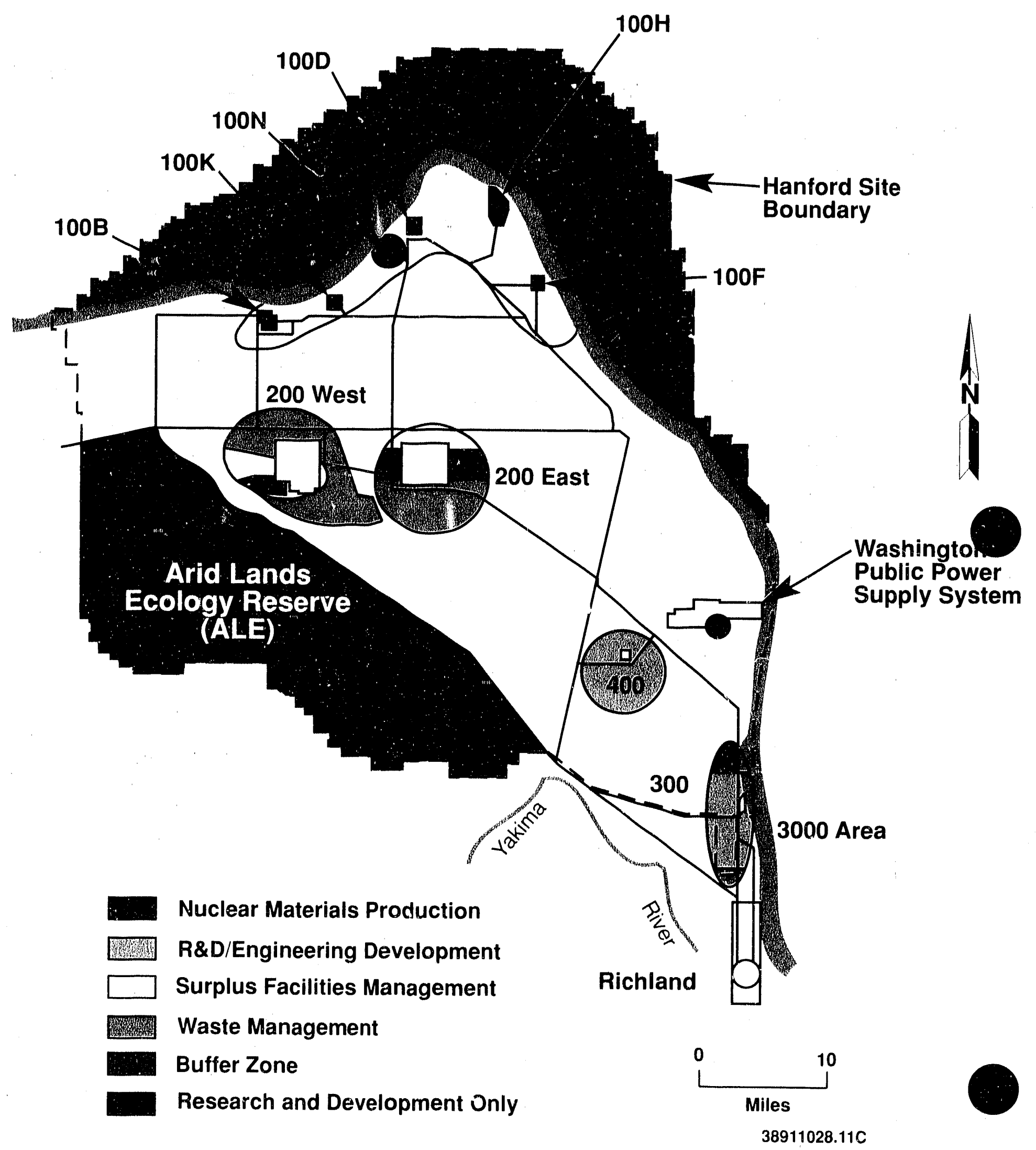


DOE/RL-89-15

Figure 4-5. The Mothballed Washington Public Power Supply System Nuclear Plant No. 1.

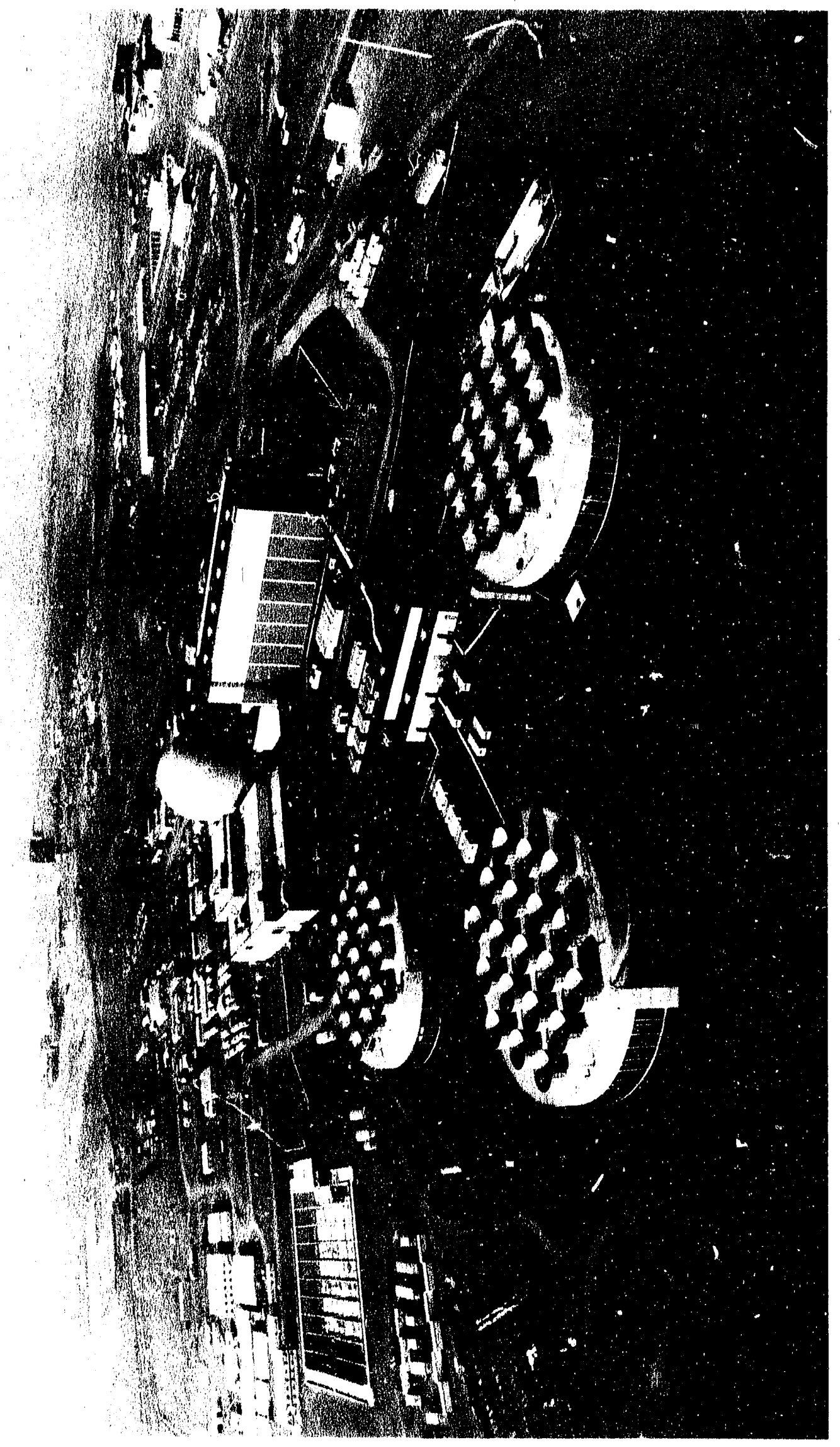


4.4.3.2 Space Nuclear Power. In the high-case scenario, the space nuclear power activities mentioned in the medium-case scenario would increase. A potential customer, NASA, has plans to bulld a permanent space station in 1994, colonize the moon between 2005 and 2010 , and send a space vehicle with crew members to Mars between 2010 and 2020. In this scenario, the Hanford Site could become a major space nuclear power center for the Nation.

4.4.3.3 Fast Flux Test Facility. The FFTF would continue to evolve into a multi-mission facility (Figure 4-6). The first steps of this evolution are already visible with the addition of the testing program for space power. fuels and materials. Also planned is a broadening of the LMR testing program in the FFTF to include experiments aimed at demonstrating the inherent safety characteristics of LMR plants.

In a different technology area, the capabilities of the FFTF as a powerful neutron source are finding application in the production of isotopes for medical and industrial uses. One of the most promising areas is the production of $153 \mathrm{Gd}$. Gadolinium-153 can be used to make radiographic pictures of bone structures in the same manner as normal x-ray photographs, but the pictures are more sensitive than $x$-ray photographs or computerized axial tomography (CAT)-scan pictures. The FFTF is now producing the first samples of this isotope.

The city of Richland and the Benton and Frankl in County Public Utility Districts have a cooperative agreement with the DOE to explore the possibility of a utility-owned power generation addition to the FFTF. In the high-case scenario, construction and operation of the FFTF Power Addition Project would further broaden the mission of the FFTF, provide the capability to obtain long-term operating experience with LMR steam-generating equipment, and help offset the operating costs of the FFTF. The FFTF Power Addition Project would provide an additional 200 construction-related jobs.

4.4.3.4 R\&D/Engineering Development. The R\&D/engineering development activities build on the medium-case scenario with the development of the Pacific Northwest Technology Complex (PNTC), which is in early stages of conceptualization. The motto of the PNTC, is "Sharing science, engineering, research and development with users throughout the Pacific Northwest." The visionary plan for the PNTC proposes establishment of the following "parks" and their associated activity centers. These parks would be located in the southern portion of the 300 Area and adjoining public and private land.

\section{Space Science \& Technology Parks}

- SP-100 and Multi-megawatt Systems

- Space Energy Storage and Generation Center

- Space Materials and Processing Center

- Superconducting Magnetic Energy Storage Applications.

\section{Nuclear Power Parks}

- Washington Public Power Supply System

- Fast Flux Test Facility Power Addition

- Utility Engineering Center. 
DOE/RL-89-15

Figure 4-6. Fast Flux Test Facility's Multiple Mission Capability.

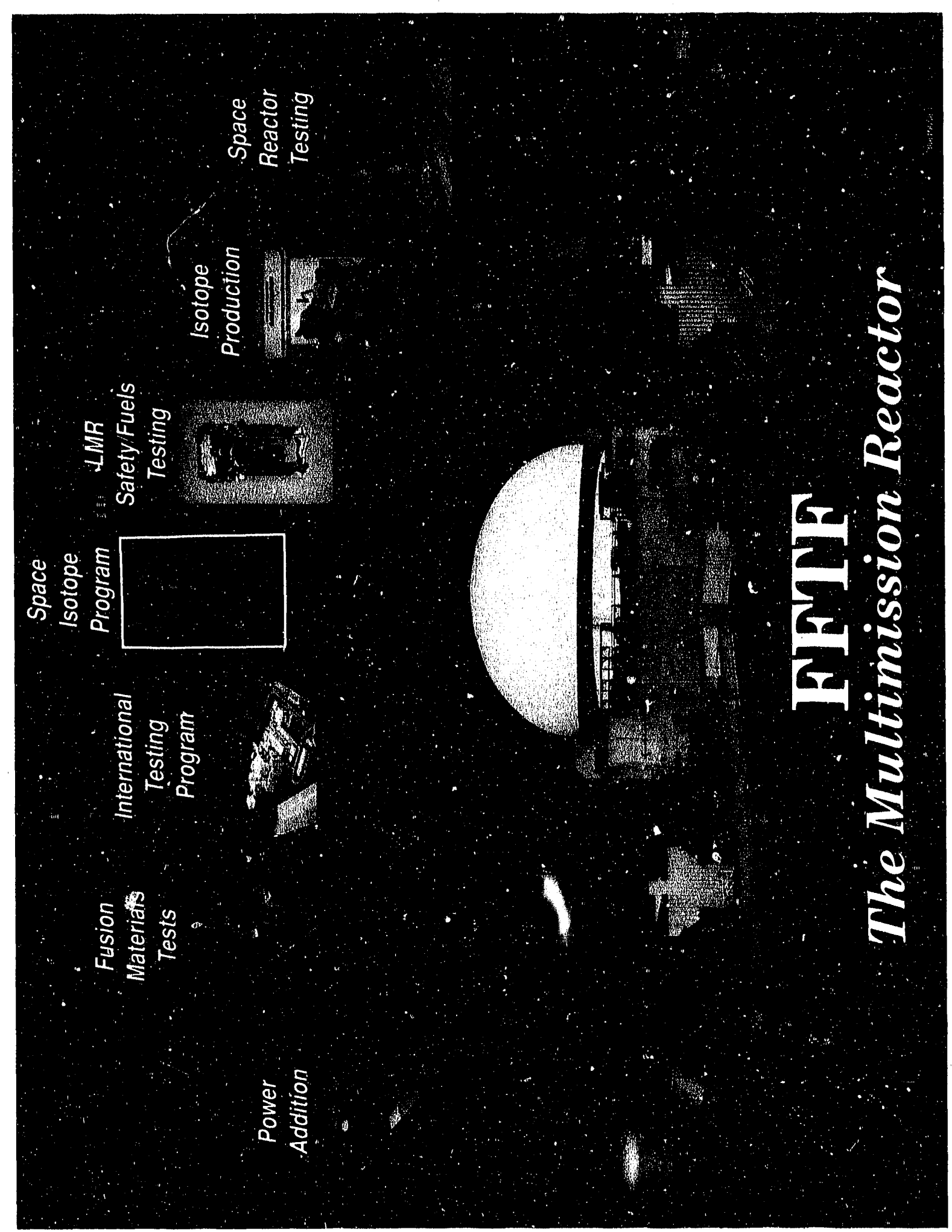


Isotopes, Energy, and Physics Parks

- Fast Flux Test Facility

- Applications Research and Development Center

- Production and Packaging Center

- Sources and Processing Center.

\section{Environmental Technology and Demonstration Parks}

- Industrial and Municipal Waste Center

- Northwest Hazardous Waste Center

- Nuclear Waste Technology Center

- Waste Technology Demonstration Sites

- Arid Lands Ecology Reserve.

Automation. Manufacturing, and Management Technology Parks

- Computer Integrated Manufacturing Center

- Artificial Intelligence Applications and Demonstration Center

- Rohotics and Mechanical Systems Center

- Ser. 's and Controls Center

- Non iructive Testing, Inspection, and Measurements Center

- Business and Office Systems Center.

Advanced Materials Park

- Ceramics Center

- Composites and Polymer Composites Center

- Advanced Metals and Intermetallics Center

- Thin Films and Applications Center.

Mclecular Sciences Research Park

- Molecular Science Research Center

- Molecular Applications and Demonstrations Center.

Mathematical. Computing, and Software Sciences Park

- Washington Higher Educatior Telecommunication Services (WHETS) Northwest/Washington State University

- Computer Systems Integration Center

- Scieitific Computing Network

- Telecommunications and Information Management Center

- Advanced Computing Center.

Electronics and Microelectronics Parks

- Advanced Microelectronics Center

- Synthesis, Measurements, and Testing Center

- Optoelectronics Center.

Biotechnology Park

- Noninvasive Diagnostics Center

- Genetic Engineering Center 
$\mathrm{DOE} / \mathrm{RL}-89-15$

- Prosthesis and Artificial Organ Center

- Biochemical Processing Center

- Biotechnology Applications Support Center.

\section{Agricultural Development Park}

- New Agricultural Products Center

- Food Science and Processing Center

- Agricultural Plant and Equipment Development Center

- New Agricultural Products Center

- Food Science and Processing Center

- Irrigated Crop Production Protection Center

- Enology and Viticulture Research and Development Center

- Agricultural Experiment Center.

\section{Policy Park}

- Public Policy Center

- International Trade and Support Center

- Educational Policy Center

- Domestic Trade Center

- Strategic Alliances Center.

\subsection{MASTER PLAN DEVELOPMENT}

The initial selection of the Hanford Site as a government reservation was heavily influenced by security and safety concerns surrounding nuclear energy during World War II. Plants were located miles apart on the assumption that if one had an accident or was attacked, damage to the others would be minimized or avoided.

In contrast, the evolving national nuclear policy, along with a better understanding of nuclear $\mathrm{plant}$ technology, has altered original siting concepts. The recent trend has been to consolidate like activities and functions, to improve efficiency, to reduce costs, and to enhance energy conservation and security.

With this consolidation philosophy in mind, and recognizing that a site development plan is largely dependent on program changes, the previously identified scenarios were developed to forecast the range of program activities that are possible at the Hanford Site during the next $20 \mathrm{yr}$.

After the range of possible programs was identified, the next step was to determine the ideal relationships a.long these functions without regard for physical site constraints. From this analysis, the optimum or Ideal site Plan was developed and became a theoretical goal against which the existing Site was compared. Through such comparisons, potential improvements and changes became apparent. The Master Plan (Section 5.0) presents recommendations regarding site development that were formulated within the Hanford Site constraints. 


\subsection{IDEAL SITE PLAN}

The Ideal Site Plan is illustrated schematically, has io scale, and is not site-specific. This allows development of ti.2 Ideal $\mathrm{Pl}$ an without regard for physical or environmental site constraints. One comprehensive plan is necessary to optimize functional relationships between activities and facilities.

Optimum relationships are relationships that result in the greatest effectiveness possible between two or more entities (activitias and facilities). This is achieved by locating entities as close as possible to each other to ensure accessibility and improve security.

The Ideal Site Plan, shown in Figure 4-7, is basically a linear arrangement with two functional areas: Bracket 1 , the area farthest from populated areas, is reserved for nuclear fuel cycle activities; and Bracket 2 , the area closest to populated areas, is reserved for common support activities, such as research laboratories, engineering, maintenance, computing, storage, administration, and centralized utilities. Because environmental restoration is a reclamation issue rather than development, it is not considered as part of the "Ideal Plan."

The Ideal Site Plan focuses on the nuclear fuel cycle area located in the north. This area is laid out according to the steps in the nuclear fuel cycle: fuel fabrication, fuel irradiation, interim storage for spent fuel, fuel reprocessing, and waste treatment processes. Defense and nondefense nuclear facilities are close to each other to take advantage of similar siting requirements (e.g., geological suitability, proximity to water, transportation routes, utilities and disposal processes, and facilities). Nuclear prototype, demonstration, and production facilities with similar activities are also located near each other in this generalized northern area.

The efficient operation of each plant requires that employees, fuel, and waste material move in and out quickly. This is balanced with the need to minimize access portals to afford greater security protection. The linear arrangement provides easy access, but separates the waste access lines from the employee access 1 ines. Fuel and waste enter the facilities from the north, while employees enter from the south. This no-conflict traffic pattern is one of the most important characteristics of the Ideal Site Plan.

Research and development areas consist primarily of laboratories and related support facilities. The R\&D functions are consolidated to maximize operating efficiency and technical capabilities. In this location, the R\&D area can support the nuclear fuel cycle activities, or interact with industry and government to apply technology developed in the laboratories to commercial products and services.

The R\&D areas provide a buffer zone between nuclear fuel cycle activities and populated areas. Environmentally sensitive R\&D activities that contain SNM are located away from populated areas, closer to nuclear activities. For security and safety reasons, a buffer zone surrounds the entire site to physically separate it from populated areas. 
DOE/RL-89-15

Figure 4-7. Ideal Site Plan.
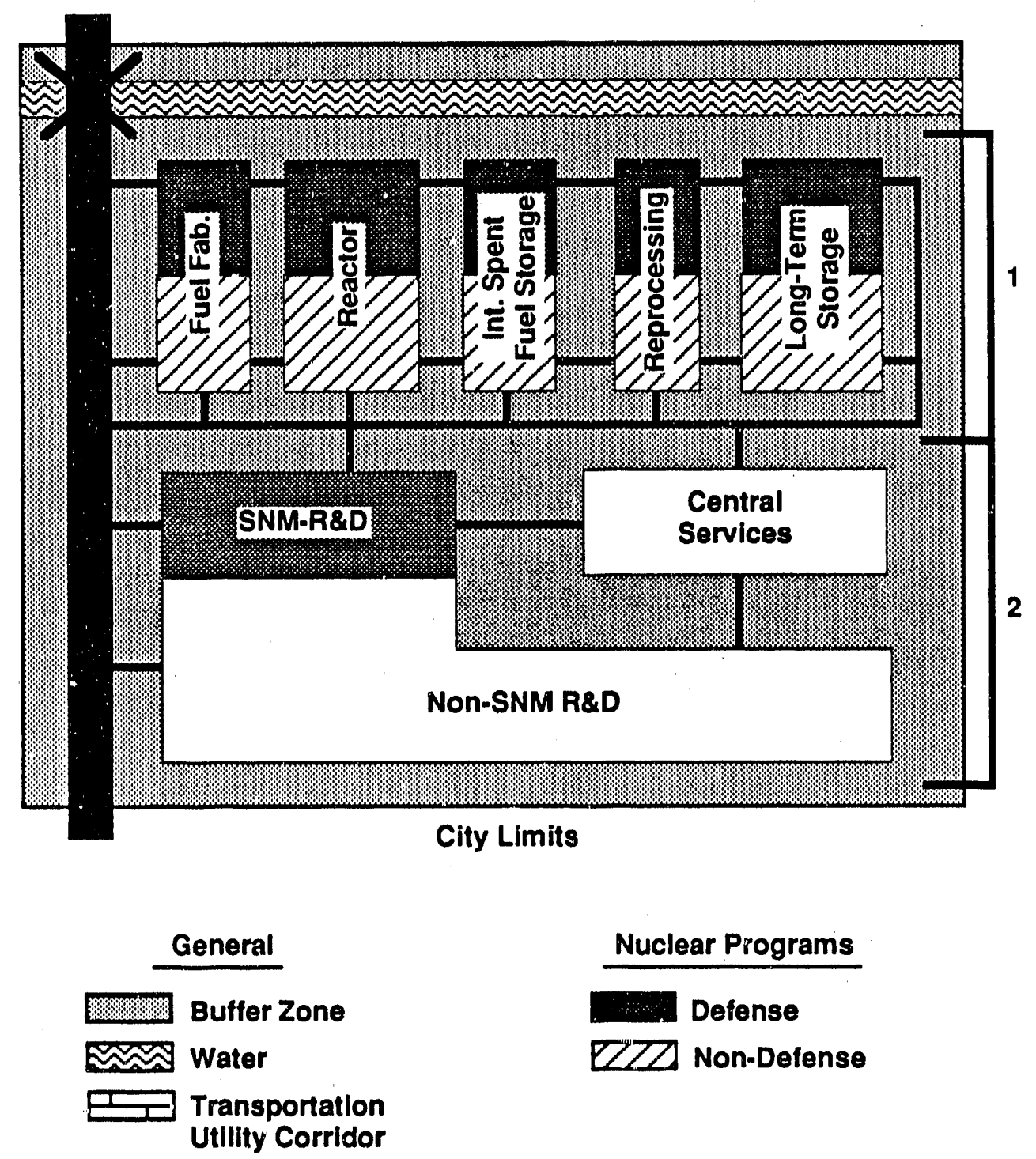

39001069.26 


\subsection{ANALYSIS OF ALTERNATIVES}

Previous sections of the Site Development Plan identified the Hanford Site constraints, probable future activities, and the ideal functional arrangement of those activities. This portion of the Plan integrates the preceding information into the siting process and shows how future activities could be ideally arranged on the Hanford Site, given the constraining factors.

The siting process has been refined to choosing locations for the basic activities of the site. The judgments about the ideal use of the land focus on the location and relationship of key activities. The chosen key activities are environmental restoration and technology development, R\&D/engineering development, reactor operation, fuel fabrication, and interim storage for spent fuel. Processing facilities and activities were assumed to be located in the 200 Areas. Disposal and lnig-term storage activities were assumed to be located near the 200 Areas. The location of processing, disposal, and long-term storage activities was assumed to be the same for all alternatives.

To further simplify the presentation of the alternatives, only general area locations are shown. The R\&D/engineering development areas include heavy/light laboratories, administration, engineering development and demonstration, maintenance, storage, and other support facilities.

The best alternatives that most closely match the Ideal Site Plan were developed into the Master Plan summary (Section 5.0). Site constraints were blended in at that point to reflect a more precise and realistic site development plan.

\subsubsection{Environmental Restoration and Technology Development}

Since 1944 the Hanford Site has been generating radioactive, hazardous (chemically hazardous), and mixed wastes as a byproduct of its assigned missions; production of SNM being the most significant. Before enactment of relatively recent environmental legislation, predominantly RCRA and CERCLA, the DOE managed the storage and disposal of these wastes under requirements established by authority of the Atomic Energy Act. Since passage of RCRA and CERCLA, the DOE, including the DOE-RL, has estabilished programs to achieve compliance with these laws. The DOE programs include activities to comply with regulations for the generation, transportation, treatment, storage, and disposal (TSD) of wastes produced in operating facilities, and for the characterization and cleanup of wastes at inactive waste sites. In addition, the DOE has set up programs for management and action on radioactively contaminated surplus facilities. The programs set up for surplus facilities are called D\&D programs, are driven by the Atomic Energy Act, and are controlled by DOE orders.

In 1989, the Hanford Site emerged into the Tri-Party Agreement, which is an agreement among the DOE, the EPA, and Ecology. The primary objectives of the Tri-Party Agreement are to bring the Hanford Site into compliance with state and federal hazardous waste laws, and to clean up the Hanford Site in a timely manner. 
The environmental restoration program is divided into three subprograms, which are being implemented throughout the Hanford Site: (1) Environmental Restoration Remedial Actions, (2) environmental restoration D\&D, and (3) technology development and demonstration.

The primary objective of the Environmental Restoration Remedial Action program is to bring all known waste sites at the Hanford Site into compliance with applicable federal, state, and local environmental laws and regulations. Secondary objectives include the following:

- Providing information, emphasis, and accountability for all Environmental Restoration Remedial Action needs resulting from past Hanford Site hazardous waste activities

- Providing an identifiable, coherent program by which all activities supporting Environmental Restoration Remedial Action can be coordinated and reported

- Preparing and managing the budgeting and scheduling of CERCLA, RCRA $3004(u)$, and selected TSD closure activities for all of the Hanford Site.

To carry out the mission and objectives outlined in the previous paragraph, the Hanford Site has been divided into 4 aggregate areas, 78 operable units, and about 1,500 waste management units. The waste management unit is the entity that is assessed, characterized, and remediated. of the approximately 1,500 waste management units that have been identified, about 1,127 are addressed by the Environmental Restoration Remedial Action program. The remainder of the waste management units are not addressed by Environmental Restoration Remedial Action because they are principally surplus facilities or active TSD units. Assessment, characterization, and remediation activities on individual waste management units are carried out in groupings called operable units, which form the basis for planning, scheduling, budgeting, and establishing the working order and some of the applicable environmental restoration milestones for the DOE and the Tri-Party Agreement (Ecology et al. 1989).

The second subprogram, environmental restoration D\&D, concerns the many DOE-owned facilities at the Hanford Site that were used for nuclear materials production and have been retired from service and declared excess. There are currently about 115 separate facilities that the HSFP manages, consisting of large concrete and cement block structures used to house chemical separations processes, nuclear production reactors, underground effluent water systems and storage tanks, and ancillary buildings. The majority of these facilities have residual radioactive contamination requiring surveillance, maintenance, and ultimate disposal. The HSFP office has the responsibility for managing and monitoring these facilities at the Hanford Site for the DOE.

Certain activities related to D\&D of structures by the DOE may be subject to RCRA. Whenever D\&D activities result in the generation of hazardous wastes, the TSD of those wastes are subject to the Tri-Party Agreement. 
The third subprogram, environmental restoration technology development and demonstration, is divided into two main categories: (1) technology development and demonstration activities within the Environmental Restoration Hazardous Waste Remedial Action Program (HAZWRAP) activities that focus on technology development and demonstration activities having applications at the national level. Some HAZWRAP activities are being conducted at the Hanford Site.

\subsubsection{R\&D/Engineering Development}

The alternative sites for $R \& D /$ engineering development on the Hanford Site are shown in Figure 4-8. Two general R\&D activities are considered: Non-SNM, which is work that does not involve the Use of SNM; and SNM, which is work involving the use of SNM and/or work involving significant levels of radioactive materials.

Alternatives include locating non-SNM and SNM activities together to make use of common support facilities, staff, and laboratories. Also shown in Figure 4-8 are geographically separate areas to locate environmentally sensitive activities toward the interior of the Hanford Site. Key elements of the alternative sites for each type of Ráuiangineering development activity are discussed below.

Two general areas are identified for non-SNM R\&D/engineering development. Both areas are close to public access and are located so that they provide a buffer by distance or geographical barrier to nuclear development or sensitive facilities located in the interior of the Hanford Site. Facilities such as the EMSL, SP-100 GES, and space fabrics prototype and production facilities would be located here. In addition, the unused and remote areas of the Site are available for facilities like SMES/ETM and the companion High-Temperature Superconductivity Power Applications Center, which would include transmission and distribution testing.

Four areas are identified for SNM R\&D/engineering development activities. All of the alternative sites are located away from routine public access or populated areas. Facilities for space isotope production, space power systems fabrication, space power generation distribution, linear accelerator(s), and some RDDT\&E facilities would be located here.

\subsubsection{Reactors}

The alternatives for locating new reactors on the Hanford Site are shown in Figure 4-9. Two general functions for reactors were considered: defense (e.g., the replacement production reactor) and nondefense (e.g., a demonstration (MR). Key elements of the alternative sites for reactors are discussed below.

Four alternative sites were identified for defense reactors. Three are located in the central portion of the Hanford Site, away from populated areas. These sites are a more secure location because they are further from the river, which is accessible to the public. The site to the north is away from populated areas but is not as secure a location because of proximity to 


\section{Figure 4-8. Alternative Locations for R\&D/Engineering} Development on the Hanford Site.

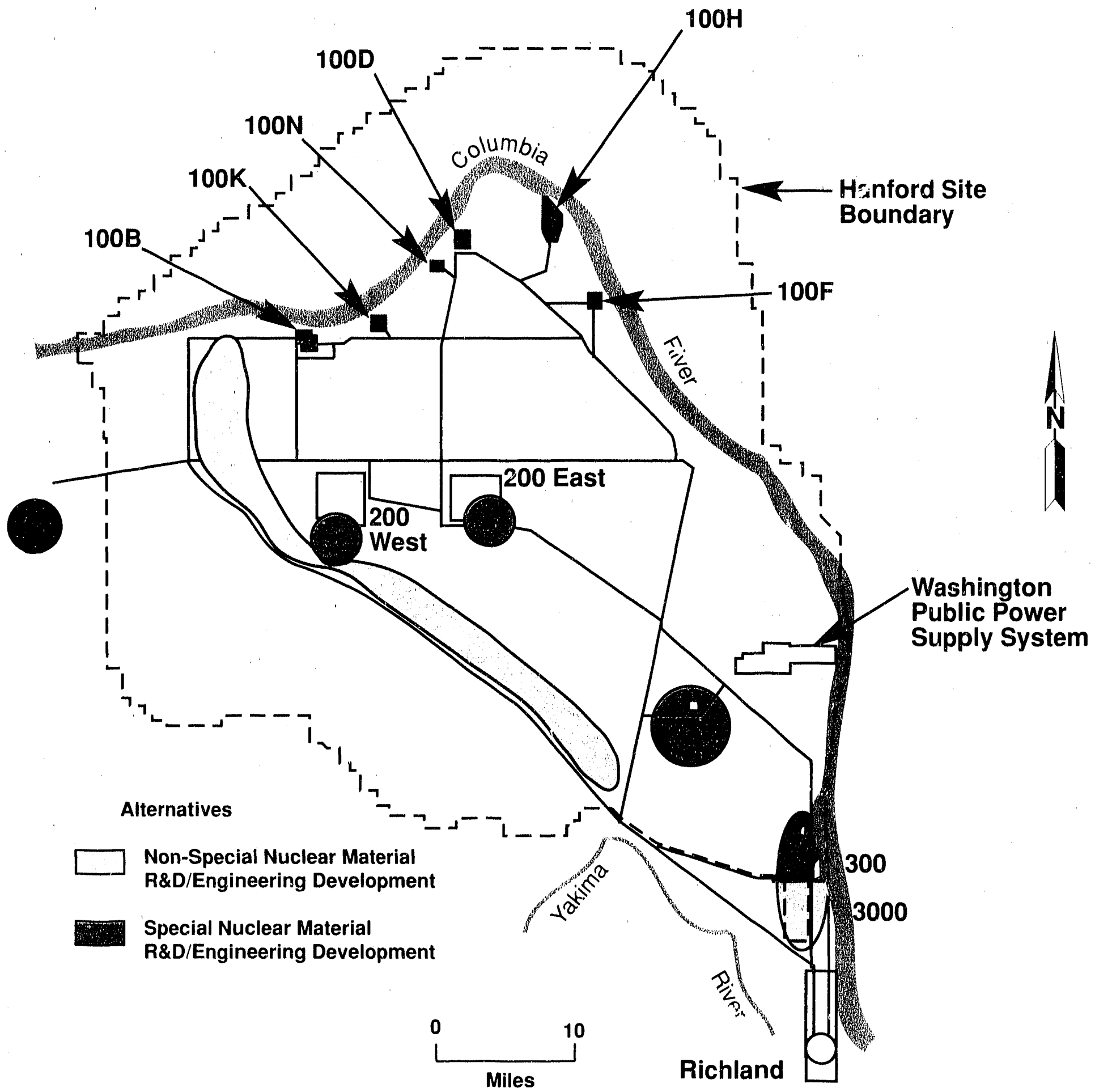


Figure 4-9. Mlternative Locations for Reactors on the Hanford Site.
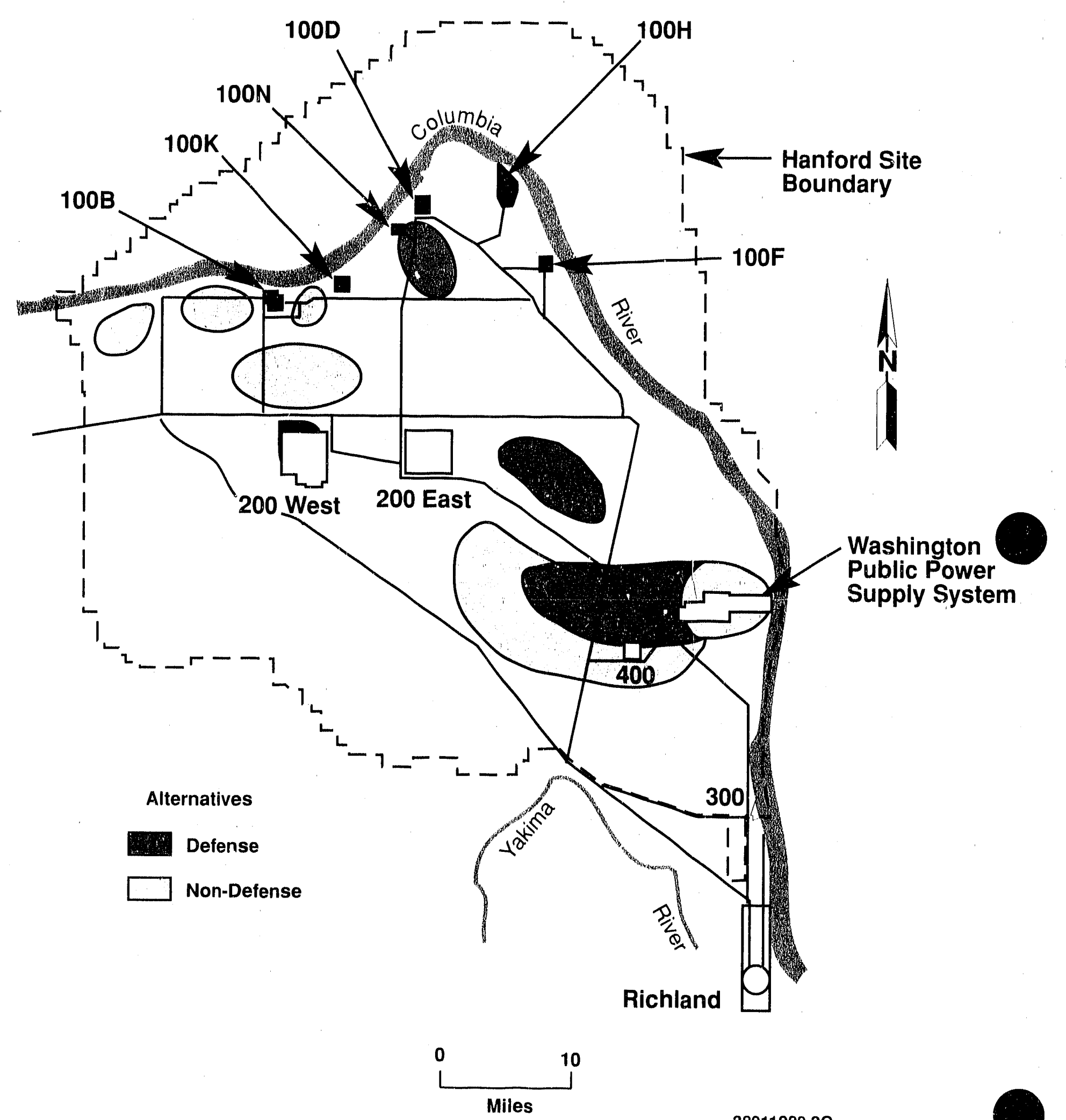
the river and routine public access. Most of these sites were identified as potential reactor sites in early site selection studies for a new production reactor.

All but one of the alternative site plans suggest that defense reactor development be separated from other development activities. The only exception is the Washington Public Power Supply System site.

Several alternative sites are identified for nondefense reactors. Options range from proximity to public highways and the river (for convenient access), to more secure locations in the center of the Hanford Site. Reactor sites are grouped in areas to taike advartage of similar site requirements, such as proximity to water and locations that are away from capable faulting.

\subsubsection{Fuel Fabrication}

The alternative sites for fuel fabrication facilities on the Hanford Site are shown in Figure 4-10. Two general functions for fuel fabrication facilities were considered: defense (e.g., fuel for the new production reactor) and nondefense (e.g., fuel for advanced reactors). Key elements of the alternative sites for each type of fuel fabrication facility are discussed below.

There are four alternatives for locating new defense fuel fabrication facilities on the Hanford Site. Alternative 1 is to expand the existing facilities in the 300 Area. Alternative 2 is to locate defense fuel fabrication facilities in the 200 Areas, which would be a more isolated and secure location. Alternative 3 is to locate defense fuel fabrication facilities in the FMEF in the 400 Area. Alternative 4 (not shown on the figure) is to locate new defense fuel fabrication facilities at the same site as the new defense reactor (see Figure 4-9 for alternative reactor sites). Another option would be to locate defense fuel fabrication facilities offsite.

There are three alternatives for nondefense fuel fabrication facilities on the Hanford Site. Alternative 1 is to expand existing facilities in the 300 Area. Alternative 2 is to locate nondefense fuel fabrication facilities in the 400 Area. Aiternative 3 (not shown) is to locate fuel fabrication facilities with new nondefense reactors (see Figure 4-9 for alternative reactor sites). Another option would be to locate nondefense fuel fabrication facilities offsite.

\subsubsection{Interim Storage of Spent Fuel}

Two general types of interim storage facilities for spent fiel were considered for the Hanford Site: defense (e.g., interim spent fuel storage facilities for the new production reactor) and nondefense (e.g., interim spent fuel storage facilities for advanced reactors).

The first alternative for siting defense or nondefense interim spent fuel storage facilities would be to locate them near the reactor site. The second alternative would be to locate the facilities near the reprocessing areas, which are assumed to be near the 200 and 400 Areas. A third 


\section{Figure 4-10. Alternative Locations for Fuel Fabrication}

Facllities on the Hanford Site.

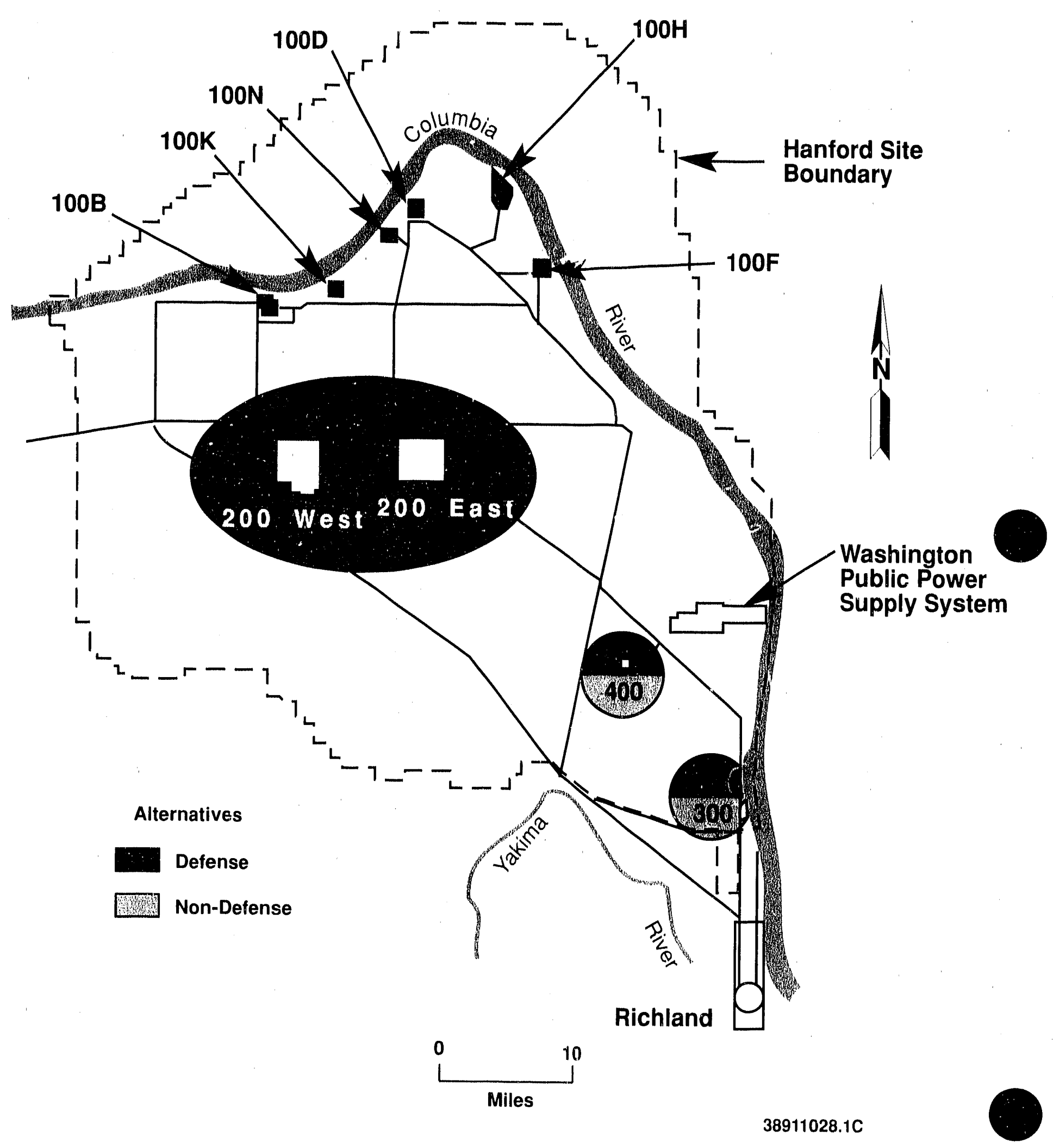


alternative would be a standalone facility. The likely siting area for such a facility is shown in Figure 4-11. This area is removed from populated areas, close to the reprocessing areas, and centered among the potential reactor sites.

\subsection{ALTERNATIVES COMBINED WITH SCENARIOS}

This section combines the siting alternatives, discussed in Sections 4.7.1 through 4.7.5. with the three scenarios and attempts to graphically display each development case.

Figure 4-12 illustrates the low-case scenario. Figure 4-13 illustrates the medium- and high-cases. Characteristics common to all scenarios were identified. There are at least three primary activity centers in all cases. They are located near the 200, 300, and 400 Areas. Activity in the 100 Areas will gradually be reduced or eliminated.

During preliminary studies to develop a Master Plan for the Hanford Site, planners envisioned three different Master Plans to address the unique characteristics associated with each scenario. However, on further evaluation, one Master Plan with phased improvements seemed to accommotate all the possibilities. Figures 5-1, 5-2, and 5-3 in Section 5.0 demonstrate this philosophy.

The chosen concept emphasizes consolidation of similar functions and centralization of compatible facilities. Processing, storage, treatment, and disposal of wastes will primarily be located in the 200 Areas. The 200 Areas will also have a primary focus on cleanup and environmental restoration activities.

Administrative and support functions that have a high volume of interaction with operations should gradually be relocated from the 100,300 , 700 , and 1100 Areas and established in the 200 and 400 Areas. The R\&D activities would be relocated from other areas, where practical, and concentrated in the 300 Area. Advanced reactors would be located near the 400 Area. Consolidating similar functions and personnel, and locating support activities near their primary operating areas, would satisfy a major goal of the Site Development Plan.

To accomplish this activity, marginal facilities in the 200,300 , and 400 Areas should be disposed of, site and area utility systems upgraded, and new facilities built to accommodate future long-term needs. Additional engineering studies will be needed to assess the functional adequacy and remaining life of systems, and to determine other miscellaneous needs.

Figure 4-14 illustrates the basic concept for developing a Master Plan. Surrounding areas would be maintained as buffer zones. This concept is expanded more fully in Section 5.0. 


\section{Figure 4-11. Potential Location for Interim Spent Fuel
Storage on the Hanford Site.}

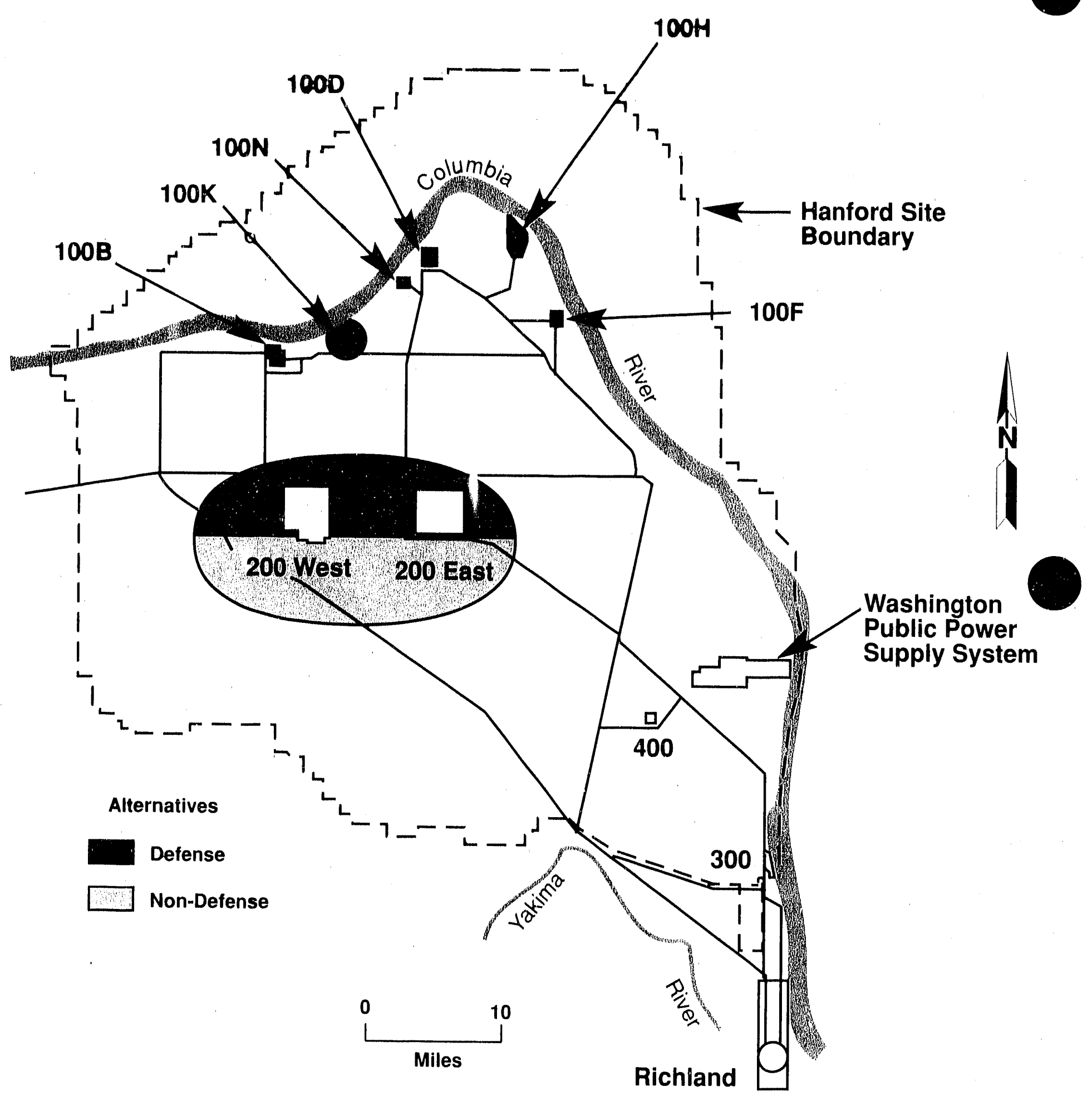


Figure 4-12. Low-Case Scenario, Including Alternatives.

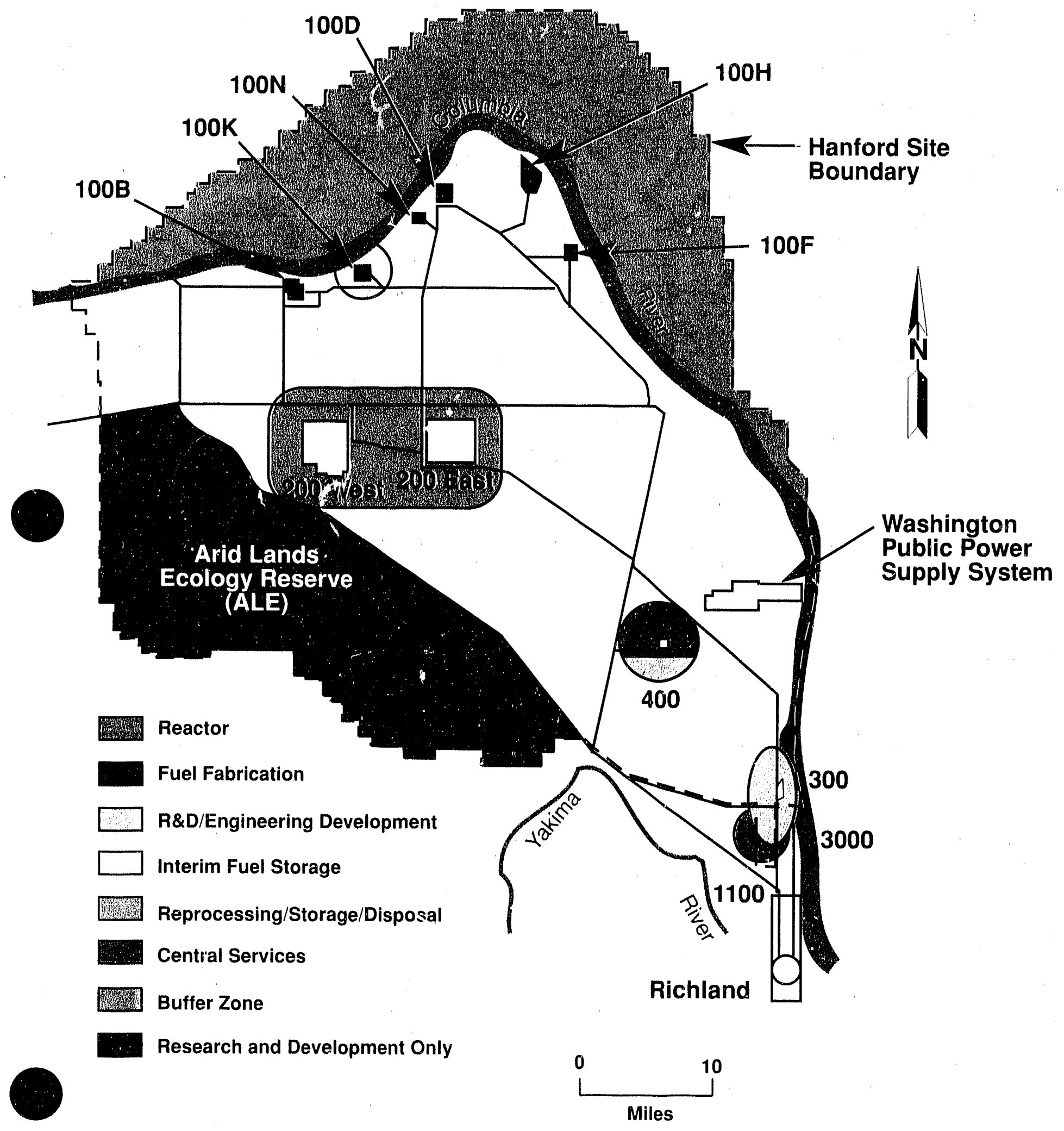


Figure 4-13. Medium- and High-Case Scenarios, including Alternatives.

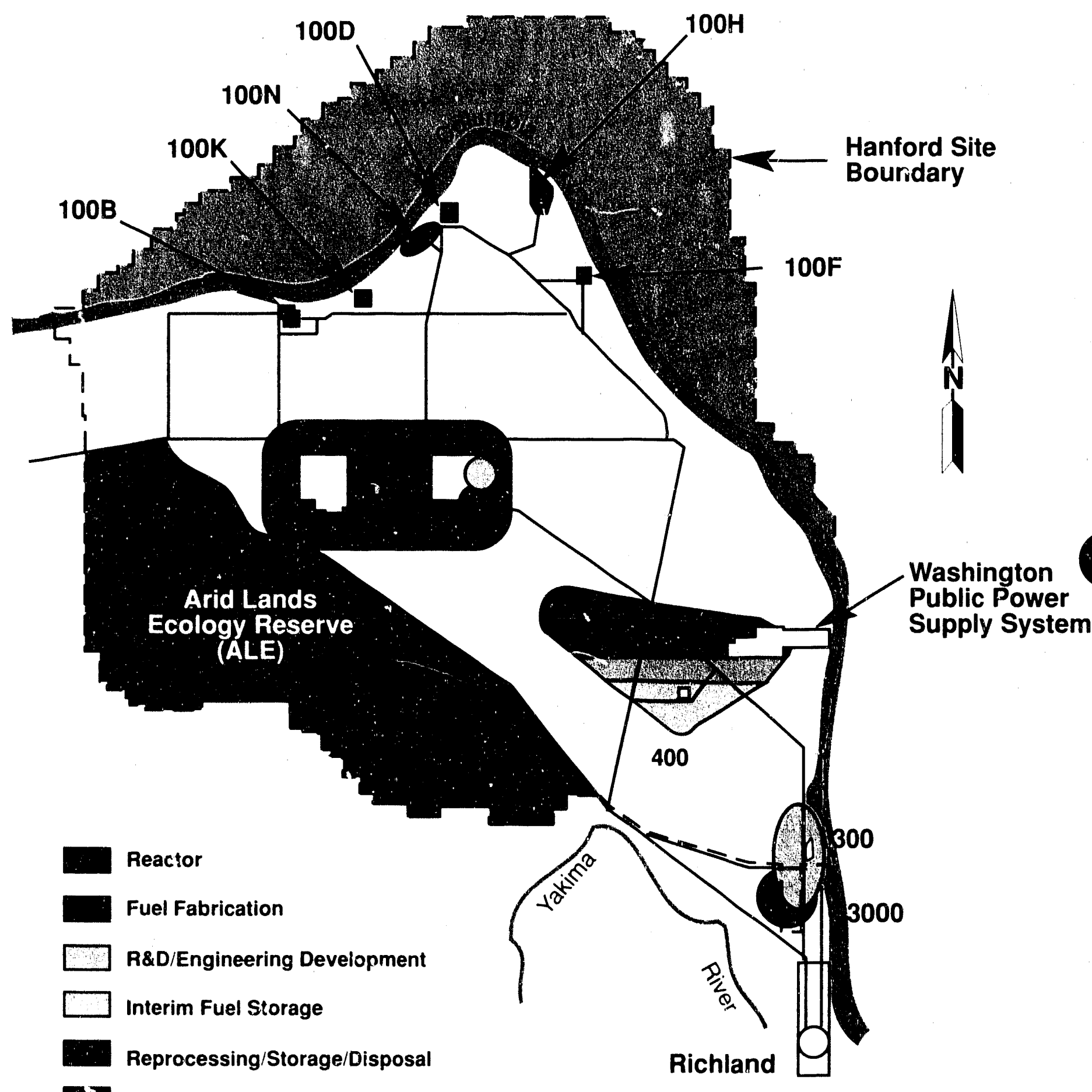

Central Services

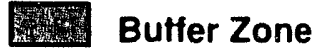

Research and Development Only

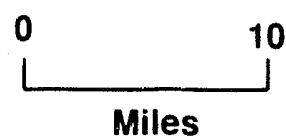




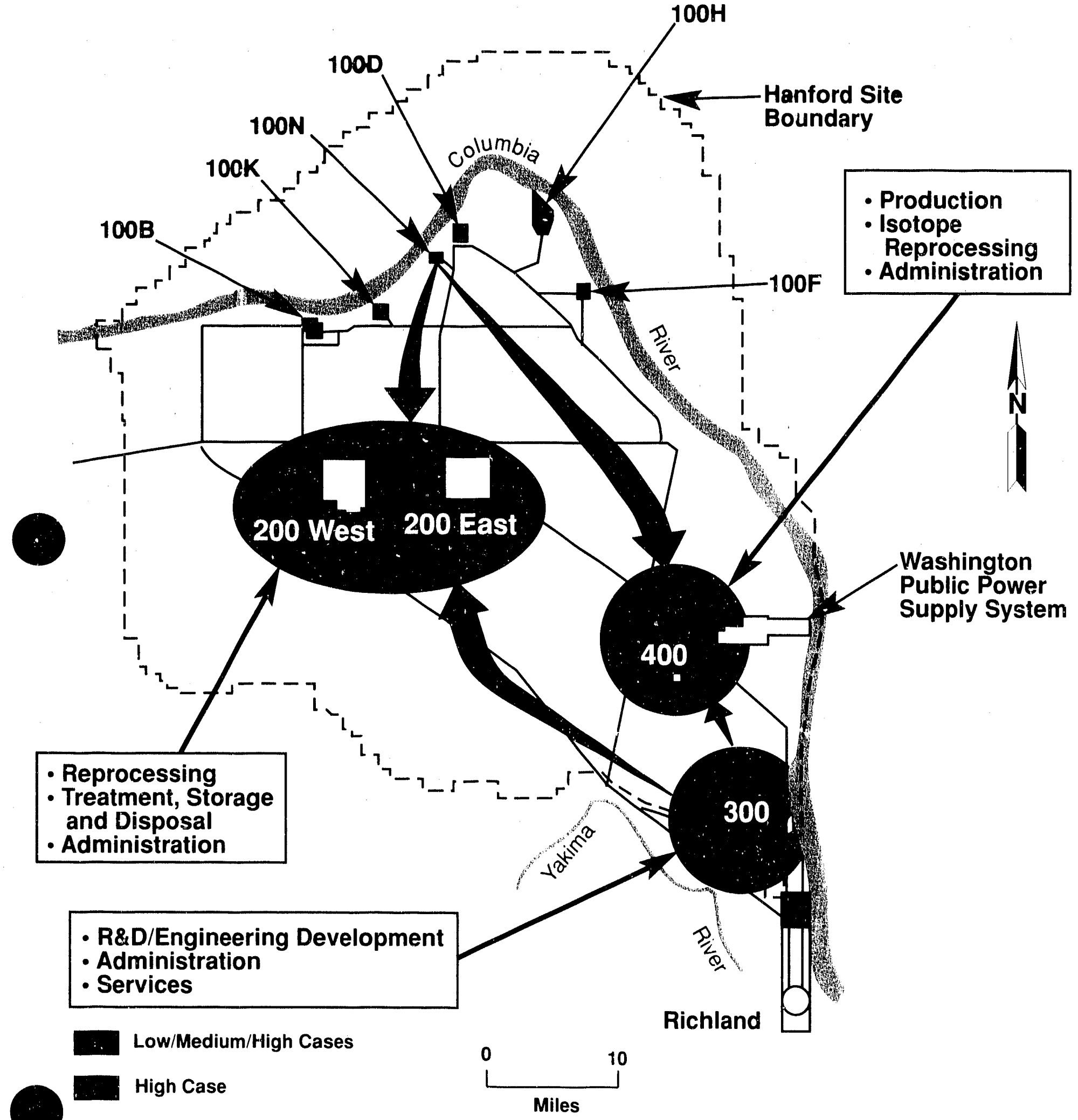




\subsection{REFERENCES}

DOE, 1985, Comprehensive Environmental Response Compensation, and Liability Act Program, DOE Order 5480.14, U.S. Department of Energy, Washington, D.C.

DOE, 1987, Final Environmental Impact Statement: Disposal of Hanford Defense High-Level Transuranic and Tank Wastes, DOE/EIS-0113, Volumes 1-5, U.S. Department of Energy, Washington, D.C.

Ecology, EPA, and DOE, 1989, Hanford Federal Facility Agreement and Consent Order, Washington State Department of Ecology, U.S. Environmental Protection Agency, and U.S. Department of Energy, 0lympia, Washington.

Resource Conservation and Recovery Act, PL 94-580 as amended 42 USC 6501 et seq.

WHC, 1989, Hanford Site Strategic Facilities Plan, DOE/RL 89-01, Westinghouse Hanford Company for the U.S. Department of Energy, Richland, Washington. 


\subsection{MASTER PLAN}

The Master Plan identifies the proposed configuration of the Hanford Site for the next $20 \mathrm{yr}$. The discussion of the plan is based on the existing conditions, goals, assumptions, analysis, and long-range missions discussed in Sections 3.0 and 4.0. Topics covered in this section include future 7 and use and functional loration, facility/mission planning, utilities, transportation, security, safety, and environmental issues.

\subsection{FUTURE LAND USE AND FUNCTIONAL LOCATION}

Figures 5-1, 5-2, and 5-3 use the "opportunities and constraints" map developed in Section 3.10 .3 as a base. The base map illustrates how existing constraints affect future land use and functional location. A new legend is added to show the major land use and functional location associated with the three scenarios forecasted for the Hanford Site during the next $20 \mathrm{yr}$. They illustrate a phased increase in land use needs from the low-case to the high-case scenario. Graphically depicted, the low- and medium-case land use needs are actually subsets of the high-case scenario. The combination of low-, medium-, and high-case elements represent the Hanford Site Master Plan. Though not shown for the sake of clarity, environmental restoration will be aggressively pursued throughout the Hanford Site in accordance with the Tri-Party Agreement and the overall Environmental Restoration Remedial Action program.

To a great extent, this configuration approaches the Ideal Plan (Figure 5-4) in its arrangement of plant functions. Unlike the Ideal Plan, however, the Master Plan reflects the realities of the inherent site constraints, such as areas with slopes greater than 6\%, 100-yr flood plains, cultural resources, and critical habitats for threatened or endangered species.

Nuclear fuel cycle activities are located predominantly in the northern part of the Hanford Site. The research and development (R\&D) activities and central services are located to the south.

Reprocessing activities are located primarily in the 200 Area. This area is centrally located on the Hanford Site, similar to the Ideal Plan. Located nearby are the interim and long-term fuel storage areas, fuel fabrication, and reactor sites. Fuel fabrication and interim spent fuel storage areas are located next to the reactors they serve.

Defense and nondefense activities are located close to each other to take advantage of similar functional requirements. Special nuclear materials (SNM) and non-R\&D areas are also located near each other. Environmentally sensitive activities (e.g., work involving significant levels of radioactive materials or SNM), however, are relocated from the 300 Area to the central portion of the Site. As in the Ideal Plan, the non-SNM R\&D area is located on the southern edge of the Hanford Site and serves as a buffer between certain nuclear activity areas--nuclear fuel cycle and SNM R\&D areas--and the Richland city limits. 
Figure 5-1 Land Use and Functional Location for Low-Case Scenario.

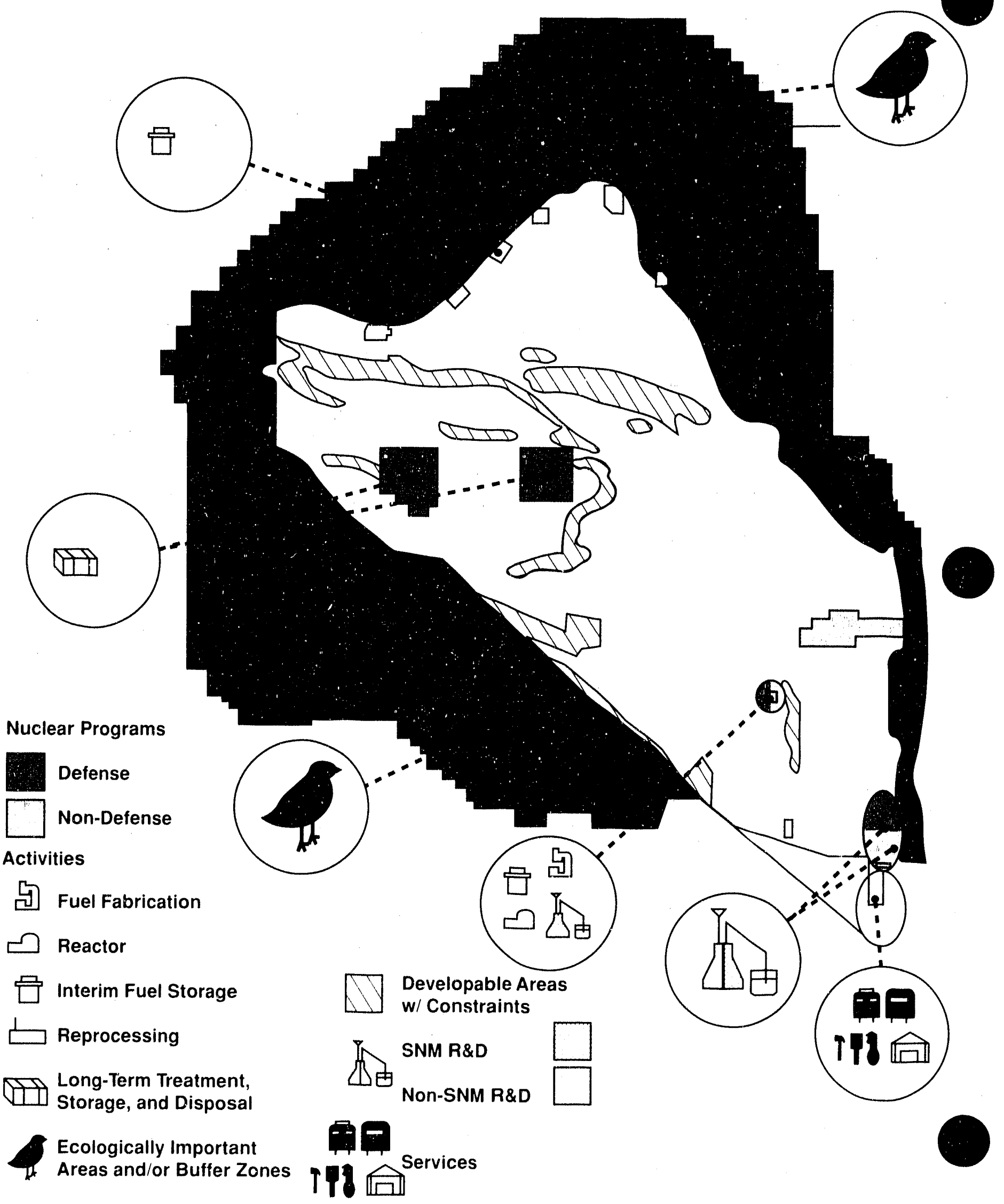


Figure 5-2. Land Use and Functional Location for Medium-Case Scenario.

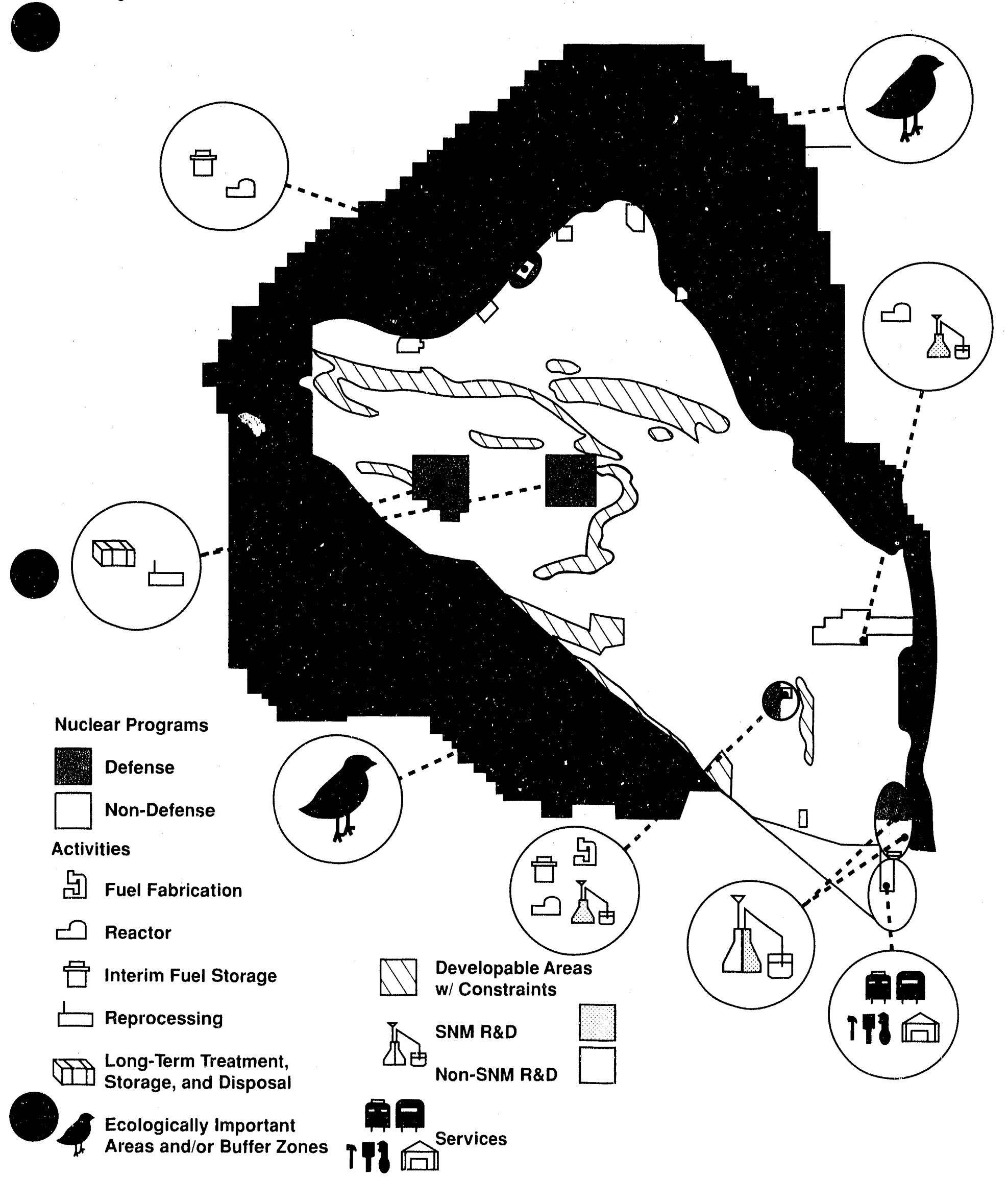


Figure 5-3. Land Use and Functional Location for High-Case Scenario Master Plan

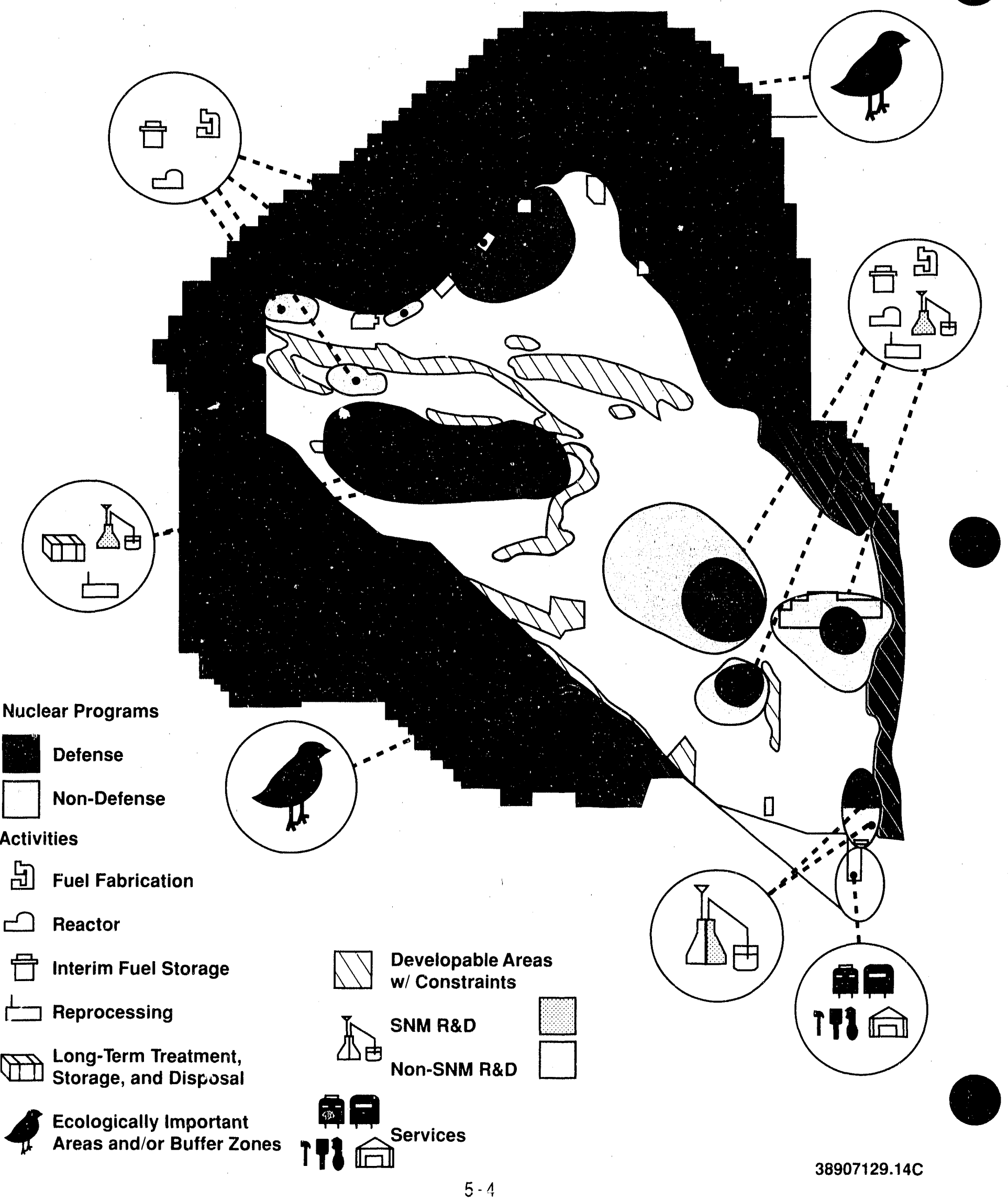


DOE/RL-89-15

Figure 5-4. Ideal Site Plan.
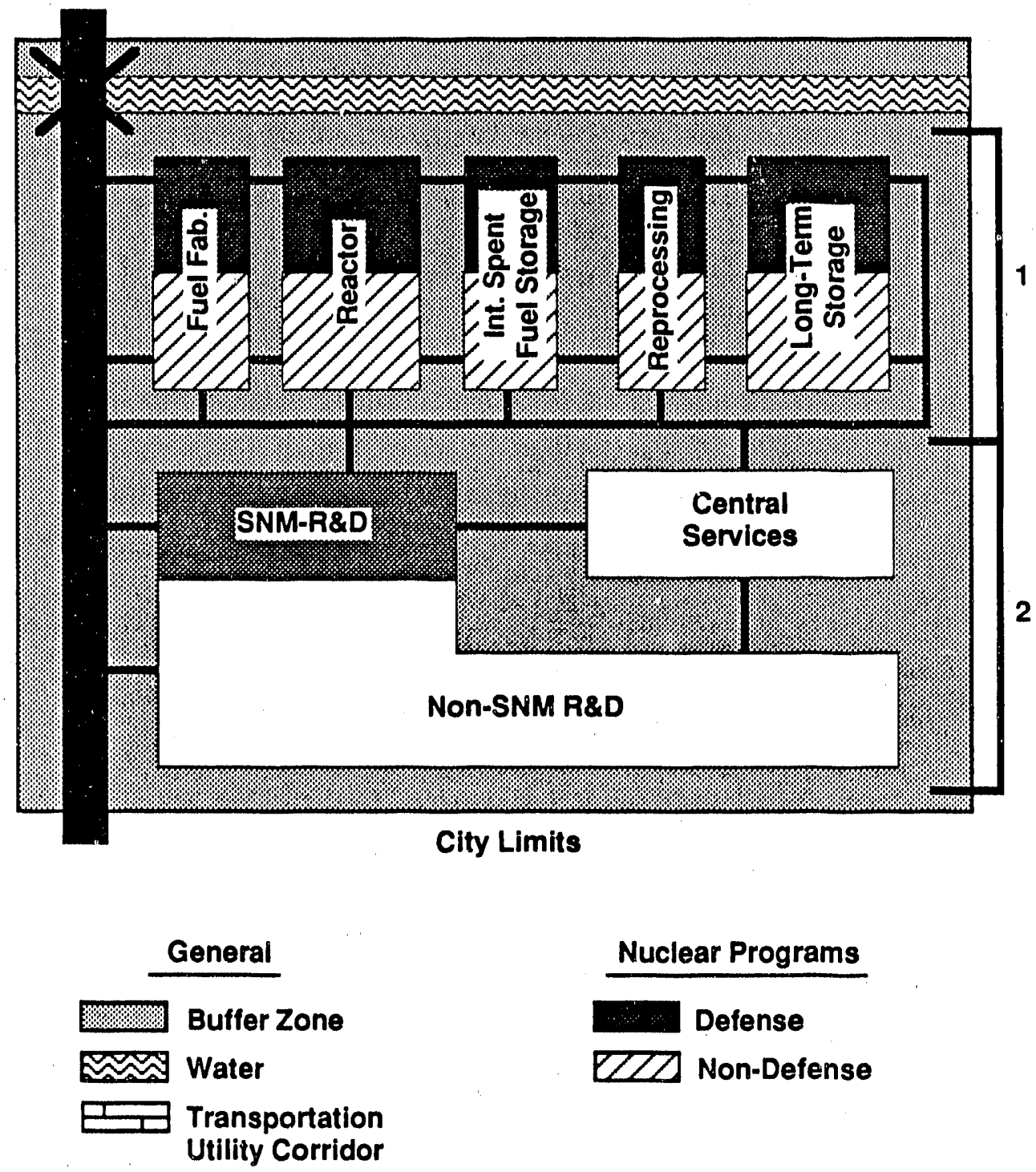

39001069.26 
Ecologically important areas and/or buffer zones are preserved around the periphery of the Hanford Site, except at the 300 Area and Washington Public Power Supply System locations. No changes to the existing boundaries are identified.

Administrative and related support activities are located primarily near the principal activity centers in the central and southern parts of the Hanford Site. Unused land areas will be held in reserve for future potential needs that have not yet been identified.

Functional relationships and siting in the broadest sense are reflected by the Master Plan, whereas detailed area plans, the Local Area Planning Analyses, will be used to convey more specific information.

The Master Plan forms the basic foundation that will guide the development of the Hanford Site. The following subsections show how the Master Plan satisfies the specific goals arid objectives defined in Section 4.0.

\subsubsection{Acquisition Cost}

Facilities are expensive to acquire; they involve long lead times for budgeting and construction. The three planning scenarios identified the range of realistic programmatic activity and resultant facility needs that may occur at the Hanford Site during the next $20 \mathrm{yr}$. Facilities that were not considered realistic during this 20-yr time were not included in the plan because of the anticipated limited funding sources.

\subsubsection{Operation and Maintenance}

The need to decrease operating budget requirements, as well as more stringent justification requirements for new facilities, dictate that existing facility assets be well utilized and well maintained to ensure success in meeting mission requirements. The Master Plan satisfies the goal of reducing costs and improving efficiency by identifying strategically important facilities and areas; conserving, where practical, the use of existing utility systems and associated corridors, road, and railway networks; centralizing similar functions; consolidating work in underutilized facilities and areas; and shutting down unused facilities and areas.

\subsubsection{Design Life}

Once sited, most of the Hanford Site's facilities remain in their original location for the rest of their useful lives. Many of these facilities are used well beyond their intended design lives. Even mobile office trailers have remained at their original sites for many years. The Master Plan accounts for the long-term use of facilities and illustrates long-term optimal locations. 


\subsubsection{Location}

Identifying proper locations for new facilities is very important. For example, it would be costly to build a major facility in what later turns out to be the wrong location, or to construct a waste storage facility on the only site a U.S. Nuclear Regulatory Commission (NRC)-licensed reactor could have been built. Detailed site characterization studies have been performed for many years at the Hanford Site, and additional new studies will likely occur as needed. By identifying the future land use and functional locations in the Master Plan based on known physical constraints and assumed future activities (scenarios), the possibility of locating major facilities in the wrong places is reduced.

\subsubsection{Prioritization/Justification}

Hanford Site goals were identified earlier. In the Master Plan, many of these priorities are met, as noted in the following examples:

- Aggressively pursue environmental restoration throughout the Hanford Site

- Restrict processing and storage of radioactive and mixed waste to the 200 and 400 Areas and adjacent land areas

- Continue to plan and allocate suitable areas of land for future program and facility needs

- Establish the 300 Area and adjacent land areas to the south as the location for the multiprogram R\&D laboratory at the Hanford Site

- Locate fuel fabrication and interim spent fuel storage activities with reactor operations.

\subsubsection{Energy Conservation}

Section 4.8 addressed the intent to centralize functions and consolidate work in underutilized facilities. With this goal in mind, the Master Plan strategy is to gradually relocate activities from the 100 Areas to the central and southern portions of the Hanford Site. This relocation will shorten the travel time for delivery of goods, personnel, and information, which, in turn, will help conserve energy. The shutdown of unused facilities, implied in the Master Plan, will reduce operating and maintenance costs.

\subsubsection{Ecological/Environmental Benefits}

The Master Plan maintains land areas that are considered ecologically/ culturally important and maintains buffer zones for environmentally sensitive activities, such as radioactive waste disposal grounds. 


\subsubsection{Efficiency of Operation}

Locating similar functions and process-related activities together is a major emphasis in the Master Plan. Additional studies are needed to assist development of the Hanford Site at the least cost for labor, material resources, or organizational effort.

\subsubsection{Changing Security and Regulatory Requirements}

In addition to the more traditional site selection criteria discussed in Section 3.10.3, two factors (security and packaging and shipping of radioactive mixed chemicals) will affect future site selections. Changes in both of these criteria will likely force many parts of the nuclear fuel cycle to be sited in one place, where practicable. Constraints on shipping, treatment, storage, and disposal of liquid radioactive mixed chemicals could be an important factor affecting the ability to ship byproducts to another plant for further processing and to do research and sample analyses at centralized locations.

\subsubsection{0 liorking Conditions}

Implementing the Master $\mathrm{Pl}$ an would improve working conditions and employee morale by doing the following:

- Shortening commuting distances to work

- Improving lines of communication by physically locating similar functions closer together

- Enhancing orderly development at the Hanford Site.

Improving the appearance of the work place would also raise employee morale. Numerous aboveground and overhead utilities (e.g., poles, pipes, and wires) are obstacles and, in many cases, unsightly. The 300 Area is a prime example of this. Burying wires and pipes or camouflaging the utilities is proposed, where appropriate. Phasing out the requirement for steam heating, by installing heat pumps in new facilities, will lead to the eventual removal of the deteriorated steam power plant and the labyrinth of steam lines throughout the area. Landscaping consisting of a mixture of trees, plants, low-maintenance groundcovers, and grasses would improve the appearance of the Hanford Site. Architectural standards could be developed and enforced to improve the appearance of facilities. Specific improvements are addressed in the detailed area plans.

\subsubsection{Community Relations}

The Master Plan illustrates the creation of a buffer zone between Hanford Site operations and populated areas, and the relocation of environmentally sensitive activities away from the populated areas. This concept may help contribute to improved community relations. 


\subsubsection{Program Effectiveness}

The goals, assumptions, and possible activity trends that affect program effectiveness were identified in Section 4.0. The optimum arrangement of these programs was evaluated, and the most realistic and beneficial alignment of these functions is shown in the Master Plan. These data will likely stimulate thoughts on further improvements in program effectiveness and can be evaluated in greater detail in the Local Area Planning Analyses and incorporated into future revisions of the Master Plan.

\subsubsection{Cost Effectiveness}

The cost of planning is small when compared to the cost of constructing or operating. Investing in a Master Plan provides a tool to contain programmatic cost increases.

\subsubsection{Space Planning}

The Master Plan builds on the planning analysis discussion (Section 4.0) of three major activity centers at the Hanford Site (near the 200, 300, and 400 Areas). This concept implies that there will be a need for additional studies in these areas to ensure that facilities are adequate for long-term use. For example, detailed assessments may show the need to construct additional permanent office space to support increased programmatic effort. The Master Plan identifies the location of strategically important facilities and, thus, the areas for related support facilities.

\subsection{FUTURE FACILITY/MISSION PLANNING}

Several new facilities and missions are identified in the three activity scenarios discussed in Section 4.0. In many cases, the new facilities/ missions have been assigned to general areas. Only in a few instances have site selection reviews been completed specifically to locate the site of a facility within a particular area.

Table 5-1 identifies the new facilities/missions, the areas in which they are located, and the scenario with which each facility is associated.

Figure 5-5 shows the general locations of the major new facilities proposed for the Hanford Site. The Hanford Site development maps in Appendix $B$ also show the locations of new construction projects that have been proposed during the next 5 yr that change the outline of an existing facility or create standalone space. The Five-Year Plan (Section 6.0) provides additional details about many of these short-range projects. 
Table 5-1. Locations of New Facilities/Missions.

\begin{tabular}{|c|c|c|}
\hline Facility/mission & Area & Scenario \\
\hline $\begin{array}{l}\text { Waste Receiving and } \\
\text { Processing Facility }\end{array}$ & 200 West & $A 11$ \\
\hline $\begin{array}{l}\text { Hanford Waste } \\
\text { Vitrification Plant }\end{array}$ & 200 East & $A 11$. \\
\hline $\begin{array}{l}\text { Environmental and Molecular } \\
\text { Sciences Laboratory }\end{array}$ & 300 & Al1 \\
\hline Space Isotope Production & 400 & A11 \\
\hline Power Systems Fabrication & 400 & A11 \\
\hline New disposal ground & 200 & $M, H$ \\
\hline Special Analysis Facility. & 300 & $M, H$ \\
\hline SP-100 Facility & 300 & $M, H$ \\
\hline $\begin{array}{l}\text { Hazardous Waste Treatment } \\
\text { Facility }\end{array}$ & 300 & $M, H$ \\
\hline $\begin{array}{l}\text { Liquid metal } \\
\text { reactor demonstration }\end{array}$ & 400 & $\mathrm{M}, \mathrm{H}$ \\
\hline $\begin{array}{l}\text { Superconducting Magnetic } \\
\text { Energy Storage }\end{array}$ & 600 & $M, H$ \\
\hline Chemical Processing Facility & 200 East & $H$ \\
\hline Analytical Laboratory & 200 East & $H$ \\
\hline Hanford Computer Center & 300 & $H$ \\
\hline $\begin{array}{l}\text { Weapons return/scrap } \\
\text { receiver }\end{array}$ & 400 & $H$ \\
\hline $\begin{array}{l}\text { Production accelerator } \\
\text { development }\end{array}$ & 400 & $H$ \\
\hline
\end{tabular}

$H=H i g h-$ cast.

$M=$ Medium-case. 
Figure 5-5. Locations of New Facilities.

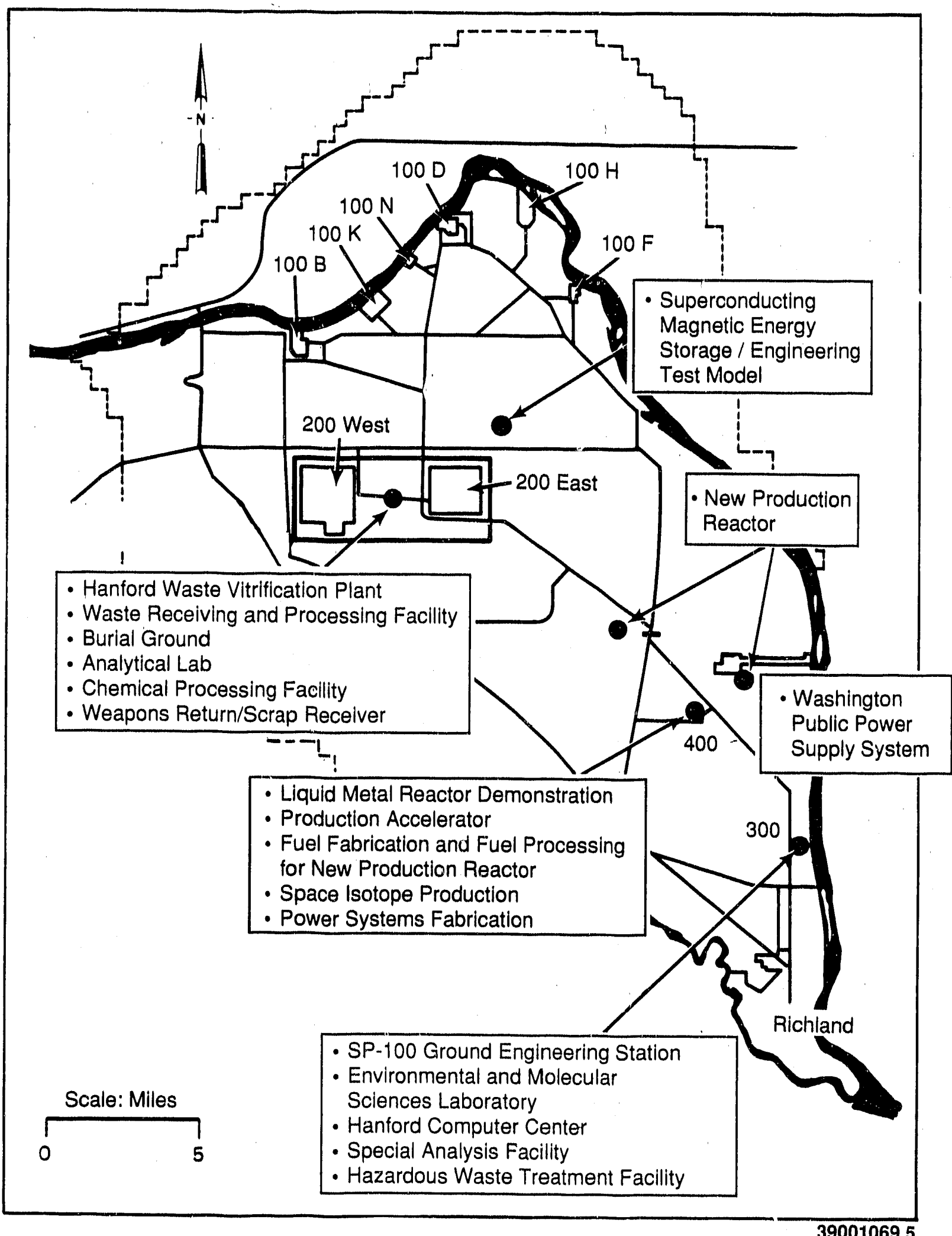




\subsection{UTILITIES}

In the Master Plan, every effort was made to keep the utility and transportation "coridors" from expanding. This will help maintain the amount of land available for future uses. The locations of these corridors are identified in Section 3.0, "Existing Conditions." New facilities are lacated where they can access the services provided by the existing utility and transportation corridors. Locating facilities such as substations within the corridors is permitted, but not encouraged.

The future capacity requirements and sources for the electrical, water, and telecommunications utilities associated with the three planning scenarios are described in the following subsections.

\subsubsection{Electrical Utilities}

In the low-case scenario, no acverse impact on electrical utilities is foreseen. Electrical power demand will likely decrease as production facilities are decommissioned.

In the medium-case scenario, several new facilities are added. Table 5-2 shows the expected electrical requirements for some of these facilities.

\begin{tabular}{|c|c|}
\hline Facility & $\begin{array}{l}\text { Maximum electrical } \\
\text { requirement per } \\
\text { year (MW) }\end{array}$ \\
\hline $\begin{array}{l}\text { Waste Receiving and } \\
\text { Processing Facility }\end{array}$ & $<1.0$ \\
\hline $\begin{array}{l}\text { Hanford Waste Vitrification } \\
\text { Plant }\end{array}$ & 16.5 \\
\hline $\begin{array}{l}\text { Environmental and Molecular } \\
\text { Sciences Laboratory }\end{array}$ & 7.0 \\
\hline
\end{tabular}

The power needs associated with a new production reactor and related support facilities are being studied. This is also the case with other facilities being built in the high-case scenario. Some deficiencies, however, have been identified in the eiectrica? system. For example, al though enough power is available through the Bonneville Power Administration (BPA), a subsiation is needed to meet requirements for projected expansion in the south end of the 300 Area. Proposed cor-active measures are outlined in the Five-Year Plan (Section 6.0). 
The city of Richland and the BPA will continue to be the source of electrical power, as described in Section 3.4. No difficulties are foreseen in obtaining power for facilities in the medium-and high-case scenarios.

\subsubsection{Water Utilities}

The only interarea water system is the export water line described in Section 3.0. This line pumps water from the Columbia River to the 200 Areas in the north-central part of the Hanford Site. Proposed projects that will affect this system include the Waste Receiving and Processing (WRAP) facility and the Hanford Waste Vitrification Plant (HWVP). The water requirements of these facilities are expected to add 1,500 gal/min to the current demand of $22,000 \mathrm{gal} / \mathrm{min}$. The Columbia River will supply the water to meet this additional demand. Physically obtaining an adequate supply of water from the Columbia River for the facilities at the Hanford Site has not been a problem in the past. No foreseeable scarcity of water will affect facility operations.

Current inadequacies in the pumping and distribution system would 1 imit delivery of water to new end uses. Proposed corrective measures are outlined in the Five-Yedr Plan (Section 6.0). In the high-case scenario, an additional export water system may need to be installed to serve the central portion of the Hanford Site, but no further information is available at this $t$; me.

\subsubsection{Telecommunications}

Future trends in telecommunications will continue to provide improved capabilities. No shortage of communications system capability is anticipated if currently planned capabilities are funded and implemented. Telecommunications is categorized into three areas: the general usage data network, the telephone system, and the radio system.

The general usage network will likely become less dependent on the microwave system and will become more dependent on the use of fiber optics as higher speeds, physical and communications security, and capacity requirements affect the system. The microwave system will probably remain as a backup system.

By 1992, a new integrated voice/data telecommunications system will be in place. In the future, a new type of trunked radio system that would permit more efficient use of the radio-frequency spectrum is expected to replace the existing system.

\subsection{FUTURE TRANSPORTATION}

As noted in Section 2.0, the Hanford Site is well served by a regional transportation network that encompasses railroad, air, water, and highway systems. Transportation network capacities are sized to meet any demands associated with Hanford Site activities contemplated in the Master Plan. 
Onsite transportation systems include well-developed road and railroad systems. The Hanford Site is accessible by barges traveling from the Pacific ocean via the Columbia River. Components as large as commercial power reactor vessels for the Washington Public Power Supply System reactors and a nuclear plant stearn generator from the Surrey Reactor in Virginia have successfully been moved onto the Site via ocean-going barges. More recently, reactor compartments from decommissioned Navy submarines have been transported to the Hanford Site for storage.

The Hanford Site highway and railroad systems are located to serve current Hanford Site needs and, with some upgrades, will serve the needs foreseen in the Master Plan. The need for new major alignments is not foreseen, although rail spurs and local access roads would be required under the medium-case and high-case scenarios. Major new projects will include access roads, parking lots, and related traffic control systems.

\subsection{FUTURE SECURITY}

The continued protection of U.S. Department of Energy (DOE) facilities, materials, and information at the Hanford Site will remain the mission of the Hanford Site Safeguards and Security Program under the Master Plan.

\subsubsection{Hanford Site Safeguards and Security Program}

The Hanford Site Safeguards and Security Program will be structured to provide appropriate security measures to meet DOE and regulatory requirements applicable to each Hanford Site operating area. Development and application of appropriate security systems and security practices for each operating area will continue to be based on DOE threat guidance, specific threat and target analyses, and thorough evaluations of assumed risks and target vulnerabilities.

A coordinated Hanford Site security posture will be maintained to ensure that appropriate and compatible security nrocedures and systems are provided. These procedures will be tailored to the specific needs of individual operating locations within the Hanford Site.

\subsubsection{Safeguards and Security Planning Bases}

As discussed in Section 4.0, three different scenarios have been identified to cover the range of activities likely to occur at the Hanford site during the next $20 \mathrm{yr}$. The following sections describe security planning impacts associated with each of these scenarios.

5.5.2.1 Safeguards and Security Planning Impacts for the Low-Case Scenario. Under the low-case scenario, the Hanford Site's defense mission would end and nuclear materials production operations would cease. A corresponding major reduction in the overall Hanford Site Safeguards and Security Program would also occur. Security activities would then primarily consist of providing an "industrial security" level of protection for inactive facilities, as 1011 as appropriate security measures for the R\&D activities remaining at the Hanford Site. Greater emphasis would be placed on automated

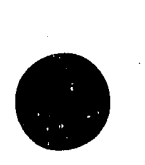


systems to reduce the costs of the protective force. The presumed broadbased reductions in the Hanford Site activities would occur gradually enough to allow properly coordinated and managed cutbacks in corresponding safeguards and security activities.

\subsubsection{Safeguards and Security Planning Impacts for the Medium-Case} Scenario. A major characteristic of the medium-case scenario is the maintenance of existing production and support facilities for the short term. Security planning would focus on the clear need for a shift from the existing, widely dispersed Hanford Site operations to more centralized and consolidated activity centers. Such an arrangement would parallel the Ideal Site Plan, in which facilities closest to populated areas are reserved for R\&D or administrative uses and nuclear fuel cycle activities are located farthest from populated areas and grouped with other closely related activities.

Current administrative and support functions, which are associated with operations, would gradually migrate from the 100 Areas to the existing 200 and 400 Areas. Waste storage and disposal functions would be centralized and consolidated in the 200 Areas. The existing 400 Area would be broadened to accommodate all production activities, which is consistent with the idealized goal to centralize and isolate such functions from populated areas. The 400 Area would encompass previously identified prime sites for any new reactor facilities and the adjacent commercial reactor site presently identified as a candidate for conversion to a production reactor. Land around each of these consolidated functional areas would be maintained as buffer zones.

Consolidating like functions into these specialized activity canters takes advantage of similar siting requirements for similar facilities and produces significant economies because of the improved functional arrangerient of activities that are located together. This sort of general site consolidation also promotes the most effective utilization of security resources because the largely homogeneous facilities in each operating area would share common safeguards and security requirements and would need similar physical protection systems. Likewise, uniform and consistent security procedures and practices could be developed and applied, because of the similarity of facilities and activities at a given operating area.

\subsubsection{Safeguards and Security Planning Impacts for the High-Case Scenario.} Security planning impacts applicable to the high-case scenario include (1) construction and operation of a new production reactor or accelerator and support facilities, (2) construction and operation of new fuel fabrication and processing facilities, and (3) construction of new analytical facilities to support production. This scenario represents the situation in which the greatest change in overall site security conditions might be envisioned. The technological and procedural advancements discussed here would also be applicable to the medium-case scenario.

5.5.2.3.1 Planned Security Zones in the High-Case Scenario. The land surrounding each of the future functional operating areas will be maintained as buffer zones. Even though the new consolidated areas will be larger, the areas will still be relatively widely dispersed within the Hanford Site boundaries. The large buffer zones will be more effective because the more security-sensitive operations will be concentrated nearer to the center of the Hanford Site. 
All planning scenarios include assumptions of continued maintenance of the special-use land areas adjacent to the Hanford Site. The Arid Lands Ecology Reserve (ALE) on the southwest side of the Hanford Site and the controlled-access recreation area and the state game refuge on the north side of the Hanford Site will be maintained throughout the 20-yr planning period. These areas will continue to provide large buffer zones around most of the Hanford Site boundary. General public access to the Hanford Site, currently permitted up to the Wye Barricade, will not be allowed beyond the perimeter of the expanded 400 Area.

Appropriate security zones, as described and defined in Section 3.6, will be established in each of the operating areas. As a minimum, the perimeter of each area will be designated as a Limited Area. Most of the new facilities in the 200 and 400 Areas will be enclosed within Protected Areas and access will be limited to persons who have a legitimate need for such access. However, the number of separate Protected Areas and security zones in each area will be minimized to be consistent with the inherent need for minimizing the overall size of a given security zone, thus allowing efficient access control. The efficiencies gained by enclosing similar facilities into a single Protected Area or security zone must always be balanced against the resultant logistics difficulties associated with such physical protection measures. Also, future facilities and security areas should be designed to limit the worker population to the minimum number needed to efficiently perform the work. This action will significantly reduce the target exposure and reduce the cost of safeguards and securitj' measures at the new facilities.

5.5.2.3.2 Planned Fences in the High-Case Scenario. Security fences will be maintained around each operating area. As a minimum, a single-fence perimeter (Limited Area) will be maintained. Two fences with a minimum clear isolation zone of $100 \mathrm{ft}$ between them and at least $100 \mathrm{ft}$ from all buildings, if possible, will surround designated Protected Areas. To the extent practical, the total length of fence line for a given security zone should be held to a minimum to reduce continuous surveillance needs and costs. However, zones also must be large enough to provide necessary detection and delay times. The zones should also allow for facility/mission expansion within existing boundaries.

The typical configuration of security fences (chainlink fencing topped with barbed wire outriggers with an 8-ft total height) has changed little since the World War II era when the Hanford Site was established. However, it is reasonable to expect that new fencing configurations will be developed in the future. As technology developments advance, the state of the art, more automated intrusion detection and monitoring devices will be incorporated into fence systems.

5.5.2.3.3 Planned Lighting in the High-Case Scenario. The type of security lighting used in each operating area will remain similar to that presently used. Low-energy consumption lighting will be used to produce the best uniform light levels available at reasonable cost. However, the minimum lighting levels required by standards and regulations can be expected to increase for future instaliations because of the continued improvements in outdoor lighting technology. 
Perimeter and yard lighting will be provided for new or upgraded security zones, with adequate consideration given to the following.

- Lighting must provide adequate and uniform visibility for human and/or automated surveillance of the security zone involved.

- The total energy consumption of lighting installations must be carefully evaluated and maintained as low as practicable.

- Provisions should be made to reduce the interference of installed outside lighting with night vision levels available inside security guard stations, i.e., the effects of reflected glare should be minimized to enhance the effectiveness of visual surveillance activities.

5.5.2.3.4 Planned Barriers in the High-Case Scenario. Increased emphasis will be placed on incorporating effective barriers into future Hanford Site physical protection system installations. In the near term, the types of barriers described in Section 3.6 of this plan will continue to be used. This particular area of security technology can be expected to advance in response to the worldwide spread of terrorism. Hanford Site security personnel will continue to follow and evaluate new developments in barrier technology for application to the Hanford Site's special protection needs. Special consideration will be given to the advancement and application of unobtrusive, effective barriers and access denial systems that can be manually or automatically deployed when needed.

5.5.2.3.5 Planned Portals in the High-Case Scenario. The primary focus for future access control to designated security zones will be the application of increasingly automated access control portals that can be easily and fully integrated into the existing security and instrumentation systems at a given facility. These portals also will employ fully integrated security subsystems such as explosives detectors, SNM detectors, metal detectors, biometrics identity verification equipment (e.g., retina scan, hand geometry, fingerprint scan), package inspection, and access control and identification equipment, as appropriate to the particular security zone.

Access control portals will be provided for new or upgraded security zones with adequate consideration given to the following.

- Portal equipment detection probabilities must be maximized consistent with reasonable cost and the acceptability of recognized vulnerabilities.

- Interferences between individual pieces of installed portal detection equipment must be minimized.

- Processing times for access portals and overall access control systems must be as short as possible, consistent with a sufficiently high detection ensurance. 
- The number of access points for a given security zone must be minimized, consistent with the operating needs of the specific area. The advances expected in portal technology should be fully utilized to minimize the more traditional reliance on the protective force.

- Portal designs should be standardized based on proven operating demonstration.

5.5.2.3.6 Other Improvements in the High-Case Scenario. Future safeguards and security provisions will involve greater reliance on automated systems to reduce costs for security measures. The Hanford Site will rely on automated equipment for security zone surveillance, access control and personnel accountability, intrusion and contraband detection, and nuclear materials accountability. Future activities will focus increasing attention on Material Control \& Accountability (MC\&A) systems and on the implementation of human reliability programs.

Safeguards and security covers a range of activities designed to deter, prevent, detect, and delay unauthorized access, theft, diversion, or sabotage of SNM, classified matter, and DOE property. These activities include the development and application of technical systems and procedures for physical protection to prevent unauthorized access to SNM and systems providing quantitative data on the location and use of SNM, i.e., MC\&A measures.

During the last few years, requirements to mitigate the threat from potential inside adversaries have significantly increased. Future requirements are expected to place even greater emphasis on meeting the threat from insiders. Insider threat is generally countered by human reliability measures (e.g., security clearances, preemployment screening, and psychological testing), nuclear MC\&A systems, and physical protection systems and procedures (access controls, personnel search techniques, interior barriers, personnel identification systems, and surveillance techniques). More stringent rules, regulations, orders, and standards related to countering the insider threat are expected.

In the future, security planning activities will take full advantage of vulnerability assessment techniques and cost-risk-benefit analyses to allow for application of proper and uniform protective measures at DOE facilities.

\subsection{FUTURE SAFETY}

Environmental, safety, and health protection will continue to receive emphasis and priority as an integral part of the DOE programs and policies executed by DOE-Richland Operations office (RL).

\subsubsection{Policy and Organization Responsibilities}

The primary responsibility for protecting the environment and government property and ensuring the health and safety of the emplnyees and the public will continue to rest with line management in the DOE-RL and Hanford Site contractor organizations. The operations and engineering contractor is 
responsible for emergency response to any abnormal conditions and for the operation of the Hanford Site's Emergency Control Centers.

The DOE and contractor management are dedicated to the assurance of a safe and healthy workplace, the protection of the environment, the safety and health of the public, and the protection of government property. Plans and actions will be formulated and implemented for achieving and maintaining Hanford Site-wide compliance to DOE and regulatory requirements.

\subsubsection{Safety Considerations for Principal Hanford Site Facilities}

Many Hanford Site facilities were constructed as long ago as World War II and are still in use. These facilities, and others built during subsequent years, were designed and constructed according to standard practices applicable at the time of construction. Since construction, information on impacts associated with natural forces (e.g., earthquakes, tornadoes) has substantially increased. As a consequence, codes and standards have become increasingly stringent, requiring major upgrades if they are to be raised to contemporary standards.

The Hanford Site policy, for the period covered by this Master Plan and beyond, is that any facility or system identified as deficient relative to contemporary safety codes and standard design criteria, which ensure mitigation under natural forces, will be handled in one of the following ways:

- Be modified and upgraded to meet current requirements, if cost effective and necessary to maintain required margins

- Continue to operate if within acceptable risk operating constraints

- Be downgraded to a lower acceptable use

- Be replaced with a facility or system meeting applicable criteria

- Be shut down for future decontamination and decommissioning (D\&D).

The resolution of the future status of an existing facility will be based on the risk of continued or restricted operation, feasibility and cost of upgrading or replacement, and/or impact on the DOE program goals, if shut down. New facilities and systems will be constructed and operated in accordance with all applicable criteria.

5.6.2.1 Low-Case Scenario. Many of the facilities identified for operational curtailment under this scenario are older facilities that were designed and constructed to less stringent criteria. Shutdown of operations and removal of radionuclide inventories from those facilities would eliminate any future need or costs to upgrade them. Removal of radionuclide inventories would require the disposal, storage, or transfer of the inventories to facilities where they would be adequately retained and protected. A facility in shutdown status, before D\&D, will be under periodic surveillance to ensure that adequate control of any remaining residual hazards is maintained. 
Facilities, which continue operating to achieve DOE programmatic goals, will be assessed on the basis of risk of continued or constrained operation and/or the feasibility of modifying or upgrading the facility or its systems to meet contemporary requirements.

5.6.2.2 Medium-Case Scenario. New or upgraded facilities would comply with applicable design and construction criteria. The cost and feasibility of upgrading facilities would be assessed on a case-by-case basis.

The key systems of the Fast Flux Test Facility (FFTF) were built to appropriate contemporary standards and will continue operation with the system improvements expected of any operating reactor.

The Plutonium Finishing Plant (PFP) operation is contingent on demonstration that the risks associated with its continued operation are acceptable. The Plutonium-Uranium Extraction (PUREX) nitrate and offsite scrap processing would continue at the PFP until capability could be transferred to a facility, such as the Fuels and Materials Examination Facility (FMEF), meeting all contemporary design criteria.

5.6.2.3 High-Case Scenario. Action plans under this scenario are similar to those for the medium-case scenario. Existing facilities would be upgraded as necessary to meet contemporary requirements. The PFP would be replaced by a facility that meets contemporary design criteria. Until replaced, the PFP would operate with appropriate modification or upgrades to ensure that associated risks are acceptable.

A new reactor and related support facilities would be built to NRC and applicable standards. The reactor would employ full containment for cores and vessels.

\subsection{FUTURE ENVIRONMENTAL ISSUES}

Major potential future environmental issues include the following.

- Bills are being considered to allow Washington State to regulate and permit the transport of radioactive materials within the state.

- It is yet to be decided whether the treated effluent disposal systems will discharge to the soil or to the Columbia River.

- The U.S. Environmental Protection Agency (EPA) may authorize Washington State to regulate water discharges at federal facilities.

- Results of studies commissioned by the Hanford Reach Study Act (PL 100-605) could impact development of the Columbia River and adjacent lands.

- A "pay as you go" proposal is being discussed with Congress that would require that funds for waste disposal be set aside out of the nuclear production budget. 
None of these potential future requirements would preclude any of the alternatives considered in Section 4.0. The impacts of the above issues are summarized for each planning scenario considered.

\subsubsection{Low-Case Scenario}

Under the low-case scenario, nuclear materials production would be terminated and the Hanford Site activities would include waste treatment/ storage/disposal, decommissioning, and research. Water discharge would be an important issue. Transport of radioactive waste offsite for disposal, depending on the location of the first repository, could be regulated by the state. The state would control transport routes and permits and inspect shipments. Washington State would regulate the dangerous and extreme $7 y$ hazardous waste. Extremely hazardous waste cannot be disposed in Washington State because no approved disposal facility exists for such waste (WAC 173-303). There are currently no United States facilities that are commercially licensed to dispose of mixed waste. The Hanford Site has submitted Part B applications for mixed-waste disposal facilities.

\subsubsection{Medium-Case Scenario}

Waste disposal activities would proceed as outlined in the environmental impact statement for Hanford Site defense waste (DOE 1987). All of the issues noted under the low-case scenario would apply. The impacts in all cases would be to increase the costs of activities to comply with state requirements and to pay for waste disposal associated with production. New facilities would need to include effluent recycling systems to reduce or eliminate water discharges.

\subsubsection{High-Case Scenario}

The applicability of the issues would be identical to those of the lowand medium-case scenarios; however, the costs would be greater because of the additional facilities and operations.

\subsection{REFERENCES}

DOE, 1987, Final Environmental Impact Statement: Disposal of Hanford Defense High-Level and Transuranic Tank Wastes, DOE/EIS-0113, Volumes 1-5,

U.S. Department of Energy, Washington, D.C.

Dangerous Waste Regulations, WAC 173-303. 
DOE/RL-89-15

\subsection{FIVE-YEAR PLAN}

The Five-Year Plan is a short-range, facilities oriented, implementation plan for the long-term strategies and objectives established by the Planning Analysis (Section 4.0) and the Master Plan (Section 5.0). The Five-Year $\mathrm{Pl}$ an describes and locates specific projects that are scheduled within fiscal year (FY) 1990 through FY 1994, as well as any other facility-related actions that may be required. Except for Hanford Surplus Facilities Program (HSFP) and Strategic Facilities Utilization Program (SFUP) [formerly Strategic Facilities Initiative (SFI)] projects, project information presented in the Five-Year Plan is limited to projects proposed for line item (LI) or general plant project (GPP) funding.

This Five-Year Plan is presented in seven sections that correspond to the seven facilities goals outlined in Section 4.1.3. Fach section is further divided to show what facilities actions are planned for each scenario described in the Planning Analysis. Facilities actions are presented in tabular format showing the proposed funding year, project number, and project title. The appearance of "XXX" in the Project Number column indicates that a project number has not yet been assigned. The location for new construction project: and demolition projects can be found on the maps in Appendix B. A more detailed description of each project can be found in Appendix C.

The projects listed for each scenario in the following sections build on previous scenarios. That is, the medium-case scenario assumes that projects in the low-case scenario will also be accomplished. In the same manner, the high-case scenario assumes that projects in the low- and medium-case scenarios will be accomplished.

\subsection{GOAL NUMBER 1}

Goal No. 1 is to renovate existing facilities or construct new facilities based on their life cycle plan, cost effectiveness, and functional requirements. There are approximately 1,100 buildings on the Hanford Site. The approach for meeting this goal will be directed toward developing and implementing a program for performing effective inspections and making accurate facility condition assessments. Activities resulting from the recently initiated Capital Assets Management Program will also help achieve this goal.

Facility upgrades necessary for regulatory compliance are included in projects that contribute to achievement of this goal. Projects such as those that are part of the Hanford Environmental Compliance (HEC) LI or that comply with the terms and objectives of the Tri-Party Agreement are assumed to be included in all scenarios. Tables 6-1, 6-2, and 6-3 list the renovation and upgrade projects that contribute to this goal in the low-, medium- and high-case scenarios, respectively. Projects listed in Section 6.2 related to locating new facilities will also contribute to the achievement of this goal. 
Table 6-1. Goal Number 1--Low-Case Projects. (sheet 1 of 3 )

\begin{tabular}{|c|c|c|c|}
\hline Year & Project No. & Project title & $\operatorname{TEC}(\$ K)$ \\
\hline $\begin{array}{l}1989 \\
1989 \\
1989 \\
1989\end{array}$ & $\begin{array}{l}89-R-111 \\
B-629 \\
B-696 \\
C-028\end{array}$ & $\begin{array}{l}\text { Building Utilities, Phase I } \\
\text { Route } 4 \text { S/Wye Road Improvement } \\
\text { Steam Plant Electrical Upgrade } \\
\text { Building } 2706-T \text { HEPA Exhaust Sys. Upgrade, } \\
\text { Phase I }\end{array}$ & $\begin{array}{r}3,000 \\
784 \\
620 \\
960\end{array}$ \\
\hline $\begin{array}{l}1989 \\
1989 \\
1989 \\
1989 \\
1989 \\
1990 \\
1990 \\
1990 \\
1990 \\
1990 \\
1990\end{array}$ & $\begin{array}{l}F-010 \\
F-012 \\
F-013 \\
F-014 \\
L-005 \\
B-468 \\
B-631 \\
B-634 \\
B-690 \\
C-023 \\
C-031\end{array}$ & $\begin{array}{l}\text { Solid Waste Cask Upgrade } \\
\text { MASF Building Cask Loading Station } \\
\text { Open Waste Container Storage Cell } \\
\text { MASF Building Upgrades } \\
\text { Water System Upgrade, } 200 \text { East Area Laterals } \\
\text { Railroad Upgrade Mainline } \\
\text { PFP Fire Protection \& Loss Limitation (LI) } \\
\text { PFP Nitrate Handling System (LI) } \\
\text { Stealn System Safety and Productivity Upgrade } \\
\text { Enclosed Material Handling } \\
\text { PFP Liquid Effluent Treatment Facility } \\
\text { (HEC LI) }\end{array}$ & $\begin{array}{r}350 \\
1,200 \\
184 \\
647 \\
900 \\
10,700 \\
3,300 \\
9,300 \\
3,100 \\
1,000 \\
18,000\end{array}$ \\
\hline $\begin{array}{l}1990 \\
1990 \\
1990 \\
1990 \\
1990 \\
1990 \\
1990\end{array}$ & $\begin{array}{l}C-076 \\
E-019 \\
L-001 \\
L-006 \\
L-007 \\
L-035 \\
L-046\end{array}$ & $\begin{array}{l}2706-T \text { Conditioned Air Supply } \\
300 \text { Area Coal Handling Efficiency Upgrades } \\
\text { Fire Water Storage \& Distribution Upgrades } \\
\text { Route } 3 / 4 \text { S Intersection Safety Improvement } \\
\text { Water System Safety Conipliance, } 200 \text { West Area } \\
\text { Safety Compliance, Phase I }(\$ 28,600 K) \\
300 \text { Area Emergency Elec. Sys. Safety \& } \\
\text { Reliability Upgrades }\end{array}$ & $\begin{array}{r}615 \\
1,130 \\
1,800 \\
1,100 \\
900 \\
0 \\
1,150\end{array}$ \\
\hline 1990 & $W-001$ & $\begin{array}{l}\text { 222-S Ventilation and Electrical System } \\
\text { Upgrade, W-001 }\end{array}$ & 6,300 \\
\hline $\begin{array}{l}1990 \\
1990 \\
1990 \\
1990 \\
1990\end{array}$ & $\begin{array}{l}W-056 \\
W-066 \\
W-093 \\
X X X \\
X X X\end{array}$ & $\begin{array}{l}\text { B-Plant NCAW Process Control Upgrade, W-056 } \\
\text { AZ Tank Farm Electrical Upgrade, W-066 } \\
\text { HEHF Facilities Upgrades } \\
\text { EUO }_{2} \text { Pellet Pressing Process Station } \\
\mathrm{EUO}_{2} \text { Sintering/Debind and Characterization } \\
\text { Stations }\end{array}$ & $\begin{array}{r}1,200 \\
700 \\
1,200 \\
1,000 \\
700\end{array}$ \\
\hline $\begin{array}{l}1990 \\
1990\end{array}$ & $\begin{array}{l}x X X \\
X X X\end{array}$ & $\begin{array}{l}\text { FFTF Operational Assurance Program } \\
\text { Fuel Assembly Equipment } \\
\text { Installation/Connection }\end{array}$ & $\begin{array}{r}1,800 \\
300\end{array}$ \\
\hline 1990 & $x x x$ & $\begin{array}{l}\text { Pu- } 238 \text { Production in FFTF (Space Isotope } \\
\text { Program) }\end{array}$ & 51,500 \\
\hline $\begin{array}{l}1991 \\
1991\end{array}$ & $\begin{array}{l}91-E-322 \\
B-524\end{array}$ & $\begin{array}{l}329 \text { Building Compliance } \\
300 \text { Area Elect Distr Conver \& Safety } \\
\text { Improvements, Phase l }\end{array}$ & $\begin{array}{l}7,300 \\
6,500\end{array}$ \\
\hline $\begin{array}{l}1991 \\
1991 \\
1991 \\
1991 \\
1991 \\
1991\end{array}$ & $\begin{array}{l}C-X X X \\
D-395 \\
L-008 \\
W-027 \\
W-041 \\
W-124\end{array}$ & $\begin{array}{l}\text { 211-U Chemical Storage Area Upgrade } \\
\text { Safety Compliance } \\
\text { Building Fire Alarm System Improvements } \\
271-B \text { HVAC Upgrade } \\
\text { Environmental Hot Cell Expansion } \\
\text { 222-S Wastewater BAT (Best Available } \\
\text { Technology) }\end{array}$ & $\begin{array}{r}520 \\
950 \\
900 \\
950 \\
16,400 \\
520\end{array}$ \\
\hline
\end{tabular}


Table 6-1. Goal Number 1--Low-Case Projects. (sheet 2 of 3)

\begin{tabular}{|c|c|c|c|}
\hline Year & Project No. & Project title & TEC (\$K) \\
\hline $\begin{array}{l}1992 \\
1992 \\
1992 \\
1992 \\
1992 \\
1992 \\
1992 \\
1992 \\
1992\end{array}$ & $\begin{array}{l}92 D-X X X \\
92 D-X X X \\
92 D-X X X \\
92 D-X X X \\
92 D-X X X \\
92 L-E R D-X X X \\
C-004 \\
L-017 \\
L-019\end{array}$ & $\begin{array}{l}\text { Environmental Upgrade } \\
\text { Nonradioactive Liquid Effluent Monitors } \\
\text { Radiological Exhaust Air Sampler } \\
\text { Radionuclide Liquid Effluent Monitors } \\
\text { Safety Upgrades } \\
326 \text { Building Safety Compliance } \\
\text { PRF Organic Cleanup } \\
200 \text { East Steam System Rehabilitation, Phase II } \\
\text { Road, Ground, \& Lighting Safety Improvements, } \\
300 / 1100 \text { Areas }\end{array}$ & $\begin{array}{r}1,100 \\
900 \\
600 \\
400 \\
900 \\
4,000 \\
650 \\
36,000 \\
7,200\end{array}$ \\
\hline $\begin{array}{l}992 \\
992\end{array}$ & $\begin{array}{l}\mathrm{L}-020 \\
\mathrm{~L}-047\end{array}$ & $\begin{array}{l}\text { Steam Plant Upgrade, } 200 \text { East } \\
300 \text { Area Elect Distr Conver \& Safety } \\
\text { Improvements. Phase II }\end{array}$ & $\begin{array}{r}1,100 \\
12,600\end{array}$ \\
\hline $\begin{array}{l}1992 \\
1992 \\
1992 \\
1993 \\
1993 \\
1993 \\
1993 \\
1993 \\
1993\end{array}$ & $\begin{array}{l}L-X X X X \\
X X X X \\
X X X X \\
93 D-X X X X \\
93 D-X X X \\
L-024 \\
L-025 \\
L-X X X \\
L-X X X\end{array}$ & $\begin{array}{l}384 \text { Building Electrical Upgrades } \\
\text { Environmental Corrective Activities } \\
\text { Waste Source Control and Minimization } \\
\text { Fire Protection } \\
\text { Work Place Air Monitoring } \\
\text { Export Water Diesel Pump Upgrade } \\
\text { Railroad Upgrade-Richland Yard } \\
300 \text { Area Condensate System Replacement } \\
300 \text { Area Steam Line Support Pole Safety } \\
\text { Improvements }\end{array}$ & $\begin{array}{r}900 \\
2,700 \\
1,100 \\
600 \\
800 \\
3,000 \\
8,000 \\
1,000 \\
880\end{array}$ \\
\hline $\begin{array}{l}1993 \\
1993\end{array}$ & $\begin{array}{l}L-X X X X \\
L-X X X\end{array}$ & $\begin{array}{l}300 \text { Area Steam, Water and Electrical Meters } \\
\text { Steam Plant Emergency Generator Upgrade, } 200 \\
\text { East Area }\end{array}$ & $\begin{array}{r}650 \\
1,000\end{array}$ \\
\hline 993 & $\begin{array}{l}L-X X X X \\
W-087\end{array}$ & $\begin{array}{l}\text { Steam Plant Structural Improvements, } 300 \text { Area } \\
222-S \text { Radioactive Liquid Waste Line } \\
\text { Replacement }\end{array}$ & $\begin{array}{r}1,100 \\
14,000\end{array}$ \\
\hline $\begin{array}{l}1993 \\
1993 \\
1994 \\
1994 \\
1994 \\
1994 \\
1994 \\
1994 \\
1994 \\
1994 \\
1994\end{array}$ & $\begin{array}{l}W-095 \\
X X X \\
94 D-X X X X \\
94 D-X X X X \\
B-636 \\
C-021 \\
C-X X X \\
C-X X X \\
L-X X X \\
L-X X X \\
L-X X X\end{array}$ & $\begin{array}{l}\text { TRUEX Process in B Plant } \\
\text { Waste Source Control and Minimization } \\
\text { Fire Separations } \\
\text { Life Safety Code Upgrades } \\
\text { PFP Services and Utilities Upgrade } \\
\text { B-636 PFP Services \& Utilities (LI) } \\
\text { RCRA/CERCLA (LI) } \\
\text { T Plant Ventilation Upgrade } \\
\text { Building Utilities Replacement, } 300 \text { Area } \\
\text { Export Water Line Replacement, } 300 \text { Area } \\
\text { Steam Plant Electrical Safety Improvements, } \\
300 \text { Area }\end{array}$ & $\begin{array}{r}170,000 \\
1,100 \\
5,000 \\
3,000 \\
10,000 \\
10,000 \\
2,000 \\
12,000 \\
4,000 \\
3,000 \\
1,100\end{array}$ \\
\hline $\begin{array}{l}1994 \\
1994 \\
1995 \\
1995 \\
1995\end{array}$ & $\begin{array}{l}L-X X X X \\
L-X X X \\
95 D-X X X X \\
95 D-X X X X \\
C-X X X\end{array}$ & $\begin{array}{l}\text { Steam Plant Upgrade, } 200 \text { East } \\
\text { Steam System Rehabilitation, Phase III } \\
\text { Fire Protection } \\
\text { Work Place Air Monitoring } \\
\text { B-641 Protected Area S\&S Upgrade (LI) }\end{array}$ & $\begin{array}{r}1,100 \\
15,000 \\
600 \\
800 \\
4,000\end{array}$ \\
\hline
\end{tabular}


Table 6-1. Goal Number 1--Low-Case Projects. (sheet 3 of 3 )

\begin{tabular}{llllr}
\hline Year & Project No. & \multicolumn{1}{c}{ Project title } & TEC (\$K) \\
\hline 1995 & C-XXX & PFP Ventilation \& Filtration Upgrade & (LI) & 18,000 \\
1995 & L-XXX & 300 Area Alternative 115 KV Source & 5,000 \\
1995 & L-XXX & Primary Substation Ground Grid Replacement & 1,000
\end{tabular}

** Total **

527,360

CERCLA = Comprehensive Environmental Response, Compensation, and Liability Act.

FFTF = Fast Flux Test Facility.

$H E C=$ Hanford environmental compliance.

HEHF = Hanford Environmental Health Foundation.

HEPA = high-efficiency particulate air (filter).

HVAC = heating, ventilation, and air conditioning.

LI = line item.

MASF = Maintenance and Storage Facility.

NCAW = neutralized current acid waste.

PFP = Plutonium Finishing Plant.

PRF = Plutonium Reclamation Facility.

RCRA = Resource Conservation and Recovery Act.

S\&S = Safeguards and Security.

TRUEX = transuranic (waste) extraction. 
Table 6-2. Goal Number 1--Medium-Case Projects.

\begin{tabular}{|c|c|c|c|}
\hline Year & roject No. & Project title & TEC (\$K) \\
\hline & $\begin{array}{l}X X X \\
D-387 \\
D-392 \\
L-009 \\
L-059 \\
W-064 \\
X X X \\
B-582 \\
L-010 \\
L-015 \\
L-021\end{array}$ & \multirow{3}{*}{$\begin{array}{l}\text { Radioactive Solid Waste Tracking System } \\
\text { Laboratory Addition, } 318 \text { Building } \\
\text { Refrigerated Air Conditioning, } 325 \text { Building } \\
\text { Steam Plant Upgrade, } 200 \text { East } \\
300 \text { Area Ash Pond Replacement } \\
\text { B Plant Waste Minimization Upgrades } \\
\text { Long Test Assembly } \\
\text { Street and Fence Lighting, } 200 \text { Areas } \\
\text { Water System Instrument Upgrades } \\
\text { Route } 3 / 11 \text { I Intersection Safety Improvement } \\
\text { Route } 4 \text { S/Central Landfill Intersection Safety } \\
\text { Improvement } \\
200 \text { Area Electrical Distribution Upgrade } \\
3000 \text { Area Sanitary Water System Upgrades } \\
\text { Repave } 3000 \text { Area Roads } \\
\text { Standards Laboratory Expansion, 300 Area } \\
\text { Buildiny } 616 \text { Upgrades } \\
\text { Building } 331 \text { Renovation } \\
325 \text { Building Facility Compliance/Renovation } \\
\text { Route } 11 A / 200 W \text { North Gate Intersection Safety } \\
\text { Improvement } \\
272-W \text { Pipe/Machine Shop Electrical Upgrades } \\
300 \text { Area Wood Building Weatherization } \\
\text { Building Utilities, Phase II } \\
300 \text { Area Process Sewer Main Upgrades } \\
\text { Building } 324 \text { Facility Compliance/Renovation } \\
\text { Rattlesnake Mountain Road Safety Upgrade } \\
\text { Steam Plant Rehabilitation, 300 Area } \\
\text { Resurface } 200 \text { Area Primary Roads } \\
\text { Site Services Fac. Maint. Shop Expansion }\end{array}$} & $\begin{array}{r}250 \\
1,100 \\
1,100 \\
1,100 \\
750 \\
1,080 \\
1,200 \\
1,100 \\
1,000 \\
1,100 \\
1,100\end{array}$ \\
\hline $\begin{array}{l}y 2 \\
92 \\
92 \\
92 \\
92 \\
93 \\
93 \\
93\end{array}$ & $\begin{array}{l}029 \\
X X X \\
X X X \\
X X X X \\
X X X \\
L-E R D-X X X \\
391 \\
027\end{array}$ & & $\begin{array}{r}1,100 \\
1,100 \\
900 \\
770 \\
500 \\
6,000 \\
6,000 \\
1,100\end{array}$ \\
\hline $\begin{array}{l}993 \\
993 \\
994 \\
994 \\
994 \\
994 \\
994 \\
995 \\
995\end{array}$ & $\begin{array}{l}L-X X X \\
L-X X X \\
94 L-E R D-X X X \\
L-X X X \\
L-X X X \\
L-X X X \\
L-X X X \\
L-X X X \\
L-X X X\end{array}$ & & $\begin{array}{l}1,000 \\
650 \\
4,000 \\
4,000 \\
5,000 \\
1,100 \\
1,100 \\
1,100 \\
1,100\end{array}$ \\
\hline & & & \\
\hline
\end{tabular}

Table 6-3. Goal Number 1--Higii-Case Projects.

\begin{tabular}{llll}
\hline Year & Project No. & \multicolumn{1}{c}{ Project title } & TFC (SK) \\
\hline 1991 & $X X X$ & $\begin{array}{l}\text { Processing Fast Flux Test Facility (FFTF) } \\
\text { Fuel in the Fuels and Materials Examination }\end{array}$ & 19,900 \\
1993 & $W-100$ & $\begin{array}{l}\text { Facility } \\
\text { Waste Receiving and Processing Facilit: } \\
\text { Module II }\end{array}$ & 90,000 \\
1993 & $X X X$ & $\begin{array}{l}\text { FFTF Advanced Control Room \& Simulator } \\
\text { Upgrades } \\
\text { FFTF System/Component Oper:t nnal Assurance }\end{array}$ & 10,200 \\
1993 & $X X X$ & & 144,600 \\
\hline Total $\star *$ & & &
\end{tabular}




\subsection{GOAL NUMBER 2}

Goal No. 2 is to site new facilities based on functional requirements, type of occupancy, utility availability, safety and environmental requirements, and relationship to existing facilities. The Master Plan provides guidelines for development of 1 and and facilities that, when followed, will allow this goal to be achieved. Tables 6-4 and 6-5 list the projects that contribute to this goal in the low- and medium-case scenarios, respectively. There are currently no new facility projects of this type in the high-case scenario. Projects listed in this section also contribute to ti,e achievement of Goal No. 1.

\subsection{GOAL NUMBER 3}

Goal No. 3 is to minimize the use of trailers, temporary, substandard, and leased facilities. In the low- and medium-case scenarios, facilities requirements will increase as the workforce gradually increases. This is especially true in the area of office space. There is already a significant shortfall in office space availability at the Hanford Site. This, coupled with a growing workforce, is driving the acquisition of trailers and the continued use of other temporary or substandard buildings. The projects listed in Tables 6-6 and 6-7 will help achieve Goal No. 3. These projects were also listed in Section 6.2. In general, office projects relate to all aspects of this goal, while the other projects usually do not contribute to the el imination of trailers at the site. It is hoped that programs or actions resulting from ongoing modernization studies will be a viable source of funding for some of these projects to replace old, substandard buildings with new facilities to meet long-term needs.

In the high-case scenario it is expected that program-life projections will justify construction of permanent facilities and result in the elimination of many temporary or substandard fac?lities. In all scenarios, as trailers and temporary or substandard facilities are vacated, they will be evaluated for possible further use, be sold as excess, as in the case of trailers, or otherwise disposed of. Many of the older office and support facilities will be turned over to the HSFP for removal and disposal of asbestos-containing materials before demolition. Still others will become marginal facilities with dispositions planned as part of the SFUP projects developed in the Hanford Site Strategic Facilities Plan (WHC 1989).

\subsection{GOAL NUMBER 4}

Goal No. 4 is to continue to implement the HSFP long-term deactivation and decommissioning program. The HSFP long-term decontamination and decommissioning (D\&D) is a prioritized plan that will continue to proceed regardless of scenario. The rate of decommissioning activity will depend ori the amount of funding allocated specifically for that program. Table 6-8 lists the projects planned that will contribute to accomplishing this yoal within the next $5 \mathrm{yr}$. 
Table 6-4. Goal Number 2--Low-Case Projects. (sheet 1 of 2)

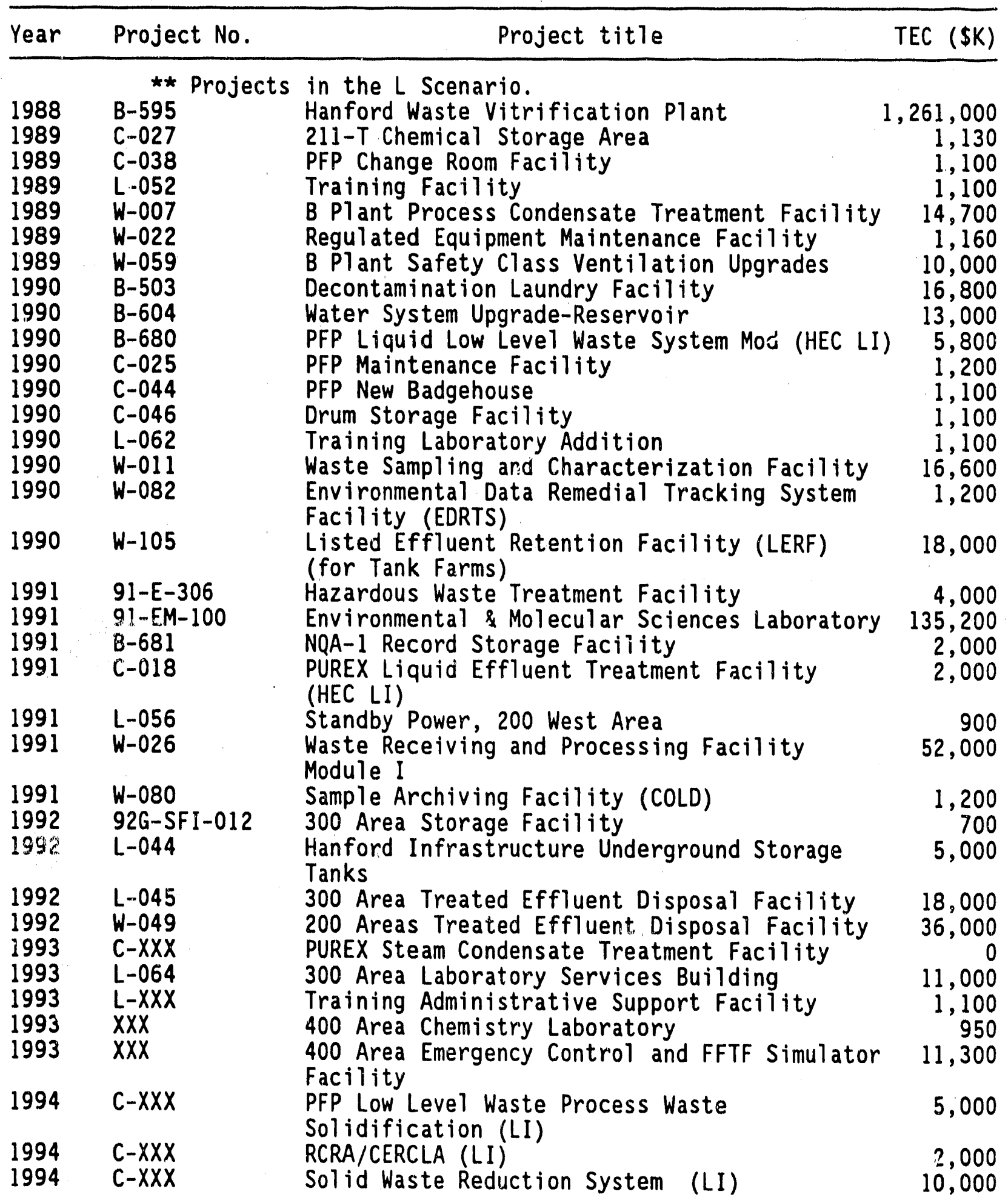


Table 6-4. Goal Number 2--Low-Case Projects. (sheet 2 of 2)

\begin{tabular}{|c|c|c|c|}
\hline Year & Project No. & Project title & TEC (\$K) \\
\hline $\begin{array}{l}1994 \\
1994 \\
1994 \\
1994 \\
1994\end{array}$ & $\begin{array}{l}L-013 \\
L-031 \\
L-X X X \\
L-X X X \\
L-X X X\end{array}$ & \multirow{3}{*}{$\begin{array}{l}\text { Centralized Maintenance Shop } \\
\text { Centralized Fabrication Shop } \\
\text { Engineering/Construction Center } \\
\text { Fire Stacion, } 600 \text { Area } \\
\text { Hanford Infrastructure Fuel 0il Underground } \\
\text { Storage Tanks } \\
\text { Low-Level Waste B\&C Storage } \\
\text { Emergency Response Training } \\
\text { Hanford Energy Services Center } \\
\text { Mask Cleaning and Decontamination Facility, } \\
200 \text { West Area } \\
\text { Technical Support Center }\end{array}$} & $\begin{array}{l}1,800 \\
4,000 \\
5,000 \\
4,500 \\
5,000\end{array}$ \\
\hline $\begin{array}{l}1994 \\
1995 \\
1995 \\
1995\end{array}$ & $\begin{array}{l}W-051 \\
L-X X X \\
L-X X X \\
L-X X X\end{array}$ & & $\begin{array}{r}9,000 \\
1,000 \\
5,000 \\
800\end{array}$ \\
\hline 1995 & $L-X X X$ & & 1,000 \\
\hline \multicolumn{3}{|c|}{$\star \star$ Total $\star \star$} & $1,701,540$ \\
\hline
\end{tabular}

CERCLA = Comprehensive Environmental Response, Compensation, and Liability Act.

FFTF = Fast Flux Test Facility.

$H E C=$ Hanford environmental compliance.

$L I=$ line item.

PFP = Plutonium Finishing Plant.

PUREX = Plutonium-Uranium Extraction.

RCRA = Resource Conservation and Recovery Act. 
Table 6-5. Goal Number 2--Medium-Case Projects.

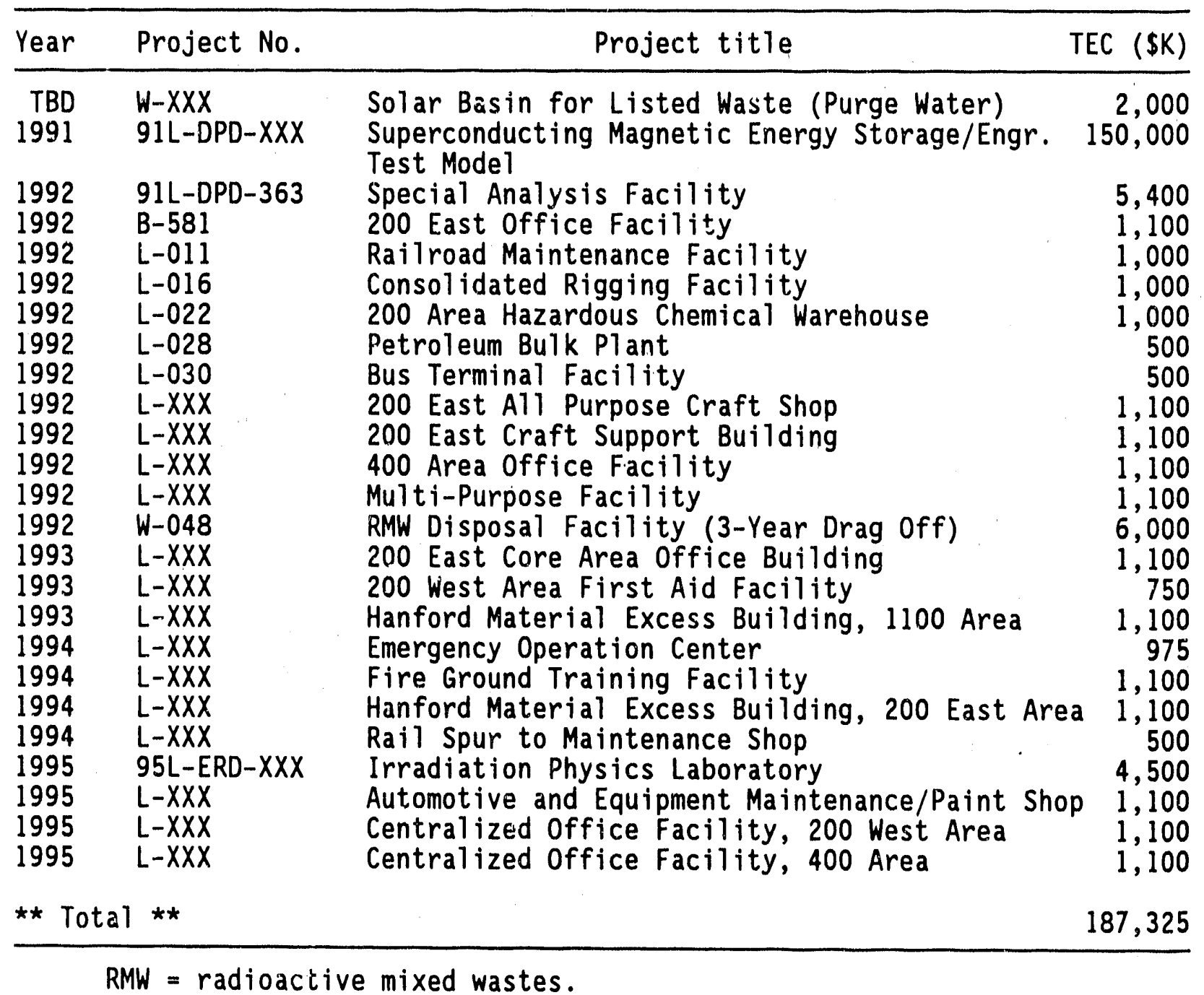


Table 6-6. Goal Number 3--Low-Case Projects.

\begin{tabular}{|c|c|c|c|}
\hline Year & Project No. & Project title & TEC (\$K) \\
\hline $\begin{array}{l}1989 \\
1990 \\
1992 \\
1992\end{array}$ & $\begin{array}{l}\text { W-022 } \\
\text { B-503 } \\
92 G-S F I-012 \\
\text { L-044 }\end{array}$ & \multirow{4}{*}{$\begin{array}{l}\text { Regulated Equipment Maintenance Facility } \\
\text { Decontamination Laundry Facility } \\
300 \text { Area Storage Facility } \\
\text { Hanford Infrastructure Underground Storage } \\
\text { Tanks } \\
300 \text { Area Laboratory Services Building } \\
\text { Centralized Maintenarce Shop } \\
\text { Centralized Fabrication Shop } \\
\text { Engineering/Construction Center } \\
\text { Hanford Infrastructure Fuel Oil Underground } \\
\text { Storage Tanks } \\
\text { Mask Cleaning and Decontamination Facility, } \\
200 \text { West Area }\end{array}$} & $\begin{array}{r}1,160 \\
16,800 \\
700 \\
5,000\end{array}$ \\
\hline $\begin{array}{l}1993 \\
1994 \\
1994 \\
1994 \\
1994\end{array}$ & $\begin{array}{l}L-064 \\
L-013 \\
L-031 \\
L-X X X \\
L-X X X\end{array}$ & & $\begin{array}{r}11,000 \\
1,800 \\
4,000 \\
5,000 \\
5,000\end{array}$ \\
\hline 1995 & $L-X X X$ & & 800 \\
\hline ** To & $1 \star \star$ & & 51,260 \\
\hline
\end{tabular}

Table 6-7. Goal Number 3--Medium-Case Projects.

\begin{tabular}{|c|c|c|c|}
\hline Year & Project No. & Project title & TEC (\$K) \\
\hline $\begin{array}{l}1992 \\
1992 \\
1992 \\
1992 \\
1992 \\
1992 \\
1992 \\
1992 \\
1993 \\
1993 \\
1995\end{array}$ & $\begin{array}{l}B-581 \\
L-011 \\
L-016 \\
L-028 \\
L-030 \\
L-X X X X \\
L-X X X \\
L-X X X \\
L-X X X \\
L-X X X \\
L-X X X\end{array}$ & $\begin{array}{l}200 \text { East Offica Facility } \\
\text { Railroad Maintenance Facility } \\
\text { Consolidated Rigging Facility } \\
\text { Petroleum Bulk Plant } \\
\text { Bus Terminal Facility } \\
200 \text { East All Purpose Craft Shop } \\
200 \text { East Craft Support Building } \\
400 \text { Area Office Facility } \\
200 \text { East Core Area Office Building } \\
200 \text { West Area First Aid Facility } \\
\text { Automotive and Equipment Maintenance/Paint } \\
\text { Shop }\end{array}$ & $\begin{array}{r}1,100 \\
1,000 \\
1,000 \\
500 \\
500 \\
1,100 \\
1,100 \\
1,100 \\
1,100 \\
750 \\
1,100\end{array}$ \\
\hline $\begin{array}{l}1995 \\
1995\end{array}$ & $\begin{array}{l}L-X X X X \\
L-X X X\end{array}$ & $\begin{array}{l}\text { Centralized Office Facility, } 200 \text { West Area } \\
\text { Centralized Office Facility, } 400 \text { Area }\end{array}$ & $\begin{array}{l}1,100 \\
1,100\end{array}$ \\
\hline \multicolumn{3}{|c|}{$\star \star$ Total $\star \star$} & 12,550 \\
\hline
\end{tabular}


Table 6-8. Goal Number 4--Hanford Surplus Facilities Program Projects.

\begin{tabular}{ll}
\hline Year & \multicolumn{1}{c}{ Project No. } \\
\hline A11 XXX & \multicolumn{1}{c}{ Project title } \\
A11 XXX & 100 and 200 Areas Surveillance and Maintenance \\
$1992 X X X$ & 100 Area Ancillary Facilities \\
A11 XXX & 100 Area Effluent Facilities \\
A11 XXX & 100 Area Reactors \\
A11 Through 1992 XXX & $100 / 200 / 300$ Areas Site Cleanup of Non-Orphan Facilities \\
A11 After 1992 XXX & $183-H$ Solar Basins D\&D (Decommissioning) \\
A11 Through 1993 XXX & 183-H Solar Basins D\&D (Surveillance/Maint.) \\
1992 & 201-C Semiworks D\&D \\
A11 XXX XXX & 224-B Concentration Facility \\
A11 XXX & Defense D\&D Program Administration \\
\hline
\end{tabular}

$D \& D=$ decontamination and decommissioning.

HSFP = Hanford Surplus Facilities Program.

\subsection{GOAL NUMBER 5}

Goal No. 5 is to meet the General Services Administration (GSA) space use standard for office space. This goal is a primary consideration in the development and maintenance of office and light laboratory space. In the low- and medium-cases, temporary facilities, additional leased space, and some new construction projects will be needed to accommodate the gradual increase in the workforce size. New construction will be the primary method used to meet this goal in the high-case scenario.

In general, these standards are designed into new construction and upgrade projects. Construction projects designed to achieve Goal No. 3 (Tables 6-9 and 6-10) would contribute to meeting this goal.

\subsection{GOAL NUMBER 6}

Goal No. 6 is to consolidate, convert, mothball, or dispose of marginal, deteriorated, and underutilized facilities. The Hanford Site Strategic Facilities Plan (HSSFP) meets this objective. The HSSFP is required by the SFUP, formerly the SFI. The HSSFP separates the Hanford Site Facilities into two categories based on 5-yr projections: "strategically required" facilities and "marginal" facilities. It provides a comparison of future facility requirements against existing capacities and proposes projects to eliminate or consolidate marginal facilities (i.e., those facilities that are not fully utilized or are no longer required to accomplish program missions). The objective of the SFUP is to increase the operating efficiency of the Hanford Site by maximizing facility use and minimizing unnecessary facility operation and maintenance costs. 
Table 6-9. Goal Number 5--Low-Case Projects.

\begin{tabular}{|c|c|c|c|}
\hline lear & Project No. & Project title & TEC (\$K) \\
\hline & $\begin{array}{l}L-0 \\
C-0 \\
L-0 \\
W-0 \\
W-0\end{array}$ & \multirow{2}{*}{\multicolumn{2}{|c|}{$\begin{array}{lr}\text { Hanford Waste Vitrification Plant } & 1,261,000 \\
\text { Training Facility } & 1,100 \\
\text { PFP Maintenance Facility } & 1,200 \\
\text { Training Laboratory Addition } & 1,100 \\
\text { Waste Sampling and Characterization Facility } & 16,600 \\
\text { Environmental Data Remedial Tracking System } & 1,200 \\
\text { Facility (EDRTS) } & \\
\text { HEHF Facilities Upgrades } & 1,200 \\
\text { Hazardous Waste Treatment Facility } & 4,000 \\
329 \text { Building Compliance } & 7,300 \\
\text { Environmental \& Molecular rciences Laboratory } & 135,200 \\
\text { NQA-1 Record Storage Facility } & 2,000 \\
300 \text { Area Laboratory Services Building } & 11,000 \\
\text { Training Administrative Support Facility } & 1,100 \\
\text { Centralized Maintenance Shop } & 1,800 \\
\text { Centralized Fabrication Shop } & 4,000 \\
\text { Engineering/Construction Center } & 5,000 \\
\text { Fire Station, 600 Area } & 4,500 \\
\text { Emergency Response Training } & 1,000 \\
\text { Hanford Energy Services Center } & 5,000 \\
\text { Technical Support Center } & 1,000\end{array}$}} \\
\hline $\begin{array}{l}90 \\
91 \\
91 \\
91 \\
91 \\
93 \\
93 \\
94 \\
94 \\
94 \\
94 \\
94 \\
95 \\
95\end{array}$ & $\begin{array}{l}W-093 \\
91-E-3 \\
91-E-3 \\
91-E M- \\
B-681 \\
L-064 \\
L-X X X \\
L-013 \\
L-031 \\
L-X X X \\
L-X X X \\
L-X X X \\
L-X X X \\
L-X X X X\end{array}$ & & \\
\hline & & & $1,466,300$ \\
\hline
\end{tabular}

HEHF = Hanford Environmental Health Foundation.

PFP = Plutonium Finishing Plant. 
Table 6-10. Goal Number 5--Medium-Case Projects.

\begin{tabular}{|c|c|c|c|}
\hline Year & Project No. & Project title & TEC (\$K) \\
\hline 1991 & $91 L-D P D-X X X$ & $\begin{array}{l}\text { Superconducting Magnetic Energy Storage/Engr. } \\
\text { Test Model }\end{array}$ & 150,000 \\
\hline $\begin{array}{l}1991 \\
1992 \\
1992 \\
1992 \\
1992 \\
1992 \\
1992 \\
1992 \\
1992 \\
1992 \\
1992 \\
1993 \\
1993 \\
1993 \\
1993 \\
1994 \\
1994 \\
1994 \\
1995 \\
1995 \\
1995 \\
1995 \\
1995\end{array}$ & $\begin{array}{l}D-387 \\
91 L-D P D-363 \\
B-581 \\
L-016 \\
L-030 \\
L-X X X \\
L-X X X \\
L-X X X \\
L-X X X \\
L-X X X \\
W-X X X \\
93 L-E R D-X X X \\
D-391 \\
L-X X X \\
L-X X X \\
L-X X X \\
L-X X X \\
L-X X X \\
95 L-E R D-X X X \\
L-X X X \\
L-X X X \\
L-X X X \\
L-X X X\end{array}$ & $\begin{array}{l}\text { Laboratory Addition, } 318 \text { Building } \\
\text { Special Analysis Facility } \\
200 \text { East Office Facility } \\
\text { Consolidated Rigging Facility } \\
\text { Bus Terminal Facility } \\
200 \text { East All Purpose Craft Shop } \\
200 \text { East Craft Support Building } \\
400 \text { Area Office Facility } \\
\text { Multi-Purpose Facility } \\
\text { Standards Lahoratory Expansion, } 300 \text { Area } \\
\text { Building } 616 \text { Upgrades } \\
\text { Building } 331 \text { Renovation } \\
325 \text { Building Facility Compliance/Renovation } \\
200 \text { East Core Area Office Building } \\
200 \text { West Area First Aid Facility } \\
\text { Building } 324 \text { Facility Compliance/Renovation } \\
\text { Emergency Operation Center } \\
\text { Hanford Material Excess Building, 200 East Area } \\
\text { Irradiation Physics Laboratory } \\
\text { Automotive and Equipment Maintenance/Paint Shop } \\
\text { Centralized Office Facility, 200 West Area } \\
\text { Centralized Office Facility, } 400 \text { Area } \\
\text { Site Services Fac. Maint. Shop Expansion }\end{array}$ & $\begin{array}{r}1,100 \\
5,400 \\
1,100 \\
1,000 \\
500 \\
1,100 \\
1,100 \\
1,100 \\
1,100 \\
770 \\
500 \\
6,000 \\
6,000 \\
1,100 \\
750 \\
5,000 \\
975 \\
1,100 \\
4,500 \\
1,100 \\
1,100 \\
1,100 \\
1,100\end{array}$ \\
\hline \multicolumn{3}{|c|}{ ** Total ** } & 194,595 \\
\hline
\end{tabular}


The strategic facility requirements analysis section of the HSSFP compares the Hanford Site's existing capacities with the projected program needs to determine if they are adequate and where shortages and/or surpluses exist. Most of the Hanford Site's assets are adequate as described in Section 3.0. The major shortage is in office space, particularly near the 200, 300, 400, 700 , and 3000 Areas. This information helped identify the location of future activity centers. Shortages in maintenance and storage facilities were also identified close to these activity centers.

Operational requirements for facilities change with time, and underutilized facilities have been routinely converted for other uses. As noted in Section 3.4.2.1, approximately 30\% of the existing Hanford Site facilities are currently being used for purposes other than their original design.

To achieve the objective of the SFUP, the HSSFP identifies and proposes dispositions for marginal facilities that are not covered by another corrective program. Seven specific types of actions are proposed by the HSSFP from FY 1990 to FY 1994: deactivate, convert, consolidate, demolish, disposal personal (excess), other, and no SFUP action. These specific types of actions are defined as follows.

- Deactivation. Deactivation of U.S. Department of Energy (DOE)-owned facilities was recommended when no near-term mission was identified and disposal was inappropriate or excessively costly.

- Convert. When found to be economical, the use of a facility can be converted to allow use by another program or project.

- Consolidate. Where several underutilized facilities existed, consideration was given to consolidate them into one facility. This approach allowed additional functions and personnel to be accommodatied. Consideration was given to the demolition or deactivation of any vacated facilities.

- Demolish. Demolition was considered when it was not feasible to convert, consolidate, or otherwise deactivate a marginal facility.

- Disposal personal. Disposal of personal property (generally any movable items not permanently affixed to and a part of the real estate) was considered when it was not feasible to convert, consolidate, or otherwise deactivate marginal personal property. The disposal of trailers as personal property follows the proceciures outlined in DOE Order 4300.1B (DOE 1987).

- Other. "Other" allows a narrative explanation for facility disposition that is unique to the situation or circumetances. The other category was assigned to marginal facilities when a facility transfer to HSFP was planned.

- No SFUP Action. The action "None" or "Do Nothing" was assigned to marginal facilities when one or more of the following issues applied:

- There was no identified short-term requirement for the facility, but the condition and replacement cost dictated that disposal of the facility was uneconomical. 
- The disposition action was covered as part of another program (also referred to as Normal Programmatic Action).

- A unique facility, with an uncertain future, but which would not be reasonable to duplicate or replace.

- A regulation prohibits removal, rehabilitation, or disposal of a facility.

Approximately 1,355 facilities consisting of buildings (e.g., shops, warehouses, plants, offices) and other structures (e.g., roads, transformers, water lines) were evaluated. Of these 1,355 facilities, 189 were underuti1ized and classified as "marginal." Each marginal facility was provided with a recommendation for disposition. Of the 189 marginal facilities, 72 were recommended for SFUP action (conversion, consolidation, deactivation, disposal, demolition, or other), and 117 were recommended for no SFUP action. Proposed action and savings for each of the marginal facilities are listed in Appendix $C$, Table C-4, Marginal Facilities Disposition Yearly Plan Through FY 1994. Considering all projects as a whole, summary costs and savings are presented below:

Cost (\$)

\begin{tabular}{ll}
\hline Project costs: & $8,201,400$ \\
Less one-time savings: & $6,814,100$ \\
TOTAL: & $1,390,300$
\end{tabular}

Savings (\$)

\begin{tabular}{lr}
\hline Annual Savings: & 808,100 \\
Payback in years: & $1.7 \mathrm{yr}$
\end{tabular}

The one-time savings represent an avoidance of new construction or upgrade cost: inrough conversion or consolidation of facilities. The annual savings consist of reduced or eliminated operating costs to maintain facilities through deactivation, disposal, or demolition.

\subsection{GOAL NUMBER 7}

Goal No. 7 is to develop a viable and attractive plan for private enterprise to finance, design, construct, operate, and decommission large, complex facilities. The three principal objectives of private sector participation are as follows:

- Enhance timely response to environmental and waste management requirements

- Reduce cost to the federal government and expand private sector involvement in environmental cleanup

- Utilize private sector expertise in waste management and environmental restoration activities and contribute to the diversification of the Hanford Site economy.

The concept for privatization involves the private sector (1) leasing land; (2) designing, constructing, and operating the facility; and (3) returning the land to its original state after completion. 
Five candidate projects were presented to private sector representatives in November 1989. They are as follows:

- Waste Receiving and Processing Facility

- Raw material (flyash) feed for Hanford Grout Program

- Plutonium Finishing Plant Liquid Waste Immobilization

- Treated Effluent Disposal Facility for Hanford Site 200 Areas

- Plutonium-Uranium Reduction Extraction Liquid Effluent Treatment Facility.

Project values are expected to range from $\$ 5$ million to $\$ 150$ million. It is hoped that institutional issues such as contracting mechanisms and liability can be resolved so that at least two of these projects can be contracted in FY 1990.

\subsection{REFERENCES}

DOE, 1987, Real Property and Site Development Planning, DOE Order 4300.1B, U.S. Department of Energy, Washington, D.C.

WHC, 1989, Hanford Site Strategic Facilities Plan, DOE/RL 89-01, Westinghouse Hanford Company for the U.S. Department of Energy, Richland, Washington. 
D0E/RL-89-15

APPENDIX A

BIBLIOGRAPHY

$$
\text { A- } / 2
$$


DOE/RL-89-15

\section{BIBLIOGRAPHY}

AEC, 1969, The Hanford Story, Information Brochure, Atomic Energy Commission, Richland Operations Office, Richland, Washington.

Backman, G. E., B. J. McMurray, N. P. Nisick, and C. R. Richey, 1981, General Safety Assessment Document for PNL Managed Nonreactor Nuclear Facilities, PNL-3280, Pacific Northwest Laboratory, Richland, Washington.

Berg, J. W., Jr. and C. D. Baker, 1963, "Oregon Earthquakes, 1841 through 1958," Bulletin of the Seismological Society of America, $53(1)$, pp. $95-108$.

Bingham, J. W., C. J. Londquist, and E. H. Baltz, 1970, Geolo'ic Investigation of Faulting in the Hanford Region, Washington, Open File Report, U.S. Geological Survey, Washington, D.C.

Blume, John A. and Associates, Engineers, 1971, A Summary Report, Seismic Evaluation and Development of Ground Acceleration and Response Spectra for FFTF site, JABE-WADCO-03, prepared for WADCO by John A. Blume and Associates, San Francisco, California, for WADCO, Richland, Washington.

Caggiano, J. A. and D. W. Duncan (editors), 1983, Preliminary Interpretation of the Tectonic Stability of the Reference Repository Location, Cold Creek Syncline, Hanford Site, RHO-BW-ST-19P, Rockwell Hanford Operations, Richland, Washington.

Coffman, J. L. and C. A. VonHake, 1973, Earthquake History of the United States, Publication 41-1 (revised edition), National Oceanic and Atmospheric Administration and U.S. Geologic Survey, Washington, D.C..

Coombs, H. A., W. G. Milne, 0. W. Nutt1i, and D. B. Slemmons, 1976, Report of the Review Panel on the December 14, 1872 Earthquake, Washington Public Power Supply System Preliminary Safety Analys is Report, WNP 1/4 Amendment 23, Subappendix 2R A, Richlard, Washington.

Craig, R. G. and J. P. Hanson, 1985, Erosion Potential from Missoula Floods in the Pasco Basin, Washington, PNL-5684, prepared by Kent State University for Pacific Northwest Laboratory, Richland, Nashington.

DOE, Hanford Site Graphic Overview System, Graphic Overview System of DOE's Effluent and Environmental Monitoring Programs, compiled for the U.S. Department of Energy by EG\&G, Las Vegas, Nevada.

DOE, 1981, Site Development Planning Hancibook, DOE/AD/C6212-1, U.S. Department of Energy, Washington, D.C.

DOE, 1984, Draft Environmental Assessment, Reference Repository Location, Hanford Site, Washington, DOE/RW-0017, U.S. Department of Energy, Washington, D.C. 
DOE, 1986, Disposal of Hanford Defense High-Leve1, Transuranic, and Tank Waste, Hanford Site, Richland, Washington Draft Environmental Impact Statement, DOE/EIS-0113, 3 vol., U.S. Department of Energy, Washington, D.C.

DOE, 1986, Process Facility Modifications Project, Hanford Site (Draft), Final Environmental Impact Statement, DOE/EIS-0115D, U.S. Department of Energy, Washington, D.C.

$\mathrm{DOE}-\mathrm{RL}, 1982$, Site Characterization Report for the Basalt Waste Isolation Project, DOE/RL 82-3 (3 vol.), U.S. Department of Energy-Richland Operations Office, Richland, Washington.

DOE-RL, 1986, Request for Proposal, Operations and Engineering Contract for the Hanford Site, Number DE-RPC6-86RL10930, U.S. Department of EnergyRichland Operations Office, Richland, Washington.

Eddy, P. A., C. S. Cline, J. T. Rieger, and J. R. Raymond, 1985, Ground Water Monitoring at the Hanford Site, January-December 1984, PNL-5408, Pacific Northwest Laboratory, Richland, Washington.

ERDA, 1975, Final Environmental Statement Waste Management Operations Hanford Reservation, Richland, Washington, ERDA-1538, 2 vol., Energy Research and Development Administration, Washington, D.C.

ERDA, 1975, "Hanford, Yesterday, Today and Tomorrow," The Hanford Project, Second Edition, Information Brochure, Energy Research and Development Administration, Richland Operations Office, Richland, Washington.

ERDA, 1976, Evaluation of Impact of Potential Flooding Criteria on the Hanford Project, RL0-76-4, Energy Research and Development Administration, Richland Operations Office, Richland, Washington.

Environmental Compliance Task Force, 1986, Hanford Environmental Management Frogram Plan, U.S. Department of Energy-Richland Operations Office, Richland, Washington.

Fickeisen, D. H., R. E. Fitzner, R. H. Sauer, and J. L. Warren, 1980, Wildlife Usage, Threatened and Endangered Species and Habitat Studies an the Hanford Reach, Columbia River, Washington, Prepared by Battelle, Pacific Northwest Laboratory, Richland, Washington, for the Seattle District Corps of Engineers, Seattle, Washington.

Foster, R. F., 1952, "Biological Problems Associated With the Discharge of Pile Effluent into the Columbia River," pp. 11-13, Biology ResearchAnnual Report, 1951, H. A. Kornberg (ed.), HW-25021, General Electric Company, Richland, Washington.

Franklin, J. F., 1977, "The Biosphere Reserve Program in the United States," Science, 195:262-267.

Gephart, R. E., P. A. Eddy, R. C. Arnett, and G. A. Robinson, 1976, Geohydrologic Study of the West Lake Basin, ARH-CD-775, Atlantic Richfield Hanford Company, Richland, Washington. 
Gephart, R. E., R. C. Arnett, R. G. Baca, L. S. Leonhart, and F. A. Spane, Jr., 1979, Hydrologic Studies Within the Columbia Plateau, Washington: An Integration of Current Knowledge, RHO-BWI-ST-5, Rockwell Hanford Operations, Richland, Washington.

Graham, M. J., M. D. Hall, S. R. Strait, and W. R. Brown, 1981, Hydrology, the Separations Area, RHO-ST-42, Rockwell Hanford Operations, Richiand, Washington.

Gray, R. H. and D. D. Dauble, 1977, "Checklist and Relative Abundance of Fish Species from the Hanford Reach of the Columbia River, "Northwest Science $51(3): 208-215$.

Hajek, B. F., 1966, Soil Survey, Hanford Project in Benton County, Washington, BNWL-243, Battelle Pacific Northwest Laboratory, Richland, Washington.

Hickerson and Associates, 1986, TRI-CITIES FACTS: for Industry, Tri-City Industrial Development Council, Richland-Kennewick-Pasco, Washington.

Jamison, J. D., 1982, Site Description, Standardized Input for Hanford Environmental Impact Statements, Part II: Site Description, PNL-3509 PT 2, Pacific Northwest Laboratory, Richland, Washington.

Jones, M. G. and K. R. Fecht, 1977, "Exploratory Trenching Across the Wallula Gap Fault, South-Central Washington," American Geophysical Inion Transactions 58(12):1248.

Kaldor, S. F., ed., October-December 1985, "Hanford Contractor Consolidation," Hanford Quarterly, Vol. 1, No. 1, U.S. Department of Energy-Richl and Operations Office, Richland, Washington.

Kaldor, S. F., ed., 1986, Hanford Quarterly, Vol. 1, Issue 2, U.S. Department of Energy-Richland Operations Office, Richland, Washington.

Kaldor, S. F., ed:, 1986, Hanford Quarterly, Vol. 1, Issue 3, U.S. Department of Energy-Richland Operations Office, Richland, Washington.

LaSala, A. M., Jr., G. C. Doty, and F. J. Pearson, Jr., 1973, A Preliminary Evaluation of Regional Groundwater Flow in South-Central Washington, U.S. Geological Survey Open File Report, Washington, D.C.

Leonhart, L. S., 1979, Surface Hydrologic Investigations of the Columbia Plateau Region, Washington, RHO-BWI-ST-6, Rockwell Hanford Operations, Richland, Washington.

Leonhart, L. S., 1980, Assessment of the Effects of Existing Major Dams Upon a Radioactive Waste Repository Within the Hanford Site, RHO-BWI-LD-26, Rockwell Hanford Operations, Richland, Washington.

Malone, S. D., 1978, Annual Technical Report on Earthquake Monitoring of the Hanford Region, Eastern Washington, Geophysics Program, University of Washington, Seattle, Washington. 
Malone, S. D., 1979, Annual Technical Report on Earthquake Monitoring of the Hanford Region, Eastern Washington, Geophysics Program, University of Washington, Seattle, Washington.

Mckee, E. H., P. R. Hooper, and W. D. Kleck, 1981, "Age of Imnaha Basalt 0ldest Basalt Flows of the Columbia River Basalt Group, Northwestern United States," Isochron West, 31:31-33.

Meinhardt, C. C. and J. C. Frostenson, 1979, Current Status of 200 Area Ponds, RHO-CD-798, Rockwell Hanford Operations, Richland, Washington.

Meyers, D. A., 1978, Environmental Monitoring Report on the Status of Ground Water Beneath the Hanford Site, January-December 1977, PNL-2624, Pacific Northwest Laboratory, Richland, Washington.

Mitchel1, T. H. and K. A. Bergstrom, 1983, "Pre-Columbia River Basalt Group Stratigraphy and Structure in the Central Pasco Basin, "Preliminary Interpretation of the Tectonic Stability of the Reference Repository Location, Cold Creek Syncline, Hanford Site, J. A. Caggiano and D. W. Duncan (eds.), RHO-BWI-ST-19P, Rockwell Hanford Operations, Richland, Washington.

Myers, C. W. and S. M. Price (principal authors), 1979, Geologic Studies of the Columbia Plateau: A Status Report, RHO-BWI-ST-4, Rockwell Hanford Operations, Richland, Washington.

NRC, 1982, Draft Environmental Statement Related to the Construction of Skagit/Hanford Nuclear Project, Units 1 and 2, Docket No. STN 50-522 and STN 50-523, Puget Sound Power and Light Company, Picific Power and Light Company and Washington Water Power Company, Portland General Electric Company. NUREG-0894, Nuclear Regulatory Commission, Washington, D.C., and Washington State Energy Facility Site Evaluation Council, Diympia, Washington.

PNL, 1987, Environmental Monitoring at Hanford for 1986, PNL-6120, prepared for the U.S. Department of Energy by Pacific Northwest Laboratory, Richland, Washington.

Price, K. R., 1986, Environmental Monitoring at Hanford for 1985, PNL-5817, Pacific Northwest Laboratory, Richland, Washington.

Rasmussen, N. H., 1967, "Washington State Earthquakes 18.0 through 1965," Bulletin of the Seismological Society of America, $57(3): 463-476$.

Raymond, J. R. and D. J. Brown, 1963, Ground Water Exchange with Fluctuating Rivers, HW-SA-3198, General Electric Company, Richland, Washington.

Rockwel1, 1980, General Safety Assessment Document for Rockwell Managed Nonreactor Nuclear Facilities, RHO-CD-457, Rockwell Hanford Operations, Richland, Washington.

Rogers, L. E. and W. H. Rickard, 1977, Ecology of the 200 Area Plateau Waste Management Environs: A Status Report, PNL-2253, Pacific Northwest Laboratory, Richland, Washington. 
Rohay, A. C. and J. D. Davis, 1983, "Contemporary Deformation in the Pasco Basin Area of the Central Columbia Plateau," Preliminary Interpretation of the Tectonic Stability of the Reference Repository Location, Cold Creek Syncline, Hanford Site, J. A. Caggiano and D. W. Duncan (eds.), RHO-BW-ST-19P, Richland, Washington.

Scott, M. J., D. B. Belzer, R. J. Ness, R. W. Schultz, and P. A. Stokowski, 1987, The Economic and Community Impacts of Closing Hanford's $N$ Reactor and Nuclear Materials Production Facilities, PNL-6295, Pacific Northwest Laboratory, Richland, Washington.

Skaggs, R. L. and W. H. Walters, 1981, Flood Risk Analysis of Cold Creek Near the Hanford Site, RHO-BWI-C-120, prepared for Rockwell Hanford Operations by Pacific Northwest Laboratory (PNL-4219), Richland, Washington.

Smith, E. D. and R. J. Thygesen, 1987, Basalt Waste Isolation Project, Facility Resource Acquisition Plan, SD-BWI-PD-018, Rockwell Hanford Operations, Richland, Washington.

Stone, W. A., J. M. Thorp, O. P. Gifford, and D. J. Hoitink, 1983, Climatological Summary for the Hanford Area, PNL-4622, Pacific Northwest Laboratory, Richland, Washington.

Tallman, A. M., K. R. Fecht, M. C. Marratt, and G. V. Last, 1979, Geology of the Separation Areas, Hanford Site, South-Central Washington, RHO-ST-23, Rockwell Hanford Operations, Richland, Washington.

UNC, 1978, N-Reactor Updated Safety Analysis Report, UNI-M-90 (7 vol.), United Nuclear Industries, Inc., Richland, Washington.

Vaughan, B. E. and W. H. Rickard, 1977, Hanford National Environmental Research Park (NERP), A Descriptive Summary of the Site and Site-Related Research Programs, 1952-1977, PNL-2299, Pacific Northwest Laboratory, Richland, Washington.

Watkins, N. D. and A. K. Baksi, 1974, "Magnetostratigraphy and Oroclinal Folding of the Columbia River, Steens, and Owyhee Basalts in Oregon, Washington and Idaho," American Journal of Science, 274:148-189.

Watson, D. G., 1970, Fall Chinook Salmon Spawning in the Columbia River Near Hanford 1947-1969, BNWL-1515, Batte!le-Northwest Laboratory, Richland, Washington.

Watson, E. C., C. D. Becker, R. E. Fitzner, K. A. Gano, K. L. Imhoff, R. F. McCallum, D. A. Myers, T. L. Page, K. R. Price, J. V. Ramsdell, D. G. Rice, D. L. Schreiber, L. A. Skumatz, D. J. Sommer, J. J. Tawil, R. W. Wallace, and D. G. Watson, 1984, Environmental Characterization of Two Potential Locations at Hanford for a New Production Reactor, PNL-5275, Pacific Northwest Laboratory, Richland, Washington.

Western Geophysical Research, 1977, "Evaluation of Microearthquake Activity in Eastern Washington," Preliminary Safety Analysis Report, Amendment 23, Appendix 2RJ, WilP Project No. 1, prepared for Washington Public. Power Supply System, Richland, Washington. 
WPPSS, WPPSS Nuclear Project No. 1, Preliminary Safety Analysis Report, Vol. 2, Washington Public Power Supply System, Richland, Washington.

WPPSS, Preliminary Safety Analysis Report, Amendment 23, Vols. 1 and 2, WPPSS Nuclear Project No. 1, Washington Public Power Supply System, Richland, Washington.

Wukelic, G. E., H. P. Foote, S. C. Blair, and C. D. Begej, 1981, Monitoring Land- and Water-Use Dynamics in the Columbia Plateau Using RemoteSensing Computer Analysis and Integration Techniques, RHO-BW-CR-122P/PNL-4047, Rockwell Hanford Operations, Richland, Washington. 
DOE/RL-89-15

APPENDIX B

\section{HANFORD SITE AREA MAPS}

B-1/2 
i 2

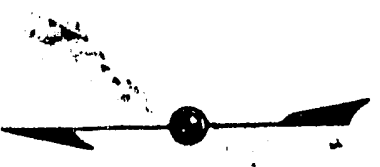

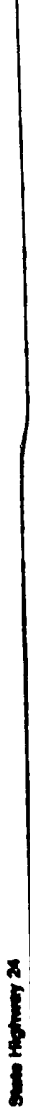

!

F

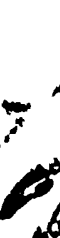

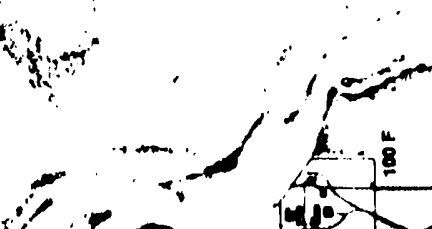

$i$

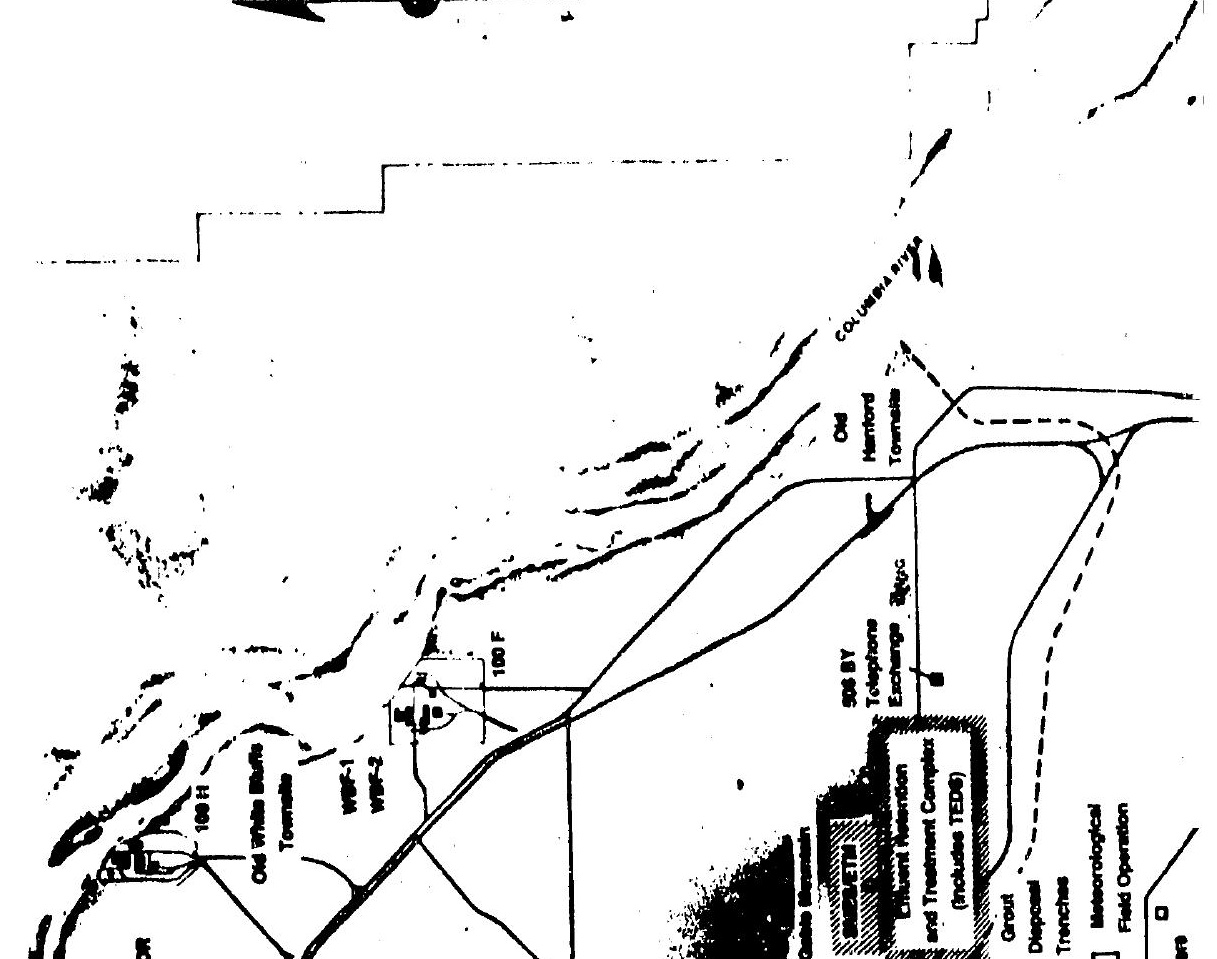

I

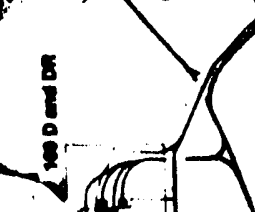


'

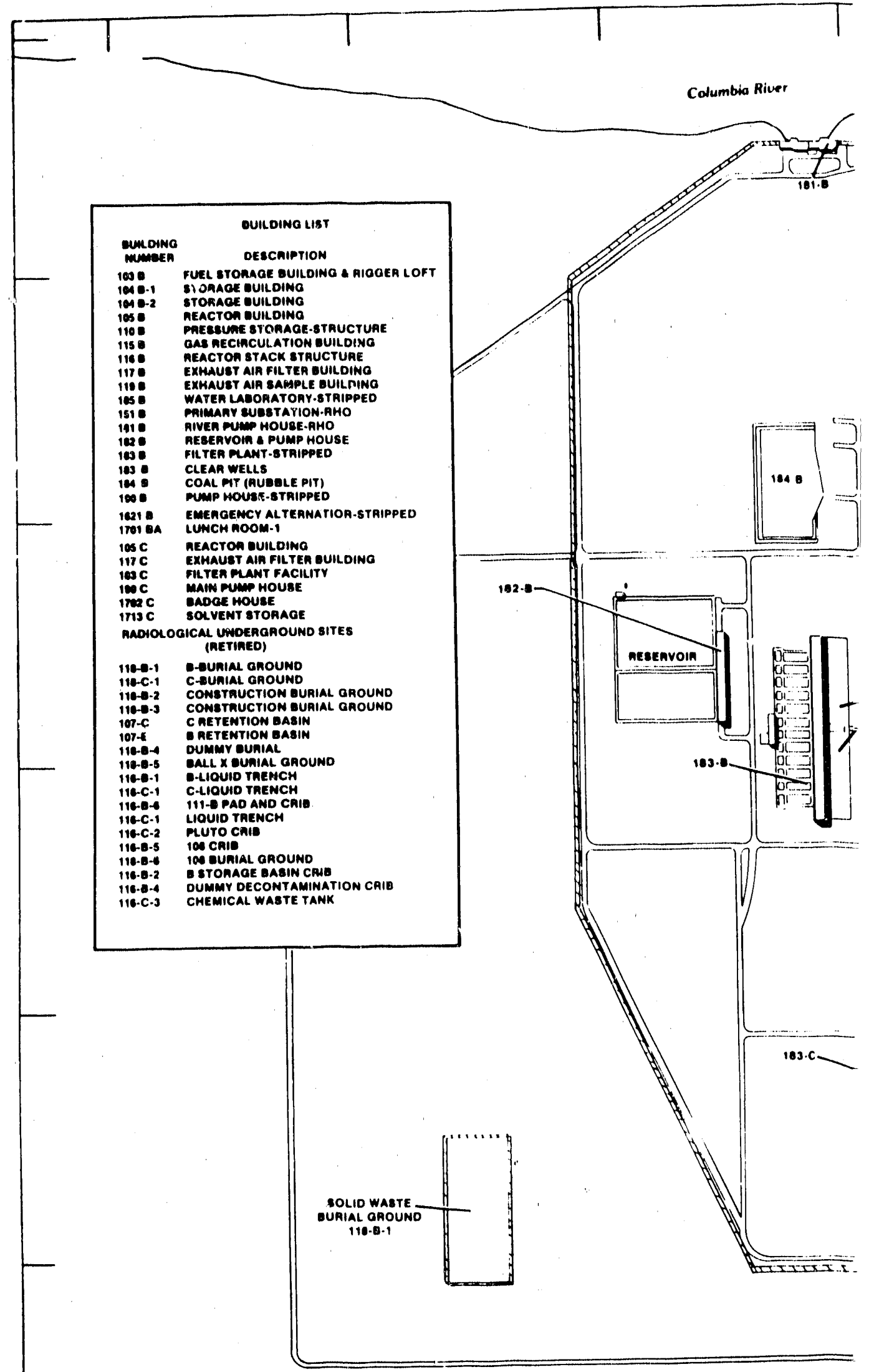




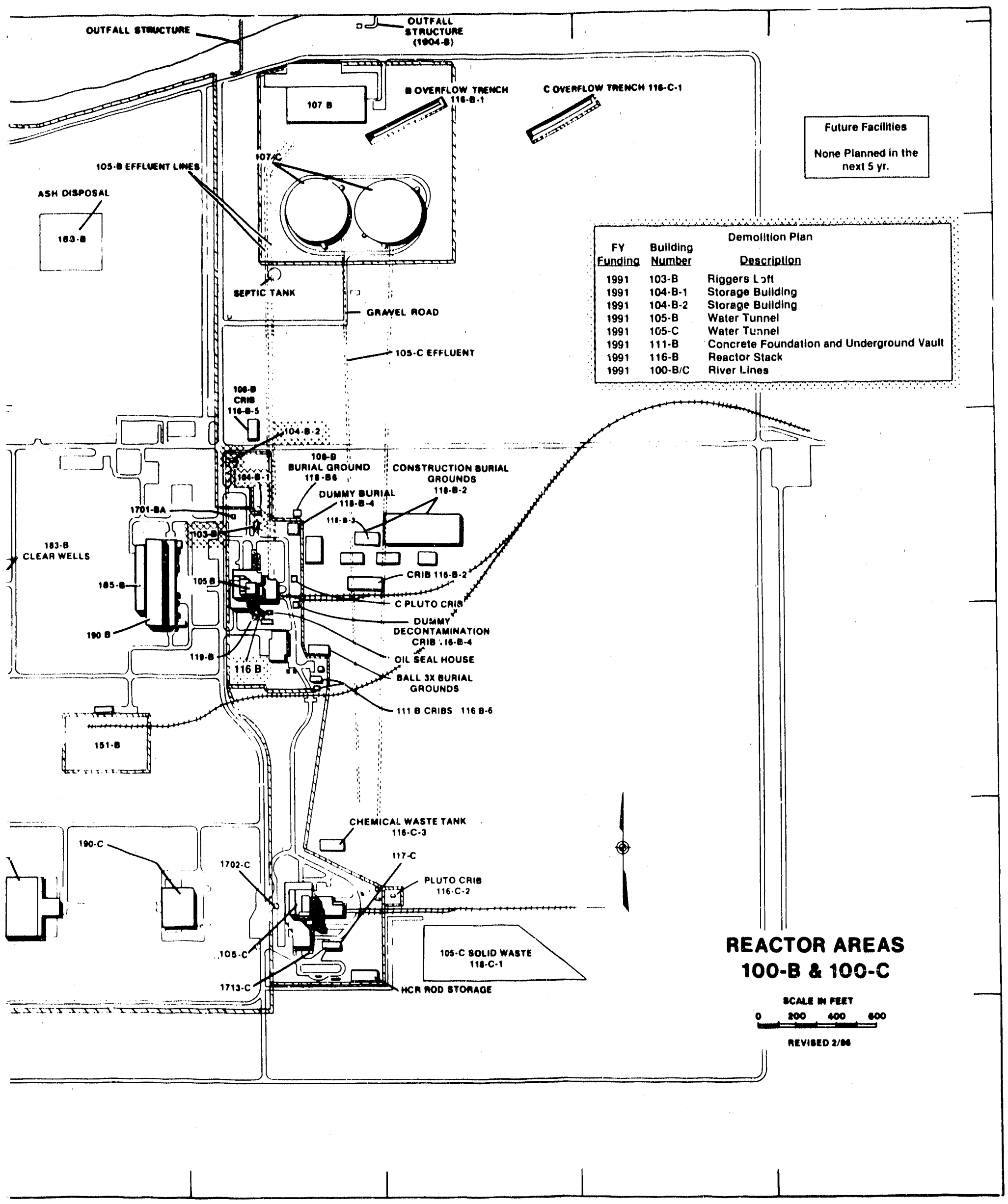




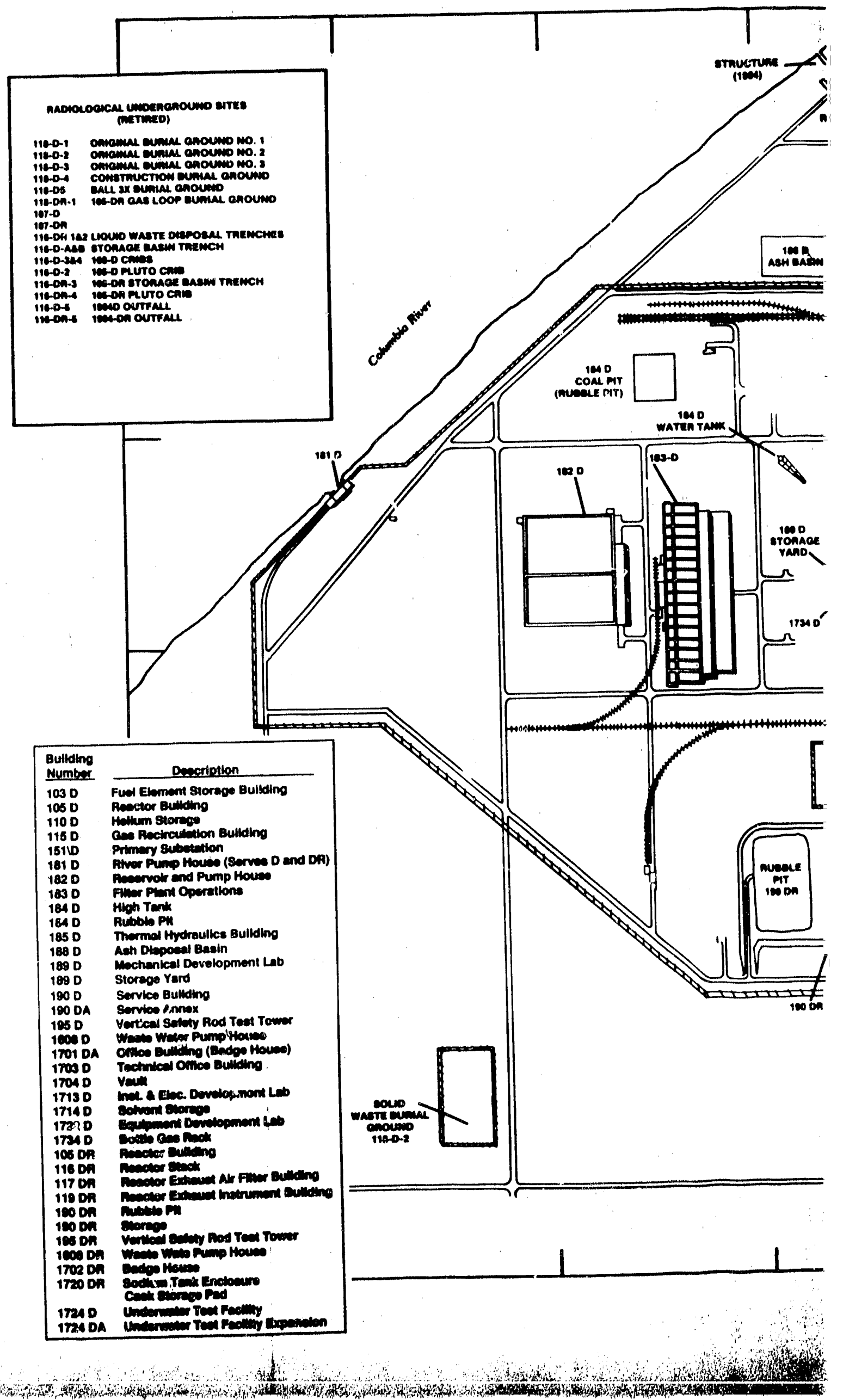




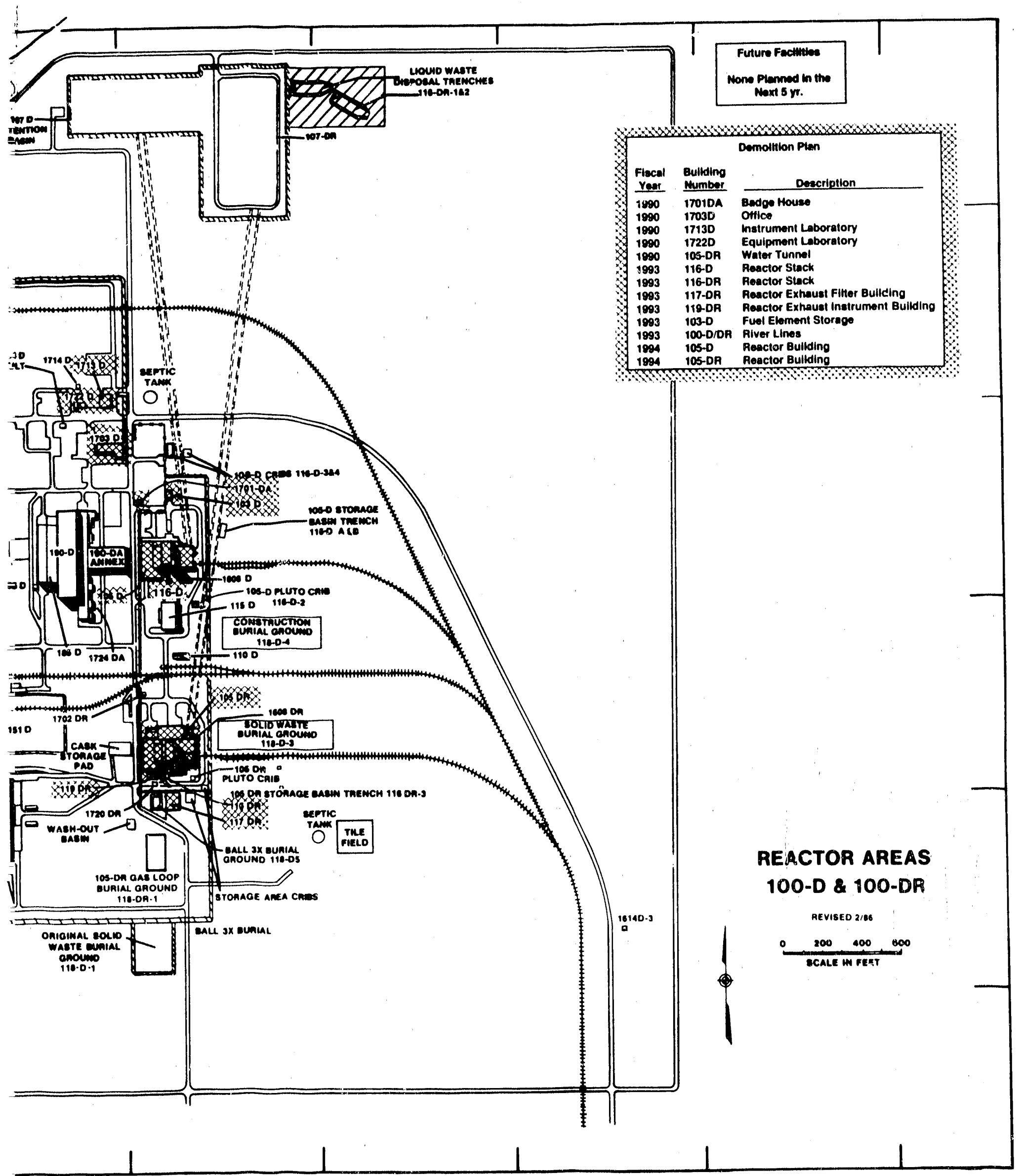




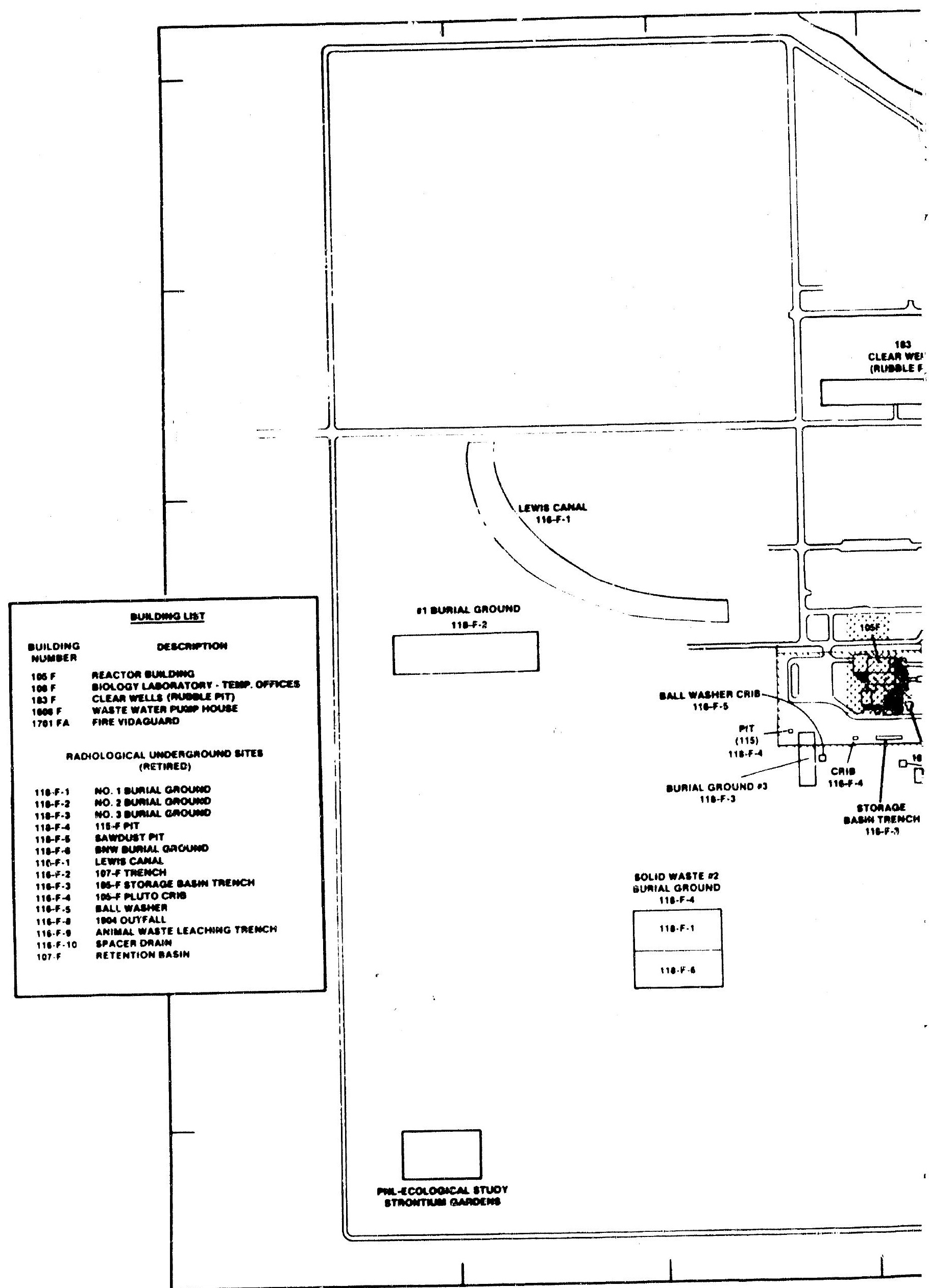




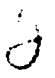

s

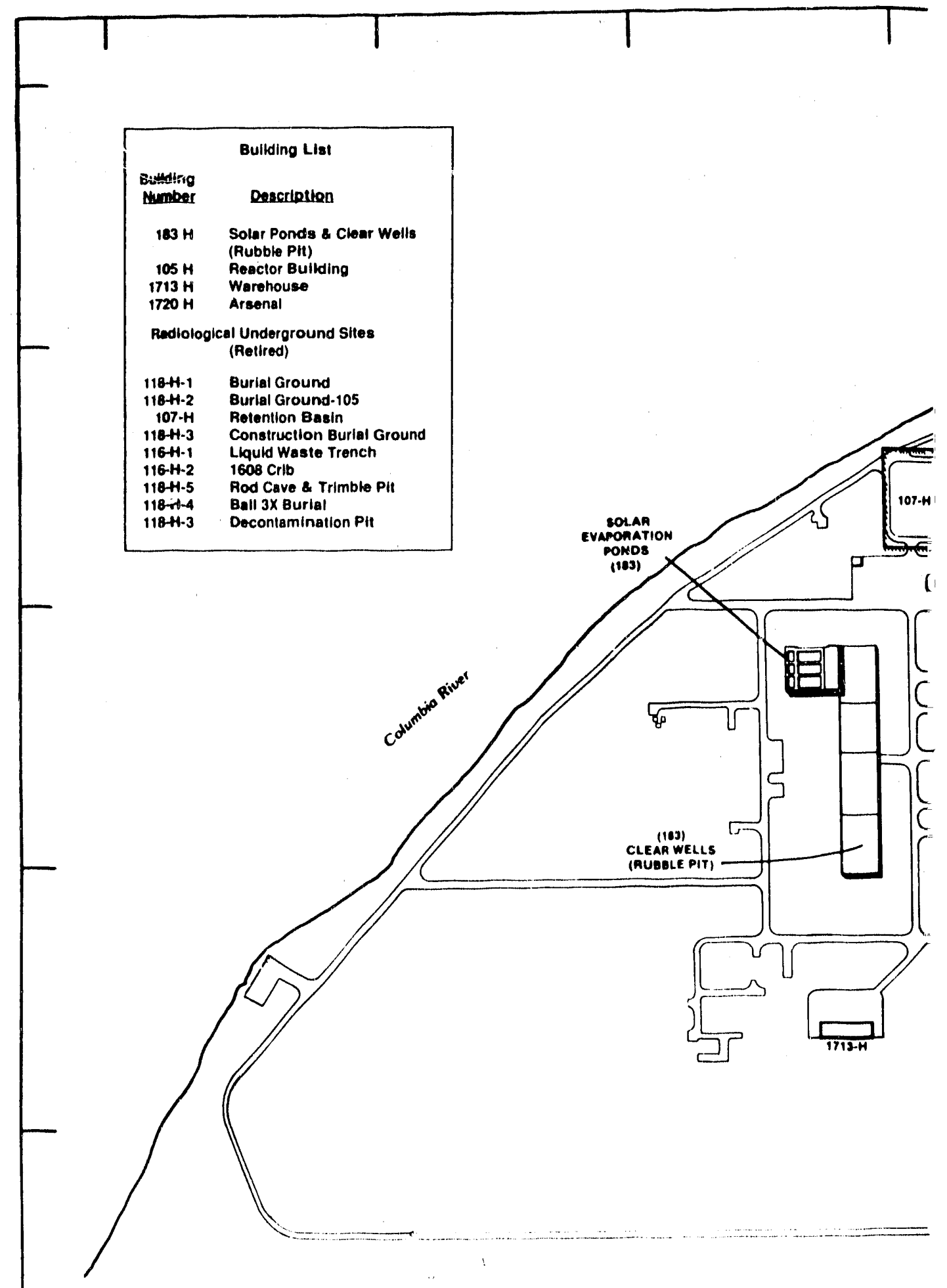

Bultding List

Reactor Bullding

Underground Sites

Burial Ground

Waste Trench

all 3x Burial

$18-6-4$ 


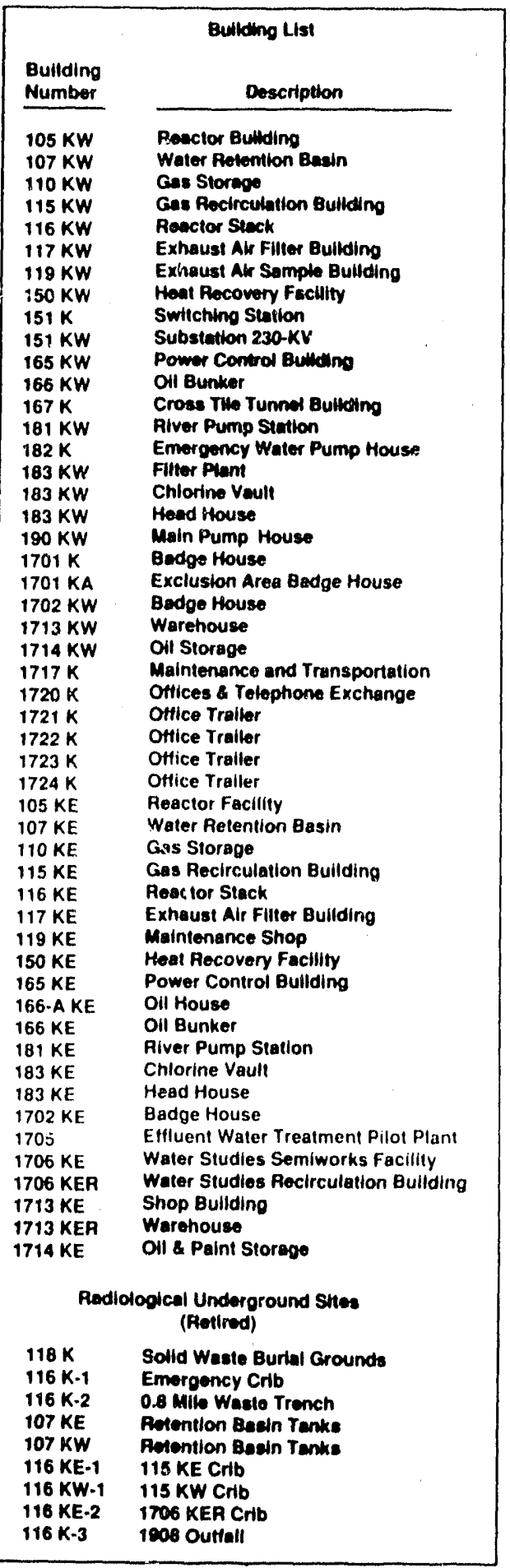

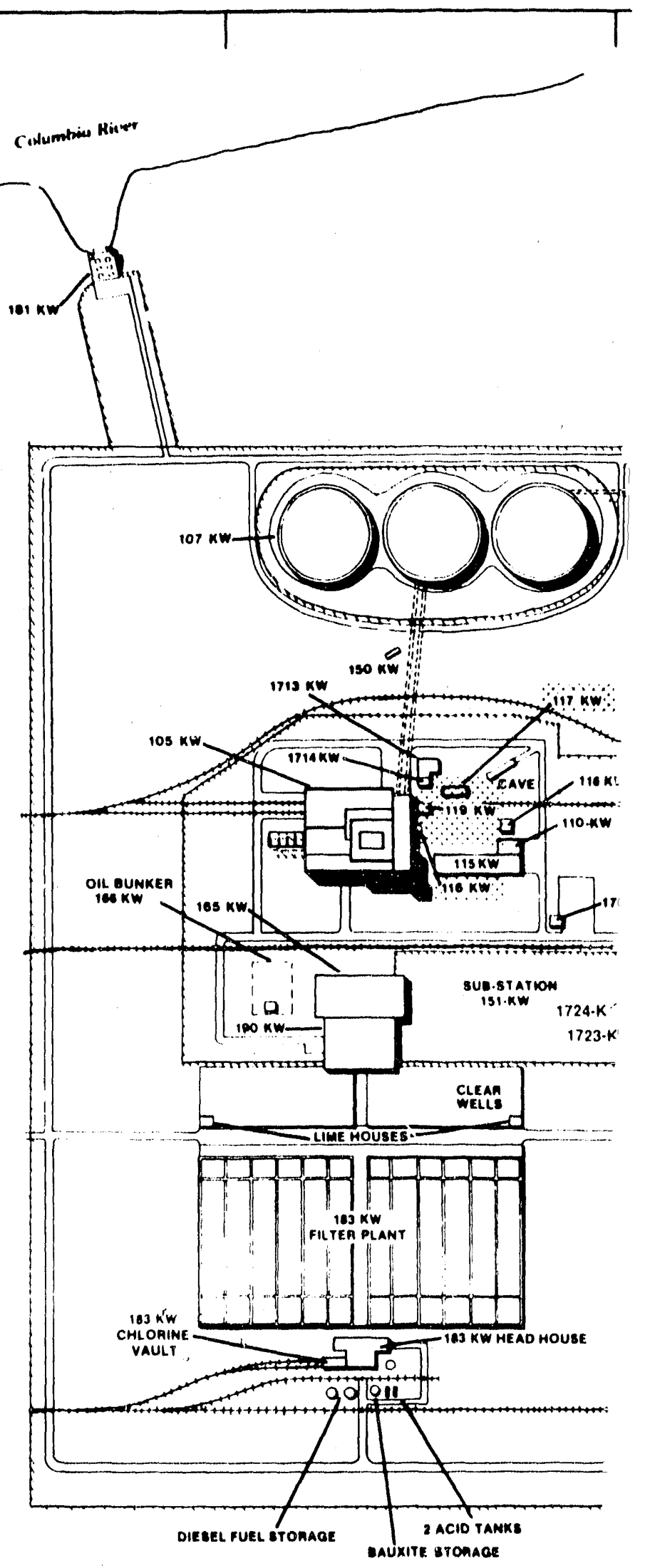




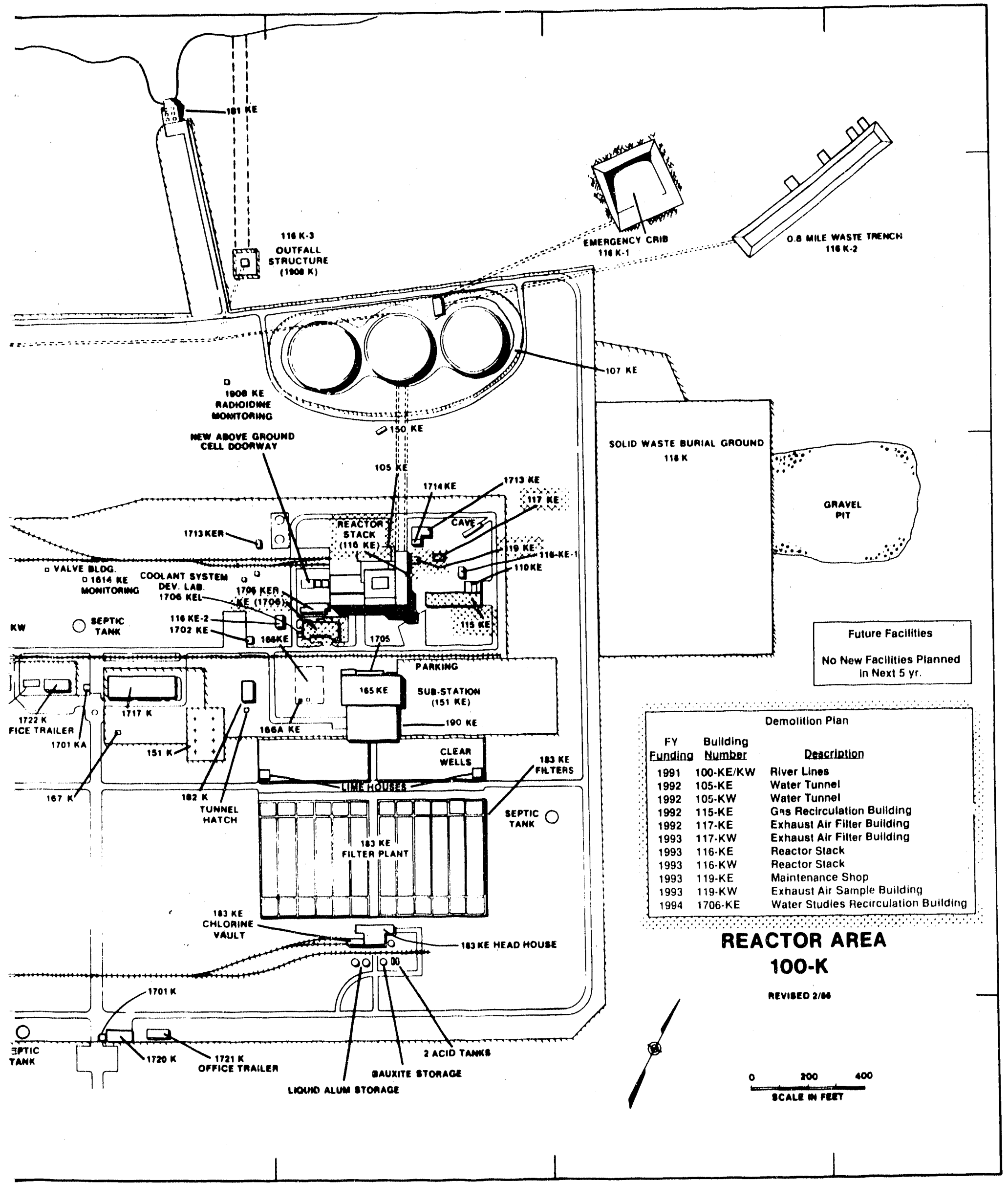




\section{$c$

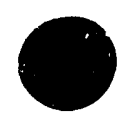

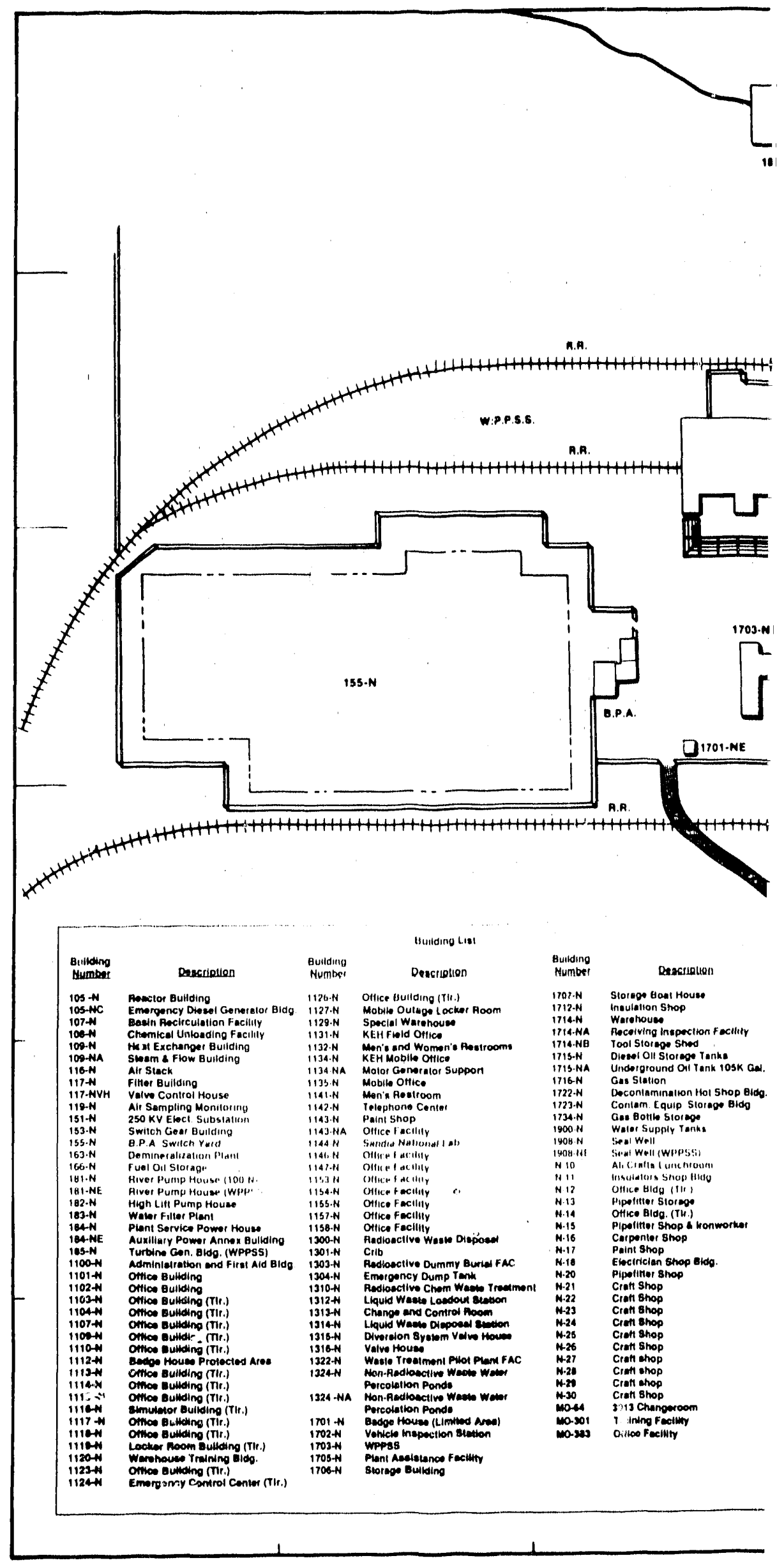




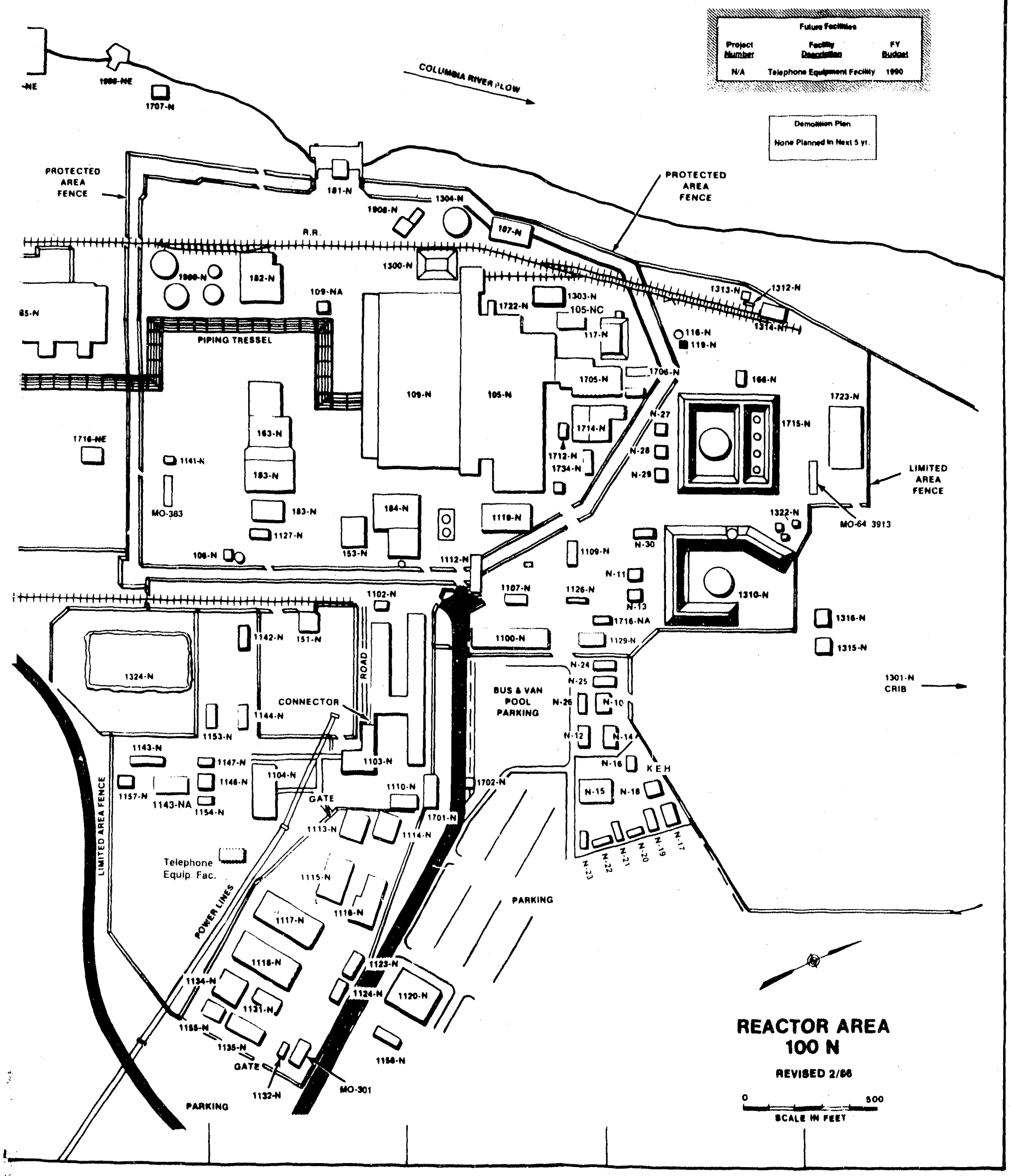




\section{BUILDING LIST}

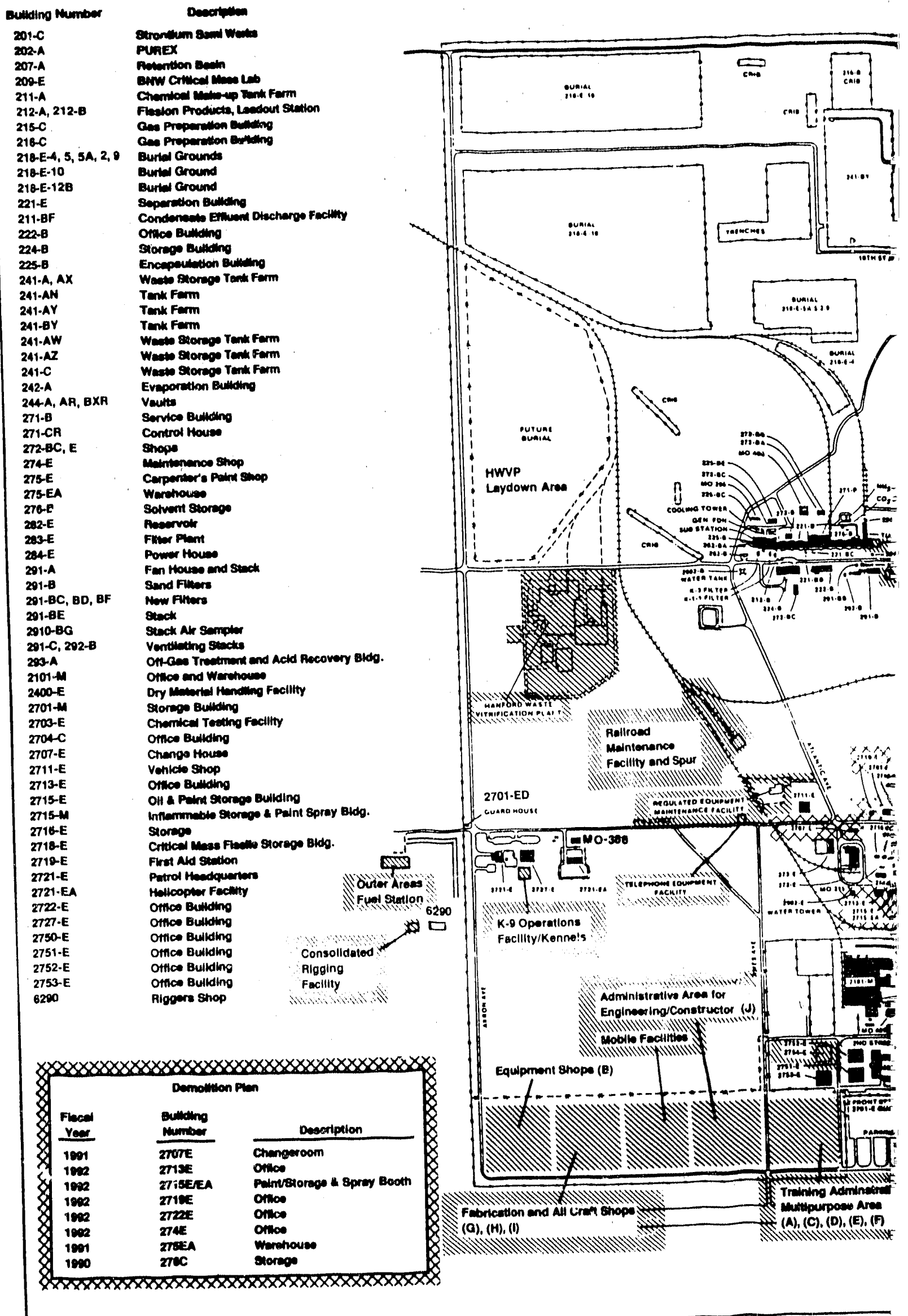




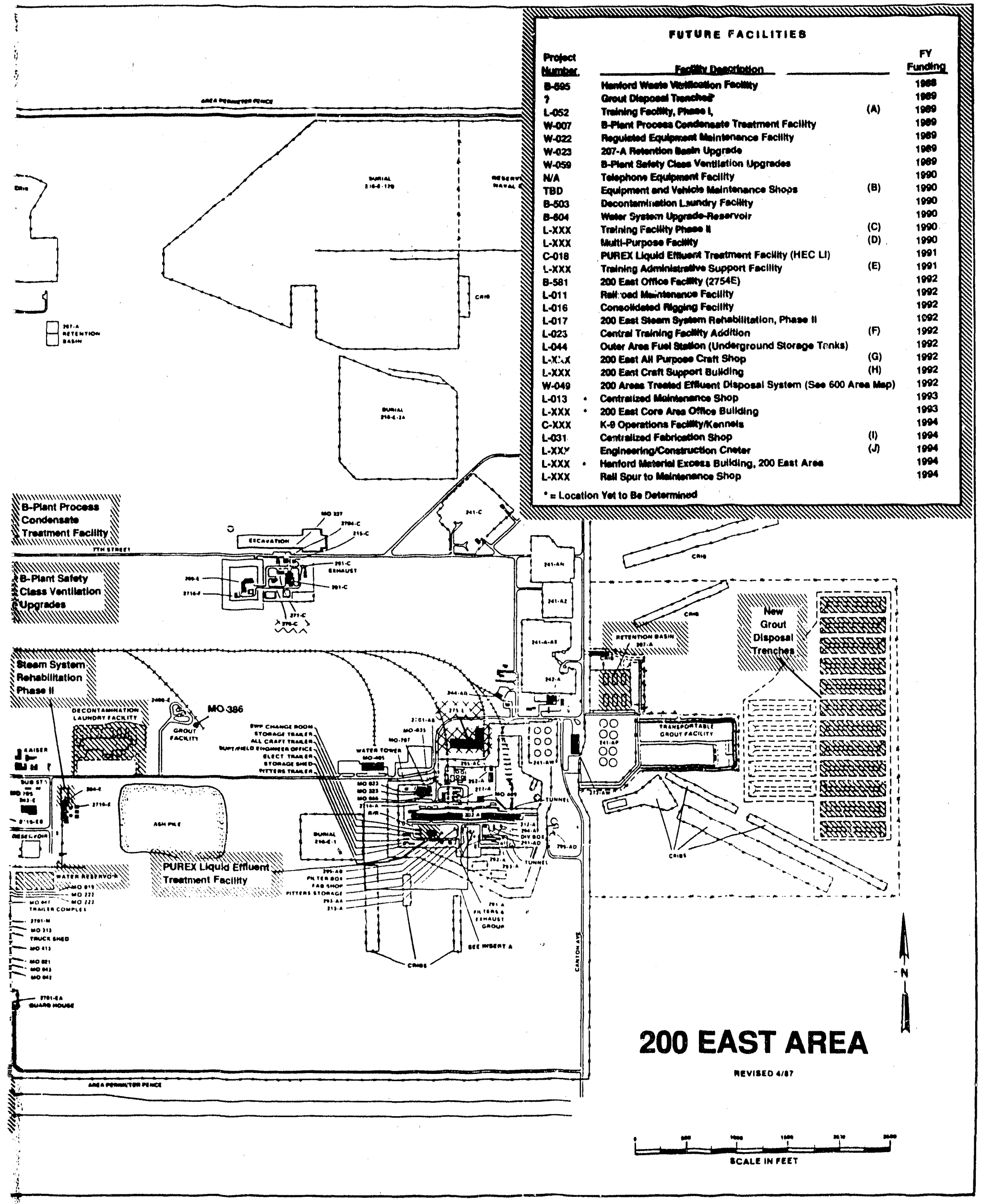


$j$

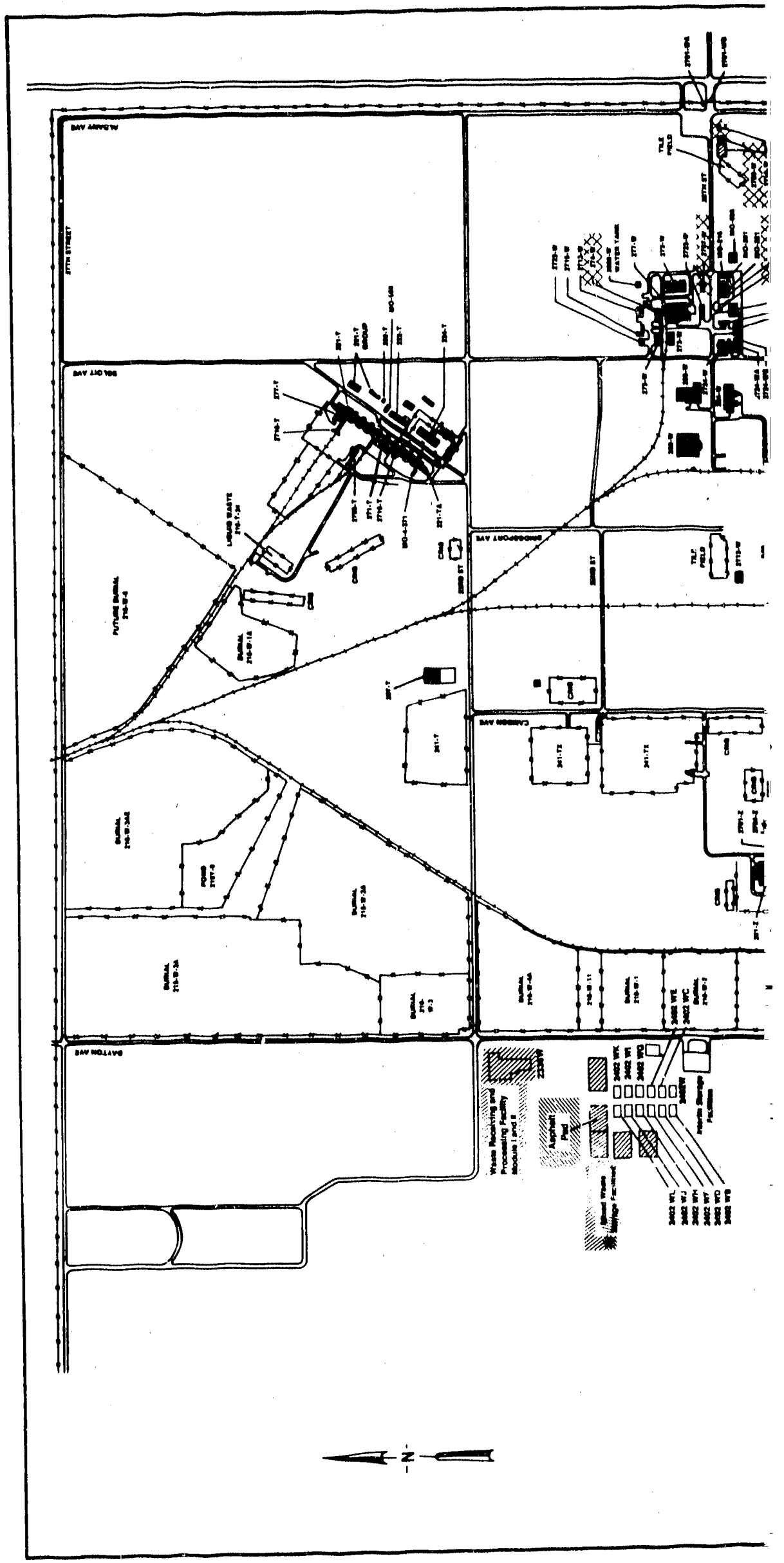




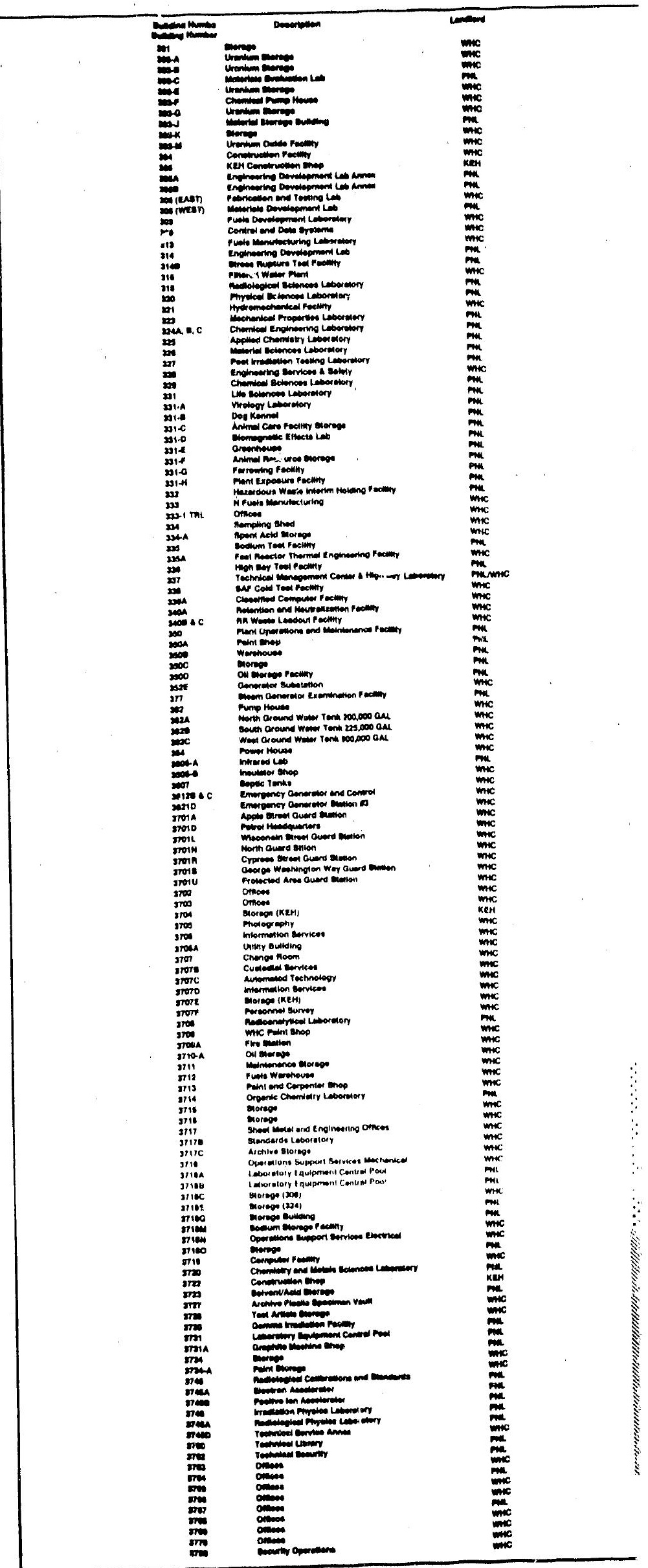




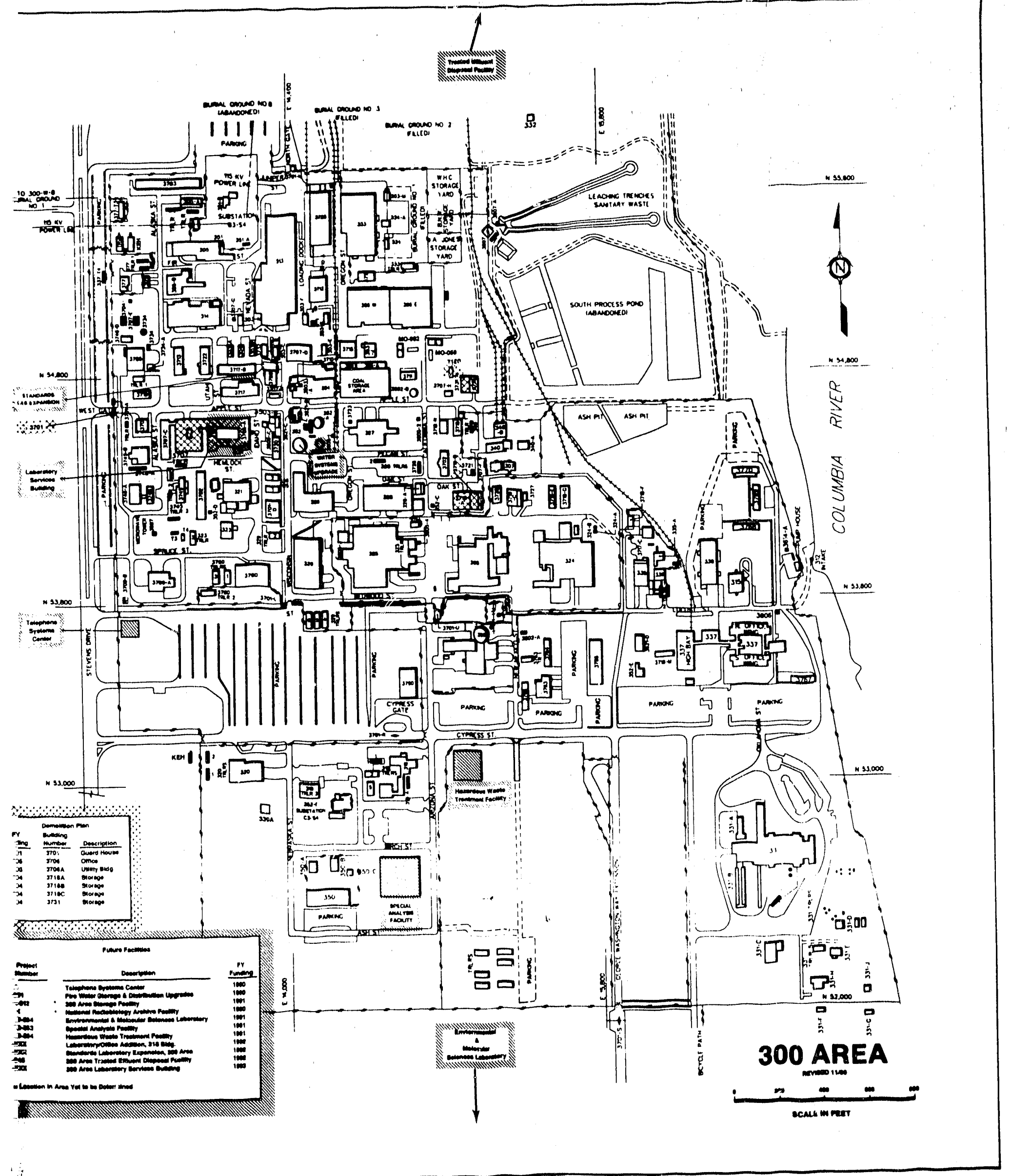




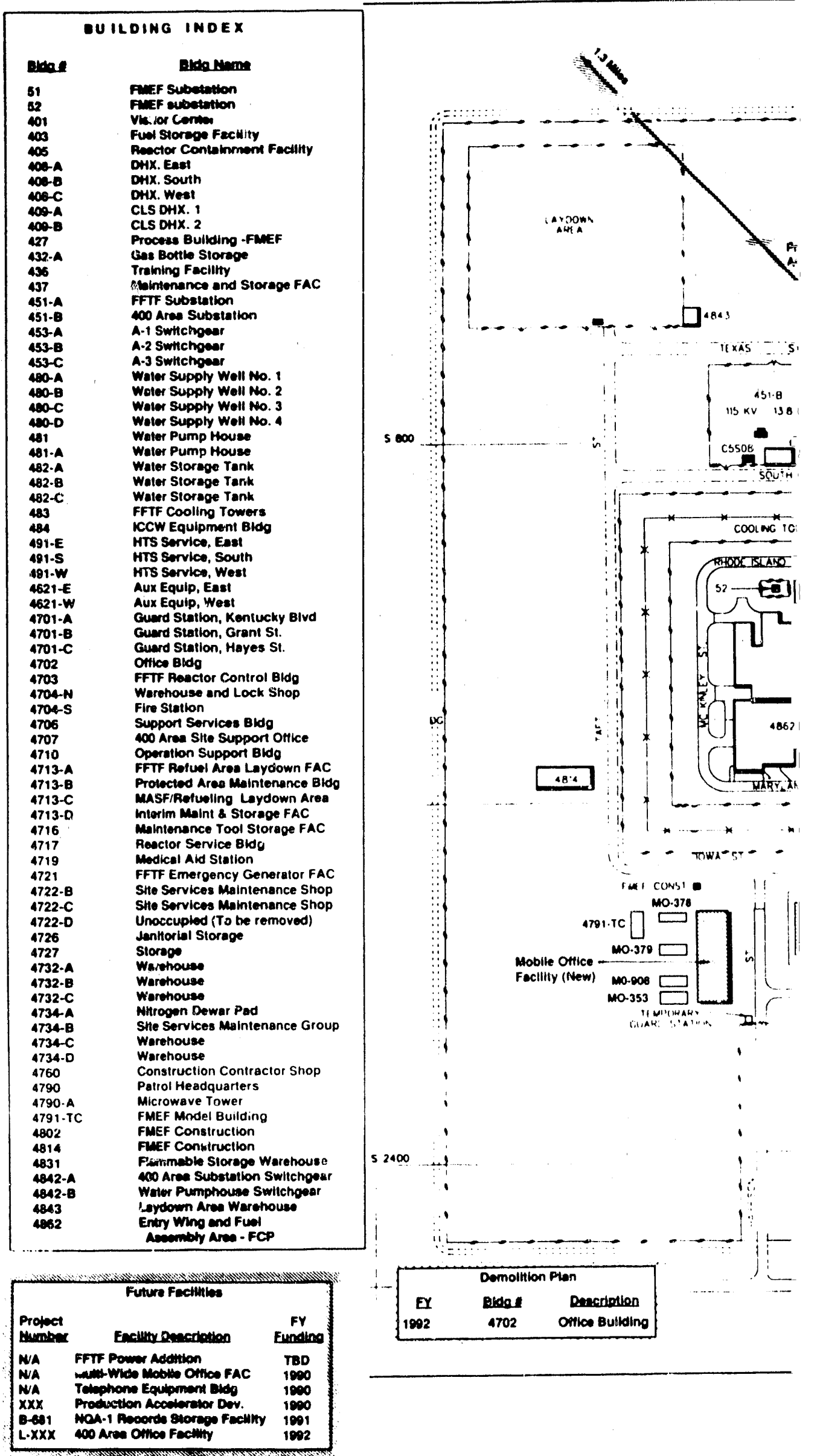




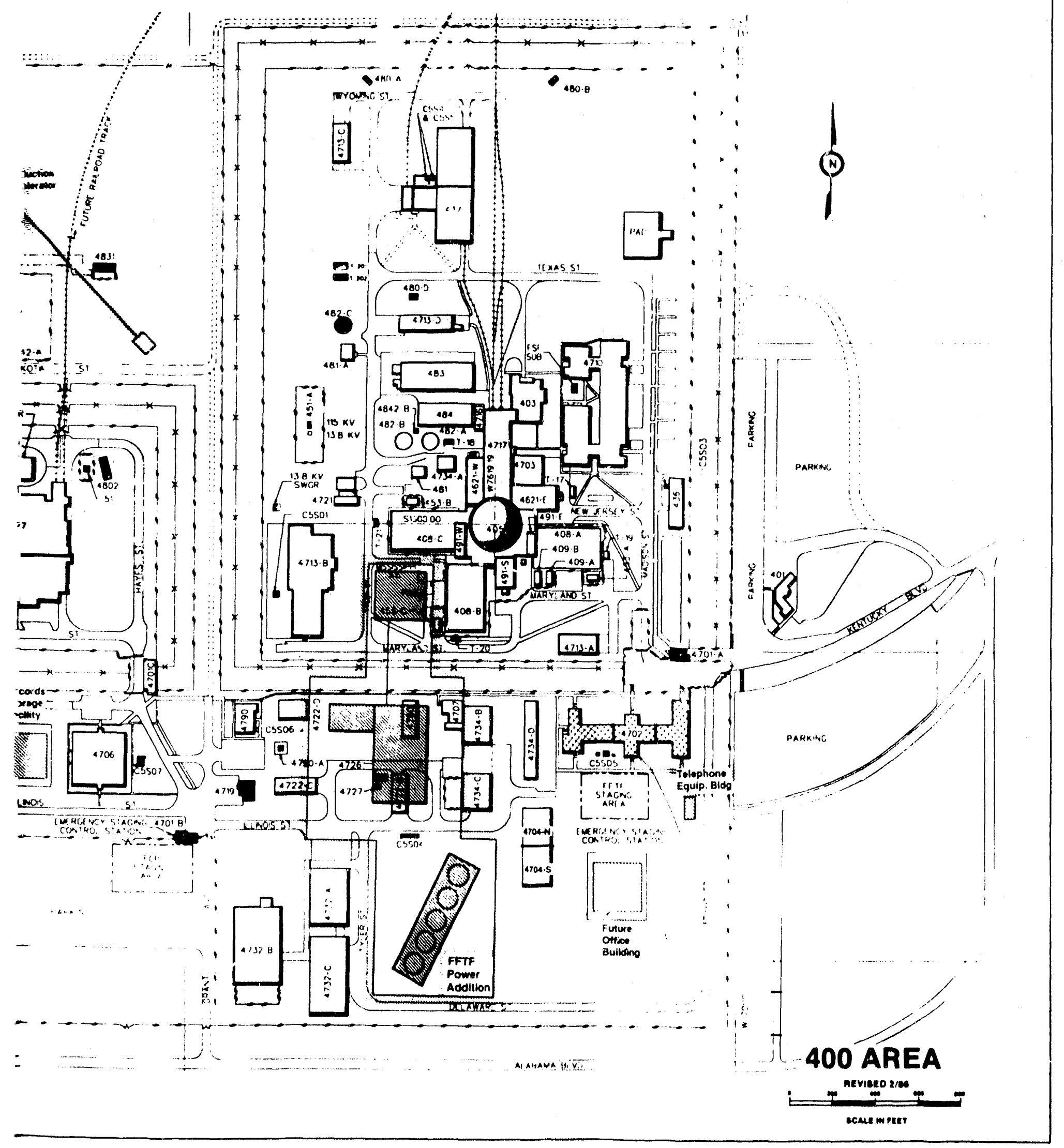




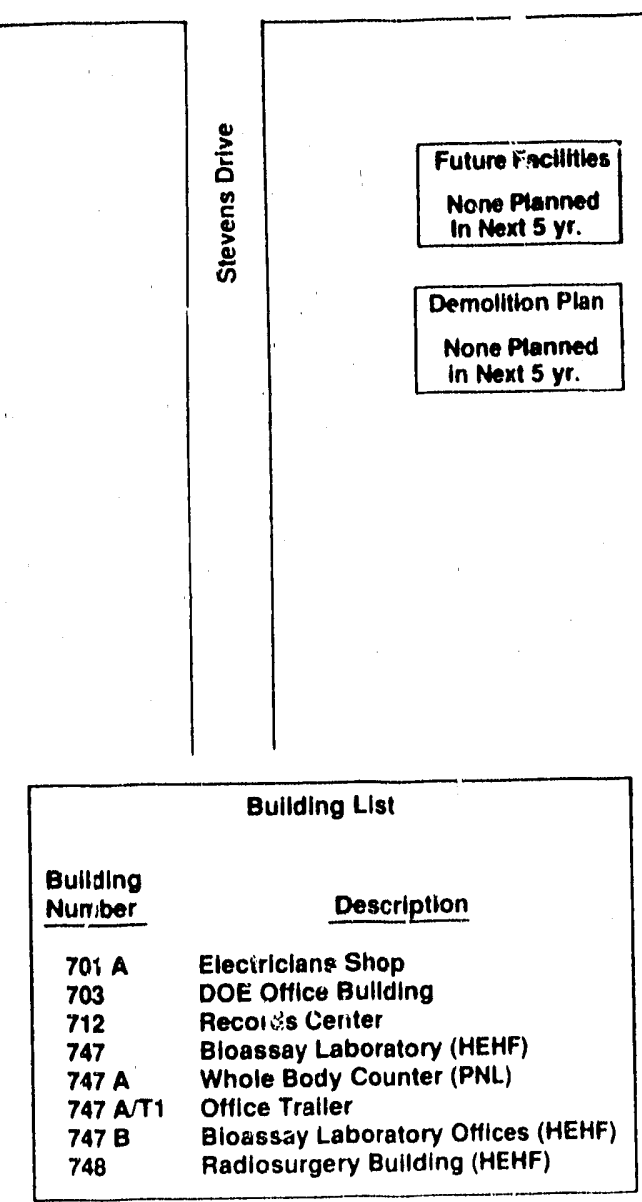

700 AREA

REVISED $2 / \mathrm{E}$

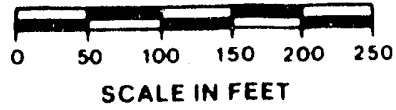

[..- DOE Property

748

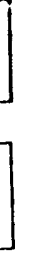




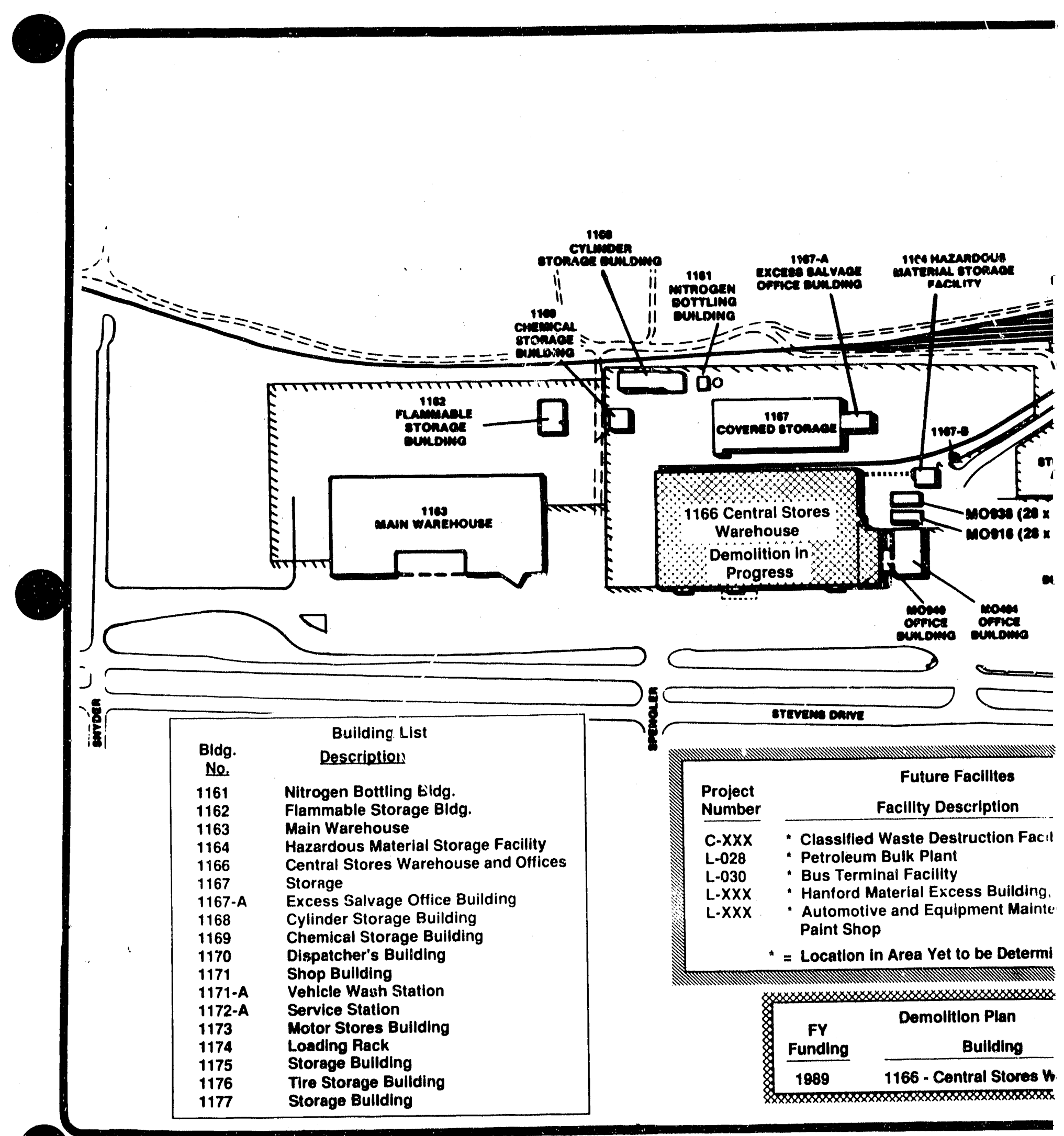




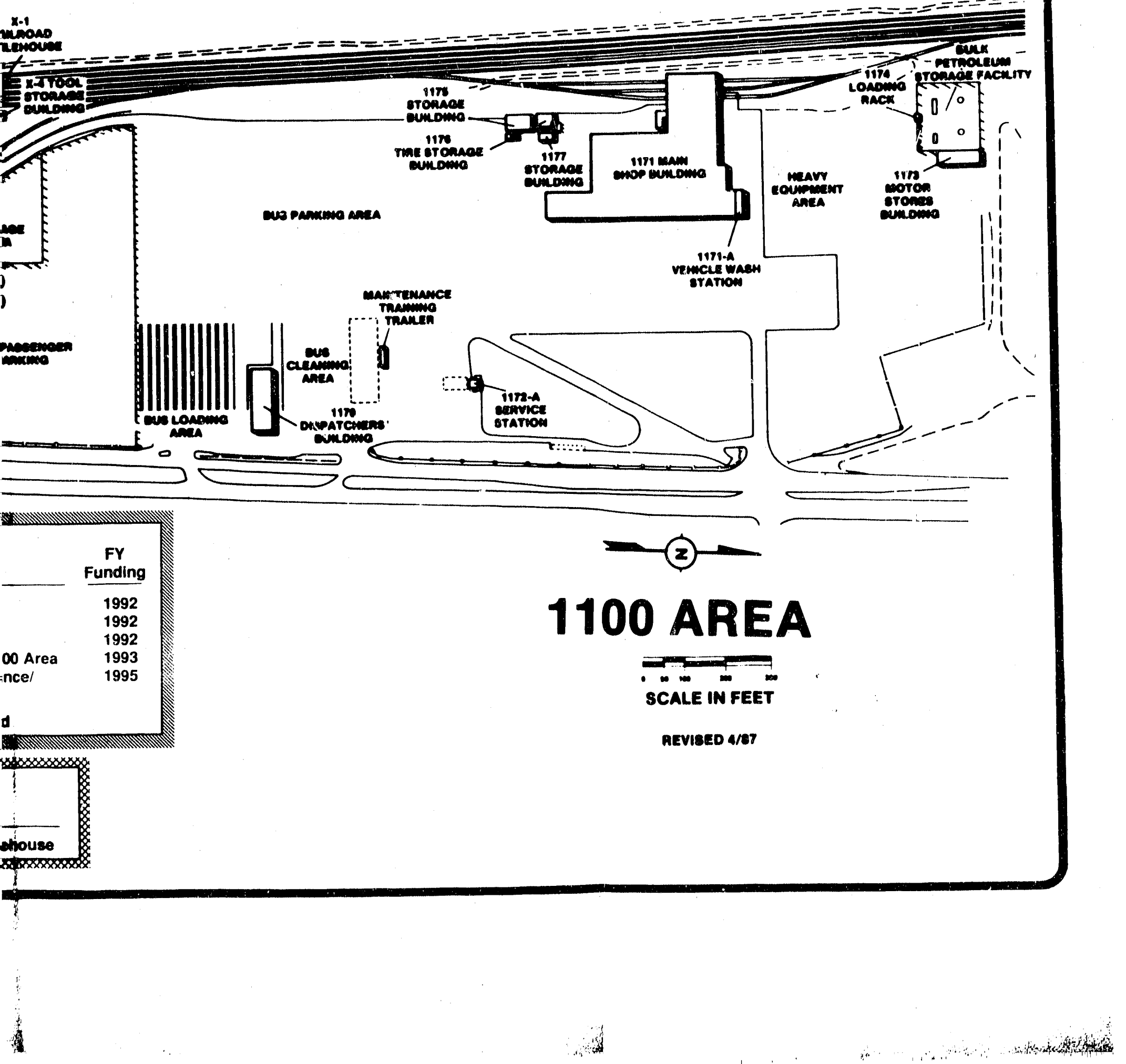


j

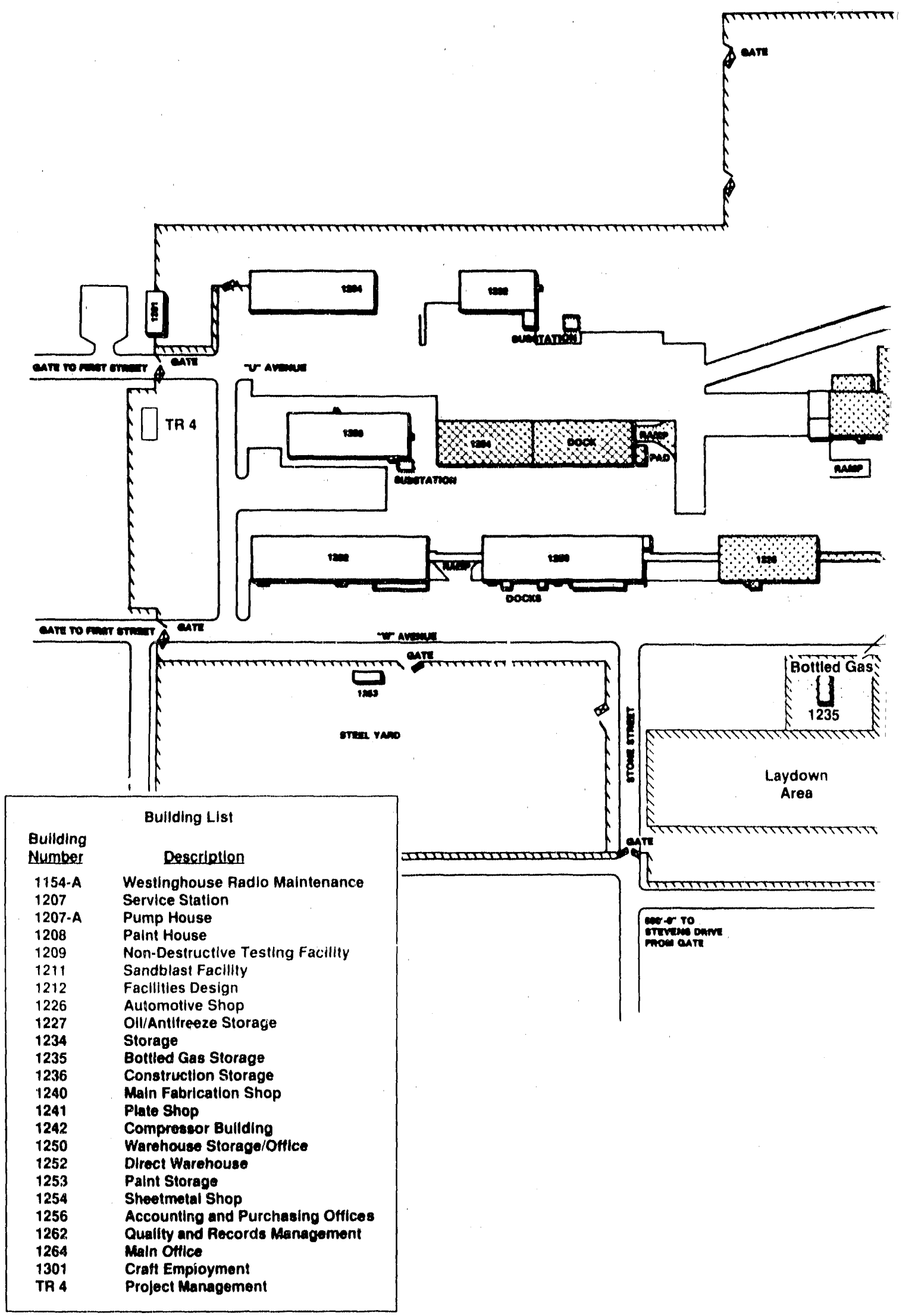




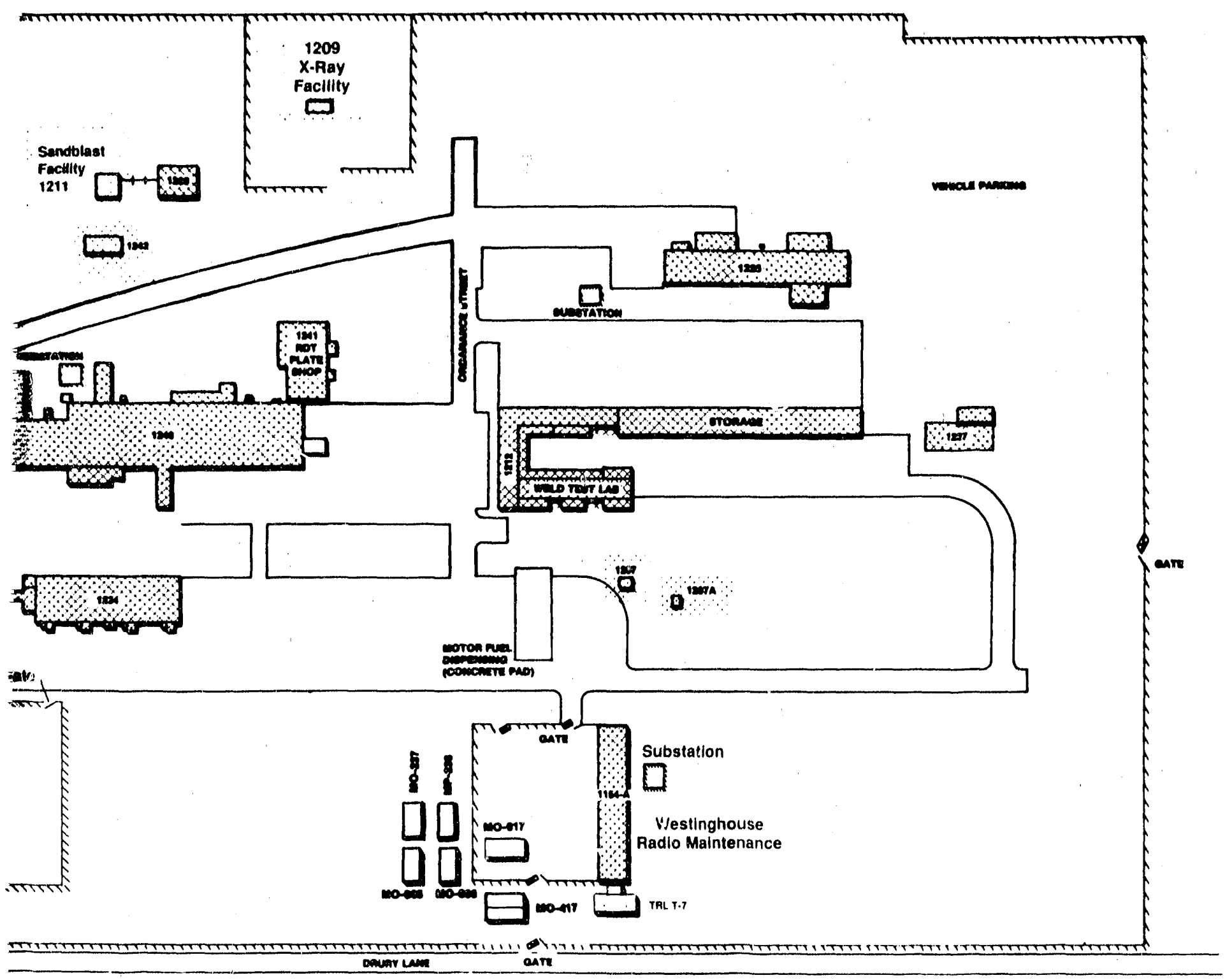

\begin{tabular}{|c|c|c|c|}
\hline \multirow{2}{*}{$\begin{array}{l}\text { Future Facilities } \\
\text { None Planned In the } \\
\text { Next } 5 \mathrm{yr} \text {. }\end{array}$} & \multicolumn{3}{|r|}{ Derinolition Plan } \\
\hline & $\begin{array}{l}\text { Fiscal } \\
\text { Year }\end{array}$ & $\begin{array}{l}\text { Building } \\
\text { Number }\end{array}$ & Description \\
\hline & $\begin{array}{l}1990 \\
1990 \\
1994 \\
\text { TBD } \\
\text { TBD } \\
1990 \\
1991 \\
1990 \\
1993 \\
\text { TBD } \\
1893 \\
1994 \\
1994 \\
1984 \\
1990\end{array}$ & $\begin{array}{l}1207 \\
1207-A \\
1208 \\
1209 \\
1211 \\
1212 \\
1226 \\
1227 \\
1234 \\
1235 \\
1236 \\
1240 \\
1241 \\
1242 \\
1254\end{array}$ & $\begin{array}{l}\text { Service Station } \\
\text { Service Station Pumphouse } \\
\text { Paint Shop } \\
\text { Nondestructive Testing Facillty } \\
\text { Sandblast Facillty } \\
\text { OA Weld TestWarehouse/Otices } \\
\text { Automotlve Shops } \\
\text { Automotlve Storage } \\
\text { Warehouse } \\
\text { Bottled Ges Storage } \\
\text { Warehouse } \\
\text { Fabricaflon Shop } \\
\text { Piate Shop } \\
\text { Compreesor House } \\
\text { Sheoimetal Shop }\end{array}$ \\
\hline
\end{tabular}

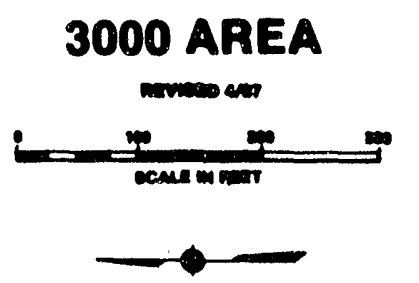


DOE /RL-89-15

APPENDIX C

\section{PROPOSED PROJECTS}

$c-1 / 2$ 
DOE/RL-89-15

\section{CONTENTS}

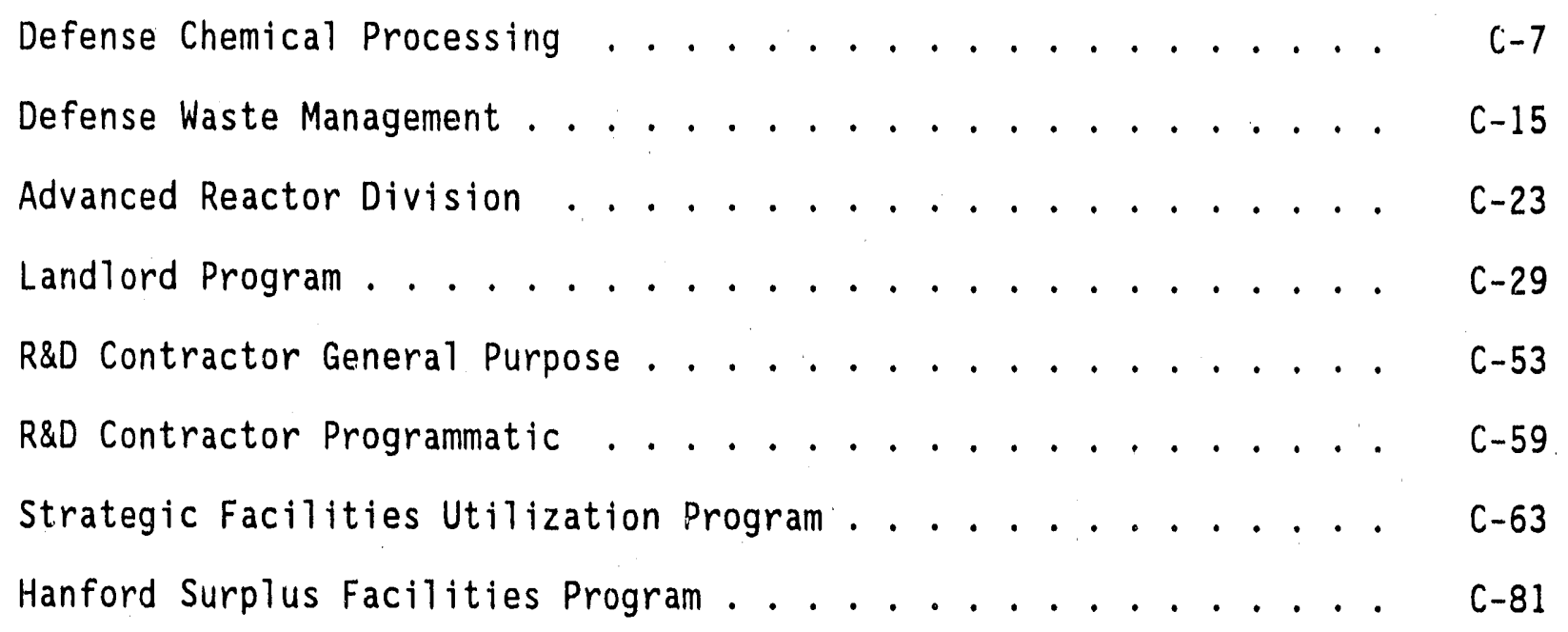




\section{APPENDIX C}

\section{PROPOSED PROJECTS}

This appendix contains detafled information about the projects listed in the Five-Year Plan section of this document.

Tables are provided for Defense Chemical Processing, Defense Waste Management Advanced Reactor Division (Nuclear Energy), Landlord Program, Research and Development (R\&D) Contractor General Purpose, R\&D Contractor Programmatic, Strategic Facilities Utilization Program (formerly Strategic Facilities Initiative), and Hanford Surplus Facilities Program. Programs are sorted in the order of area name, proposed funding year, project number, and project title. There are no Line Item or General Plant Projects proposed for the Defense Reactor Division. 


\section{CHEMICAL PROCESSING CAPITAL PROJECTS}

PLANNED THROUGH FY 1995

The following 28 projects are being submitted by the Chemical Processing (Defense) Program. 
DOE/RL - $89-15$

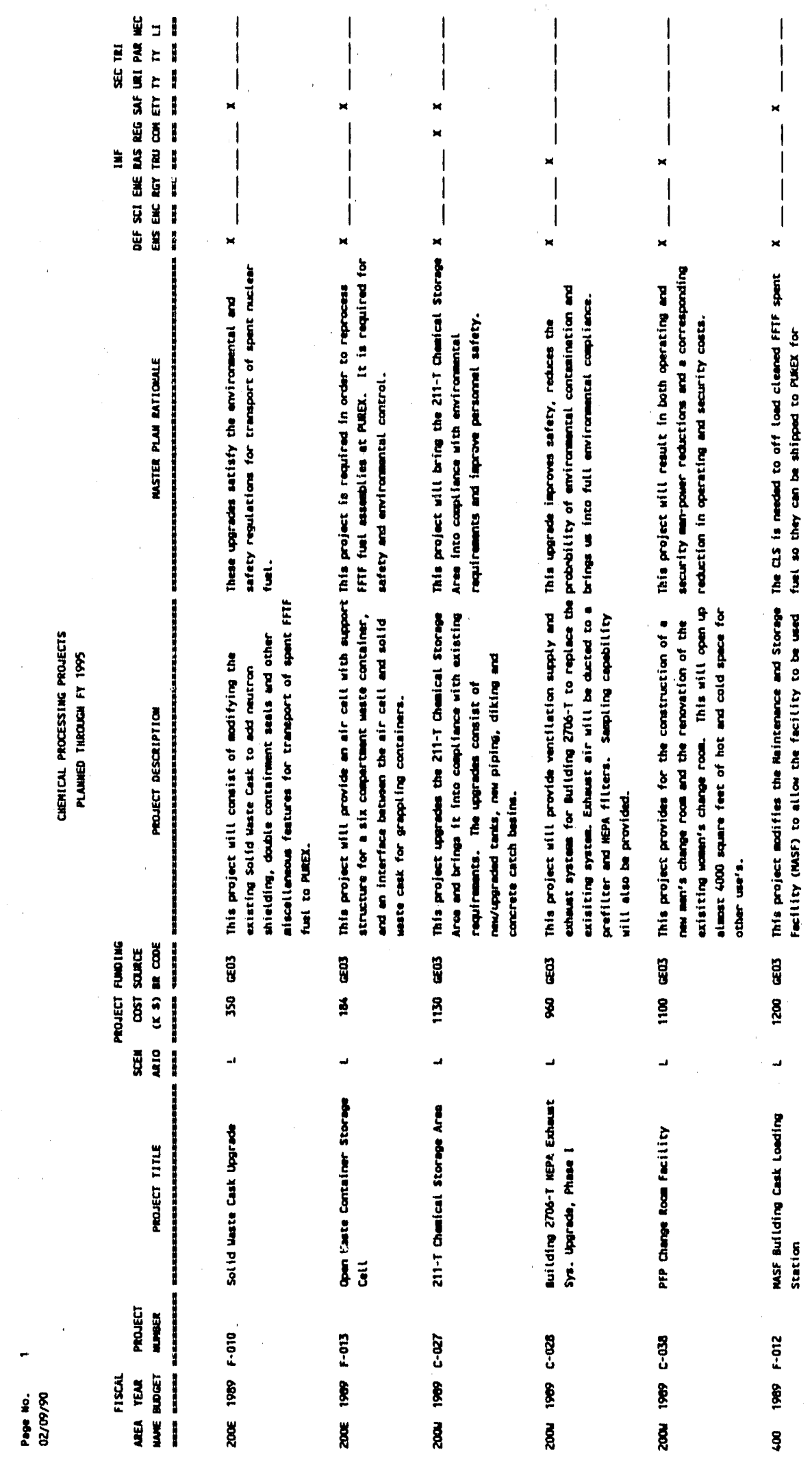


DOE/RL - $89-15$

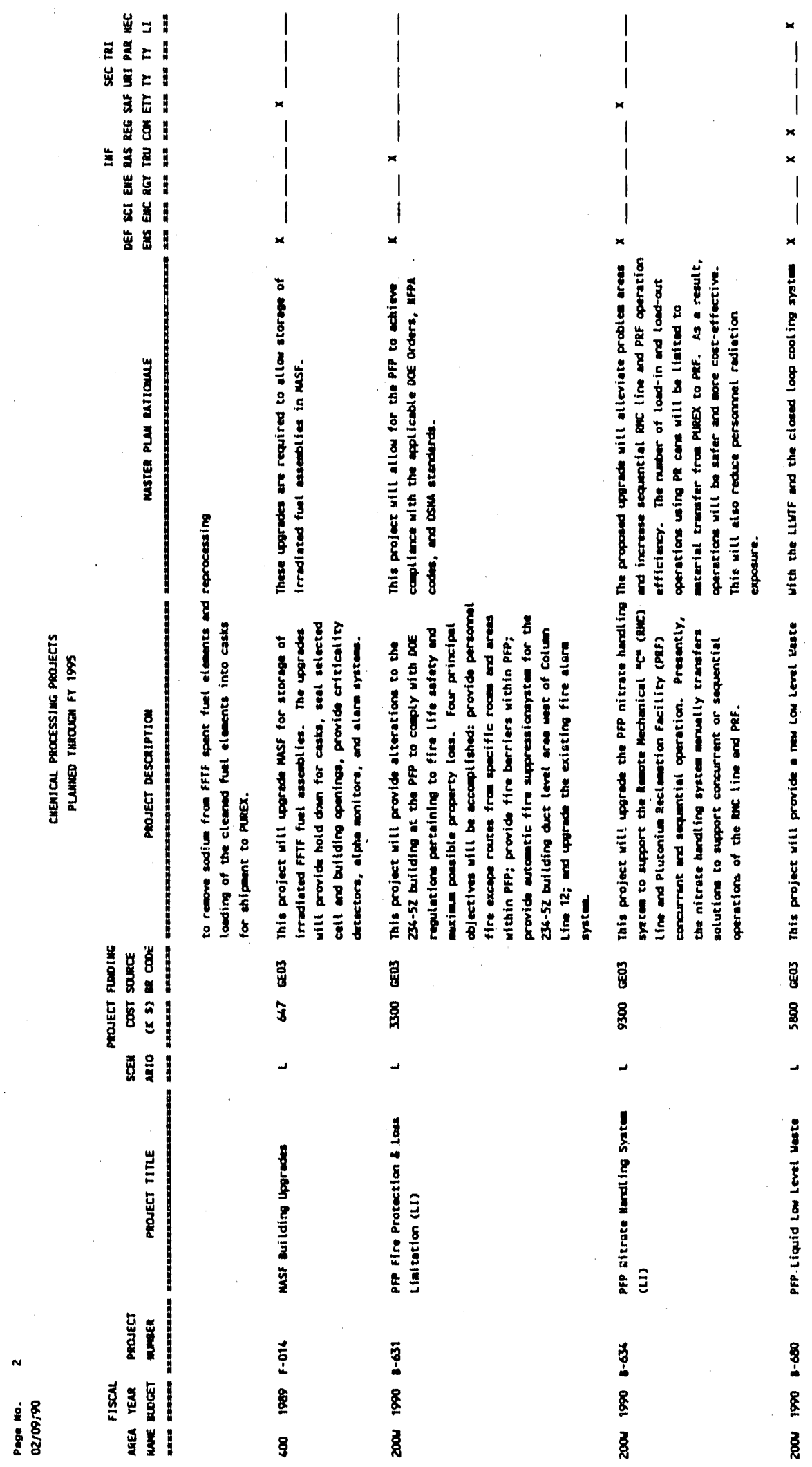


DOE/RL-89- 15

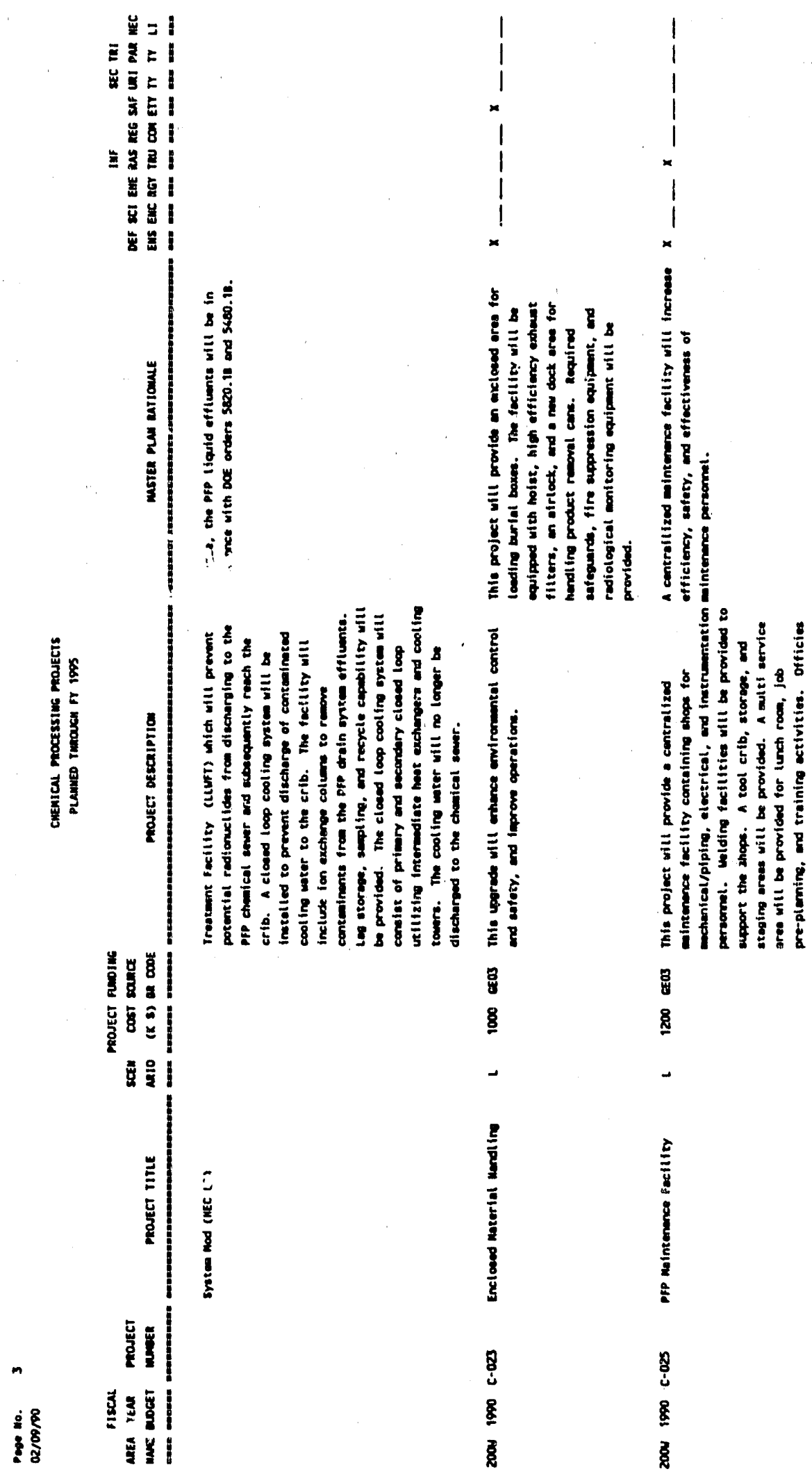


DOE/RL $-89-15$
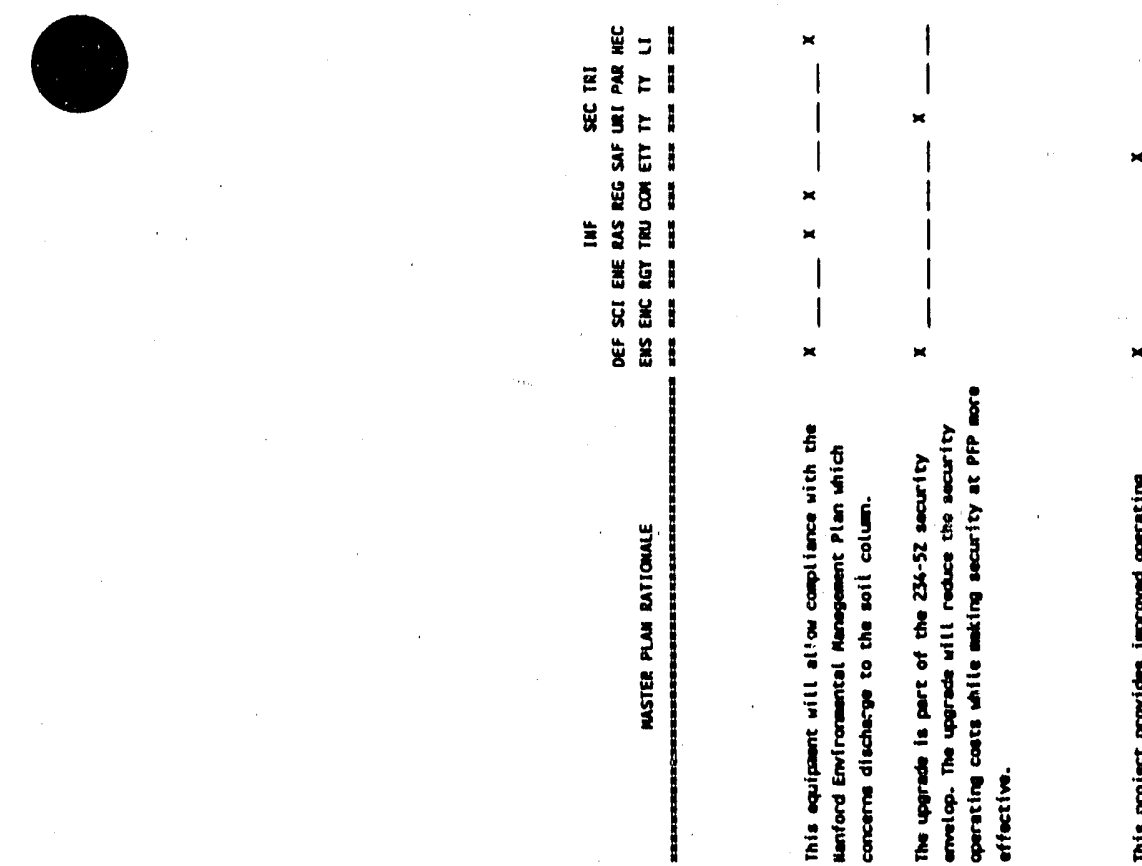

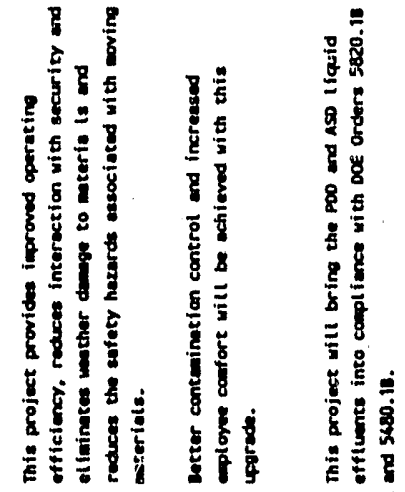
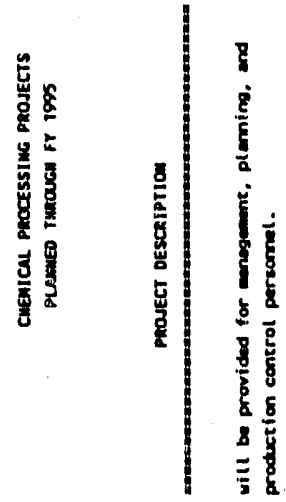

:

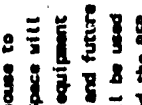

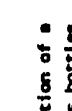

$\frac{1}{8}$

ह

(1)

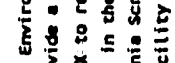

$8 \frac{8}{5}=\frac{8}{3}$

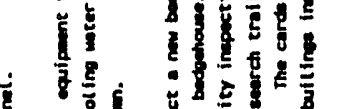

5

造

(.)

萡

s.

5
8
8

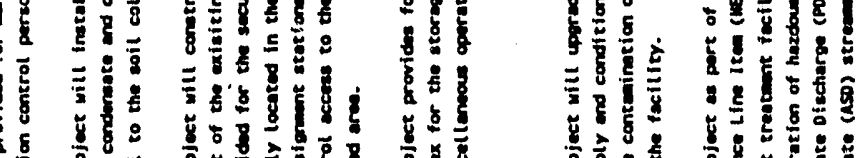

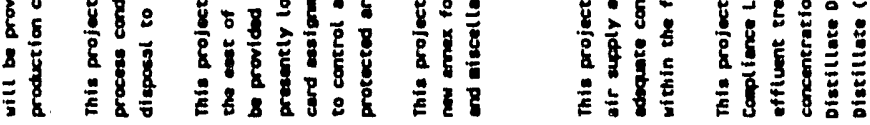

|

8
8
8

$\begin{array}{lll}8 & 8 & 8 \\ 8 & \vdots & 8\end{array}$

을

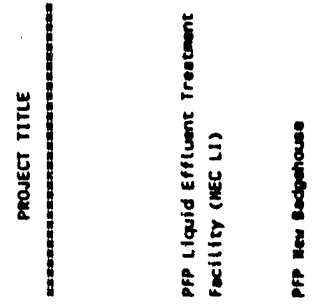

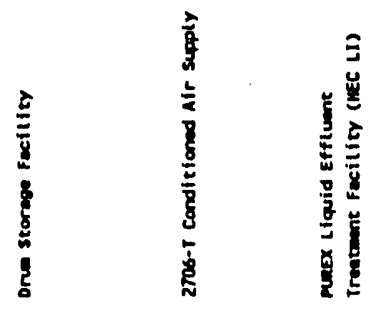

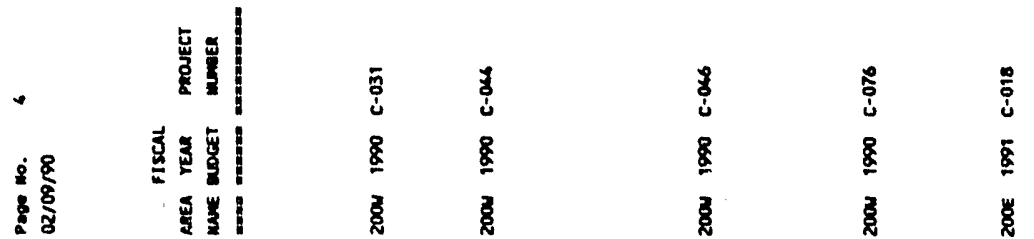


DOE/RL - 89- 15

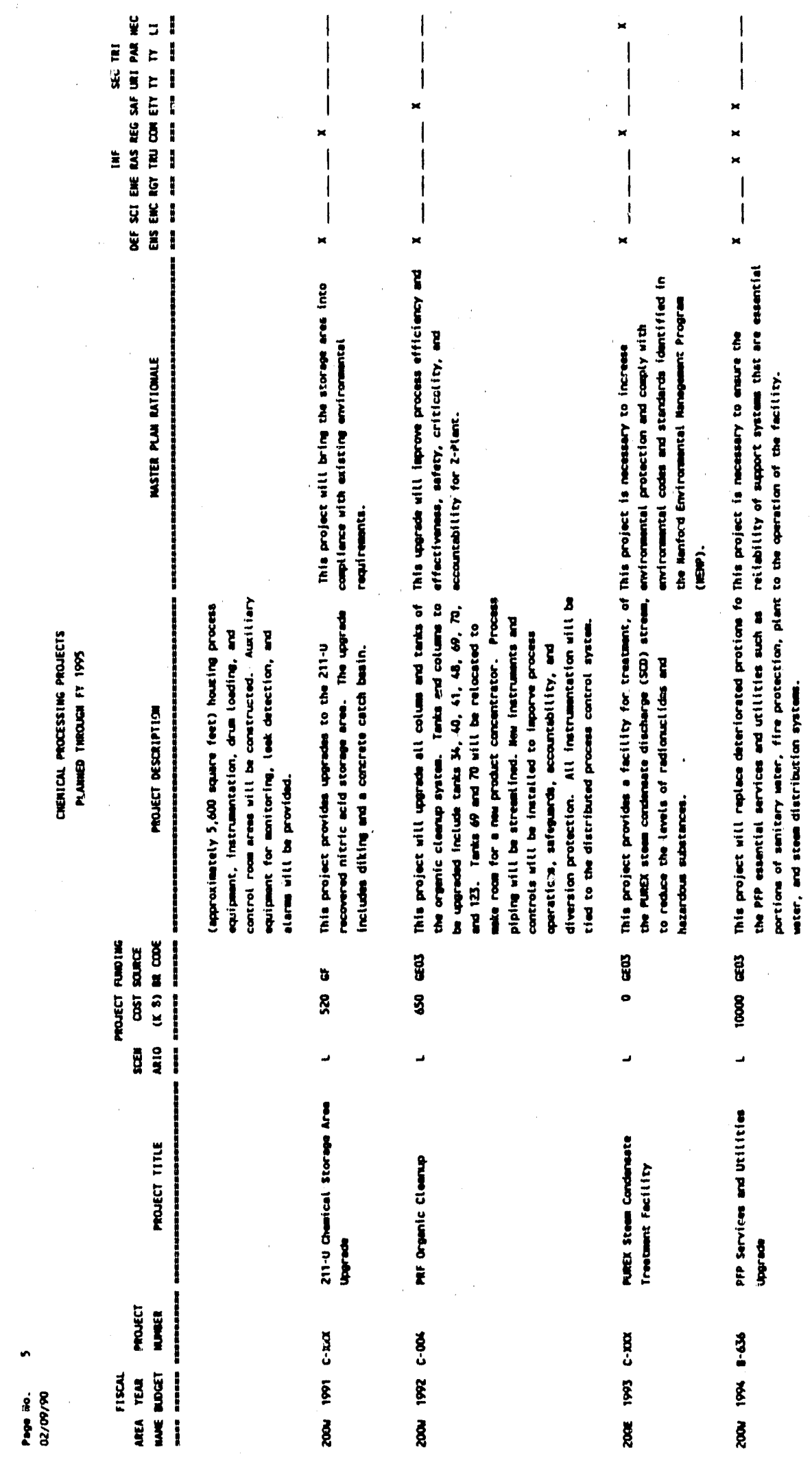


DOE/RL - $89-15$

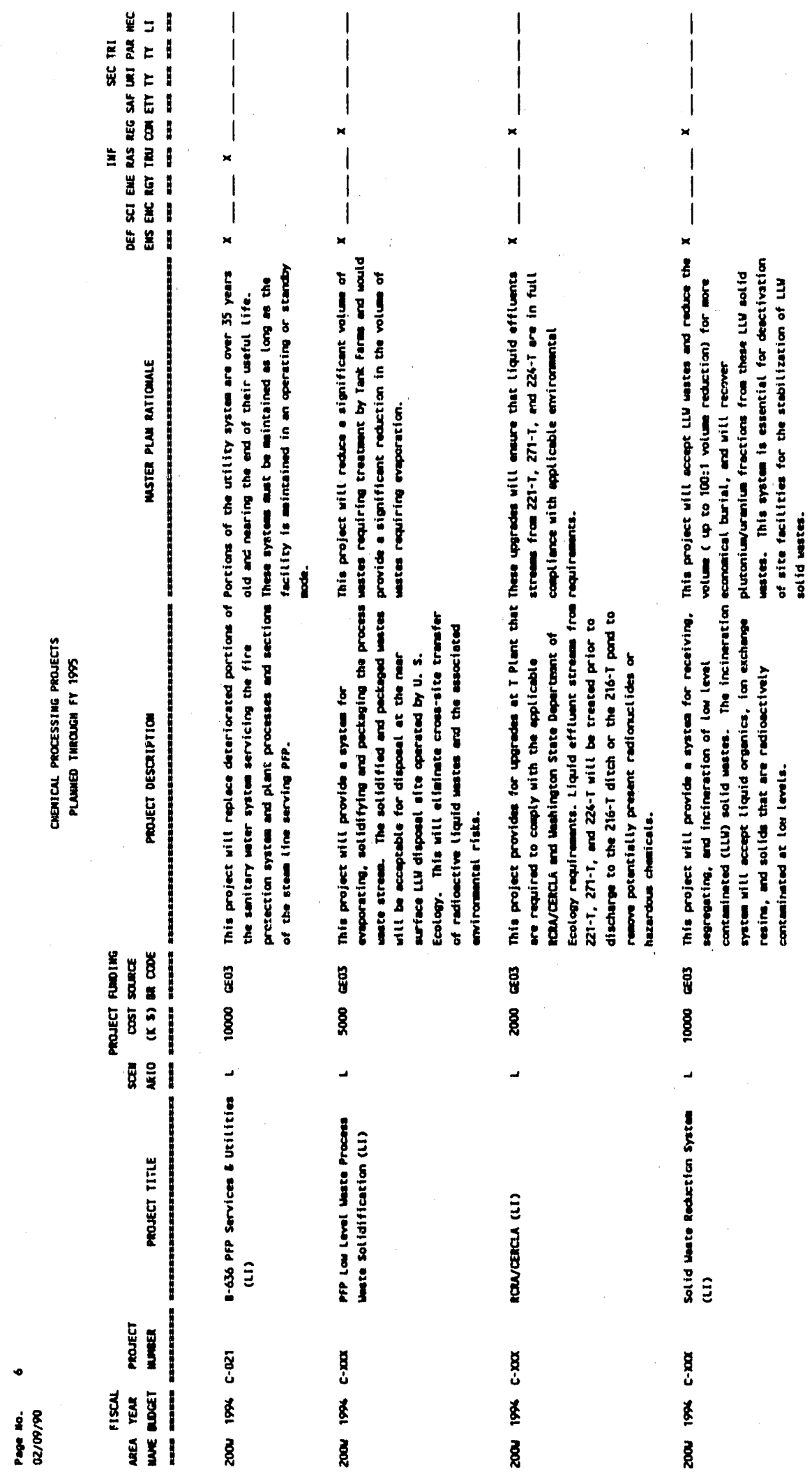


DOE/RL - 89- 15

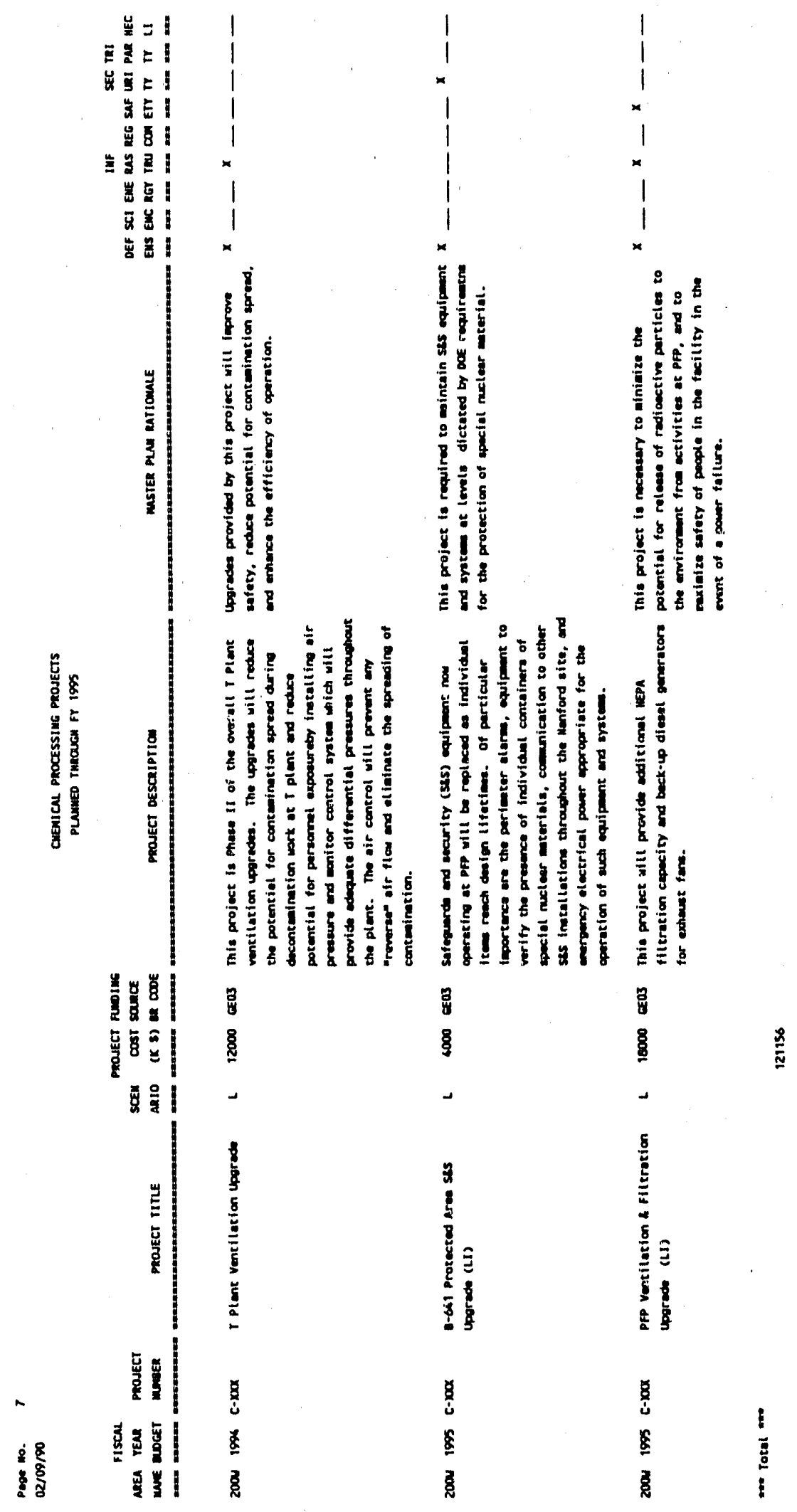


DOE/RL - 89-15

\section{DEFENSE WASTE MANAGEMENT CAPITAL PROJECTS}

PLANNED THROUGH FY 1995

The following 27 projects are being submitted by the Environmental Restoration and Defense Waste Management Program. 
DOE/RL - 89- 15

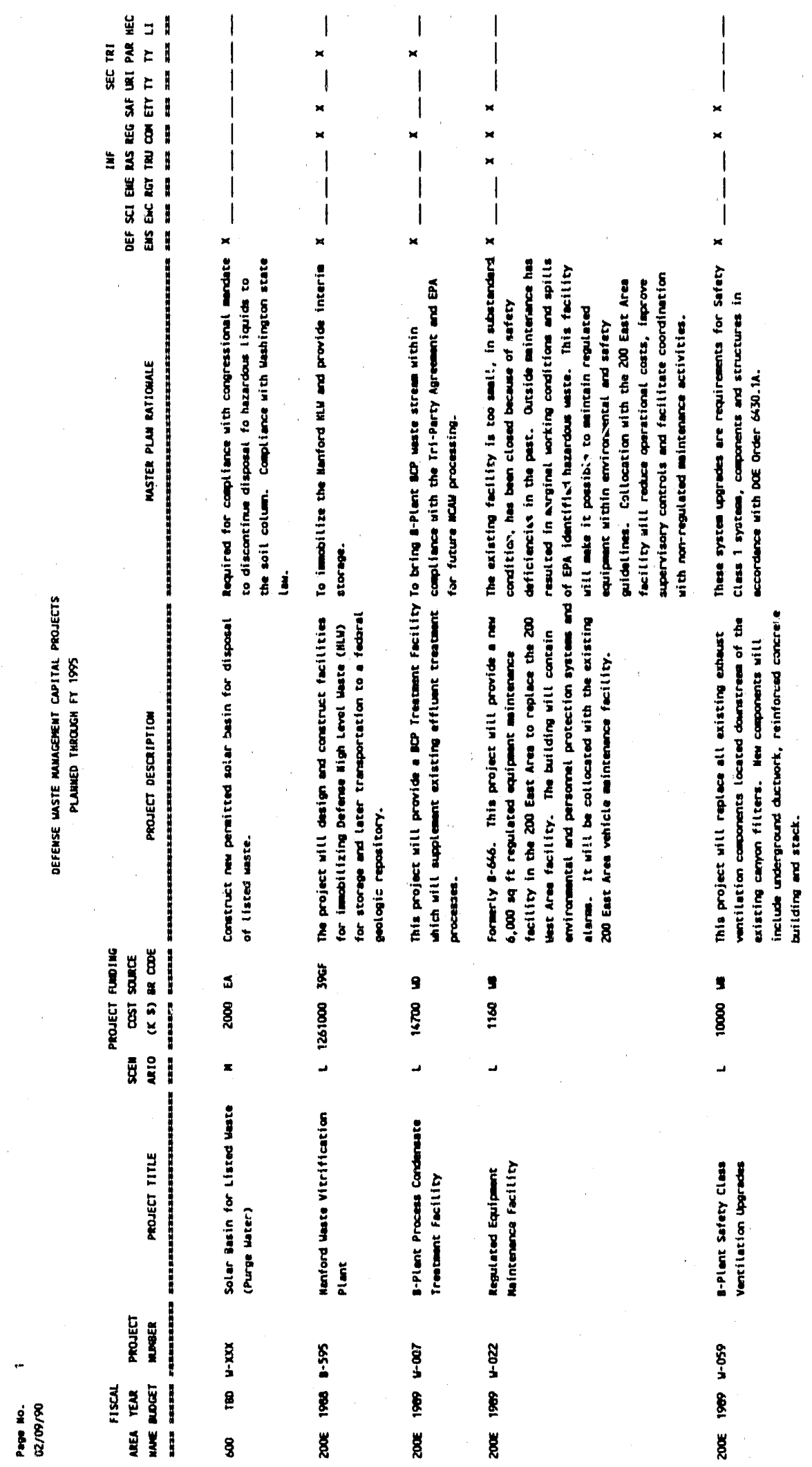


$D 0 E / R L-89-15$
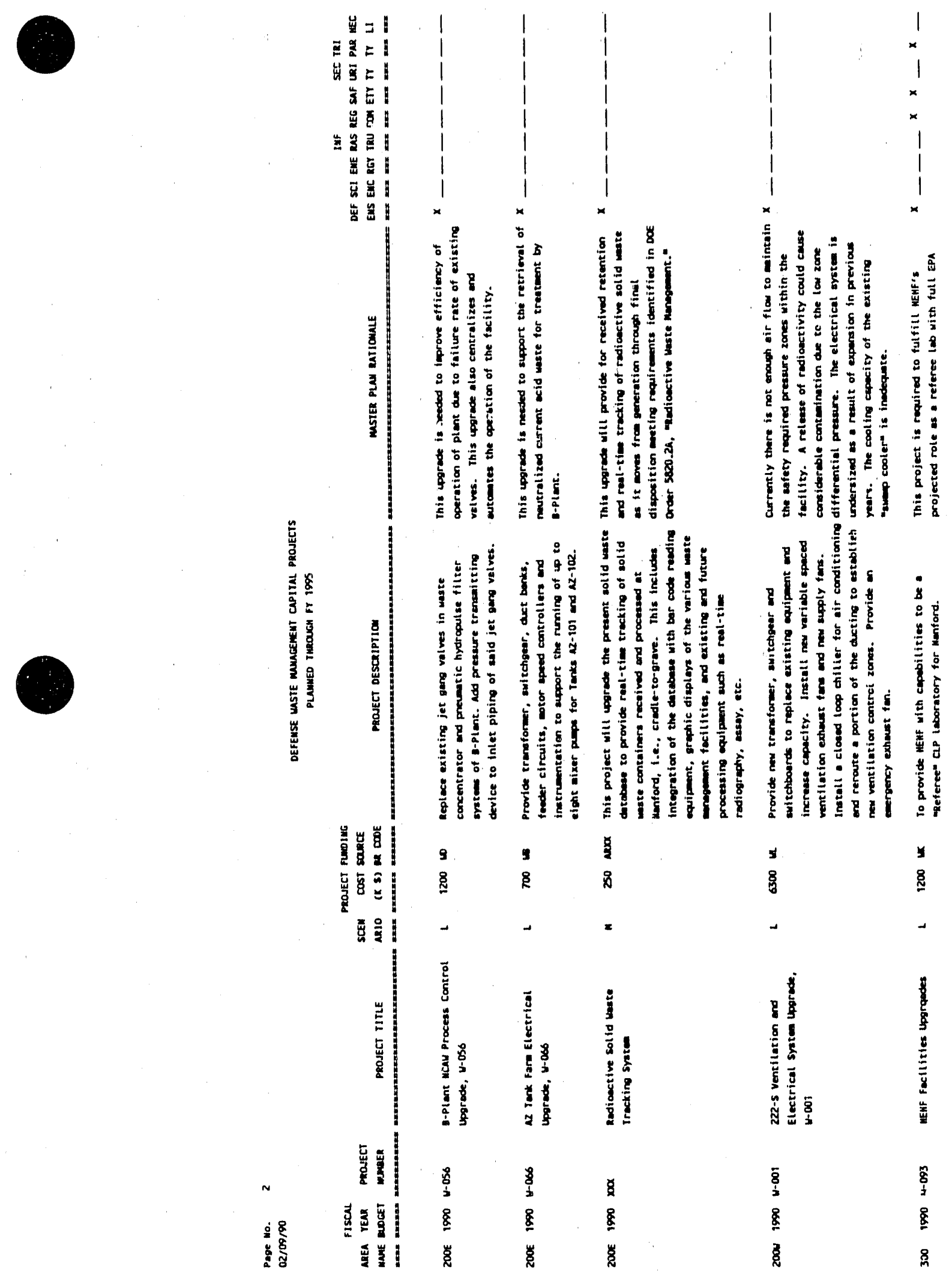
DOE/RL-89-15

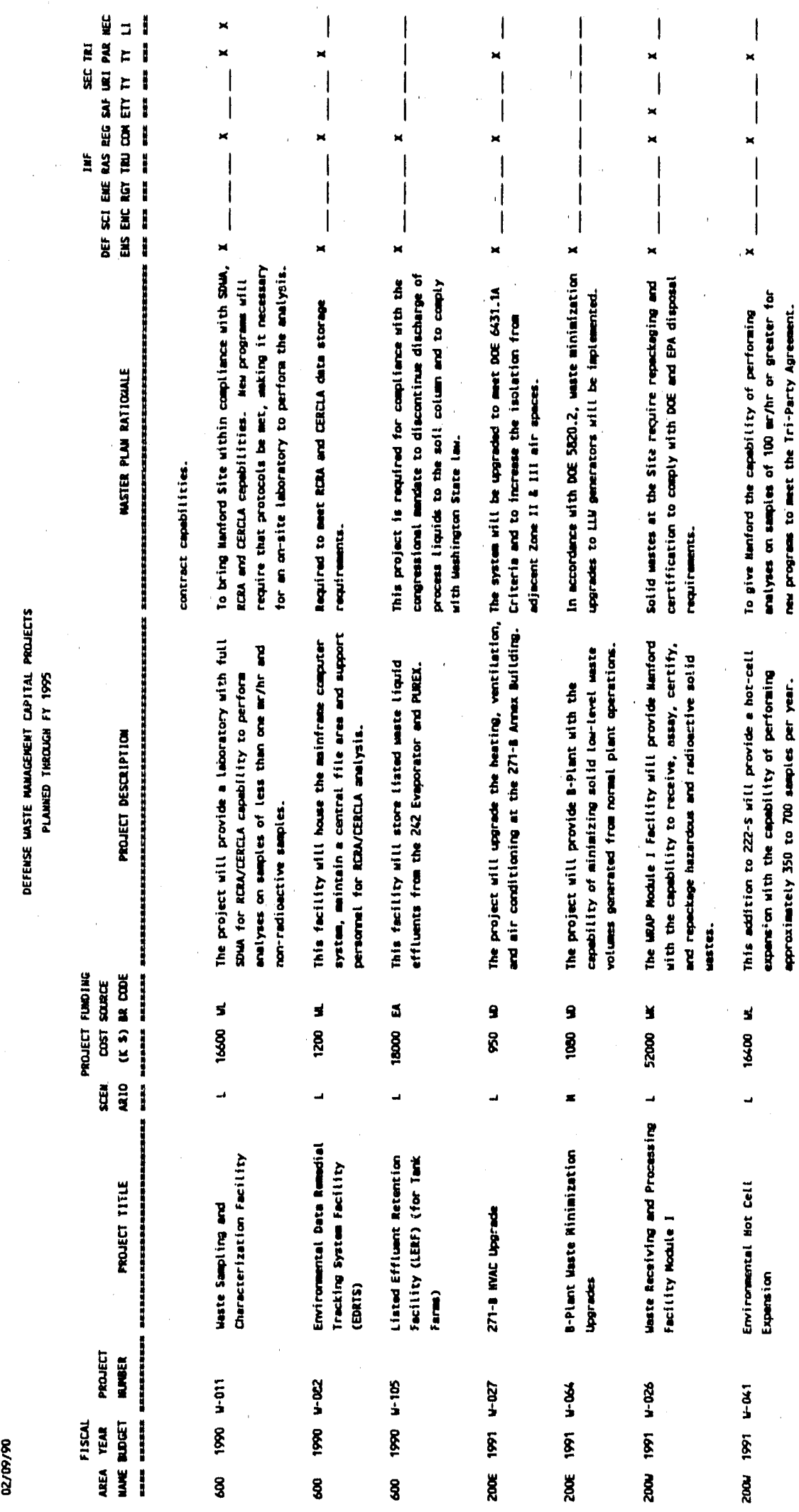


DOE/RL - 89- 15
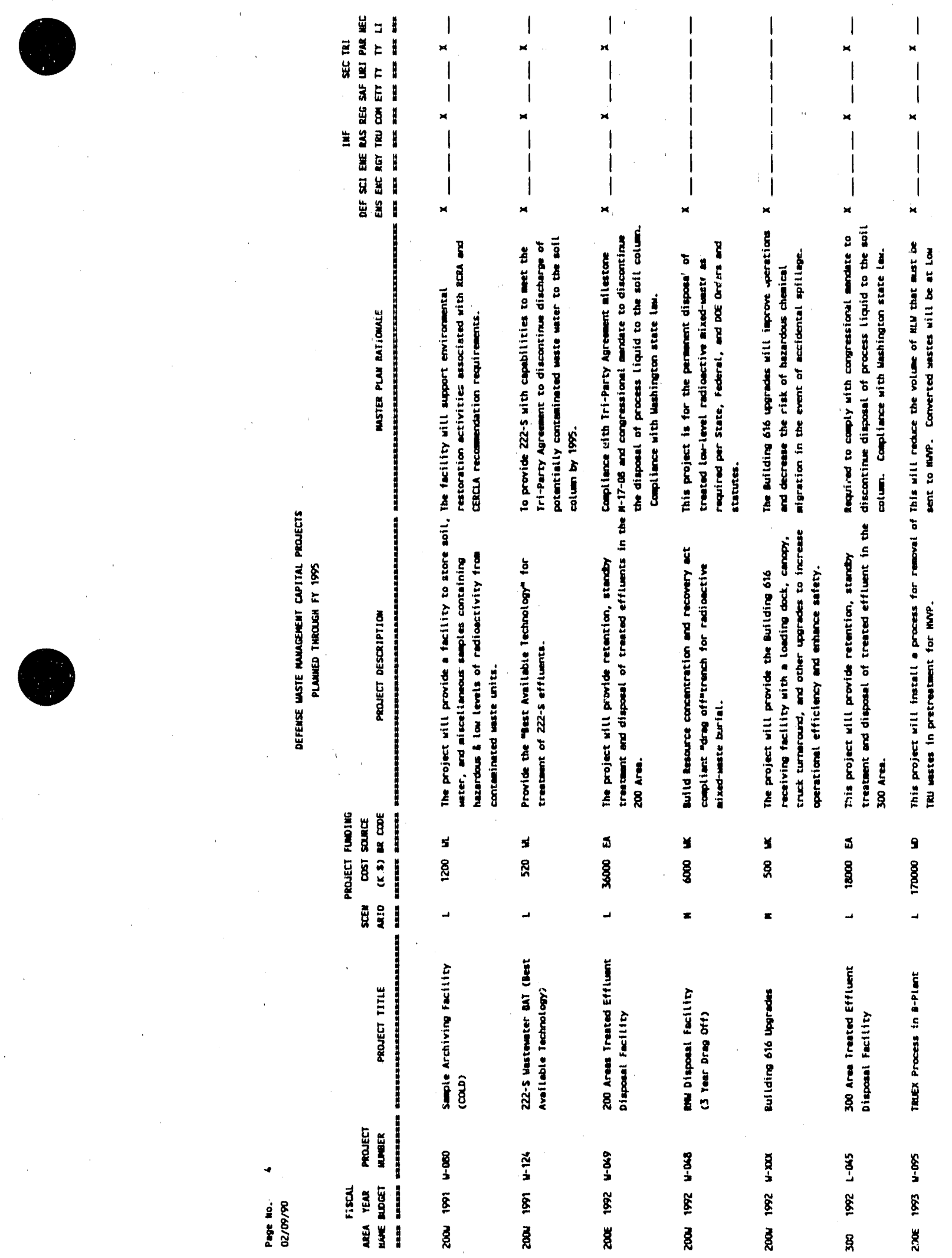
DOE/RL $-89-15$
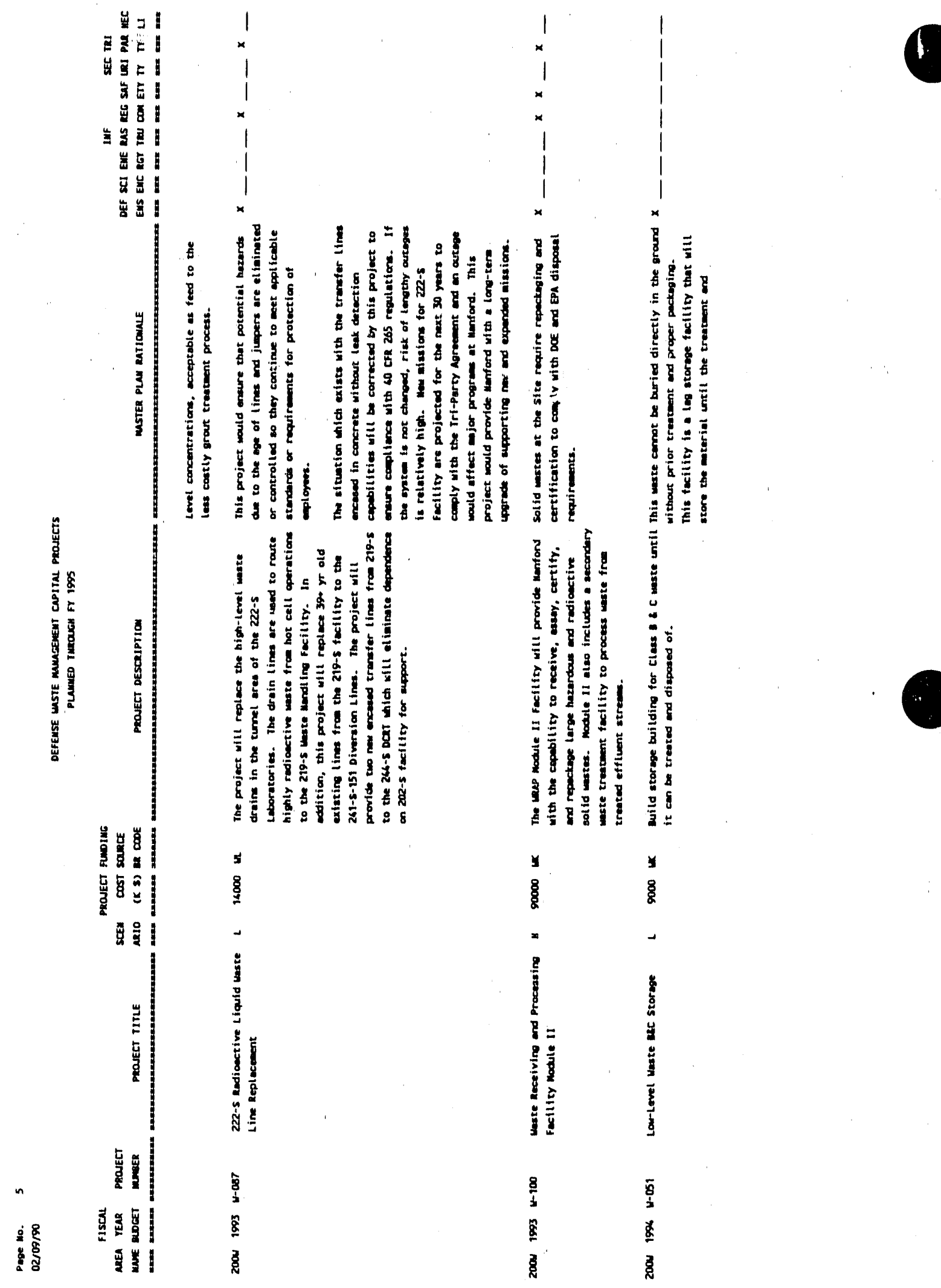
DOE/RL - $89-15$

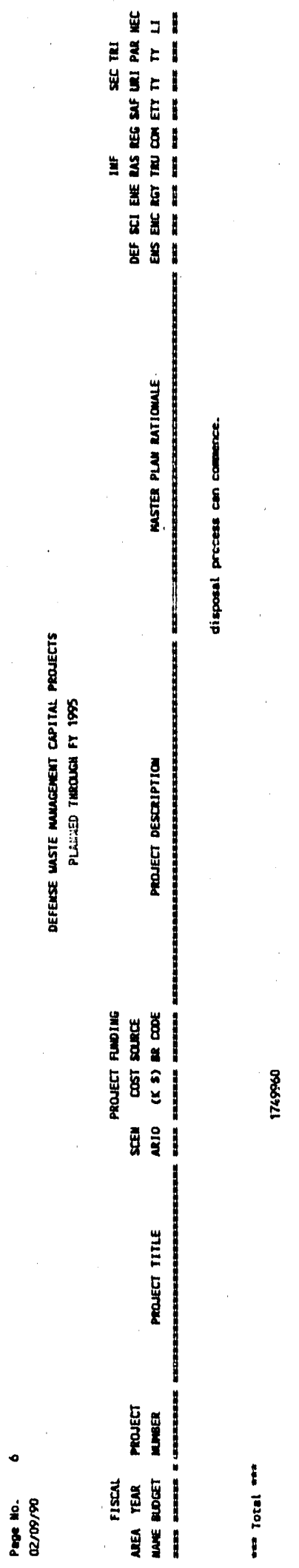

c. $21 / 22$ 
DOE/RL-89-15

\section{ADVANCED REACTOR DIVISION CAPITAL PROJECTS \\ PLANNED THROUGH FY 1995}

The following 28 projects are being submitted by the Advanced Reactor Division. 

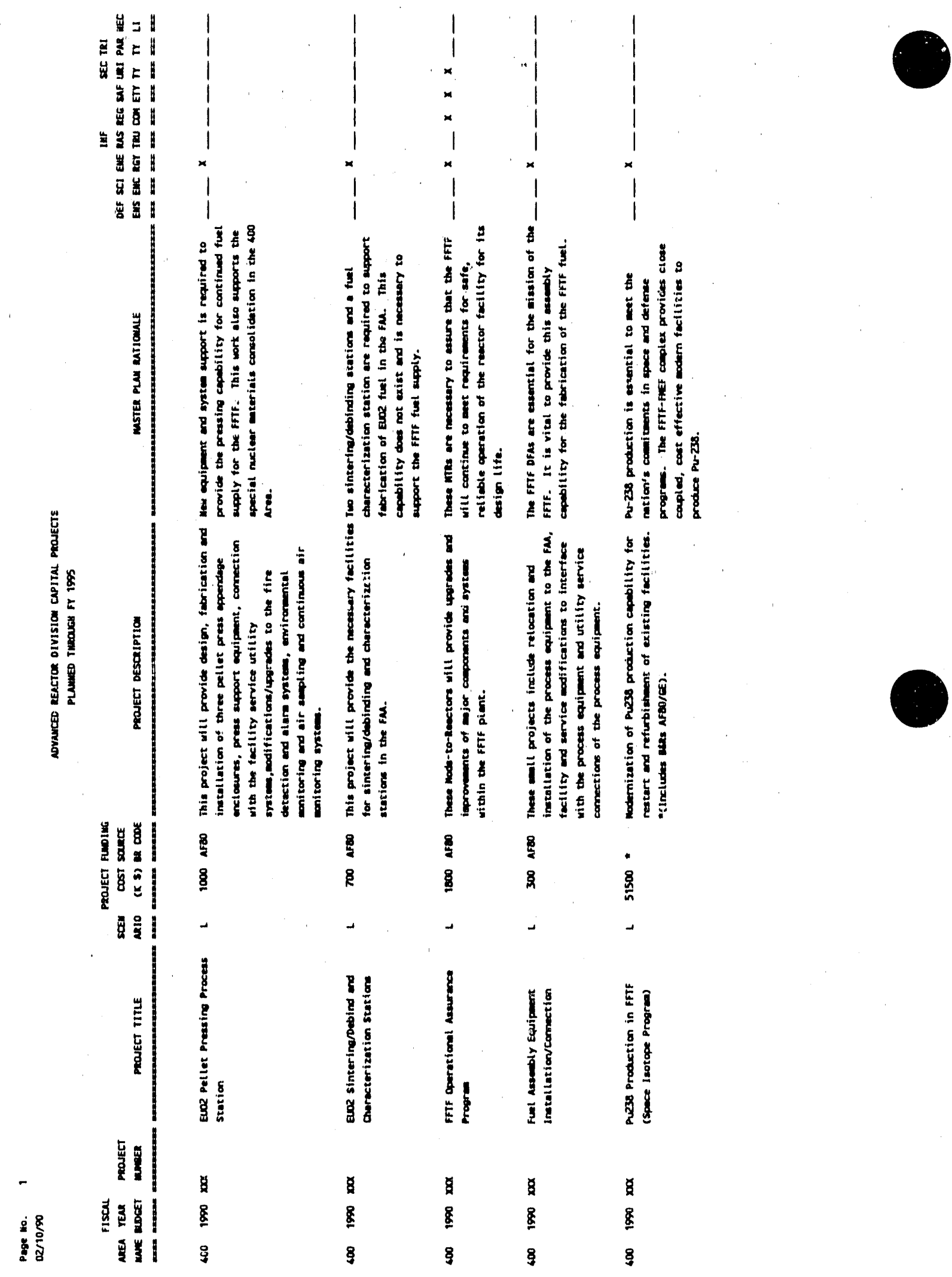

चं

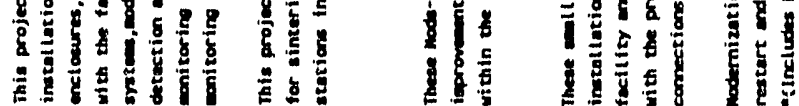

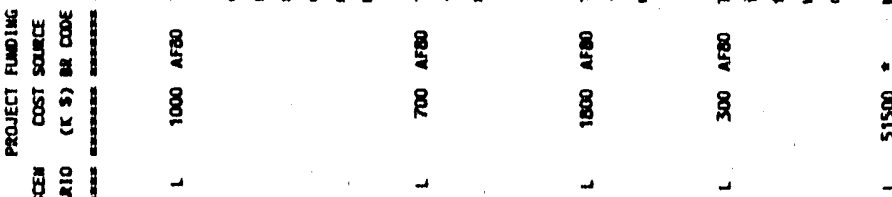


DOE/RL - 89- 15

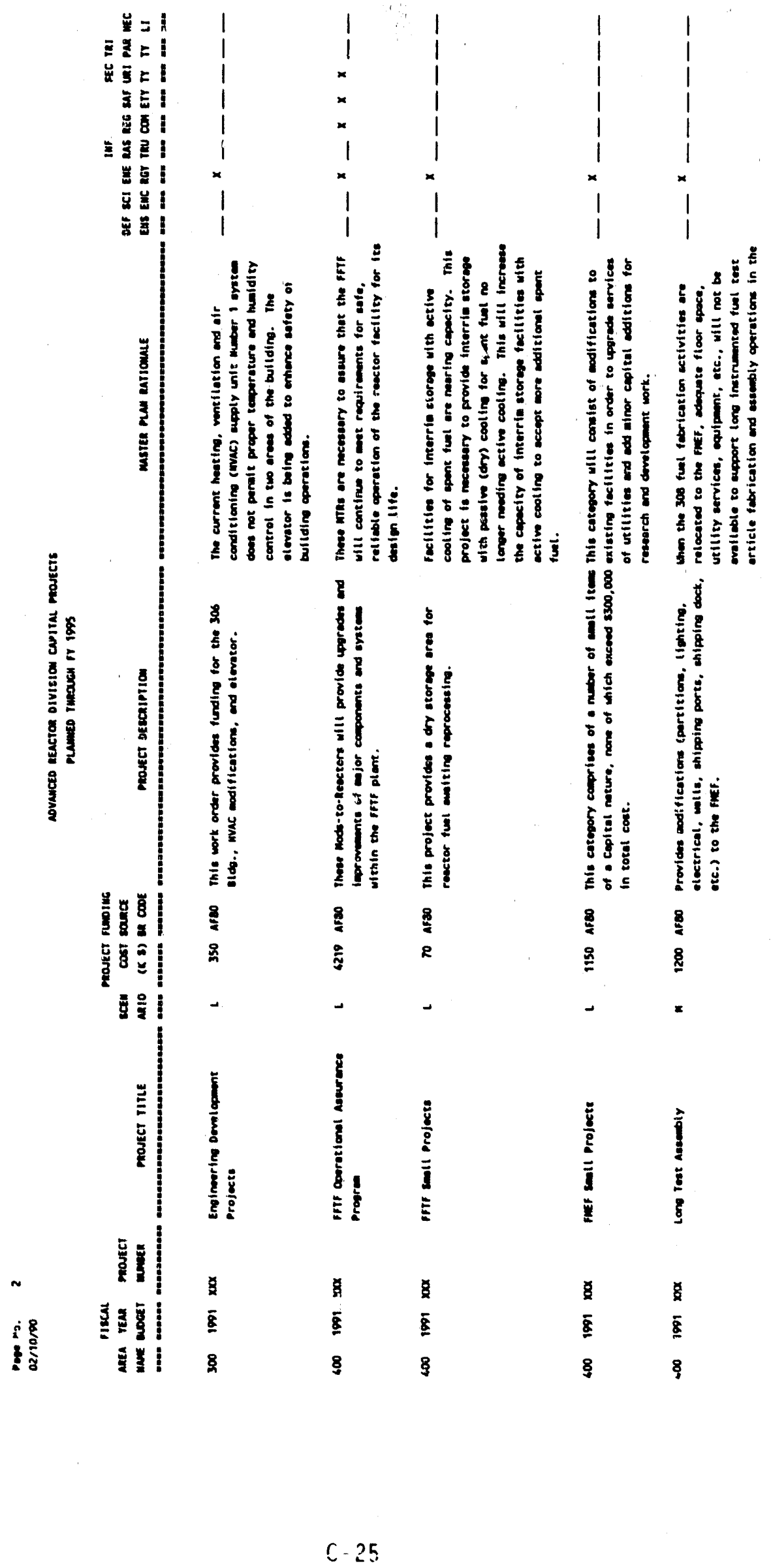


DOE/RL - $89-15$

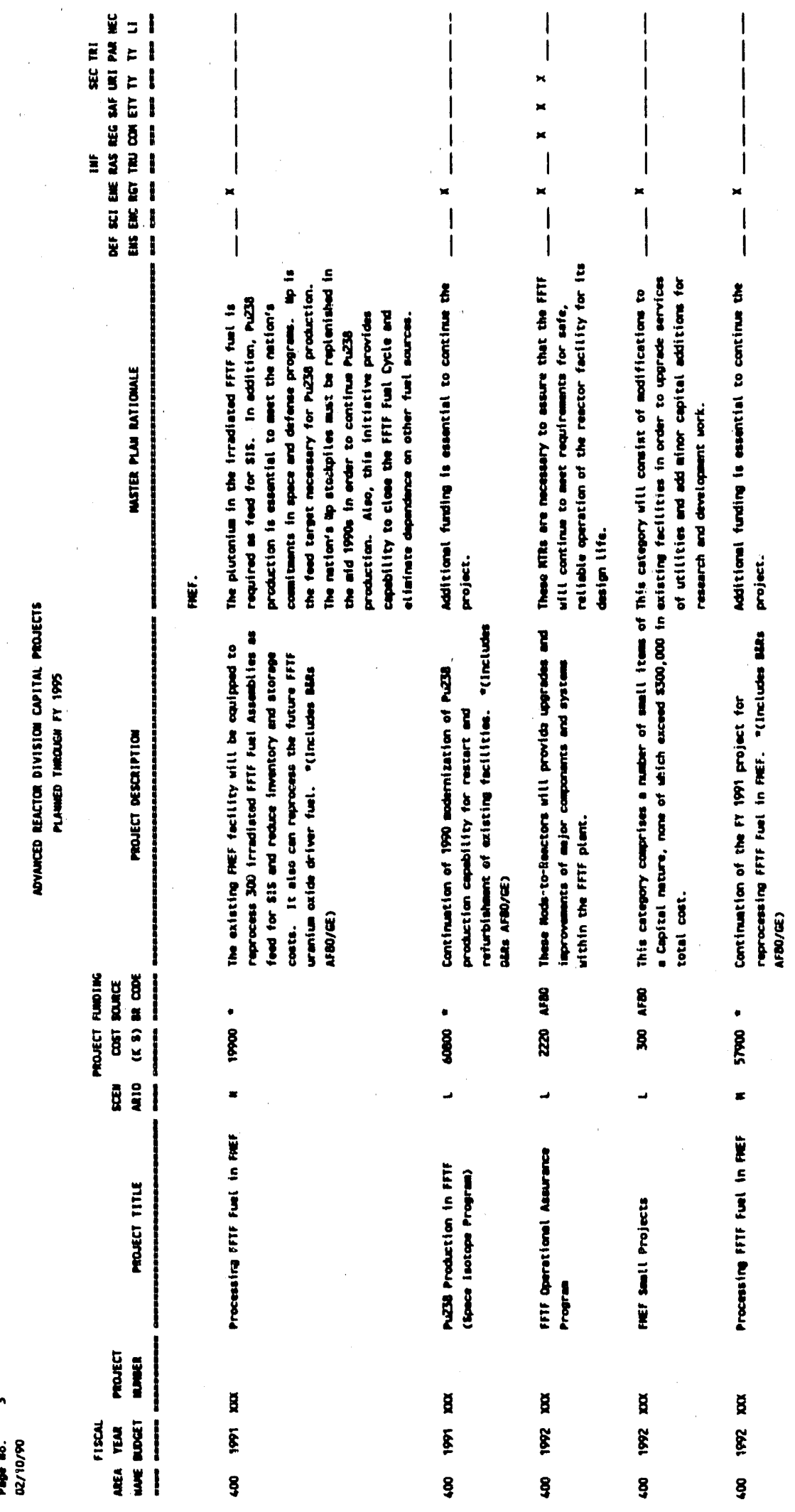



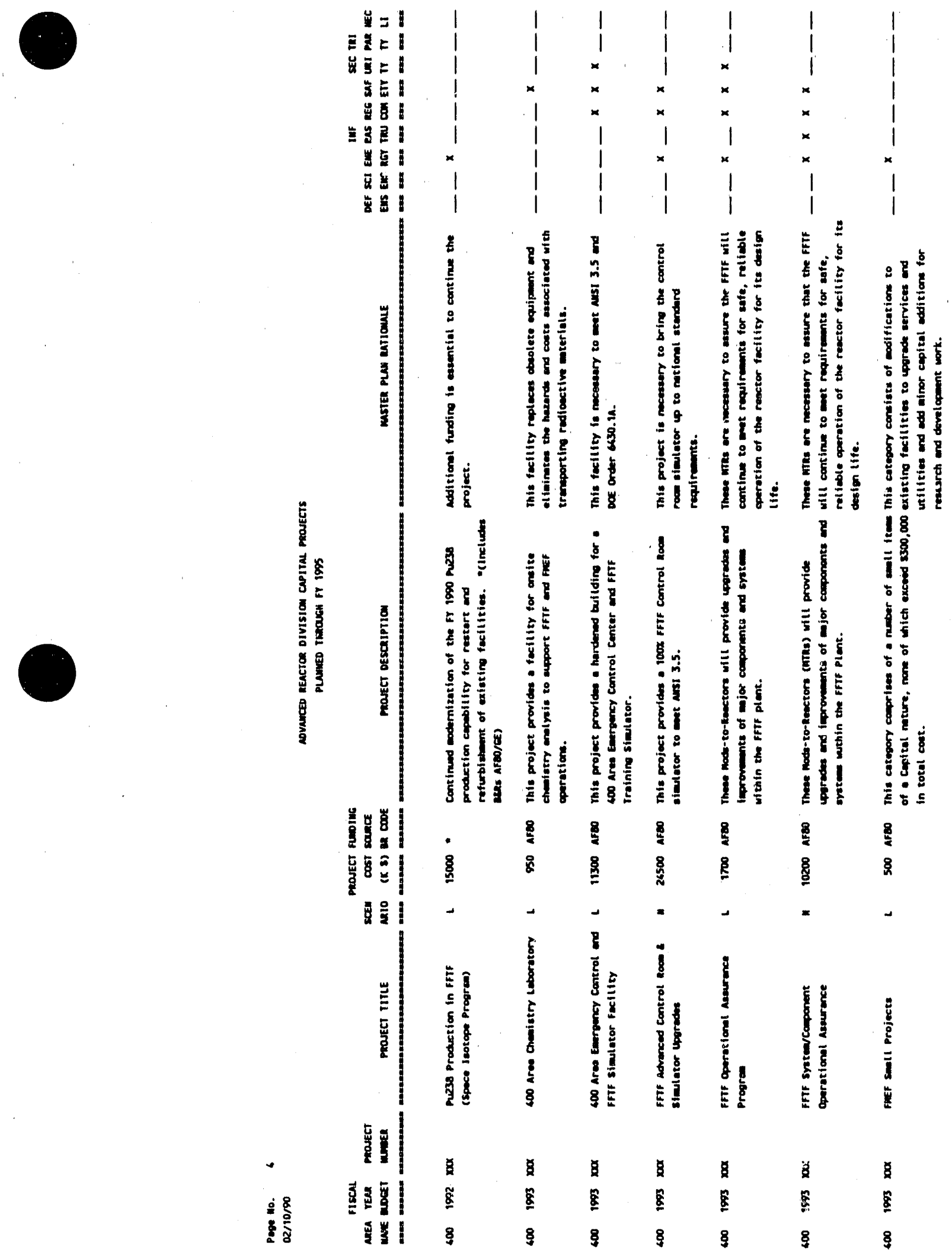
DOE/RL - $89-15$

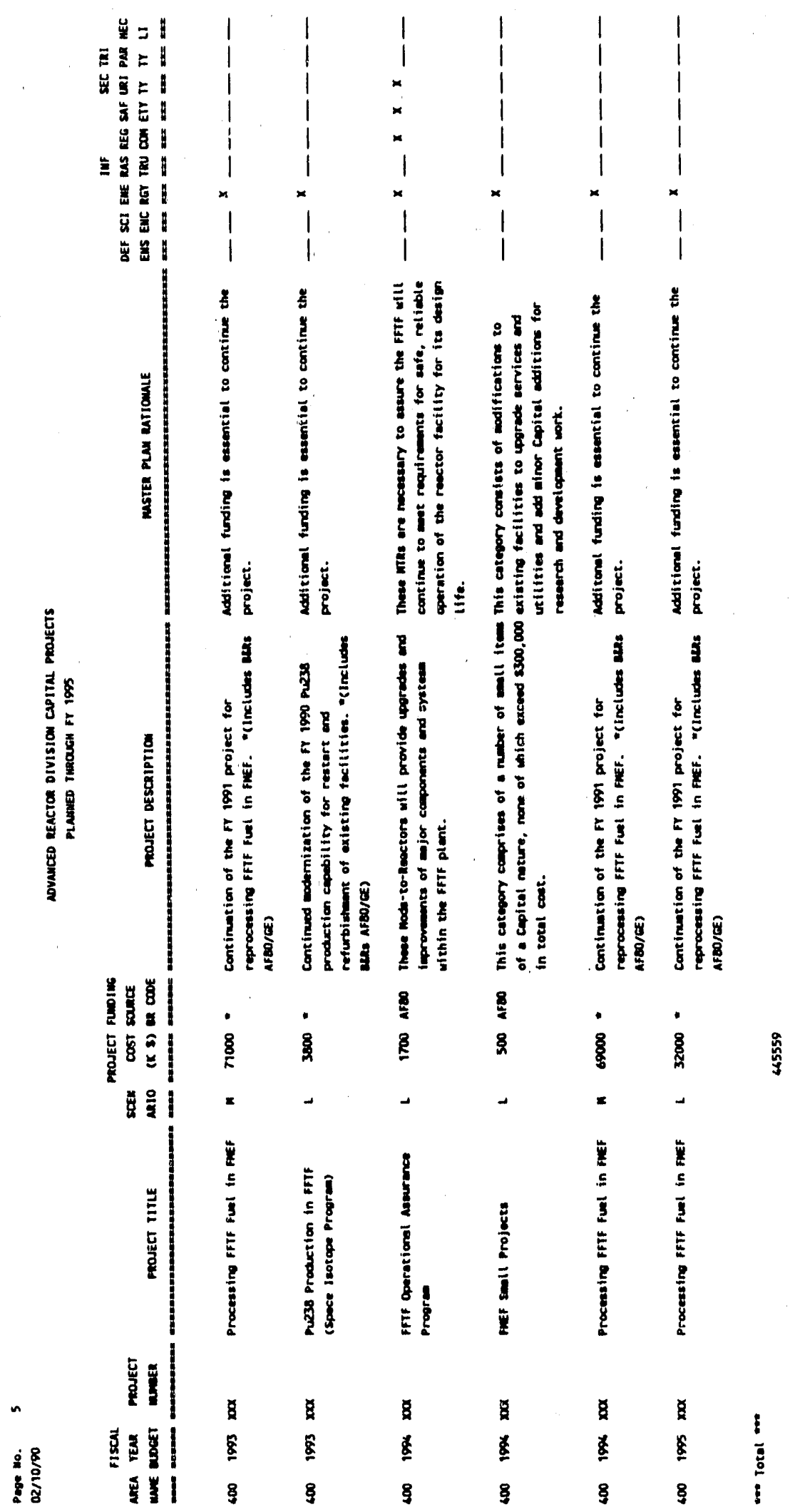


DOE/RL - 89-15

\section{LANDLORD PROGRAM CAPITAL PROJECTS}

PLANNED THROUGH FY 1995

The following 105 projects are being submitted by the Landlord Program. 
DOE/RL - 89- 15

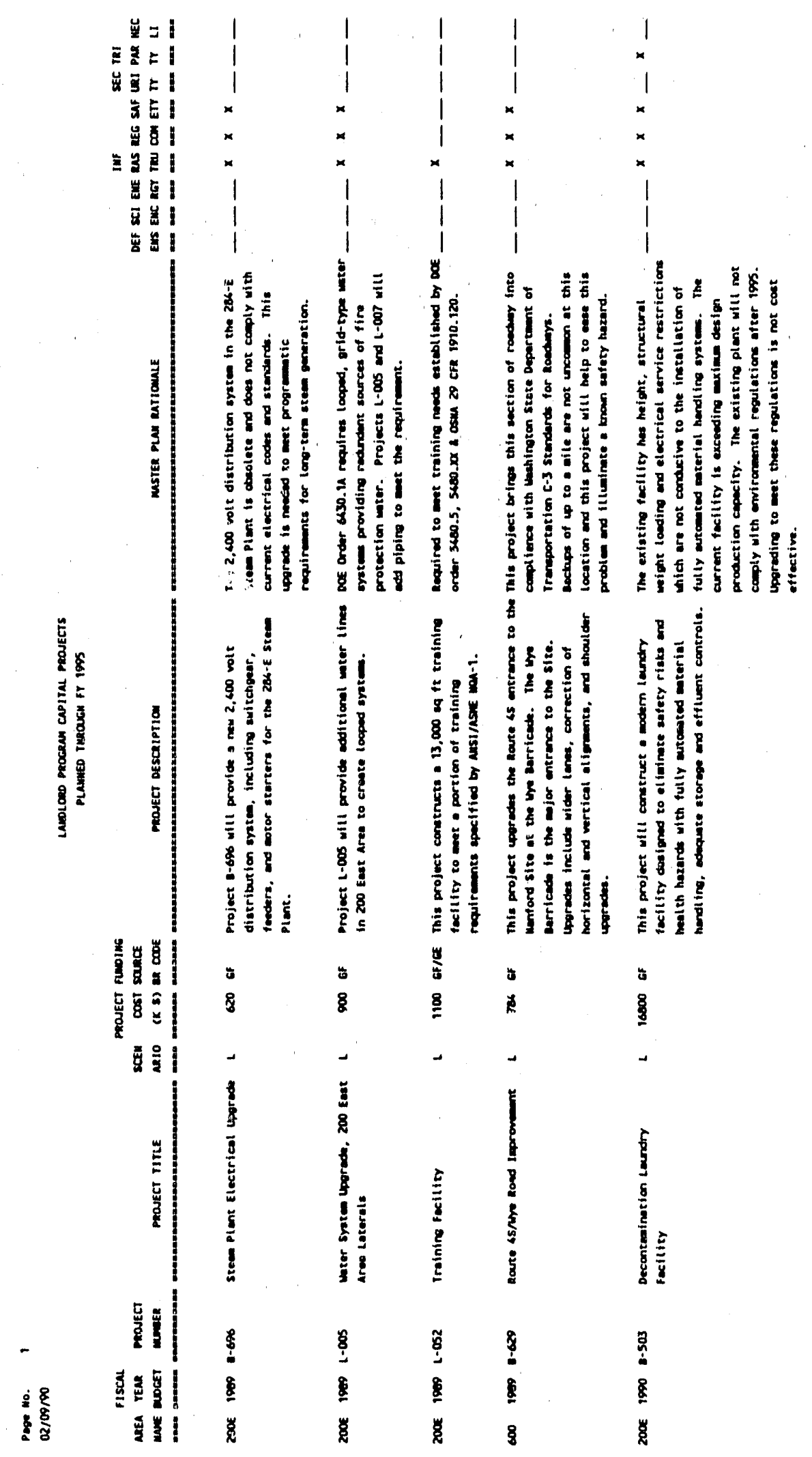


DOE/RL - $89-15$

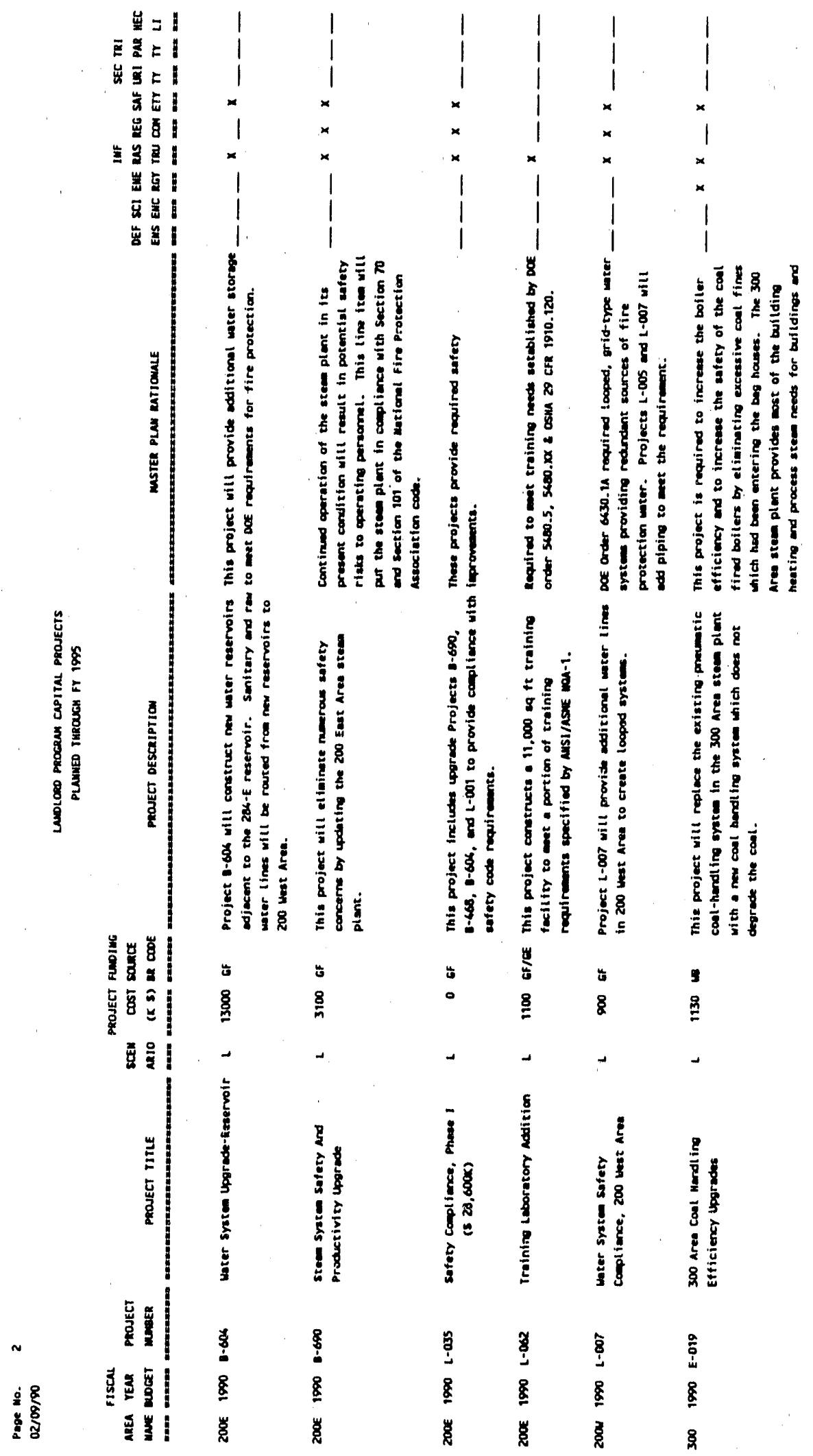




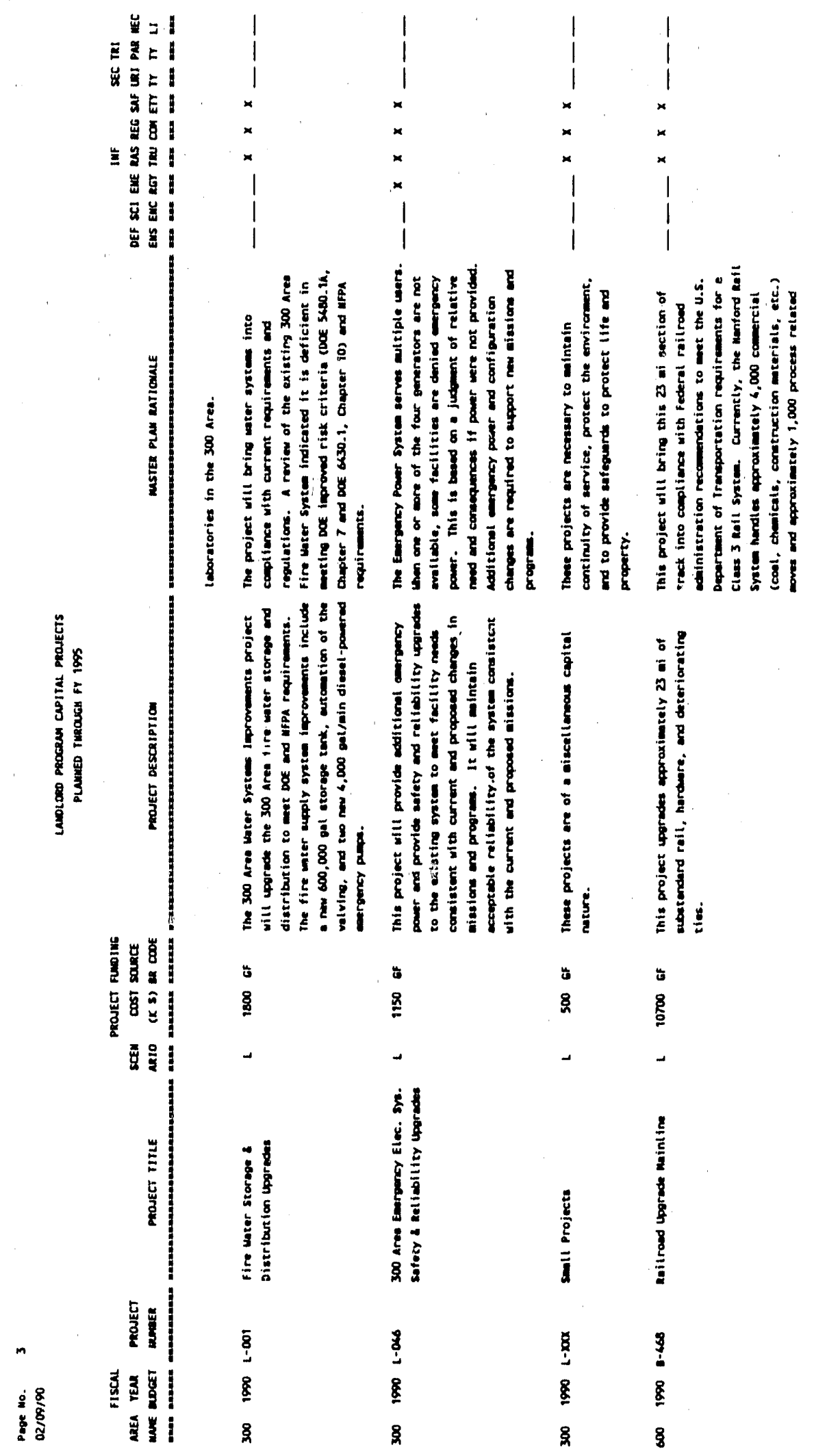


DOE/RL - 89- 15

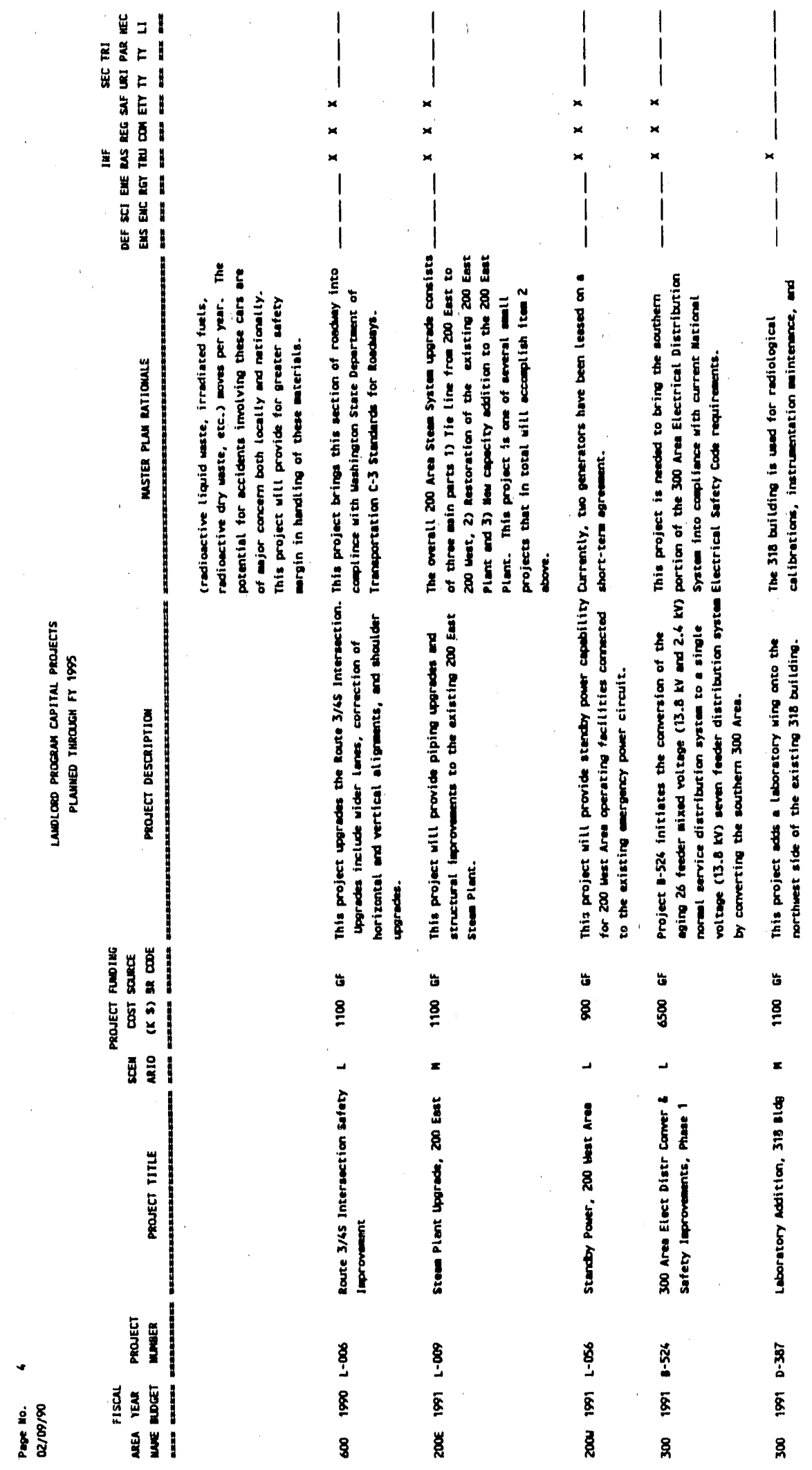




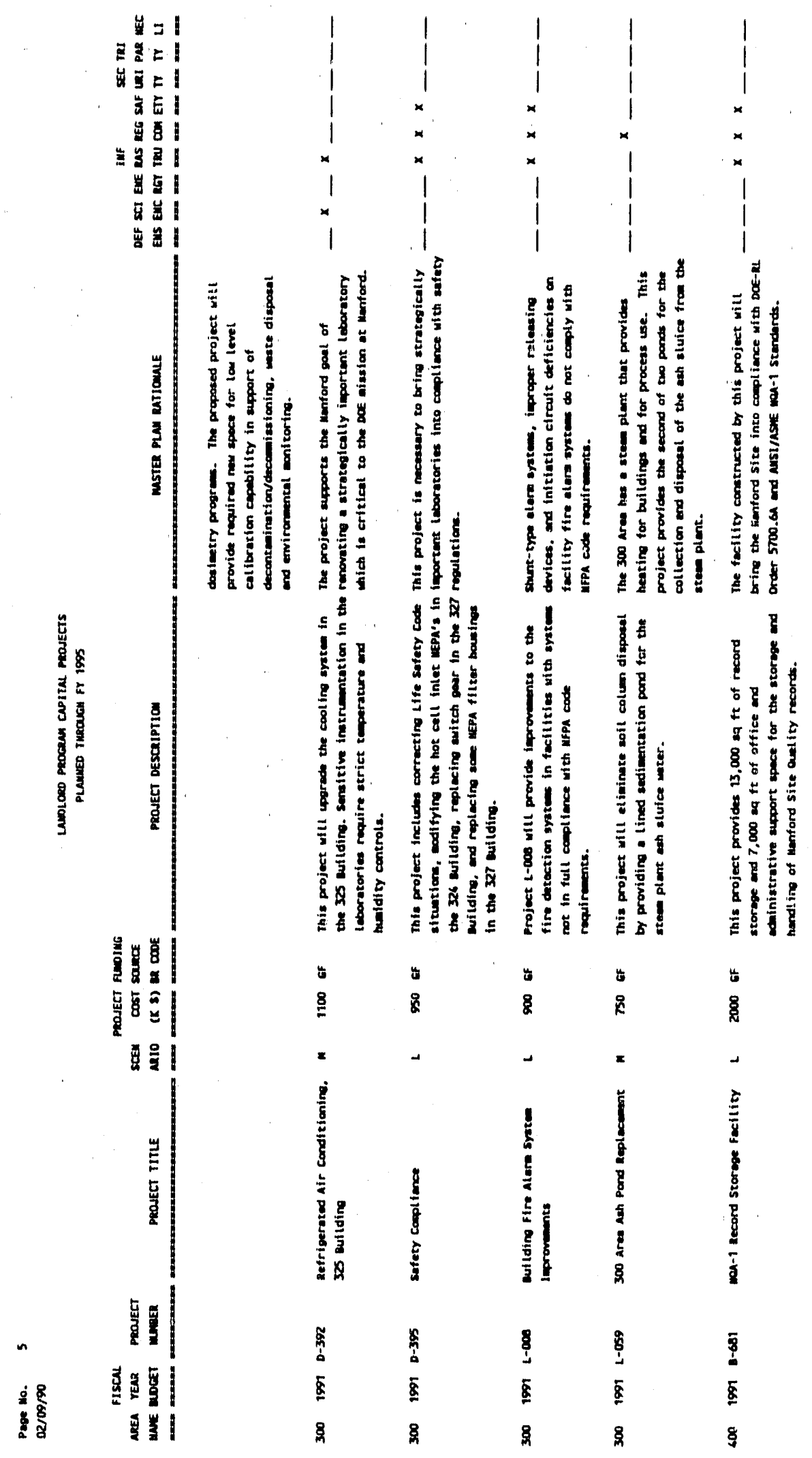


DOE/RL $.89-15$
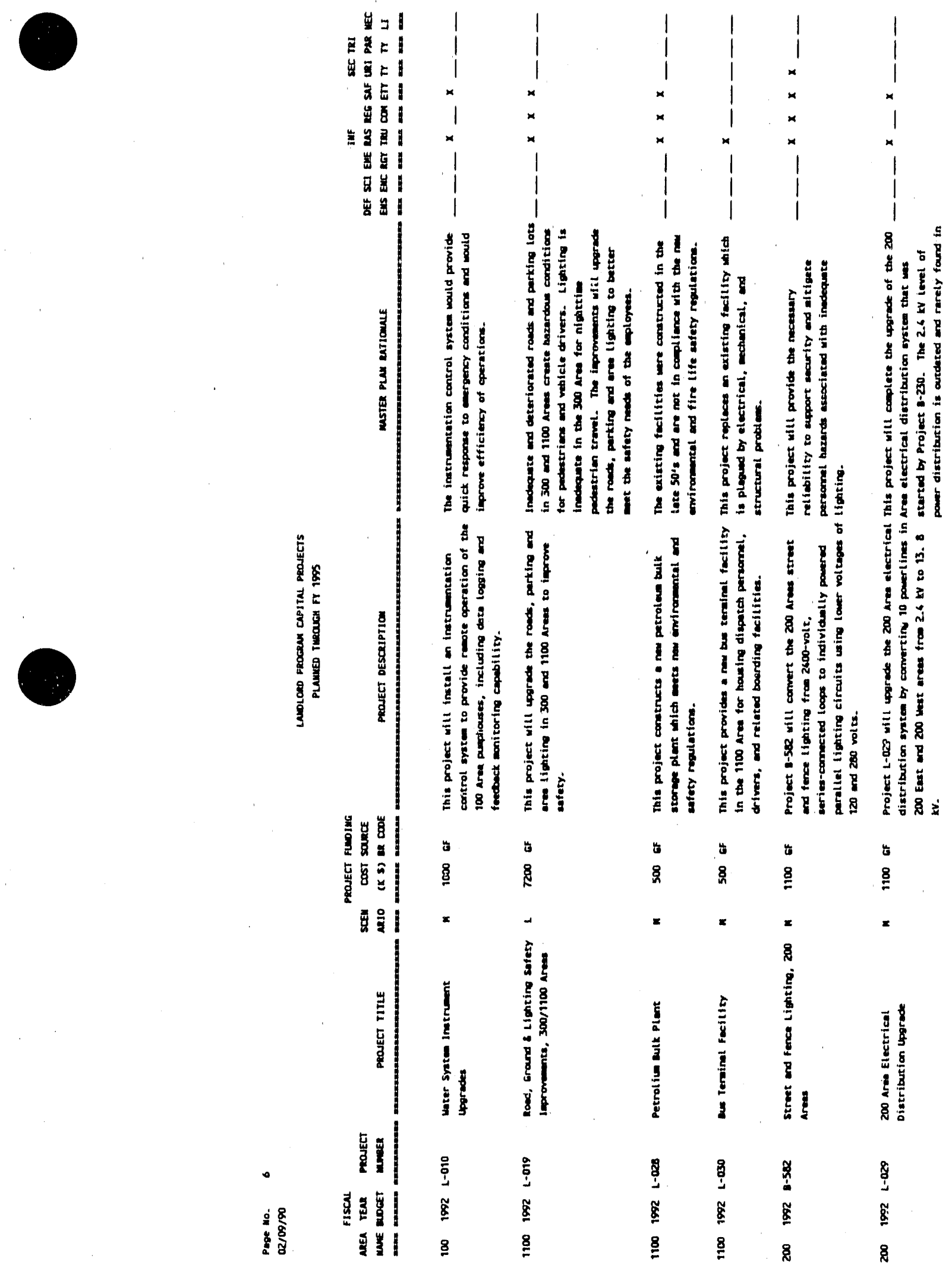
DOE/RL - $89-15$
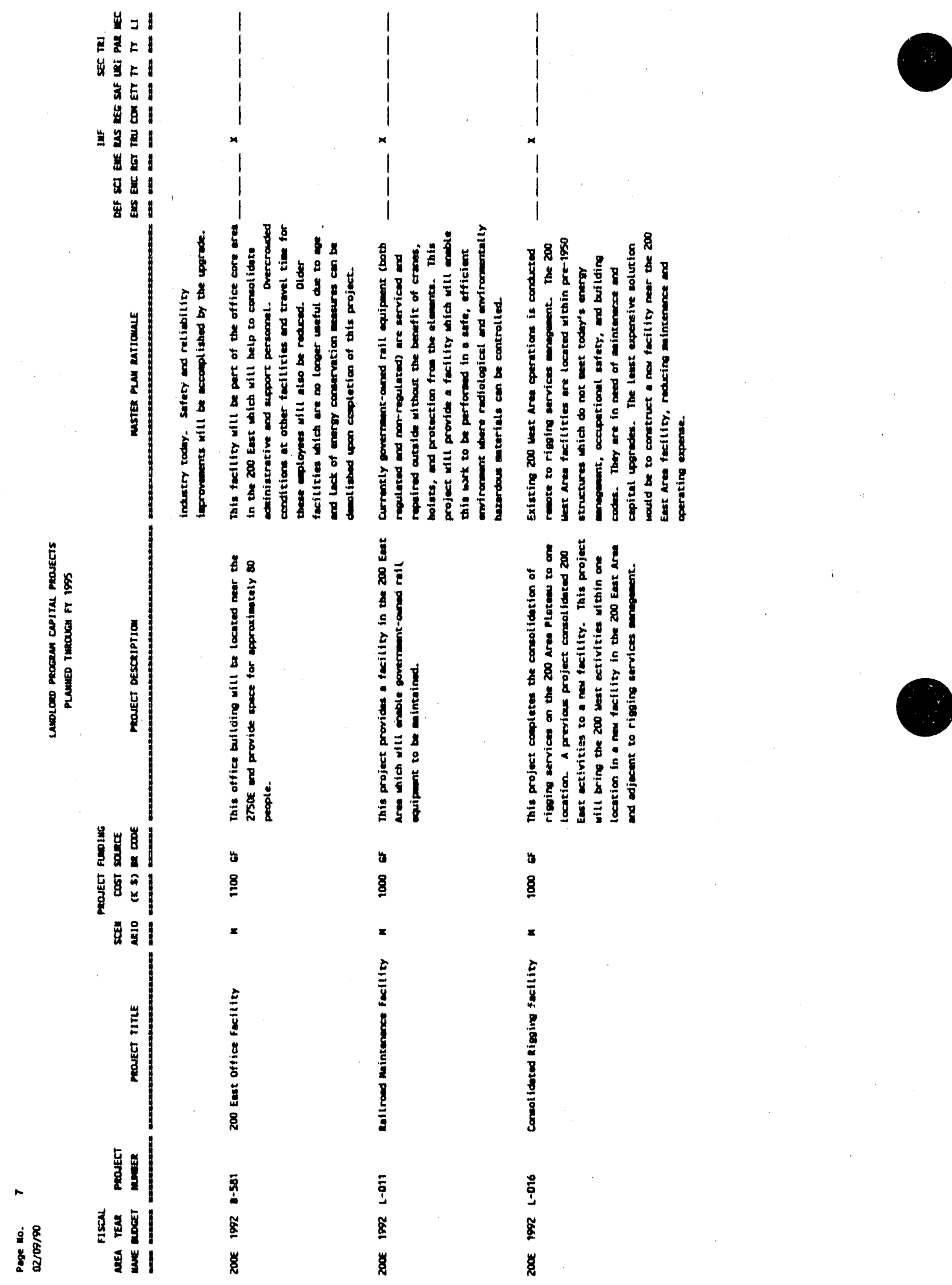

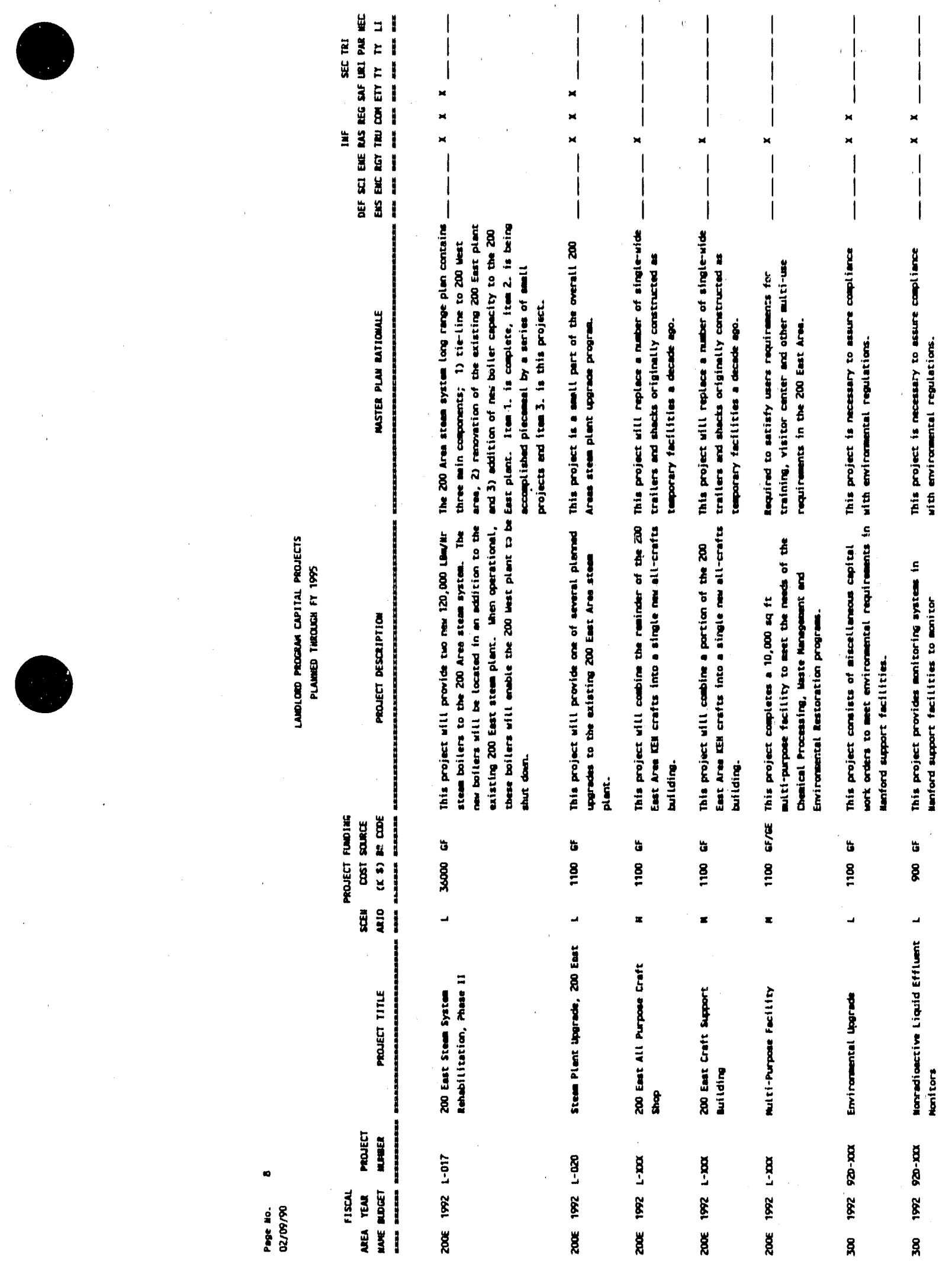
DOE/RL - $89-15$

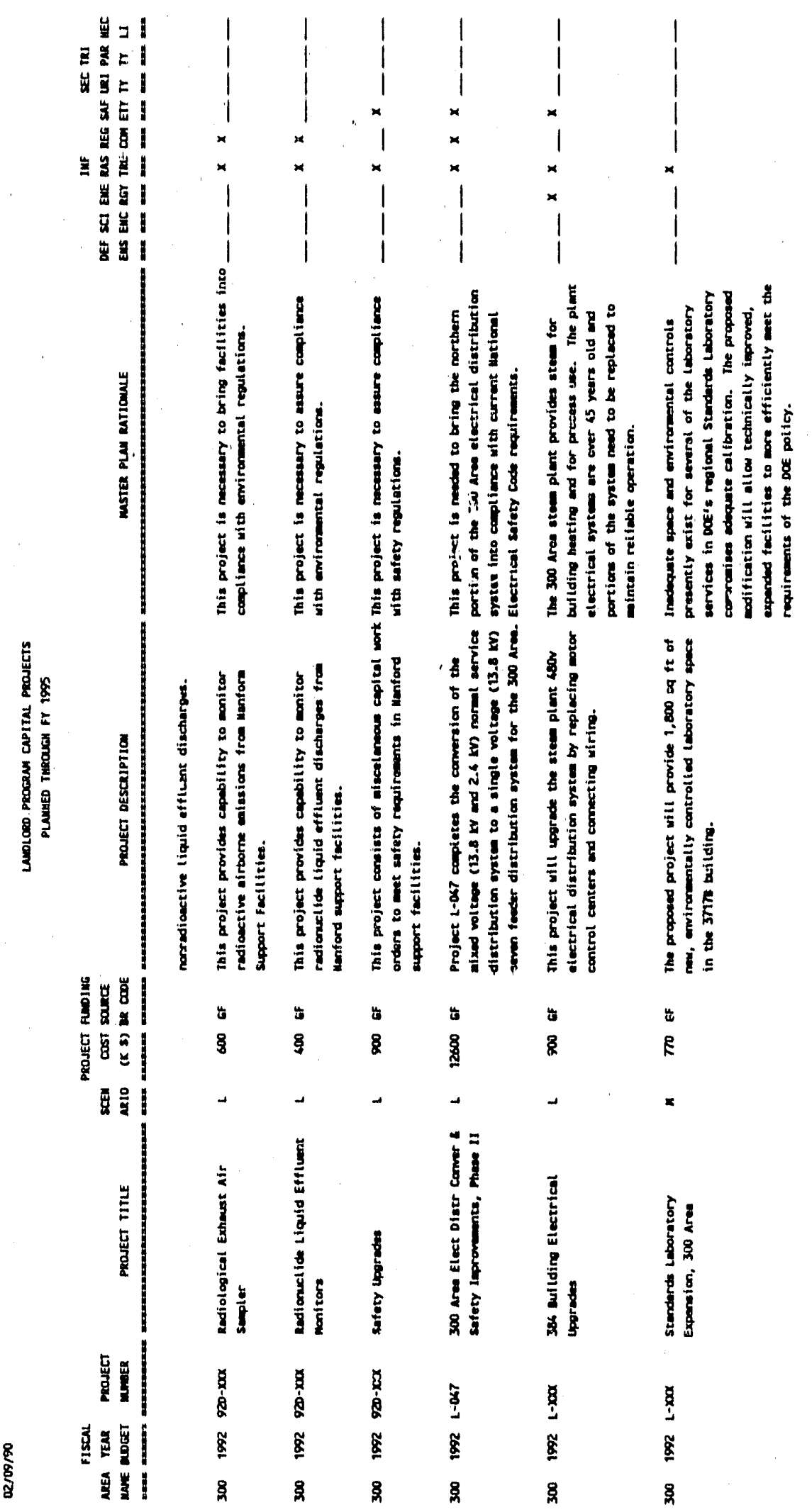


DOE/RL - 89- 15
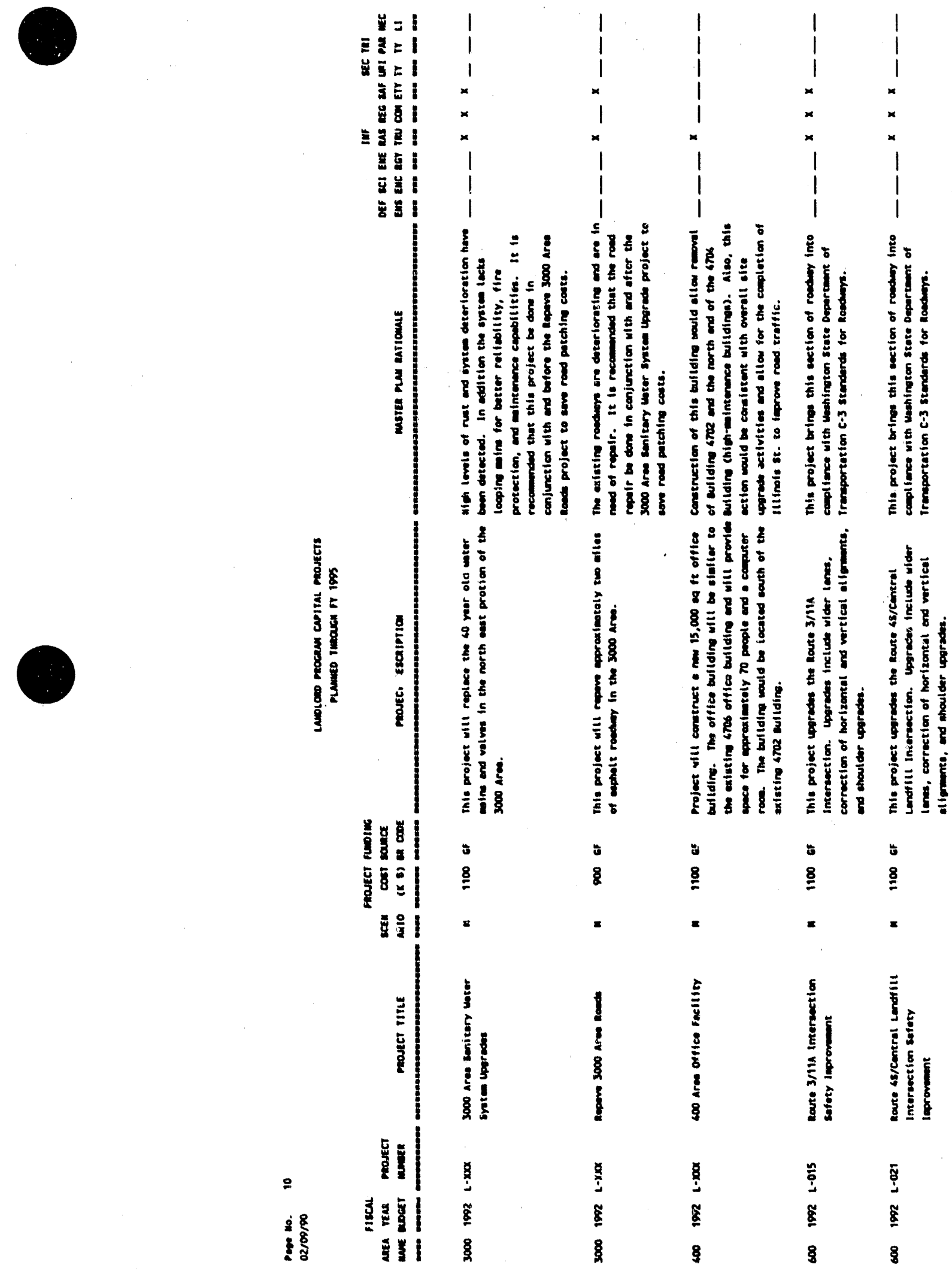
DOE/RL - 89- 15

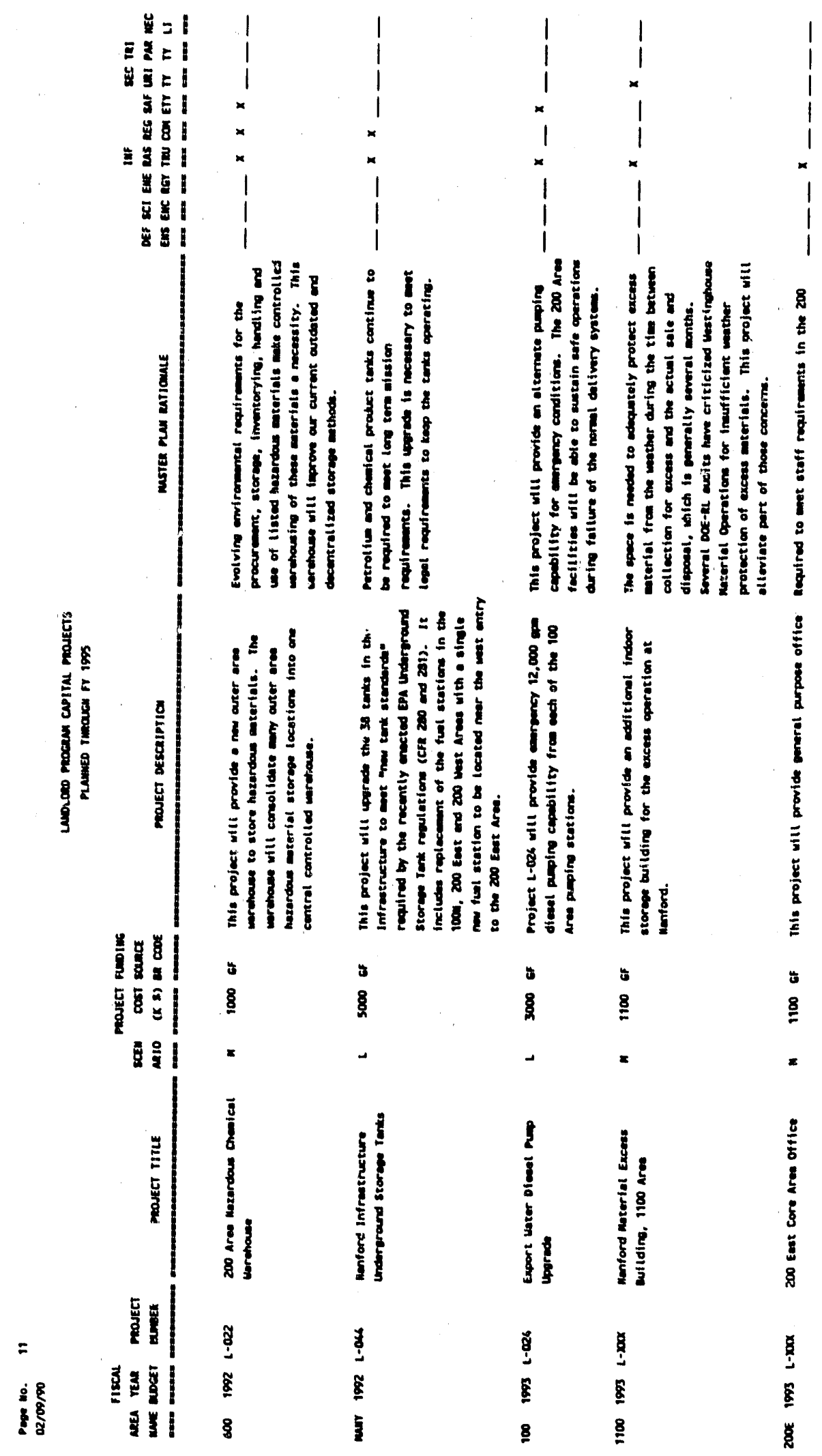




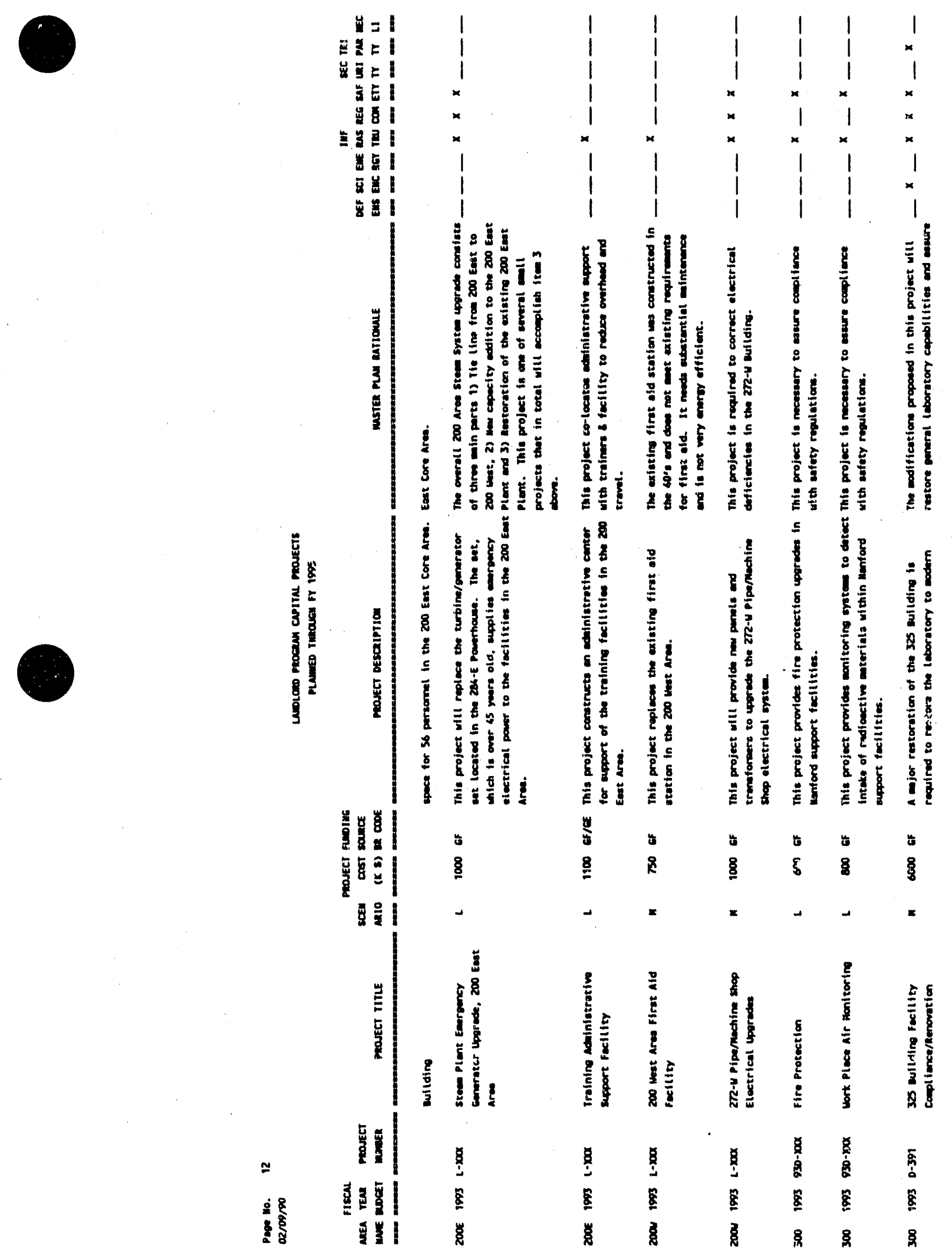


DOE/RL - 89- 15

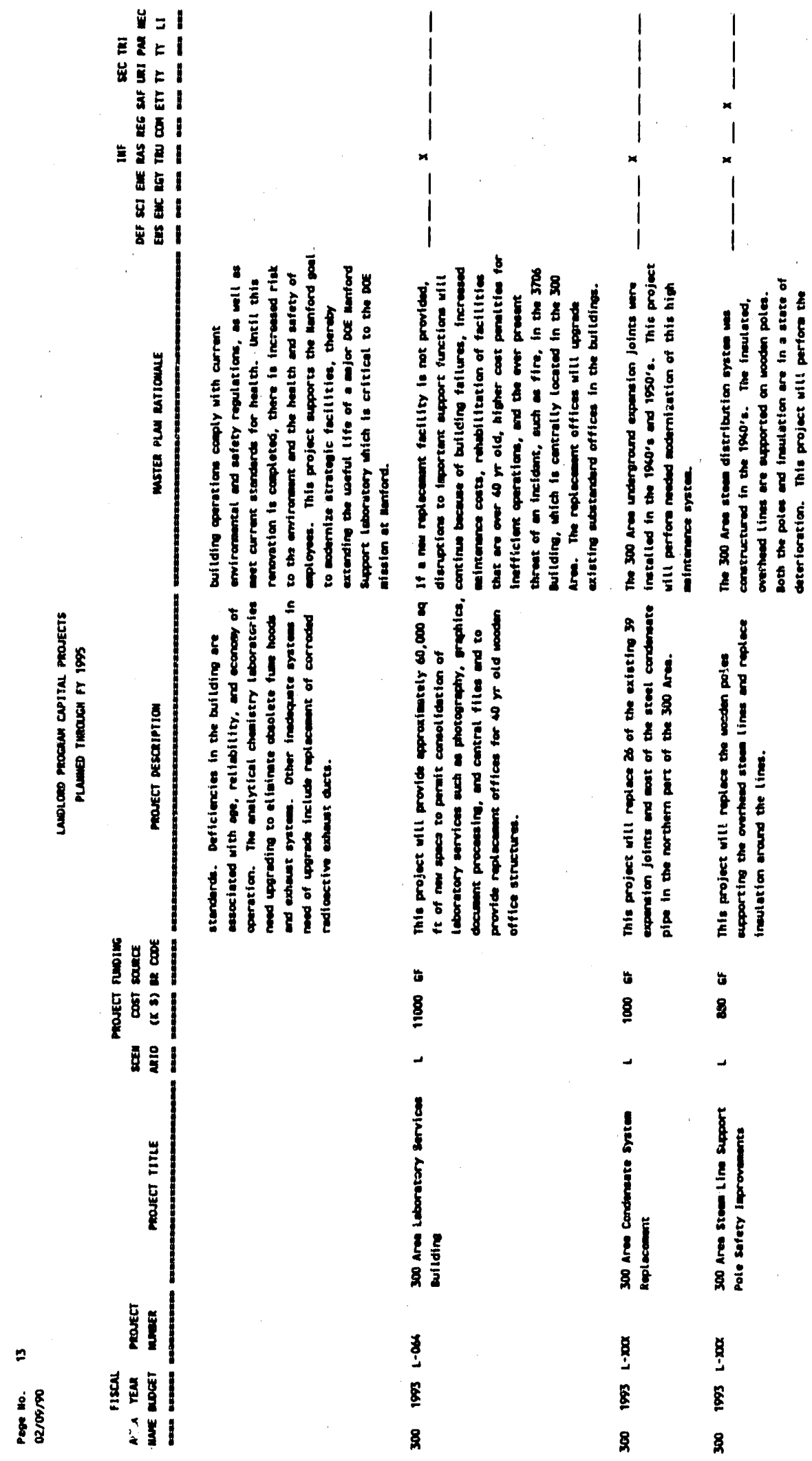


DOE/RL-89- 15
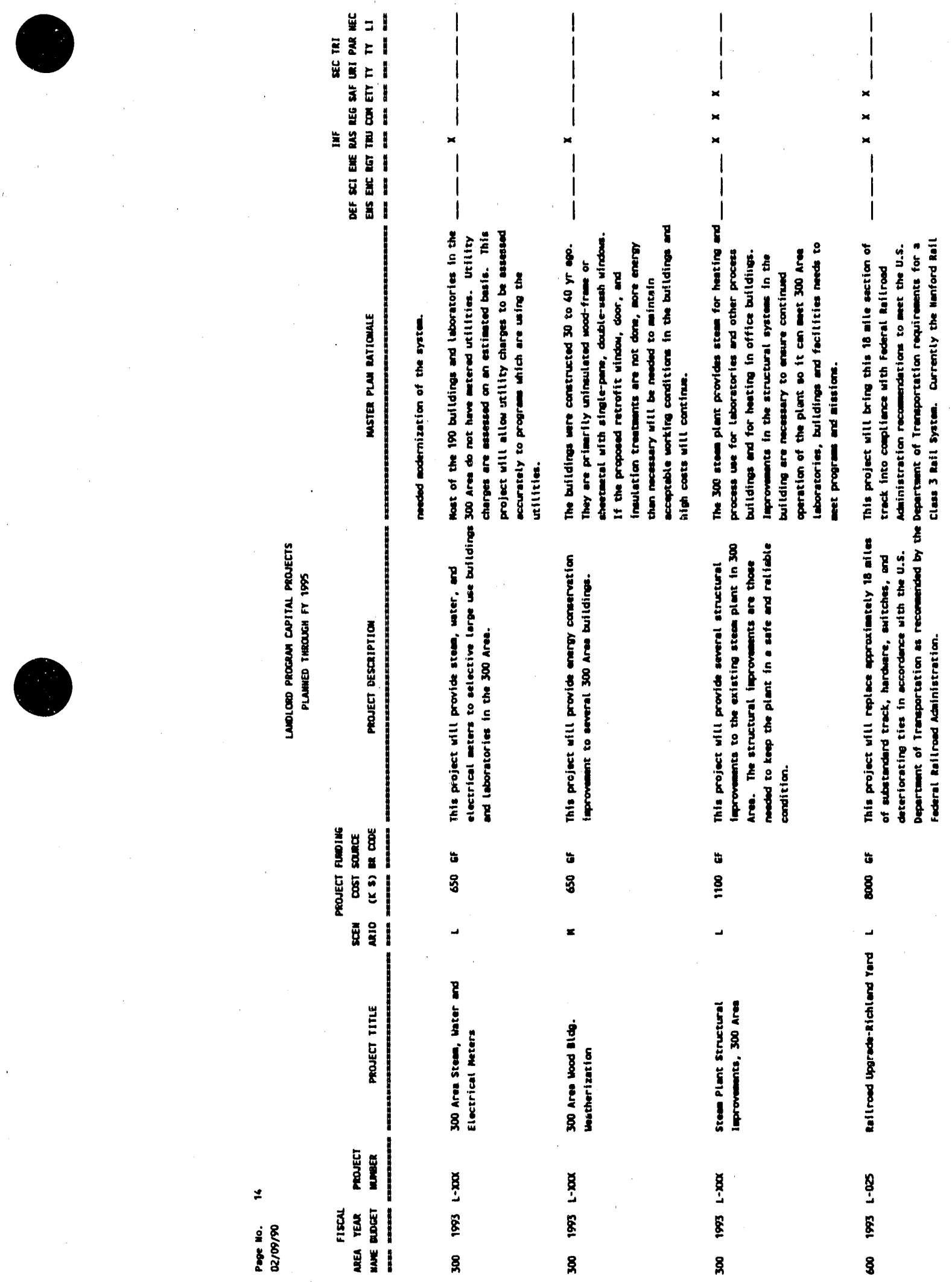
DOE/RL - $89-15$

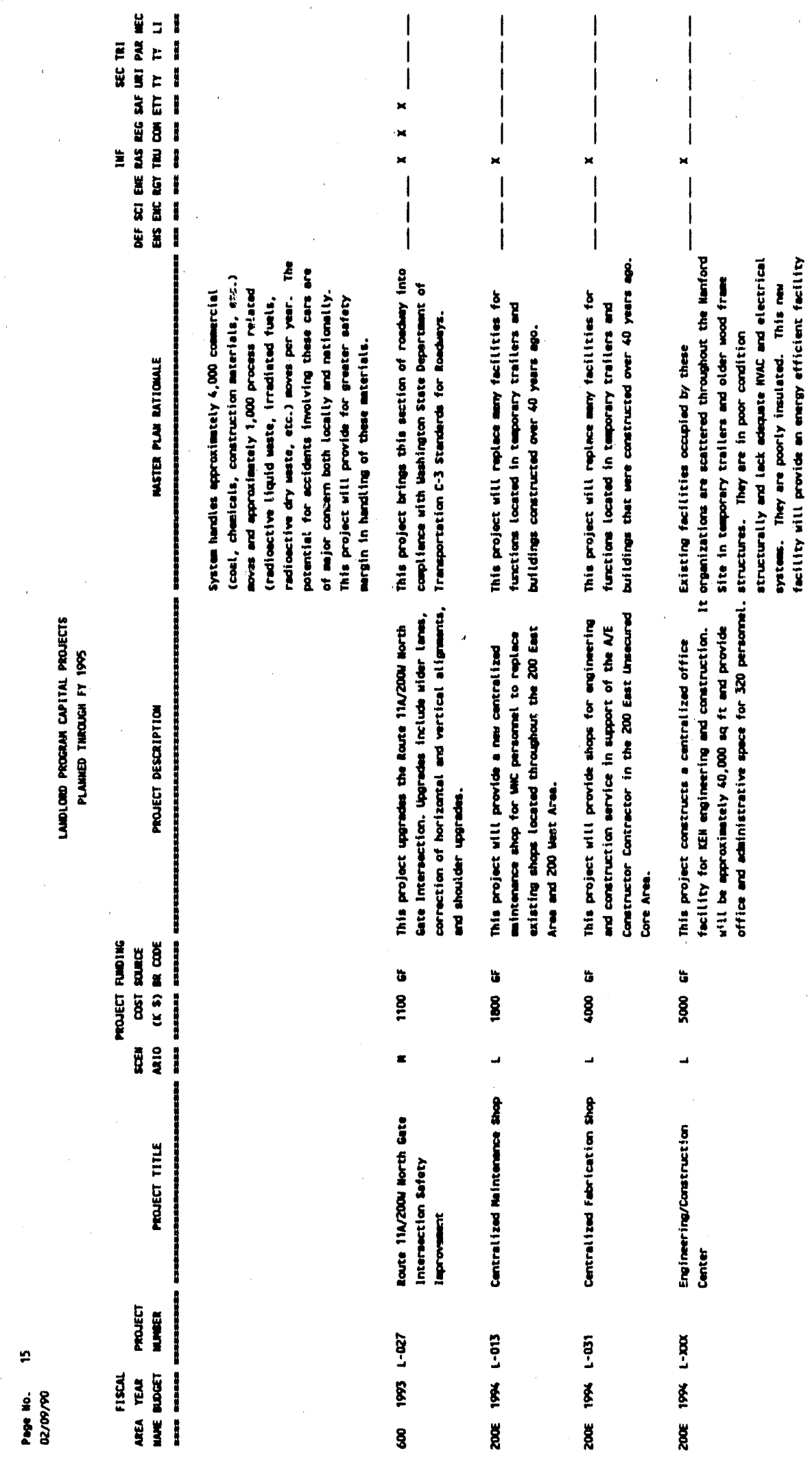


DOE/RL-89-15
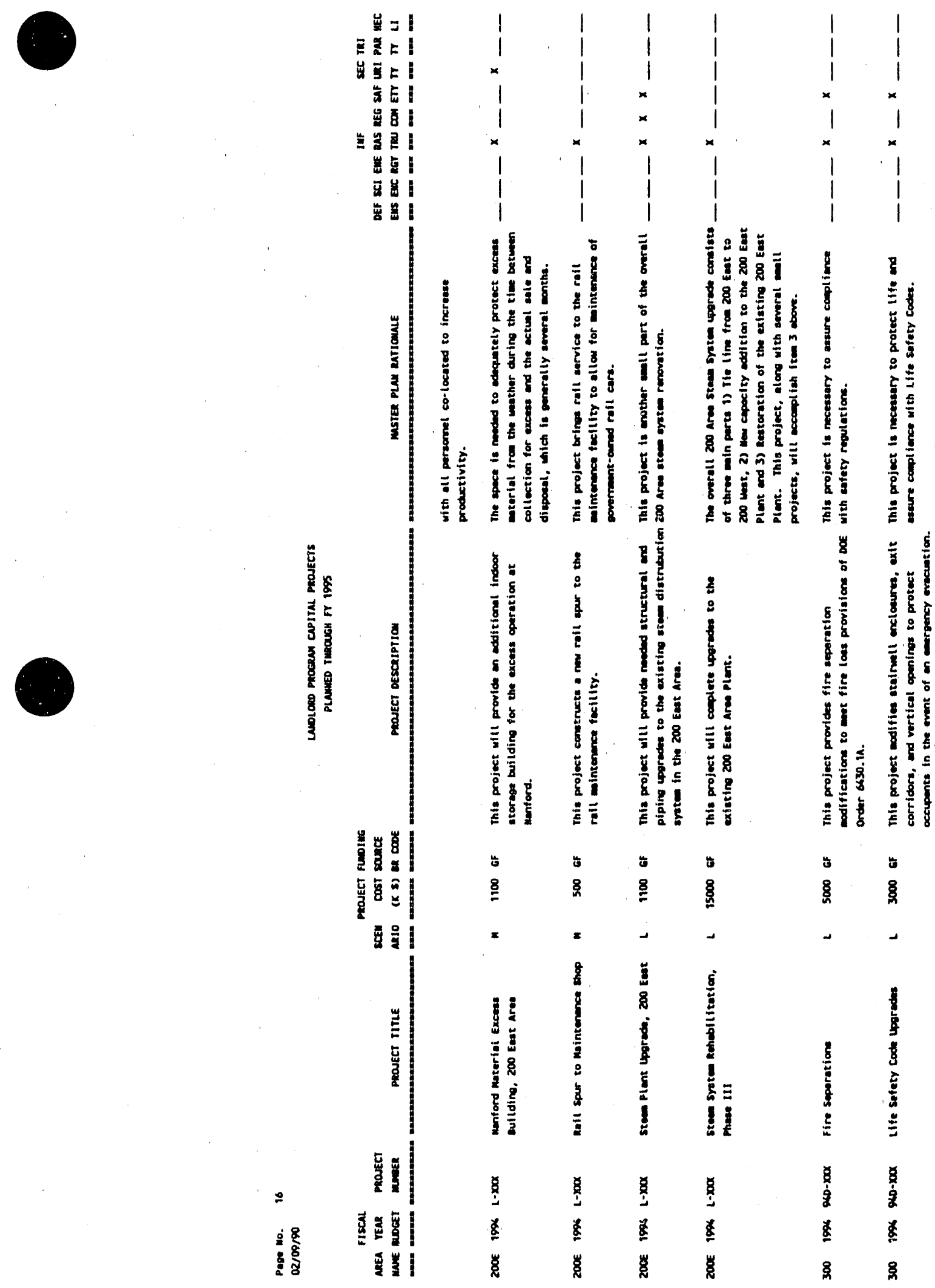
DOE/RL-89- 15

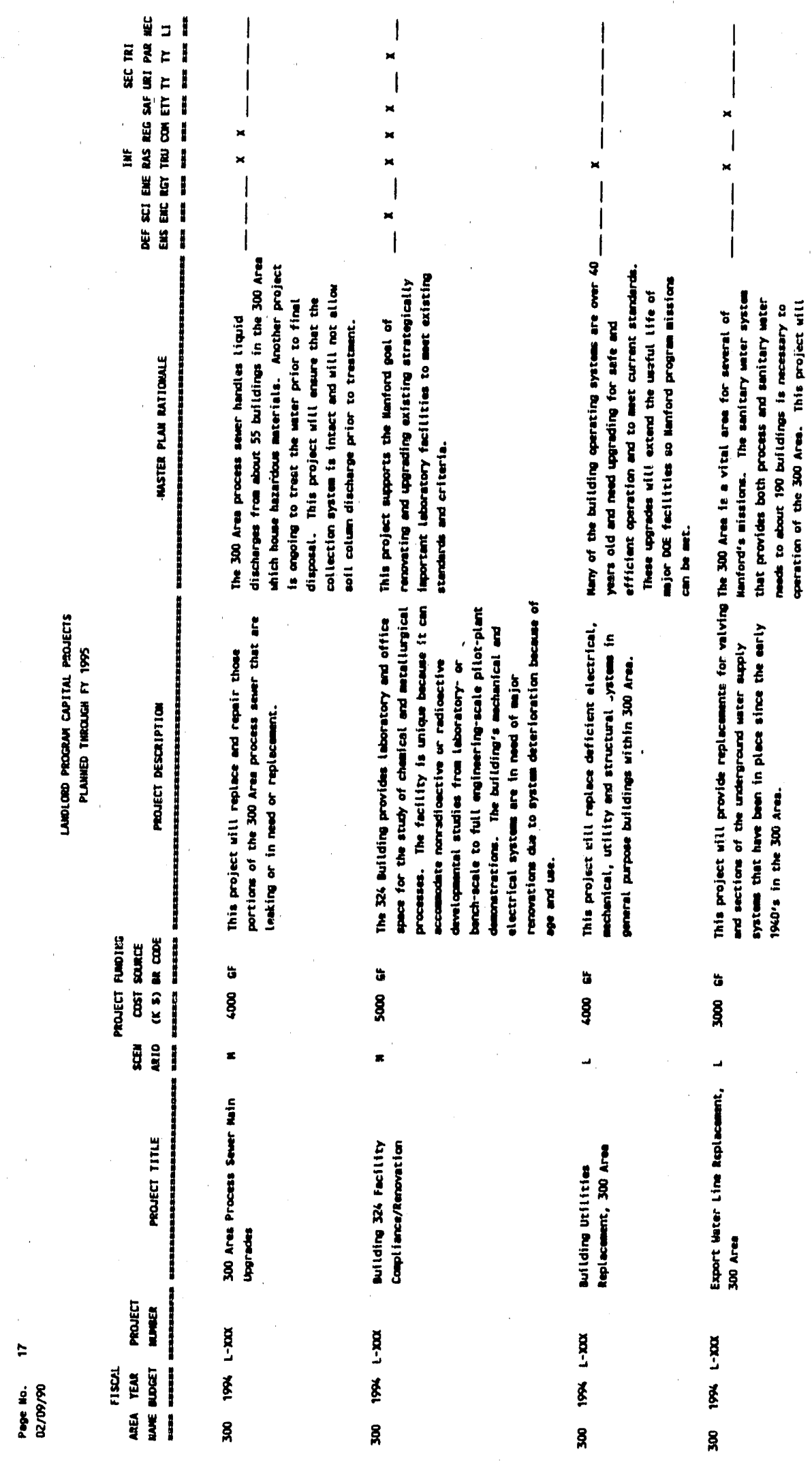


DOE/RL - 89- 15
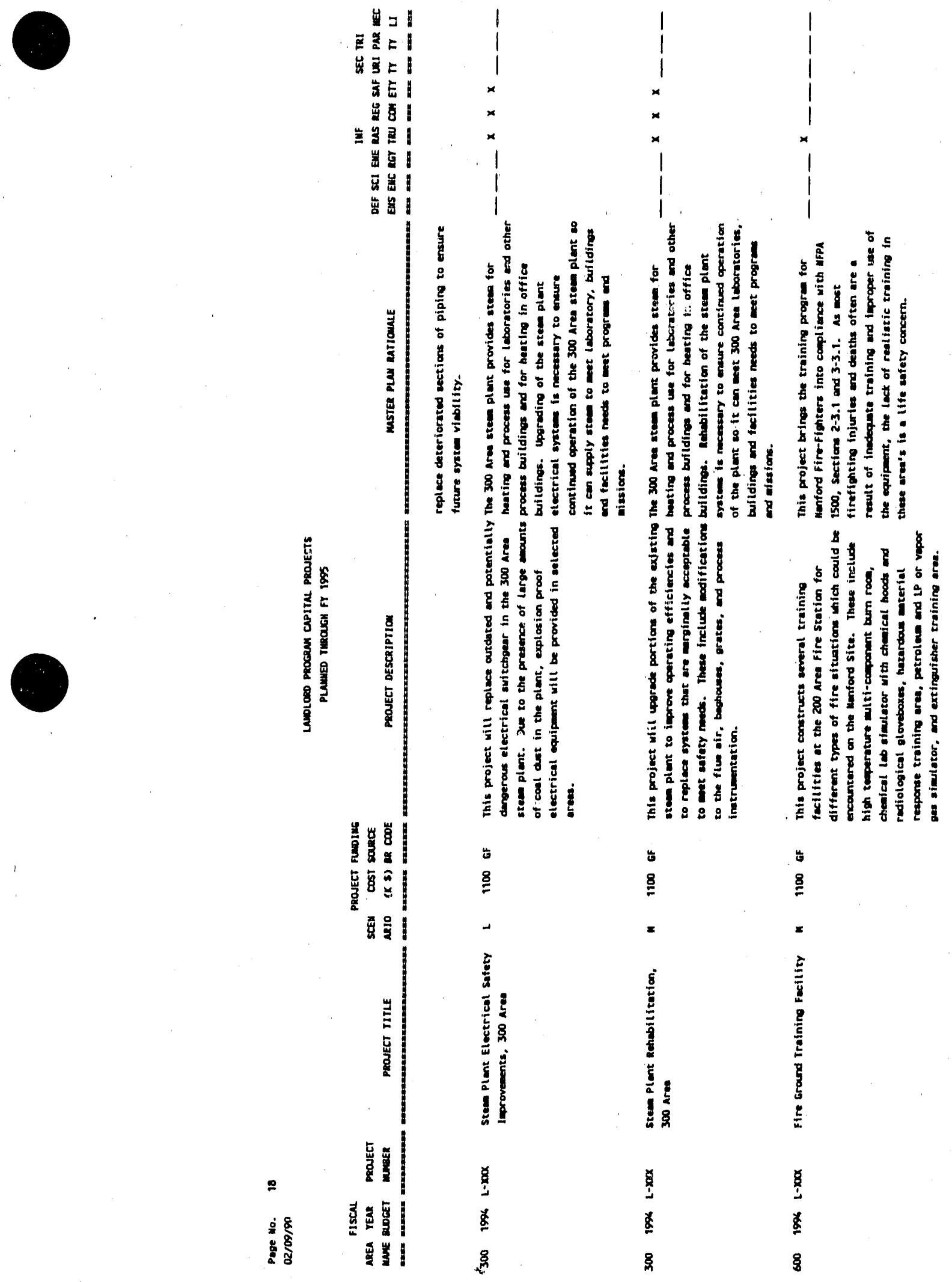
DOE/RL - 89- 15

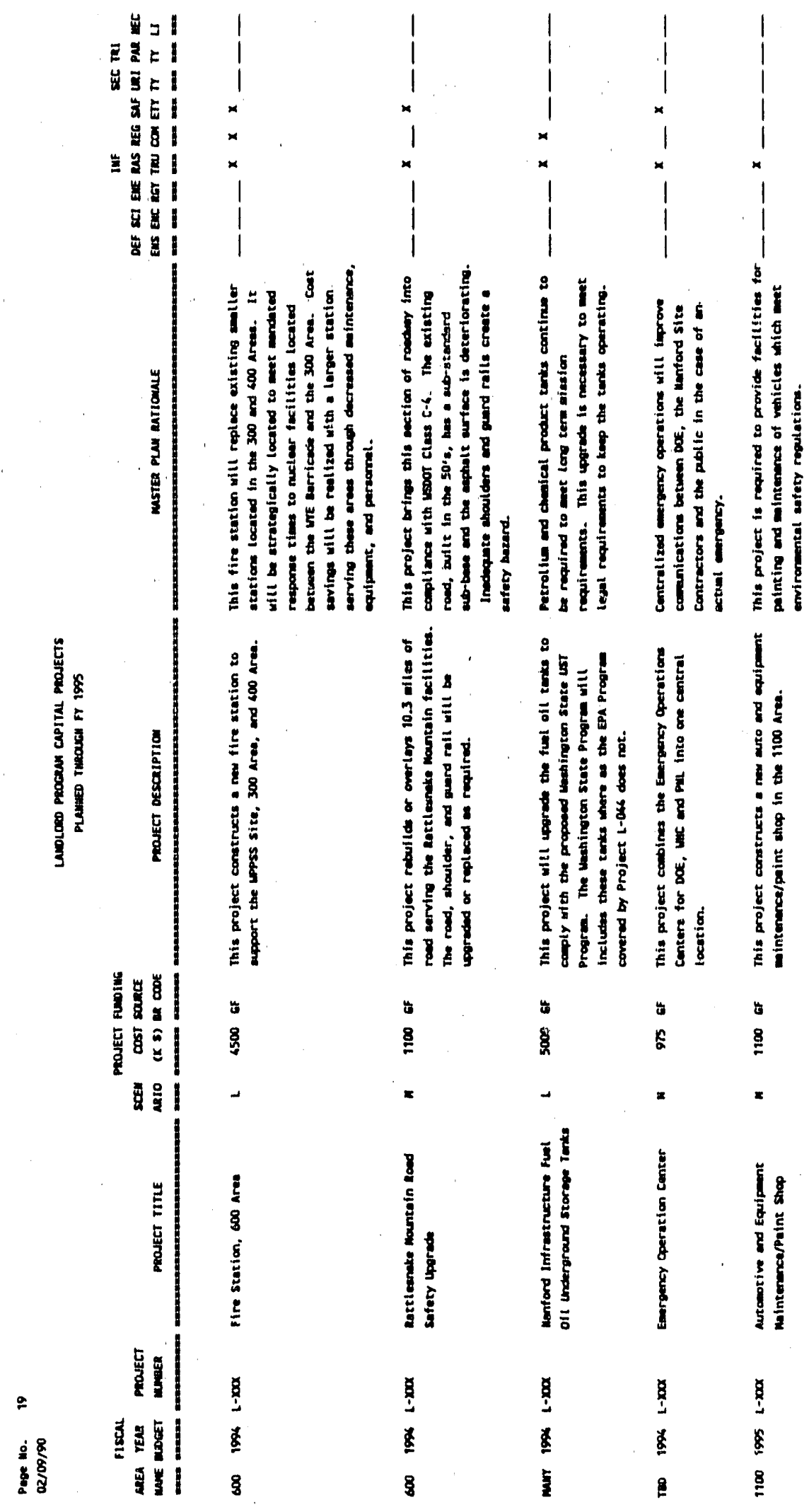


DOE/RL - $89-15$

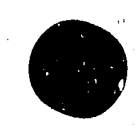

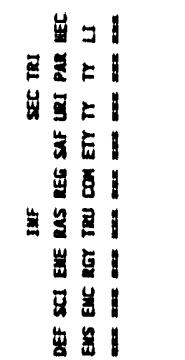
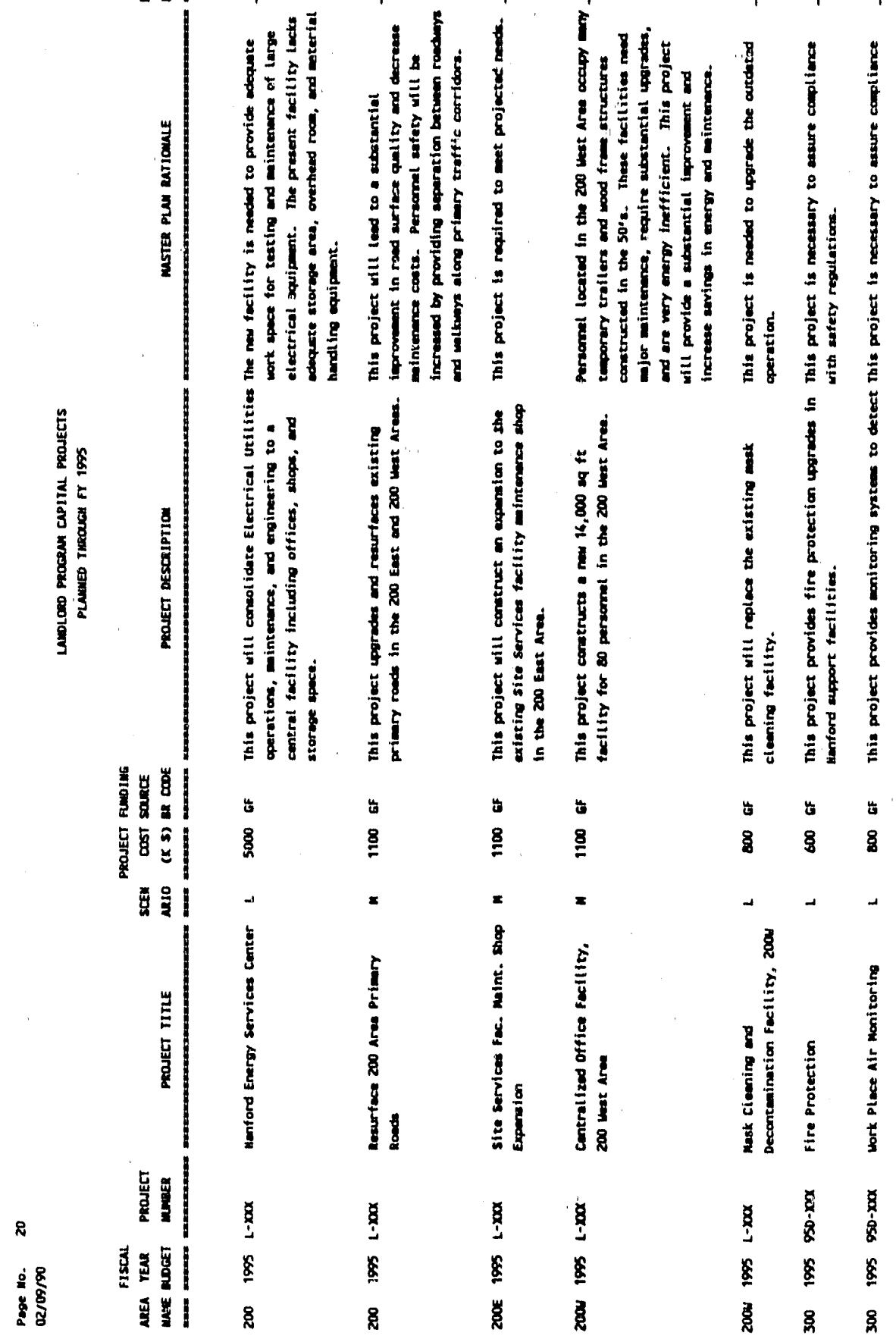

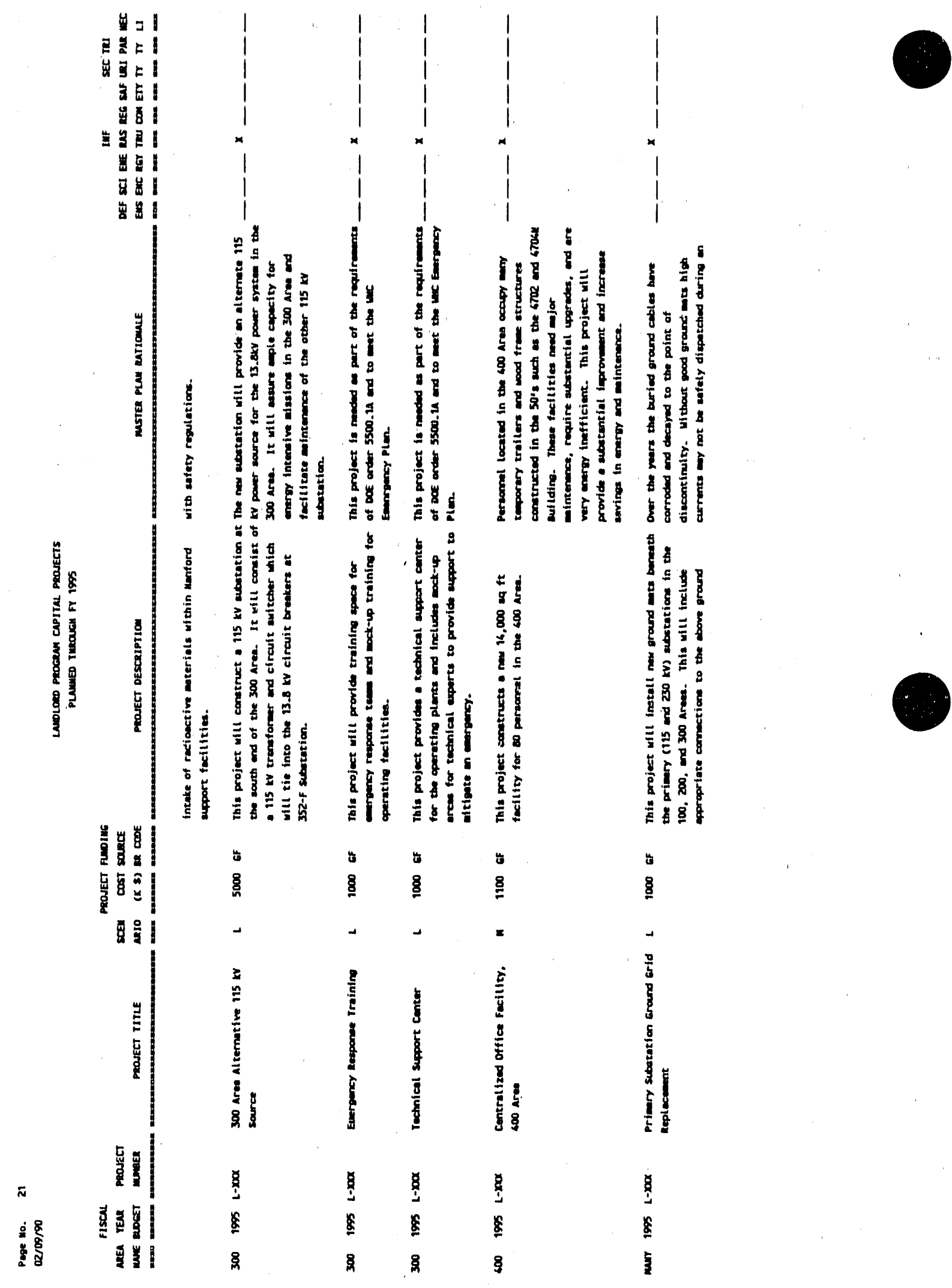
DOE/RL-89-15
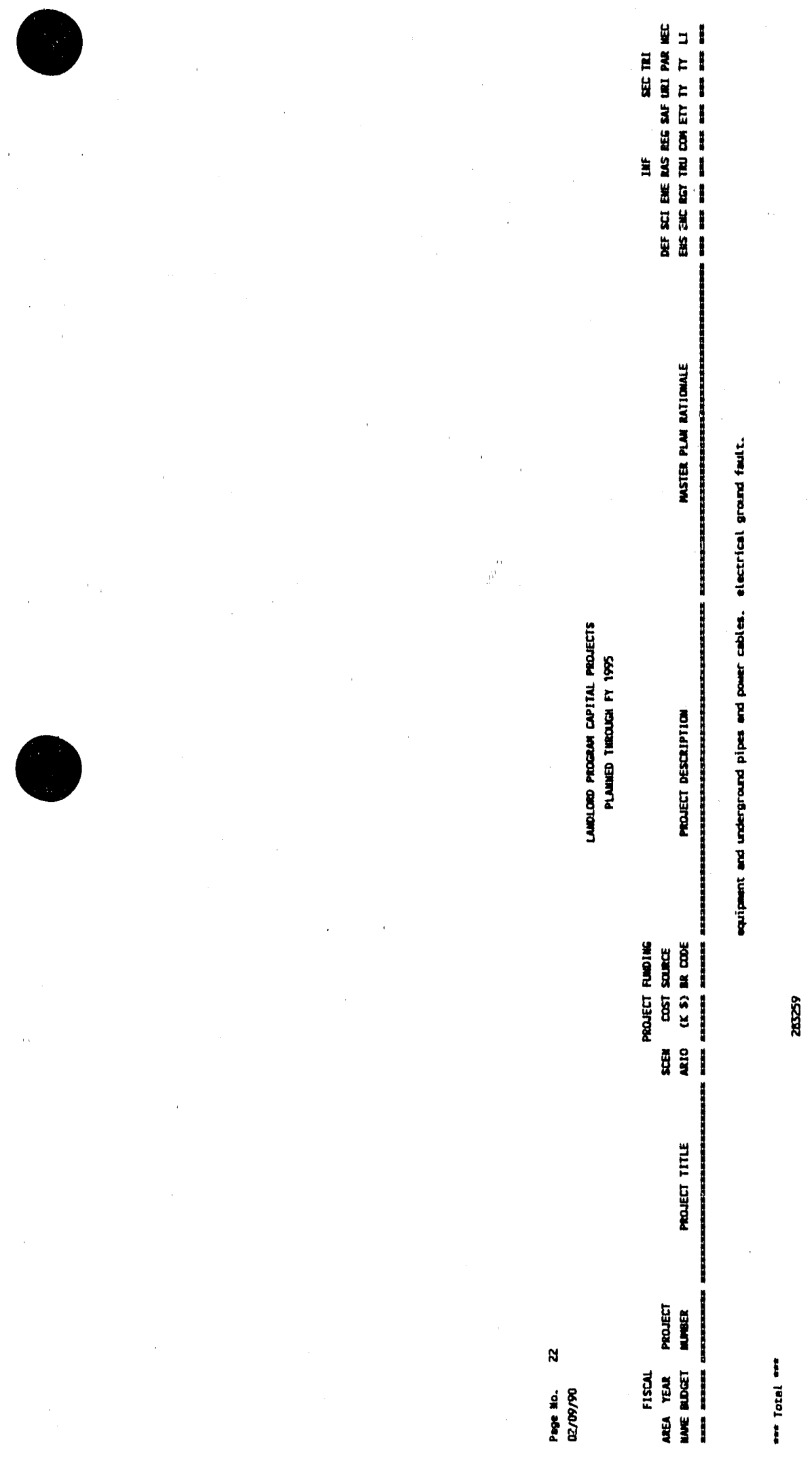

$c-5 / 52$ 
DOE/RL-89- 15

R\&D CONTRACTOR GENERAL PURPOSE FACILITIES CAPITAL

PROJECTS PLANNED THROUGH FY 1995

The following 17 projects are being submitted by the R\&D contractor for facilities, but not as part of the Landlord Program submittal. 
DOE/RL - 89- 15

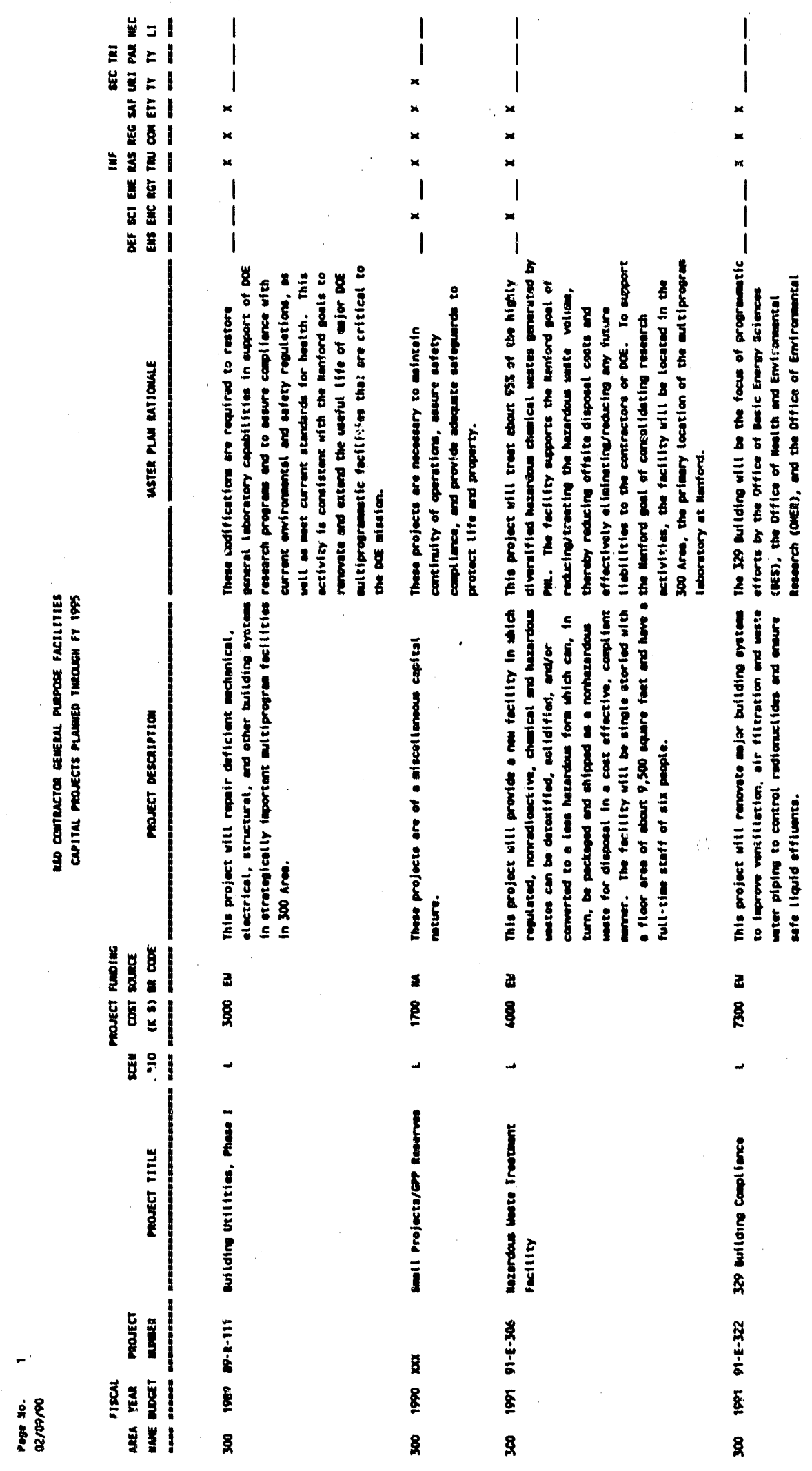



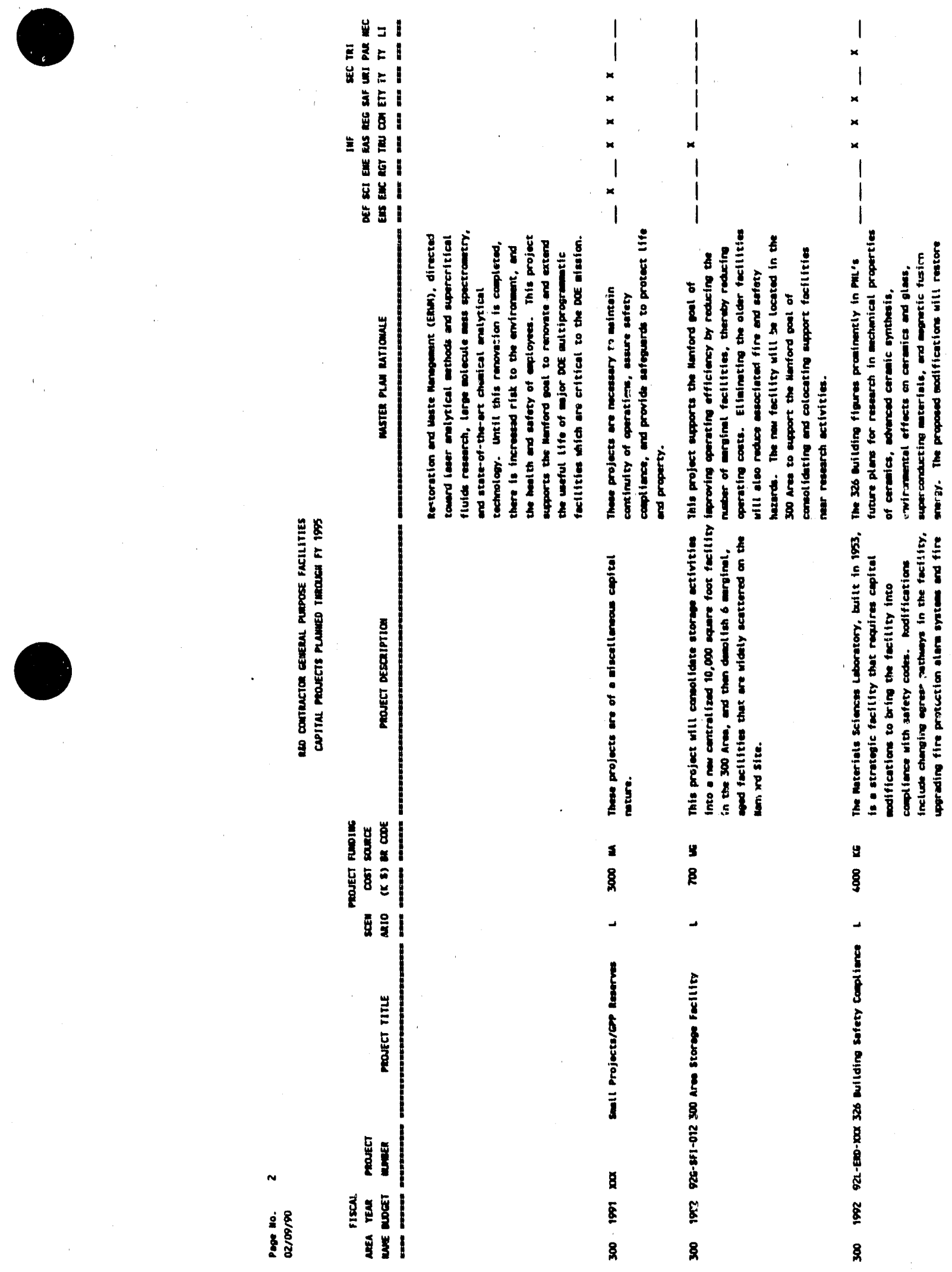
DOE/RL - 89- 15

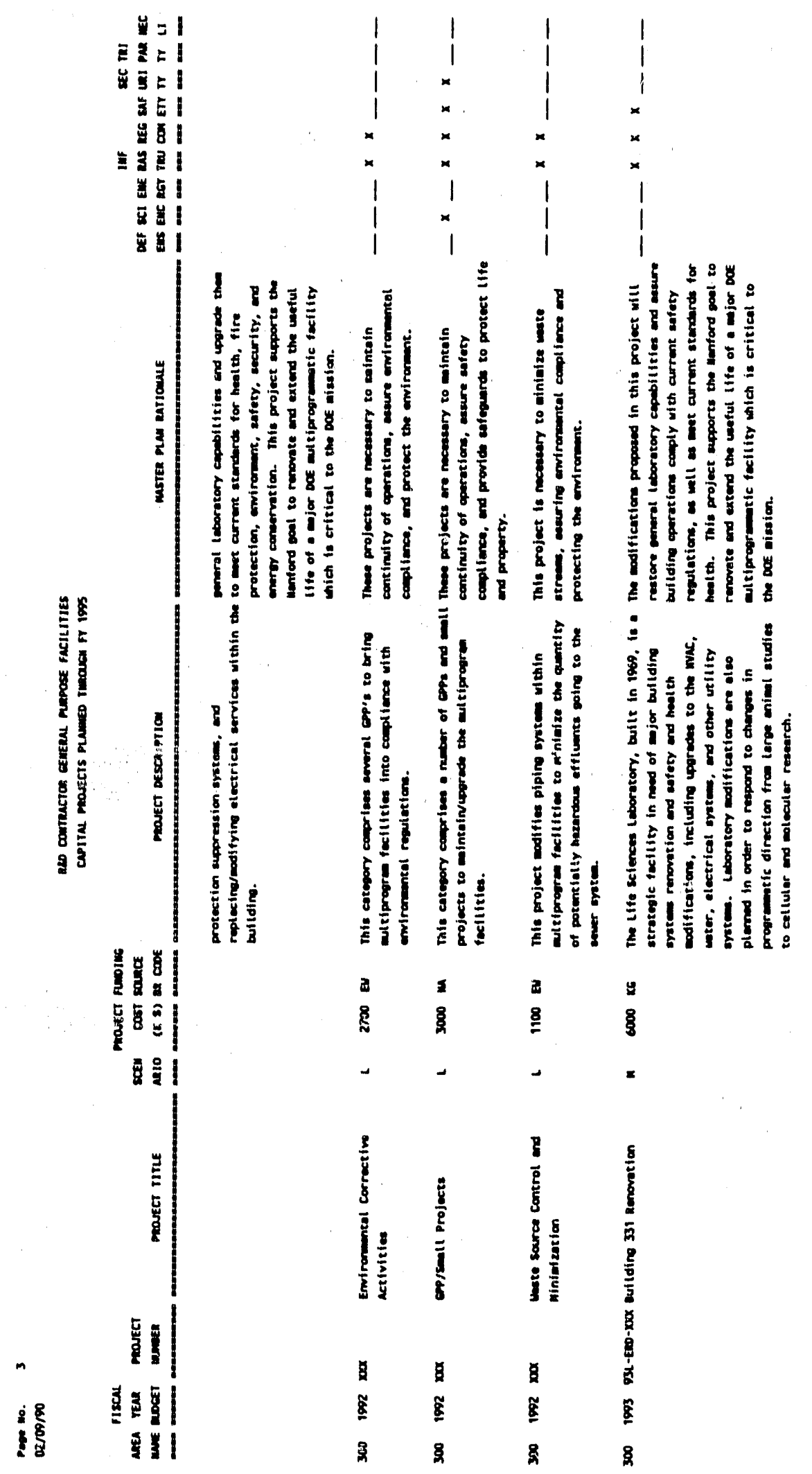


DOE/RL - 89- 15
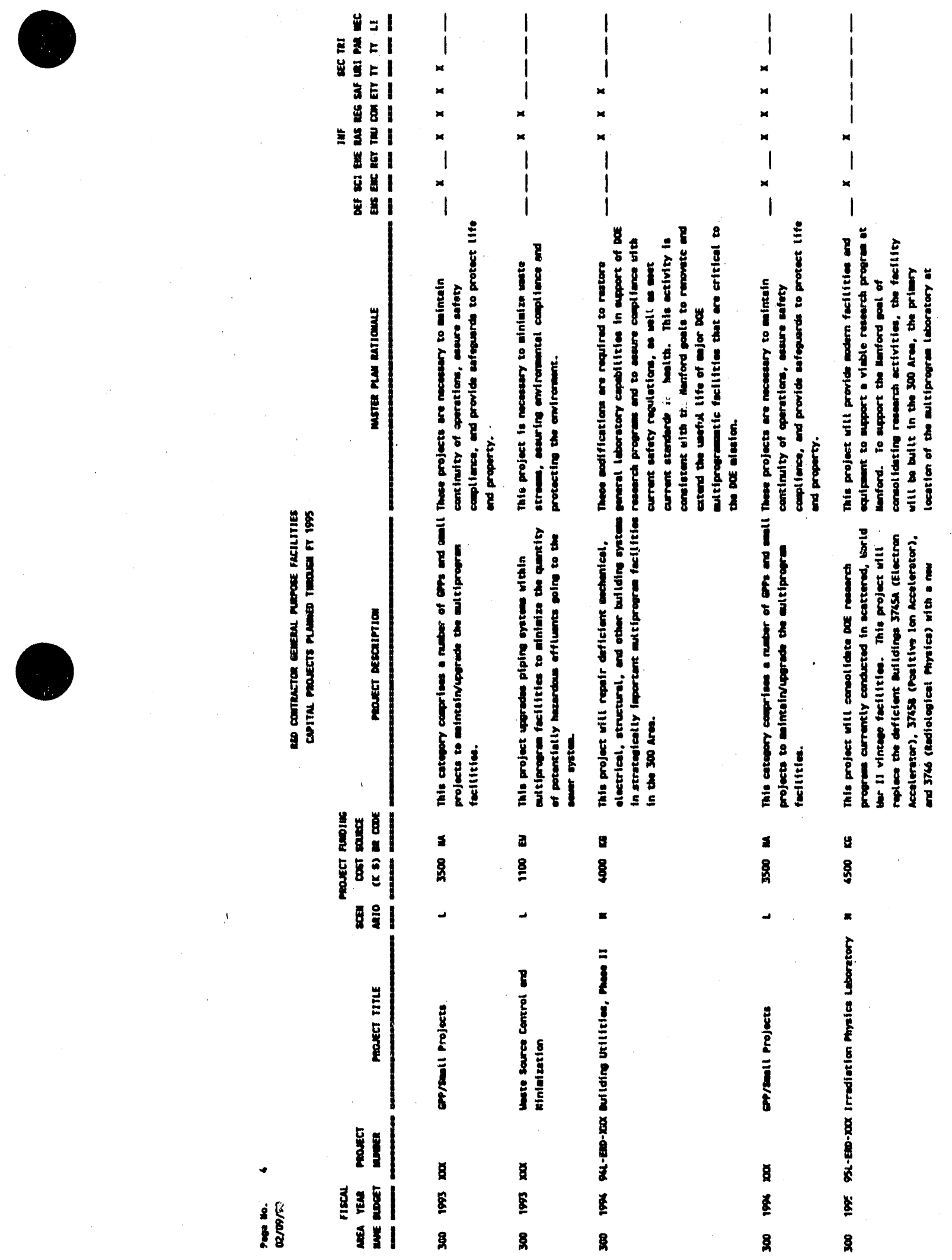
DOE/RL - 89- 15

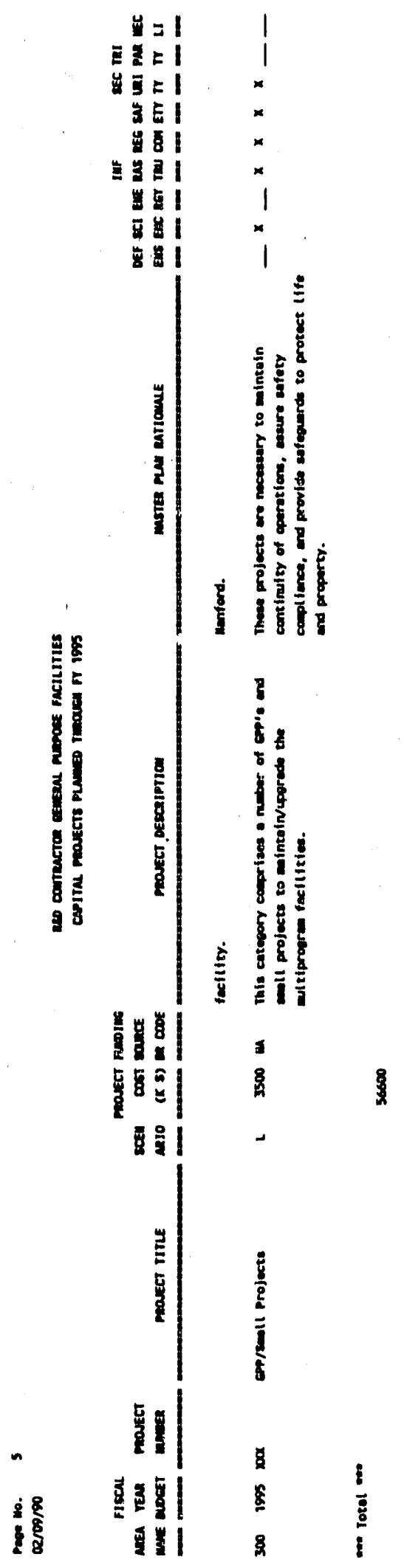


DOE/RL-89-15

R\&D CONTRACTOR PROGRAMMATIC FACILITIES CAPITAL

PROJECTS PLANNED THROUGH FY 1995

The following three projects are being submitted by the R\&D contractor for scientific research facilities. 
DOE/RL - 89- 15

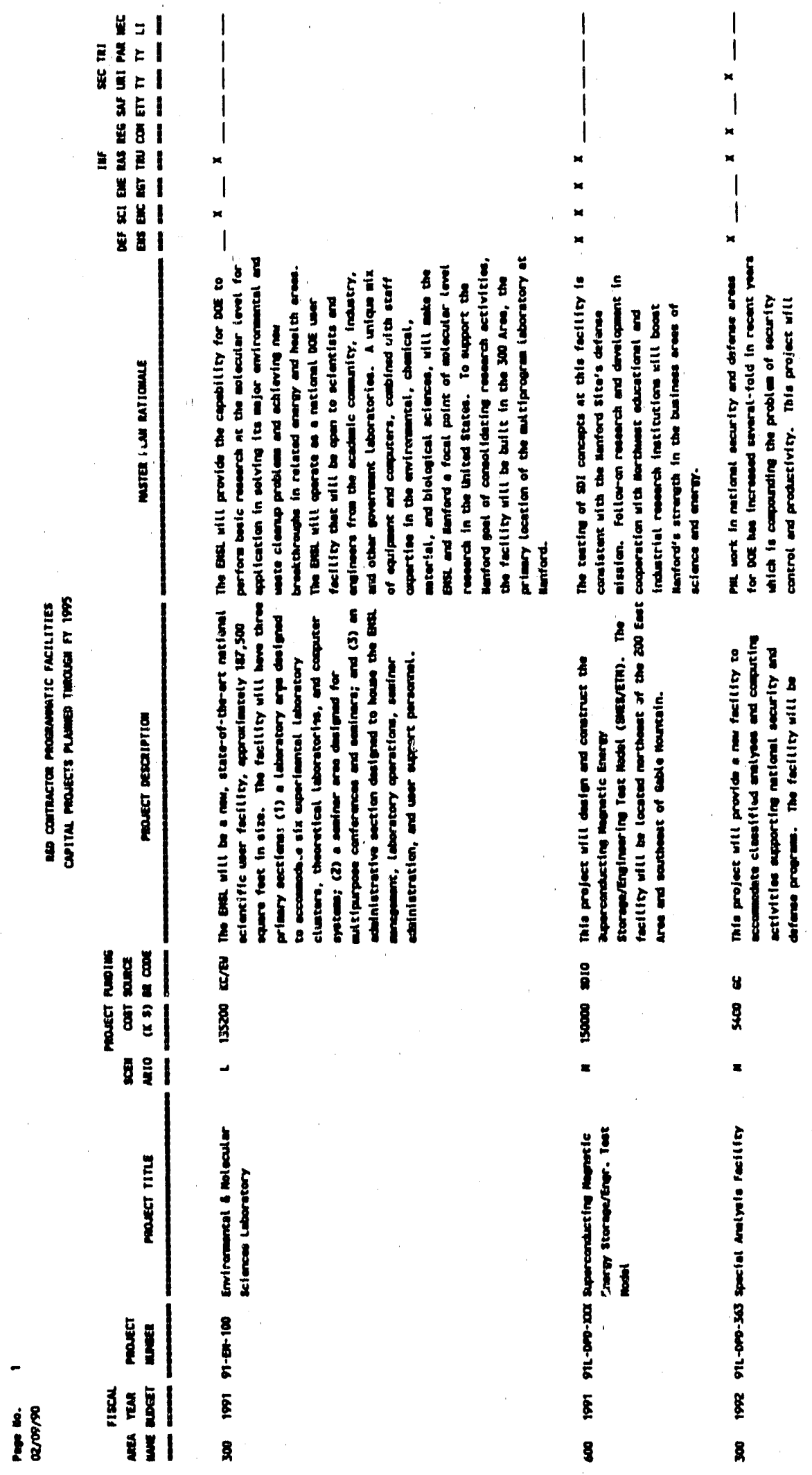


DOE/RL - 89- 15

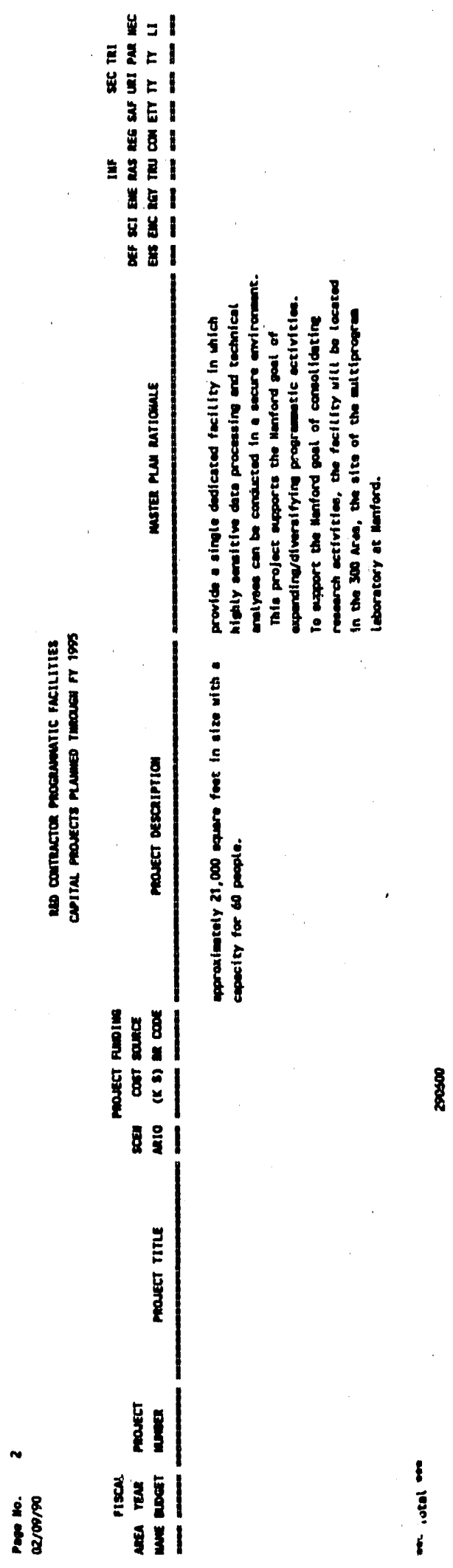

c-61/62 
DOE /RL-89-15

HANFORD STRATEGIC FACILITIES UTILIZATION PROGRAM PROJECTS PROPOSED THROUGH FY 1994

The following 24 projects are being submitted by the Strategic Facilities Utilization Program (SFUP), formerly the Strategic Facilities Initiative (SFI). 


\section{DISPOSITION OF MARGINAL FACILITIES}

"Marginal Facilities Disposition Yearly Plan Through FY 1994" (Table C-2) groups the marginal facilities by their proposed fiscal year action. The disposition for other structures is 1 isted in "Marginal Other structures Disposition Yearly Plan" (Table $C-4)$. Other structures with a disposition of "do nothing" represent facilities that are already classified in a standby status or are in the process of being excessed. No further action is required for these facilities. A brief description for Tables $\mathrm{C}-2$ and $\mathrm{C}-4$ headings can be found in Tables $C-1$ and $C-3$, respectively.

The Hanford Site contractors and the U.S. Department of Energy-Richland Operations office will be responsible for monitoring the performance and accrued savings resulting from the implementation of the Hanford Site Strategic Facilities Plan. The plan will be revised annually to report the status of ongoing actions and propose new marginal facilities actions. The annual updates of the plan will reflect the changing needs for facilities, influenced by changes in Hanford Site missions and the rearrangement and consolidation of similar activities and work groups. The scope of the Hanford Site Strategic Facilities Plan addresses strategic facilities in a manner that meets the DOE Order $4300.1 \mathrm{~b}$ requirements.

The following table describes the fields and codes used in Table $c-2$. 
Table C-1. Marginal Facilities Disposal Table Definitions. (sheet 1 of 2)

1. Area: The general location where the facilities are located on the Hanford Site.

2. Building: The official facility number as listed in the RPIS.

3. Building Name: Name or description of the facility. If the facility is unnamed, a brief description was given.

4. Area Available: The size or quantity of the facility. If the facility is unnamed, a brief description was given.

5. Unit: How the facility is measured using units such as $\mathrm{ft}^{2}, \mathrm{mi}$, and KVA, as expressed in the RPIS or as appropriate.

6. Condition code: The condition rating system provided in the inactivation guidance as shown below:

Physical

Condition

Excellent Performs to original specifications. Generally requires only preventive maintenance. Easily restorable to "1 ikenew" performance.

Good

Performs to important original specifications with extra operation attention and reasonable extra maintenance. Downtime does not affect operations.

Adequate Meets program requirements/departmental mission assignments, but cannot perform to all original specifications. Corrective, as well as preventive maintenance required/costs not excessive. Downtime does not unduly affect operations.

Fair Occasional substandard output even with careful operator attention. Repetitive corrective maintenance needed. Total maintenance costs exceed economic operations. Operations occasionally impeded by downtime.

Poor Consistent substandard performance. Excessive maintenance costs. Operations continually threatened by breakdowns.

7. Funding program: The disposition program that will, or is planned to, accomplish the required action(s) as identified by the two-digit Budget and Reporting (B\&R) Code level. 
Table C-1. Marginal Facilities Disposal Table Definitions. (sheet 2 of 2)

\begin{tabular}{|c|c|}
\hline $\begin{array}{l}\text { B\&R } \\
\text { Code }\end{array}$ & Description \\
\hline $\begin{array}{l}\text { AF } \\
\text { GE } \\
\text { GF } \\
\text { HA } \\
\text { KC } \\
\text { WG } \\
40 \\
80\end{array}$ & $\begin{array}{l}\text { Nuclear Energy Research and Development } \\
\text { Materials Production } \\
\text { Defense Waste and Transportation Management } \\
\text { Environmental Research and Development } \\
\text { Basic Energy Sciences } \\
\text { Strategic Facilities Utilization Program } \\
\text { Cost of Reimbursable Work for Other Federal Agencies } \\
\text { Reconciling Production }\end{array}$ \\
\hline
\end{tabular}

8. Action: The proposed project action(s) with terms consistent with the FY 1990 Controller's field budget call, such as consolidate or demolish, or none where no action is appropriate.

9. 01d Maintenance Dollars Per Year: The sustaining maintenance costs, (e.g., janitorial, painting, roofing, and heating, ventilating, and air conditioning) associated with the facility described.

10. Action cost: The amount of funds required to accomp 1 ish this project expressed in FY 1990 dollars.

11. New Maintenance Dollars Per Year: The sustaining maintenance costs associated with the facility as a result of the action taken or planned.

12. Savings Per Year: The annual costs that would be avoided or saved through the actions proposed or taken.

13. Replace Avoidance of a One-Time Savings: A cost presented on the bas is of a one-time savings.

14. Simple Payback in Years: This is derived by subtracting the replacement avoidance from the total cost of the project and then dividing by the estimated total annual savings and expressing the results in years and one-tenth fractions of a year.

15. Proposed Funding Year: The proposed fiscal year that funding should be awarded for completion of planned projects. 
DOE/RL-89- 15

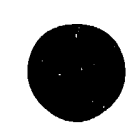

离

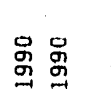

甾

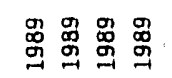

兽骂哭骂

$\stackrel{g}{g}$

苞。

a

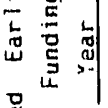

品品 鴣

品品品品

品喿品喝

$\stackrel{\circ}{9}$

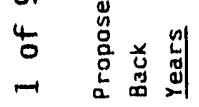

$\exists$

怘号

ร:

总势部

跑

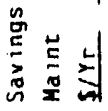

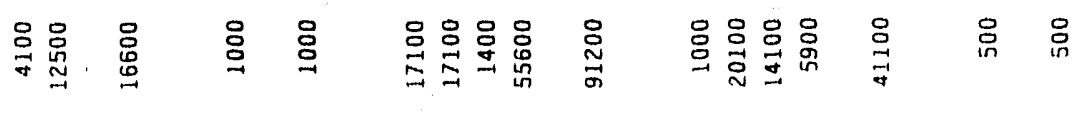

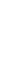

(1)

辜

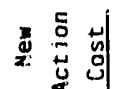

蒙装

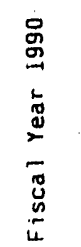

总总总 总

总总 总

$\circ \circ$

\begin{tabular}{ll}
$\frac{5}{5}=\frac{5}{n}$ \\
\hdashline
\end{tabular}

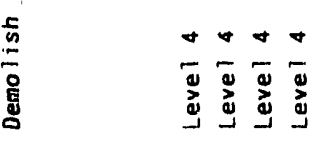

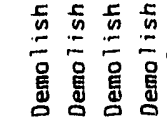

$\frac{5}{\frac{5}{0}}$

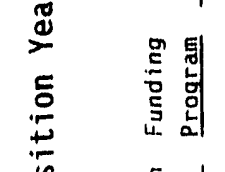

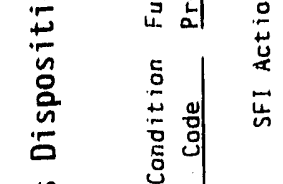

$\$$

\

$\vdots$

à

点点点象

昰告点告

出

淽

絧岂

盛

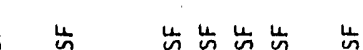

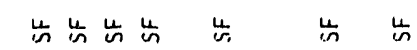

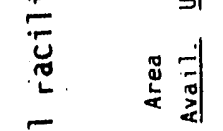

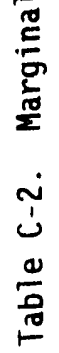

崖

:
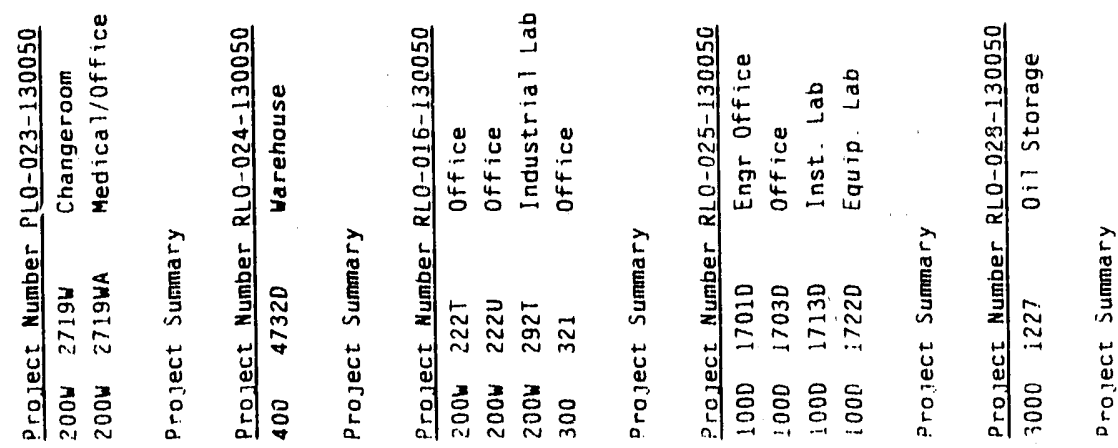
DOE/RL-89- 15

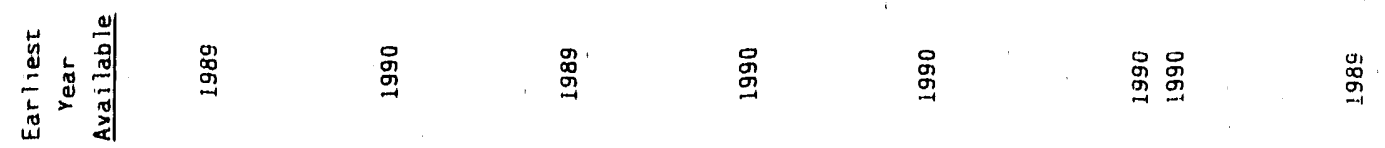

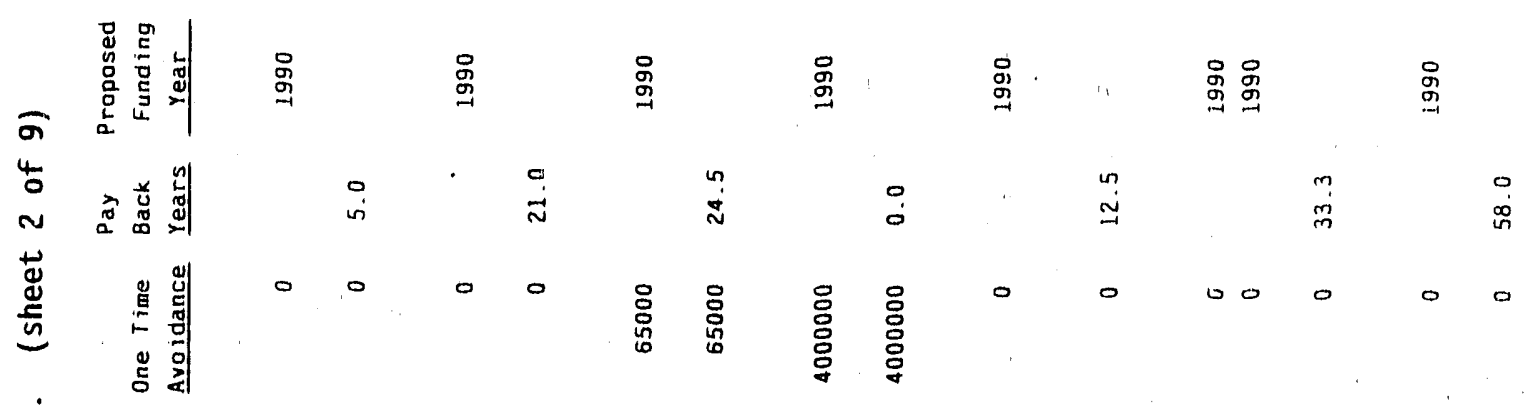

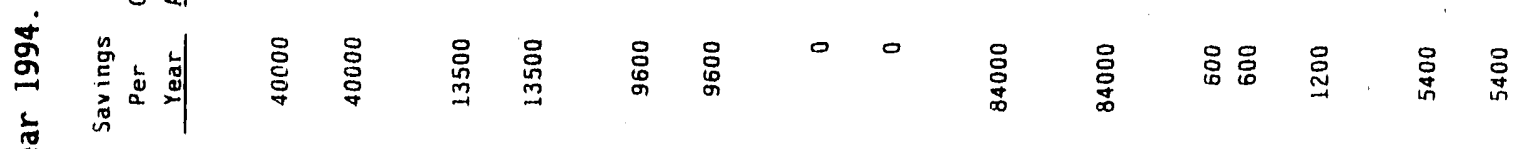

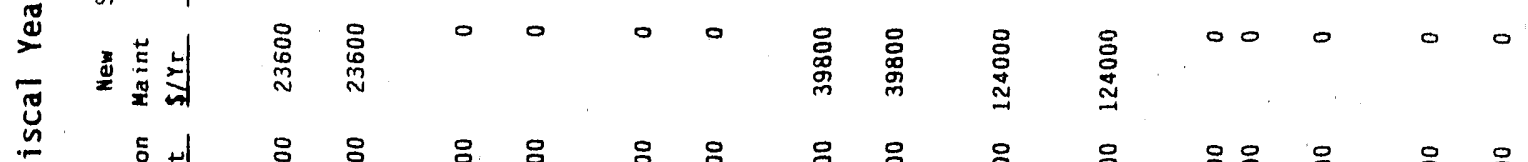

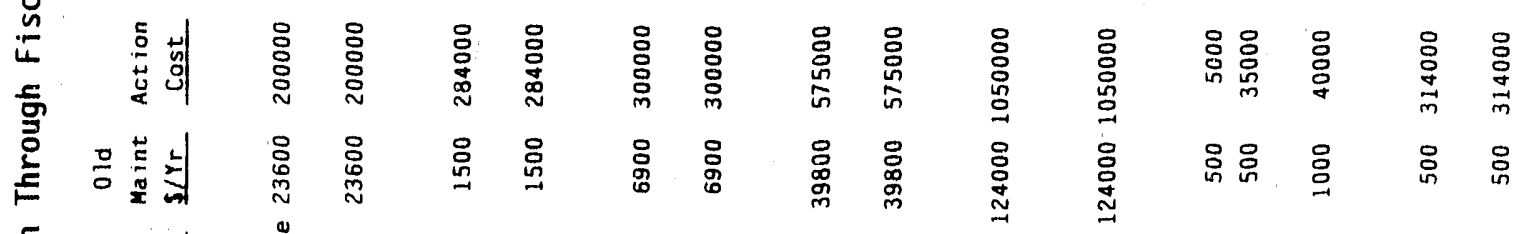

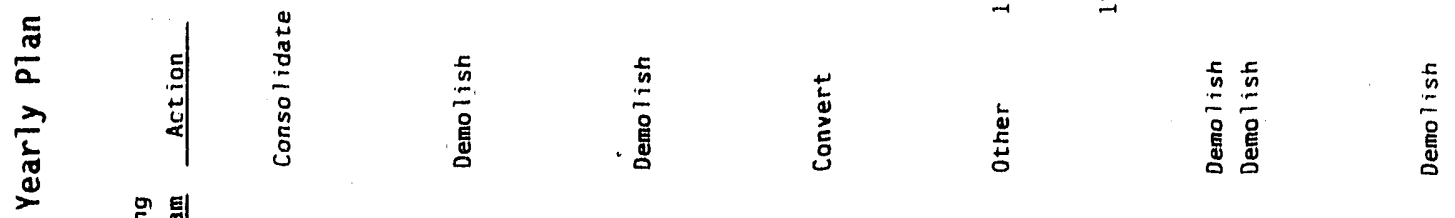

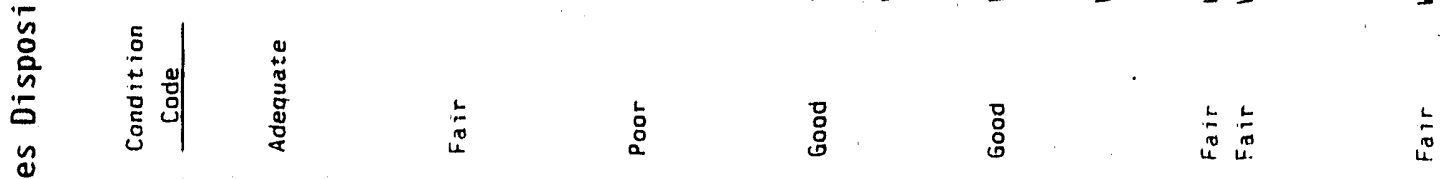

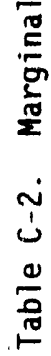

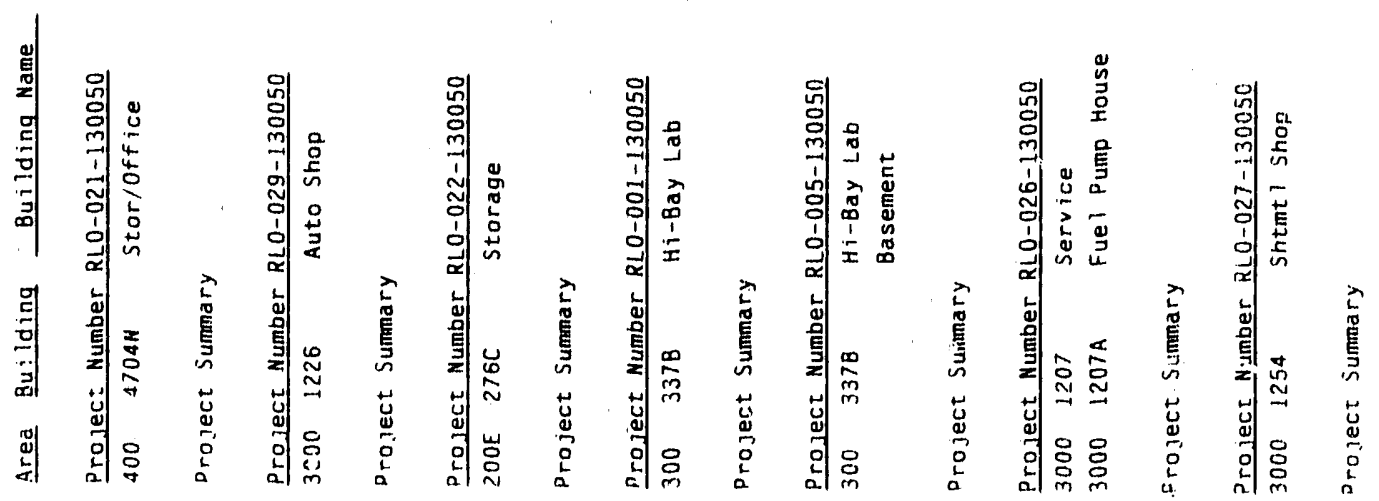


$D O E / R L-89-15$

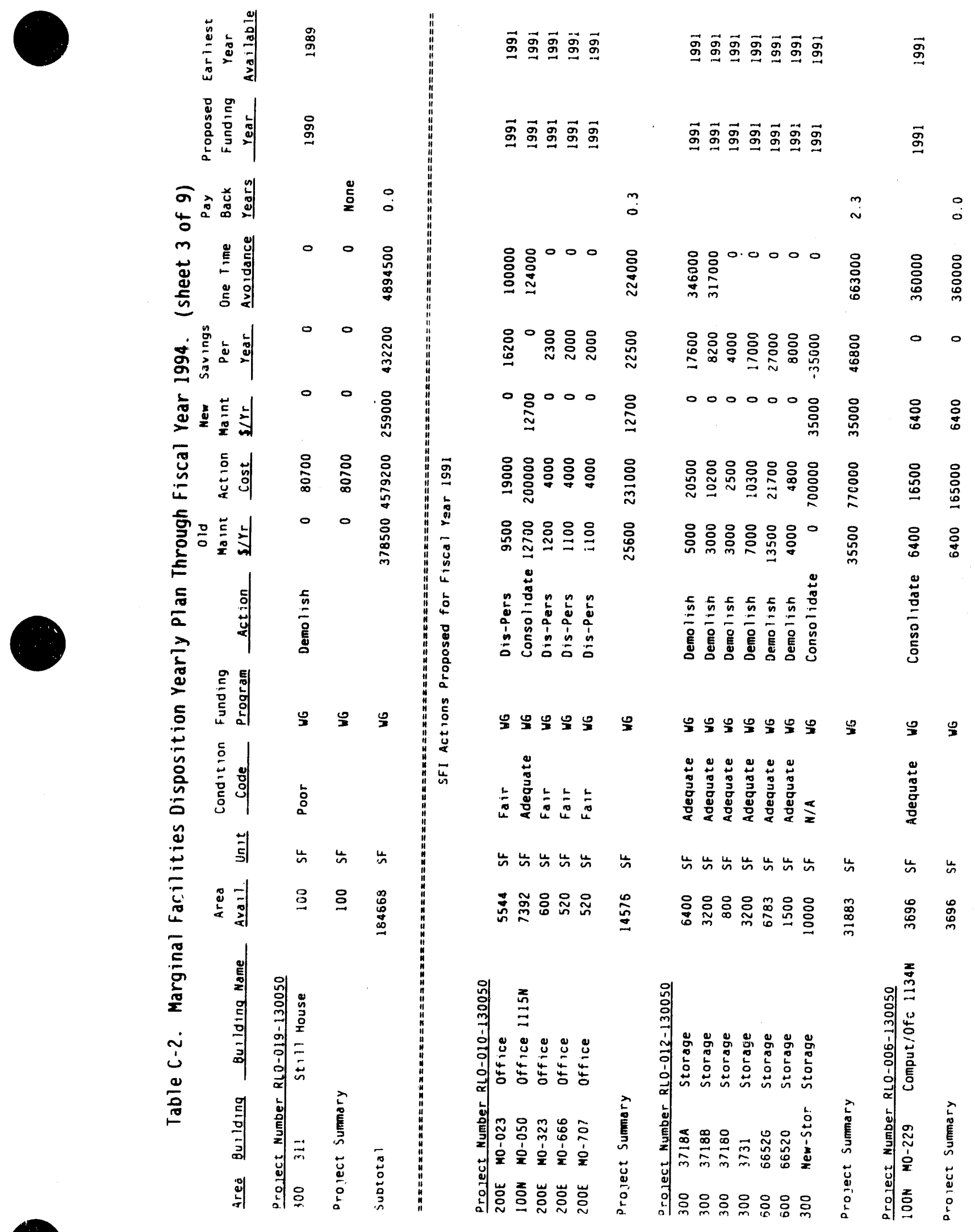




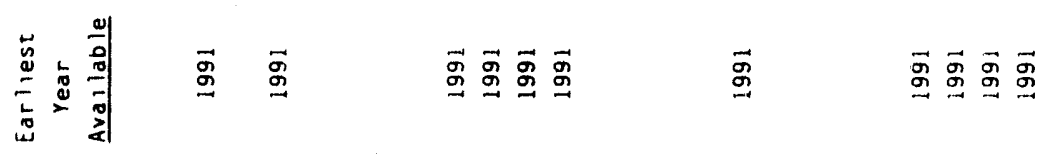

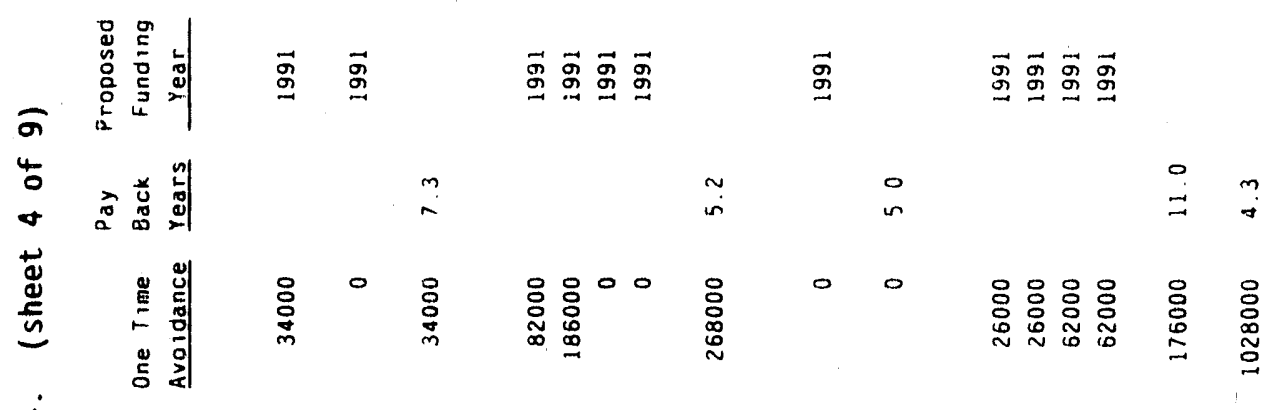

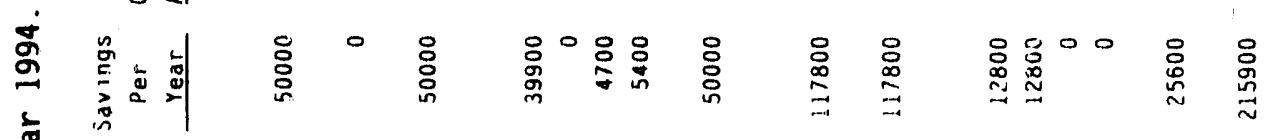

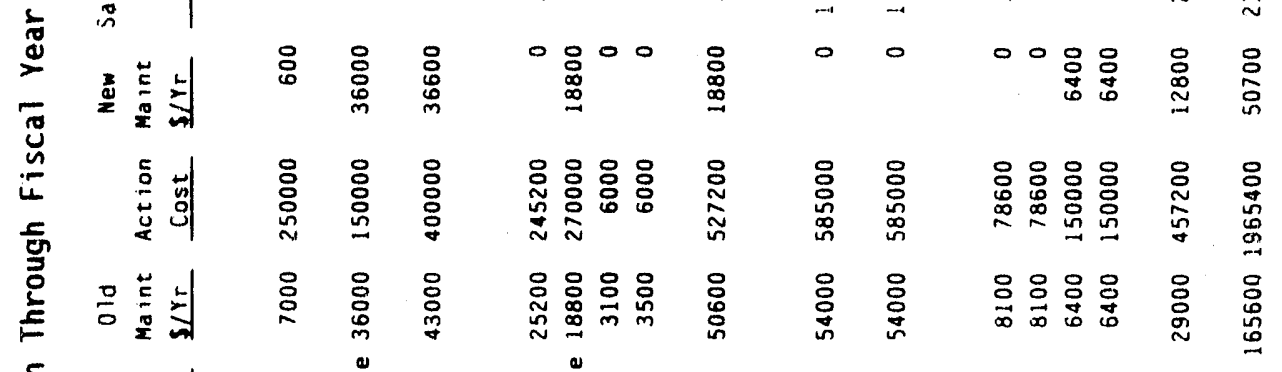

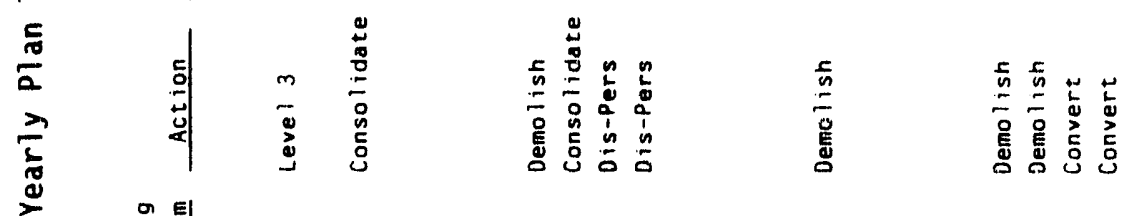

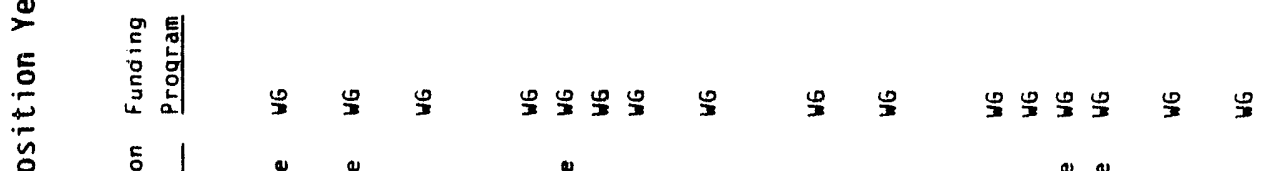

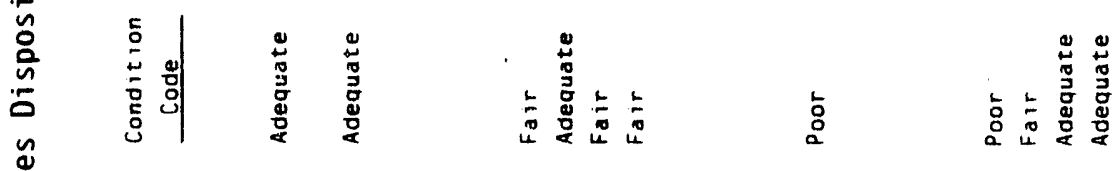

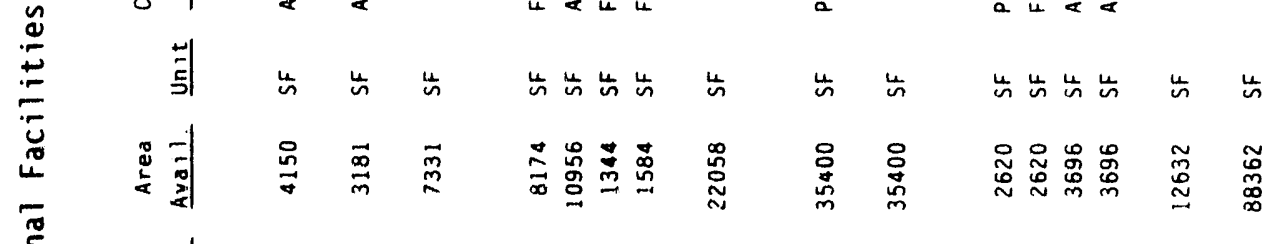

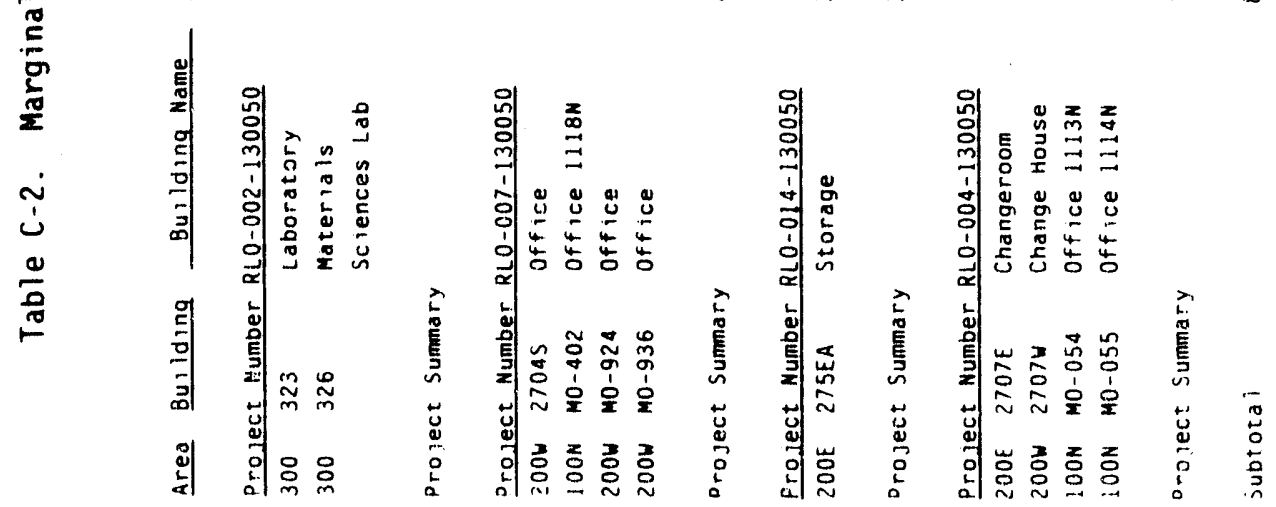



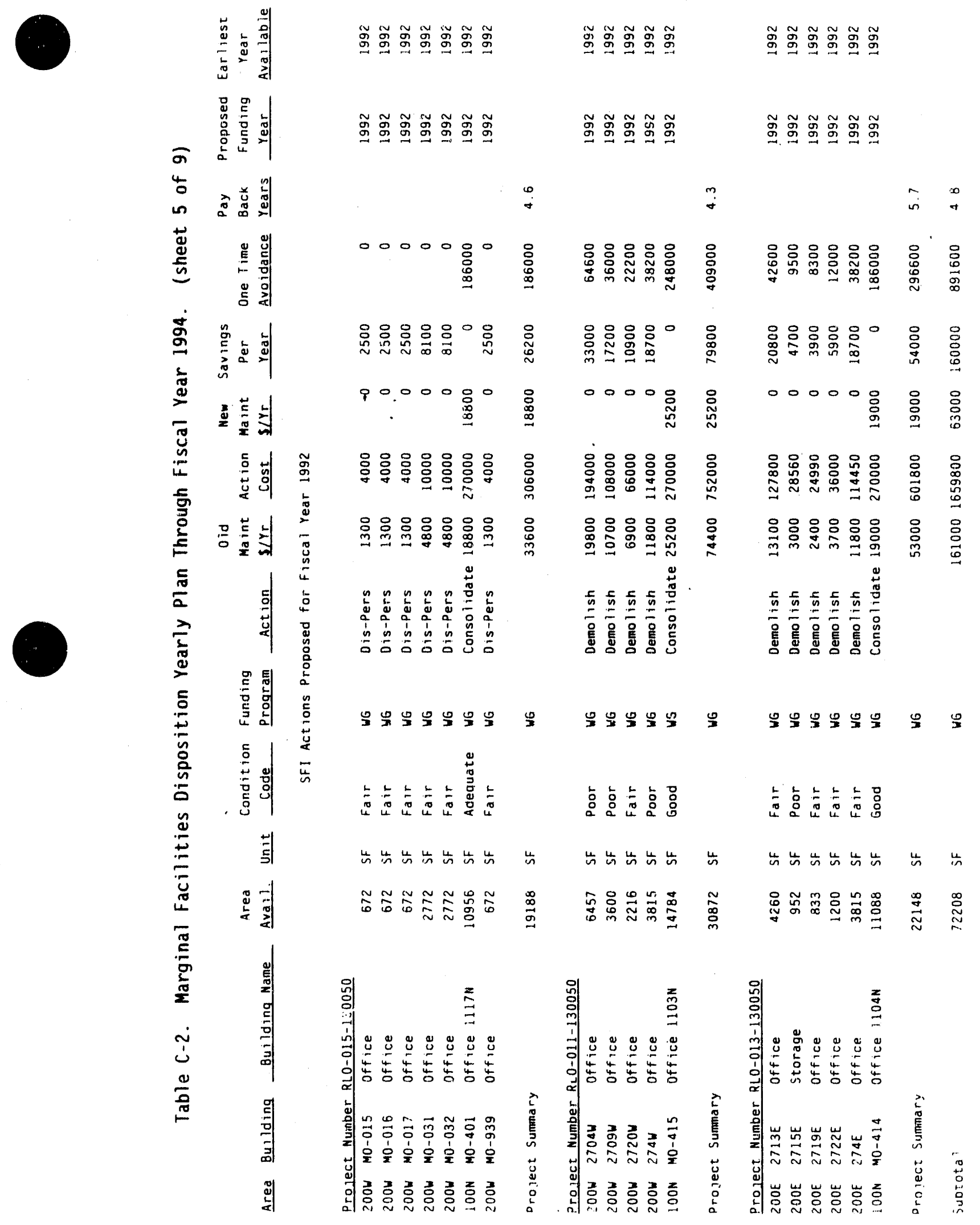


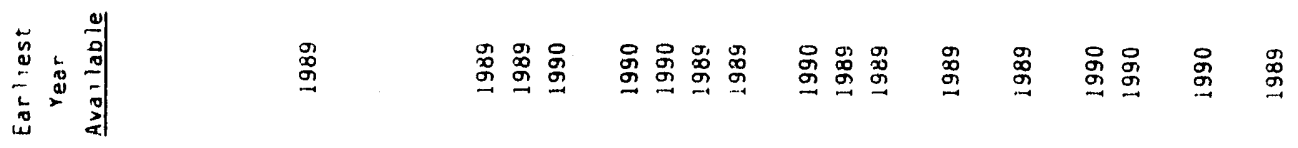

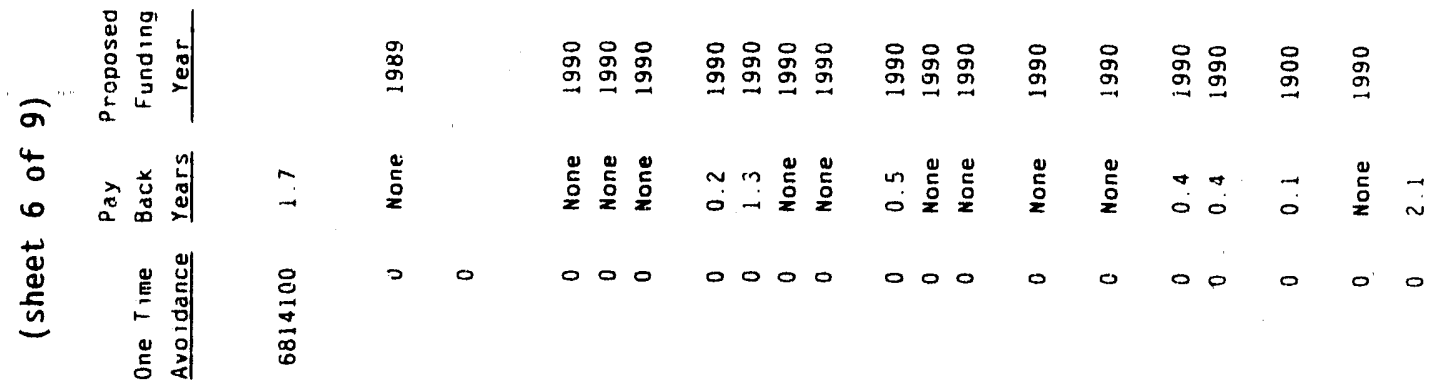

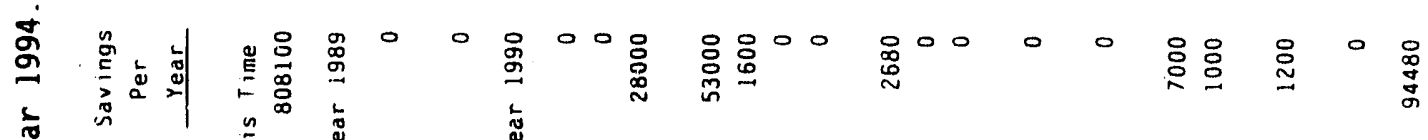

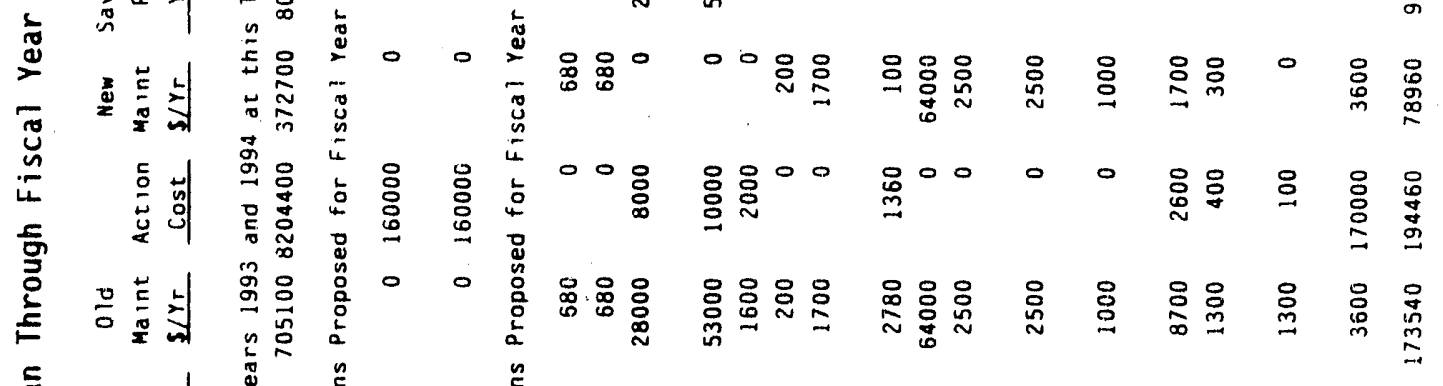

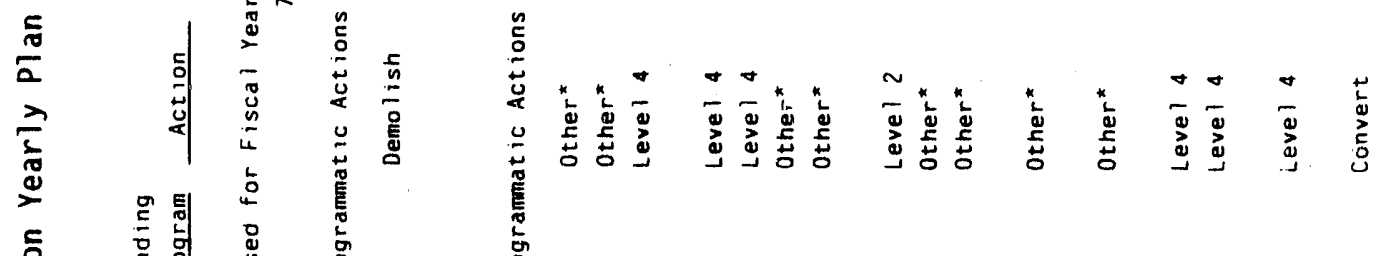

$\frac{n}{\frac{\pi}{a}}$

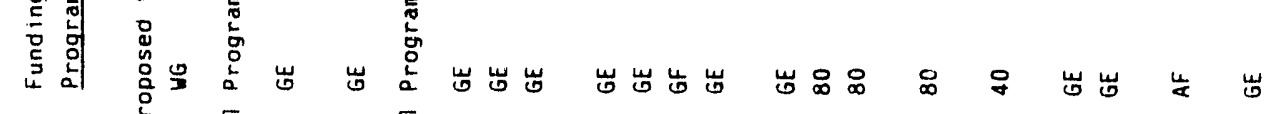

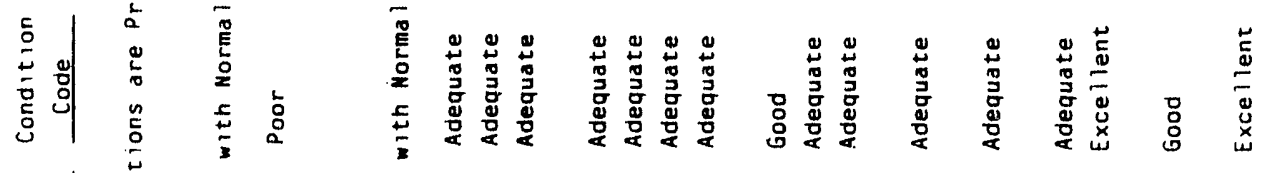

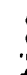

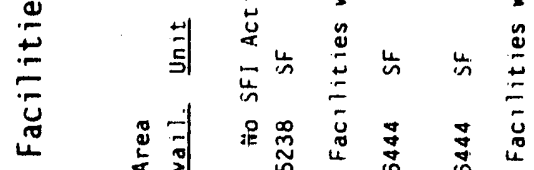

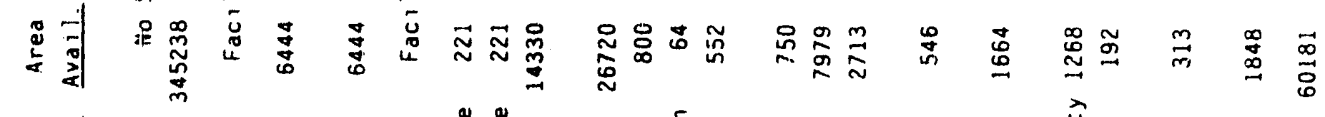

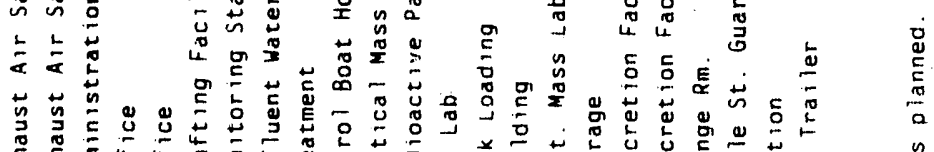

$\stackrel{\sim}{\sim} \quad$ 章

$\stackrel{\frac{0}{\pi}}{\sim}$

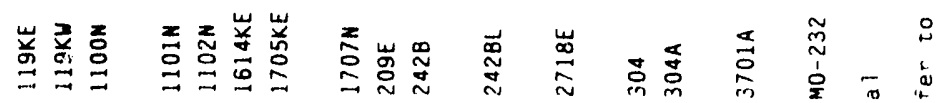

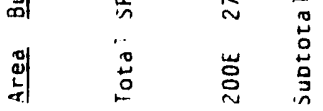

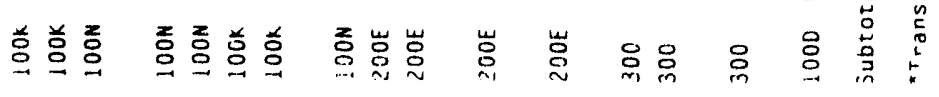


DOE/RL-89- 15

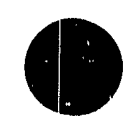

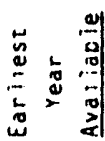

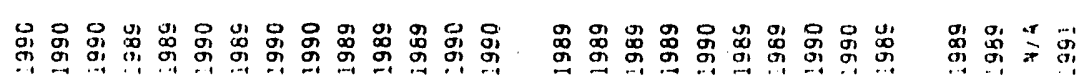

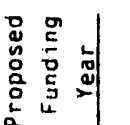

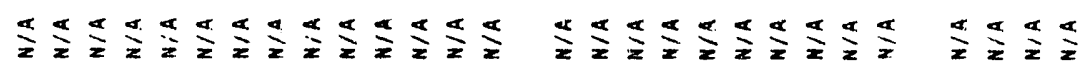

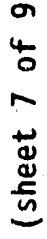

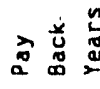

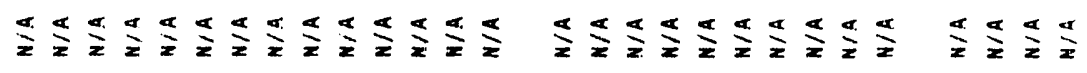

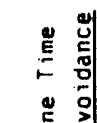

00000000000000

00000

a

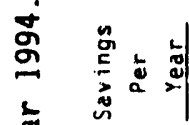

$\stackrel{2}{2}$

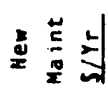

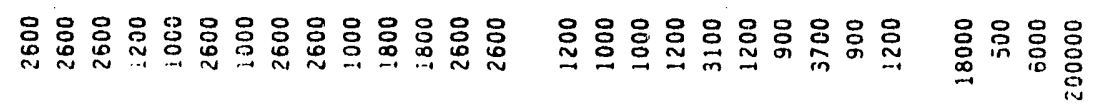

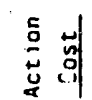

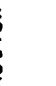

응 点

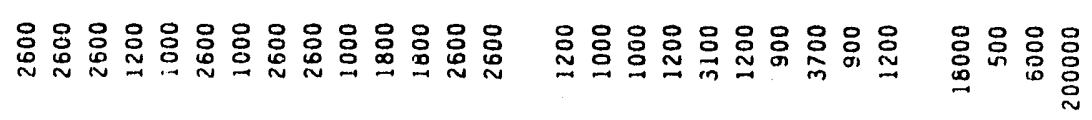

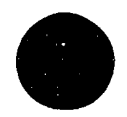

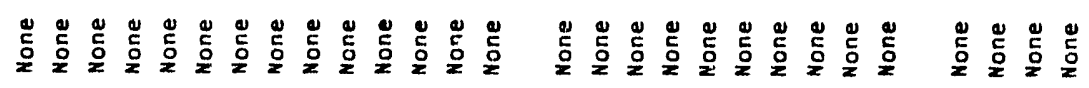

是卧

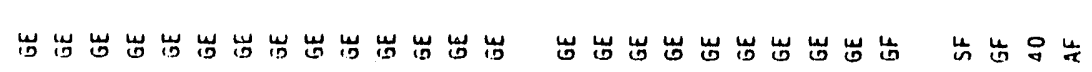

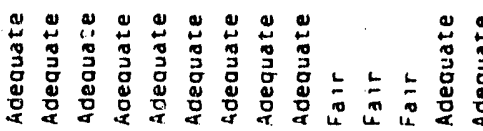

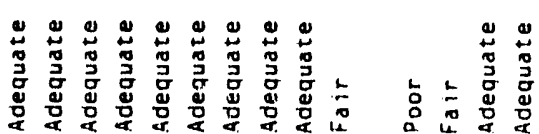

해

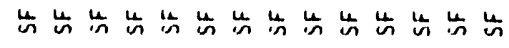

出出落出出出出出出出出出出告

势.

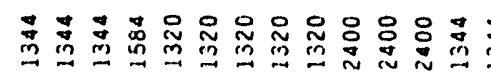

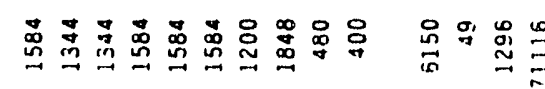

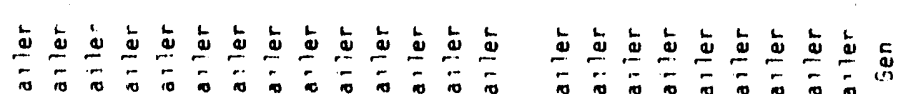

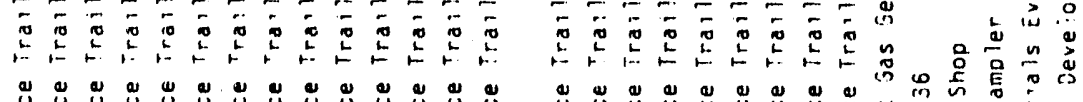

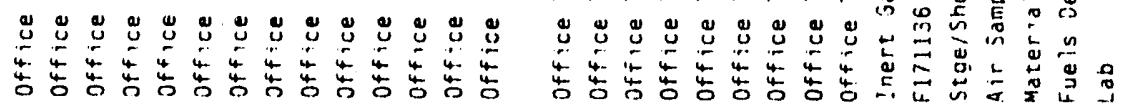

章

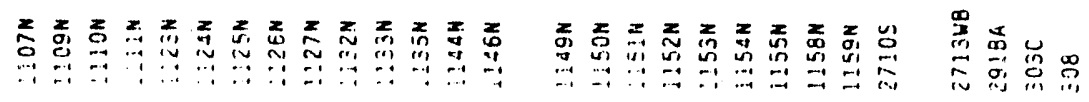

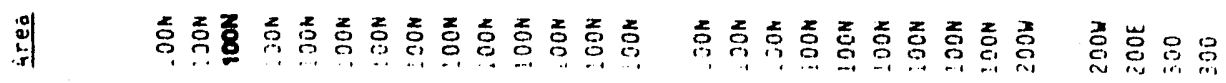


DOE/RL - 89- 15

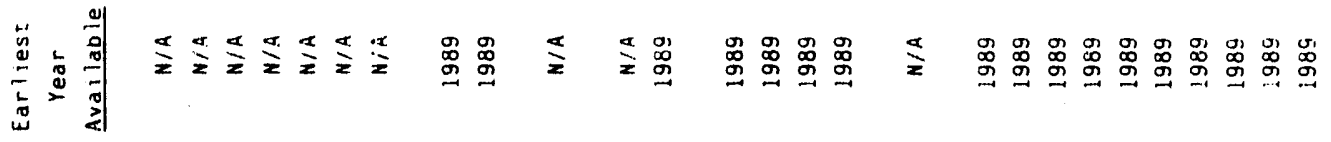

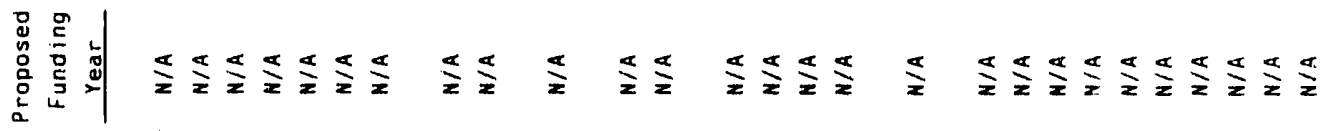

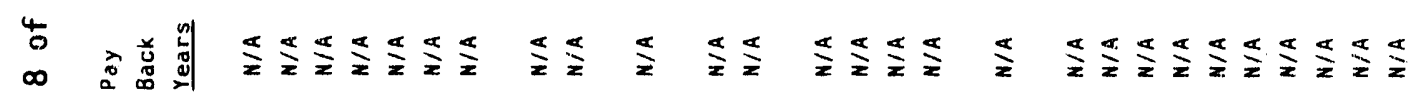

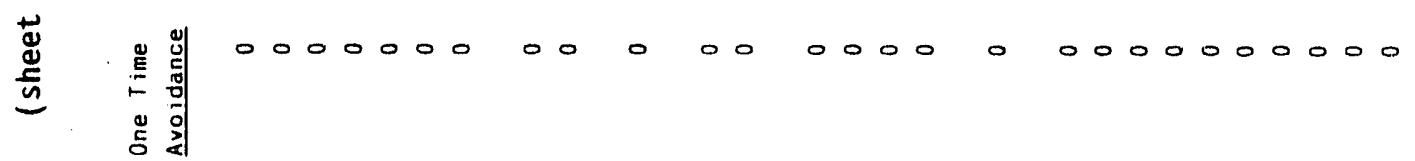

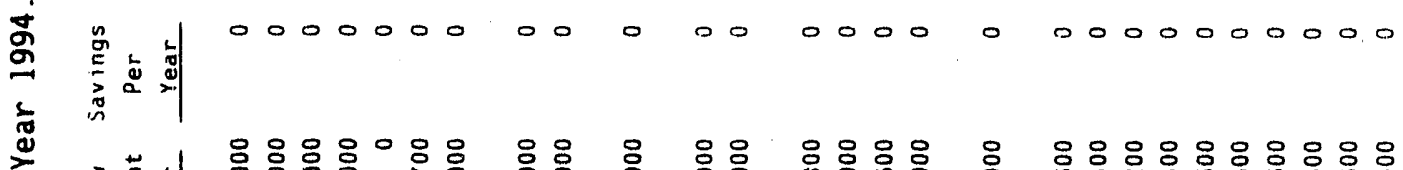

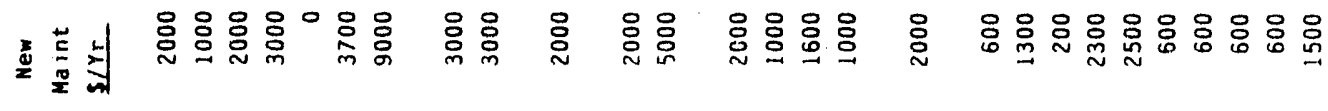

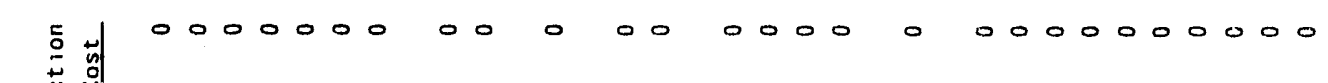

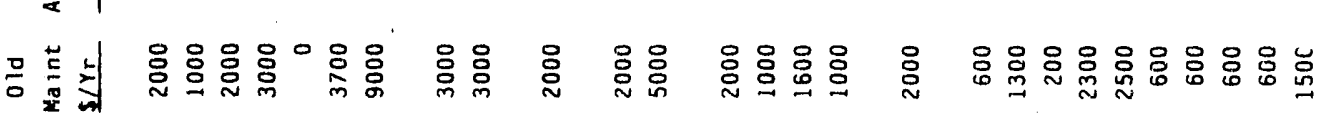

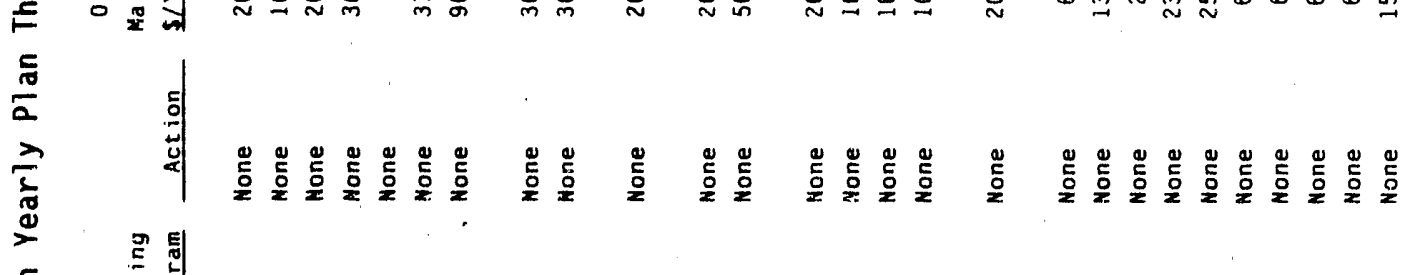

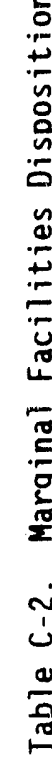

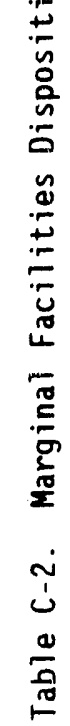

䆓亮

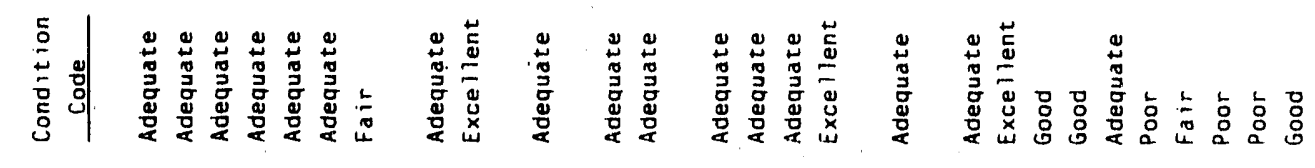

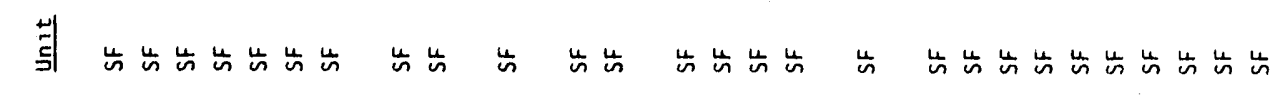

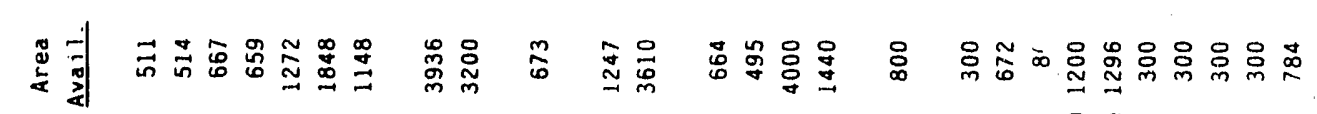

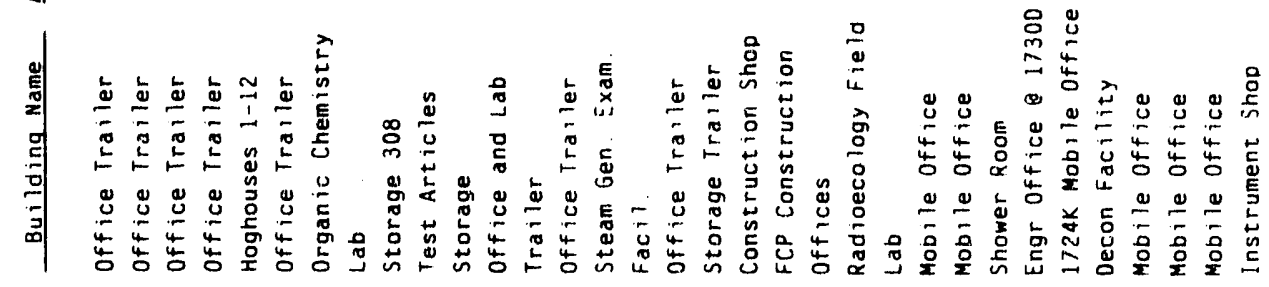

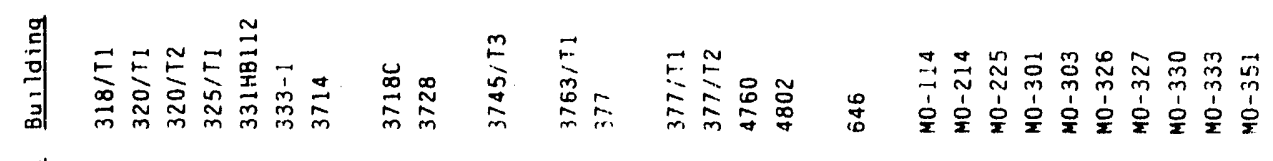

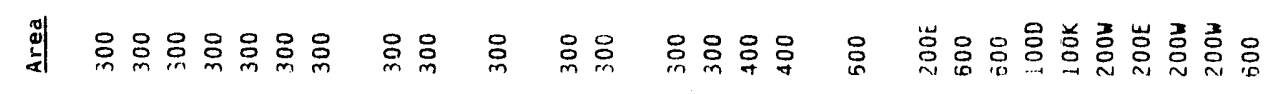




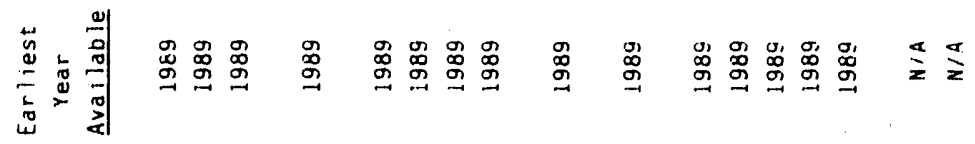

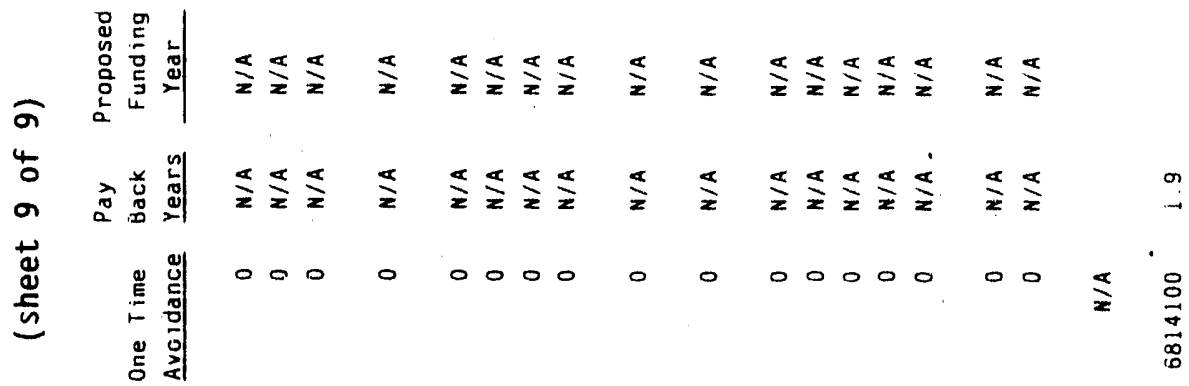

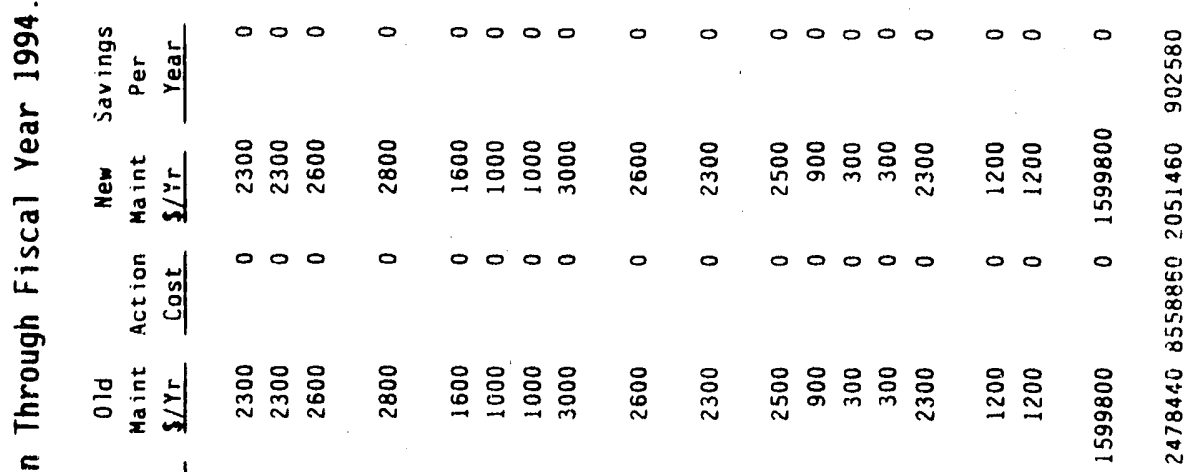

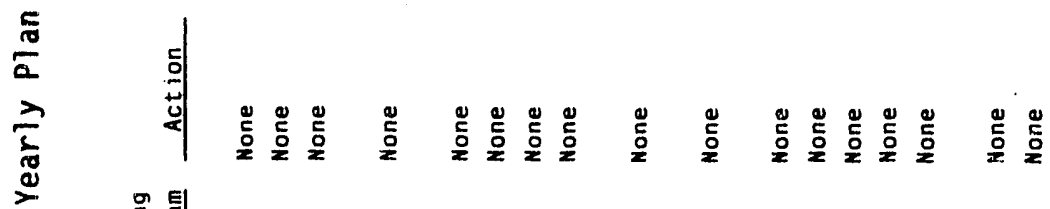

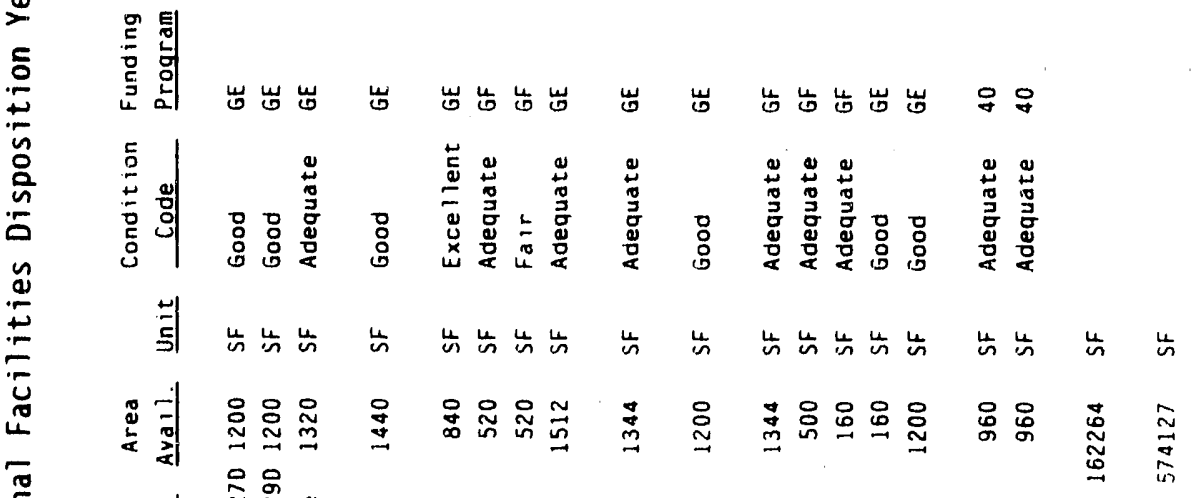

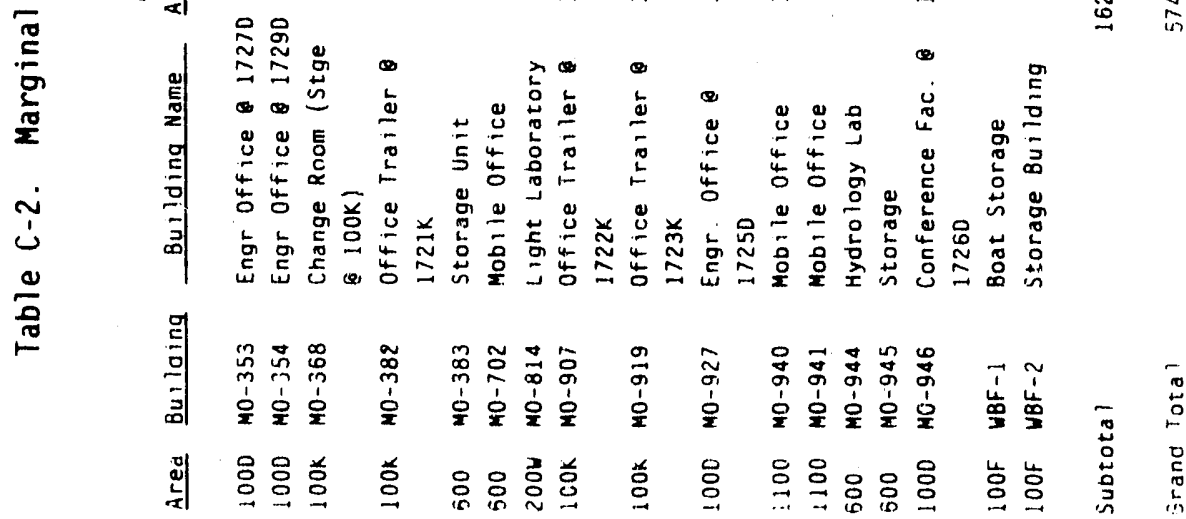


Table C-3. Marginal Other Structures Disposition Table Definitions. (sheet 1 of 2)

1. Area: The general location where the facilities are lncated on the Hanford Site.

2. Building: The official facility number as listed in the RPIS.

3. Building Name: Name or description of the facility. If the facility is unnamed, a brief description was given.

4. Area Available: The size or quantity of the facility that is marginal.

5. Unit: How the facility is measured using units such as $\mathrm{ft}^{2}$, mi, and kVA, as expressed in the RPIS or as appropriate.

6. Condition Code: The condition rating system provided in the inactivation guidance as shown below:

Physical

Condition

Definition

Excellent Performs to original specifications. Generally requires only preventive maintenance. Easily restorable to "likenew" performance.

Good

Performs to important original specifications with extra operation attention and reasonable extra maintenance. Downtime does not affect operations.

Adequate Meets program requirements/departmental mission assignments, but cannot perform to all original specifications. Corrective, as well as preventive maintenance required/costs not excessive. Downtime does not unduly affect operations.

Fair Occasional substandard output even with careful operator attention. Repetitive corrective maintenance needed. Total maintenance costs exceed economic operations. operations occasionally impeded by downtime.

Poor Consistent substandard performance. Excessive maintenance costs. Operations continually threatened by breakdowns.

7. Funding program: The disposition program that will, or is planned to, accomplish the required action(s) as identified by the two-digit Budget and Reporting (B\&R) Code level. 
Table C-3. Marginal Other Structures Disposition Table Definitions. (sheet 2 of 2)

\begin{tabular}{ll} 
B\&R & \multicolumn{1}{c}{ Description } \\
Code & \\
AF & Nuclear Energy Research \& Development \\
GE & Materials Production \\
GF & Defense Waste \& Transportation Management \\
$H A$ & Environmental Research \& Development \\
KC & Basic Energy Sciences \\
IIG & Strategic Facilities Utilization Program \\
40 & Cost of Reimbursable Work for other Federal Agencies \\
80 & Reconciling Production
\end{tabular}

8. Action: The proposed project action(s) with terms consistent with the FY 1990 Controller's field budget call, such as consolidate or demolish, or none where no action is appropriate.

9. 01d Maintenance Dollars Per Year: The sustaining maintenance costs, (e.g., janitorial, painting, roofing, and heating, ventilating, and air conditioning) associated with the facility described.

10. Action Cost: The amount of funds required to accomplish this project expressed in FY 1990 dollars.

11. New Maintenance Dollars Per Year: The sustaining maintenance costs associated with the facility as a result of the action taken or planned.

12. Savings Per Year: The annual costs that would be avoided or saved through the actions proposed or taken.

13. Replace Avoidance of a One-Time Savings: A cost presented on the basis of a one-time savings.

14. Simple Payback in Years: This is derived by subtracting the replacement avoidance from the total cost of the project and then dividing by the estimated total annual savings and expressing the res 17 ts in years and one-tenth fractions of a year.

15. Proposed Funding Year: The proposed fiscal year that funding should be awarded for completion of planned projects. 
DOE/RL-89- 15

פ

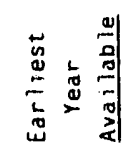

兽

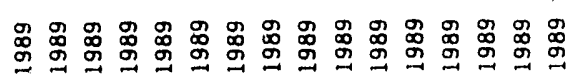

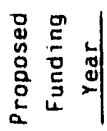

量 量

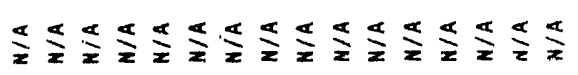

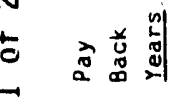

$\frac{\nwarrow}{z} \frac{x}{z}$

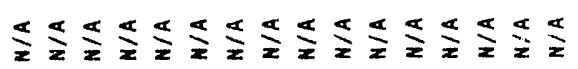

离

รั

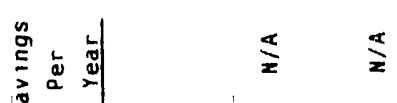

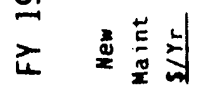

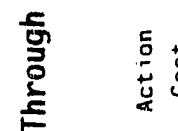

뭉 䓂案

星氧

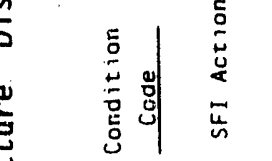

$\stackrel{\frac{c}{n}}{\frac{n}{0}}$

$\frac{2}{0}$

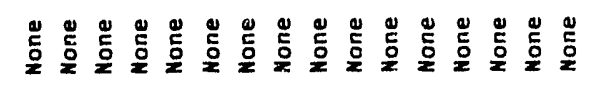

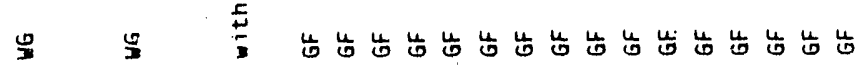

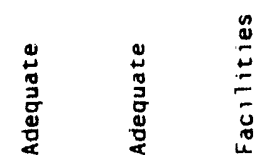

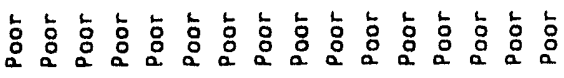

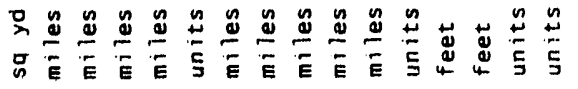

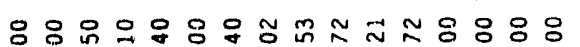
mं山

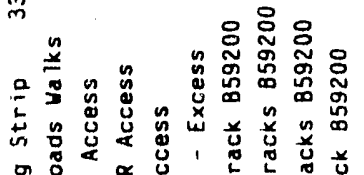

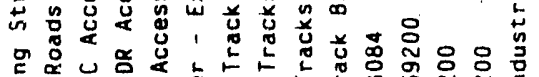

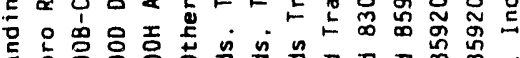

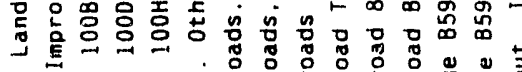

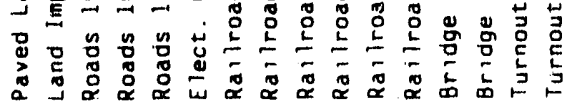

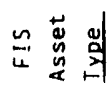

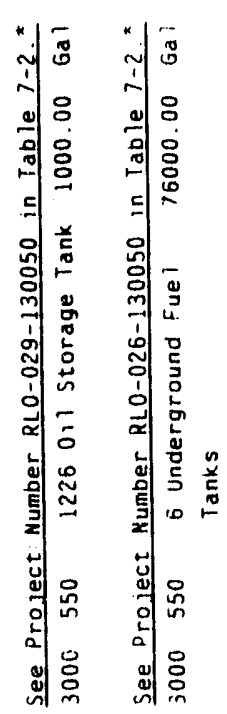

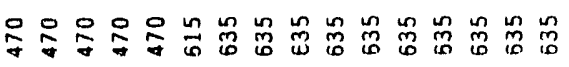

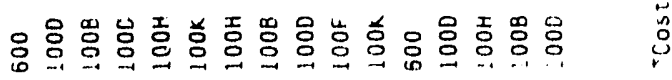




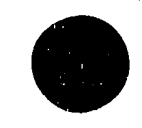

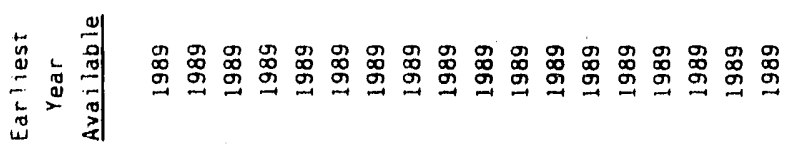

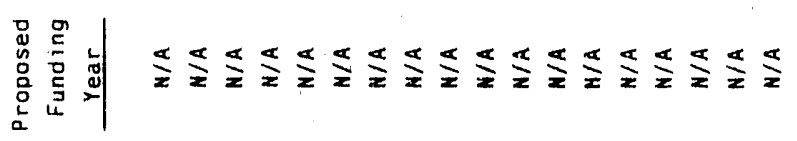

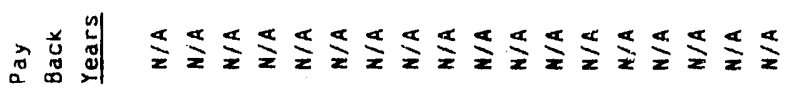

崖兽

量 0 年 00000000000000000.

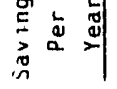

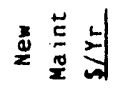

沗

竞苟

응 点

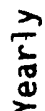

(?)

管

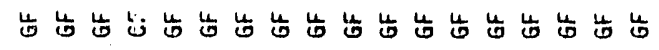

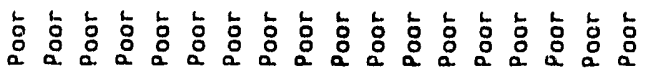

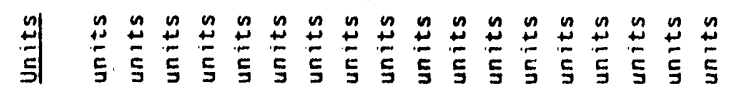

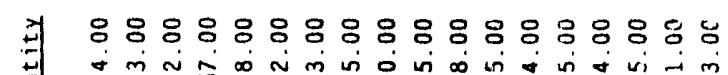

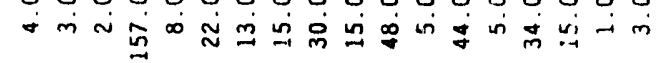

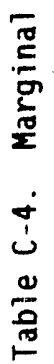

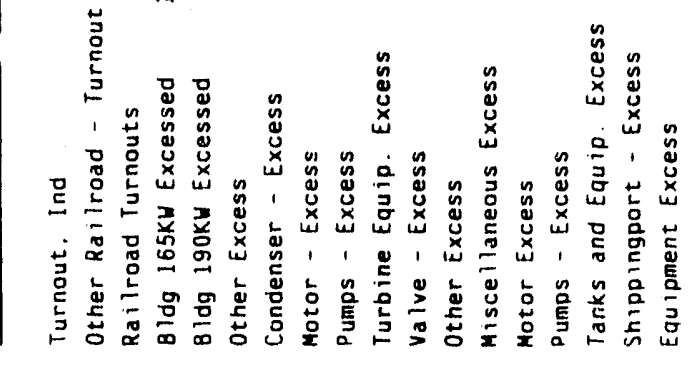

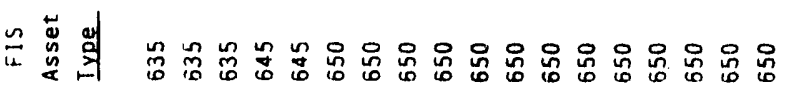

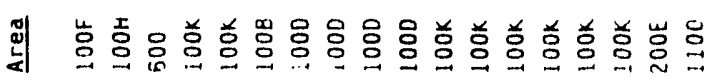


DOE/RL-89-15

HANFORD SURPLUS FACILITIES PROGRAM

PROJECTS PLANNED THROUGH FY 1995

The following 12 projects are being accomplished by the Hanford Surplus Facilities Program (HSFP). These are multi-year programs whose completion schedules will be determined by the rate of funding support. 

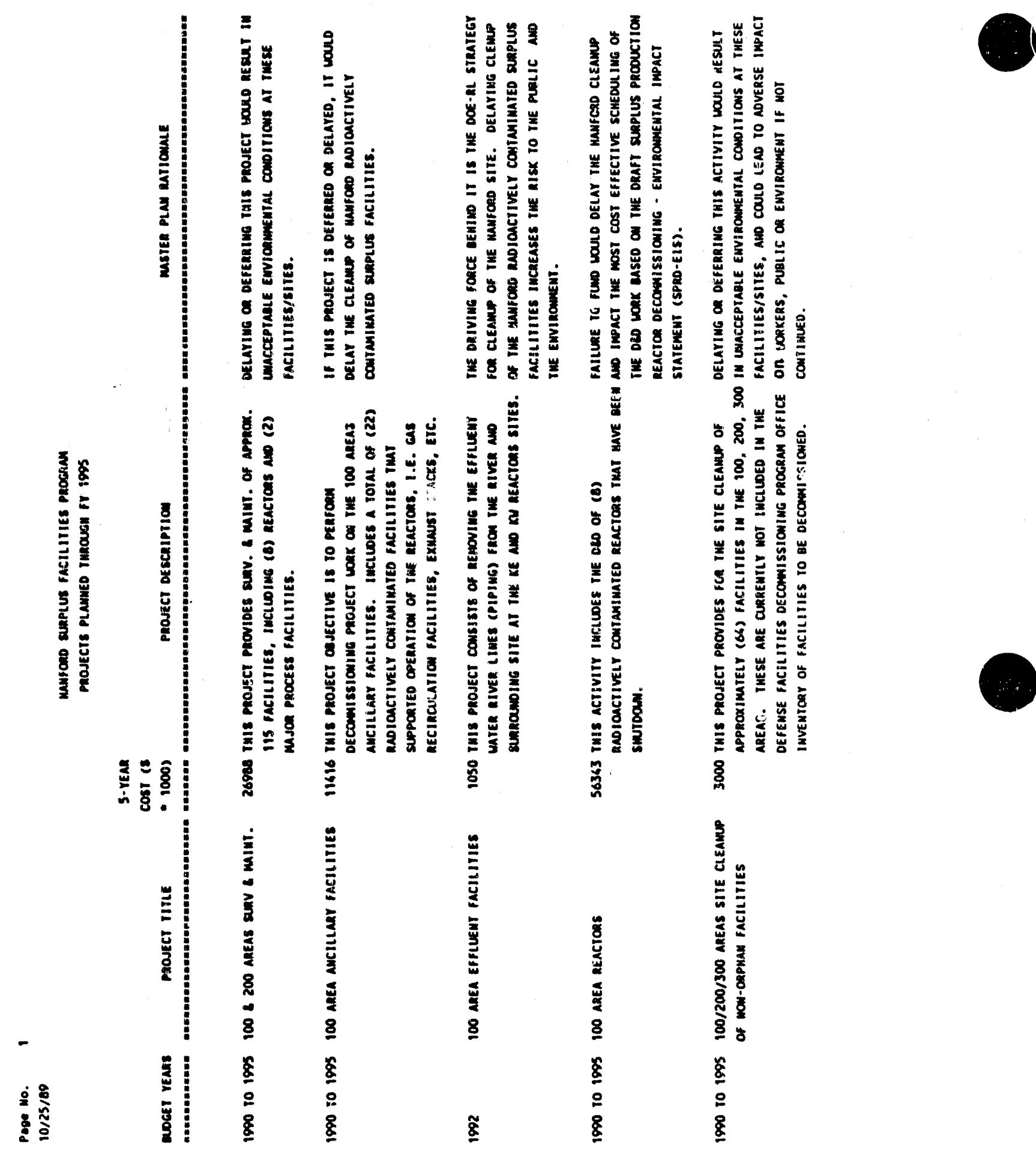
DOE/RL-89-15
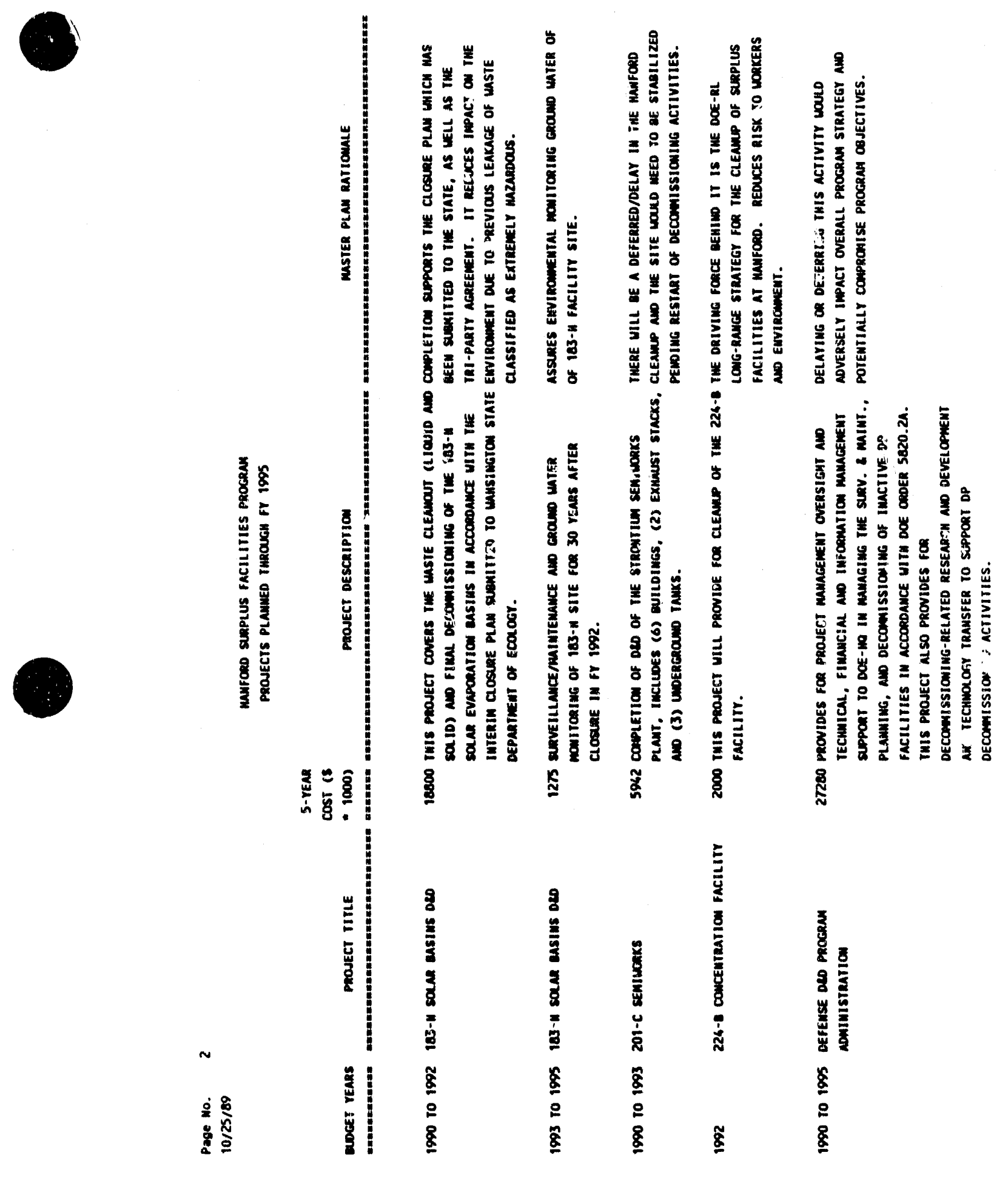


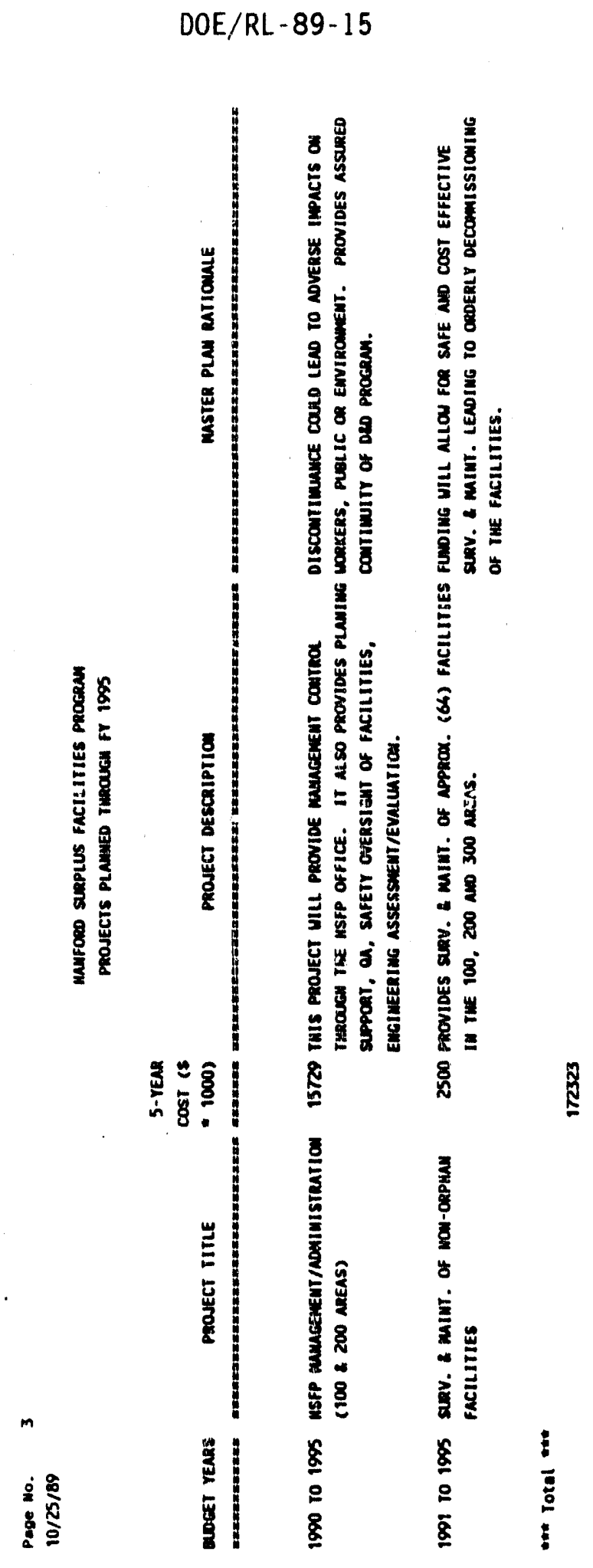



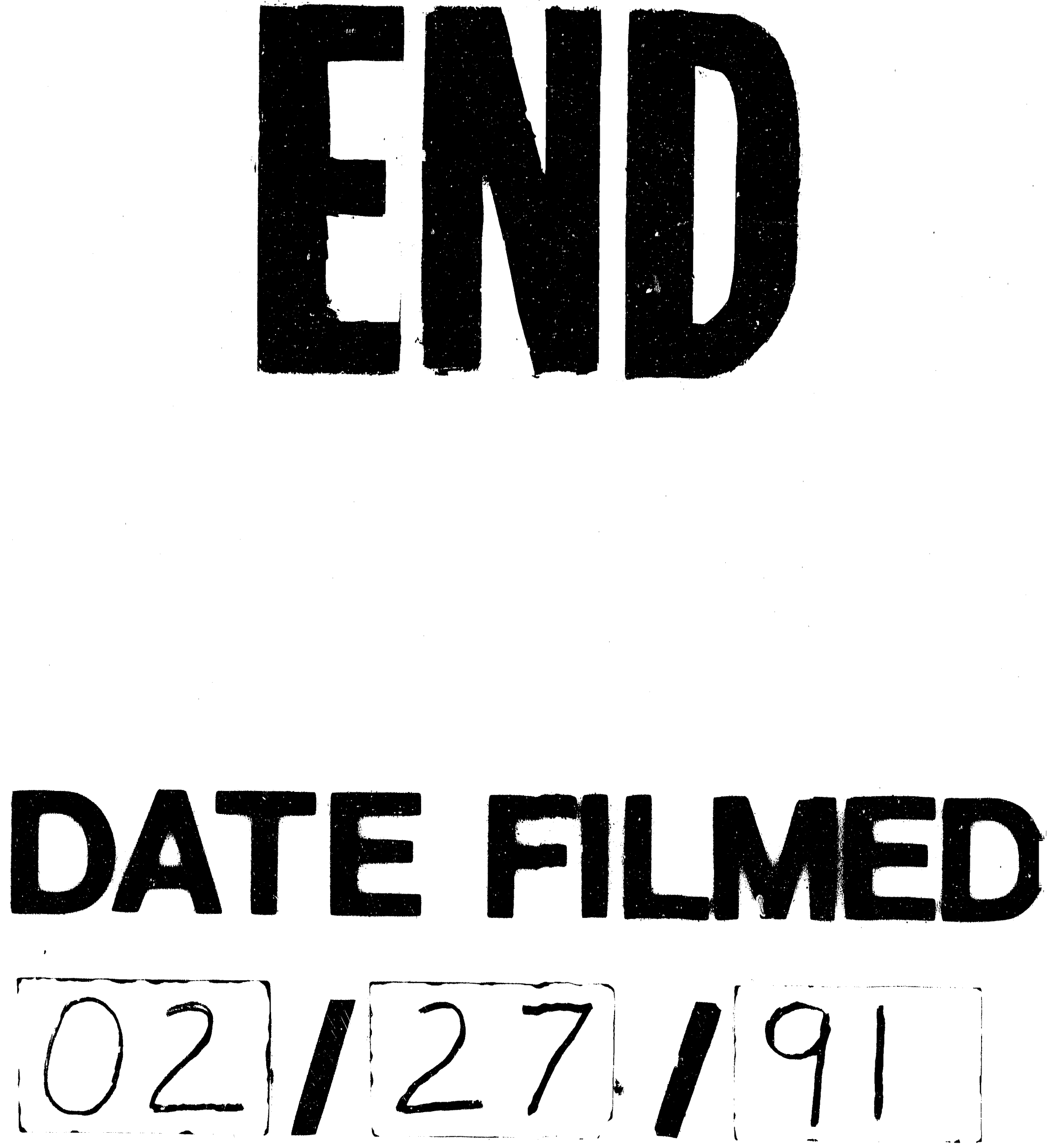
